\title{
Composition and Properties of the Pierre Shale and Equivalent Rocks, Northern Great Plains Region
}

GEOLOGICALSURVEY PROFESSIONALPAPER1064-B 


\section{Geochemistry of the Pierre Shale and Equivalent Rocks of Late Cretaceous Age}

GEOLOGICAL SUR VEY PROFESSIONAL PAPER 1064

This volume was published

as separate chapters $A$ and $B$

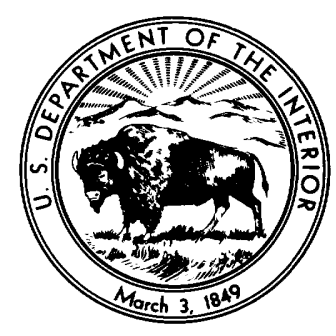

UNITED STATES GOVERNMENT PRINTING OFFICE, WASHINGTON: 1980 
COMPOSITION AND PROPERTIES OF THE PIERRE SHALE AND EQUIVALENT ROCKS, NORTHERN GREAT PLAINS REGION 


\section{CONTENTS}

[Letters designate the chapters]

(A) Mixed-layer clay in the Pierre Shale and equivalent rocks, northern Great Plains region, by Leonard G. Schultz.

(B) Composition and properties of the Pierre Shale and equivalent rocks, northern Great Plains region, by Leonard G. Schultz, Harry A. Tourtelot, James R. Gill, and Josephine G. Boerngen. 


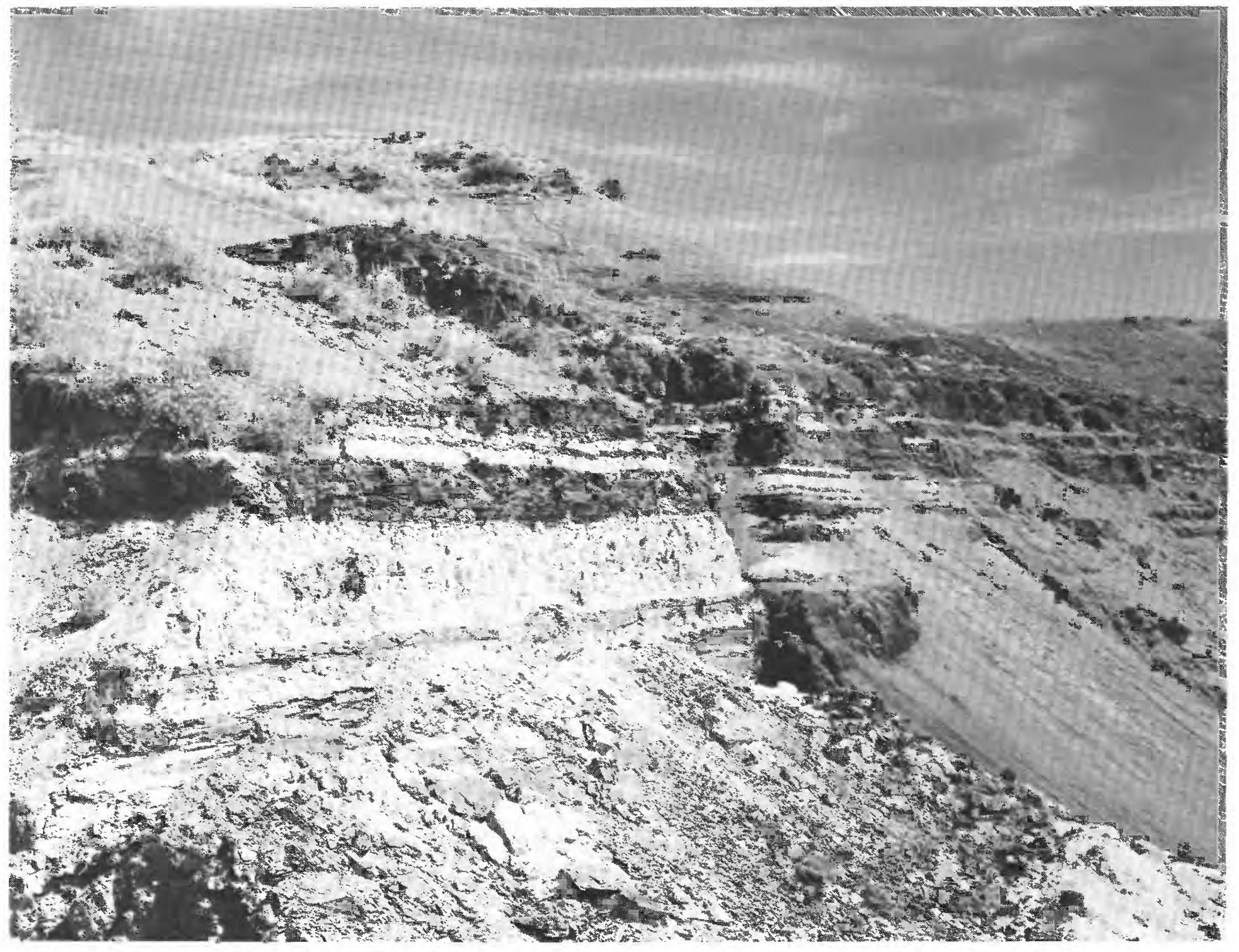

Sharon Springs Member of the Pierre Shale in cliffs north of the Cheyenne River, 3 mi west of Oral, S. Dak., showing typical buttress weathering of hard, black, organic-rich shale and the light Ardmore Bentonite Beds. The most prominent bentonite is $3 \mathrm{ft}$ thick, from which came sample 259572 (tables 1 and 2). Sample 259571, an ordinary shale from the Mitten Member (loc. 18, pl. 1), came from the gentle, brush-covered slope in the upper right of the photograph. 


\section{Composition and Properties of the Pierre Shale and Equivalent Rocks, Northern Great Plains Region}

By LEONARD G. SCHULTZ, HARRY A. TOURTELOT, JAMES R. GILL, and JOSEPHINE G. BOERNGEN

GEOCHEMISTRY OF THE PIERRE SHALE AND EQUIVALENT ROCKS OF LATE CRETACEOUS AGE

GEOLOGICAL S U R VEY PROFES IONAL PAPER 1064 - B

Mineralogical and chemical study, including trace elements, of marine and nonmarine rocks of Late Cretaceous age

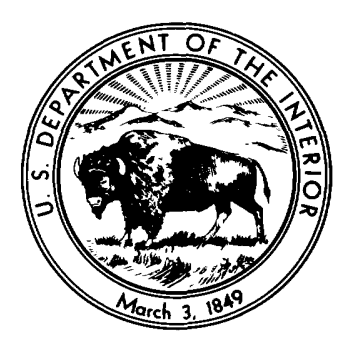

UNITED STATES GOVERNMENT PRINTING OFFICE, WASHINGTON: 1980 


\section{UNITED STATES DEPARTMENT OF THE INTERIOR}

\section{CECIL D. ANDRUS, Secretary}

\section{GEOLOGICAL SURVEY}

H. William Menard, Director

Library of Congress Cataloging in Publication Data

Main entry under title:

Composition and properties of the Pierre Shale and equivalent rocks, northern Great Plains region.

(Geochemistry of the Pierre Shale and equivalent rocks of Late Cretaceous age)

(Geological Survey Professional Paper 1064-B)

Bibliography: p. B82

1. Geology, Stratigraphic-Cretaceous. 2. Shale-Great Plains. 3. Geology-Great Plains.

I. Schultz, Leonard Gene, 1926- II. Series. III. Series: United States Geological Survey Professional Paper 1064-B.

QE688.C65

$551.7^{\prime} 7$

$79-607045$

For sale by the Superintendent of Documents, U.S. Government Printing Office Washington, D.C. 20402 


\section{CONTENTS}

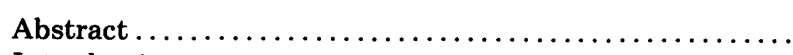

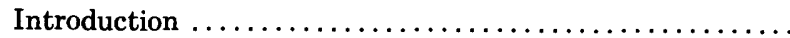

Acknowledgments $\ldots \ldots \ldots \ldots \ldots \ldots \ldots \ldots \ldots \ldots \ldots \ldots$

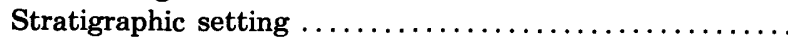

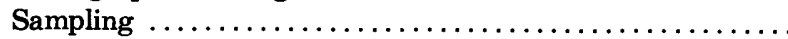

Methods

Types of shale and other rock in the Pierre Shale and

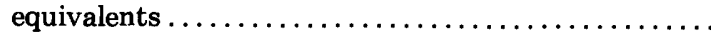

Suitability of outcrop samples-weathering $\ldots \ldots \ldots \ldots \ldots$

Mineralogical composition $\ldots \ldots \ldots \ldots \ldots \ldots \ldots \ldots \ldots \ldots$

Methods of analysis . . . . . . . . . . . . . . . . . . . .

Hydroxide or chlorite interlayers-heated code

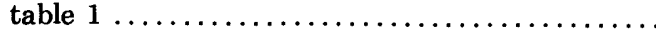

Exchangeable cations-air-dried code, table $1 \ldots \ldots$

Anorthite content of plagioclase . . . . . . . . . . .

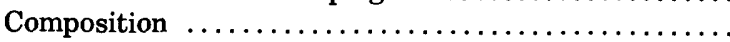

Pierre Shale and equivalents-the whole unit .......

Environment of deposition .....................

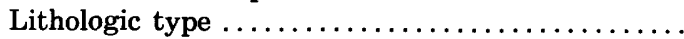
Ordinary shale and siltstone $\ldots \ldots \ldots \ldots \ldots \ldots$

Organic-rich shale..$\ldots \ldots \ldots \ldots \ldots \ldots \ldots \ldots$

Shale directly above bentonite ..............

Frothy-weathering shale .................

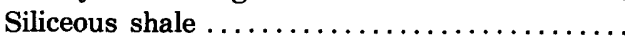

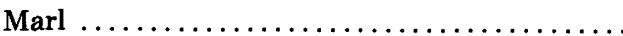

Volcanic-rich shale $\ldots \ldots \ldots \ldots \ldots \ldots \ldots \ldots$

Volcanic-rich siltstone .....................

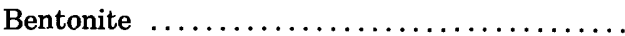

Regional and stratigraphic variation .............

Illite, beidellite, and montmorillonite in mixedlayer clay ...

Clay minerals in total clay-mineral fraction ........

Minerals in the total sample .................

Types of quartz ........................

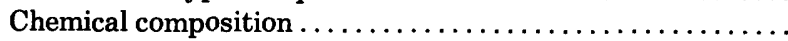

Major, minor, trace, and rock-forming elements-ter-

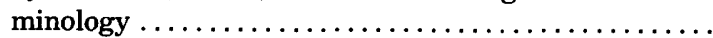

Explanation of table $1 \ldots \ldots \ldots \ldots \ldots \ldots \ldots \ldots$

\begin{tabular}{r|r} 
Page \\
B1 \\
2 \\
3 \\
3 \\
5 \\
5 \\
5 \\
8 \\
9 \\
9 \\
9 \\
11 \\
11 \\
12 \\
12 \\
13 \\
15 \\
15 \\
15 \\
17 \\
17 \\
18 \\
19 \\
21 \\
21 \\
25 \\
28 \\
29 \\
29 \\
30 \\
39 \\
40 \\
40 \\
40 \\
\end{tabular}

Page

Chemical composition-Continued

Methods .............................. B40

Abundance of elements in the Pierre Shale and some statistical considerations ...................

Distribution and occurrence of elements within the Pierre

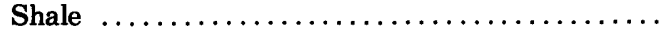

Rock-forming constituents ..................

Major elements .......................

Minor elements-sulfur and carbon ...........

Trace elements and some minor elements ..........

Some tools for determination of occurrence..... Occurrence of elements in other shale....... Correlation coefficients ................ Heavy minerals and size-fractionation......

Minor elements $\left(\mathrm{TiO}_{2}, \mathrm{P}_{2} \mathrm{O}_{5}, \mathrm{~F}\right.$, and $\left.\mathrm{Cl}\right) \ldots \ldots \ldots$.

Trace elements occurring mainly in heavy resistates $(\mathrm{Zr}, \mathrm{Y}, \mathrm{Yb}, \mathrm{La}$, and $\mathrm{Sn}) . \ldots \ldots \ldots$.

Trace elements occurring almost entirely in clay minerals (Sc and B) .................

Trace elements having multiple occurrences $(\mathrm{Ga}$, $\mathrm{Pb}, \mathrm{Ba}, \mathrm{Sr}$, and $\mathrm{Mn}) \ldots \ldots \ldots \ldots \ldots \ldots$

Trace elements associated with sulfur or organic matter.

Interrelations between sulfur (pyrite), organic matter, and their related elements ......

Sulfur-related elements ( $\mathrm{Co}, \mathrm{Ni}$, and $\mathrm{Zn})$..... Organic-matter-related elements $(\mathrm{Cd}$; $\mathrm{Cr}, \mathrm{V}$, and $\mathrm{Cu} ; \mathrm{Mo}$, Se, and $\mathrm{As} ; \mathrm{U}) . . . \ldots \ldots \ldots . . .$.

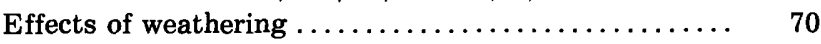

Interrelated physical and chemical properties .......... 72

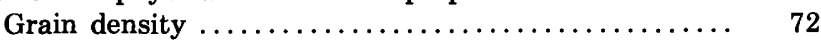

Bulk density and porosity ................... 73

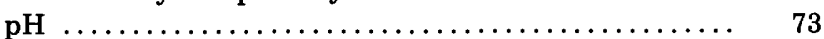

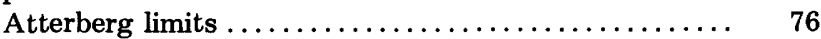

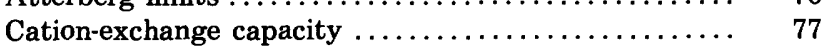

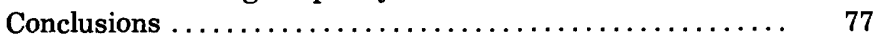

References cited $\ldots \ldots \ldots \ldots \ldots \ldots \ldots \ldots \ldots \ldots \ldots \ldots \ldots \ldots \ldots \ldots, 82$

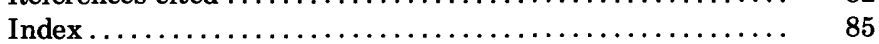

\section{ILLUSTRATIONS}

FrontisPIECE. Photograph of the Sharon Springs Member showing Ardmore Bentonite Beds and buttress weathering of organicrich shale.

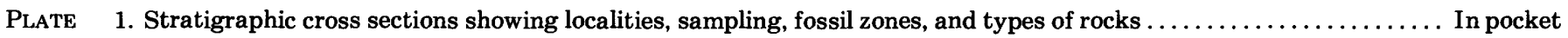

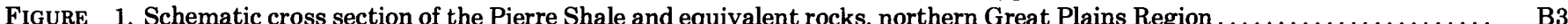

2. Photomicrograph showing platelets of organic matter in organic-rich shale from Sharon Springs Member ............ 6

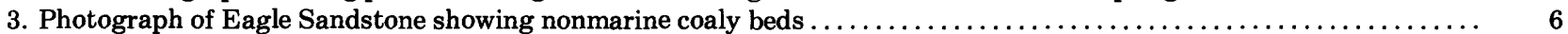

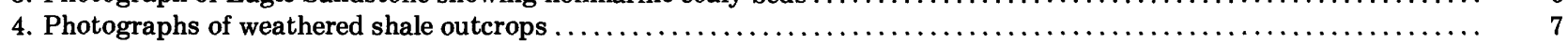

5. X-ray diffraction traces showing effects of interlayer hydroxide sheets on the collapse of heated smectite $\ldots \ldots \ldots \ldots . . .6$

6. Ternary diagram showing types of layers in mixed-layer clay of the Pierre Shale and equivalent rocks ............ 
FigURE 7. Cumulative curves showing abundance of minerals in different environments of deposition of the Pierre Shale and equiv-

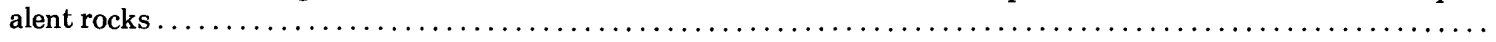

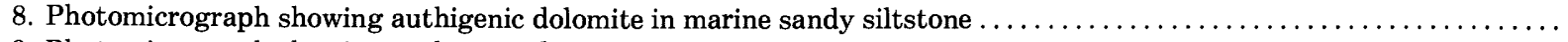

9. Photomicrograph showing authigenic dolomite in nonmarine silty claystone $\ldots \ldots \ldots \ldots \ldots \ldots \ldots \ldots \ldots \ldots$

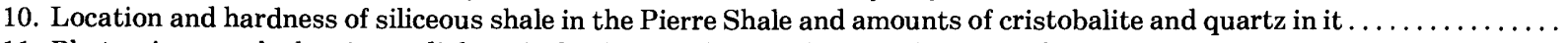

11. Photomicrograph showing radiolaria in frothy-weathering shale, DeGrey Member $\ldots \ldots \ldots \ldots \ldots \ldots \ldots \ldots \ldots$

12. Photomicrograph showing rhombic authigenic dolomite in sandy marlstone, Crow Creek Member $\ldots \ldots \ldots \ldots \ldots \ldots$

13. Photomicrograph showing authigenic dolomite in fine-grained marlstone, Crow Creek Member $\ldots \ldots \ldots \ldots \ldots \ldots \ldots$

14. Photomicrograph of volcanic-rich sandy siltstone, Cokedale Formation $\ldots \ldots \ldots \ldots \ldots \ldots \ldots \ldots \ldots \ldots \ldots \ldots$

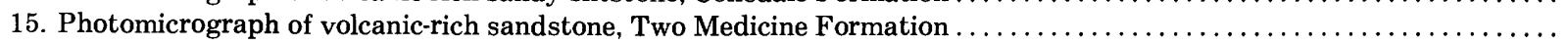

16. Photomicrograph of chloritized volcanic sandstone, Lennep Sandstone $\ldots \ldots \ldots \ldots \ldots \ldots \ldots \ldots \ldots \ldots \ldots \ldots \ldots \ldots$

17. Photomicrographs of volcanic ash partly altered to clinoptilolite, Ardmore Bentonite Beds $\ldots \ldots \ldots \ldots \ldots \ldots \ldots \ldots$

18. Photograph of invertebrate borings in zeolitized bentonite bed $\ldots \ldots \ldots \ldots \ldots \ldots \ldots \ldots \ldots \ldots \ldots \ldots \ldots \ldots \ldots$

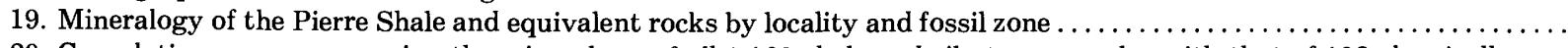

20. Cumulative curves comparing the mineralogy of all 1,160 shale and siltstone samples with that of 192 chemically analyzed samples.

21. Cumulative curves showing abundance of major and minor elements in different environments of deposition of the Pierre

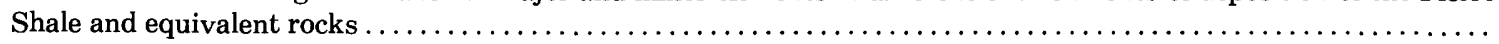

22. Cumulative curves showing abundance of trace elements in different environments of deposition of the Pierre Shale and equivalent rocks

23. Composition of chemically analyzed samples of the Pierre Shale and equivalent rocks by locality $\ldots \ldots \ldots \ldots \ldots \ldots \ldots$

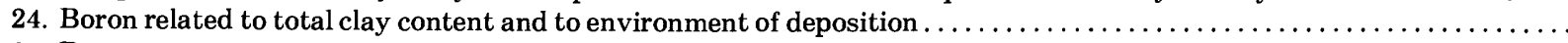

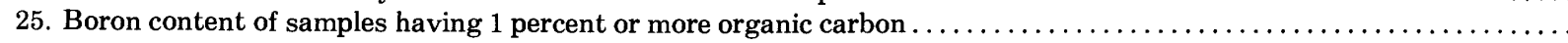

26. Trace elements reported to be associated with organic matter or sulfur related to amounts of organic carbon in the Pierre Shale and equivalent rocks....

27. Cumulative curves for physical properties (density, porosity, Atterberg limits, cation exchange capacity, and $\mathrm{pH}$ ) of the Pierre Shale and equivalent rocks.

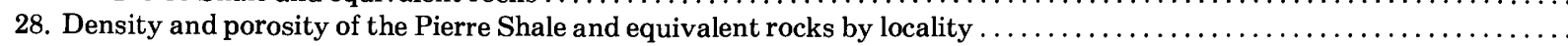

\section{TABLES}

TABle 1. Chemical, mineralogical, and physical-properties data for 226 samples of Pierre Shale and equivalent rocks ...........

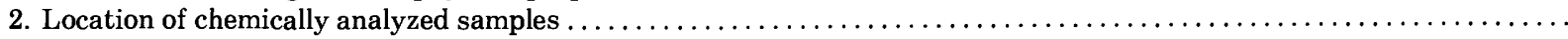

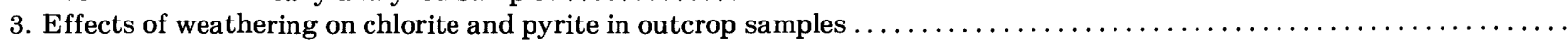

4. Anorthite content of plagioclase from bentonite as determined by X-ray methods and optically $\ldots \ldots \ldots \ldots \ldots \ldots \ldots$.

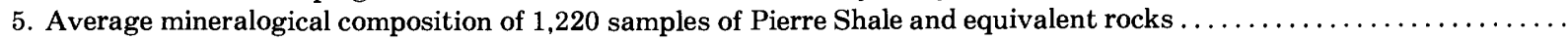

6. Average mineralogical composition of different types of rock in the Pierre Shale and its equivalents $\ldots \ldots \ldots \ldots \ldots \ldots \ldots$

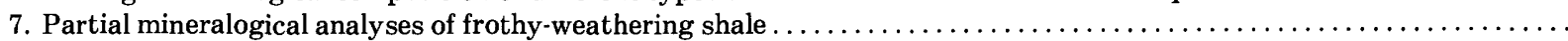

8. Mineralogy of shale and marl from different members of the Pierre Shale and from the Niobrara Formation in the Missouri River area.

9. Average mineralogical composition of nonmarine volcanic-rich rock from Dearborn River and other localities ..........

10. Mineralogical composition of typical bentonite and of some unusual bentonites from the Pierre Shale and equivalent rocks.

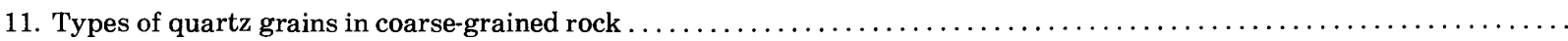

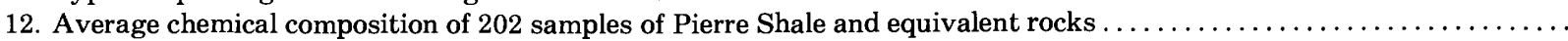

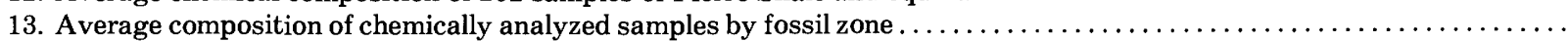

14. Average chemical composition of different types of rock in the Pierre Shale and equivalents $\ldots \ldots \ldots \ldots \ldots \ldots \ldots \ldots$

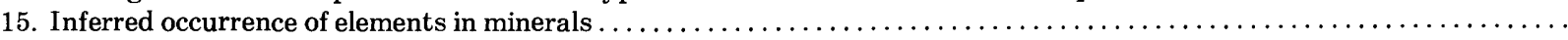

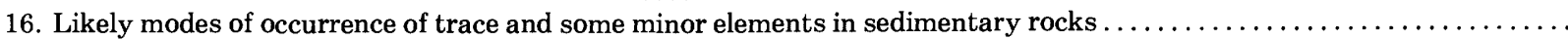

17. Correlation coefficients between mineral and chemical constituents in the Pierre Shale and equivalent rocks ..........

18. Heavy minerals in selected samples...

19. $\mathrm{TiO}_{2}, \mathrm{P}_{2} \mathrm{O}_{5}$, and $\mathrm{MnO}$ in whole and less-than- 0.25 -mm fractions of 15 samples of Pierre Shale and equivalent rocks $\ldots \ldots \ldots$

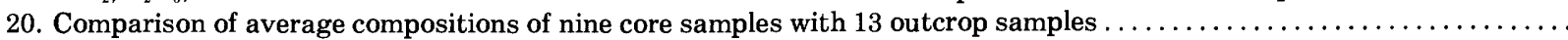

21. Comparison of selected elements in outcrop and core samples of organic-rich shale from the Sharon Springs Member .....

22. Average values of physical properties and related data for various types of rock in the Pierre Shale and equivalent rocks .

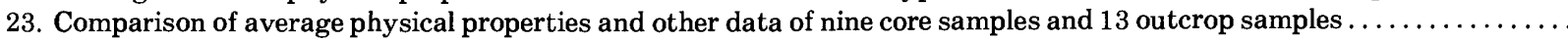

24. Correlation coefficients between physical properties and selected compositional features . . . . . . . . . . . . . . . . . . .

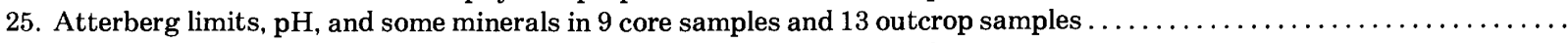

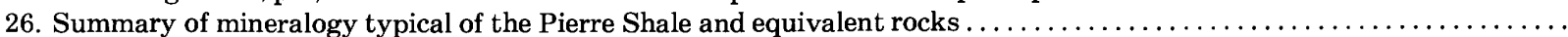

27. Chemical composition of the Pierre Shale and equivalent rocks compared with other rocks $\ldots \ldots \ldots \ldots \ldots \ldots \ldots \ldots$ 


\title{
COMPOSITION AND PROPERTIES OF THE PIERRE SHALE AND EQUIVALENT ROCKS, NORTHERN GREAT PLAINS REGION
}

\author{
By Leonard G. Schultz, Harry A. TOurtelot, James R. Gill ${ }^{1}$, \\ and JOSEPHINE G. BOERNGEN
}

\section{ABSTRACT}

The Pierre Shale and equivalent rocks of Late Cretaceous age consist in the east-central Dakotas of several hundred feet of offshoremarine shale and minor marl; in west-central Montana near the sediment source the equivalents of the Pierre Shale consist of several thousand feet of volcanic-rich and mostly nonmarine sediments; and in the area between, both types of rock are separated by tongues of nearshore-marine siltstone and sandstone that mark three major transgressions of the sea across the area. The major-, minor-, and trace-element composition was determined for 226 samples of these rocks, and the mineralogical composition was determined for 1,350 samples. Slurry pH, Atterberg limits, and grain and bulk densities were determined on some samples.

The arithmetic mean, in percent, and standard deviation (in parentheses) of major and minor elements, mostly in shale and siltstone and excluding the 23 chemically analyzed bentonite samples, are as follows:
$\mathrm{SiO}_{2} \ldots \ldots . .60 .8(7.9)$
$\mathrm{Al}_{2} \mathrm{O}_{3} \ldots . . .14 .4(2.5)$
$\mathrm{Fe}_{2} \mathrm{O}_{3} \ldots \ldots .3 .4(1.4)$
$\mathrm{Na}_{2} \mathrm{O}$
$\mathrm{K}_{2} \mathrm{O}$....... $2.4(0.57)$
$\mathrm{H}_{2} \mathrm{O}-\ldots . .3 .2(1.3)$
$\mathrm{H}_{2} \mathrm{O}+\ldots . .4 .3(1.2)$
$\mathrm{MgO} \ldots \ldots . . . .2 .2(1.0)$
$\mathrm{TiO}_{2} \ldots . . .0 .58(0.12)$
$\mathrm{P}_{2} \mathrm{O}_{5} \ldots .0 .14(0.073)$
$\mathrm{S}$............. 0.37(1.1)
F ............. 0.71(0.15)
$\mathrm{Cl} \ldots . . . .0 .16(0.024)$
$\mathrm{CO}_{2} \ldots \ldots . . .2 .1(7.0)$
C, organic.
$0.94(1.8)$

The mean and standard deviation of minerals as determined by $\mathrm{X}$-ray methods, excluding bentonite samples, is as follows: clay minerals, 53 (20); quartz, 24 (13); cristobalite, 1 (5); potassium-feldspar, 1 (2); plagioclase, 6 (7); anorthite content from 20 to 40 percent; calcite, 5 (14); dolomite, 4 (7); organic matter, 1 (2); and sparsely scattered gypsum, jarosite, pyrite, zeolites, augite, siderite, and probably minor amounts of hydrated iron-manganese (Fe-Mn) oxides. The mean and standard deviation of the clay-mineral fraction is as follows: mixed-layer illite-smectite, $70(20)$; illite, 16 (9); chlorite, 3 (6); and kaolinite, 9 (13). The mixed-layer clay, except in the Montana disturbed belt, is a random interlayering of 20 to 60 percent illite-type layers, about 35 percent beidelite-type layers, and the remainder montmorillonite-type layers; chlorite or vermiculite layers are rare.

Most bentonite differs from shale in its small quartz content, rarely more than a few percent, in the more calcic composition and hightemperature thermal state of its plagioclase, and in its rare kaolinite, near absence of chlorite, and lack of illite-either free or mixed layered with smectite. Bentonite commonly consists of more than 90 percent smectite in which montmorillonite is interlayered with a smaller amount of beidellite.

The clay-mineral composition of marine rock, including proportions of layers in the dominant illite-smectite, averages about the same as in the nonmarine rock, though in the latter the composition is more variable. The average content of major chemical constituents also is closely similar, partly because the large clay content of fine-grained offshore-marine shale is balanced by the small clay content of nearshore-marine siltstone and sandstone. In addition, the alumina and alkalic elements in an average of 10 percent more clay in marine rock are partly balanced by these constituents in the 5 percent more feldspar in nonmarine rock. Much of the observed regional and stratigraphic variation in major constituents is the result of the three major east-west migrations of the depositional sites of nearshore-marine sandstone and siltstone. Dolomite is found almost exclusively in relatively coarse-grained rock, particularly in nearshore-marine siltstone where diagenetic dolomite is expected, but it is found almost as frequently in nonmarine siltstone. Amounts of minor constituents are nearly equal in marine and nonmarine rocks, except that pyrite and consequently sulfur are relatively sparse in nonmarine rock. Average amounts of organic matter found in marine and nonmarine rocks are nearly identical. However, organic matter in nonmarine rock occurs almost entirely in volumetrically minor coaly beds, whereas in most marine shale a fraction of a percent of finely and widely disseminated organic matter imparts characteristically gray hues, which contrast with light pastel colors characteristic of most nonmarine rock.

Lithologic variations in shale that provide the basis for stratigraphic subdivision of fine-grained offshore-marine rock in the east are caused by minor variations in mineralogical composition. Thin plates of organic matter impart the characteristic toughness and fissility of organic-rich marine shale. Highly expanding sodium ( $\mathrm{Na}$ ) smectite and, to a smaller degree, large amounts of any smectite impart the frothy or popcorn weathered texture characteristic of some units. Cristobalite or, to a smaller degree, quartz cement derived from radiolarian opal imparts the hard, brittle character to siliceous shale. Calcite, mostly as coccoliths and other shell fragments, is abundant in marl units but is sparse and usually absent in shale. 
The vast majority of detritus that formed the Pierre Shale came from the west. The eastern borderland of the Pierre sea contributed only to minor local increases in kaolinite and quartz. Most of the illite, chlorite, and probably kaolinite came from erosion of older rocks, mostly from the soutliwest, as these minerals are most abundant in Wyoming. The major sources of sediments were the Elkhorn Mountains Volcanics and similar volcanic piles just west of the sampled area, which contributed two-thirds to three-fourths of the material in the Pierre Shale and its equivalents in the area studied, including the illite-smectite, the plagioclase, probably most of the quartz, and, of course, the bentonite. The illite-smectite clay that was formed by weathering of the volcanic debris on land was changed little on entering the marine environment or after burial. The main exception is at one locality in the Montana disturbed belt where the mixed-layer clay is 60 to 80 percent illite regularly interyered mostly with beidellite. This feature of the clay must be secondary, due to changes similar to those taking place in depth-diagenesis.

The arithmetic mean, in ppm (parts per million), and standard deviation (in parentheses) of trace-element concentration in the Pierre Shale and its equivalents, exclusive of bentonites, are as follows:

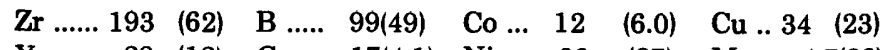

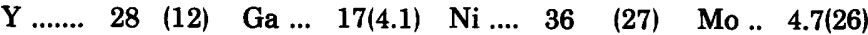

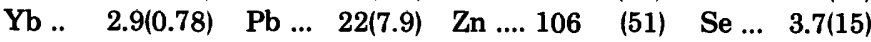

$\mathrm{La}$..... 39 (25) $\mathrm{Ba} . .650(300) \quad \mathrm{Cd} . . \quad 0.93(1.2) \quad$ As .. 14 (35)

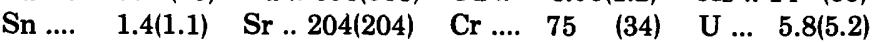

Sc ..... $16 \quad(5.0) \quad \mathrm{Mn} .720(275) \quad \mathrm{V} \ldots . .156 \quad$ (97)

The major hosts of most trace elements in shale in the Pierre Shale are the clay minerals. Principal exceptions are marine organic matter that concentrates some elements, listed later, and heavy resistate minerals like zircon that concentrate zirconium $(\mathrm{Zr})$, yttrium (Y), ytterbium (Yb), lanthanum (La), and tin (Sn). Some titanium (Ti) occurs in anatase, but the anatase is so fine grained that it cannot be differentiated from the clay minerals as a host of Ti. Minor hosts for gallium $(\mathrm{Ga})$, lead $(\mathrm{Pb})$, barium $(\mathrm{Ba})$, strontium $(\mathrm{Sr})$, and probably Mn, and, very locally, boron (B), are the feldspars; calcite is a minor host for $\mathrm{Sr}$ and $\mathrm{Mn}$, clinoptilolite for $\mathrm{Ba}$ and $\mathrm{Sr}$, hydrated Fe-Mn oxide for $\mathrm{Mn}$, and, in volcanic-rich rock, augite, biotite, and magnetite for $\mathrm{Mn}$ and probably also for cobalt (Co), nickel (Ni), chromium (Cr), vanadium (V), and copper (Cu).

Chromium, cadmium (Cd), V, Cu, molybdenum (Mo), selenium (Se), arsenic (As), and uranium (U) are concentrated in the several percent of organic matter in marine organic-rich shale, and $\mathrm{Co}, \mathrm{Ni}$, and zinc $(\mathrm{Zn})$ seem to be more concentrated in pyrite that is closely associated with the organic matter. The concentration of $\mathrm{Cr}$ and $\mathrm{Co}$ is slight, but the concentration of Mo, Se, As, and possibly Cd and $\mathrm{U}$ is large enough to make a significant contribution to the amount of these elements contained in the Pierre Shale and equivalent rocks as a whole. Most of these elements seem not to be concentrated in the 1 percent or less of organic matter present in most of the marine rocks of Pierre age or in the large amounts of organic matter in nonmarine coaly rocks.

The average content of $B$ is $110 \mathrm{ppm}$ in marine rock and $71 \mathrm{ppm}$ in nonmarine rock. Much of the difference, however, is due to the larger content of clay minerals in the marine rock and to the exceptionally low average of $39 \mathrm{ppm} B$ in nonmarine volcanic-rich rock. Exclusive of the volcanic-rich rock and normalized to 100 percent clay, content of $\mathrm{B}$ in marine and nonmarine clay minerals differs only slightly. $\mathrm{Zn}, \mathrm{Cr}, \mathrm{Cu}, \mathrm{Se}, \mathrm{As}$, and probably chlorine $(\mathrm{Cl})$ are all more concentrated in the clay of marine rock, and in the Pierre Shale and equivalents these elements appear to be as good as, if not better, indicators of environment of deposition than $B$.

Compared with other marine shales, the Pierre Shale tends to contain less $\mathrm{CaO}, \mathrm{K}_{2} \mathrm{O}$, and $\mathrm{Fe}_{2} \mathrm{O}_{3}$ and more $\mathrm{H}_{2} \mathrm{O}$ due to the Pierre's small content of calcite and hydrated Fe oxides and to the more smectitic and less illitic composition of its clay. The small $\mathrm{Sr}$ concentration in the Pierre Shale also is related to small calcite content. The Pierre Shale contains twice as much Se as other marine shales, probably because of the large contribution of volcanic material. Reasons are not obvious, however, for less than a third as much Sn and $\mathrm{La}$ in the Pierre Shale and equivalents as in other shales.

Of the Atterberg limits of the Pierre Shale and equivalent rocks, the plastic limit, mostly 20 to 40 percent, is directly related to the total amount of smectite, and the liquid limit, mostly 40 to 130 percent, is directly related to $\mathrm{Na}$ smectite. The grain density of most rocks is uniformly about 2.6. The bulk density, in contrast, increases rather consistently from about 2.0 in the east to 2.4 in the west; the increase in the west is apparently due to greater burial by younger sediments and more compaction. The slurry $\mathrm{pH}$ of most samples is alkaline, but some samples of weathered rock are acid.

Acid solutions caused by oxidation of pyrite during weathering have leached some chlorite, have caused a marked decrease in the liquid limit of some shale, and have caused appreciable decrease in the pyrite-associated trace elements $\mathrm{Co}, \mathrm{Ni}$, and $\mathrm{Zn}$ in pyritic organic-rich shale. However, neither trace nor major-element content of most other outcrop samples is significantly altered by weathering of the sampled rock.

\section{INTRODUCTION}

Shale makes up from one-half to three-fourths of all sedimentary rock and underlies more of the Earth's land surface than any other rock (Pettijohn, 1957, p. 10). In addition, the clayey nature of shale gives it special geochemical significance. The small particle size of clay minerals allows many colloidal processes to operate, which, along with the ion-exchange capacity of most clay minerals, are commonly thought to make the composition of clays generally responsive to changes in setting that take place during sedimentation and diagenesis. When sedimentation and diagenesis take place in marine waters, the general trend of these changes is thought to result in clayey rocks containing larger quantities of metallic elements than other rock types. This trend is greatly emphasized if organic matter is deposited along with the clay minerals (Krauskopf, 1955; Vine and E. B. Tourtelot, 1969). Metals concentrated in shale by sedimentation and diagenesis may be source materials for ore deposits after the shale is metamorphosed, and understanding the way these metals are distributed in a large body of shale may lead to better search for such ore deposits. The metals in shale may be released into the environment during weathering and erosion with beneficial or harmful effects on soils and the chemical quality of water depending on the amounts of metals in the shale and the nature of weathering involved (Tourtelot, 1971).

For these kinds of reasons, the Geological Survey in 1956 began the investigation of the mineralogical and chemical composition of the Pierre Shale and equivalent rocks to determine their genesis by means of comparison of time-equivalent marine and nonmarine 
rocks. In addition, several physical properties of the shale were measured and compositional factors controlling them interpreted.

A number of published reports describing the results of preliminary investigations, various stages of progress, and collateral investigations of mineralogy, stratigraphy, geochemistry, and isotopic composition are referenced throughout this report. This report presents most of the data on mineralogy and chemical composition and summarizes the relations between the data and our interpretations of them. In a companion report (Schultz, 1978), some details of the X-ray interpretation, composition, and genesis of the ubiquitous mixed-layer clay of the Pierre Shale and equivalents are given that do not fit conveniently into this report.

\section{ACKNOWLEDGMENTS}

E. P. Rothrock and A. F. Agnew, both formerly State geologists of South Dakota, provided much information on the distribution of the Pierre Shale in South Dakota and extended many helpful courtesies. W. M. Laird, formerly State geologist of North Dakota was similarly helpful for that State. A. H. Burling, at the time project geologist, Oahe Unit, U.S. Army Corps of Engineers, Pierre, S. Dak., provided access to excavations and drill-hole cores at the Oahe and Big Bend Dams as well as much information on the stratigraphic subdivisions of the Pierre Shale revealed therein.

All analyses were made in the laboratories of the U.S. Geological Survey. L. B. Riley, L. C. Peck, A. T. Myers, and L. F. Rader assisted in planning the analytical work and aided in the interpretation of some of the data. L. F. Rader and P. R. Barnett investigated the precision of analyses. Claude Huffman, Jr., and I. C. Frost participated in some special studies of the composition of the Pierre Shale.

We should like to emphasize the very great contribution made throughout the course of the Pierre Shale investigations by W. A. Cobban. Mr. Cobban not only participated in the field work, leading to a particularly fruitful, independent collaboration with $\mathrm{Mr}$. Gill, but also made freely available his knowledge of the stratigraphy and paleontology of Upper Cretaceous rocks of the Western Interior region.

\section{STRATIGRAPHIC SETTING}

Rocks of Pierre age were deposited in a north-south trending trough nearly 1,000 miles (mi) across that extended from the Canadian arctic at least as far south as New Mexico and at times to the Gulf of Mexico. This study covers only the northern Great Plains Region (pl. 1). In this area the rocks of Pierre age form a sedimentary wedge that thins from several thousand feet in the west to less than 1,000 feet (ft) in the east. Almost all of the sediments were derived from the west, so that in the east, far from the source areas, sediments are almost exclusively fine-grained shale and marlstone that were deposited in an offshore marine environment. These very fine grained rocks grade westward into silty shale and nearshore marine siltstone and sandstone in the middle and western parts of the basin. The marine sandstone, in turn, grades westward into a thick series of alternating lenticular coarse- and fine-grained continental deposits, in many of which volcanic debris is conspicuous. The volcanic debris came mostly from the Elkhorn Mountains Volcanics (fig. 1, index map; Klepper and others, 1957).

The summary of the stratigraphy that follows comes mainly from Gill and Cobban (1973); (for more details, see Tourtelot, 1962, p. 4-7; Gill and Cobban, 1961, 1965, 1966, and 1973, and Schultz, 1965). The nomenclature used applies mostly to major stratigraphic units in the bulk of the area studied. Little attempt is made to discuss stratigraphic relations in peripheral areas, such as northern Wyoming, where much of the nomenclature is considerably different and related to areas farther south in that state. A very generalized cross section with most of the stratigraphic terms used in the figures and tables is shown in figure 1.

Ammonite zones have been traced across the marine parts of the Pierre and make it possible to compare six successively younger groups of rock of roughly equal

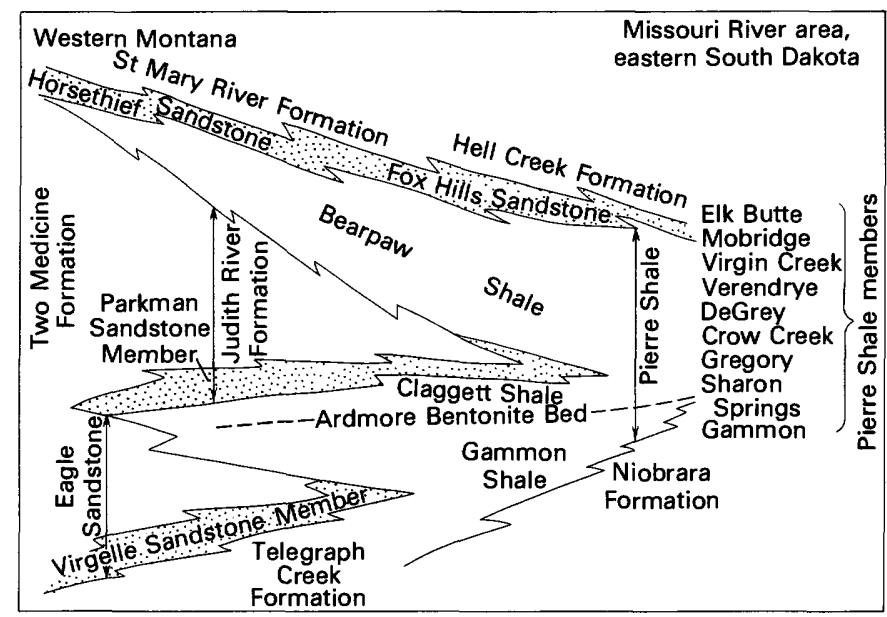

FIgURE 1.-Schematic cross section of the Pierre Shale and equiv. alent rocks, northern Great Plains Region. Marine sandstones are stippled, and rocks above and to the left of them are nonmarine, whereas rocks below and to the right are marine shale. Not to scale. 
time span (Gill and Cobban, 1973). The fossil zones also make it possible to recognize the effects across the basin of three major marine transgressions and regressions during Pierre time that are indicated on plate 1 by westward extension of shale tongues overlain by eastward extensions of tongues of marine sandstone. These marine sandstone tongues are commonly underlain by transition zones of marine siltstones that are several tens to more than $100 \mathrm{ft}$ thick. Nonmarine and brackish-water deposits, of course, extended farthest east during the marine regressions and overlie the marine sandstones.

The earliest of three major marine regressions is the Telegraph Creek-Eagle regression in the time of fossilzone 1 (pl. 1). In the west the mostly marine Virgelle Sandstone Member and any overlying nonmarine and brackish deposits are collectively referred to as the Eagle Sandstone. Transitional silty beds below are exceptionally thick and are called the Telegraph Creek Formation. These rocks grade eastward into the Gammon Shale and still farther east into marl of the Niobrara Formation. An east-west gradation also occurs within the Niobrara Formation, with interbedded shale, calcareous shale, and minor marl in the west grading eastward into chalk in areas along the Missouri River.

The Claggett transgression during the time of fossil zone 2 was marked by deepening and expansion of the sea in which fine-grained shale, like the Claggett Shale, was deposited as much as $200 \mathrm{mi}$ west of similar deposits in fossil zone 1 . In the eastern part of the area, a remarkable organic-rich unit, the Sharon Springs Member, was deposited. It weathers to a distinctive, bare, buttresslike outcrop and commonly has one or more bentonite beds near its base (frontispiece). The bentonite beds and any shale partings are most commonly known as the Ardmore Bentonite Bed, but locally have been given other names such as the Pedro Bentonite (Rubey, 1930), which is herein abandoned in favor of Ardmore. Also, the Ardmore is modified to Ardmore Bentonite Beds, because almost everywhere more than one bed is included (frontispiece). The Ardmore can be recognized far beyond the areal limits of the Sharon Springs Member of the Pierre in marine rock throughout the area of study where it is assigned to other formations. Thus these bentonites are a useful time marker at the base of fossil zone 2 even where fossils are absent. The upper part of fossil zone 2 commonly is not nearly so organic rich, and around the Black Hills where it is thick it is called the Mitten Member.

The middle marine regression, called the Judith River regression, occurred during the time of fossil zone 3 , and it is remarkable for the seeming rapidity and extent with which the effects of shallowing extended across the basin. The nearshore-marine Parkman Sandstone extends about $200 \mathrm{mi}$ into the basin, and a silty phase in the Black Hills area, the Red Bird Silty Member of the Pierre, is recognized an additional $200 \mathrm{mi}$ to the east (pl. 1). The Missouri River area was so far from the western source, even during this marine regression, that coarse clastic material did not reach there; shallowing is evidenced by lenticular marl beds interbedded with shale in the Gregory Member. In southeasternmost South Dakota, deposition apparently was extremely slow during the time of fossil zones 2 and 3 , and periodically it probably ceased altogether. In the Wheeler bridge area (pl. 1, loc. 24) deposition of organic-rich shale similar to that of the Sharon Springs Member of the Pierre apparently persisted from the time of fossil zone 2 into the time of fossil zone 3 . Behind the eastward-advancing nearshore sandstone, the nonmarine rocks of the Judith River Formation extended as far as northeastern Wyoming and east-central Montana (pl. 1, locs. 10, 13, and 14). In western Montana the volcanic-rich nonmarine equivalents are assigned to the Two Medicine Formation, which includes rocks considerably older and younger than those on fossil zone 3. Particularly volcanic-rich sediments equivalent to the Two Medicine Formation are locally called the Livingston Group (pl. 1, loc. 1), containing several formations.

The Bearpaw transgression during the time of fossil zones 4 and 5 widened the Pierre sea to its maximum extent, especially in northern and central Montana. In the east, deposition of fine-grained shale was fairly rapid, and the considerable variety in the types of shale deposited form the basis for distinguishing several members of the Pierre Shale in the Missouri River area, such as the Virgin Creek, Verendrye, and DeGrey Members (pl. 1, fig. 1). Though generally a time of a wide sea and deep water, in the southeastern area (locs. 22-25) water shallowing due to local uplift (Crandell, 1952) caused slight erosion of sea-bottom sediments followed by deposition in the Crow Creek Member of some locally derived (eastern) sandy material and carbonate sediment. Several thin carbonate beds above the Crow Creek Member also reflect continued local shallow-water conditions (pl. 1).

The third and final major regression of the Pierre sea, called the Fox Hills regression, extended over a remarkably long time span, with the western shoreline oscillating back and forth but generally moving from western areas in the time of the lower part of fossil zone 5 to the Missouri River area in the time of the upper part of fossil zone 6 . In the east, effects of the shallowing were first indicated by carbonate deposition in the Mobridge Member of the Pierre. The 
amount of carbonate increases progressively from slightly calcareous shale interbedded with noncalcareous shale in the north (locs. 19 and 20) to a thick marl on the southeast (locs. 25-26). The Elk Butte Member of the Pierre represents a temporary deepening of the seawater in eastern South Dakota (pl. 1, locs. 19-26) at about the time of the upper Lewis transgressive tongue of the Salt Creek area (loc. 10). In the Missouri River area, the nearshore marine rocks of the Fox Hills Sandstone are fairly fine-grained, mostly argillaceous siltstone, but farther west, massive sandstone characterizes the nearshore marine deposits of the Fox Hills and equivalent formations like the Lennep and Horsethief Sandstones. These marine units are followed by nonmarine sediments of the St. Mary River, Hell Creek, and Lance Formations.

\section{SAMPLING}

\section{METHODS}

Two types of samples taken are referred to as analytical and nonanalytical. Both types, 226 analytical and 1,123 nonanalytical, received standard mineralogical analysis, mainly by X-ray diffraction techniques. Analytical samples, in addition, were chemically analyzed for major and trace elements (table 1). Samples were collected in 1956, 1957, and 1961. The 1956 analytical samples formed the basis for a preliminary report of the Pierre Shale (Tourtelot, 1962), and 13 of these, bearing identification numbers C871 to C891, are also included in this report. The 69 analytical samples collected in 1957, bearing sample numbers 259526 to 259595 , came from the Missouri River area in South Dakota and Nebraska and from around the Black Hills. The 144 analytical samples collected in 1961, bearing numbers 159709 to 159858 , came from the western areas. Land-survey locations of analytical samples are in table 2. Nonanalytical samples are not listed separately, but their approximate geographic and stratigraphic locations, together with those of the analytical samples, are shown on plate 1.

Sections to be sampled were first measured by hand level or plane table and separated into lithologic units. Field designations of lithology are the principal basis for lithologic grouping of samples. Analytical samples, weighing about 10 pounds (lb), were taken from the least weathered outcrops in the thickest shale or siltstone units, and each sample represents 1 to $3 \mathrm{ft}$ of rock. Nonanalytical samples, weighing about $0.5 \mathrm{lb}$, came from other parts of thick units, from thin units, and from sandstone beds. Few analytical samples of sandstone were taken, as this is primarily a study of shale, but siltstone is well represented. The best outcrops were usually in stream banks or roadcuts, but reasonably fresh-looking material usually could be sampled by digging into other outcrops a foot or two. In some areas where nonanalytical samples were desired, however, any available outcrops were sampled, regardless of apparent quality, usually with a 5 -ft soil auger.

Sections are grouped for statistical purposes into 28 localities, most of which represent the entire thickness of the Pierre Shale or equivalents (pl. 1). A few localities, such as Dearborn River (loc. 2), Mosby (loc. 14), and Red Bird (loc. 16), are essentially continuous and complete sections. Most localities are composites of sections within 5 or $10 \mathrm{mi}$ of each other, but a few localities extend over more than $50 \mathrm{mi}$, as around the Black Hills (locs. 17 and 18). One locality (19) and parts of two others (locs. 22 and 23) are drill cores.

The number of samples from each locality varies considerably, depending upon the variety of rock types present and the outcrops available. Generally, about 40 to 50 samples were taken within each locality, about one-fifth of which were analytical. In the western areas the sampling interval averaged about $50 \mathrm{ft}$. In the much thinner eastern sections, the sampling interval averaged 10 to $20 \mathrm{ft}$, and where lithology varied over short stratigraphic distances the sampling was on intervals of only a few feet. In this latter case, relatively few analytical samples were taken to avoid biasing the mean chemical composition of the shales with rock masses of insignificant volume.

When analytical samples were taken, a representative piece was wrapped in aluminum foil to slow the air-drying process and minimize breakup (Tourtelot, 1961). Such pieces were used for procedures requiring undisturbed material, like thin sectioning and density determination. The remainder was ground to 100 mesh and separated by a Jones splitter into portions for chemical analysis, X-ray analysis, and determination on some samples of $\mathrm{pH}$ and Atterberg limits. For nonanalytical samples, a small representative piece was picked out and hand ground to less than $5 \mu \mathrm{m}$ (micrometers) for X-ray analysis. Analytical samples were similarly hand ground for X-ray analysis.

\section{TYPES OF SHALE AND OTHER ROGK IN THE PIERRE SHALE AND EQUIVALENTS}

Shale is generally defined as a fine-grained detrital sedimentary rock consisting largely of clay minerals, though other constituents, such as quartz or calcite of diagenetic or biogenic origin, may also be present (American Geological Institute, 1972). Although fissility is emphasized in most definitions of shale, the 
term "shale" often is used imprecisely for any clayey fine-grained sedimentary rock or for stratigraphic units composed mostly of such rock (see, for example, Tourtelot, 1960).

The Pierre Shale in South Dakota, where the unit was originally described, consists only partly of fissile, fine-grained, clayey rock that is properly called shale by almost any definition. Much of the formation consists of claystone having little fissility. In addition, the present study includes many other stratigraphically equivalent rocks, such as sandstone, siltstone, and nonmarine fine-grained claystone. For simplicity, in this report the term "shale" has no implication of fissility and applies equally to clayey marine and nonmarine rocks. Also, in most parts of the text and in all tables of this report, the term "siltstone" refers to the coarser grained rocks as a group, including both siltstone and sandstone, in contrast with the finer grained group of rocks referred to as "shale." "Siltstone" is adopted as the general term because siltstone is more prevalent than sandstone in the Pierre Shale and its equivalents.

Samples were classified in the field into several principal types of shale to compare rocks throughout the area.

Organic-rich marine shale is very dark gray to black and weathers to very thin, tough plates, commonly with abundant fish-scale impressions on the bedding planes. The characteristic toughness is imparted by plates of organic matter (fig. 2), and, because of the toughness, such shale weathers to buttresslike outcrops. In the marine parts of the Pierre Shale, organicrich shale occurs almost exclusively in fossil zone 2 in the Sharon Springs Member and in the stratigraphically equivalent Pembina Member of North Dakota

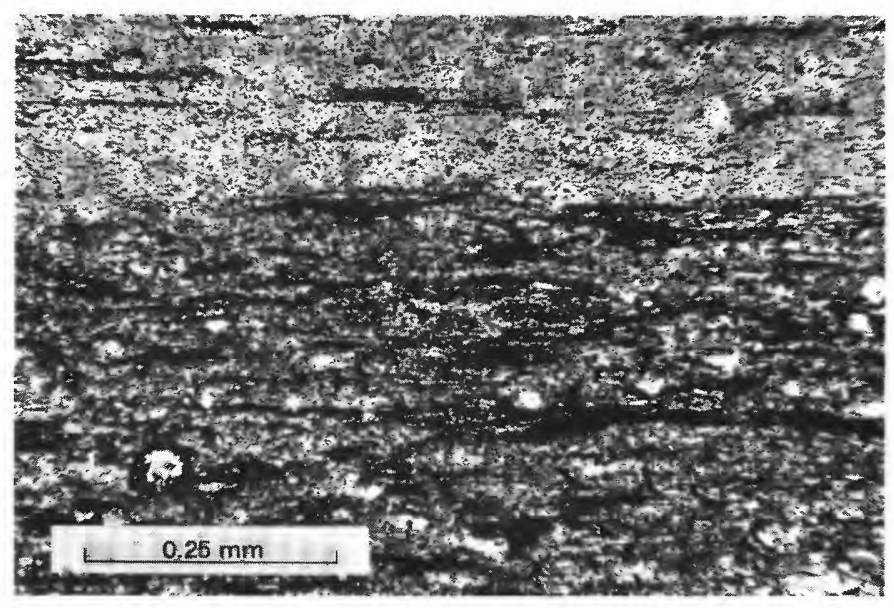

FIGURE 2.-Platelets of organic matter (dark) in organic-rich shale from the Sharon Springs Member of the Pierre Shale, sample 259582, locality 16. Plain light.

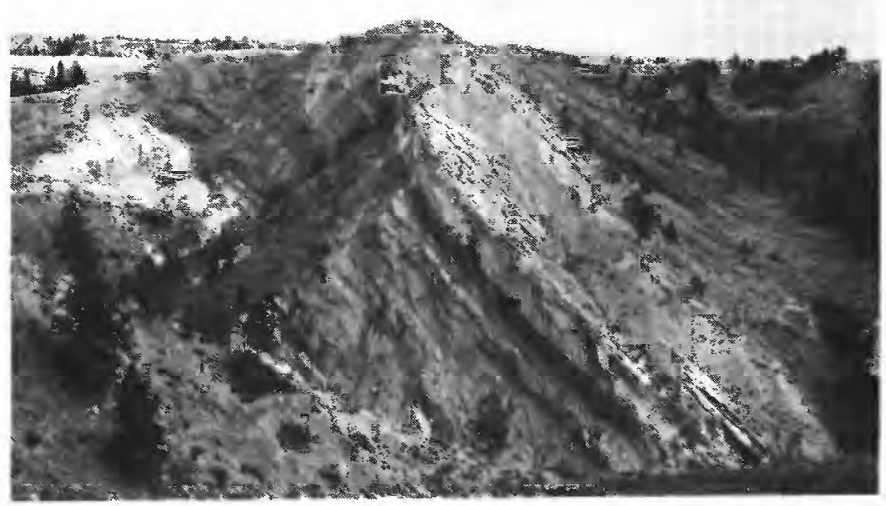

FIGURE 3.-Eagle Sandstone near the mouth of the Judith River, locality 9 , with dark coaly beds in middle and upper part and the white Virgelle Sandstone Member at its base. The Telegraph Creek Formation is below, to the left, and the Claggett Shale is above, in the tree-covered slopes to the right.

(loc. 28, pl. 1), but in southeastern South Dakota it apparently also occurs in fossil zone 3 in rocks equivalent to the Gregory Member (loc. 24, pl. 1).

Nonmarine equivalents of the Pierre Shale also contain highly organic-rich rocks. Such rocks, however, do not have the toughness characteristic of the shale in the Sharon Springs Member; instead they are coaly and form dark bands in otherwise generally light colored nonmarine rocks (fig. 3). Where they occur very close to obviously marine rocks, such coaly shales probably are brackish-water deposits.

Siliceous shale is found in the Pierre Shale only in the DeGrey and Virgin Creek Members along the Missouri River in South Dakota. The shale weathers to unusually hard, brittle, light-gray chips (fig. $4 A$ ). The most siliceous shale is found in the northern part of the Missouri River area (locs. 20 and 21). Here it makes up all but the upper few feet of the DeGrey Member and the lower half of the Virgin Creek Member. Southward the siliceous shale of the DeGrey becomes interbedded with bentonitic or frothy-weathering shale (fig. $4 B$ ), and frothy-weathering shale makes up the entire DeGrey Member southeast of Chamberlain (loc. 23). The siliceous character of the lower part of the Virgin Creek Member persists throughout the Missouri River area, at some places more than $50 \mathrm{mi}$ west of the river, though it is less well developed to the south.

Frothy-weathering shale in the Pierre contains highly expansible clay that weathers to a distinctive loose frothy popcornlike surface (fig. $4 B$ ). Along the Missouri River, frothy-weathering shale makes up most of the upper part of the Virgin Creek Member, the lowermost part of the Verendrye Member, those parts of the DeGrey Member that are not siliceous shale, and the part of the Gregory Member above the 


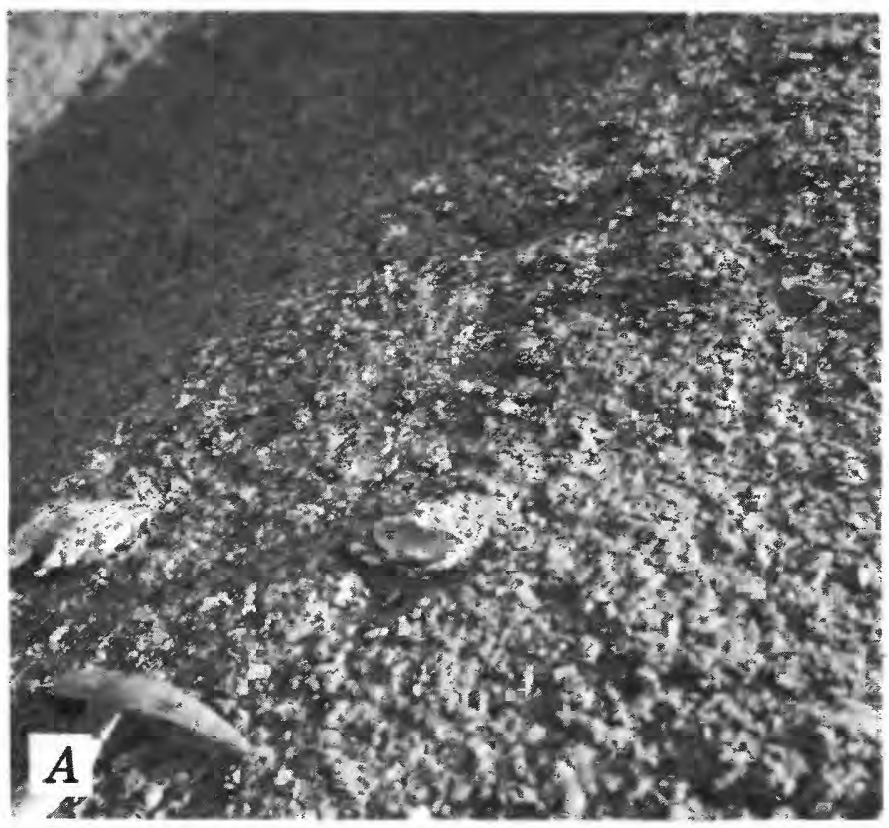

Figure 4.-Types of weathering in the Pierre Shale. $A$, Angular chips of siliceous shale in lower part of the Virgin Creek Member, 1 mi south of Promise, S. Dak., locality 21; nodules are of gypsumencrusted apatite. $B$, Popcorn-weathered surface (lower left) of frothy-weathering shale in the lower part of the Verendrye Member, $0.5 \mathrm{mi}$ southwest of Ft. Pierre, S. Dak., locality 22; banded outcrop in middle ground is of light siliceous shale interbedded with darker frothy-weathering shale in the DeGrey Member; Bad River in background. $C$, Cracked weathering surface of ordinary shale in the middle of the Verendrye Member, same locality as $B$; disintegrated nodule is of siderite.

marl beds. In the Black Hills area, the Monument Hill and Kara Bentonitic Members are predominantly frothy weathering. Frothy-weathering shale is fairly common in marine and nonmarine rock of other areas, but it occurs so sporadically that it is not shown separately on plate 1 . Also not shown on plate 1 because of scale are the few feet of frothy-weathering shale that characteristically grade upward from bentonite beds into ordinary shale.

The great bulk of the shale in the Pierre is neither organic rich, siliceous, conspicuously frothy weathered nor conspicuously fissile. This ordinary shale is medium to dark gray, soft, and weathers to form a cracked surface (fig. $4 \mathrm{C}$ ) suggestive of less swelling and shrinking than frothy-weathered shale (fig. $4 B$ ). Most of the shale from the western areas is of this ordinary variety, and along the Missouri River it makes up most of the Elk Butte and Verendrye Members, the lower part of the Gregory Member that is not marl, and in places the upper part of the Sharon Springs Member. Ordinary shale is not silty in the eastern area, but generally is silty in the central area, and almost invariably is silty in the western area. Thus, shales from
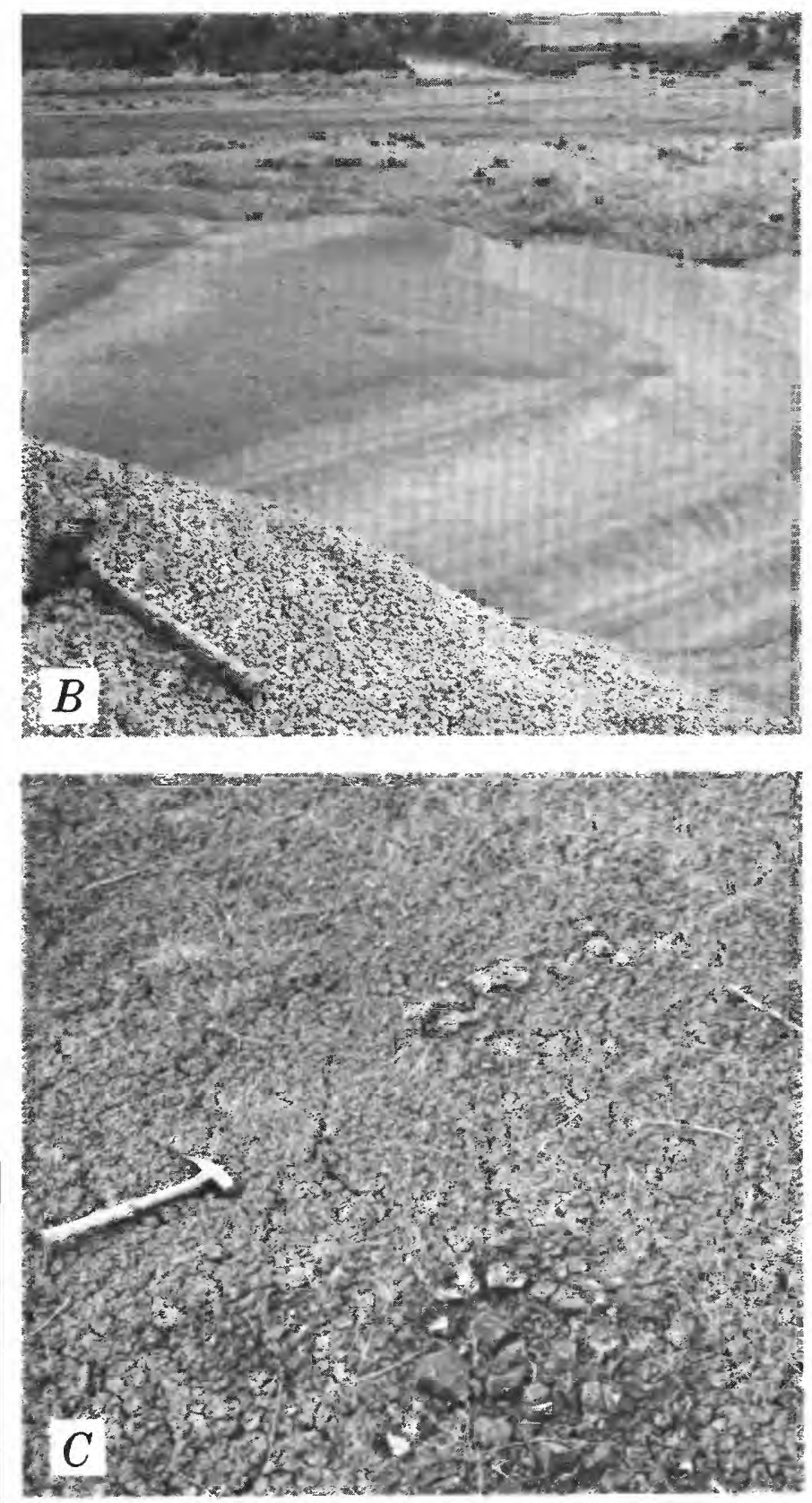

eastern and western areas are not exactly comparable because of their inherently different grain size.

Many Pierre-equivalent sedimentary rocks are volcanic rich. Volcanic material was the precursor of much detrital material deposited throughout the basin, but the term "volcanic" is applied only where volcanic particles are identified in the rocks in the field. Thus, the term is applied mostly to coarsegrained rocks, though in areas such as Livingston and Dearborn River (locs. 1 and 2) where volcanic debris is abundantly conspicuous in the coarse parts of thick intimately interbedded, coarse- and fine-grained se- 
quences, the finer grained rocks are classified as volcanic-rich shale. Away from the volcanic source areas, volcanic content is identified mainly as sand-size clay-aggregate grains that are composed of highly smectitic clay seemingly altered from volcanic glass. Such material is commonly accompanied by abundant coarse biotite flakes and euhedral feldspar grains.

Other rock types, such as marl, bentonite, shale directly above bentonite, and rocks identified by their grain size such as siltstone or sandstone, also were considered in interpreting variation in mineral and chemical composition. Such rocks are discussed later as required.

\section{SUITABILITY OF OUTCROP SAMPLES- WEATHERING}

Investigations of shale throughout a region as large as the northern Great Plains must depend upon samples which, even with digging, are within the zone of weathering. The degree to which weathering has altered the mineralogy is investigated in this report by comparison in table 3 of three groups of unweathered core samples with more or less equivalent outcrop samples. The Irish Creek well (loc. 19) was cored through the entire thickness of the Pierre Shale and is roughly comparable with the 563 shale samples from all stratigraphic zones in the eastern area, most of which are outcrop samples. Construction work at Oahe Dam during field work for this study permitted a much more exact comparison between core samples and an equal number of outcrop samples that come from the same two fossil zones and within $5 \mathrm{mi}$ of the damsite. The third comparison, between organic-rich shale from the Sharon Springs Member, is considered separately because, as will be shown, such shale is more easily and extensively weathered than other parts of the Pierre Shale. The 10 Sharon Springs core samples include 5 from the Irish Creek well and 5 from cores at the Big Bend damsite (northern edge of loc. 23). All of the minerals making up the samples were considered, but only chlorite and pyrite (table 3 ) are appreciably sensitive to weathering.

The average amount of chlorite in the Irish Creek and Oahe core samples (samples having no detected chlorite excluded from the average) is only 0.6 percent more than in equivalent outcrop samples; but, as the amount of chlorite in many samples is near the detection limit of about 1 percent, even a small decrease in the amount or crystallinity of chlorite causes a marked increase in the number of samples in which chlorite is not detected. Thus, excluding the Sharon Springs samples, chlorite was detected in more than ninetenths of the core samples but in only about two-thirds to three-fourths of the outcrop samples. The sparser chlorite content of outcrop samples is presumably due to weathering. Absence of chlorite in the great majority of Sharon Springs outcrops (table 3 ) indicates much more severe weathering, which, as will be seen, is related to oxidation of pyrite.

Pyrite is abundant only in the organic-rich shale of the Sharon Springs Member. In other fresh shale from cores, pyrite was detected in 30 to 45 percent of the samples (table 3). Detection of pyrite in only 13 percent of the outcrop samples from the eastern area and in no outcrop samples from near Oahe Dam shows that most of the pyrite in outcropping Pierre Shale has been oxidized. The average 7.6 percent pyrite in 80 percent of

TABLE 3.-Effects of weathering on chlorite and pyrite in outcrop samples of Pierre Shale

[Chlorite and pyrite analyses by X-ray methods]

\begin{tabular}{|c|c|c|c|c|c|c|}
\hline & \multicolumn{2}{|c|}{ Entire Pierre Shale } & \multicolumn{2}{|c|}{$\begin{array}{c}\text { Fossil zones 4-5 } \\
\text { loc. } 22\end{array}$} & \multicolumn{2}{|c|}{$\begin{array}{c}\text { Sharon Springs Member } \\
\text { locs. } 19-28 \\
\end{array}$} \\
\hline & $\begin{array}{l}\text { Irish } \\
\text { Creek } \\
\text { core }\end{array}$ & $\begin{array}{l}\text { Eastern } \\
\text { area } \\
\text { outcrop }\end{array}$ & $\begin{array}{l}\text { Oahe } \\
\text { cores }\end{array}$ & Outcrop & Cores & Outcrop \\
\hline 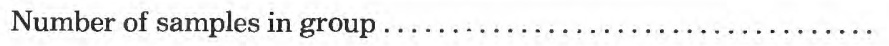 & 34 & 563 & 27 & 27 & 10 & 26 \\
\hline \multicolumn{7}{|c|}{ Chlorite } \\
\hline 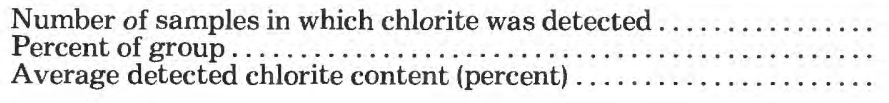 & $\begin{array}{l}31 \\
91 \\
4.0\end{array}$ & $\begin{array}{r}387 \\
69 \\
3.4\end{array}$ & $\begin{array}{l}26 \\
96 \\
2.8\end{array}$ & $\begin{array}{l}21 \\
77 \\
2.2\end{array}$ & $\begin{array}{c}8 \\
80 \\
3.2\end{array}$ & $\begin{array}{r}1 \\
4 \\
5.0\end{array}$ \\
\hline \multicolumn{7}{|c|}{ Pyrite } \\
\hline $\begin{array}{l}\text { Number of samples in which pyrite was detected } \ldots \ldots \ldots \ldots \ldots \ldots \ldots \\
\text { Percent of group } \ldots \ldots \ldots \ldots \ldots \ldots \ldots \ldots \ldots \ldots \\
\text { Average detected pyrite content (percent) } \ldots \ldots \ldots \ldots \ldots \ldots \ldots \ldots\end{array}$ & $\begin{array}{l}10 \\
30 \\
1.3\end{array}$ & $\begin{array}{r}72 \\
13 \\
2.5\end{array}$ & $\begin{array}{l}12 \\
45 \\
2.6\end{array}$ & $\begin{array}{l}0 \\
0 \\
-\end{array}$ & $\begin{array}{l}8 \\
80 \\
7.6\end{array}$ & $\begin{array}{r}5 \\
19 \\
9.2\end{array}$ \\
\hline
\end{tabular}


the core samples of the Sharon Springs Member (table 3 ) indicates a much larger amount of original pyrite than in other shale. Much pyrite has been oxidized in outcrop samples, because pyrite was detected in only 5 of the 26 outcrop samples. Three of these five samples are the chief basis for the 9.2 percent average pyrite and 5.0 percent average chlorite in outcrop samples of the Sharon Springs. These three samples come from a large roadcut only a few years old at the west end of the Missouri River bridge at Chamberlain (loc. 23). Two of the samples contain 15 and 25 percent pyrite respectively and one of them contains 5.0 percent chlorite. Even these amounts probably are smaller than those originally present, as it seems clear at the outcrop that pyrite is being oxidized. Sulfuric acid, formed from pyrite oxidation products, undoubtedly accounts for the leaching of nearly all the chlorite from most outcrop samples of the Sharon Springs Member. Gypsum and jarosite in outcrops also indicate the presence of pyrite before weathering.

Pyrite and chlorite are the only two mineral constituents discernibly affected by weathering of sampled outcrops, and these are minor constituents in most of the Pierre Shale. As will be seen in later parts of this report, the major and trace-element content, like the mineralogy, is also not much altered by weathering. However, Sharon Springs outcrops may be considerably altered by weathering and some physical properties of other rocks may be changed. Nevertheless, most constituents of most samples of even the most weathered outcrops sampled are representative of the fresh rock, so outcrop samples should be suitable for geochemical investigation. These conclusions are similar to those resulting from previous studies of weathering of the Pierre Shale in the northern Great Plains area by Tourtelot (1962, table 5, figs. 7 and 8 ) and studies of weathering of the Sharon Springs Member in its type area in western Kansas by Gill, Cobban, and Schultz (1972b, table 6).

\section{MINERALOGICAL COMPOSITION}

\section{METHODS OF ANALYSIS}

Thin sections of all analytical samples and of a few nonanalytical samples were examined by standard petrographic techniques. Photomicrographs illustrate some observed textural and mineralogical relations, primarily in the coarser grained rocks. In the finegrained rocks petrographic identification of most minerals was not possible.

Mineralogy was determined primarily from X-ray diffraction data, supplemented by chemical data for the analytical samples. Most of the methods used to estimate the abundance of minerals have been described previously (Schultz, 1964). Methods subsequently developed for estimation of proportions of illite-, beidellite-, and montmorillonite-type layers in mixed-layer illite-smectite are described separately (Schultz, 1978). The breakdown of mineralogy in table 1 and most other tabulations in this report is threefold. First, the proportions of illite-, beidellite-, and montmorillonite-type layers in the mixed-layer clay are given, and these proportions are scaled to a total of 100 percent. Second, proportions of the five common clay minerals are given, including the mixed-layer clay that is further described by the first breakdown; these five clay proportions also total 100 percent. Third, percentages of minerals in the whole rock are given, with the five clay minerals grouped together as total clay. The mineral percentages for the total sample are not normalized to 100 percent but are as determined from intensities of certain X-ray diffraction peaks (Schultz, 1964). Totals for individual samples are generally in the range of $95 \pm 10$ percent. Deviations probably represent mostly errors in quantitative estimations, but the general tendency towards totals slightly below 100 percent probably reflects small amounts of material amorphous to X-rays, like organic matter, and minerals present in amounts too small, generally 1-2 percent, to diffract a detectable X-ray pattern.

The two features of the expanding clays that are given in table 1 under "Codes for collapse and spacing characteristics of smectite" need additional explanation. Also, the means by which the properties of plagioclase were determined require some preliminary discussion.

HYDROXIDE OR CHLORITE INTERLAYERS-HEATED CODE, TABLE 1

The term "heated" in table 1 , under the heading "Codes for collapse and spacing characteristics of smectite," refers to the degree to which the expanding clay collapses when heated to $300^{\circ}$ or $550^{\circ} \mathrm{C}$ to give a nearly symmetrical X-ray reflection near $10 \mathrm{~A}$ (angstroms) similar to the dotted-line trace in figure $5 A$. Appreciable noncollapse is indicative of interlayer hydroxide sheets, usually either magnesium $(\mathrm{Mg})$ or aluminum (Al) hydroxide. Most samples of smectitic clay from the Pierre Shale collapsed completely when heated to $300^{\circ} \mathrm{C}$; this result is interpreted to mean that the clay contains no interlayer hydroxide sheets. Such clays are indicated in table 1 by heated-code 1 . The sequence of X-ray traces from figure $5 A$ to $5 E \mathrm{il}$ lustrates an increasing stability and frequency of the hydroxide sheets. If the hydroxide sheets are well enough developed so that they do not collapse when 
heated to $550^{\circ} \mathrm{C}$, then, together with an adjacent smectite layer, the combination can be considered as chlorite.

The most common type of noncollapse on heating is that shown in figure $5 A$, in which the hydroxide sheets prevent complete collapse at $300^{\circ} \mathrm{C}$, but the sheets are so imperfectly developed that they collapse at $550^{\circ} \mathrm{C}$. Such imperfectly developed interlayer hydroxide sheets are indicated by heated-code 2 in table 1 .

The interlayer hydroxide sheets illustrated in figure $5 B$, however, withstand heating to $550^{\circ} \mathrm{C}$, and, as explained above, can be considered together with an adjacent smectite layer as chlorite. The noncollapsing interlayers illustrated by figures $5 A$ and $5 B$ produced only an asymmetry of the peak near $10 \mathrm{~A}$, and the interlayers constitute only a minor part of the clay. The noncollapsing chlorite layers illustrated by figures $5 C$ and $5 D$ are major parts of the clay and cause shifting of the peak position from that of heated smectite to somewhere between 10 and $14 \mathrm{~A}$. In a few samples chlorite-type structures alternate regularly with an almost equal number of expanding smectite layers (fig. $5 C$ ); such interlayering gives a nearly rational sequence of basal orders with diagnostic superorders at 23.5- or 31.5-A $d$-spacings that are the sum of the approximately 14-A layer thickness of chlorite plus either the 10- or 17-A thickness of heated or glycolated smectite. More commonly (fig. $5 D$ ), dominant chlorite layers are randomly interlayered with smectite layers, producing a broad reflection between 12 and $13.5 \mathrm{~A}$ after $550^{\circ} \mathrm{C}$ heating. All such chlorite interlayering, regardless of its frequency (fig. $5 B-D$ ), is indicated in table 1 by heat code 3.

Rarely, the development of the interlayer hydroxide sheet is so complete that the X-ray pattern (fig. $5 E$ ) differs from one for ideal chlorite only by asymmetry of the 14-A reflection toward higher angles after $550^{\circ} \mathrm{C}$ heating and by the relative weakness of the second basal reflection at about $7 \mathrm{~A}$. Such material is recorded as chlorite, even though chlorite normally gives a 7-A reflection that is considerably stronger than its 14-A reflection. The best example of such chlorite in table 1 is sample 159777 from locality 6 .

Chloritic interlaying is not well represented in the samples in table 1 because it occurs mostly in sandstone, particularly volcanic-rich sandstone, and, as

Figure 5.-Effects of interlayer hydroxide sheets on the collapse of heated smectite from the Pierre Shale and equivalent rocks. Smoothed X-ray diffraction traces $(A-E)$ are solid line for material saturated with ethylene glycol, dashed for material heated to $300^{\circ} \mathrm{C}$, and dotted for material heated to $550^{\circ} \mathrm{C}$. Short vertical lines indicate ideal $d$-spacings of chlorite (C) and heated smectite (S). $\operatorname{CuK} \alpha$.

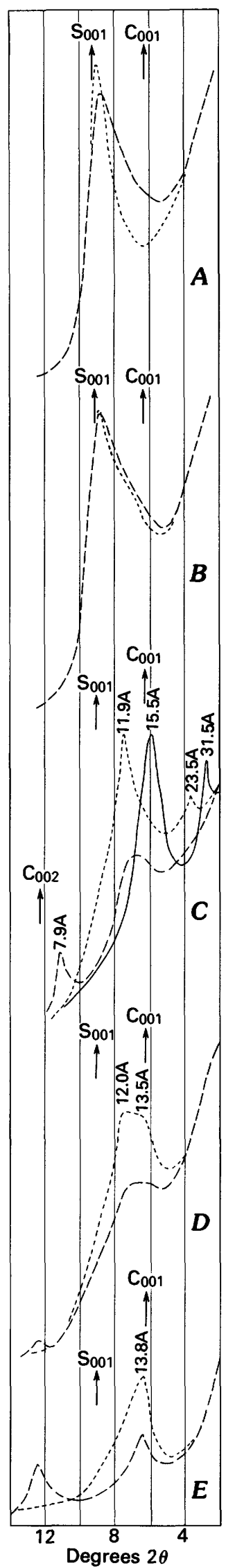


previously explained, sandstone is not well represented in the analytical samples. Clays used for the traces in figure $5 C-E$ are all from nonanalytical samples of sandstone in the upper part of the Dearborn River section (loc. 2).

Tests for solubility in warm $6 \mathrm{~N} \mathrm{HCl}$ were made on 21 samples containing large amounts of chlorite-interlayered clay such as those illustrated in figure $5 C-E$, as well as on 64 of the more common samples containing several percent of unmixed chlorite. Normal $\mathrm{Mg}-\mathrm{Fe}$ trioctahedral chlorite is soluble; insoluble chlorite is assumed to be an $\mathrm{Al}$ dioctahedral chlorite. All of the chlorite in the 64 samples and most of that in the 21 samples was soluble. Only three of the latter samples contained soluble chlorite. Thus, the solubility tests indicate that (1) the small amount of chlorite present in most samples is normal trioctahedral chlorite, and (2) the chloritelike interlayers of mixed-layer clay are more commonly Fe-Mg- than Al-rich types.

\section{EXCHANGEABLE CATIONS-AIR-DRIED CODE, TABLE 1}

The amount of water adsorbed between the layers of smectite and the resulting $d$-spacing is dependent on the exchangeable cation and the relative humidity (Grim, 1968, p. 80; Mooney, Keenan, and Wood in MacEwan, 1961, p. 171). At relative humidities between 20 and 40 percent, under which diffraction traces for this study were made, $\mathrm{Na}^{+}$smectite imbibes one water layer and gives a $d$-spacing of about $12.5 \mathrm{~A}$, indicated by air-dried code 1 , in table 1 under the heading "Codes for collapse and spacing characteristics of smectite." Smectite with $\mathrm{Ca}^{+2}$ as the dominant exchangeable cation imbibes two water layers and gives a 15.5-A $d$-spacing, indicated by air-dried code 2. A 1.5 code indicates an intermediate $d$-spacing and probably a mixture of exchangeable $\mathrm{Na}^{+}$and $\mathrm{Ca}^{+2}$.

\section{ANORTHITE CONTENT OF PLAGIOCLASE}

Plagioclase comprises a solid-solution series of albite $\left(\mathrm{NaAlSi}_{3} \mathrm{O}_{8}\right)$ and anorthite $\left(\mathrm{CaAl}_{2} \mathrm{Si}_{2} \mathrm{O}_{8}\right)$ in which the composition customarily is expressed by the proportion of anorthite (An). Thus, plagioclase containing $\mathrm{An}_{30}$ is composed of 30 percent $\mathrm{CaAl}_{2} \mathrm{Si}_{2} \mathrm{O}_{8}$ and the complementary 70 percent $\mathrm{NaAlSi}_{3} \mathrm{O}_{8}$ is understood.

Optical properties, given in many standard texts, and the X-ray pattern of plagioclase of different compositions are distinctive (Smith, 1956; Smith and Yoder, 1956). If plagioclase makes up about 5 percent or more of samples from the Pierre Shale or equivalents, the anorthite content usually can be interpreted from the X-ray powder pattern; anorthite in table 1 and most other tables is so determined. If plagioclase is too sparse for anorthite determination from a whole sample, it frequently can be determined from an X-ray trace of the coarser grained material that settles first from the clay-water slurry used to prepare oriented clay aggregates. Such X-ray-determined values of anorthite are correct, however, only if the plagioclase is a low-temperature form. If it is a high-temperature or intermediate form, then anorthite cannot be correctly determined by X-ray, and values determined from the $d$-spacing curves for low-temperature plagioclase will be systematically too high. Optically, however, high- and low-temperature plagioclase differ very little. The anorthite content determined by the X-ray method was checked optically on 20 samples of different plagioclase composition that were concentrated from the Pierre Shale by size and density fractionation. Good agreement between optical and X-ray determinations for all but one bentonite sample shows that the low-temperature X-ray parameters used are appropriate for most of the Pierre Shale.

Three considerations led to a further optical investigation of all 11 of the 21 analytical samples of bentonite for which the anorthite content was determined (table 1): (1) the discrepancy of optical and X-ray values for anorthite content of plagioclase in the bentonite included in the original group of 20 samples; (2) differences, described in the section on "Bentonites," in the appearance of plagioclase in thin sections of bentonite and of other types of rock; and (3) rapid quenching implicit in the explosive-eolian origin of bentonite, which might be expected to preserve hightemperature minerals. The optical and X-ray determinations are compared in table 4. Optical determinations, with one exception, vary little; for all but the one sample, an oil of 1.556 refractive index is between the $Y$ and $Z$ indices of the plagioclase, and the indicated anorthite content is 40 to $\mathbf{4 5}$ percent. In eight samples

TABLE 4.-Anorthite content, in percent, of plagioclase from bentonite as determined by $X$-ray methods and optically by index of refraction, Pierre Shale and equivalent rocks

\begin{tabular}{lccc}
\hline Sample No. & Locality No. & X-ray & Optical \\
\hline 159846 & 3 & 40 & 40 \\
159765 & 7 & 60 & 45 \\
159769 & 7 & 50 & 45 \\
159770 & 7 & 50 & 45 \\
159789 & 8 & 40 & 45 \\
159752 & 14 & 45 & 40 \\
159758 & 14 & 50 & 45 \\
159740 & 15 & 50 & 40 \\
259567 & 18 & 20 & 30 \\
259544 & 22 & 50 & 45 \\
259554 & 22 & 55 & 40 \\
\hline
\end{tabular}


the optical determinations are 5 to 15 percent below the X-ray determinations, which indicates that most plagioclase in bentonite is not low temperature and that the anorthite content given for plagioclase in bentonite in other tables of this report tends to be too high.

\section{COMPOSITION}

\section{PIERRE SHALE AND EQUIVALENTS-THE WHOLE UNIT}

The mineralogical composition of most of the Pierre Shale and equivalent rocks is fairly simple, and most of the major components are uniformly distributed (table 5). Distribution around the mean is indicated by the standard deviation for major mineral components, by minimum and maximum values, and by percentiles. Clay minerals and quartz are predominant in virtually all samples, and plagioclase was detected in 85 percent of the samples. Clay minerals make up the bulk of most samples, but in a few, quartz, feldspars, calcite, or zeolites may be dominant. For minerals detected in less than half of the samples, the percent of samples in which the mineral was detected is given in brackets in the standard deviation column, rather than the deviation. It is deemed more meaningful that cristobalite, for example, occurs in 6 percent of the 1,220 samples and, by calculation $(1.1 \div 0.06=18.3)$, averages about 18 percent in the 73 samples in which it was detected, than that the standard deviation about the 1.1-percentcristobalite mean for all 1,220 samples is 5.3 percent. Potassium feldspar commonly is about one-fifth as abundant as plagioclase and, accordingly, was detected in relatively few samples. Calcite occurs in about one-fourth of the samples, mostly in small amounts, but in one-tenth of the samples it is abundant enough so that the samples have been classified as marl. Dolomite occurs in about one-third of the samples, commonly in amounts of several percent but rarely as much as 40 percent. Gypsum, jarosite, pyrite, and zeolites were detected commonly in small amounts and only in a few samples. Siderite and augite were detected even more sporadically. Several other minerals, like apatite and zircon, were detected by special separations or microscopic techniques but not by routine X-ray analysis. As will be shown, most of the minerals that occur sporadically do so in certain types of rock.

Mixed-layer clay is the dominant type of clay in most samples of Pierre Shale (table 5). As summarized in figure 6 , proportions of montmorillonite and illite layers vary widely and are generally complementary, whereas the proportion of beidellite layers is relatively constant at about $35 \pm 10$ percent. Mixed-layer clay having more than about 60 to 65 percent illite layers
TABLE 5.-Average mineralogical composition of 1220 samples of the Pierre Shale and equivalent rocks.

[Where mineral was found in less than 50 percent of samples, the percentage of samples where found is shown in brackets. Samples include shale, siltstone, and marl but not bentonite. $>$, greater than]

\begin{tabular}{|c|c|c|c|c|c|c|c|c|c|}
\hline \multirow{2}{*}{$\begin{array}{c}\text { Arithmetic } \\
\text { mean }\end{array}$} & \multirow{2}{*}{$\begin{array}{l}\text { Standard } \\
\text { deviation }\end{array}$} & \multirow{2}{*}{$\underset{\text { detected }}{\text { Minimum }}$} & \multicolumn{5}{|c|}{ Percentile } & \multirow{2}{*}{$\underset{\text { detected }}{\text { Maximum }}$} & \multirow{2}{*}{$\begin{array}{l}\text { Ratio } \\
P_{95} / P_{5}\end{array}$} \\
\hline & & & $\mathrm{P}_{5} \overline{\mathrm{H}}$ & 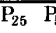 & $\overline{P_{50}} 1$ & $\overline{P_{75} 1}$ & $\overline{\mathrm{P}}_{95}$ & & \\
\hline \multicolumn{10}{|c|}{ Proportion of layers in mixed-layer clay (percent) } \\
\hline Illite ..... & 17 & 0 & 10 & 30 & 45 & 55 & 65 & 80 & \\
\hline Beidellite .......... 35 & 9 & 5 & 20 & 30 & 35 & 40 & 50 & 80 & 2.5 \\
\hline Montmorillonite ...223 & 17 & 0 & 0 & 10 & 20 & 30 & 60 & 90 & $>60$ \\
\hline \multicolumn{10}{|c|}{ Proportion of clay minerals in total clay (percent) } \\
\hline Mixed layer. & 34 & 0 & 37 & 61 & 74 & 83 & 98 & 100 & \\
\hline Illite ......... & 9 & 0 & 0 & 11 & 16 & 22 & 33 & 53 & $>33$ \\
\hline Chlorite.. & 6 & 0 & 0 & 0 & 2 & 4 & 9 & 100 & $>9$ \\
\hline Kaolinite .... & 13 & 0 & 0 & 2 & 5 & 10 & 41 & 90 & $>41$ \\
\hline \multicolumn{10}{|c|}{ Proportion of minerals in total sample (percent) } \\
\hline Total clay . & 20 & 5 & 15 & 40 & 60 & 70 & 80 & 90 & 5.3 \\
\hline Quartz ... & 13 & 0 & 7 & 16 & 22 & 30 & 50 & 90 & 7.1 \\
\hline Cristobalite ......... & [6] & 0 & 0 & 0 & 0 & 0 & 5 & 40 & $>5$ \\
\hline Potassium feldspar. 1.1 & [42] & 0 & 0 & 0 & 0 & 1 & 5 & 20 & $>5$ \\
\hline Plagioclase ........ & 7 & 0 & 0 & 1 & 4 & 9 & 20 & 45 & $>20$ \\
\hline Calcite ....... & [28] & 0 & 0 & 0 & 0 & 2 & 35 & 90 & $>35$ \\
\hline Dolomite . & {$[36]$} & 0 & 0 & 0 & 0 & 6 & 20 & 40 & $>20$ \\
\hline Siderite $\ldots \ldots \ldots \ldots \ldots, 0.1$ & [1] & 0 & 0 & 0 & 0 & 0 & 0 & 25 & (1) \\
\hline Gypsum & [9] & 0 & 0 & 0 & 0 & 0 & 2 & 40 & $>2$ \\
\hline Jarosite. & [3] & 0 & 0 & 0 & 0 & 0 & 0 & 18 & $(1)$ \\
\hline 0.2 & {$[6]$} & 0 & 0 & 0 & 0 & 0 & 1 & 25 & $>1$ \\
\hline Zeolite $\ldots \ldots \ldots \ldots \ldots, 0.6$ & [10] & 0 & 0 & 0 & 0 & 0 & 3 & 70 & $>3$ \\
\hline
\end{tabular}

${ }^{1}$ Indeterminate.

has an IS-ordered interlayering (Schultz, 1978, p. 11) and was found in this study only at the Dearborn River locality (loc. 2). Mixed-layer clay from all other localities is randomly interlayered. Smectite having no interlayering of illite-type layers, with few exceptions, occurs only in bentonite. Illite as a separate mineral, showing no appreciable mixed layering, commonly makes up 10 to 25 percent of the clay minerals, kaolin-

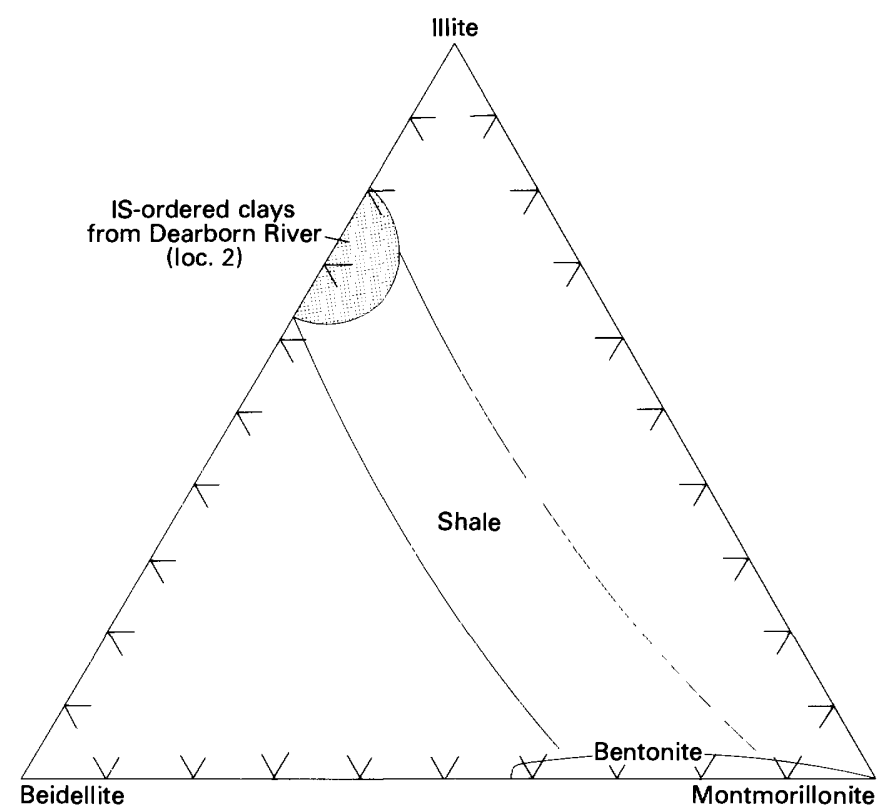

FIgURE 6.-Types of layers in mixed-layer clay of the Pierre Shale and equivalent rocks. Chlorite interlayers, present in a few samples (fig. 5), are not shown. Summarized from Schultz (1978, fig. 9). 
ite commonly makes up a few percent to 10 percent, and chlorite rarely makes up more than a few percent. Chlorite was detected in 61 percent of the samples, whereas other clay minerals were rarely absent. As mentioned previously, absence of chlorite in some samples is due to weathering of outcrops.

\section{ENVIRONMENT OF DEPOSITION}

Variation in mineralogy of sediments from different environments of deposition in the Pierre Shale and its equivalents is shown in figure 7. Also, though table 6 pertains mainly to rock type, much of these data are closely related to the same environmental factors in figure 7. For example, the 836 marine and 268 nonmarine shale and siltstone samples in the 1st and 13th columns of table 6 are the same samples from which the cumulative curves of figure 7 were derived, and the marine siltstone samples in columns 4 and 5 of table 6 make up most of the 340 nearshore marine samples of figure 7. For the cumulative curves of figure 7, nearshore- and offshore-marine samples are grouped together as marine, and the freshwater and brackishwater samples are grouped as nonmarine. Differences between the four individual environmental classifications (F, B, N, and O, fig. 9) are shown by their mean values plotted above the cumulative curves. The arrangement of curves for minerals in figure 7 is similar to their sequence on all of the tables, except that cristobalite, gypsum, jarosite, pyrite, and zeolite are grouped on the lower line of figure 7 because the percentages above the curves for the four environments are percentages of samples in which the mineral was found rather than mean content in all samples, as is the case for all the other more common minerals. Also, the arrangement of minerals is not necessarily the order in which they are discussed.

The range of content of total clay is similar in nonmarine and marine rocks, from 5 to 85 and 90 percent, respectively (fig. 9). However, the average clay content of the marine rock is about 10 percent more than for the nonmarine rock, and the difference is mainly in the shale (table 6). Within the marine samples, claymineral content of the nearshore rock is about 40 percent, compared to the overall mean of 58 percent (table 6 ) and to the 70 percent mean for offshore-marine samples. The total clay-mineral contents of freshwater and brackish-water sediment differ only slightly from the overall mean of 46 percent for nonmarine rock (table 6).

The distribution of quartz and the feldspars is generally opposite to that of the clay. The amount of quartz in nearshore-marine samples is nearly double the 15 to 25 percent in most offshore-marine shale, but the mean of quartz in all marine samples is only slightly less than the mean in all nonmarine rock (table 6). Much of the quartz in offshore-marine shale is so fine grained that it cannot be resolved under the microscope from the dominant mass of clay minerals, and in size fractionation most quartz persists in sizes smaller than $1 \mu \mathrm{m}$ and some even in sizes smaller than $0.25 \mu \mathrm{m}$. Distribution of potassium feldspar is much like that of quartz, though in much smaller amounts. Plagioclase distribution differs from these in that it is considerably more abundant in nonmarine than in either nearshoreor offshore-marine rock.

The calcite distribution shown in figure 7 does not include marine marl. The offshore-marine shale contains little or no calcite, but a few of the coarser nearshoremarine samples contain appreciable amounts. Calcite distribution in nonmarine rocks is similarly uneven, but with little difference between the brackish-water and freshwater facies.

Dolomite distribution, although generally similar to that of calcite, is still more uneven. In marine rocks dolomite occurs almost exclusively in the nearshore facies, where it is present in most samples, commonly in amounts of about 10 percent but as much as 40 percent. The dolomite frequently occurs in euhedral grains (fig. 8) similar to the primary dolomite described by Sabins (1962)-primary in that it formed on the sea bottom near the site of deposition and before burial. The surprising aspect of dolomite distribution in the Pierre Shale and equivalents is its occurrence in about a quarter of the nonmarine rocks in grains similar to those in nearshore-marine rocks (fig. 9), which indicates either that dolomite may also form diagenetically under nonmarine conditions or that the dolomite is detrital. Because dolomite is so soft, the sharp unrounded corners of some of the dolomite grains in figure 9 indicate that at least part of them are not detrital.

Cristobalite was found only in offshore marine shale-as will be shown, almost exclusively in siliceous shale.

Pyrite, usually in small amounts, was found only in marine rocks, most commonly in offshore-marine facies. Gypsum and jarosite derived from weathering of pyrite have a similar distribution.

Zeolites, including clinoptilolite, heulandite, and laumontite, were recognized in about one-tenth of the freshwater and offshore-marine samples, but in few nearshore-marine and in no brackish-water samples.

Mixed-layer clay makes up an average of about 70 percent of the clay minerals in both marine and nonmarine rocks. The proportion of mixed-layer clay is less uniform in the nonmarine rock, however, and in about 12 percent of the nonmarine rock it is the only 

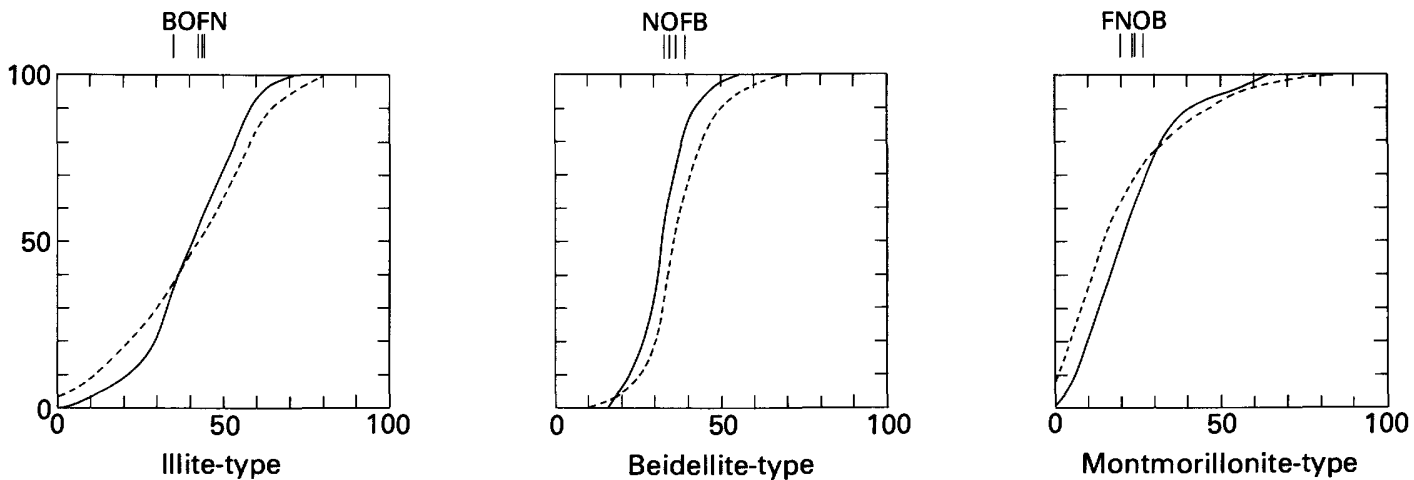

LAYERS AS PERCENT OF MIXED-LAYER CLAY
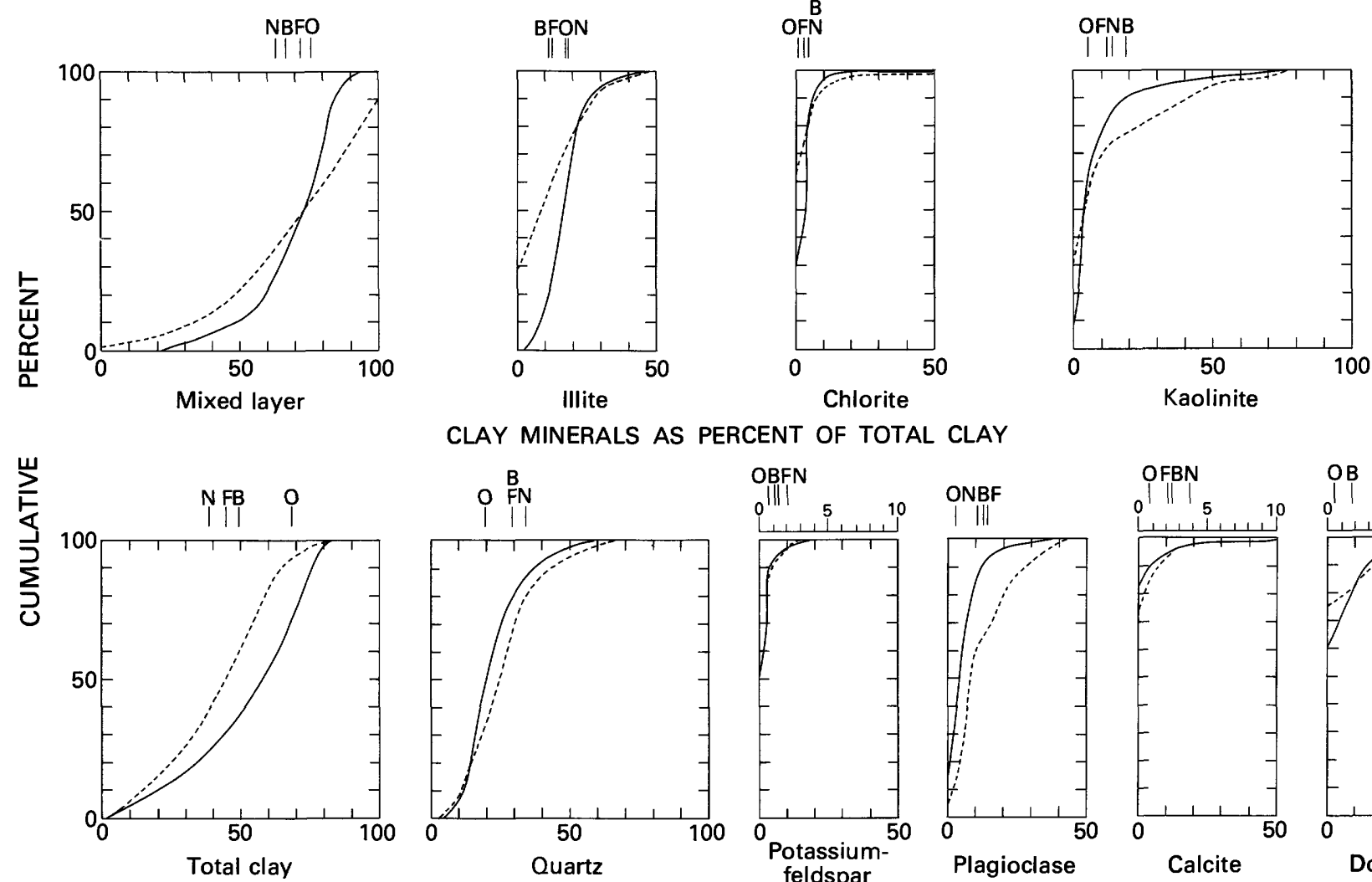

CLAY MINERALS AS PERCENT OF TOTAL CLAY
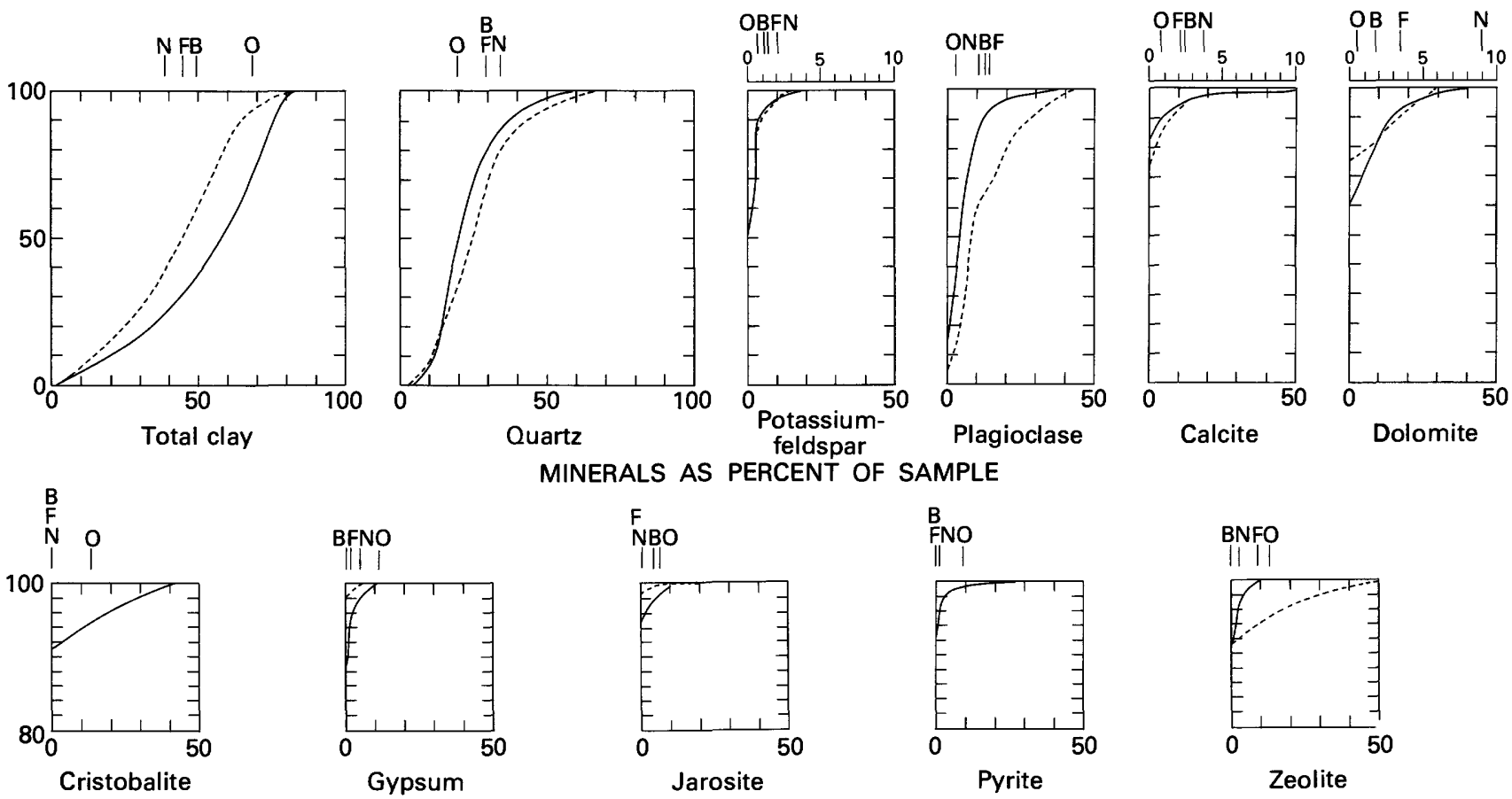

MINERALS AS PERCENT OF SAMPLE

Figure 7.-Abundance of minerals in the Pierre Shale and equivalent rocks related to environment of deposition. Cumulative curves are for 836 marine and 268 nonmarine shale and siltstone samples. Solid lines, marine samples; dotted lines, nonmarine samples. Short vertical lines above curves indicate the arithmetic mean content of 496 offshore-marine (O), 340 nearshore-marine (N), 39 brackish-water (B), and 229 freshwater (F) samples, except that for cristobalite, gypsum, jarosite, pyrite, and zeolite the percent of samples in which the mineral was found is shown. Scales for means of potassium feldspar, calcite, and dolomite are expanded to a maximum of 10 percent. 


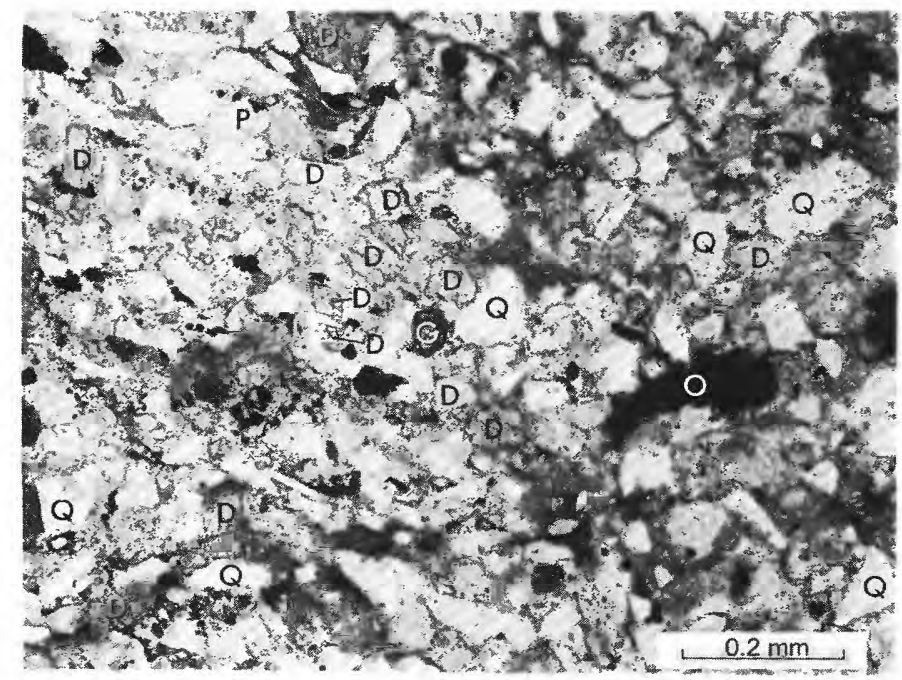

FIGURE 8.-Authigenic dolomite in marine sandy siltstone from the Telegraph Creek Formation, loc. 8, sample 159797 (pl. 1). Plain light. Dolomite (D) in well-formed rhombs and other sharply outlined irregular grains. Quartz $(Q)$ and sparse plagioclase $(P)$ are angular. Clay matrix is poorly oriented. Most opaque material is organic matter (O). High-relief grain in center probably is garnet.

clay detected. Accordingly, the proportion of nunmarine samples in which illite, chlorite, and kaolinite were not detected is relatively high. Otherwise, the distribution of illite, chlorite, and kaolinite is generally similar, except that very large amounts of kaolinite are most common in a few brackish-water samples.

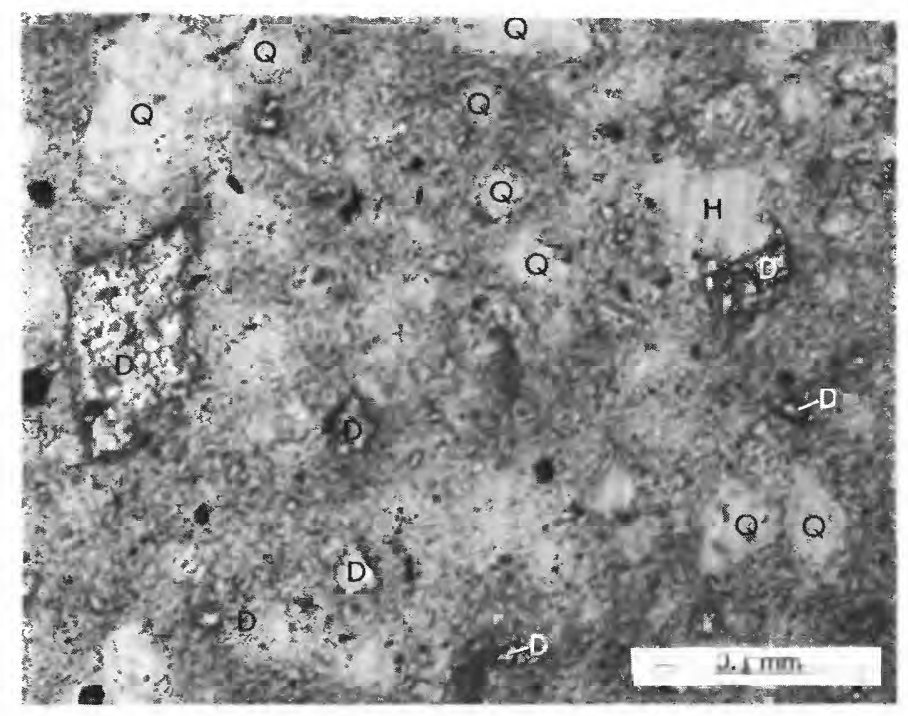

Figure 9.-Authigenic dolomite in nonmarine silty claystone from the Two Medicine Formation, loc. 4, sample 159853 (pl. 1). Plain light. Dolomite (D) in well-formed rhombs and sharply bordered irregular shapes in clay with sparse, subangular quartz (Q). A hole $(H)$ in the slide borders one grain of dolomite.
Types of layers in the mixed-layer clay, like the clays in general, are fairly similar in marine and nonmarine rocks. Variation is somewhat greater in nonmarine rock, but the averages (table 6) differ by only a few percent.

\section{LITHOLOGIC TYPE}

The mineralogy of most types of rock in the Pierre Shale and its equivalents is fairly similar (table 6). Except for bentonite, obvious expected differences for marl, or grain-size differences between shale and siltstone, variations between groups are mostly small differences in proportions of minerals rather than gross differences in the mineral suites contained. As will be seen, however, a few rock types do contain distinctive amounts of individual minerals.

In addition to the usual minerals estimated from $\mathrm{X}$-ray analysis, the amount of organic matter was estimated in table 6 from the amount of organic carbon (C) measured for the analytical samples in order to give more realistic totals for some groups.

\section{ORDINARY SHALE AND SILTSTONE}

The term "ordinary" refers to rock that shows none of the special characteristics used to distinguish other rock types, such as siliceous, frothy, or volcanic rich. The 300 samples of ordinary marine shale and the 39 samples of ordinary nonmarine shale are very similar in composition (table 6); the main differences are that marine shale contains slightly more clay, a smaller proportion of which is mixed-layer clay, which in turn is slightly more montmorillonitic. Both marine and nonmarine siltstone contain mixed-layer clay that tends to be more montmorillonitic than that in ordinary shale. The total amount of clay minerals in siltstone is about half that in shale, the difference being made up by larger amounts of quartz, feldspars, and dolomite in the coarser-grained rock. Calcareous shale and siltstone both are more dolomitic than their noncalcareous counterparts, especially so in the nonmarine groups. The ordinary nonmarine rock, as previously pointed out in connection with figure 7 , contains little or no gypsum, jarosite, zeolite, or organic matter.

\section{ORGANIC-RICH SHALE}

Marine organic-rich shale samples (table 6) are mostly from the Sharon Springs Member of the Pierre (pl. 1). Much of the organic matter occurs as thin plates (fig. 2) oriented parallel with the bedding. The plates impart a high degree of fissility and toughness to the rock. Distinctive mineralogical features are the large amounts of organic matter, usually several percent or 
TABLE 6.-Average mineralogical composition of different [Values are arithmetic means, except where mean is less than 1 percent, the percentage of samples

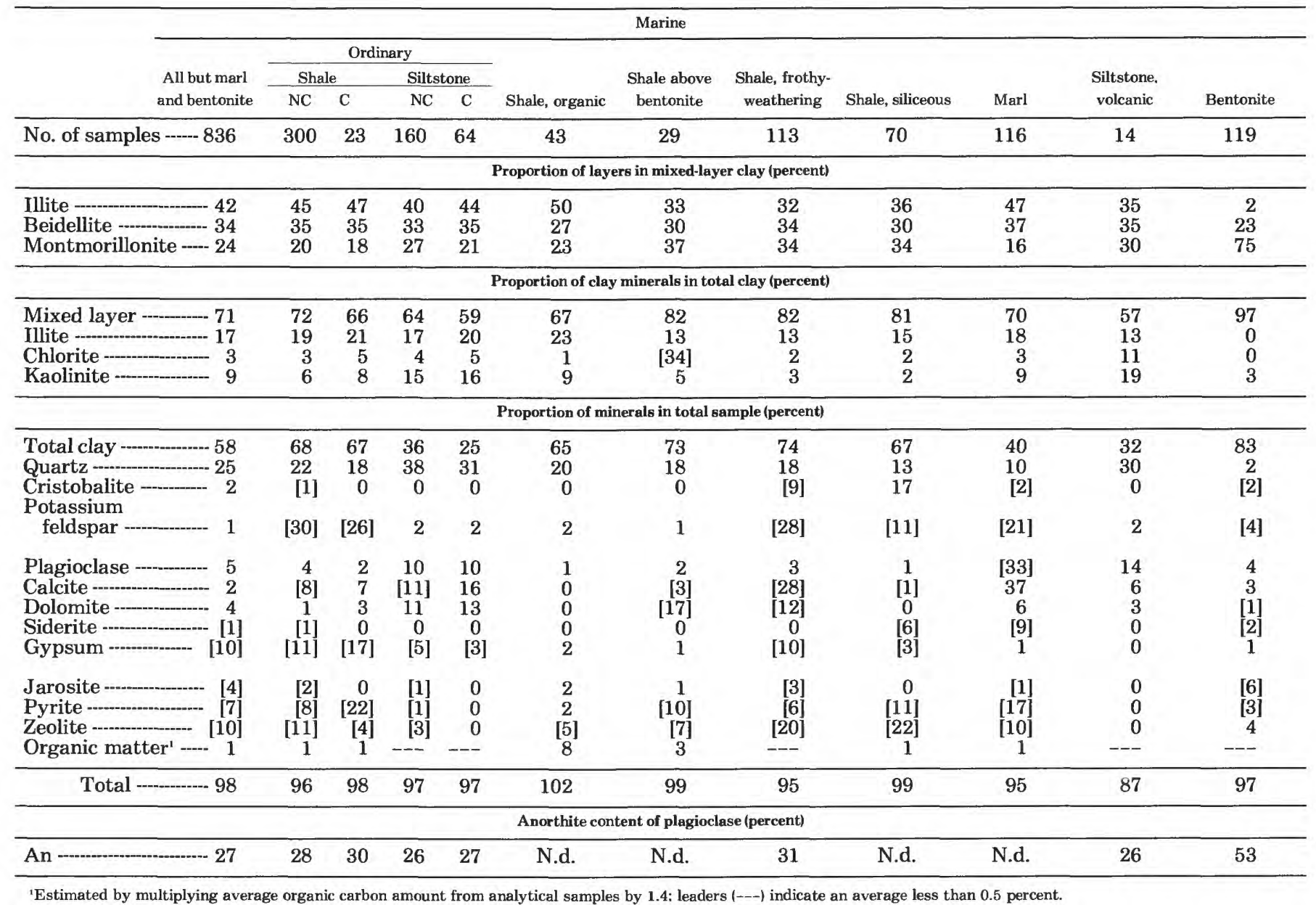

${ }^{1}$ Estimated by multiplying average organic carbon amount from analytical samples by 1.4: leaders (---) indicate an average less than 0.5 percent.

more, as well as pyrite and jarosite or gypsum derived from the pyrite. The proportion of nonexpanding illitetype layers in the mixed-layer clay is above average, as is the proporiton of free illite. The chlorite content is distinctly low because of outcrop weathering (see section on "Suitability of outcrop samples-weathering"). The amount of plagioclase is below average and kaolinite and potassium feldspar contents are slightly above the averages for ordinary marine shale, differences, except for potassium feldspar, that also might reflect weathering. As will be shown, much of the potassium feldspar in marine organic-rich shale is diagenetic in origin.

Nonmarine organic-rich shale lacks fissility and toughness and resembles its marine counterpart only in the dark color and the large content of organic matter (table 6). The nonmarine shale is coaly, and some of the beds sampled grade into thin, low-grade coal beds. Mineralogically, the mixed-layer clay is not as illitic but is more beidellitic than the marine equivalents. The nonmarine coaly shale contains even less chlorite but considerably more kaolinite than its marine equivalents. Several coaly shale samples contain very large amounts of kaolinite of a poorly crystallized variety, and feldspars are especially sparse in such kaolinitic samples. Thus, some, but by no means all, of the coaly nonmarine shale samples seem to show the effects of leaching by which kaolinite is formed from feldspars and perhaps other clay minerals. One analytical sample that seems to show effects of such leaching is from the Columbus section (159784, table 1 , loc. 6 ), containing 38 percent kaolinite, 50 percent beidellite layers in the mixed-layer clay, and no chlorite. The leaching agent probably was organic acid. Another highly leached sample, though not organic rich, is from Cut Bank (159857, table 1, loc. 4), containing 70 percent kaolinite, 70 percent beidellite layers, and stable interlayer Al hydroxite (heated code of 3 , table 1 ; and 
types of rock in the Pierre Shale and its equivalents

in which mineral was detected is shown in brackets. N.d, no data; $\mathrm{C}$, calcareous; NC, noncalcareous]

\begin{tabular}{|c|c|c|c|c|c|c|c|c|c|c|c|}
\hline \multicolumn{12}{|c|}{ Nonmarine } \\
\hline & \multicolumn{4}{|c|}{ Ordinary } & \multirow[b]{3}{*}{ Shale, organic } & \multirow{3}{*}{$\begin{array}{l}\text { Shale, frothy- } \\
\text { weathering }\end{array}$} & \multirow{3}{*}{$\begin{array}{l}\text { Shale, } \\
\text { volcanic }\end{array}$} & \multirow{3}{*}{$\begin{array}{l}\text { Siltstone, } \\
\text { volcanic }\end{array}$} & \multirow[b]{3}{*}{ Bentonite } & \multirow{3}{*}{$\begin{array}{c}\text { Dearborn } \\
\text { River }\end{array}$} & \multirow{3}{*}{$\begin{array}{c}\text { All but } \\
\text { Dearborn River } \\
\text { and bentonite }\end{array}$} \\
\hline All but & \multicolumn{2}{|c|}{ Shale } & \multicolumn{2}{|c|}{ Siltstone } & & & & & & & \\
\hline bentonite & $\mathrm{NC}$ & $\mathbf{C}$ & NC & $\mathrm{C}$ & & & & & & & \\
\hline No. of samples -..-- 268 & 39 & 4 & 49 & 25 & 25 & 14 & 30 & 66 & 17 & 53 & 213 \\
\hline \multicolumn{12}{|c|}{ Proportion of layers in mixed-layer clay (percent) } \\
\hline $\begin{array}{l}\text { Illite } \\
\text { Beidellite } \\
\text { Montmorillonite --- } 21 \\
21\end{array}$ & $\begin{array}{l}51 \\
36 \\
13\end{array}$ & $\begin{array}{l}48 \\
37 \\
15\end{array}$ & $\begin{array}{l}39 \\
37 \\
24\end{array}$ & $\begin{array}{l}30 \\
35 \\
35\end{array}$ & $\begin{array}{l}40 \\
40 \\
20\end{array}$ & $\begin{array}{l}31 \\
41 \\
28\end{array}$ & $\begin{array}{l}54 \\
35 \\
11\end{array}$ & $\begin{array}{l}35 \\
38 \\
27\end{array}$ & $\begin{array}{l}15 \\
31 \\
64\end{array}$ & $\begin{array}{r}67 \\
30 \\
3\end{array}$ & $\begin{array}{l}38 \\
39 \\
23\end{array}$ \\
\hline \multicolumn{12}{|c|}{ Proportion of clay minerals in total clay (percent) } \\
\hline 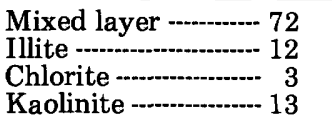 & $\begin{array}{r}79 \\
15 \\
1 \\
5\end{array}$ & $\begin{array}{r}77 \\
18 \\
1 \\
4\end{array}$ & $\begin{array}{r}58 \\
17 \\
3 \\
22\end{array}$ & $\begin{array}{r}57 \\
20 \\
3 \\
20\end{array}$ & $\begin{array}{c}63 \\
13 \\
{[12]} \\
24\end{array}$ & $\begin{array}{r}84 \\
11 \\
1 \\
4\end{array}$ & $\begin{array}{r}92 \\
2 \\
1 \\
5\end{array}$ & $\begin{array}{r}80 \\
5 \\
8 \\
7\end{array}$ & $\begin{array}{c}99 \\
0 \\
{[6]} \\
1\end{array}$ & $\begin{array}{r}85 \\
5 \\
7 \\
3\end{array}$ & $\begin{array}{r}70 \\
14 \\
2 \\
14\end{array}$ \\
\hline \multicolumn{12}{|c|}{ Proportion of minerals in total sample (percent) } \\
\hline 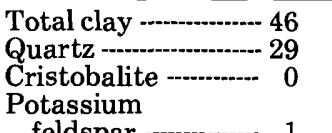 & $\begin{array}{r}62 \\
25 \\
0\end{array}$ & $\begin{array}{r}53 \\
22 \\
0\end{array}$ & $\begin{array}{r}35 \\
41 \\
0\end{array}$ & $\begin{array}{r}25 \\
30 \\
0\end{array}$ & $\begin{array}{r}58 \\
32 \\
0\end{array}$ & $\begin{array}{r}55 \\
30 \\
0\end{array}$ & $\begin{array}{r}65 \\
20 \\
0\end{array}$ & $\begin{array}{r}34 \\
23 \\
0\end{array}$ & $\begin{array}{r}70 \\
10 \\
0\end{array}$ & $\begin{array}{r}48 \\
21 \\
0\end{array}$ & $\begin{array}{r}45 \\
31 \\
0\end{array}$ \\
\hline feldspar -..--..--- 1 & 1 & 1 & 3 & 3 & 1 & 1 & [13] & [15] & [6] & [4] & 2 \\
\hline 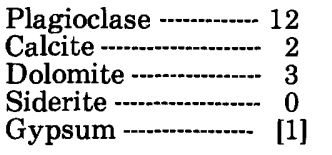 & $\begin{array}{c}6 \\
{[13]} \\
1 \\
0 \\
0\end{array}$ & $\begin{array}{r}3 \\
7 \\
12 \\
0 \\
0\end{array}$ & $\begin{array}{c}11 \\
{[14]} \\
5 \\
0 \\
0\end{array}$ & $\begin{array}{r}13 \\
13 \\
15 \\
0 \\
0\end{array}$ & $\begin{array}{c}5 \\
0 \\
{[5]} \\
0 \\
0\end{array}$ & $\begin{array}{r}10 \\
0 \\
4 \\
0 \\
0\end{array}$ & $\begin{array}{r}10 \\
1 \\
0 \\
0 \\
0\end{array}$ & $\begin{array}{c}23 \\
2 \\
{[6]} \\
0 \\
{[7]}\end{array}$ & $\begin{array}{c}9 \\
2 \\
0 \\
0 \\
{[6]}\end{array}$ & $\begin{array}{c}13 \\
4 \\
2 \\
0 \\
{[2]}\end{array}$ & $\begin{array}{r}12 \\
2 \\
4 \\
0 \\
{[1]}\end{array}$ \\
\hline 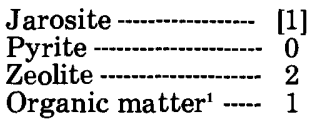 & $\begin{array}{r}0 \\
0 \\
0 \\
--\end{array}$ & $\begin{array}{r}0 \\
0 \\
0 \\
--\end{array}$ & $\begin{array}{c}0 \\
0 \\
{[2]} \\
--\end{array}$ & $\begin{array}{r}0 \\
0 \\
0 \\
--\end{array}$ & $\begin{array}{c}{[7]} \\
0 \\
0 \\
5\end{array}$ & $\begin{array}{r}0 \\
0 \\
0 \\
--\end{array}$ & $\begin{array}{c}0 \\
0 \\
{[6]} \\
--\end{array}$ & $\begin{array}{c}{[1]} \\
0 \\
7 \\
---\end{array}$ & $\begin{array}{r}0 \\
0 \\
4 \\
--\end{array}$ & $\begin{array}{c}{[2]} \\
0 \\
5 \\
---\end{array}$ & $\begin{array}{r}{[1]} \\
0 \\
1 \\
---\end{array}$ \\
\hline Total -..--..-... 95 & 95 & 98 & 95 & 99 & 101 & 100 & 96 & 89 & 95 & 93 & 97 \\
\hline \multicolumn{12}{|c|}{ Anorthite content of plagioclase (percent) } \\
\hline An & 27 & 30 & 31 & 28 & 30 & 28 & 35 & 37 & 50 & 25 & 34 \\
\hline
\end{tabular}

'Estimated by multiplying average organic carbon amount from analytical samples by 1.4; leaders (---) indicate an average less than 0.5 percent.

fig. 5B); such highly aluminous components as beidellite and $\mathrm{Al}$ hydroxide are likely precursors of kaolinite.

\section{SHALE DIRECTLY ABOVE BENTONITE}

The 29 samples in this group all came from within 1 $\mathrm{ft}$ above a bentonite bed and are mostly from the Sharon Springs Member of the Pierre. They are closely related to and share many of the properties of marine organic-rich shale, such as moderately high organic content, above-average amounts of pyrite and sulfate minerals, relatively large amounts of potassium feldspar, and small amounts of plagioclase. The main difference is in the more montmorillonitic character of the clay. Deposition of the nearly pure volcanic ash that formed the bentonite beds apparently did not cease abruptly but continued so that volcanic ash formed a significant part of the overlying shale, thereby producing shale significantly more montmorillonitic than shale resulting wholly from detrital transport and deposition. In some of the lower parts of the Sharon Springs Member, in the Ardmore Bentonite Beds, bentonites are so closely spaced that all the thin intervening shale beds are significantly affected by upward gradation from bentonite beds (frontispiece). Such shale is not represented in the average composition of the 43 samples of organic-rich marine shale in table 6 . Any montmorillonitic clay in the shale above bentonite that developed directly from vitric ash, however, is so homogenized with detrital mixed-layer clay that the two clay minerals cannot be distinguished from each other by X-ray analysis.

\section{FROTHY-WEATHERING SHALE}

Frothy-weathering shale occurs in both marine and nonmarine parts of the Pierre Shale (table 6) but it is most common in marine rock. Frothy-weathering shale tends to be more montmorillonitic than most other 
types of shale (table 6), though not greatly so, and many frothy shale samples are less montmorillonitic than average. The explanation for frothy weathering seems to lie both in the montmorillonitic clay and in its exchangeable cations, as determined by air-dried $d$-spacings (see the section on "Exchangeable cations-air dried code"). The partial mineral analyses of 12 samples in table 7 show the common compositional range of frothy shale. Samples 1-6 do not contain particularly large amounts of clay or proportions of mixed-layer illite-smectite, and the proportion of montmorillonite-type layers in the mixed-layer clay is lowall features that are not expected to cause swelling or frothy weathering. The one feature that all six samples have in common is exchangeable $\mathrm{Na}^{+}$, indicated by the " 1 " or " 1.5 " for the air-dried code at the bottom of table 7. In most samples of the Pierre Shale, $\mathrm{Ca}^{+2}$ is the predominant exchangeable cation (table 1). Yet, the exchangeable $\mathrm{Na}^{+}$cannot be the sole cause of frothy weathering, as samples $7-12$ in table 7 all have a predominance of exchangeable $\mathrm{Ca}^{+2}$, indicated by the air-dried code. All of the second six samples, however, do contain exceptionally large amounts of mixed-layer illite-smectite, in which montmorillonite layers are abundant. Thus, either moderate amounts of $\mathrm{Na}^{+}$ montmorillonite, or large amounts of $\mathrm{Ca}^{+2}$ montmorillonite, or both, cause frothy weathering of the shale.

\section{SILICEOUS SHALE}

The distinctive mineralogical feature of most siliceous shale in the Pierre Shale is large amounts, averaging about 17 percent (tables 6 and 8), of a disordered variety of cristobalite that gives a broad $\mathrm{X}$-ray reflection at about $4.1 \mathrm{~A}$. The amounts and various forms of $\mathrm{SiO}_{2}$ also show a pronounced regional relationship with the hardness of the siliceous shale (fig. 10). In area A where siliceous shale is very hard, amounts of cristobalite are high -20 to 40 percent-and many quartz amounts are exceptionally low-about 5 percent. In area $B$, where siliceous shale is notably softer, amounts of cristobalite are generally lower and the amounts of quartz tend to be higher, particularly in the 20 samples having no detectable cristobalite. Thus, one form or another of silica cement appears to give siliceous shale its characteristic hardness.

Murata and Larson (1975) have shown that siliceous Tertiary Monterey Shale, in California, is caused by silica cement derived from diatoms. Opaline silica from the diatoms recrystallizes first to cristobalite cement beginning at a burial depth of about $2,000 \mathrm{ft}$ and an estimated temperature of $50^{\circ} \mathrm{C}$; the cristobalite recrystallizes to microcrystalline quartz cement at a burial depth of about $6,000 \mathrm{ft}$ and an estimated temperature of $110^{\circ} \mathrm{C}$. Diatoms do not occur in the Pierre Shale but radiolaria do. Calvert (1966) showed that radiolaria, like diatoms, are made up of amorphous opal. Davis (1970) has shown that radiolaria are the source of $\mathrm{SiO}_{2}$ cement for the well-known Mowry Shale of Early Cretaceous age in the Western Interior.

Clearly recognizable radiolaria are found in the Pierre Shale, but not in thin sections of siliceous shale. The best radiolaria seen (fig. 11) are in frothyweathering shale interbedded with siliceous shale. Such a relation is expectable, actually, for if opaline

TABLE 7.-Partial mineralogical analyses of 12 selected samples of frothy-weathering shale that illustrate their range of composition, Pierre Shale

\begin{tabular}{|c|c|c|c|c|c|c|c|c|c|c|c|c|}
\hline Sample No. .............. & 1 & 2 & 3 & 4 & 5 & 6 & 7 & 8 & 9 & 10 & 11 & 12 \\
\hline \multicolumn{13}{|c|}{ Proportion of layers in mixed-layer clay (percent) } \\
\hline $\begin{array}{l}\text { Illite } \\
\text { Beidelite } \ldots \ldots \ldots \ldots \ldots \ldots \ldots \ldots \\
\text { Montmorillonite } \ldots \ldots \ldots \ldots \ldots \ldots\end{array}$ & $\begin{array}{l}55 \\
25 \\
20\end{array}$ & $\begin{array}{l}50 \\
35 \\
15\end{array}$ & $\begin{array}{r}50 \\
45 \\
5\end{array}$ & $\begin{array}{l}55 \\
30 \\
15\end{array}$ & $\begin{array}{l}50 \\
40 \\
10\end{array}$ & $\begin{array}{l}45 \\
30 \\
25\end{array}$ & $\begin{array}{l}25 \\
35 \\
40\end{array}$ & $\begin{array}{l}15 \\
20 \\
65\end{array}$ & $\begin{array}{l}25 \\
30 \\
45\end{array}$ & $\begin{array}{l}25 \\
40 \\
35\end{array}$ & $\begin{array}{l}15 \\
30 \\
55\end{array}$ & $\begin{array}{l}10 \\
25 \\
65\end{array}$ \\
\hline \multicolumn{13}{|c|}{ Proportion in total clay (percent) } \\
\hline Mixed-layer clay ........... & 72 & 75 & 68 & 89 & 93 & 75 & 80 & 95 & 86 & 90 & 95 & 86 \\
\hline \multicolumn{13}{|c|}{ Proportion in total sample (percent) } \\
\hline Clay minerals $\ldots \ldots \ldots \ldots$ & 75 & 65 & 75 & 65 & 70 & 80 & 80 & 85 & 75 & 85 & 90 & 80 \\
\hline \multicolumn{13}{|c|}{ Exchangeable cation (air-dried code) } \\
\hline $\mathrm{Na}, 1 ; \mathrm{Na}=\mathrm{Ca}, 1.5 ; \mathrm{Ca}, 2$ & 1 & 1 & 1.5 & 1 & 1 & 1.5 & 2 & 2 & 2 & 2 & 2 & 2 \\
\hline
\end{tabular}


TABLE 8.-Mineralogy of shale and marl from different members of the Pierre Shale and from the Niobrara Formation in the Missouri River area

[Values are artihmetic means or, in brackets, percent of samples in which detected]

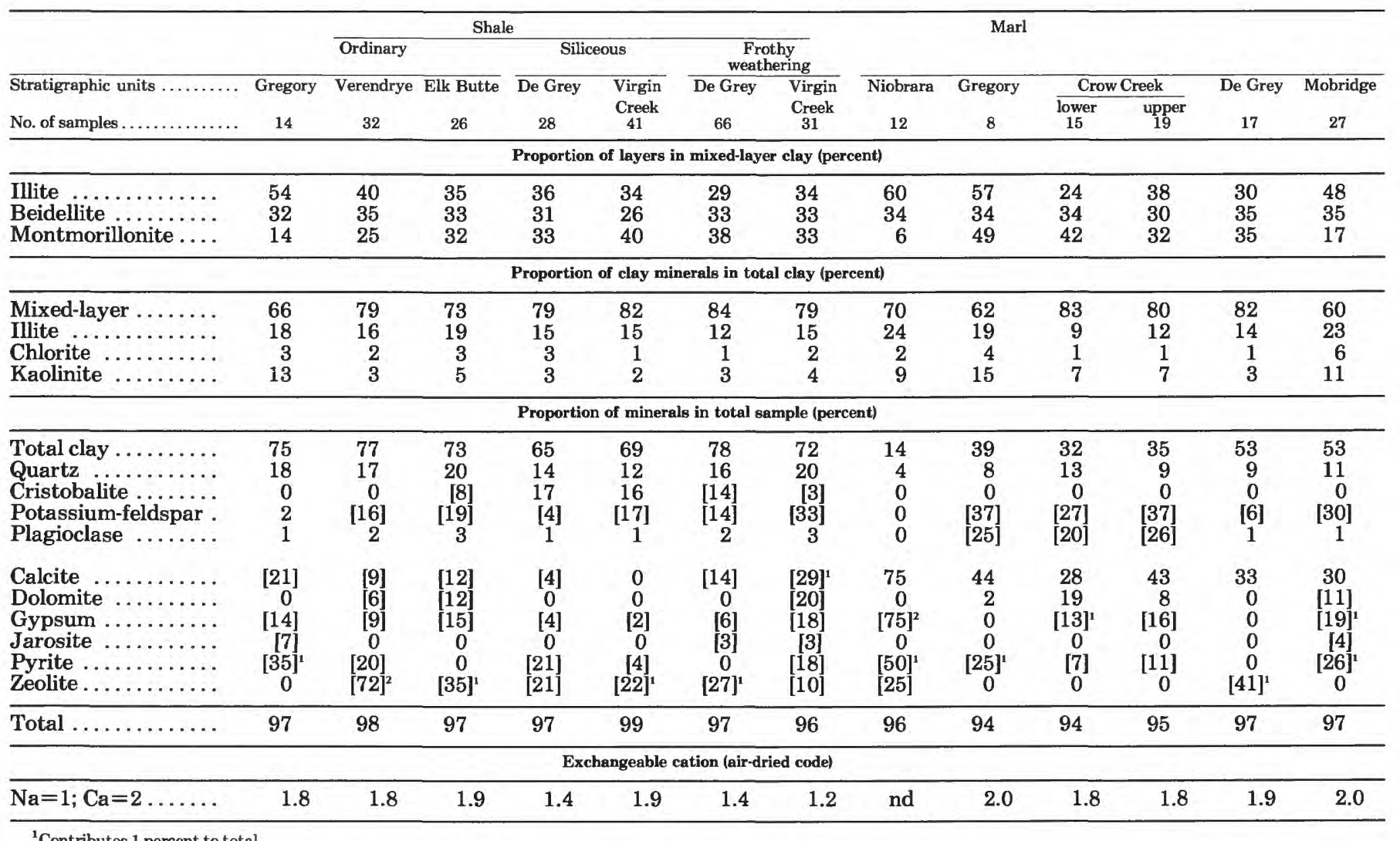

Contributes 1 percent to total.

silica recrystallized in place so as to preserve the radiolarian outline, then it would not disperse to form $\mathrm{SiO}_{2}$ cement throughout the shale. In area A (fig. 10) the dispersed $\mathrm{SiO}_{2}$ formed large amounts of cristobalite that, acting as a diluent, decreased the average amount of quartz; whereas in area B the opal dissolved, dispersed, and recrystallized partly as cristobalite and partly as quartz, so the average amount of quartz tends to be above average.

Although derivation of cristobalite and quartz cement in the Pierre Shale from amorphous radiolarian opal seems quite analogous to its derivation from diatomaceous opal in the Monterey Shale, the controlling influence of depth of burial reported for the Monterey Shale-2,000 ft for conversion of opal to cristobalite and $6,000 \mathrm{ft}$ for conversion to quartz (Murata and Larson, 1975)-does not seem applicable to the Pierre Shale. Burial of the Pierre Shale in area A (fig. 10) under $2,000 \mathrm{ft}$ of younger sediments is reasonable; estimates from density measurements (Schultz, 1978) are of this order of magnitude. Estimated burial depth in area B to the southeast (locs. 24 to 26) was less than that in area A, however, so quartz cement might be expected in area $A$ rather than area $\mathrm{B}$. In any case, $6,000 \mathrm{ft}$ of burial is not reasonable to us for either areas $\mathrm{A}$ or $\mathrm{B}$, and the opalcristobalite-quartz status should be about the same in the two areas. Mizutani (1970) showed that time, as well as temperature and pressure (depth of burial), influences the degree of transformation of opal to cristobalite to quartz, which could account for some differences between the Miocene and Pliocene Monterey Shale and the Cretaceous Pierre Shale; but no reasonable combination of the three factors-time, temperature, and pressure-seems capable of accounting for cristobalite in area A and quartz in area B within the Pierre Shale. In the Pierre Shale the course of recrystallization of radiolarian opal seems to be influenced, instead, by the amount of opal present; if large, it recrystallized to cristobalite, and if small, it recrystallized partly to quartz.

\section{MARL}

Marl forms distinct beds only in the marine strata (table 6). The type of clay contained in marl is similar to that in the ordinary marine shale. On the average, 

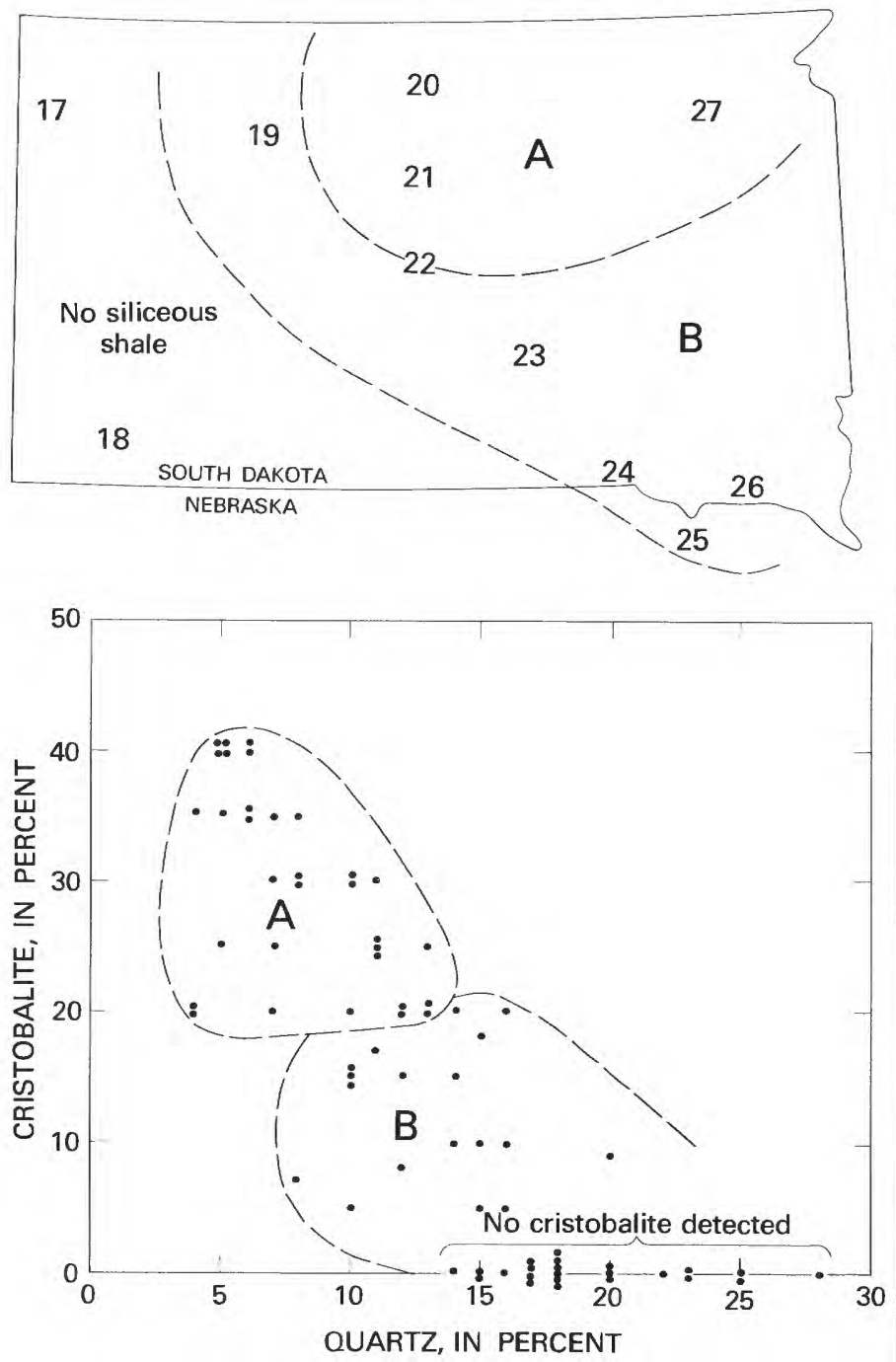

Figure 10.-Location and hardness of siliceous shale in the Pierre Shale and amounts of cristobalite and quartz in it. Numbers on outline map are sample localities (table 2). In area A siliceous shale is very hard, in area B it is notably softer, and outside areas $A$ and $B$ siliceous shale was not recognized.

marl differs from other rock types mainly in the large amount of calcite that it contains and the correspondingly lesser amounts of the other major mineral constituents. However, dolomite is distinctly more abundant, and pyrite and gypsum are detected more frequently in marl than in most marine shale.

The clay mineralogy of marl beds, particularly that of the mixed-layer clay, differs markedly with the stratigraphic level within the Pierre Shale (table 8), and the variation is closely related to the mineralogy of adjacent shales. In marl of the Niobrara Formation and of the Gregory Member in the lower part of the Pierre Shale (pl. 1, fig. 1), mixed-layer clay contains notably few montmorillonite-type layers, similar to the mixed-layer clay in shale of the associated Gregory (table 8) and Sharon Springs Members (table 6, marine organic-rich shale). Higher in the stratigraphic section of the Pierre, the marl in the Crow Creek and DeGrey Members is much more montmorillonitic, as is the siliceous and frothy-weathering shale of the DeGrey Member. Marl in the Mobridge Member contains an intermediate proportion of montmorillonite layers, somewhat like the mixed-layer clay in the overlying Elk Butte Member. Thus, along the Missouri River, variations in the clay in different types of rock seems related to the part of the section in which they occur, and distinctive lithologic characteristics are determined by other factors, such as the amount of calcite, cristobalite or quartz cement, organic matter, or the exchangeable cations on the mixed-layer clay.

Marl of the Crow Creek Member is unique in the Pierre Shale. It is the only marl bed that consistently contains authigenic dolomite and coarse grains of detrital quartz (fig. 12); its basal part is exceptionally montmorillonitic (table 8); it is the only marl having a sharp, unconformable basal contact with pebbles of shale and phosphate nodules just above the unconformity that have been eroded from the underlying shale (Schultz, 1965, p. B15 and pl. 2); it is one of the few parts of the Pierre Shale containing conspicuous amounts of detritus derived from the east. The Crow Creek was deposited along the eastern margin of the Pierre sea during temporary and local shallowing that was related to uplift of the Precambrian Sioux Quartzite in eastern South Dakota (Crandell, 1952). What further emphasizes the local nature of the shallowing is that the Crow Creek Member was deposited during the time of fossil zone 4 (pl. 1), a time of general deepening and westward transgression of the Pierre sea. Formation of the dolomite grains (figs. 12 and 13), many of

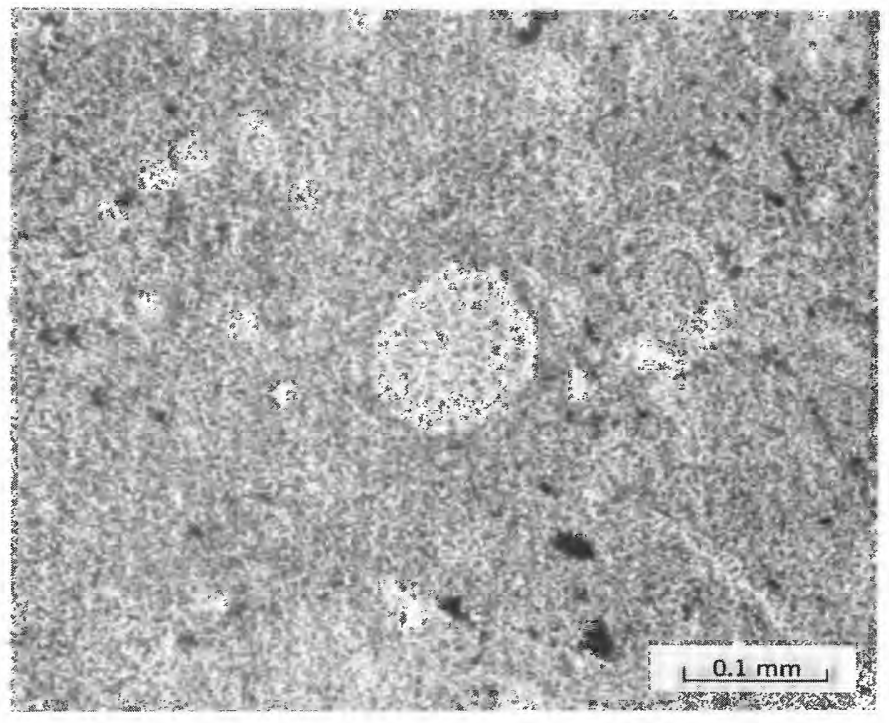

FIGURE 11.-Radiolaria in frothy-weathering shale from the DeGrey Member of the Pierre Shale at locality 23, sample 259550. Plain light. 


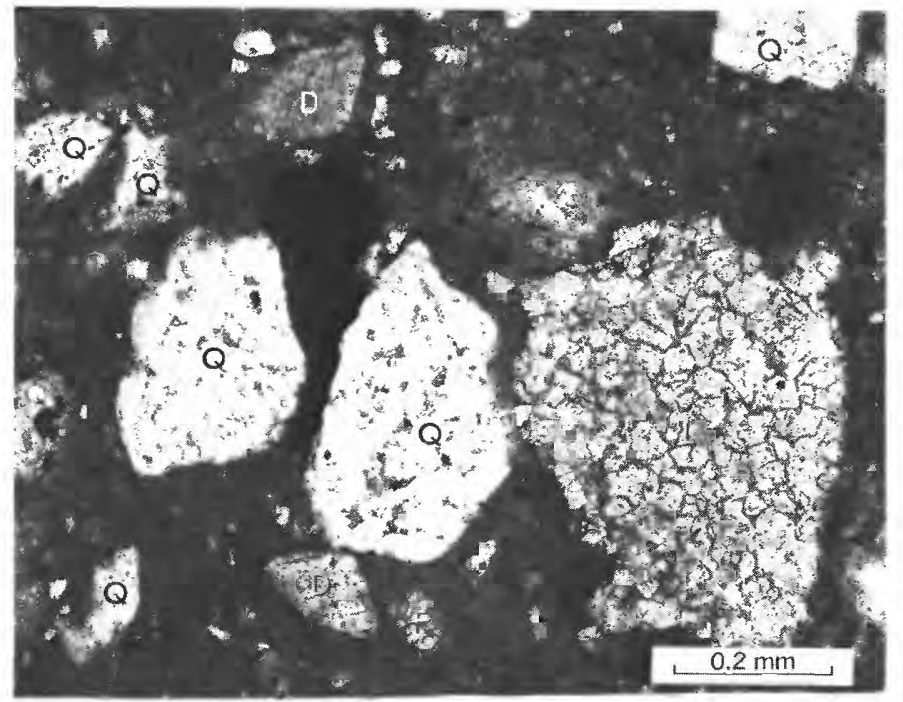

FIGURE 12.-Rhombic authigenic dolomite in sandy marlstone from the basal part of the Crow Creek Member of the Pierre Shale, locality 26, thin section S57-37-4B. Plain light. Dolomite (D), quartz $(\mathrm{Q})$, and polycrystalline limestone $(\mathrm{L})$ in fine-grained matrix of cocoliths and clay. Opaque area between two large grains of strained quartz is iron oxide. Foraminifera $(F)$ are sparse.

which have euhedral outlines, was related to changes in temperature and concentration of $\mathrm{CO}_{2}$ in shallow seawater in the same way as was formation of similar dolomite grains in nearshore marine siltstone. The dolomite grains are largest (fig. 12) and most abundant (table 8 ) in the basal sandy part of the marl, though

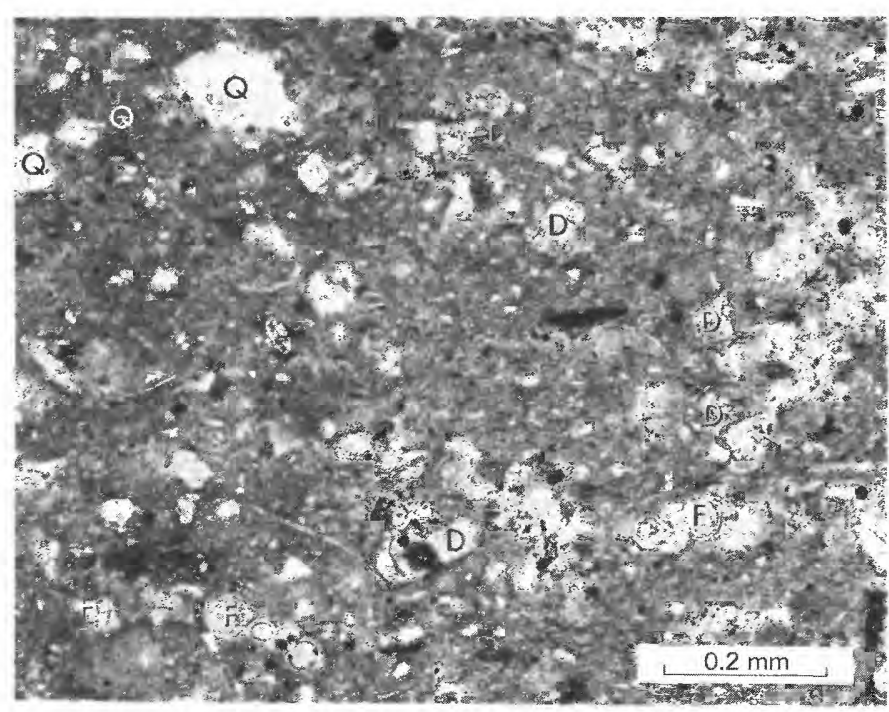

FIGURE 13.-Authigenic dolomite in fine-grained marlstone in the upper part of the Crow Creek Member of the Pierre Shale, locality 23 , thin section S59-44-2u. Plain light. Authigenic dolomite (D) in well-formed rhombs and irregular crystals, quartz (O), and abundant foraminifers (F). Largest quartz grain is polycrystalline. Opaque areas are pyrite. smaller dolomite grains (fig. 13) are about half as abundant in the upper fine-grained parts. Although clearly recognizable tuff fragments are not found in thin sections of the Crow Creek Member, the exceptionally high montmorillonite content, particularly of the basal part, suggests that volcanic debris formed an unusually large proportion of the detrital components of the marl. Such volcaniclastic grains could not have been transported by ocean currents across the wide expanse of the Pierre sea, except possibly as floating pumice; however, were this the case, no reason is apparent why pumice should be concentrated particularly in the Crow Creek member or why distinctive textures of pumice fragments are not seen. More likely the volcaniclastic precursor for the montmorillonitic clay was eolian, as it was for bentonite; it fell mostly along the eastern land margin of the Pierre sea, was weathered, and then was washed westward by stream and shallow marine currents, producing the most recognizable flood of debris in the Pierre Shale to come from the eastern shore of the sea.

\section{VOLCANIC-RICH SHALE}

Volcanic-rich shale is too fine grained for recognition of volcanic particles in the field. It is so designated because it is intimately interbedded with coarser grained pyroclastic rocks. Therefore, volcanic-rich shale is recognized only in nonmarine rock (table 6), near the volcanic source, where pyroclastic rock is abundant (pl. 1). Volcanic-rich shale contains several percent more plagioclase than most shale and very little free illite, but the proportion of illite-type layers in mixed-layer clay is higher than in any other shale (table 6). The reasons for these compositional features are discussed in the following section.

\section{VOLCANIC-RICH SILTSTONE}

Pyroclastic detritus is most abundant in the west near the volcanic source (pl. 1, locs. 1 and 2) and tuffaceous siltstone and sandstone extend into marine environments 200-300 mi east of the main volcanic pile (pl. 1, locs. 10, 13, and 14). Such coarse-grained pyroclastic sediments contain abundant silt-, sandand, in some places, pebble-size tuff grains, commonly together with euhedral and angular broken grains of plagioclase, biotite, and other primary mineral grains from volcanic rock. Plagioclase is characteristically abundant (table 6), and most of it is fresh, although some grains are partly altered to clay (at B in fig. 14 and $A$ in fig. 15) or replaced by calcite.

The paucity of visible quartz is a striking feature revealed by study of thin sections like those in figures 


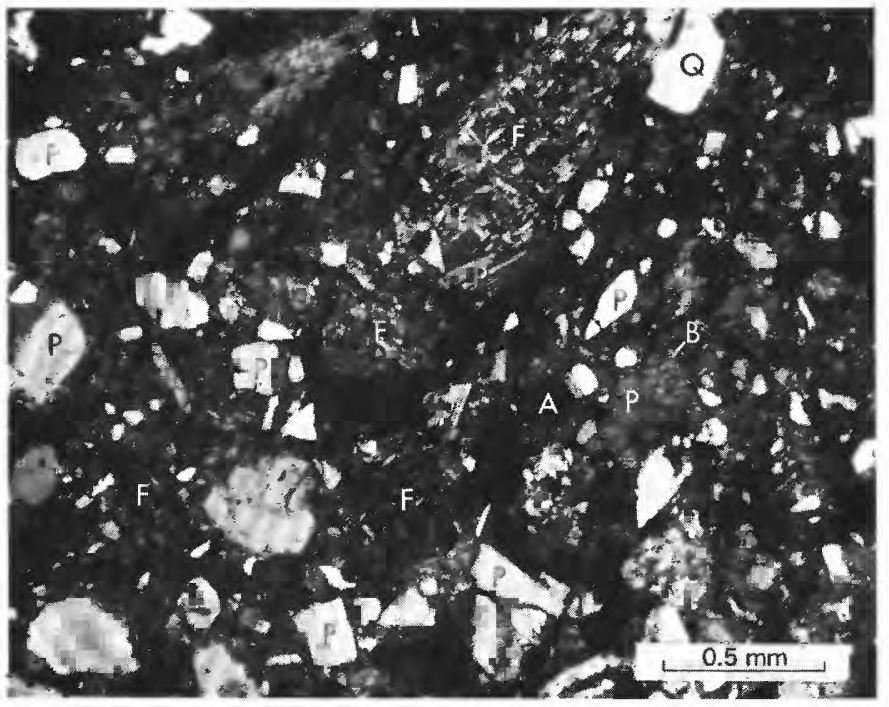

FiguRE 14.-Volcanic-rich sandy siltstone from the Cokedale Formation, locality 1, sample 159827. Crossed polarizers. Fragments of volcanic rock $(F)$, plagioclase $(P)$, and quartz $(Q)$ in a matrix of unoriented clay. Quartz grain at A having pseudohexagonal boundaries may be a bipyramidal quartz phenocryst. Some plagioclase grains, such as at $B$, are partly replaced by clay.

14 and 15 , and this observation partly involves what seemed at first the fairly simple problem of distinguishing quartz from plagioclase. Most plagioclase grains are recognized from their twinning, zoning, crystal habit, and their strongly biaxial interferance figures when such are obtainable. Most quartz grains have nondescript shapes and only rarely can be identified from the characteristic hexagonal outline of bipyramidal quartz phenocrysts or less certainly identified by straight crystal edges of broken bipyramids. The uniaxial character of quartz certainly distinguishes it from plagioclase, but many such quartzlike grains do not give usable interference figures, and many of those that do are clearly biaxial and therefore must be plagioclase. Quartzlike grains without interference figures are labeled as questionable (O?, fig. 15), but tabulated as quartz. Thus, the amount of optically identified quartz probably was overestimated. Nevertheless, the amount of optically identified quartz was far smaller than the amount of quartz indicated by X-ray, whereas the amount of optically identified plagioclase was roughly comparable with its X-ray determination. For example, sample 159827 contains 16 percent quartz and 36 percent plagioclase (table 1), but in its photomicrograph (fig. 14) only one euhedral grain and one other questionable grain of quartz is seen; in sample 159836 (fig. 15) plagioclase is clearly more evident than quartz, but the two minerals are almost equally abundant (table 1).

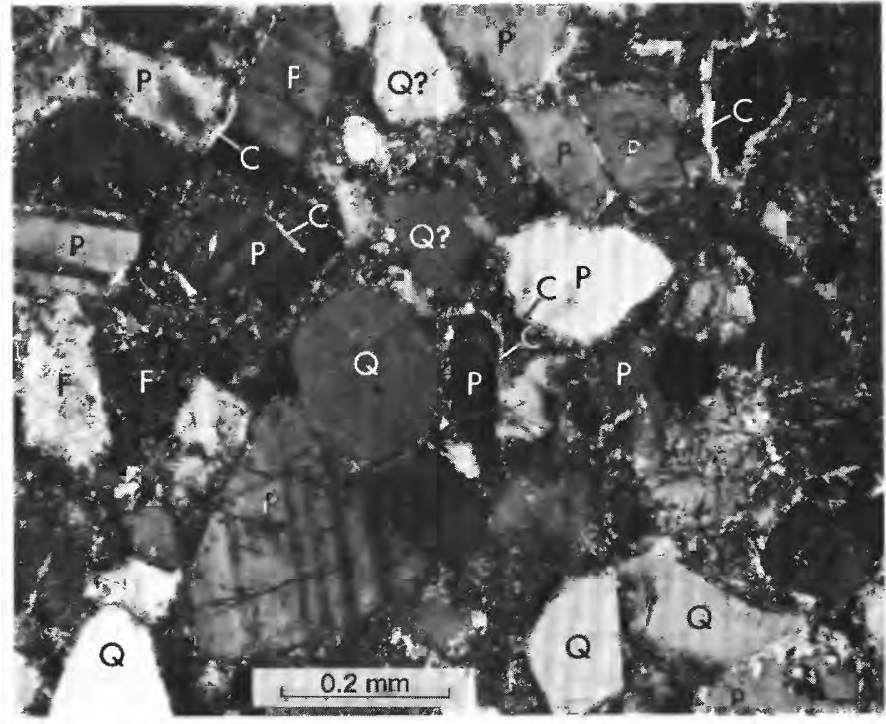

FIgURE 15.-Volcanic-rich sandstone from the Two Medicine Formation, locality 2, sample 159836. Crossed polarizers. Authigenic clay layers $(C)$ border grains of both plagioclase $(P)$ and quartz $(Q)$, which suggests that authigenic clay layers formed from the matrix rather than from the large grains they surround. Hexagonal dark grain just left of center is quartz and is probably a bipyramidal phenocryst. At A an untwinned plagioclase crystal has been irregularly replaced by clay. Rock or pumice fragments $(F)$ are sparsely present.

Thus, much of the quartz in volcanic-rich rocks must occur with the clay in the fine-grained matrix.

Nonmarine volcanic-rich shale and siltstone characteristically contain amounts of illite appreciably less than other types of rock (table 6), and many such shales contain no illite. The 13-percent average illite in marine volcanic-rich siltstone, however, is only slightly less than average, which indicates that by the time the volcanic debris reached the sea it was mixed with large amounts of nonvolcanic detritus.

The mixed-layer clay at Dearborn River (pl. 1, loc. 2), having an average of 67 percent illite-type layers (table 6 ), is much more illitic than at any other locality. Because nonmarine volcanic-rich rocks make up all but the lowest strata at Dearborn River (pl. 1), they have an appreciable effect on the average mineralogical composition of the groups of nonmarine volcanic rocks. Mixed-layer clay at Dearborn River is highly illitic in both coarse- and fine-grained rocks (table 9), and, because the 19 Dearborn River shale samples are nearly two-thirds of all the volcanic-rich shale samples but the 21 Dearborn River siltstone samples are only one-third of all the volcanic-rich siltstone samples, the Dearborn River clay has a much larger effect on the average composition of nonmarine volcanic-rich shale. The rocks at Dearborn River have been altered, perhaps by load metamorphism (Schultz, 1978); the clay rims at C in 
TABLE 9.-Average mineralogical composition of nonmarine volcanicrich rock in equivalents of the Pierre Shale from Dearborn River (loc. 2, pl. 1) and other localities

$$
\text { ['Tr., trace] }
$$

\begin{tabular}{|c|c|c|c|c|}
\hline & \multicolumn{2}{|l|}{ Shale } & \multicolumn{2}{|l|}{ Siltstone } \\
\hline & Dearborn River & Other & Dearborn River & Other \\
\hline No. of samples...... & 19 & 11 & 21 & 45 \\
\hline \multicolumn{5}{|c|}{ Proportion of layers in mixed-layer clay (percent) } \\
\hline $\begin{array}{l}\text { Illite } \ldots . . . . . . . \\
\text { Beidellite } \ldots \ldots \ldots \\
\text { Montmorillonite } \ldots .\end{array}$ & $\begin{array}{r}67 \\
29 \\
4\end{array}$ & $\begin{array}{l}32 \\
45 \\
23\end{array}$ & $\begin{array}{r}62 \\
34 \\
4\end{array}$ & $\begin{array}{l}25 \\
40 \\
35\end{array}$ \\
\hline \multicolumn{5}{|c|}{ Proportion of clay minerals in total clay (percent) } \\
\hline 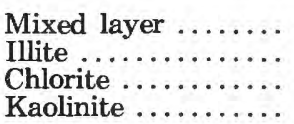 & $\begin{array}{r}96 \\
1 \\
1 \\
2\end{array}$ & $\begin{array}{r}88 \\
4 \\
1 \\
2\end{array}$ & $\begin{array}{r}59 \\
0 \\
34 \\
7\end{array}$ & $\begin{array}{r}79 \\
7 \\
5 \\
9\end{array}$ \\
\hline
\end{tabular}

Proportion of minerals in total sample (percent)

\begin{tabular}{|c|c|c|c|c|}
\hline Clay minerals ........ & 68 & 62 & 32 & 36 \\
\hline Quartz ........ & 21 & 18 & 16 & 26 \\
\hline Potassium feldspar. & 0 & Tr. & 0 & 1 \\
\hline Plagioclase ....... & 8 & 15 & 21 & 23 \\
\hline Zeolite...$\ldots \ldots \ldots$. & Tr. & 0 & 14 & 3 \\
\hline Augite..$\ldots \ldots \ldots \ldots$ & 0 & 0 & 5 & 1 \\
\hline Total ......... & 97 & 95 & 88 & 90 \\
\hline
\end{tabular}

figure 15 that surround the large grains probably recrystallized from the original clay matrix during this alteration. Therefore, the Dearborn River samples do not reflect their composition when they were deposited, which probably was much like that of the samples from localities other than Dearborn River (table 9). The number of samples from Dearborn River and their degree of alteration are not so great, however, as to appreciably change the overall composition of nonmarine rock (table 6, first and last nonmarine groups). Nevertheless, the mixed-layer clay from volcanic-rich rocks other than at Dearborn River (table 9) does contain fewer illite-type layers and more beidellite- and montmorillonite-type layers than other types of rock, a relation that is obscured by the groupings and averaging in table 6.

The average composition of coarser grained volcanicrich rock given in table 9 shows several other components, discussed more fully in the following paragraphs, that set these samples apart-chlorite, zeolite, and augite. The anorthite content of the plagioclase and mineral totals (table 6, bottom) also need further explanation.

The anorthite content of plagioclase in the marine volcanic-rich siltstone, averaging 26 percent, is about the same as for other types of marine rock (table 6), bentonite excepted. The average anorthite content of plagioclase in nonmarine volcanic-rich rock, about 35 percent for both shale and siltstone, is 5 to 10 percent higher than in most other nonmarine groups, bentonite again excepted. Anorthite content in individual volcanic-rich samples generally varies from 20 to 40 percent but may be as high as 60 percent (sample 159827 , table 1). Moreover, the anorthite content of a sample represents the dominant plagioclase present, and anorthite may vary between grains in the same sample and even within individual zoned grains. In rocks having coarse plagioclase, the anorthite determined for the whole sample is in the usual 20 to 40 percent range, but that for the coarse fraction is appreciably higher, commonly 50 to 60 percent. Such high determinations of anorthite by X-ray probably are 10 percent or so too high because they are not of low-temperature plagioclase (see section on "Anorthite content of plagioclase"). Nevertheless, the anorthite content of many of the larger plagioclase grains, perhaps about 40 to 45 percent, must be on the high side of the usual range. Some of the variation in plagioclase composition probably reflects derivation from magmas of different composition, but the general tendency for larger crystals of plagioclase to be more calcic than smaller ones probably reflects Bowen's (1922) reaction series, whereby relatively large plagioclase phenocrysts that crystallize first tend to be more calcic than the later crystallized and smaller plagioclase crystals in the groundmass. Highly calcic feldspar is rarely detected in marine siltstone and never in the shale.

Chlorite is conspicuously abundant in many marine and nonmarine volcanic-rich siltstones. The chlorite is very unevenly distributed, with large amounts in only a few of the samples. For example, the mean content of 34 percent chlorite at Dearborn River (table 9 ) is due to 12-100 percent chlorite in 6 of the 21 samples; the mean content of 5 percent chlorite for other volcanic siltstone samples (table 9) is due to $12-45$ percent chlorite in 5 of the 45 samples; and the mean content of 11 percent chlorite for marine volcanic siltstone (table 6 ) is due to $30-80$ percent in 3 of the 14 samples. Other samples of volcanic-rich siltstone contain large amounts of chloritic mixed-layer clay such as that illustrated in figure $5 C$ and $5 D$; so much so that large proportions of chloritic clay in one form or another are a characteristic feature of many volcanic-rich siltstones, especially near the western volcanic source area. In thin section greenish chlorite is seen to have many modes of occurrence (fig. 16). These multiple modes, particularly the crack fillings, indicate that most of such large amounts of chlorite is probably 
authigenic. Acicular plates of chlorite surrounding larger detrital grains also are occasionally seen. Highly chloritic volcanic-rich siltstone and sandstone has a characteristic dark-brown or greenish-brown color, perhaps due to the chlorite and fine hematite dust (fig. 16).

The zeolite minerals, heulandite and laumontite, are found in nonmarine rocks almost exclusively but very erratically in volcanic-rich siltstone and sandstone at Dearborn River and Livingston (pl. 1, locs. 2 and 1). The 34 percent average zeolite content in volcanic-rich siltstone at Dearborn River (table 9) results from 4 to 70 percent in 14 of 21 such samples, and the 3 percent average zeolite at other localities (table 9) results from 4 to 40 percent zeolite in 10 of 20 such samples at Livingston. Heulandite tends to occur in small amounts in the more clayey rocks, whereas large amounts of laumontite occur in some sandstone having no more than about 25 percent total clay. Laumontite occurs almost invariably with a high proportion of chlorite or chloritic mixed-layer clay, but the reverse is not necessarily the case. Madsen and Murata (1970) described a similar laumontite-chlorite relation in tuffaceous sandstone of the Briones Sandstone of Miocene age in California, and they attribute the association to the following reaction:

montmorillonite + calcite $\rightarrow$ chlorite +laumontite $+\mathrm{CO}_{2}$.

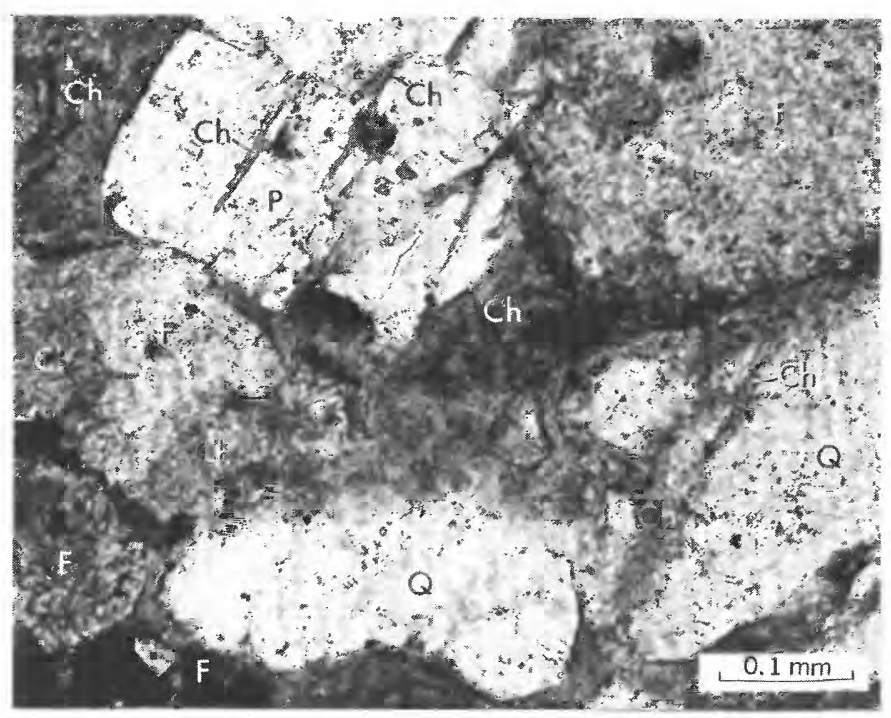

Figure 16.-Chloritized volcanic sandstone from the Lennep Sandstone, locality 6, sample 159777. Plain light. Chlorite (Ch) makes up much of the interstitial clay, fills fractures in plagioclase (P) and quartz $(\mathrm{Q})$, partly replaces ferric phenocryst in fine-grained volcanic rock fragment $(F)$ at upper right, and partly replaces finegrained rock fragment at center left. Interstitial clay also contains minute flakes of other clay minerals. The apparent opacity of the volcanic rock fragment in the lower left corner is due to hematite dust.
Calcite in the Pierre Shale is most common in the coarser grained rock. The presence of calcite, together with the greater permeability and circulation of solutions in sandstone, probably accounts for the chloritelaumontite occurrence only in sandstone equivalents of the Pierre Shale. Montmorillonite, in the pure form, is not common in the Pierre equivalents, but the everpresent mixed-layer clay or possibly unaltered tuff seem adequate sources of silicon ( $\mathrm{Si}), \mathrm{Al}$, and $\mathrm{Mg}$ in the reaction just mentioned. Such clay, however, is common in all sandstone, not just the volcanic-rich ones at Livingston and Dearborn River, so perhaps in the Pierre equivalents the reaction is one of calcite with tuff, rather than with clay.

Augite was recognized in volcanic-rich siltstone at Livingston (loc. 1) in amounts of 5 to 10 percent in 9 of 20 samples, and at Dearborn River (loc. 2) in amounts of 5 to 40 percent in 8 of 21 samples. Augite probably is still more widespread at Livingston and Dearborn River than is indicated by these numbers, as its detection limit, several percent, is high; but the geographic distribution of augite, even in small amounts, must be very restricted, because no augite-bearing samples were found at other localities. When augite is altered, the $\mathrm{Mg}^{+2}$ that is released may be incorporated into chlorite; the ferric grain in figure 16 may well have been augite. The $\mathrm{Ca}^{+2}$ and $\mathrm{Al}^{+3}$ from augite also may account for development of laumonite rather than heulandite, since laumontite has the higher $\mathrm{Al} / \mathrm{Si}$ and $\mathrm{Ca} / \mathrm{Na}+\mathrm{K}$ ratio.

Total mineral percentages of most lithologic groups are close to 100 percent-generally within 5 percent (table 6). The exceptions are all volcanic rich-both the marine and nonmarine volcanic-rich siltstone and the group of 53 nonmarine volcanic-rich rocks from Dearborn River (loc. 2). The possibility that amorphous glassy material caused the deficient totals was checked by boiling three such samples in $\mathrm{NaOH}$, which dissolves such amorphous material (Hashimoto and Jackson, 1960); no appreciable amounts were dissolved. Small amounts of several undetected minerals could account for some of the deficiency. In this connection, Viele and Harris (1965) reported epidote, biotite, hornblende, and magnetite at Dearborn River, and Roberts (1972) reported pyroxene, amphibole, biotite, and magnetite at Livingston, but most of these minerals are not detected by X-ray. However, as will be seen, though these minerals are present in heavymineral separates from several samples of Pierre Shale, the heavy minerals are so small a part of the total sample that they could not account for the deficient totals. Many highly chloritic volcanic-rich sandstone samples give deficient totals; such chlorite seems to give 020 reflections, used for quantitative estima- 
tion of total clay, that are weaker than those from mixed-layer illite-smectite and small amounts of other clays that have been used as standards for the Pierre Shale.

\section{BENTONITE}

Bentonite, as the term is used in this report, is a rock derived from wind-transported ash, predominantly vitric in character, that fell into a body of water, either an ocean or a lake, and then settled to form a discrete bed. The glassy parts are altered most commonly, but not necessarily, to smectite, and phenocrysts in the original ash usually are preserved. The rock is considered bentonite even if a limited amount of other material was mixed with the ash during settling or during reworking by bottom currents, or if the bed has been extensively replaced by minerals other than smectite, as long as the ash-fall origin is recognizable. One percent or less of the volume of the Pierre Shale and its equivalents is bentonite, thus defined. Most of the rest of the Pierre and equivalents contain large amounts of volcanic debris and thus may be called bentonitic or volcanic rich; it is not bentonite, however, because the volcanic material was transported extensively in water and, for the most part, was mixed with nonvolcanic components.

Smectite is the major constituent of the Pierre bentonite samples, and montmorillonite-type layers generally are at least twice as frequent as beidellitetype layers (sample A, table 10). Phenocrysts of plagioclase and biotite from the original vitric tuff are common nonclay minerals, and the abundance of one commonly parallels that of the other. The phenocrysts were larger than most of the associated glassy particles and are most abundant in nonmarine bentonite samples (table 6) near the source. Phenocrysts also are concentrated in the lower part of many bentonite beds far from the source. Potassium feldspar was detected in only 6 of 136 bentonite samples examined.

The plagioclase composition of the bentonite

TABLE 10.-Mineralogical composition of typical bentonite sample and of some unusual bentonite samples from the Pierre Shale and equivalent rocks

[N.d., not determined; N.a., not applicable]

\begin{tabular}{|c|c|c|c|c|c|c|c|c|c|c|c|c|c|c|c|}
\hline Sample & A & B & c & D & E & F & G & H & I & $\mathrm{J}$ & K & $\mathrm{L}$ & M & $\mathrm{N}$ & 0 \\
\hline $\begin{array}{l}\text { Locality name and no. and } \\
\text { analytical sample no. or strati- } \\
\text { graphic unit .................... }\end{array}$ & 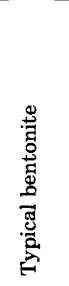 & 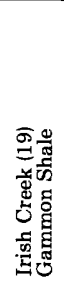 & 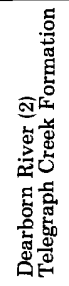 & 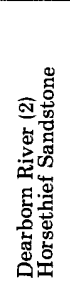 & 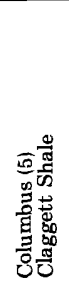 & 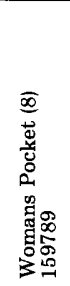 & 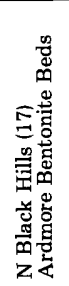 & 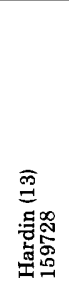 & 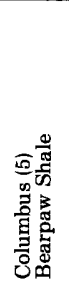 & 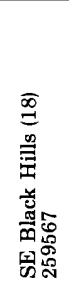 & 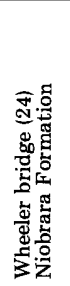 & 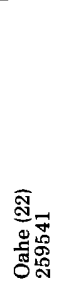 & 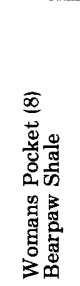 & 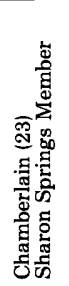 & 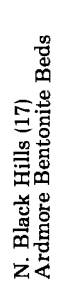 \\
\hline
\end{tabular}

Proportion of layers in mixed-layer clay (percent)

\begin{tabular}{|c|c|c|c|c|c|c|c|c|c|c|c|c|c|c|c|}
\hline $\begin{array}{l}\text { Illite } \ldots \ldots \ldots \ldots \ldots \\
\text { Beidellite } \ldots \ldots \ldots \ldots \\
\text { Montmorillonite . . . }\end{array}$ & $\begin{array}{r}0 \\
5-40 \\
60-95\end{array}$ & $\begin{array}{l}0 \\
\text { N.d. } \\
\text { n.d. }\end{array}$ & $\begin{array}{r}75 \\
25 \\
0\end{array}$ & $\begin{array}{r}0 \\
80 \\
20\end{array}$ & $\begin{array}{l}15 \\
35 \\
50\end{array}$ & $\begin{array}{r}0 \\
15 \\
85\end{array}$ & $\begin{array}{l}0 \\
\text { N.d. } \\
\text { n.d. }\end{array}$ & $\begin{array}{r}0 \\
5 \\
95\end{array}$ & $\begin{array}{r}0 \\
40 \\
60\end{array}$ & $\begin{array}{r}0 \\
20 \\
80\end{array}$ & $\begin{array}{l}0 \\
\text { N.d. } \\
\text { n.d. }\end{array}$ & $\begin{array}{l}0 \\
\text { N.d. } \\
\text { n.d. }\end{array}$ & $\begin{array}{r}0 \\
50 \\
50\end{array}$ & $\begin{array}{l}\text { N.a. } \\
\text { n.a. } \\
\text { n.a. }\end{array}$ & $\begin{array}{l}\text { N.a. } \\
\text { n.a. } \\
\text { n.a. }\end{array}$ \\
\hline
\end{tabular}

Proportion of clay minerals in total clay (percent)

\begin{tabular}{|c|c|c|c|c|c|c|c|c|c|c|c|c|c|c|c|}
\hline Mixed layer .......... & 100 & 30 & 100 & 80 & 95 & 100 & 100 & 100 & 98 & 100 & 100 & 100 & 90 & 0 & 0 \\
\hline Illite $\ldots \ldots \ldots \ldots \ldots$ & 0 & 0 & 0 & 0 & 0 & 0 & 0 & 0 & 0 & 0 & 0 & 0 & 0 & 0 & 0 \\
\hline Chlorite........... & 0 & 0 & 0 & 20 & 0 & 0 & 0 & 0 & 0 & 0 & 0 & 0 & 0 & 0 & 0 \\
\hline Kaolinite $\ldots \ldots \ldots \ldots$ & 0 & 70 & 0 & 0 & 5 & 0 & 0 & 0 & 2 & 0 & 0 & 0 & 10 & 0 & 0 \\
\hline
\end{tabular}

\begin{tabular}{|c|c|c|c|c|c|c|c|c|c|c|c|c|c|c|c|}
\hline \multicolumn{16}{|c|}{ Proportion of minerais in total sample (percent) } \\
\hline 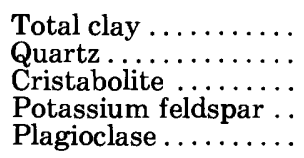 & $\begin{array}{r}80-100 \\
0-5 \\
0 \\
0 \\
0-10\end{array}$ & $\begin{array}{r}100 \\
0 \\
0 \\
0 \\
0\end{array}$ & $\begin{array}{r}80 \\
15 \\
0 \\
0 \\
4\end{array}$ & $\begin{array}{r}30 \\
23 \\
0 \\
0 \\
0\end{array}$ & $\begin{array}{r}70 \\
3 \\
0 \\
0 \\
10\end{array}$ & $\begin{array}{r}65 \\
25 \\
0 \\
0 \\
5\end{array}$ & $\begin{array}{r}50 \\
35 \\
0 \\
0 \\
0\end{array}$ & $\begin{array}{r}85 \\
5 \\
10 \\
0 \\
0\end{array}$ & $\begin{array}{r}25 \\
5 \\
0 \\
0 \\
50\end{array}$ & $\begin{array}{r}80 \\
0 \\
0 \\
1 \\
1\end{array}$ & $\begin{array}{r}20 \\
0 \\
0 \\
75 \\
0\end{array}$ & $\begin{array}{r}40 \\
0 \\
0 \\
0 \\
0\end{array}$ & $\begin{array}{r}15 \\
10 \\
0 \\
0 \\
0\end{array}$ & $\begin{array}{l}0 \\
0 \\
0 \\
0 \\
0\end{array}$ & $\begin{array}{l}0 \\
0 \\
0 \\
0 \\
0\end{array}$ \\
\hline 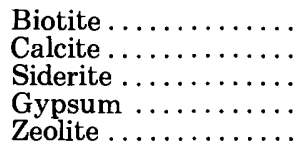 & $\begin{array}{r}0-10 \\
0 \\
0 \\
0 \\
0\end{array}$ & $\begin{array}{l}0 \\
0 \\
0 \\
0 \\
0\end{array}$ & $\begin{array}{l}0 \\
1 \\
0 \\
0 \\
0\end{array}$ & $\begin{array}{r}0 \\
5 \\
0 \\
0 \\
20\end{array}$ & $\begin{array}{r}2 \\
15 \\
0 \\
0 \\
0\end{array}$ & $\begin{array}{l}1 \\
0 \\
0 \\
1 \\
0\end{array}$ & $\begin{array}{r}0 \\
0 \\
0 \\
0 \\
15\end{array}$ & $\begin{array}{l}0 \\
0 \\
0 \\
0 \\
0\end{array}$ & $\begin{array}{r}15 \\
0 \\
0 \\
5 \\
0\end{array}$ & $\begin{array}{l}2 \\
2 \\
0 \\
2 \\
0\end{array}$ & $\begin{array}{l}0 \\
0 \\
0 \\
3 \\
0\end{array}$ & $\begin{array}{r}0 \\
0 \\
60 \\
0 \\
0\end{array}$ & $\begin{array}{r}0 \\
75 \\
0 \\
0 \\
0\end{array}$ & $\begin{array}{r}0 \\
0 \\
0 \\
0 \\
100\end{array}$ & $\begin{array}{r}0 \\
0 \\
0 \\
0 \\
35\end{array}$ \\
\hline
\end{tabular}


samples, as discussed in connection with table 4 in the section on "anorthite content of plagioclase", is mostly calcic andesine $\left(\mathrm{An}_{40-45}\right)$ and most seems to be of an intermediate or high-temperature thermal state, which is in contrast to the low-temperature oligoclase to andesine $\left(\mathrm{An}_{20-40}\right)$ in other rocks of the Pierre and equivalents (table 6). In bentonite, only about half of the plagioclase is twinned, the twinning is more widely spaced than in the other volcanic-rich rocks, and many of the twin boundaries appear fuzzy. Zoning of plagioclase is rarer and appears weaker in bentonite than in other volcanic-rich rocks. More poorly developed twinning and zoning as well as the high-temperature thermal state of plagioclase in bentonite might be expected from more rapid cooling of magma at an earlier stage of crystallization than for the material in other volcanic-rich sediment.

Quartz was detected in about 40 percent of the bentonite samples, most commonly in amounts of only a few percent, in contrast to the 10 to 30 percent in most shale. Quartz is not concentrated in the lower parts of bentonite beds, and in thin section large grains of quartz are sparse. Hence, quartz probably did not occur as phenocrysts in most of the original vitric ash. Some quartz may have been detrital in origin and was mixed with the vitric ash at the time of deposition. It seems more likely, however, that most of the quartz, like the clay, is a secondary product of ash devitrification.

Sample A in table 10 is representative of 90 percent or more of the bentonites in the Pierre and its equivalents. More or less unusual mineralogical composition are illustrated in columns $\mathrm{B}$ to $\mathrm{O}$ in table 10 .

Kaolinite is a fairly common variation from the smectite composition of typical bentonite in the Pierre Shale. Kaolinite, usually in small amounts (samples E, $I$, and $M$, table 10), was found in 20 of the bentonite samples. In only one sample, however, is kaolinite the dominant clay mineral (sample B, table 10). In such highly kaolinitic bentonite, the smectite commonly has moderately stable Al-hydroxide interlayers, similar to the clay illustrated in figure $5 B$ or $D$, that make distinction between beidellite- and montmorillonitetype layers difficult. Where the distinction can be made, as in several such bentonite samples from the Sharon Springs Member of the Pierre in Kansas (Gill, Cobban, and Schultz, 1972, table 4), beidellite-type layers usually are dominant. Such an Al-rich mineral assemblage is similar to that described for some coaly shale (p. B16), in which smectite seems to have been altered to kaolinite by organic acid solutions. Kaolinite-rich bentonite in organic-rich rocks thus has some similarity to tonsteins in coal beds. The kaoliniterich tonsteins are also thought to be the result of alteration of volcanic ash by organic acids (Spears and Rice, 1973).

Mixed-layer clay quite different from the usual montmorillonite-beidellite in bentonite (samples C, D, and $\mathrm{E}$, table 10) is mostly from the Dearborn River locality, and all of the several bentonites sampled from this locality are unusual in one way or another. Most commonly, their mixed-layer clay has an exceptionally high proportion of illite-type layers (sample C, table 10) like that in the shale and siltstone from Dearborn River (tables 6 and 9). One sample (D, table 10) contains smectite with no illite-type layers, but has an exceptionally high proportion of beidellite layers; this is the only bentonite sample in which beidellite is clearly dominant and is the only one having chlorite. In a few samples, like $M$ in table 10, beidellite and montmorillonite layers are about equally abundant. Similarly unusual composition of other bentonite at Dearborn River and of the associated shale is shown elsewhere (Schultz, 1978, table 6). Only 3 of the 136 bentonite samples analyzed for the present study, other than from Dearborn River, contain illitic mixed-layer clay (sample E, table 9; Schultz, 1978, table 6, Shawmut and Columbus, locs. 5 and 6 ). Such illite-type layers result from diagenetic alteration; but, except in the Dearborn River samples and the other three bentonite samples, such alteration seems not to have appreciably affected the clays in most rocks of Pierre age.

Quartz, although not abundant in most bentonite, was found in amounts of 10 to 35 percent in 16 samples (for example, samples C, D, F, G, and M, table 10). Some of these samples are hard and could be cemented by the quartz, although all such hard bentonites also contain zeolite that could be the cement. Other samples are soft, even though they contain as much as 25 percent quartz (sample $F$, table 10). None of the quartz was found as phenocrysts; all must be in the groundmass and result from devitrification of the ash. In most bentonite (sample A, table 10), however, excess $\mathrm{SiO}_{2}$ expected from ash devitrification has not stayed in the bentonite.

Cristobalite was found in only two bentonite samples (for example, sample $H$, table 10) and thus is not nearly as common in bentonite of the Pierre Shale and its equivalents as in many other bentonite beds (Grim, 1968, p. 567).

Plagioclase is abundant commonly at the base of bentonite beds. Bentonite from the Bearpaw Shale at Columbus (sample I, table 10) containing 50 percent plagioclase $\left(\mathrm{An}_{55}\right.$ by $\mathrm{X}$-ray) is unusual because it represents the entire $0.5 \mathrm{ft}$-thickness of the bed. It must result from some unusual winnowing of the ash fall by ocean currents that disbursed the finer grained 
part of the ash fall elsewhere.

Sample 259567 ( $\mathrm{J}$, table 10) is one of the few bentonites in the Pierre Shale containing sufficient potassium feldspar to be detected by X-ray analysis. This sample also contains exceptionally sodic plagioclase phenocrysts $\left(\mathrm{An}_{20-30}\right.$, table 4$)$. The original volcanic ash, perhaps latitic, was apparently more acidic than the ash that formed most bentonite beds in the Pierre Shale.

Potassium feldspar is the dominant mineral in only one bentonite sample collected $(K$, table 10$)$, which is from a 1-in. thick hard bed $10 \mathrm{ft}$ below the top of a high chalk bluff of the Niobrara Formation on Randall Creek, $14 \mathrm{mi}$ southeast of the Wheeler bridge locality (24). From X-ray analysis, the feldspar is a very pure monoclinic potassium feldspar containing no discernible albite in solid solution. From thin section, the sample is very fine grained, the grains mostly about 0.001 $\mathrm{mm}$ or less in diameter. The potassium feldspar is interpreted to be authigenic adularia. The parent ash must have been exceptionally potassium rich, probably rhyolitic.

The sideritic bentonite (sample L, table 10), another one-of-a-kind example, is from a 2-in.-thick bentonite bed in the upper part of the Virgin Creek Member of the Pierre. It has a granular texture and was assumed, when sampled, to be an unaltered ash. The sideritic bentonite grades laterally within $100 \mathrm{ft}$ into normal bentonite (sample 259542, table 1) composed entirely of smectite. The extremely high iron and carbonate content must have resulted from diagenetic solutions, as they could not be original components of an ash. Field relations give no clue as to why siderite should have replaced the bentonite bed at this particular place. A few bentonite beds are also largely replaced by calcite (sample $\mathrm{M}$, table 10), and smaller amounts of calcite are not uncommon in other bentonite samples (table 6).

Most of the highly zeolitic bentonite sampled from the Pierre Shale occurs in one or two beds in the lower part of the Sharon Springs Member along the Missouri River from about $20 \mathrm{mi}$ north to $20 \mathrm{mi}$ south of Chamberlain (loc. 23; sample N, table 10) and again in the Niobrara area (loc. 25). The beds range from about 0.1 to 6 in. in thickness and are composed mostly or entirely of clinoptilolite. The beds, like samples $\mathrm{G}$ and $\mathrm{O}$ in table 10, are the Ardmore Bentonite Beds. Several beds of bentonite from Dearborn River (loc. 2; sample D, table 10) contain 20 to 25 percent heulandite. (The distinction between heulandite and clinoptilolite is based on the higher thermal stability of the latter; Mumpton, 1960.) One sample from bed " $\mathrm{H}$ " of Knechtel and Patterson (1955, 1956), in the Gammon
Member of the Pierre Shale on the northeast flank of the Black Hills, contains about 75 percent phillipsite and is the only known occurrence of this zeolite in the Pierre Shale. Interestingly enough, analcite, the most common zeolite in bentonite beds in the Mowry Shale (Slaughter and Earley, 1965) of Early Cretaceous age, was not found in the bentonite beds of the Pierre.

The Pedro bentonite pit (samples $G$ and $O$, table 10) is of historical interest because it is the locality of the first clinoptilolite reported in bentonite (Bramlette and Posjnak, 1933, and later by Deffeyes, 1959). Sample O in table 10 is also of interest because it apparently contains large amounts of the original unaltered ash. The only mineral detected in the sample is clinoptilolite, estimated from X-ray analysis to be about one-third of the sample. The thin section (fig. 17A) shows classic $Y$-shaped shards better than any seen from other bentonite samples from the Pierre Shale and equivalents. With crossed polarizers (fig. 17B) birefrigent clinoptilolite is seen to rim the shards, and the isotropic black areas correspond to the two-thirds or so of the sample that is the original unaltered glass. Considering the largely unaltered state of the ash, sample $\mathrm{O}$ might not strictly be bentonite as defined at the beginning of this section; nevertheless, the sample is included in table 10 because it is the only clear example of unaltered ash recognized in this study.

Zeolite minerals are fairly common in bentonite of many ages, but, as summarized by Reynolds (1970, p. 835), the zeolite-montmorillonite relationship is complex. Why one or the other forms is not generally clear. In the Pierre Shale the only evidence we saw that may indicate a control of the alteration product is the mode of occurrence of the clinoptilolitic bentonite in the Missouri River area. The zeolitic bentonite beds have sharp contacts, both lower and upper, except that the upper part of some thicker beds show extensive burrowing (fig. 18). Also the zeolitized bentonite beds occur in a part of the Pierre Shale, the Sharon Springs Member, that is very thin (pl. 1) and has numerous diastems. The diastems are marked by trash zones (Schultz, 1964, p. B6) composed of phosphatic debris, bone and shale fragments, organic matter, sulfate minerals formed from oxidation of pyrite, and fragments of zeolitized bentonite. Thus, the ash must have been zeolitized and lithified in close contact with stagnant seawater before it was partly eroded and redeposited as fragments in trash zones. Montmorillonitic bentonite, in contrast, commonly shows little evidence of burrowing, the upper contact is characteristically gradational (see section on "Shale directly above bentonite") and fragments of it are rare in trash zones, which indicates that sedimentation was con- 

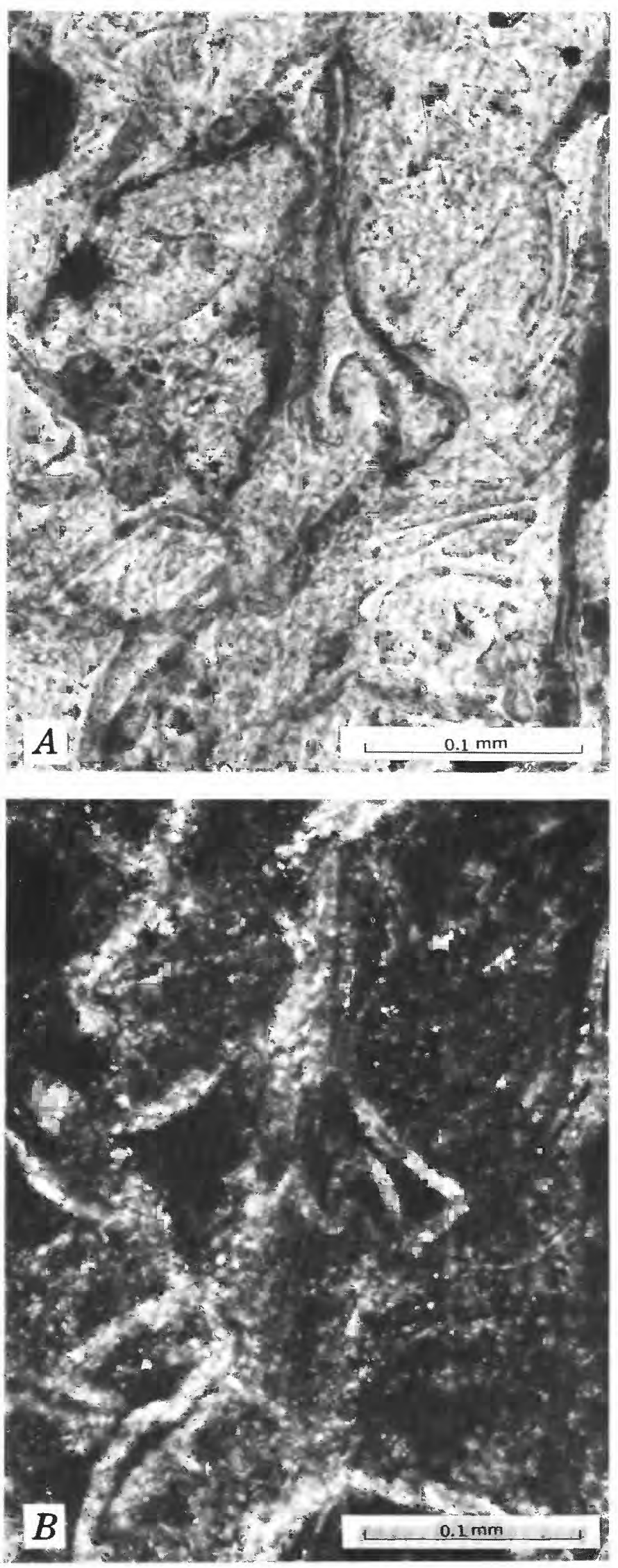

tinuous after the ash fall, and alteration to montmorillonite must have occurred after some burial and isolation from the seawater.

Much of the foregoing description of bentonite in the Pierre Shale and its equivalents concerns bentonite beds of unusual composition. Nearly half of the samples in table 10 are one-of-a-kind samples that, except for their unusual appearance which frequently suggested that they might be unaltered ash, probably would never have been sampled. Therefore, as a concluding note we wish to emphasize how little most bentonite differs from the norm of sample A in table 10 and how much this norm for bentonite-smectitic clay containing no illite-type interlayers, the absence or near absence of other clay minerals, the low quartz content, and the more calcic high-temperature plagioclase-differs from that of shale.

\section{REGIONAL AND STRATIGRAPHIC VARIATION}

The average mineral content at individual localities of each of the six fossil zones (fig. 19) shows regional and stratigraphic variations of mineralogy. The largest arrow, between localities 1 and 2 in figure $19 A$, shows the direction of sediment flow from the Elkhorn Mountains volcanic center, and the smaller arrows indicate less important sources of sediment. In addition to the three main geographic areas separated by dotted lines-West, Middle, and East-a fourth subarea, consisting of localities 27 and 28 , is separated from the eastern group. This subarea includes so few samples that averages are omitted for four of the fossil zones; it is separated because the 16 samples from fossil zone 5 (fig. 19B), which make up three-fourths of the samples from the subarea, are very siliceous and are not representative of the zone or of this easternmost subarea as a whole (pl. 1). The mineral sequence of figure $19 C-T$ is in the same order and generally in the same units as in the tables and other figures: layers in the mixed-layer clay (fig. $19 C-E$ ); clay minerals as percent of total clay (fig. $19 F-I$ ); and total clay and other minerals (fig. $19 J-T)$ mostly as percent of the sample, except that, for the less common minerals (fig. $19 L, Q-T$ ), the minimum and maximum percentage recognized is given and is followed in brackets by the percentage of samples in which the mineral was recognized.

FIGURE 17.-Volcanic ash partly altered to clinoptilolite from the Ardmore Bentonite Beds in the Pedro bentonite pit, sample $O$ in table 10, thin section G58-6-4B. Photographed areas are identical, $A$ in plain light and $B$ with crossed polarizers. Birefringent clinoptilolite rims shards, but most of the material is isotropic glass. 
ILLITE, BEIDELLITE, AND MONTMORILLONITE IN MIXED-LAYER CLAY

Proportions of the three component layers of mixedlayer clay (fig. $19 C-E$ ) are interrelated. The proportion of beidellite-type layers varies little (fig. 19D), and illite and montmorillonite tend to be complementary with wide variation between localities and fossil zones. These variations show little pattern with two exceptions.
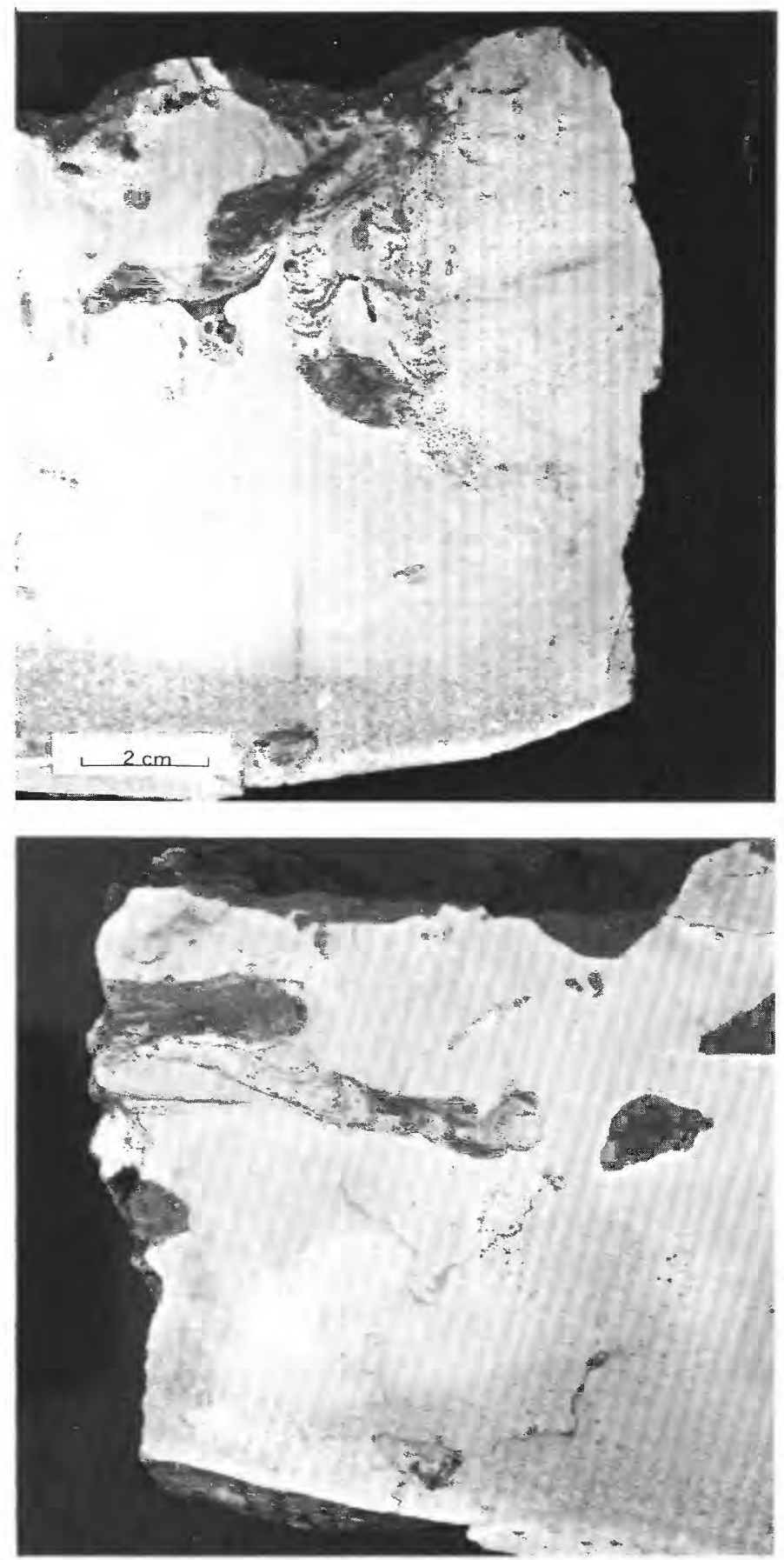

The first and most consistent variation in the mixedlayer clay is at Dearborn River (loc. 2) where the proportion of illite-type layers is generally 20 to 30 percent higher than at most other localities, and montmorillonite-type layers are correspondingly few, especially in the lower three fossil zones. As mentioned previously, clay at Dearborn River is altered by a process similar to depth metamorphism.

The second and less consistent pattern is the general tendency for mixed-layer clay in the lower fossil zones to be more illitic. This feature is best shown throughout the area in fossil zone 1; the only exceptions are in the northwest, where, at localities 4 and 9 , the 31 - and 30-percent proportions of illite-type layers are below average (fig. 19C). The highly illitic mixed-layer clay is best developed in the lower three fossil zones along the Missouri River (locs. 22-26); here this characteristic is so consistent that it has been used as one mineralogical criteria for correlation of units (Schultz, 1965). The moderately high proportion of montmorillonite-type layers of 20 and 22 percent in fossil zone 2 at two of these localities is because the unit is so thin and the bentonite beds are so numerous that many shale samples must come from just above bentonite beds; the ash fall that produced the bentonite bed also contributed to exceptionally montmorillonitic shale immediately above bentonite. The remarkable feature of such mixed-layer clay in fossil zone 2 , considering the frequency of bentonite beds, is that the clay is not more montmorillonitic than it is.

\section{CLAY MINERALS IN TOTAL CLAY-MINERAL FRACTION}

Mixed-layer clay makes up at least two-thirds of the clay-mineral fraction at all but a few localities (fig. $19 F)$. Its proportion tended to be low during times of marine regression in fossil zones 1,3 , and 6 and tended to be slightly higher to the east during times of marine transgression in fossil zones 2,4 , and 5, thereby reflecting the fine grain size of the mixed-layer clay relative to the other three common clay minerals and the consequent tendency to be transported far from the western source. However, the proportion of mixedlayer clay is particularly high at some western localities, notably Livingston and Dearborn River (locs. 1 and 2), due to exceptionally large amounts of

Figure 18.-Invertebrate borings in the top side of zeolitized bentonite bed from the Sharon Springs Member of the Pierre Shale on the northeast side of South Dakota Highway 47 bridge across Crow Creek, about 12 mi north of Chamberlain, S. Dak. (loc. 23; sample N, table 10). Photographs are of opposite sides of the same block. Both photographs are at same scale. 
altered volcanic debris from the nearby Elkhorn Mountains volcanic center (large arrow, fig. 19A). Many samples from these two localities contain no other clay mineral. The low proportion of mixed-layer clay at Elk Basin and Salt Creek (locs. 7 and 10) in fossil zone 3 probably indicates influx of nonvolcanic detritus from the southwest (fig. 19A), and the relatively low content of mixed-layer clay at Cut Bank (loc. 4) during the time of fossil zones $1,4,5$, and 6 may indicate a minor influx of nonvolcanic debris around the north end of the Elkhorn Mountains volcanic center (fig. 19A).

Illite distribution is generally fairly uniform across the area (fig. 19G). The main exception is at Dearborn River (loc. 2), particularly above fossil zone 1, where the volcanic-rich debris seems to be almost undiluted by illite-bearing nonvolcanic detritus. Nearby localities in the eastward transportation direction from Dearborn River also have small illite contents, particularly so in the rocks representative of times of marine regression in fossil zones 1,3 , and 6 when the nonmarine rocks extended farthest into the basin (pl. 1). At such times the illite-bearing nonvolcanic detritus from the northwest and southwest (fig. 19A) tended to be carried farther eastward into the basin, thereby producing the eastward increase of illite in fossil zones 1 , 3 , and 6 .

Chlorite distribution (fig. 19H), though generally quite uniform as for illite, shows weak regional trends different from illite. Unlike illite, chlorite does not increase appreciably in abundance from west to east in fossil zones 1,3 , and 6 ; in fossil zones 4,5 , and 6 chlorite shows a marked eastward decrease. The different distributions of chlorite and illite are due to large amounts of authigenic chlorite in some volcanicrich siltstones and sandstones in the west (paragraph on chlorite in section on "Volcanic-rich siltstone"), notably in upper fossil zones at Livingston, Dearborn River, and Columbus (locs. 1, 2, and 6, fig. 19H). The 5 -percent chlorite in the lower four fossil zones at Salt Creek (loc. 10) probably reflects sediments from the southwestern detrital source.

Kaolinite (fig. 19I) has several trends. Kaolinite abundance generally decreases eastward, commonly from 10 to 20 percent in the west to a few percent of the clay-mineral fraction in most eastern localities. The major exception is the volcanic-rich sediments in the west, notably at Livingston and Dearborn River (locs. 1 and 2), which contain little or no kaolinite. Sediments deposited during marine regression in fossil zones 1,3 , and 6 tend to contain kaolinite in amounts slightly above average, probably reflecting a relatively large grain size. Also, kaolinite tends to be most abundant in all of the lower three fossil zones, especially in the east. Very high kaolinite amounts in several fossil zones at
Elk Basin and Salt Creek (locs. 7 and 10) probably represent sediments from the southwest. Finally, above-average amounts of kaolinite at some of the southeasternmost localities in fossil zones $2,3,5$, and 6 may be one of the few indications of material derived from the eastern margin of the basin (fig. 19A), such as the thick kaolinitic residuum widely developed in Minnesota during Late Cretaceous time (Parham, 1970).

\section{MINERALS IN THE TOTAL SAMPLE}

Clay minerals (fig. $19 \mathrm{~J}$ ) make up an average of about 40 to 50 percent of samples in the west and about 65 to 70 percent in the east. Exceptions are those in which the composition is diluted by large amounts of calcite, such as in the Niobrara Formation of fossil zone 1 in the southeast. Abundance of clay is lowest in rocks representative of periods of marine regression in fossil zones 1,3 , and 6.

Quartz abundance (fig. 19K) averages about 25 percent in the west and 15 to 20 percent in the east. This regional variation is, as expected, opposite that of the clay minerals, because these are the two most common minerals in the Pierre Shale and their abundance must be complementary. However, quartz content does not decrease uniformly from west to east; in fact, maximum amounts in four of the six fossil zones occur in the central area (fig. 19K). This occurrence is because of the large amounts of authigenic clay and the low quartz content, commonly 15 to 20 percent, in many volcanic-rich samples in the western area, and also because the central area is the region across which shorelines tended to fluctuate so that nearshoremarine sandstone and siltstone is common there. In addition, sediments from the southwestern source area that are more quartz-rich than those from the Upper Cretaceous Elkhorn Mountains volcanics increased the quartz content at Salt Creek, Elgin Creek, and WyolaParkman (locs. 10-12) in the central area, as well as at Elk Basin (loc. 7) in the western area. Quartz, as expected, does decrease consistently from the central to the eastern area, but not as much as one might expect from the fine grain size of the offshore-marine shale. As mentioned in the section on minerals in "Environment of deposition", this small decrease is because of the extremely fine grain size of much of the quartz, so that it was in hydraulic equilibrium with clay-mineral particles and could be transported several hundred miles by currents across the Pierre sea. Coarse quartz grains, however, do occur in the Crow Creek Member of the Pierre in the Missouri River area (fig. 12), just above the unconformity at its base (pl. 1), but these clearly came from a nearby eastern source (Crandell, 1952). Stratigraphically quartz tends to be most abun- 
dant in rocks representative of periods of marine regression in fossil zones 1 and 3, but not particularly so in fossil zone 6.

Cristobalite (fig. 19L) is found in detectable amounts of 5 percent or more only along the Missouri River and in the eastern Dakotas, almost entirely in siliceous shale of the DeGrey and Virgin Creek Members of the Pierre (fossil zones 4 and 5). The abundance and frequency of occurrence generally decreases to the south and parallels the decrease in hardness of these shales.

Average amounts of potassium feldspar in the three geographic regions (fig. 19M) range from less than 1 percent to about 2 percent, and the average at few individual localities exceeds 3 percent. Most samples in which potassium feldspar was recorded contain only a barely detectable amount (about 1 percent), and only 5 percent of the samples, mostly sandstone, contain 5 percent or more. The 58 percent of the samples in which potassium feldspar was not detected (table 5) enter the statistics as zero values, so many of the averages are a fraction of a percent (fig. 19M). Distribution of potassium feldspar is much like that of quartz: a weak general west-to-east decrease, but with maximum amounts occurring most frequently in the middle geographic area; most abundant in rocks representative of periods of marine regression in fossil zones 1, 3, and 6; many high mean values at Elk Basin and Salt Creek (locs. 7 and 10, fig. 19M) from a southwestern source. Most potassium feldspar apparently is not of volcanic origin, first, because potassium feldspar is sparse in volcanic-rich sediment, and, second, because most potassium feldspar in the Pierre Shale is microcline where varieties could be distinguished. The distribution of potassium feldspar is generally in accord with the concept of relatively coarse-grained detrital potassium feldspar entering the basin north and south of the Elkhorn Mountains volcanic center, being deposited mostly near the shoreline, and becoming progressively less abundant in the fine-grained offshore-marine shale. A major and obvious exception, however, is in the southeast in fossil zone 2, where several percent of potassium feldspar is characteristic of the organic-rich shale of the Sharon Springs Member. The maximum amount measured is only 10 percent, consequently the feldspar cannot be characterized as well as the diagenetic monoclinic feldspar that is the major component in one bentonite sample ( $\mathrm{K}$, table 10$)$. The X-ray pattern of much of the potassium feldspar in the organic-rich shale also is clearly of monoclinic feldspar, however. The concentrations of monoclinic potassium feldspar, because they are so far from the volcanic source, are unlikely to be of volcanic sanidine or orthoclase. Nor does quartz (fig. 19K) show any parallel increase, as would be expected if the potassium feldspar concentrations were detrital, either from the east or west. Therefore, their occurrence and their apparent crystallographic similarity to diagenetic potassium feldspar in the bentonite indicate to us that the concentrations of potassium feldspar in the Sharon Springs Member in fossil zone 2 along the Missouri River must be authigenic. Smaller amounts of monoclinic potassium feldspar also occur in higher fossil zones in the southeast.

Plagioclase (fig. 19N) shows the strongest and most consistent east-west variation of all the minerals in rocks of Pierre age, with 5 to 20 percent found in most of the volcanic-rich western sediment and barely detectable amounts in most eastern shale. Most of the plagioclase originates from the Elkhorn Mountains volcanic center, and because plagioclase is easily weathered during erosion, transportation, and deposition, especially in fine grains, most of the surviving coarse plagioclase either remained behind with the continental sediment or was deposited with the coarsegrained nearshore-marine rock. Weathering was particularly effective in removal of the more calcic plagioclase, which is now found only in bentonite and a few volcanic-rich samples.

Calcite (fig. 19O) is abundant in the eastern area in the marl of the Niobrara Formation in fossil zone 1, in the Gregory Member of the Pierre Shale in fossil zone 3 , in the Crow Creek Member of the Pierre in fossil zone 4, and in the Mobridge Member of the Pierre in fossil zone 6 . In most shale samples, however, even small amounts of calcite are rare. Calcite is sporadically present as intergranular cement in the coarser nearshore-marine sediment of the middle geographic area and also in much of the coarser continental sediment that is not obviously volcanic rich.

Dolomite (fig. 19P) is strongly concentrated in the nearshore-marine rock of the middle geographic area and in localities just to the east during times of marine regression (fossil zones 3 and 6) and just to the west during times of marine transgression (fossil zones 2, 4, and 5). Dolomite is absent in the volcanic-rich sediment of the west, although several percent occurs in coarse-grained samples that are not obviously volcanic rich. The fairly large amounts shown in fossil zone 4 in the eastern area are all in sandy marl of the Crow Creek Member of the Pierre Shale (figs. 12 and 13) that was deposited during a local shallowing of the sea, so that environmentally the rocks are similar to other dolomitic shallow-marine sediment (fig. 8). As previously shown, the dolomite is primary and authigenic.

Gypsum, jarosite, and pyrite have similar distributions (fig. 19Q, $R$, and $S$ ), because the sulfate minerals 


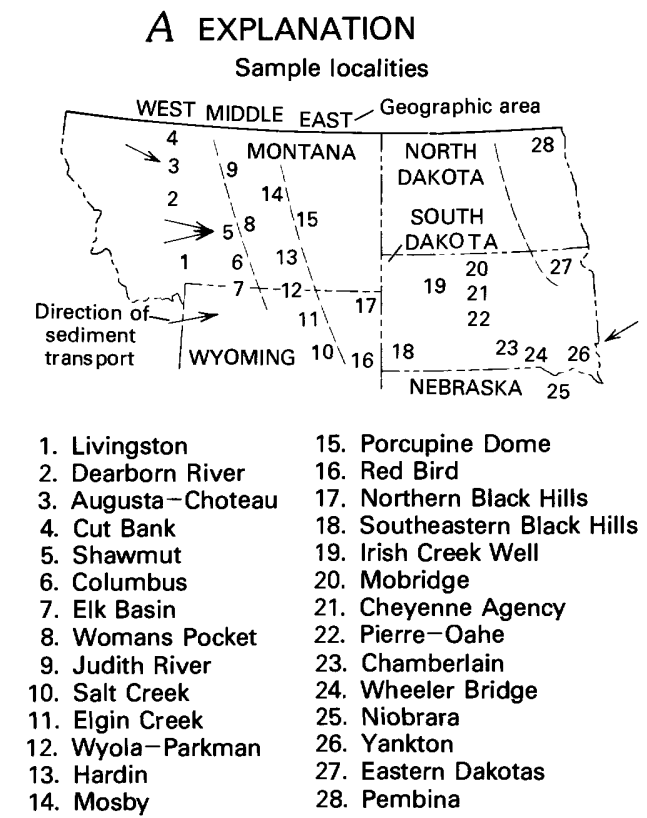

Number of samples (part $B$ )

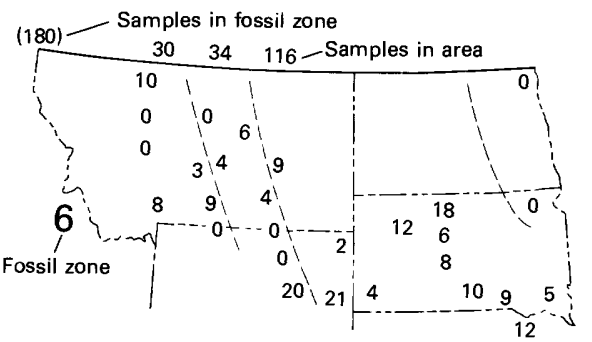

Amounts (Parts C-K, M-P)

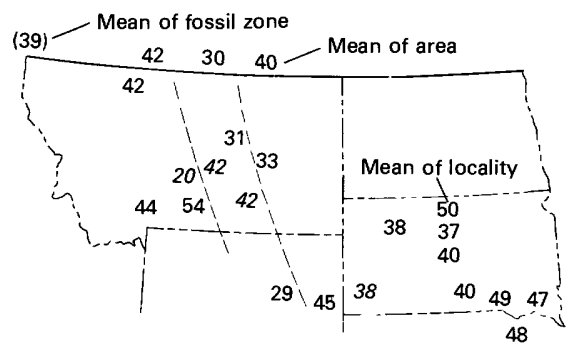

Amounts (Parts L, Q-T)

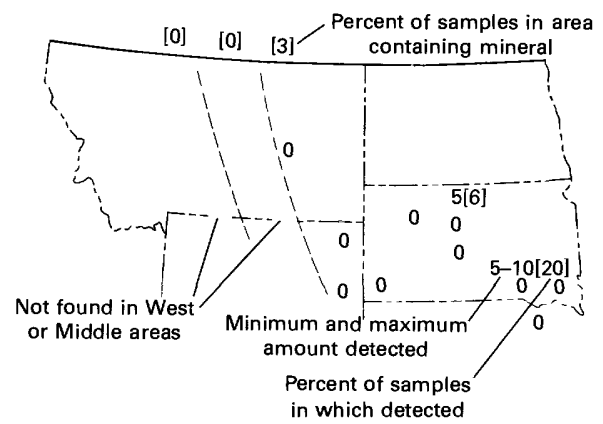

$B$
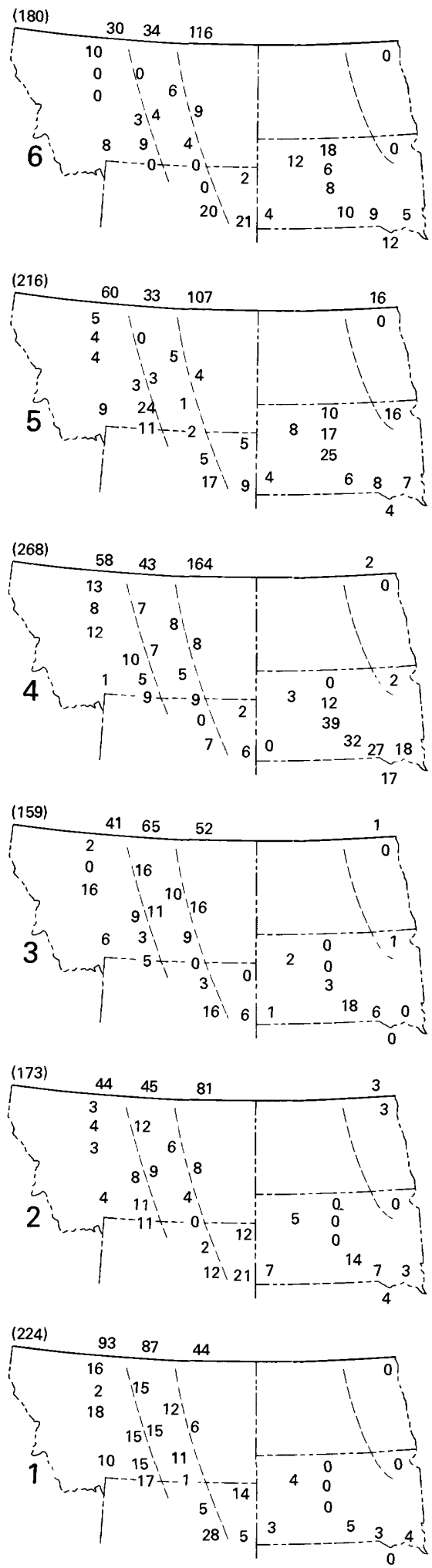

FIgURE 19.-Mineralogy of the Pierre Shale and equivalent rocks by locality and fossil zone. Bentonite is excluded. Mean values for one or two samples are omitted. 42 , mean value of more than five samples; 42 , mean value of three to five samples. 
C Illite, as percent of mixed-layer clay
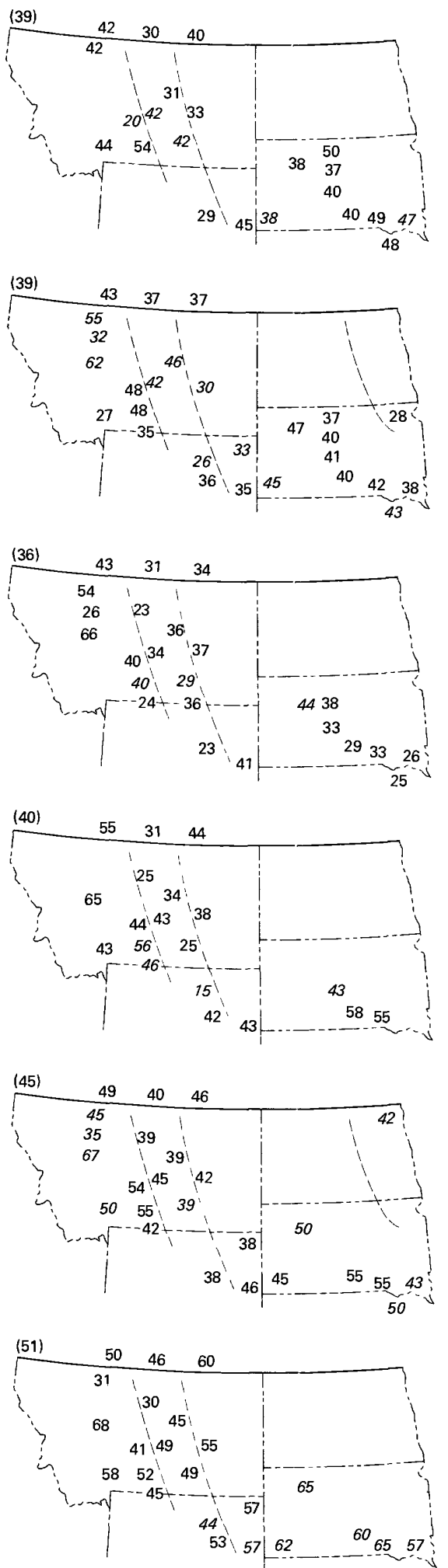

$D$ Beidellite, as percent of mixed-layer clay (37)
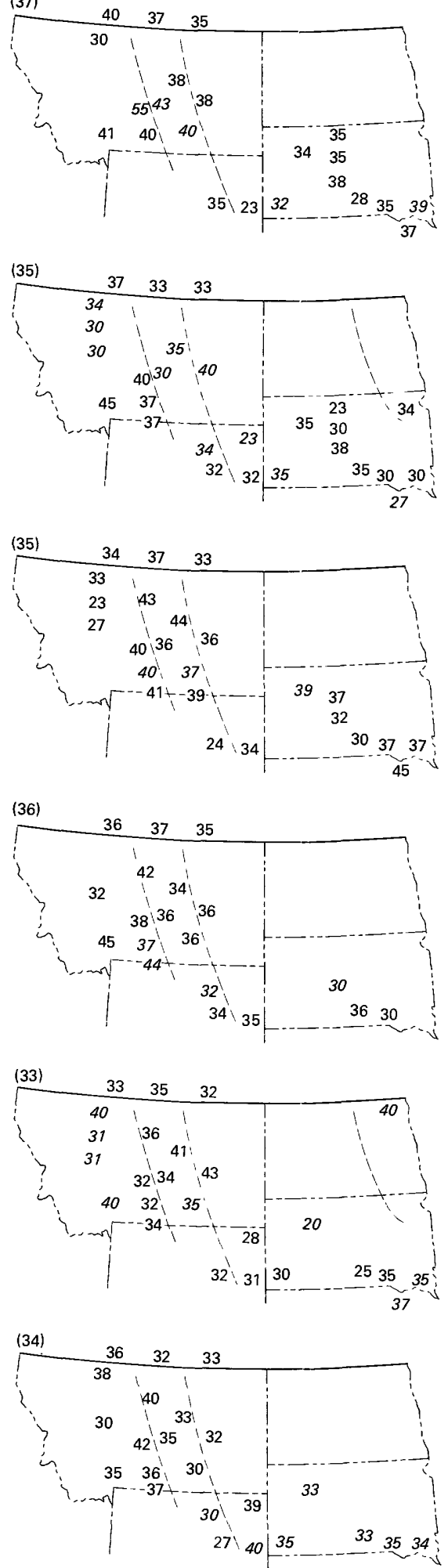

$E$ Montmorillonite, as percent of mixed-layer clay
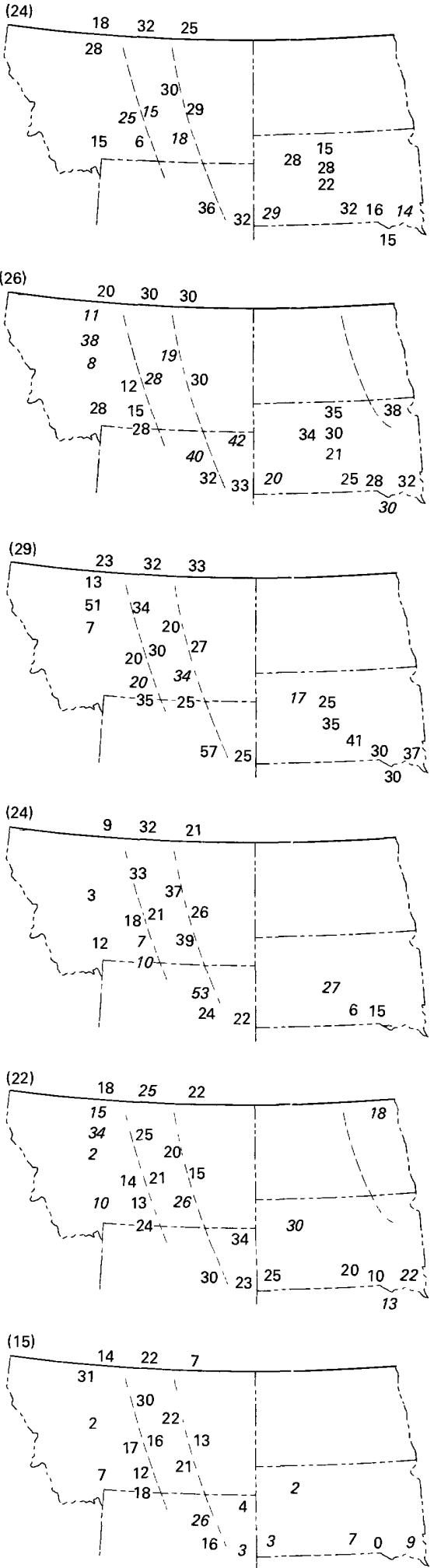

Figure 19.-Mineralogy of the Pierre Shale and equivalent rocks-Continued 
$F \quad$ Mixed-layer clay, as percent of total clay
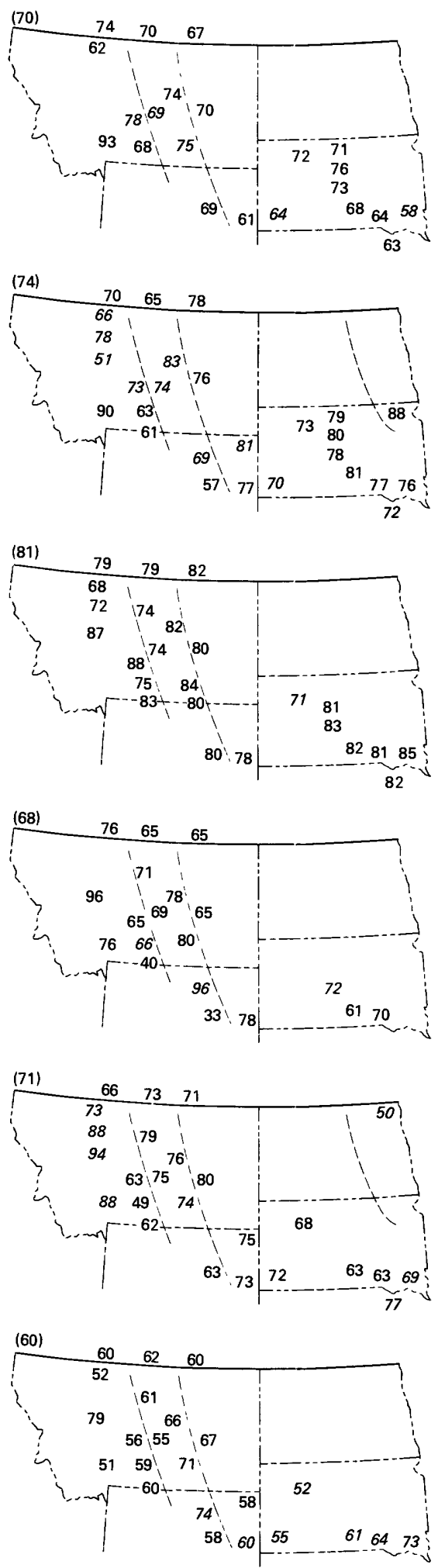
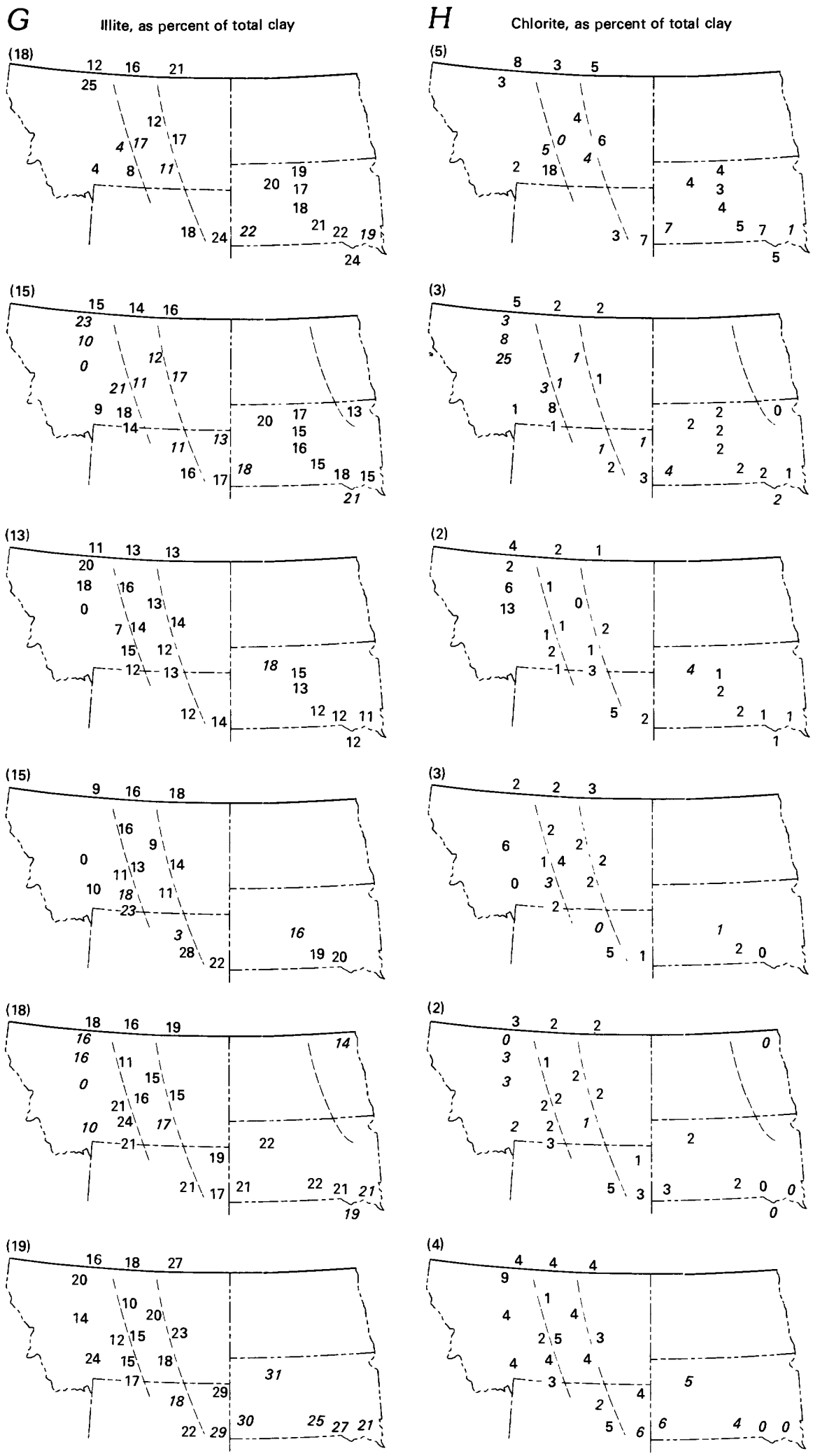

Figure 19.-Mineralogy of the Pierre Shale and equivalent rocks-Continued 

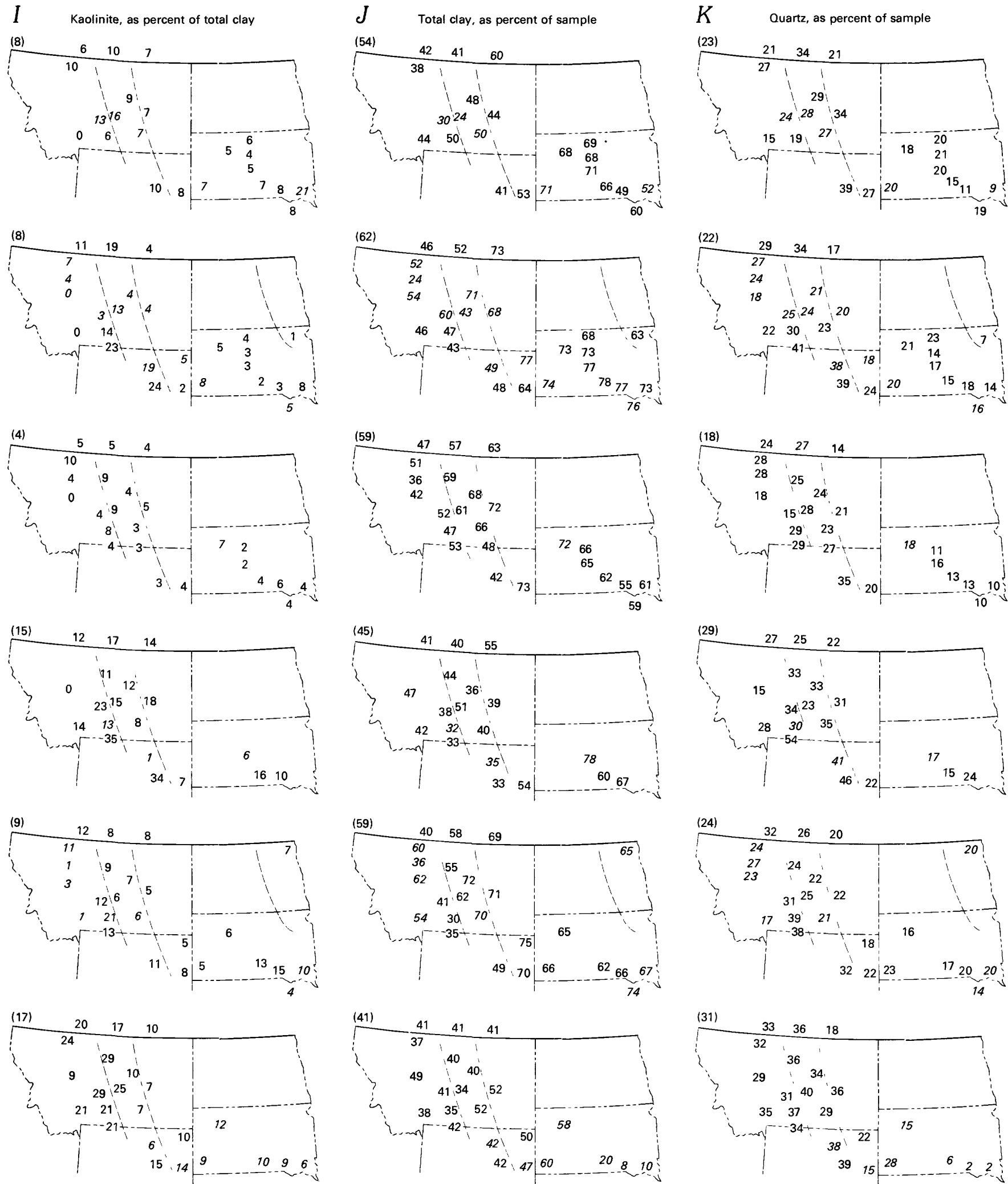

Figure 19.-Mineralogy of the Pierre Shale and equivalent rocks-Continued 
L Cristobalite, Range [percent detected]
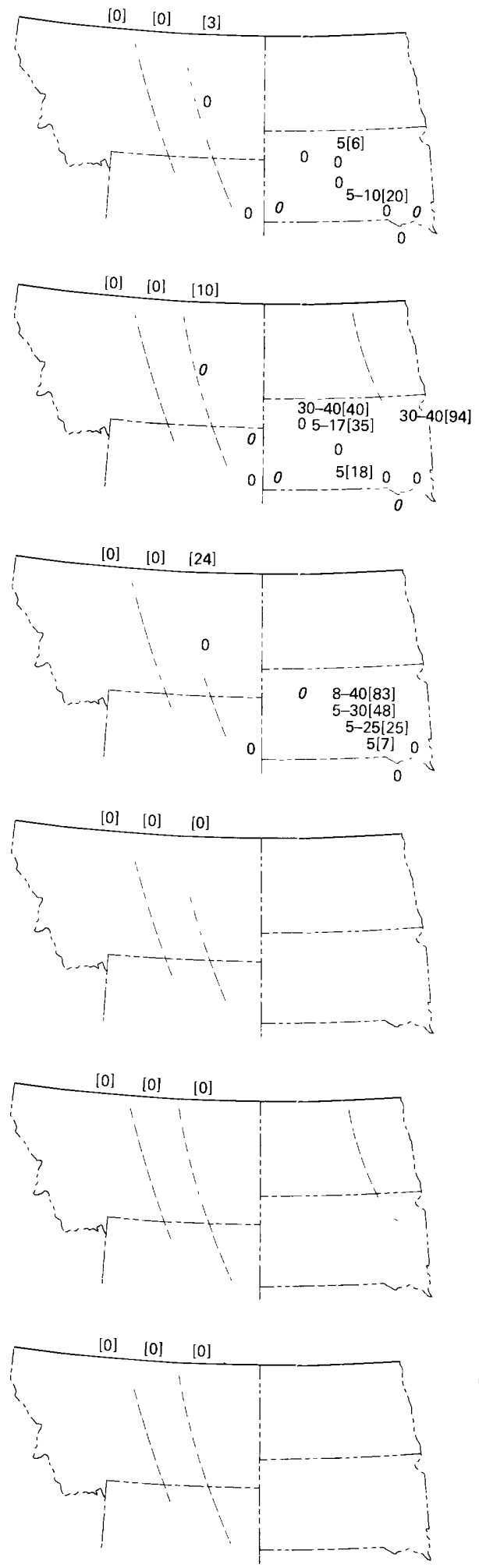

$M$ Potassium feldspar, as percent of sample

$(0.8)$
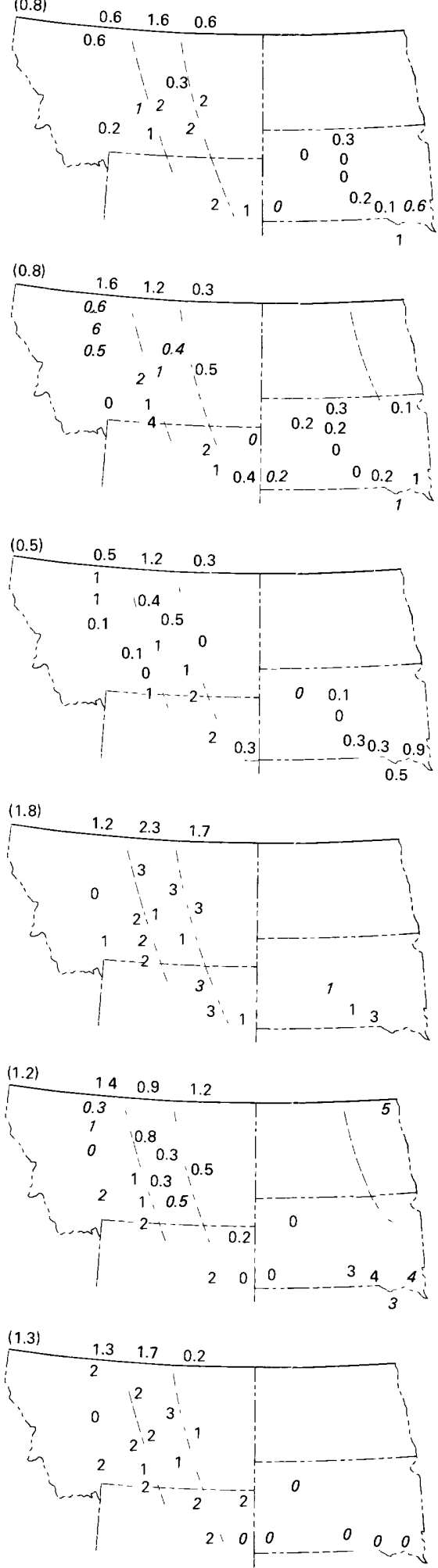

$N$

Plagioclase, as percent of sample

(7)
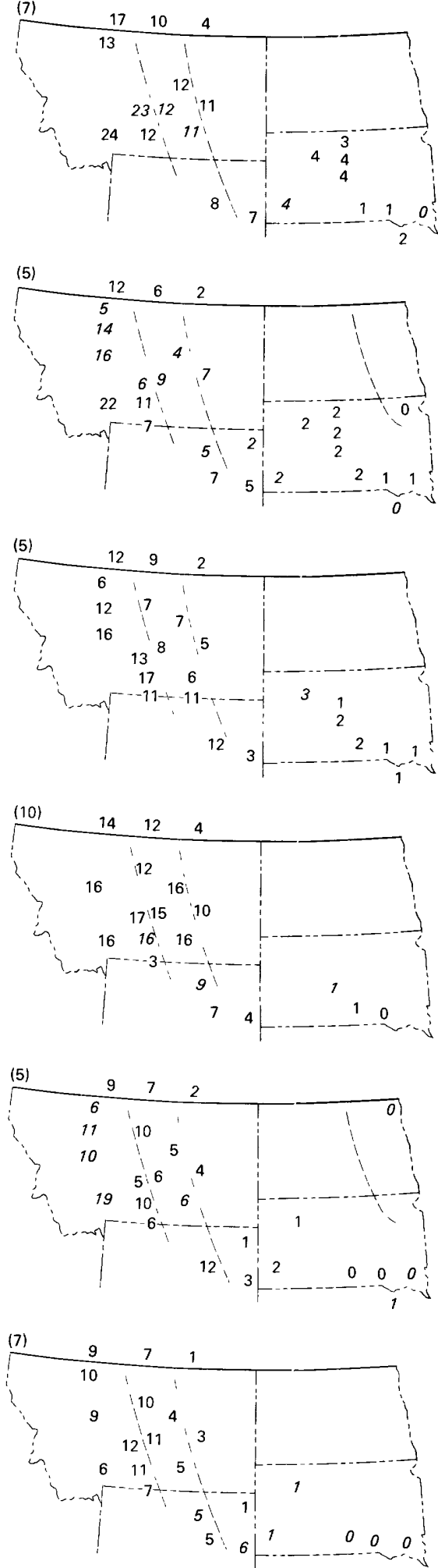

FiguRE 19.-Mineralogy of the Pierre Shale and equivalent rocks-Continued 

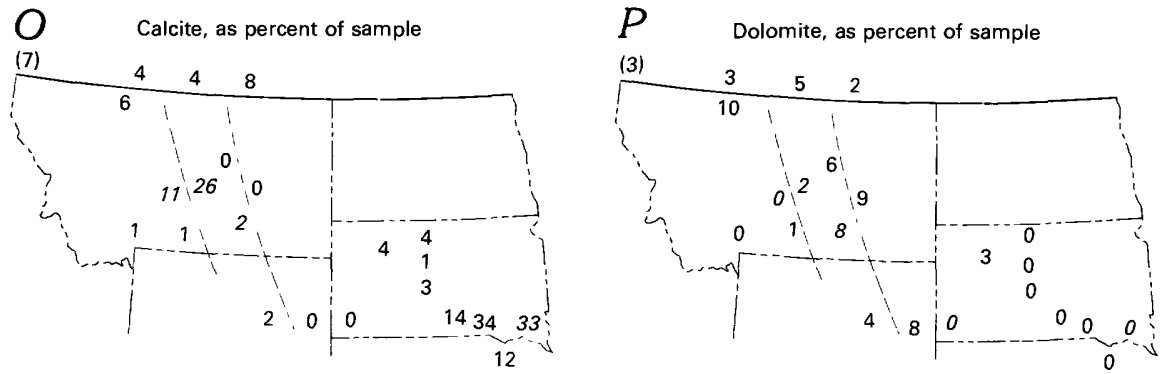

$Q \quad$ Gypsum, Range [percent detected]
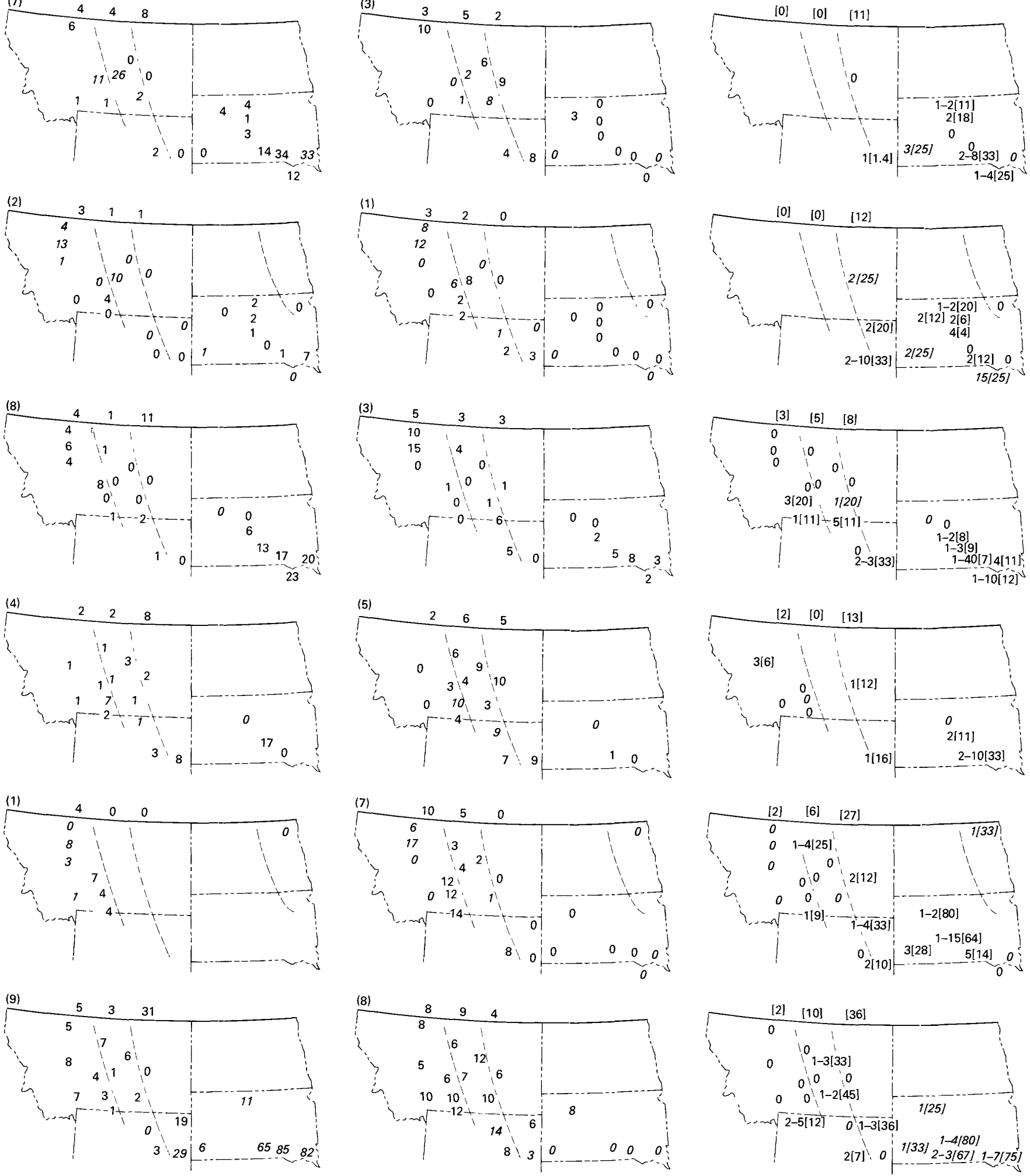

FIGURE 19.-Mineralogy of the Pierre Shale and equivalent rocks-Continued 
$R \quad$ Jarosite, Range [percent detected]
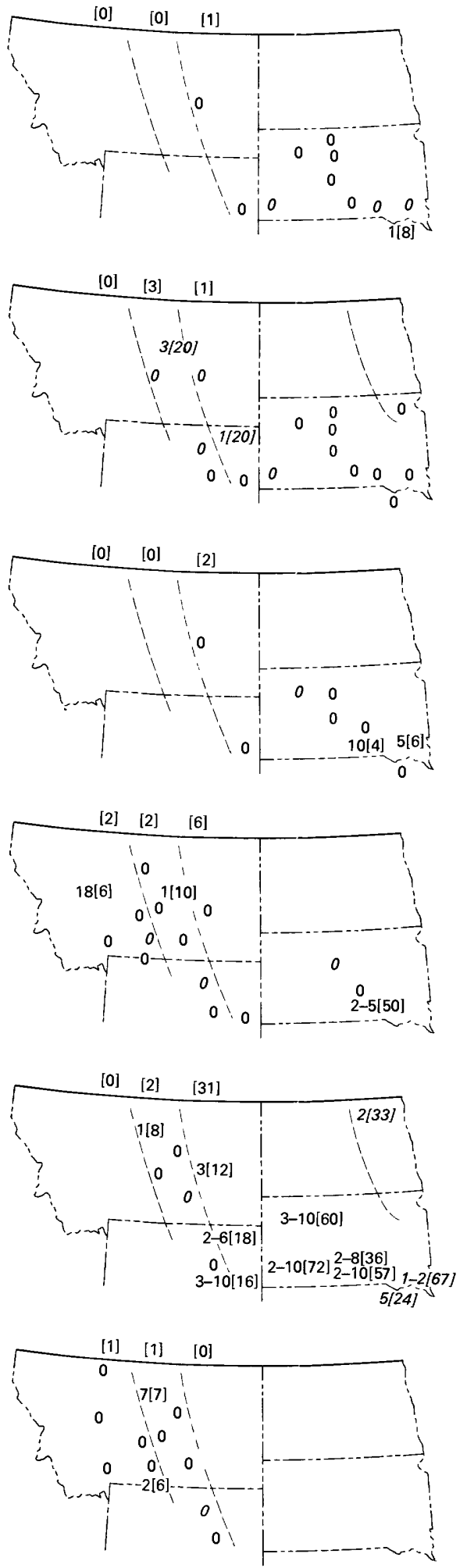

$S \quad$ Pyrite, Range [percent detected]
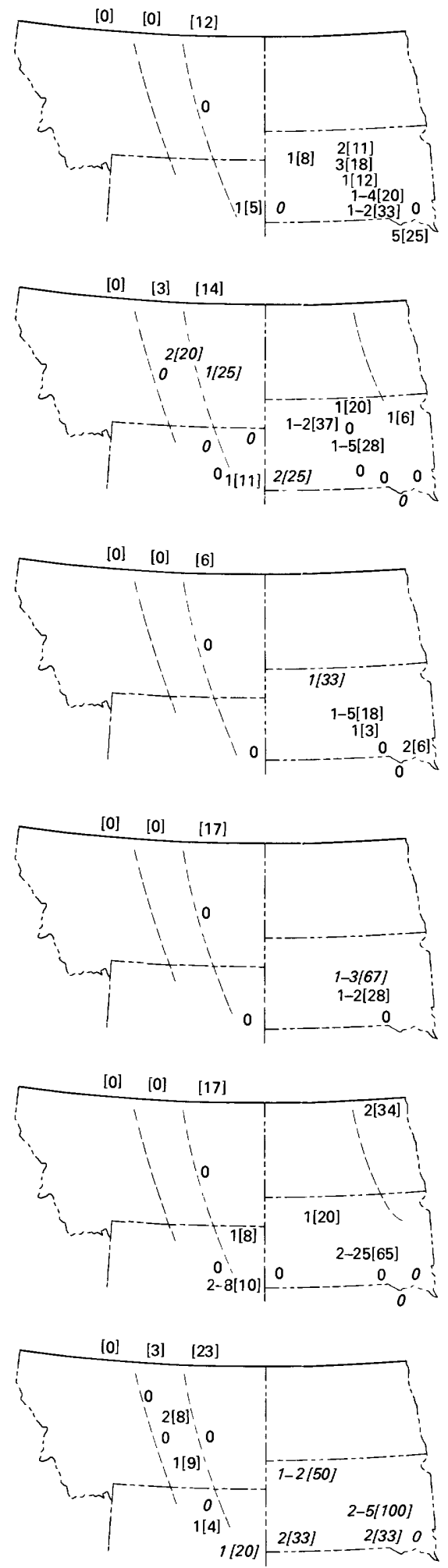

$T \quad$ Zeolites, Range [percent detected]
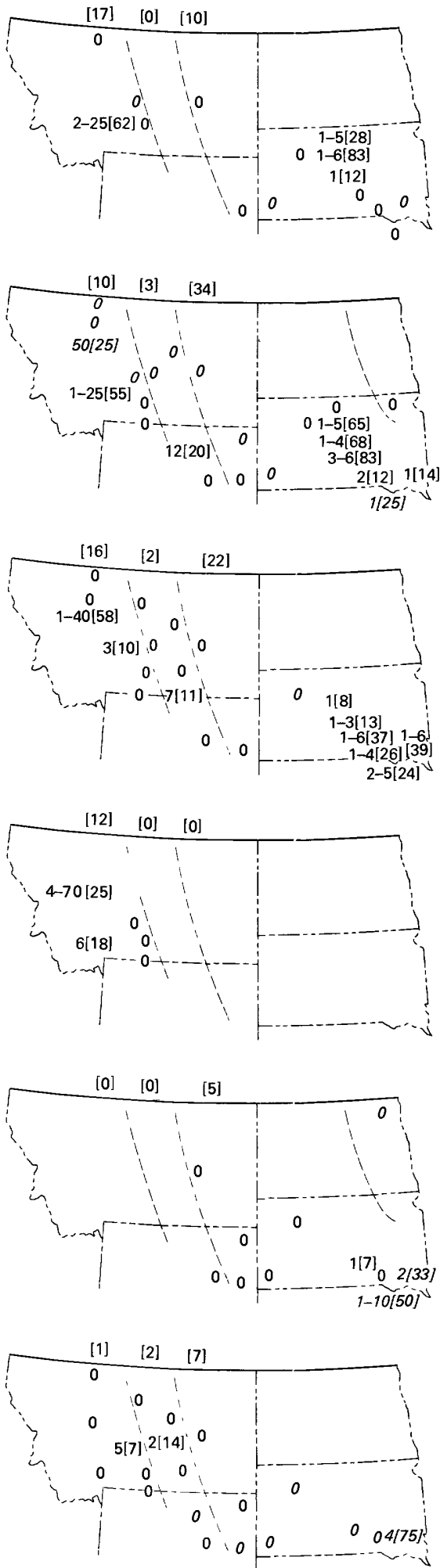

FIGURE 19.-Mineralogy of the Pierre Shale and equivalent rocks-Continued 
are surficial weathering products of the pyrite. None of the three are common in the western continental sediment. All are most common in the eastern area. Gypsum and pyrite are sporadically distributed throughout the fossil zones, but are most abundant in zone 2 and most common in the lower two zones. Jarosite is even more strongly concentrated in fossil zone 2 or in lithologically similar fissile shale in zone 3 (loc. 24).

Zeolite minerals (fig. 19T) occur in eastern and western areas, but rarely in between. Clinoptilolite occurs in small amounts in many eastern shale samples, and heulandite and laumontite occur in relatively large amounts in a few samples of western volcanic-rich rock. The zeolite minerals are probably derived from alteration of volcanic ash, and they are detected most frequently in the generally more montmorillonitic and less illitic shale of the upper three fossil zones (fig. $19 C-E$ ). The Verendrye Member (part of fossil zone 5), however, is not as conspicuously bentonitic or montmorillonitic as are several other of the eastern units (table 8), but zeolite was detected in 72 percent of the samples from this unit.

\section{TYPES OF QUARTZ}

Blatt and Christie (1963) pointed out that volcanic quartz differs optically from quartz of other origins. Although the differences are by no means entirely consistent, quartz of volcanic origin tends to occur as unstrained monocrystalline grains, whereas plutonic quartz is frequently strained, and metamorphic quartz is often unstrained or polycrystalline.

The origin of quartz in the Pierre Shale is problematical. On the one hand, bentonite typically contains little or no quartz. This observation, assuming bentonite and the volcanic-rich western sediment of the Pierre Shale were derived from the same igneous source materials, as seems probable, might suggest that the 15 to 20 percent quartz commonly found in the volcanic-rich sediment might not be of volcanic origin. Therefore, much of the quartz in the rest of the Pierre Shale also probably is not of volcanic origin. On the other hand, the absence or near absence of other than smectitic mixed-layer clay in the western volcanic-rich sediment suggests little contribution to it of nonvolcanic detritus, so that its quartz must be of volcanic origin. To support one or the other of these possibilities, the optical properties of the quartz in eight samples from across the basin of deposition were determined (table 11).

The identity of all of the quartz grains analyzed for table 11 was confirmed by their uniaxial positive character. As this could be determined only on grains about $0.1 \mathrm{~mm}$ or larger, only the coarser grained rock was suitable. Particularly in the volcanic-rich sandstone, many grains having slightly nonuniform extinction but having birefringence and relief appropriate for quartz were biaxial with a large $2 V$ and therefore must be untwinned and perhaps slightly zoned plagioclase. Hence, the need for identification with interference figures.

In volcanic-rich sandstone from near the western source eight- to nine-tenths of the quartz grains are unstrained (table 11). In the middle of the basin, far from the western source, a southern and a northern pair of samples were investigated to see if the influence of the southwestern nonvolcanic source could be detected. No such source is evident, as the southern pair does not consistently contain more strained or polycrystalline quartz than the northern pair. Nor are the marine and nonmarine samples consistently different. However, all the samples from the middle of the basin consistently do contain less unstrained monocrystalline quartz than the westernmost pair, which indicates some mixing in the middle of the basin with nonvolcanic quartz. Much more nonvolcanic quartz is

TABLE 11.-Types of quartz grains in coarse-grained rock across the basin of deposition of the Pierre Shale and equivalent rocks

\begin{tabular}{|c|c|c|c|c|}
\hline \multirow[b]{2}{*}{ Sample No. } & \multirow[b]{2}{*}{ Locality No., unit and environment } & \multicolumn{3}{|c|}{ Type of quartz grains (percent) ${ }^{1}$} \\
\hline & & Unstrained & Strained & Polycrystallin \\
\hline \multicolumn{5}{|c|}{ Near western source area, volcanic rich } \\
\hline \multirow{2}{*}{$\begin{array}{l}159827 \\
159836\end{array}$} & \multirow{2}{*}{\multicolumn{2}{|c|}{$\begin{array}{l}\text { 1, Cokedale, nonmarine .. } 91 \\
\text { 2, Two Medicine, non- } \\
\text { marine ........... } 82\end{array}$}} & 9 & 0 \\
\hline & & & 18 & 0 \\
\hline \multicolumn{5}{|c|}{ Far from western source area, north } \\
\hline 159756 & \multirow{2}{*}{\multicolumn{2}{|c|}{$\begin{array}{l}\text { 14, Judith River, non- } \\
\text { marine } \ldots \ldots \ldots \ldots \ldots . \ldots 48 \\
\text { 15, Judith River, marine.. } 74\end{array}$}} & 48 & 4 \\
\hline 159742 & & & 24 & 2 \\
\hline \multicolumn{5}{|c|}{ Far from western source area, south } \\
\hline \multirow[t]{2}{*}{$\begin{array}{l}159716 \\
159717\end{array}$} & \multicolumn{2}{|c|}{$\begin{array}{l}\text { 10, Parkman, nonmarine } .66 \\
10, \text { Parkman, marine ..... } 64\end{array}$} & $\begin{array}{l}32 \\
32\end{array}$ & $\begin{array}{l}2 \\
4\end{array}$ \\
\hline & \multicolumn{3}{|c|}{ Missouri River area, sandy marl } & \\
\hline \multirow{2}{*}{$\begin{array}{l}\text { S59-44-2u } \\
\text { S59-37-4B }\end{array}$} & \multirow{2}{*}{ 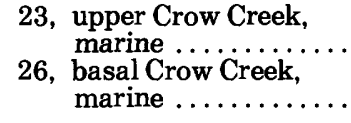 } & 14 & 56 & 30 \\
\hline & & .. 38 & 42 & 20 \\
\hline
\end{tabular}
able quartz grains were located. 
indicated in the Crow Creek Member in the Missouri River area by the predominance of strained and polycrystalline quartz, no doubt reflecting eastern-derived sediment from the Sioux Quartzite (Crandell, 1952). This coarse-grained quartz in the Crow Creek Member is, however, of very limited regional and stratigraphic range. On the basis of the types of grains, much of the quartz in the Pierre-age sediments appears most likely to be of volcanic origin.

\section{CHEMICAL COMPOSITION}

The chemical composition of the Pierre Shale and equivalent rocks was studied for a 226-sample subset of the 1,349 samples of shale, siltstone, marl, and bentonite studied mineralogically. Two analytical samples (159800 and 259541) were excluded from groupings because of their unusual composition, and the remainder were subdivided as follows:

192-shale and siltstone (134 marine and 58 nonmarine)

10-marlstone

22-bentonite

224-total

Cumulative curves, means, and standard deviations for the group of 192 chemically analysed shale and siltstone samples and for all 1,160 shale and siltstone samples mineralogically analyzed (fig. 20), though generally similar, show small differences because of inclusion of fewer coarse-grained rocks in the analytical group. The analytical set contains more total clay, though differences in the types of clay minerals are minor, it contains less quartz, feldspar, calcite, and dolomite, and with only one exception its standard deviations are smaller. Although the mineralogical differences are small, they are sufficient to require separate listings in some tables that attempt to correlate the mineralogy with the chemistry of the analytical samples.

\section{MAJOR, MINOR, TRACE, AND ROGK-FORMING ELEMENTS-TERMINOLOGY}

Our use of these four terms is not entirely conventional and partly reflects the manner in which the elements were reported from the analytical laboratories. Constituents in table 1 under the heading "Rock-forming constituents (percent)" are reported mostly as oxides. Those from silica $\left(\mathrm{SiO}_{2}\right)$ to water $\left(\mathrm{H}_{2} \mathrm{O}\right)$ are conventionally called major constituents, elements, or oxides. However, constituents from titanium oxide $\left(\mathrm{TiO}_{2}\right)$ to the two forms of carbon (organic (C, organic) and mineral (C, mineral)) are hardly major, yet they are not conveniently grouped with the trace elements; therefore they are called minor constituents or elements in this report. In parts of this report, major and minor constituents are collectively referred to as rock-forming constituents, even though it is arguable if some of the minor elements are, indeed, rock forming. In table 1, elements under the heading "Traceelement constituents (parts per million)" from zirconium $(\mathrm{Zr})$ to uranium $(\mathrm{U})$ are conventionally referred to as either trace or minor elements; we use the term "trace element" as minor is used otherwise.

\section{EXPLANATION OF TABLE 1}

Data in table 1 for rock-forming and trace elements are the basis for summaries and discussion in this section of the chemical composition of the Pierre Shale and in the following section of physical properties. The 226 samples are arranged in table 1 first according to the sample locality and second according to stratigraphic position. The locality numbers are also shown at the top of stratigraphic columns in plate 1 , and the analytical-sample numbers are shown to the right of each column. Samples in table 1 are arranged from locality 1 sequentially to locality 28 ; locality numbers generally increase from west to east (index map, pl. 1). Within localities in table 1 , samples are arranged stratigraphically, with the youngest, in fossil zone 6 , first; fossil zones on table 1 are explained in the section on "Stratigraphic setting" and are shown on plate 1. The environment of deposition is coded from " 1 " for nonmarine to "4" for offshore marine. For sulfur (S), total S (S, total) was first determined, and generally if this was 0.08 percent or more, then acid-soluble $\mathrm{S}\left(\mathrm{SO}_{3}\right)$ and acid insoluble $\mathbf{S}\left(\mathbf{S}^{-2}\right)$ were determined separately.

\section{METHODS}

All chemical elements were determined in the analytical laboratories of the U.S. Geological Survey.

Rock-forming constituents were determined mostly by rapid-rock analytical methods described by Shapiro and Brannock (1956). These rapid analyses were supplemented and checked by 51 standard rock analyses. The standard analyses can be distinguished in table 1 by the extra significant figure for oxides; for example, an analysis reporting $\mathrm{SiO}_{2}=62.83$ and $\mathrm{Al}_{2} \mathrm{O}_{3}=8.36$ percent is a standard analysis, whereas one reporting $\mathrm{SiO}_{2}=59.7$ and $\mathrm{Al}_{2} \mathrm{O}_{3}=16.3$ is a rapid analysis. Duplicate analyses are not given in table 1 , but differences between duplicate standard and rapid analyses show no more difference than reported by Tourtelot (1962, table 8) between duplicate standard analyses. Thus, the rapid analyses that are the principal basis of the major-element data of this report are 

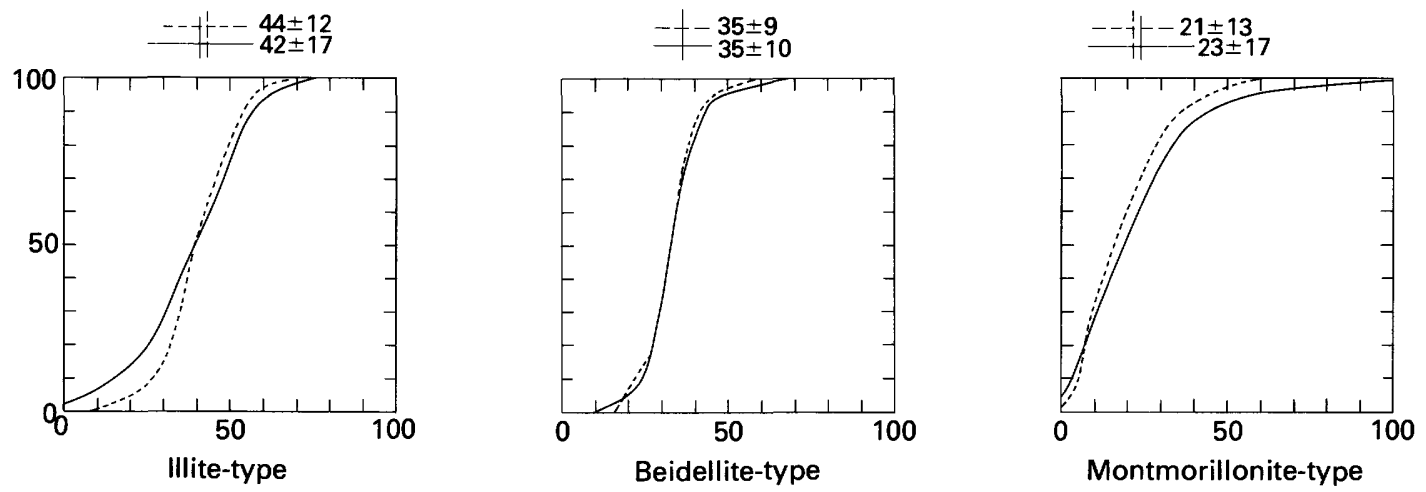

LAYERS AS PERCENT OF MIXED-LAYER CLAY
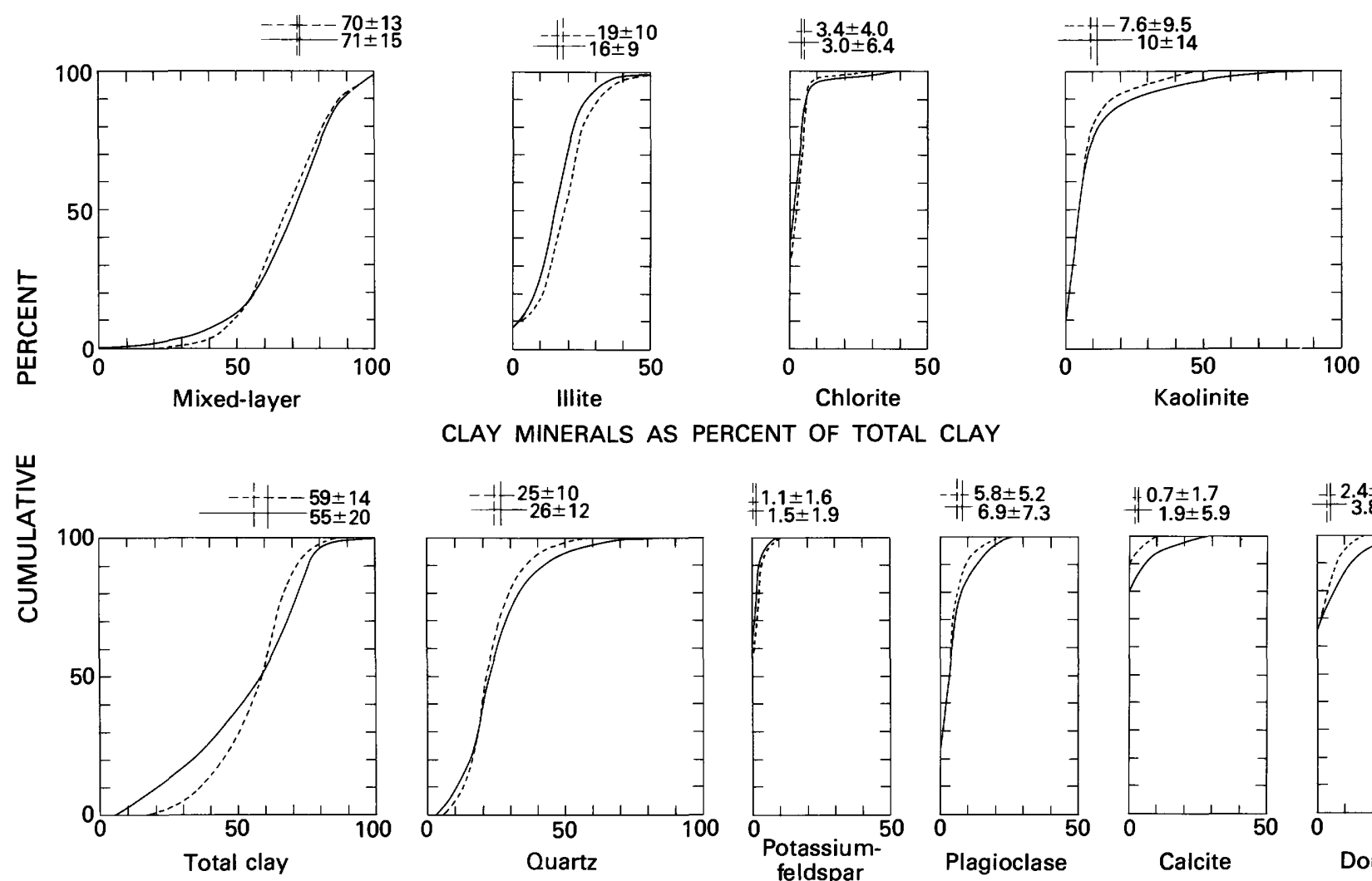

CLAY MINERALS AS PERCENT OF TOTAL CLAY
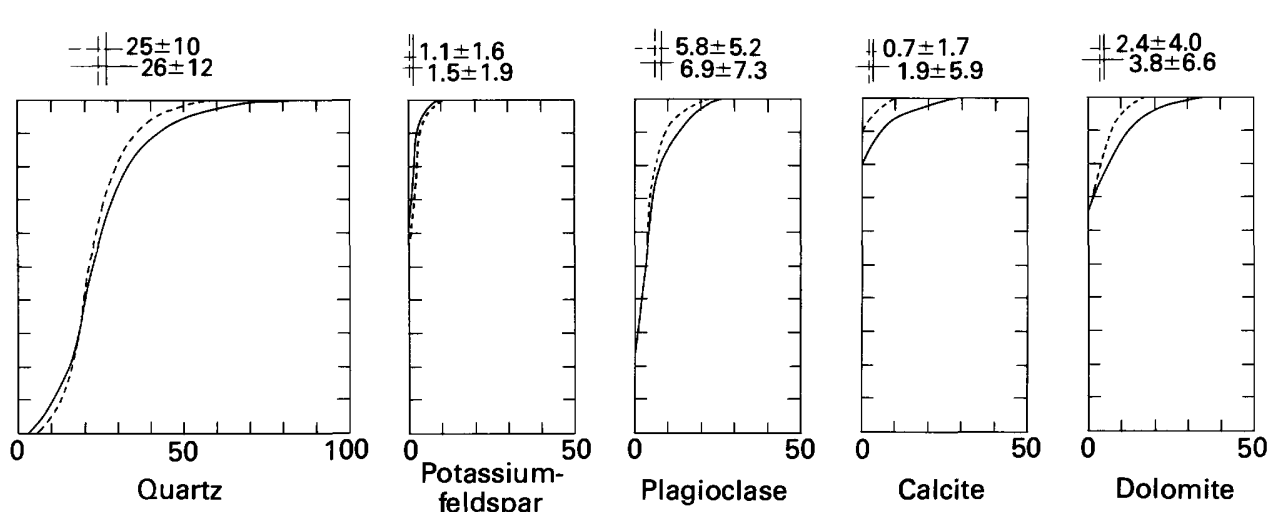

MINERAL AS PERCENT OF SAMPLE

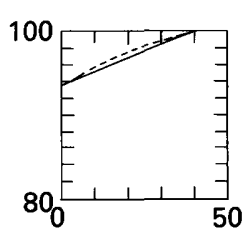

Cristobalite
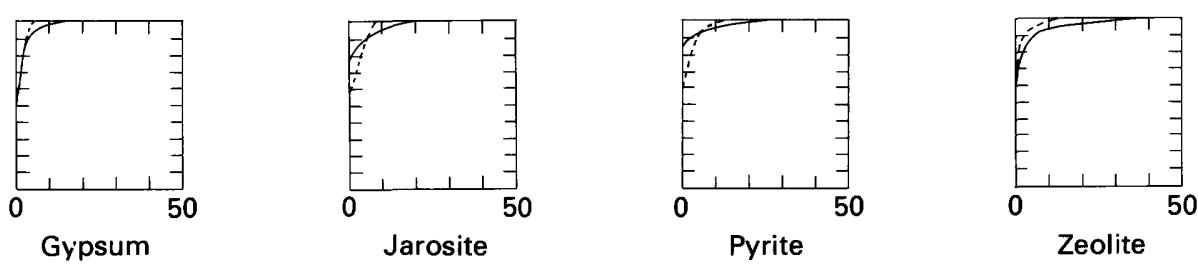

MINERAL AS PERCENT OF SAMPLE

FIGURE 20.-Mineralogy of all 1,160 shale and siltstone samples compared with that of the 192 chemically analyzed samples. Means and standard deviations are above the cumulative curves. Solid lines, all shale and siltstone; dotted lines, chemically analyzed samples only. 
suitable for their purpose, namely, to evaluate the overall composition of the Pierre Shale and its equivalents.

Trace elements were determined by both chemical and spectrographic methods. Precision for chemical methods and for organic and mineral $\mathrm{C}$ analyses was reported by Rader and Grimaldi (1961). Precision for the spectrographic methods was reported by Barnett (1961). Uranium (U) was determined only in samples C872-C891 and 259526-259595 (table 1). Cadium (Cd) was determined in 128 selected samples by Huffman (1963; Tourtelot, Huffman, and Rader, 1964). Tin (Sn) was determined in 53 selected samples by Huffman and Bartel (1964). Other analysts are listed in the headnotes of table 1 . The same chemical methods were used to determine zinc ( $\mathrm{Zn})$, selenium (Se), and arsenic (As) for all 226 samples, but other trace elements in samples C872-C891 were determined by three-step semiquantitative spectrographic analyses (Tourtelot, 1962, table 14). Three-step spectrographic analyses were also used to determine yttrium $(\mathrm{Y})$, ytterbium (Yb), and lanthanum (La) for samples 259526-259595 (table 1), but for samples 159709-159859 (table 1) these three elements were determined by quantitative spectrographic analyses comparable to those for other trace elements. Due account should be given to differences in precision when distribution of these elements is interpreted.

\section{ABUNDANCE OF ELEMENTS IN THE PIERRE SHALE AND SOME STATISTICAL CONSIDERATIONS}

Table 12 presents mean values for chemical constituents in the Pierre Shale and several measures for variation of values. The 202 samples summarized in table 12 include all of the rock types analyzed except bentonite. The 22 bentonite samples are excluded because their number, in proportion to the total sample set, represents about ten times the estimated 1 percent of bentonite in the Pierre Shale. Because sandstone is underrepresented in the chemically analysed samples, the mean values in table 12 characterize only the finer grained parts of the Pierre Shale; however, these parts make up well over three-fourths of the approximately $100,000 \mathrm{mi}^{3}$ of sediment that were originally deposited in the area studied.

The frequency distribution for chemical components was examined for normality before further computations. If the distribution is essentially normal, the arithmetic mean is nearly equal to the median value (the 50th percentile, $P_{50}$, in table 12). Judged by this criterion, most of the major constituents are normally distributed, as are the minor constituents $\mathrm{TiO}_{2}$, phosphate $\left(\mathrm{P}_{2} \mathrm{O}_{5}\right)$, fluorine $(\mathrm{F})$, and chlorine $(\mathrm{Cl})$. The one major-constituent exception is calcium $(\mathrm{CaO})$, because of very large amounts of it in marl. The various forms of $\mathrm{S}$ and $\mathrm{C}$ and many of the trace elements also are not normally distributed because of a few exceptionally large values. Where analytical values are distributed in this way, with a few very large values and no complementary very low values, the geometric mean is a better estimate of the central value. Put another way, if the geometric mean more nearly approximates the median value, the logarithms of the values are more normally distributed about the logarithm of the geometric mean than are the values themselves distributed about the arithmetic mean. Evaluation of some statistics, such as correlation coefficients, requires a nearly normal frequency distribution. Therefore, for later calculations, arithmetic values have been used for major elements and for $\mathrm{P}_{2} \mathrm{O}_{5}$, $\mathrm{F}$, and $\mathrm{Cl}$, and logarithms of values have been used for $\mathrm{C}, \mathrm{S}$, and trace elements. Regardless of frequency distribution, the arithmetic mean is reported in most tables of this report because it is the only appropriate statistic for abundance-that is, the total amount of any element in a volume of rock-and it allows comparison with most other publications.

Many of the trace elements occur in some samples in amounts that are below the limits of detection listed in the last column of table 12. Such amounts are indicated by a less-than symbol on table 1 following the minimum amount detectable. Such values are an essential part of the average composition of the Pierre Shale and equivalents, but they cannot be entered directly into statistical calculations. For calculation of mean values for this study, elements reported as less than a value have been given small assumed values from about one-third to two-thirds of the limit of detection. If only a few less-than values were reported for an element, as for Cd, most such samples probably contain an amount only slightly less than the detection limit, and about two-thirds of the minimum is substitutedfor Cd, $0.2 \mathrm{ppm}$ is substituted for "less than $0.3 \mathrm{ppm}$ ". If many less-than values were reported, as for total $S$, the average content in such samples probably is considerably below the detection limit, and about onethird the minimum value of 0.08 , or 0.02 percent, is substituted. In a few samples interference between elements make the detection limit of one of them different than in other samples; such values are excluded from the statistical calculations. The spectrographic methods used for molybdenum (Mo) and $\mathrm{U}$ in samples C870-891 had a limit of detection (10 ppm) that is 10 times higher than that of the chemical methods used on all subsequent samples; data for Mo and $U$ in these samples also are excluded from the calculations. 
TABLE 12.-Average chemical composition of 202 samples of Pierre Shale and equivalent rocks [Includes marl but not bentonite. Leaders (---), not pertinent; <, less than; >, greater than]

\begin{tabular}{|c|c|c|c|c|c|c|c|c|c|c|c|c|}
\hline & \multirow{2}{*}{$\begin{array}{l}\text { Standard } \\
\text { deviation }\end{array}$} & \multicolumn{2}{|c|}{ Geometric } & \multirow{2}{*}{$\begin{array}{l}\text { Minimum } \\
\text { detected }\end{array}$} & \multicolumn{5}{|c|}{ Percentile } & \multirow{2}{*}{$\begin{array}{c}\text { Maximum } \\
\text { detected }\end{array}$} & \multirow{2}{*}{$\begin{array}{l}\text { Ratio } \\
\mathrm{P}_{95} / \mathrm{P}_{5}\end{array}$} & \multirow{2}{*}{$\begin{array}{l}\text { Limit of } \\
\text { detection }\end{array}$} \\
\hline $\begin{array}{l}\text { Arithmetic } \\
\text { Mean }\end{array}$ & & Mean & Deviation & & $P_{5}$ & $P_{25}$ & $P_{50}$ & $P_{75}$ & $P_{95}$ & & & \\
\hline \multicolumn{13}{|c|}{ Major and minor elements (percent) } \\
\hline $\begin{array}{l}\mathrm{SiO}_{2} \ldots \ldots \ldots 6.80 .8 \\
\mathrm{Al}_{2} \mathrm{O}_{3} \ldots \ldots \ldots 14.4 \\
\mathrm{Fe} \text {, total as }\end{array}$ & $\begin{array}{l}7.9 \\
2.5\end{array}$ & --- & $\begin{array}{l}-- \\
---\end{array}$ & $\begin{array}{r}19.6 \\
6.2\end{array}$ & $\begin{array}{r}47.2 \\
9.6\end{array}$ & $\begin{array}{l}57.7 \\
13.0\end{array}$ & $\begin{array}{l}60.9 \\
14.7\end{array}$ & $\begin{array}{l}65.4 \\
16.1\end{array}$ & $\begin{array}{l}72.4 \\
17.9\end{array}$ & $\begin{array}{l}80.7 \\
21.6\end{array}$ & $\begin{array}{l}1.5 \\
1.9\end{array}$ & $\begin{array}{l}--- \\
---\end{array}$ \\
\hline $\mathrm{Fe}_{2} \mathrm{O}_{3} \ldots \ldots 4.6$ & 1.5 & -- & --- & 1.2 & 2.4 & 3.6 & 4.7 & 5.6 & 7.0 & 15.8 & 2.9 & --- \\
\hline $\mathrm{Fe}_{2} \mathrm{O}_{3} \ldots \ldots \ldots 3.4$ & 1.4 & -- & --- & .28 & 1.1 & 2.4 & 3.3 & 4.5 & 5.6 & 6.9 & 5.1 & --- \\
\hline $\mathrm{FeO} \ldots \ldots \ldots 1.1$ & 1.2 & $-\cdots$ & --- & $<.1$ & .3 & .5 & .9 & 1.3 & 2.6 & 13.7 & 8.7 & 0.1 \\
\hline MgO . . . . . . 2.2 & 1.0 & -- & --- & .24 & .7 & 1.5 & 2.1 & 2.7 & 4.0 & 5.7 & 5.7 & -- \\
\hline $\mathrm{CaO} \ldots \ldots \ldots 2.6$ & .45 & $-\cdots$ & --- & .11 & .2 & .6 & 1.2 & 2.6 & 9.3 & 37.1 & 46 & $-\cdots$ \\
\hline $\mathrm{Na}_{2} \mathrm{O} \ldots \ldots \ldots 1.1$ & .56 & -- & --- & .08 & .3 & .7 & 1.1 & 1.4 & 2.1 & 4.3 & 7.0 & --- \\
\hline $\mathrm{K}_{2} \mathrm{O} \ldots \ldots \ldots 2.4$ & .57 & -- & --- & .17 & 1.4 & 2.1 & 2.4 & 2.8 & 3.4 & 4.1 & 2.4 & --- \\
\hline $\mathrm{H}_{2} \mathrm{O}-\ldots \ldots \ldots 3.2$ & 1.3 & -- & -- & .51 & 1.3 & 2.2 & 3.1 & 4.0 & 5.6 & 8.2 & 4.3 & -- \\
\hline $\mathrm{H}_{2} \mathrm{O}+\ldots \ldots \ldots 4.3$ & 1.2 & -- & --- & 1.5 & 2.4 & 3.4 & 4.2 & 4.9 & 6.9 & 8.4 & 2.9 & -- \\
\hline $\mathrm{TiO}_{2} \ldots \ldots \ldots .58$ & .12 & -- & --- & .22 & .37 & .50 & .57 & .66 & .75 & 1.0 & 2.0 & -- \\
\hline $\mathrm{P}_{2} \mathrm{O}_{5} \ldots \ldots \ldots \ldots .14$ & .073 & --- & -- & .01 & .02 & .10 & .14 & .18 & .26 & .49 & 13 & -- \\
\hline S, total .........37 & 1.1 & 0.12 & 3.8 & -- & --- & -- & $<.08$ & .30 & 1.5 & 13.3 & $>19$ & .08 \\
\hline $\mathrm{S}^{-2} \ldots \ldots \ldots \ldots .25$ & .82 & .079 & 3.4 & --- & --- & -- & $<.08$ & .12 & 1.0 & 9.7 & $>13$ & .08 \\
\hline $\mathrm{SO}_{3} \ldots \ldots \ldots \ldots .38$ & .93 & .17 & 2.6 & --- & --- & --- & $<.2$ & .27 & 1.1 & 9.0 & $>6$ & .20 \\
\hline $\mathbf{F} \ldots \ldots \ldots \ldots .071$ & .015 & -- & -- & .02 & .05 & .06 & .07 & .08 & .10 & .13 & 2 & -- \\
\hline $\mathrm{Cl} \ldots \ldots \ldots \ldots .016$ & .024 & --- & --- & --- & $\ldots$ & $<.01$ & .01 & .01 & .04 & .13 & $>4$ & .01 \\
\hline C, organic ........ & 1.8 & .41 & 3.6 & -- & $<.05$ & $\begin{array}{l}.01 \\
.20\end{array}$ & .50 & .81 & 4.4 & 17.3 & $>88$ & .05 \\
\hline $\mathrm{C}$, mineral .......57 & 1.1 & .10 & 8.9 & -- & $<.01$ & .01 & .10 & .80 & 2.4 & 7.9 & $>240$ & .01 \\
\hline \multicolumn{13}{|c|}{ Trace elements (parts per million) } \\
\hline $\mathrm{Zr}^{1} \ldots \ldots \ldots 190$ & 62 & 180 & 1.4 & 70 & 83 & 160 & 190 & 230 & 330 & 470 & 4.0 & 10 \\
\hline $\mathbf{Y}^{1} \ldots \ldots \ldots 28$ & 12 & 26 & 1.5 & 10 & 13 & 21 & 30 & 36 & 53 & 100 & 4.1 & 10 \\
\hline $\mathbf{Y b}^{1} \ldots \ldots \ldots 2.9$ & .78 & 2.8 & 1.3 & 1.5 & 1.5 & 2.7 & 3.0 & 3.5 & 4.6 & 8 & 3.1 & 1.5 \\
\hline $\mathrm{La}^{1} \ldots \ldots \ldots 39$ & 25 & 30 & 2.1 & --- & -- & $<\mathbf{3 0}$ & 30 & 50 & 66 & 190 & $>6.6$ & 30 \\
\hline $\mathrm{Sn}^{2} \ldots \ldots \ldots 1.4$ & 1.1 & 1.1 & 2.1 & --- & -- & $<1$ & 1 & 2 & 4 & 4 & $>4.0$ & 1 \\
\hline $\mathrm{Sc}^{1} \ldots \ldots \ldots 16$ & 5.0 & 15 & 1.4 & 4 & 7.2 & 13 & 16 & 18 & 25 & 28 & 3.5 & 4 \\
\hline $\mathrm{Ga}^{1} \ldots \ldots \ldots 17$ & 4.1 & 16 & 1.4 & 2 & 8.2 & 15 & 17 & 19 & 23 & 25 & 2.8 & 2 \\
\hline $\mathbf{B}^{1} \ldots \ldots \ldots 99$ & 49 & 83 & 2.0 & $<20$ & 20 & 67 & 100 & 140 & 170 & 410 & 8.5 & 20 \\
\hline $\mathrm{Pb}^{2} \ldots \ldots \ldots 22$ & 7.9 & 20 & 1.6 & 7 & 9.6 & 16 & 22 & 26 & 37 & 44 & 3.9 & 1 \\
\hline $\mathrm{Ba}^{1} \ldots \ldots \ldots 650$ & 300 & 600 & 1.5 & 150 & 300 & 500 & 620 & 750 & 1,100 & 3,200 & 3.7 & 1 \\
\hline $\mathrm{Sr}^{1} \ldots \ldots \ldots 204$ & 204 & 160 & 1.8 & 30 & 65 & 110 & 150 & 210 & 650 & 1,800 & 10 & 1 \\
\hline $\mathrm{Mn}^{2} \ldots \ldots \ldots 720$ & 275 & 260 & 2.9 & 20 & 62 & 140 & 230 & 370 & 2,100 & 34,600 & 34 & 5 \\
\hline $\mathrm{Co}^{1} \ldots \ldots \ldots{ }_{12}$ & 6.0 & 11 & 1.7 & $<3$ & 4.1 & 8.3 & 11 & 16 & 25 & 32 & 6.1 & 3 \\
\hline $\mathrm{Ni}^{1} \ldots \ldots \ldots 36$ & 27 & 29 & 2.0 & 3 & 10 & 19 & 30 & 44 & 86 & 190 & 8.6 & 3 \\
\hline $\mathrm{Zn}^{2} \ldots \ldots \ldots 106$ & 51 & 96 & 1.6 & 27 & 40 & 74 & 96 & 130 & 195 & 380 & 4.9 & --- \\
\hline $\mathrm{Cd}^{2} \ldots \ldots \ldots \ldots 0.93$ & 1.2 & .54 & 2.0 & -- & $<0.3$ & .3 & .5 & .8 & 3 & 10 & $>10$ & .3 \\
\hline $\mathrm{Cr}^{1} \ldots \ldots \ldots 75$ & 34 & 66 & 1.6 & 4 & 30 & 50 & 71 & 95 & 130 & 260 & 4.0 & 1 \\
\hline$V^{2} \ldots \ldots \ldots 156$ & 97 & 136 & 1.7 & 25 & 60 & 100 & 140 & 180 & 330 & 740 & 5.5 & 10 \\
\hline $\mathrm{Cu}^{2} \ldots \ldots \ldots 34$ & 23 & 28 & 1.8 & 6 & 10 & 19 & 29 & 42 & 79 & 150 & 7.8 & .5 \\
\hline $\mathbf{M o}^{2} \ldots \ldots \ldots 4.7$ & 26 & 1.4 & 2.9 & $\cdots$ & --- & $<1$ & 1 & 2 & 15 & 350 & $>15$ & 1 \\
\hline $\mathrm{Se}^{2} \ldots \ldots \ldots \ldots 3.7$ & 15 & .74 & 3.9 & -- & -- & $<.5$ & .5 & 1 & 15 & 160 & $>30$ & .5 \\
\hline $\mathrm{As}^{2} \ldots \ldots \ldots 14$ & 35 & 9.2 & 2.3 & 1 & 2.5 & 6.0 & 9.3 & 14 & 36 & 490 & 14 & --- \\
\hline $\mathrm{U}^{2} \ldots \ldots \ldots \ldots 5.8$ & 5.2 & 4.5 & 1.9 & 1.3 & 1.4 & 2.8 & 3.0 & 5.2 & 16 & 28 & 11 & --- \\
\hline eU . . . . . . . 17 & 8.4 & 15 & 1.7 & --- & $<10$ & 10 & 20 & 25 & 30 & 80 & $>3$ & 10 \\
\hline
\end{tabular}

'Spectrographic analysis. ${ }^{2}$ Chemical analysis. 


\section{DISTRIBUTION AND OCCURRENCE OF ELEMENTS WITHIN THE PIERRE SHALE}

Distribution of elements according to environment of disposition (figs. 21 and 22), fossil zone (table 13), regional variation (fig. 23), and lithologic type (table 14) are, like the distribution of minerals, all interrelated. Therefore, these groupings of the data are considered together for individual elements. On the tables and figures, the major and minor elements are arranged in the order in which they appear in chemical analyses (table 1). However, trace elements are arranged so as to group those that seem to have similar modes of occurrence, that is, the mineral or minerals in which the elements occur. The occurrence of elements in minerals shown in table 15 is inferred mostly from the abundance of the elements in ordinary shale (table 14). The occurrence of major elements is fairly straightforward-obviously the rock-forming elements must occur in rock-forming minerals that mostly are abundant enough to be easily identified. Factors controlling the occurrence of the trace elements and some of the minor elements, however, are not generally so obvious, and they can be inferred only indirectly from lines of reasoning that are explained later. Because of the relatively small size of the analytical sample set, the mineralogy shown at the bottom of some of the tables and the stratigraphic, regional, and lithologic groupings are somewhat simplified compared with those in the section on "Mineralogical composition." For example, in figure 23, localities are not divided into fossil zones, some localities with few samples are combined, and localities 27 and 28 with only two samples each, none of which are of ordinary shale, are excluded.

\section{ROCK-FORMING CONSTITUENTS}

\section{MAJOR ELEMENTS}

Silica makes up nearly two-thirds of all rock types except marl (table 14), and the 61-percent average $\mathrm{SiO}_{2}$ in ordinary marine shale is distributed as follows (table 15): the clay minerals contain an average of 52 percent $\mathrm{SiO}_{2}$, so the 68 percent clay would account for 35 percent $\mathrm{SiO}_{2}(0.52 \times 0.68=0.35)$; this percentage, plus 23 percent $\mathrm{SiO}_{2}$ in quartz and 3 percent $\mathrm{SiO}_{2}$ in plagioclase and potassium feldspar, equals 61 percent. The smaller amount of clay in ordinary nonmarine shale, 59 percent, contains only 31 percent $\mathrm{SiO}_{2}$, compared with 35 percent in the marine equivalent; but this difference is more than offset by more quartz and feldspar in nonmarine shale, which raise its average total $\mathrm{SiO}_{2}$ content to 64 percent. This same interrelation of quartz, feldspar, and clay also influences other small dif-
TABLE 13.-Average composition of chemically analysed samples by fossil zone, Pierre Shale and equivalent rocks [Includes marl but not bentonite]

\begin{tabular}{|c|c|c|c|c|c|c|}
\hline $\begin{array}{l}\text { Fossil zone ........ } \\
\text { Number of samples }\end{array}$ & $\begin{array}{r}1 \\
34\end{array}$ & $\begin{array}{r}2 \\
41\end{array}$ & $\begin{array}{r}3 \\
27\end{array}$ & $\begin{array}{r}4 \\
38\end{array}$ & $\begin{array}{r}5 \\
40\end{array}$ & $\begin{array}{r}6 \\
22\end{array}$ \\
\hline \multicolumn{7}{|c|}{ Arithmetic mean of major and minor elements (percent) } \\
\hline $\begin{array}{l}\mathrm{SiO}_{2} \ldots \ldots \ldots \\
\mathrm{Al}_{2} \mathrm{O}_{3} \ldots \ldots \\
\mathrm{Fe} \text {, total }\end{array}$ & $\begin{array}{l}62.2 \\
13.8\end{array}$ & $\begin{array}{l}58.9 \\
14.8\end{array}$ & $\begin{array}{l}62.9 \\
13.5\end{array}$ & $\begin{array}{l}60.8 \\
14.2\end{array}$ & $\begin{array}{l}62.2 \\
14.9\end{array}$ & $\begin{array}{l}57.3 \\
14.8\end{array}$ \\
\hline $\begin{array}{c}\text { as } \mathrm{Fe}_{2} \mathrm{O}_{3} \ldots \\
\mathrm{Fe}_{2} \mathrm{O}_{3} \ldots \ldots \ldots \\
\mathrm{FeO} \ldots \ldots \ldots\end{array}$ & $\begin{array}{l}3.9 \\
2.7 \\
1.1\end{array}$ & $\begin{array}{l}5.3 \\
3.6 \\
1.6\end{array}$ & $\begin{array}{r}3.8 \\
2.9 \\
.8\end{array}$ & $\begin{array}{r}4.3 \\
3.5 \\
.8\end{array}$ & $\begin{array}{l}5.0 \\
3.9 \\
1.0\end{array}$ & $\begin{array}{l}5.4 \\
3.9 \\
1.4\end{array}$ \\
\hline $\begin{array}{l}\mathrm{MgO} \ldots \ldots \ldots \\
\mathrm{CaO} \ldots \ldots \ldots \\
\mathrm{Na}_{2} \mathrm{O} \ldots \ldots \\
\mathrm{K}_{2} \mathrm{O} \ldots \ldots\end{array}$ & $\begin{array}{r}2.6 \\
2.9 \\
.9 \\
2.2\end{array}$ & $\begin{array}{r}2.1 \\
1.5 \\
.9 \\
2.6\end{array}$ & $\begin{array}{l}2.0 \\
3.4 \\
1.5 \\
2.3\end{array}$ & $\begin{array}{l}2.1 \\
3.4 \\
1.2 \\
2.4\end{array}$ & $\begin{array}{l}2.0 \\
1.5 \\
1.1 \\
2.4\end{array}$ & $\begin{array}{l}2.4 \\
4.1 \\
1.3 \\
2.7\end{array}$ \\
\hline $\begin{array}{l}\mathrm{H}_{2} \mathrm{O}-\ldots \ldots \ldots \\
\mathrm{H}_{2} \mathrm{O}+\ldots \cdots \cdots \\
\mathrm{TiO}_{2} \ldots \cdots \cdots \\
\mathrm{P}_{2} \mathrm{O}_{5} \ldots \ldots \cdots\end{array}$ & $\begin{array}{l}2.5 \\
4.2 \\
.58 \\
.14\end{array}$ & $\begin{array}{l}3.5 \\
5.1 \\
.62 \\
.17\end{array}$ & $\begin{array}{l}2.6 \\
3.5 \\
.54 \\
.11\end{array}$ & $\begin{array}{l}3.4 \\
4.1 \\
.53 \\
.12\end{array}$ & $\begin{array}{l}3.7 \\
4.3 \\
.59 \\
.12\end{array}$ & $\begin{array}{l}3.3 \\
4.2 \\
.59 \\
.18\end{array}$ \\
\hline $\mathrm{S}$, total...... & .23 & .95 & .09 & .14 & .29 & .37 \\
\hline $\begin{array}{l}\mathrm{C} \text {, organic } \ldots \\
\mathrm{C} \text {, mineral ... }\end{array}$ & $\begin{array}{l}.73 \\
.85\end{array}$ & $\begin{array}{l}1.8 \\
.35\end{array}$ & $\begin{array}{l}1.1 \\
.67\end{array}$ & $\begin{array}{l}.60 \\
.73\end{array}$ & $\begin{array}{l}.62 \\
.24\end{array}$ & $\begin{array}{l}.64 \\
.73\end{array}$ \\
\hline
\end{tabular}

Arithmetic mean of trace elements (parts per million)

\begin{tabular}{ccccccc}
\hline $\mathrm{Zr} \ldots \ldots \ldots \ldots$ & 230 & 190 & 230 & 170 & 180 & 180 \\
$\mathrm{Y} \ldots \ldots \ldots \ldots$ & 35 & 26 & 29 & 28 & 26 & 27 \\
$\mathrm{Yb} \ldots \ldots \ldots \ldots$ & 3.3 & 2.8 & 2.8 & 2.8 & 2.8 & 2.6 \\
$\mathrm{La} \ldots \ldots \ldots \ldots$ & 60 & 29 & 43 & 38 & 34 & 31 \\
$\mathrm{Sn} \ldots \ldots \ldots \ldots$ & $1.0^{1}$ & 1.6 & 2.0 & 1.5 & 1.0 & 1.3
\end{tabular}

$\begin{array}{lllllll}\text { Sc } \ldots \ldots \ldots \ldots & 14 & 18 & 14 & 14 & 16 & 19\end{array}$

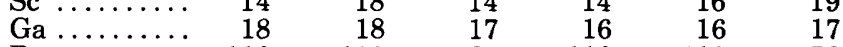

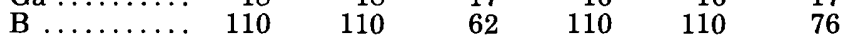

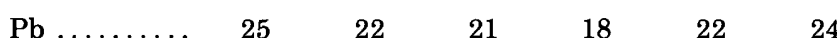

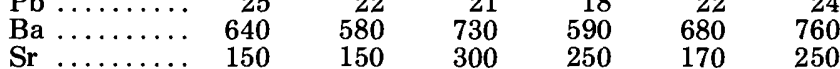

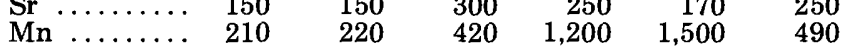

$\begin{array}{lllllll}\text { Co } \ldots \ldots \ldots & 10 & 12 & 11 & 12 & 14 & 16\end{array}$

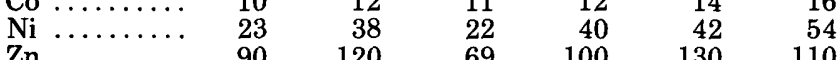

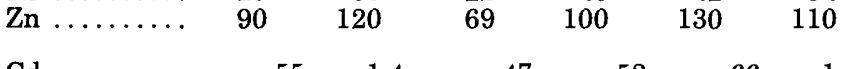

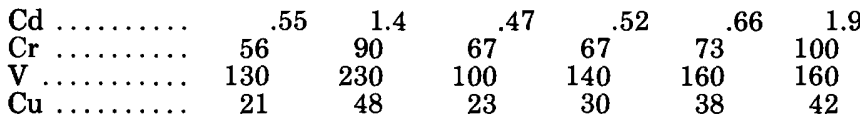

$\begin{array}{lllllll}\text { Mo } \ldots \ldots \ldots . & 1.8 & 17 & 1.3 & 1.6 & 1.4 & 2.1\end{array}$

$\begin{array}{rrrrrrr}\text { Se } \ldots \ldots \cdots \cdots & 1.8 & 17 & 1.3 & 1.6 & 1.4 & 2.1 \\ & .82 & 13 & .39 & .86 & 1.3 & 5.0\end{array}$

$\begin{array}{lllllll}\text { As } \ldots \ldots \cdots \cdots & 8.4 & 33 & 7.4 & 10 & 11 & 12 \\ \text { U } & . .9 & 11 & 2.6 & 3.2 & 3.7 & 4.7\end{array}$

$\begin{array}{lcccccc}\mathrm{U} \ldots \ldots \ldots \ldots & 3.9 & 11 & 2.6 & 3.2 & 3.7 & 4.7 \\ \mathrm{eU} \ldots \ldots \ldots & 15 & 21 & 16 & 15 & 17 & 15\end{array}$

\begin{tabular}{|c|c|c|c|c|c|c|}
\hline \multicolumn{7}{|c|}{ Minerals (percent) } \\
\hline Total clay ... & 53 & 62 & 49 & 62 & 66 & 59 \\
\hline Quartz ...... & 31 & 23 & 29 & $2 \overline{1}$ & 22 & 20 \\
\hline $\begin{array}{l}\text { Cristobalite . } \\
\text { Potassium }\end{array}$ & 0 & 0 & 0 & 3.2 & 2.0 & .4 \\
\hline feldspar ... & 1.7 & 1.8 & 2.7 & .9 & 1.0 & 1.0 \\
\hline Plagioclase & 4.7 & 3.9 & 10 & 4.9 & 4.9 & 6.9 \\
\hline Calcite ...... & 1.3 & .4 & 2.7 & 4.0 & .7 & 4.8 \\
\hline Dolomite .... & 5.6 & 2.5 & 2.5 & 1.7 & 1.0 & 1.2 \\
\hline
\end{tabular}

${ }^{1}$ Only one sample. 

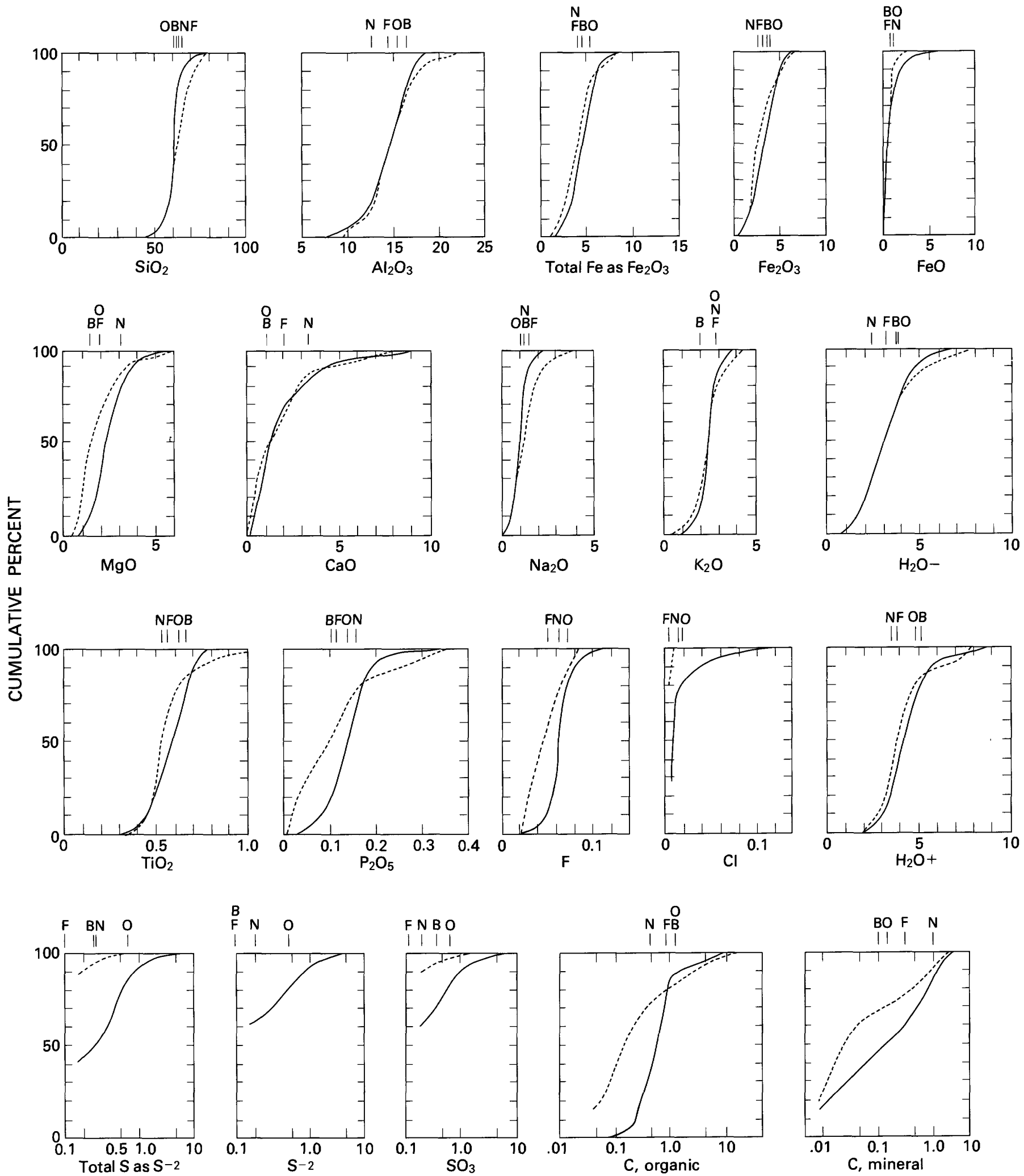

FIGURE 21.-Abundance of major and minor elements in the Pierre Shale and equivalent rocks. Cumulative curves are for 134 marine and 58 nonmarine shale and siltstone samples; solid line, marine samples; dotted line, nonmarine samples. Short vertical lines above curves indicate the arithmetic mean for 87 offshore-marine (O), 47 nearshore-marine (N), 9 brackish-water (B), and 49 freshwater $(F)$ samples. 
TABLE 14.-Average chemical composition of different types of rock in the Pierre Shale and equivalent rocks [N.d. no data; <, less than]

\begin{tabular}{|c|c|c|c|c|c|c|c|c|c|c|c|c|c|}
\hline \multirow{3}{*}{$\begin{array}{l}\text { All shale } \\
\text { and } \\
\text { siltstone }\end{array}$} & \multicolumn{7}{|c|}{ Marine } & \multicolumn{5}{|c|}{ Nonmarine } & \multirow{3}{*}{ Bentonite } \\
\hline & \multicolumn{2}{|c|}{ Ordinary } & \multirow{2}{*}{$\begin{array}{l}\text { Organic- } \\
\text { rich } \\
\text { fissile shale }\end{array}$} & \multirow{2}{*}{$\begin{array}{c}\text { Shale } \\
\text { above } \\
\text { bentonits }\end{array}$} & \multirow{2}{*}{$\begin{array}{l}\text { Frothy- } \\
\text { weathering } \\
\text { shale }\end{array}$} & \multirow{2}{*}{$\begin{array}{l}\text { Siliceous } \\
\text { shale }\end{array}$} & \multirow[t]{2}{*}{ Marl } & \multirow{2}{*}{$\begin{array}{l}\text { All shale } \\
\text { and } \\
\text { siltstone }\end{array}$} & \multicolumn{2}{|c|}{ Ordinary } & \multirow{2}{*}{$\begin{array}{l}\text { Organic- } \\
\text { rich } \\
\text { shale }\end{array}$} & \multirow{2}{*}{$\begin{array}{l}\text { Volcanic- } \\
\text { rich } \\
\text { rock }\end{array}$} & \\
\hline & Shale & Siltstone & & & & & & & Shale & Siltstone & & & \\
\hline $\begin{array}{l}\text { Number } \\
\text { of samples } 134\end{array}$ & 62 & 30 & 7 & 6 & 19 & 7 & 10 & 58 & 12 & 10 & 11 & 23 & 22 \\
\hline \multicolumn{14}{|c|}{ Arithmetic mean of major and minor elements in percent } \\
\hline $\begin{array}{l}\mathrm{SiO}_{2} \ldots \ldots .61 \\
\mathrm{Al}_{8} \mathrm{O}_{3} \ldots . . .14 \\
\mathrm{Fe}^{2} \text {, total as }\end{array}$ & $\begin{array}{l}61 \\
16\end{array}$ & $\begin{array}{l}63 \\
12\end{array}$ & $\begin{array}{l}53 \\
13\end{array}$ & $\begin{array}{l}59 \\
15\end{array}$ & $\begin{array}{l}61 \\
16\end{array}$ & $\begin{array}{l}67 \\
12\end{array}$ & $\begin{array}{l}39 \\
11\end{array}$ & $\begin{array}{l}64 \\
15\end{array}$ & $\begin{array}{l}64 \\
15\end{array}$ & $\begin{array}{l}67 \\
12\end{array}$ & $\begin{array}{l}63 \\
15\end{array}$ & $\begin{array}{l}62 \\
16\end{array}$ & $\begin{array}{l}55 \\
18\end{array}$ \\
\hline $\begin{array}{r}\mathrm{Fe}_{2} \mathrm{O}_{3} \ldots .4 .8 \\
\mathrm{Fe}_{2} \mathrm{O}_{3} \ldots \ldots .3 .5 \\
\mathrm{FeO}^{2} \ldots \ldots \ldots .1 .2\end{array}$ & $\begin{array}{l}5.4 \\
4.2 \\
1.1\end{array}$ & $\begin{array}{l}3.6 \\
2.3 \\
1.2\end{array}$ & $\begin{array}{l}6.6 \\
2.1 \\
4.1\end{array}$ & $\begin{array}{l}4.8 \\
3.7 \\
1.0\end{array}$ & $\begin{array}{l}5.0 \\
4.2 \\
.70\end{array}$ & $\begin{array}{l}4.1 \\
3.2 \\
.83\end{array}$ & $\begin{array}{l}4.5 \\
2.7 \\
1.6\end{array}$ & $\begin{array}{l}4.1 \\
3.2 \\
.80\end{array}$ & $\begin{array}{l}4.4 \\
3.3 \\
1.0\end{array}$ & $\begin{array}{l}3.4 \\
2.3 \\
1.0\end{array}$ & $\begin{array}{l}3.4 \\
2.9 \\
.49\end{array}$ & $\begin{array}{l}4.6 \\
3.8 \\
.79\end{array}$ & $\begin{array}{l}4.5 \\
3.9 \\
.50\end{array}$ \\
\hline 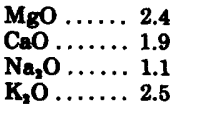 & $\begin{array}{l}2.1 \\
1.2 \\
1.1 \\
2.6\end{array}$ & $\begin{array}{l}3.4 \\
4.0 \\
1.2 \\
2.4\end{array}$ & $\begin{array}{c}1.1 \\
.92 \\
.65 \\
2.7\end{array}$ & $\begin{array}{c}2.0 \\
.72 \\
.60 \\
2.6\end{array}$ & $\begin{array}{l}2.3 \\
1.2 \\
1.3 \\
2.3\end{array}$ & $\begin{array}{l}1.7 \\
1.2 \\
.69 \\
1.8\end{array}$ & $\begin{array}{c}1.8 \\
17.4 \\
.63 \\
2.2\end{array}$ & $\begin{array}{l}1.8 \\
1.8 \\
1.3 \\
2.5\end{array}$ & $\begin{array}{l}2.1 \\
1.1 \\
1.2 \\
2.9\end{array}$ & $\begin{array}{l}2.4 \\
2.7 \\
.93 \\
2.5\end{array}$ & $\begin{array}{r}.93 \\
.34 \\
.88 \\
2.1\end{array}$ & $\begin{array}{l}1.8 \\
2.5 \\
1.8 \\
2.4\end{array}$ & $\begin{array}{l}3.0 \\
1.8 \\
1.5 \\
.45\end{array}$ \\
\hline $\begin{array}{l}\mathrm{H}_{2} \mathrm{O}-\ldots \ldots 3.2 \\
\mathrm{H}_{2} \mathrm{O}+\ldots \ldots .4 .4 \\
\mathrm{TiO}_{2} \ldots \ldots \ldots .58 \\
\mathrm{P}_{2} \mathrm{O}_{6} \ldots \ldots \ldots .14\end{array}$ & $\begin{array}{c}3.4 \\
4.8 \\
.65 \\
.15\end{array}$ & $\begin{array}{l}1.9 \\
3.1 \\
.48 \\
.16\end{array}$ & $\begin{array}{r}3.1 \\
5.4 \\
.61 \\
.15\end{array}$ & $\begin{array}{l}5.2 \\
5.7 \\
.65 \\
.18\end{array}$ & $\begin{array}{c}4.1 \\
4.4 \\
.57 \\
.11\end{array}$ & $\begin{array}{l}4.1 \\
3.9 \\
.45 \\
.09\end{array}$ & $\begin{array}{l}2.4 \\
3.0 \\
.45 \\
.22\end{array}$ & $\begin{array}{l}3.2 \\
4.1 \\
.58 \\
.11\end{array}$ & $\begin{array}{c}3.3 \\
4.1 \\
.55 \\
.13\end{array}$ & $\begin{array}{l}2.0 \\
3.4 \\
.49 \\
.11\end{array}$ & $\begin{array}{c}3.8 \\
5.4 \\
.67 \\
.06\end{array}$ & $\begin{array}{l}3.5 \\
3.9 \\
.58 \\
.14\end{array}$ & $\begin{array}{c}7.9 \\
5.2 \\
.39 \\
.10\end{array}$ \\
\hline $\begin{array}{l}\text { S, total } \ldots \ldots .46 \\
\mathbf{S}^{-2} \\
\mathbf{S O}_{3} \ldots \ldots \ldots \ldots . .30 .40 .47\end{array}$ & $\begin{array}{l}.29 \\
.18 \\
.31\end{array}$ & $\begin{array}{l}.16 \\
.11 \\
.17\end{array}$ & $\begin{array}{l}3.9 \\
2.6 \\
3.2\end{array}$ & $\begin{array}{l}.67 \\
.29 \\
1.2\end{array}$ & $\begin{array}{l}.30 \\
.16 \\
.42\end{array}$ & $\begin{array}{r}.22 \\
<.19 \\
<.20\end{array}$ & $\begin{array}{l}.95 \\
.80 \\
.49\end{array}$ & $\begin{array}{l}\quad .07 \\
<.05 \\
<.20\end{array}$ & $\begin{array}{l}<.04 \\
<.05 \\
<.20\end{array}$ & $\begin{array}{l}<.05 \\
<.05 \\
<.20\end{array}$ & $\begin{array}{r}.15 \\
<.05 \\
.35\end{array}$ & $\begin{array}{r}.04 \\
<.05 \\
<.20\end{array}$ & $\begin{array}{l}.49 \\
.14 \\
1.0\end{array}$ \\
\hline $\begin{array}{l}\text { F } \ldots \ldots \ldots \ldots . .072 \\
\text { Cl } \ldots \ldots \ldots \ldots . .019 \\
\text { C, organic.....93 } \\
\text { C, mineral ... }\end{array}$ & $\begin{array}{l}.070 \\
.013 \\
.63 \\
.24\end{array}$ & $\begin{array}{r}<1.05 \\
<1.01 \\
.41 \\
1.25\end{array}$ & $\begin{array}{l}.079 \\
.05 \\
5.9 \\
.19\end{array}$ & $\begin{array}{l}.082 \\
\text { N.d. } \\
2.5 \\
.07\end{array}$ & $\begin{array}{l}.078 \\
.013 \\
.36 \\
.12\end{array}$ & $\begin{array}{l}.082 \\
.01 \\
.58 \\
.30\end{array}$ & $\begin{array}{l}.073 \\
.02 \\
1.3 \\
3.83\end{array}$ & $\begin{array}{r}.05 \\
<.01 \\
.90 \\
.28\end{array}$ & $\begin{array}{r}.07 \\
<.01 \\
.45 \\
.26\end{array}$ & $\begin{array}{c}.05 \\
\text { N.d. } \\
.24 \\
.81\end{array}$ & $\begin{array}{l}\text { N.d. } \\
\text { N.d. } \\
3.8 \\
.01\end{array}$ & $\begin{array}{r}.05 \\
<.01 \\
.10 \\
.17\end{array}$ & $\begin{array}{c}.094 \\
\text { N.d. } \\
.05 \\
.10\end{array}$ \\
\hline \multicolumn{14}{|c|}{ Artithmetic mean of trace elements in parts per million } \\
\hline 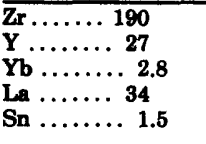 & $\begin{array}{c}170 \\
26 \\
2.8 \\
30 \\
1.3\end{array}$ & $\begin{array}{c}240 \\
31 \\
3.0 \\
47 \\
1.5\end{array}$ & $\begin{array}{c}180 \\
19 \\
3.0 \\
19 \\
1.4\end{array}$ & $\begin{array}{c}230 \\
26 \\
2.9 \\
38 \\
2.0\end{array}$ & $\begin{array}{c}180 \\
26 \\
2.6 \\
34 \\
\text { N.d. }\end{array}$ & $\begin{array}{c}130 \\
26 \\
3.0 \\
30 \\
\text { N.d. }\end{array}$ & $\begin{array}{c}140 \\
20 \\
2.0 \\
22 \\
.7\end{array}$ & $\begin{array}{c}220 \\
34 \\
3.1 \\
52 \\
1.4\end{array}$ & $\begin{array}{c}210 \\
37 \\
3.5 \\
65 \\
3.3\end{array}$ & $\begin{array}{c}220 \\
31 \\
2.8 \\
48 \\
\text { N.d. }\end{array}$ & $\begin{array}{c}260 \\
40 \\
3.1 \\
71 \\
1.5\end{array}$ & $\begin{array}{c}200 \\
31 \\
2.9 \\
40 \\
1.2\end{array}$ & $\begin{array}{c}260 \\
32 \\
2.7 \\
57 \\
2.1\end{array}$ \\
\hline $\begin{array}{l}\text { Sc } \ldots \ldots \ldots 17 \\
\text { B } \ldots \ldots \ldots 110\end{array}$ & $\begin{array}{r}18 \\
118\end{array}$ & $\begin{array}{l}12 \\
80\end{array}$ & $\begin{array}{r}17 \\
141\end{array}$ & $\begin{array}{r}19 \\
125\end{array}$ & $\begin{array}{r}17 \\
133\end{array}$ & $\begin{array}{r}14 \\
125\end{array}$ & $\begin{array}{l}17 \\
71\end{array}$ & $\begin{array}{l}13 \\
71\end{array}$ & $\begin{array}{l}14 \\
82\end{array}$ & $\begin{array}{l}11 \\
71\end{array}$ & $\begin{array}{c}13 \\
132\end{array}$ & $\begin{array}{l}15 \\
39\end{array}$ & $\begin{array}{c}9.1 \\
61\end{array}$ \\
\hline $\begin{array}{l}\mathrm{Ga} \\
\mathrm{Pb}\end{array}$ & $\begin{array}{r}18 \\
22 \\
730 \\
140 \\
500\end{array}$ & $\begin{array}{r}16 \\
22 \\
590 \\
150 \\
240\end{array}$ & $\begin{array}{r}14 \\
20 \\
600 \\
96 \\
150\end{array}$ & $\begin{array}{r}18 \\
20 \\
490 \\
100 \\
135\end{array}$ & $\begin{array}{r}15 \\
21 \\
590 \\
170 \\
560\end{array}$ & $\begin{array}{c}9.2 \\
15 \\
460 \\
100 \\
6,800\end{array}$ & $\begin{array}{r}12 \\
20 \\
440 \\
540 \\
2,700\end{array}$ & $\begin{array}{r}19 \\
24 \\
710 \\
270 \\
300\end{array}$ & $\begin{array}{r}20 \\
23 \\
610 \\
170 \\
170\end{array}$ & $\begin{array}{r}15 \\
27 \\
520 \\
140 \\
240\end{array}$ & $\begin{array}{r}19 \\
26 \\
590 \\
150 \\
120\end{array}$ & $\begin{array}{r}19 \\
22 \\
920 \\
450 \\
490\end{array}$ & $\begin{array}{r}19 \\
31 \\
700 \\
190 \\
250\end{array}$ \\
\hline 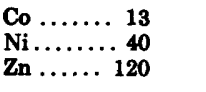 & $\begin{array}{r}13 \\
39 \\
130\end{array}$ & $\begin{array}{l}8.3 \\
23 \\
80\end{array}$ & $\begin{array}{r}13 \\
58 \\
140\end{array}$ & $\begin{array}{r}10 \\
31 \\
110\end{array}$ & $\begin{array}{r}15 \\
64 \\
140\end{array}$ & $\begin{array}{r}20 \\
59 \\
180\end{array}$ & $\begin{array}{r}15 \\
46 \\
120\end{array}$ & $\begin{array}{l}11 \\
26 \\
75\end{array}$ & $\begin{array}{l}\mathbf{1 3} \\
\mathbf{3 1} \\
\mathbf{8 5}\end{array}$ & $\begin{array}{l}7.8 \\
17 \\
84\end{array}$ & $\begin{array}{l}10 \\
19 \\
76\end{array}$ & $\begin{array}{l}13 \\
30 \\
68\end{array}$ & $\begin{array}{l}6.7 \\
25 \\
76\end{array}$ \\
\hline $\begin{array}{l}\text { Cd } \ldots \ldots \ldots . .88 \\
\text { Cr.......80 } \\
\text { v } \ldots \ldots . .180 \\
\text { Cu } \ldots \ldots \ldots .38\end{array}$ & $\begin{array}{c}90 \\
94 \\
170 \\
36\end{array}$ & $\begin{array}{c}57^{.30} \\
110 \\
20\end{array}$ & $\begin{array}{l}2.2 \\
108 \\
490 \\
90\end{array}$ & $\begin{array}{l}1.0 \\
109 \\
290 \\
60\end{array}$ & $\begin{array}{c}74^{.63} \\
160 \\
43\end{array}$ & $\begin{array}{c}70^{.71} \\
210 \\
48\end{array}$ & $\begin{array}{c}2.2 \\
78 \\
180 \\
39\end{array}$ & $\begin{array}{c}60^{.4} \\
100 \\
25\end{array}$ & $\begin{array}{c}1.5 \\
57 \\
100 \\
27\end{array}$ & $\begin{array}{l}1.5 \\
45 \\
93 \\
15\end{array}$ & $\begin{array}{l}52.35 \\
93 \\
23\end{array}$ & $\begin{array}{c}\text { N.d. } \\
72 \\
110 \\
29\end{array}$ & $\begin{array}{l}1.5 \\
9.1 \\
67 \\
11\end{array}$ \\
\hline 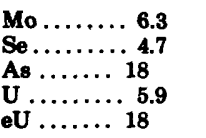 & $\begin{array}{c}1.4 \\
1.4 \\
13 \\
4.0 \\
18\end{array}$ & $\begin{array}{r}1.4 \\
.4 \\
8.7 \\
\text { N.d. } \\
16\end{array}$ & $\begin{array}{r}86 \\
60 \\
113 \\
13 \\
27\end{array}$ & $\begin{array}{l}14 \\
12 \\
33 \\
15 \\
20\end{array}$ & $\begin{array}{c}1.9 \\
1.5 \\
10 \\
3.9 \\
14\end{array}$ & $\begin{array}{c}1.3 \\
1.2 \\
12 \\
2.6 \\
9\end{array}$ & $\begin{array}{l}5.9 \\
11 \\
18 \\
5.0 \\
12\end{array}$ & $\begin{array}{r}1.3 \\
.4 \\
6.6 \\
\text { N.d. } \\
15\end{array}$ & $\begin{array}{c}1.2 \\
.3 \\
5.1 \\
\text { N.d. } \\
18\end{array}$ & $\begin{array}{r}.8 \\
.4 \\
8.6 \\
\text { N.d. } \\
15\end{array}$ & $\begin{array}{r}1.5 \\
.9 \\
6.6 \\
\text { N.d. } \\
14\end{array}$ & $\begin{array}{r}1.5 \\
.3 \\
6.5 \\
\text { N.d. } \\
15\end{array}$ & $\begin{array}{l}2.9 \\
.7 \\
5.3 \\
5.7 \\
9\end{array}$ \\
\hline \multicolumn{14}{|c|}{ Arithmetic mean of minerals in percent } \\
\hline $\begin{array}{l}\text { Total clay } 62 \\
\text { Quartz ... 23 } \\
\text { Cristobalite } 1.6 \\
\text { Potassium }\end{array}$ & $\begin{array}{r}68 \\
23 \\
0\end{array}$ & $\begin{array}{r}44 \\
33 \\
0\end{array}$ & $\begin{array}{r}58 \\
20 \\
0\end{array}$ & $\begin{array}{r}68 \\
20 \\
0\end{array}$ & $\begin{array}{l}76 \\
17 \\
2.1\end{array}$ & $\begin{array}{l}61 \\
11 \\
23\end{array}$ & $\begin{array}{r}51 \\
13 \\
0\end{array}$ & $\begin{array}{r}53 \\
28 \\
0\end{array}$ & $\begin{array}{r}59 \\
29 \\
0\end{array}$ & $\begin{array}{r}43 \\
39 \\
0\end{array}$ & $\begin{array}{r}59 \\
31 \\
0\end{array}$ & $\begin{array}{r}52 \\
23 \\
0\end{array}$ & $\begin{array}{l}88 \\
3.4 \\
0\end{array}$ \\
\hline $\begin{aligned} \text { feldspar } & 1.4 \\
\text { Plagioclase } & 4.3\end{aligned}$ & $\begin{array}{r}.8 \\
3.9\end{array}$ & $\begin{array}{l}2.6 \\
7.8\end{array}$ & $\begin{array}{l}2.8 \\
1.0\end{array}$ & $\begin{array}{l}2.9 \\
2.5\end{array}$ & $\begin{array}{r}.6 \\
3.1\end{array}$ & $\begin{array}{r}.6 \\
1.1\end{array}$ & $\begin{array}{r}.7 \\
1.3\end{array}$ & $\begin{array}{l}1.9 \\
9.1\end{array}$ & $\begin{array}{l}1.5 \\
6.8\end{array}$ & $\begin{array}{l}3.0 \\
5.9\end{array}$ & $\begin{array}{l}1.9 \\
4.2\end{array}$ & $\begin{array}{r}1.6 \\
14.2\end{array}$ & $\begin{array}{l}<.1 \\
2.9\end{array}$ \\
\hline $\begin{array}{l}\text { Calcite ........7 } \\
\text { Dolomite .. } 2.9 \\
\text { Organic }\end{array}$ & $\begin{array}{r}.4 \\
1.4\end{array}$ & $\begin{array}{l}1.1 \\
8.8\end{array}$ & ${ }^{0} .4$ & ${ }_{.6}^{0}$ & $\begin{array}{l}.8 \\
.2\end{array}$ & $0^{.3}$ & $\begin{array}{l}28 \\
1.9\end{array}$ & $\begin{array}{l}.8 \\
1.4\end{array}$ & $1.9^{.2}$ & $\begin{array}{l}1.4 \\
4.6\end{array}$ & ${ }^{0} .0$ & $\begin{array}{r}1.2 \\
.0\end{array}$ & $\begin{array}{r}1.0 \\
.0\end{array}$ \\
\hline $\begin{array}{r}\text { matter' .. } 1.3 \\
\text { Pyrite'.......5.5 }\end{array}$ & $\begin{array}{l}.8 \\
.4\end{array}$ & $\begin{array}{l}.5 \\
.2\end{array}$ & $\begin{array}{l}8.2 \\
3.9\end{array}$ & $\begin{array}{l}2.9 \\
1.3\end{array}$ & $\begin{array}{l}.5 \\
.2\end{array}$ & $\begin{array}{l}.8 \\
.2\end{array}$ & $\begin{array}{l}1.8 \\
1.6\end{array}$ & $\begin{array}{r}1.3 \\
.1\end{array}$ & $0^{.6}$ & $0^{.3}$ & $\begin{array}{r}5.2 \\
.1\end{array}$ & $\begin{array}{l}.1 \\
.0\end{array}$ & $\begin{array}{r}<.1 \\
.2\end{array}$ \\
\hline
\end{tabular}


TABLE 15.-Inferred occurrence of elements in minerals, Pierre Shale and equivalent rocks

[Amounts of minerals are from table 14, some being rounded; numbers to the left in heavier type are for marine rock and numbers to the right in lighter type are for nonmarine rock. The numbers in parentheses are the inferred amount of each element in the mineral, and for most elements these numbers apply to both marine and nonmarine rock; these values multiplied by the average percentage of the mineral in the rock give the amounts shown outside the parentheses of the element in the mineral in each type of rock. Some elements occur in different amounts in marine and nonmarine clay; the amount in nonmarine clay is shown in a second set of parentheses farthest to the right. ?, possible or doubtful; leaders (---), none or no significant amount]

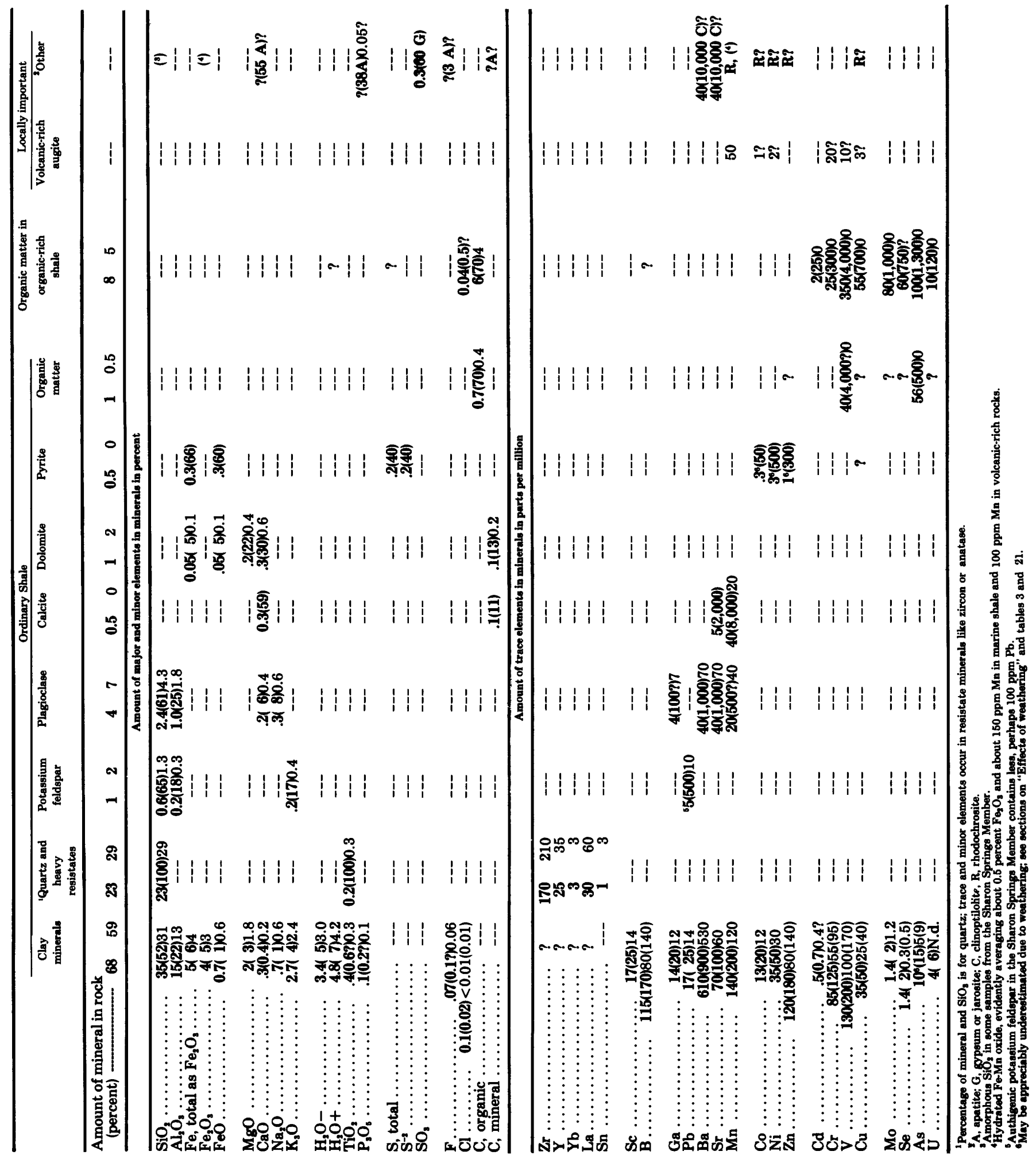



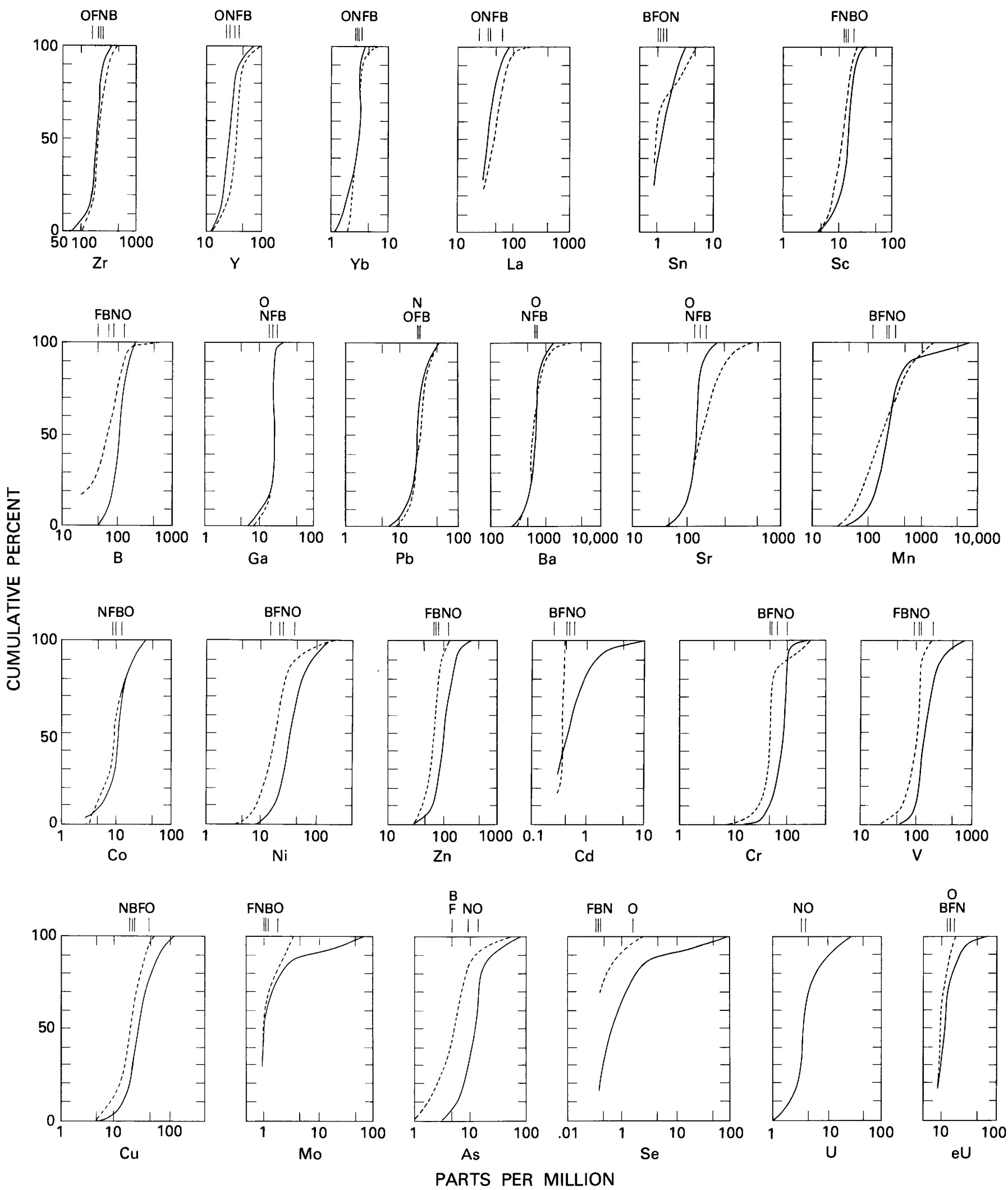

FIgURE 22.-Abundance of trace elements in the Pierre Shale and equivalent rocks. All in parts per million. Cumulative curves are for 134 marine and 58 nonmarine shale and siltstone samples; solid line, marine samples; dotted line, nonmarine samples. Short vertical lines above curves indicate the arithmetic mean for 87 offshore-marine (O), 47 nearshore-marine $(\mathrm{N}), 9$ brackish-water (B), and 49 freshwater (F) samples. 
ferences in $\mathrm{SiO}_{2}$ content between rock types (table 14). The smaller amount of $\mathrm{SiO}_{2}$ and other major oxides in marl is, of course, due to dilution by calcite. The smaller $\mathrm{SiO}_{2}$ content of marine organic-rich fissile shale is due to dilution by both organic matter and sulfur minerals. Even so, the 53-percent average $\mathrm{SiO}_{2}$ content of the seven marine organic-rich shale samples listed in table 14 includes amorphous silice in two samples (15 percent in 259561 and 8 percent in 259563 , table 1) that was not detected by X-ray but was detected by solution tests (Schultz, 1964, p. C27). However, the general agreement between chemical and mineral composition of most samples and the total mineral composition of most samples of near 100 percent indicates little or no amorphous silica. The large average $\mathrm{SiO}_{2}$ in siliceous shale, 67 percent, is due mostly to cristobalite, but the 23-percent average cristobalite content of siliceous shale is offset partly by the exceptionally small quartz content of many siliceous shale samples and partly by dilution of other silica-bearing minerals by the cristobalite itself. Such dilution of normal mineralogy and chemical composition by exceptionally large amounts of specific minerals like cristobalite or calcite is such an obvious relation that it will not be repeated for each element discussed in many of the following paragraphs. The relatively small $\mathrm{SiO}_{2}$ content of bentonite, 55 percent, is due to small quartz content.

Many of the small differences in $\mathrm{SiO}_{2}$ between the individual geographic localities (fig. $23 \mathrm{H}$ ) probably are not statistically significant, but the maximum amount of $\mathrm{SiO}_{2}, 64$ percent, occurs in the central zone where quartz-rich nearshore-marine sandstone and siltstone are abundant (fig. 23B). The smaller $\mathrm{SiO}_{2}$ content in the east, 58 percent, is due to the relative scarcity of quartz in the fine-grained offshore-marine shale (fig. $23 B$ ) that is only partly offset by $\mathrm{SiO}_{2}$ in the larger amount of clay (fig. 23A) and by cristobalite (fig. 23C). The large amount of $\mathrm{SiO}_{2}$ at Salt Creek (loc. 10) and to a lesser extent at Elk Basin (loc. 7) result from quartzrich sediments (fig. $23 B$ ) from the southwest (fig. 19A).

Differences in $\mathrm{SiO}_{2}$ content of the six fossil zones are surprisingly small (table 13). The large $\mathrm{SiO}_{2}$ content expected from large quartz content of nearshore-marine sandstone and siltstone representative of times of marine regression is only barely shown by the approximately 62 percent average $\mathrm{SiO}_{2}$ in fossil zones 1 and 3 , and is not shown at all in fossil zone 6. In large part, this small difference is because nearshore-marine sandstone is not well represented in the analytical samples. Also, the $\mathrm{SiO}_{2}$ content of fossil zones 4 and 5 is augmented to levels similar to that of zones 1 and 3 by an
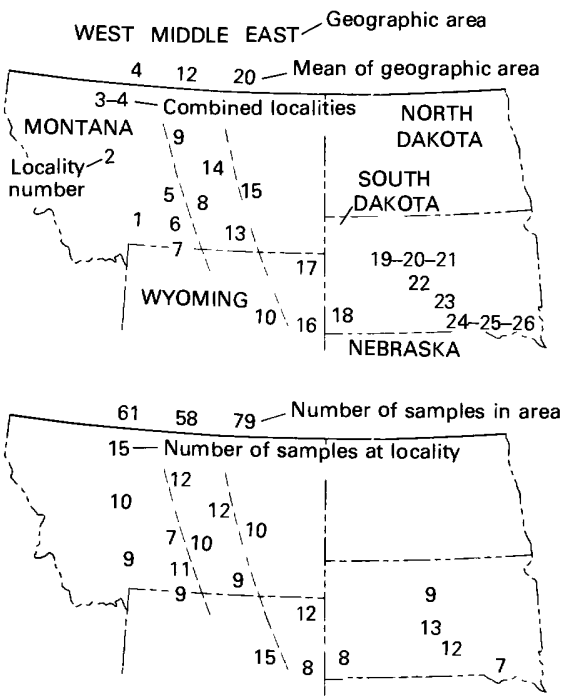

A. Total clay

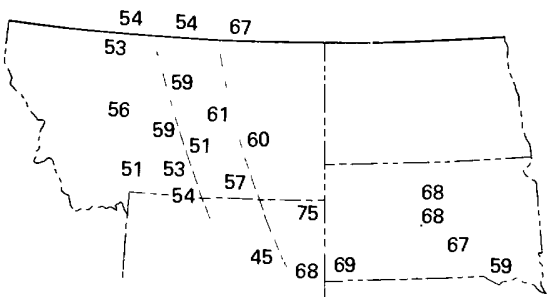

B. Quartz

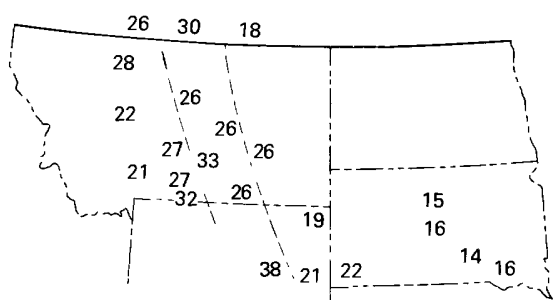

C. Cristobalite

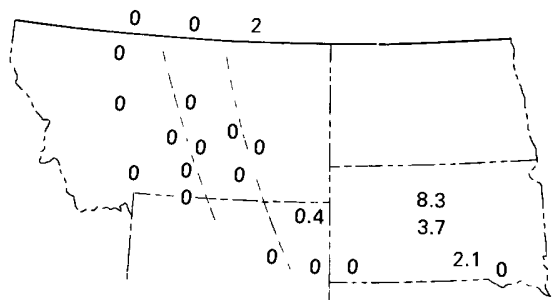

D. Potassium feldspar

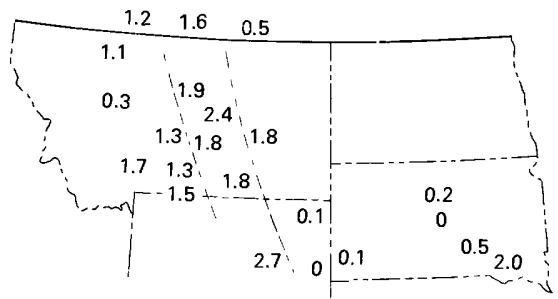

E. Plagioclase

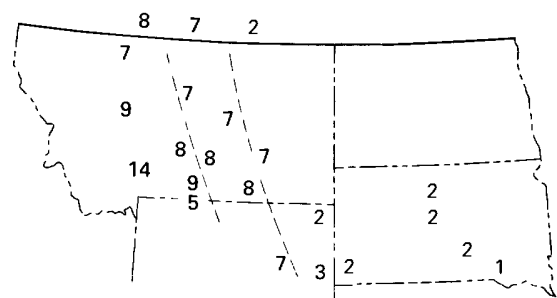

F. Calcite

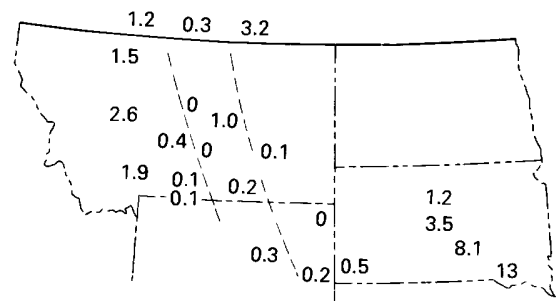

G. Dolomite

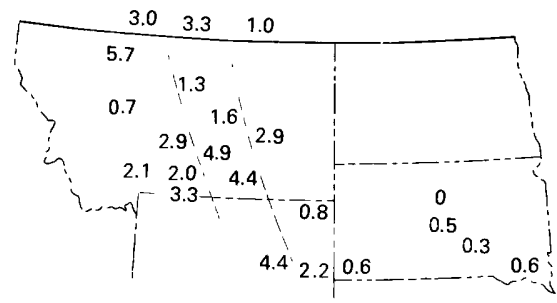

Figure 23.-Composition of chemically analyzed samples of the Pierre Shale and equivalent rocks by locality. Marl is included, bentonite is not. Values are arithmetic means; $A-V$ in percent, $A A-U U$ in parts per million. Additional locality information shown in figure 19. 
H. $\mathrm{SiO}_{2}$

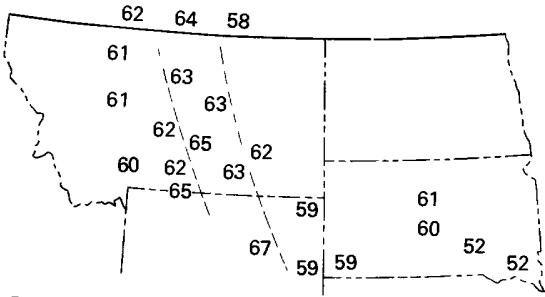

I. $\mathrm{Al}_{2} \mathrm{O}_{3}$

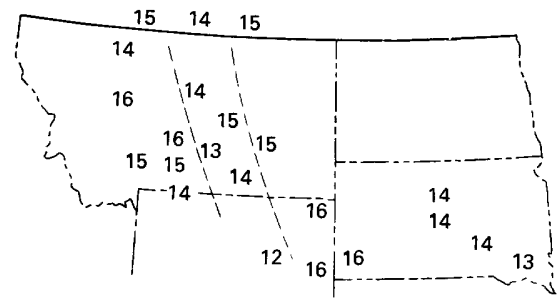

J. $\mathrm{Fe}_{2} \mathrm{O}_{3}$

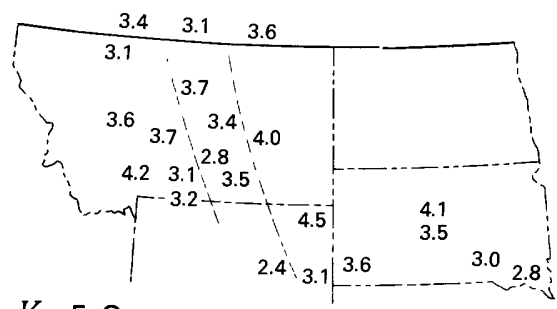

K. $\mathrm{FeO}$

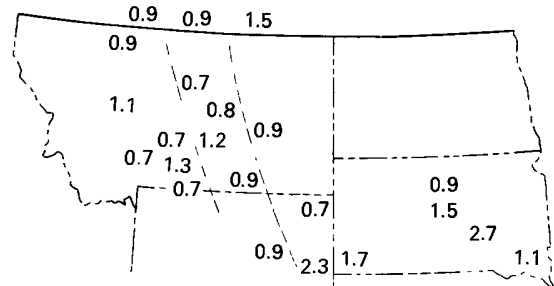

L. $\mathrm{MgO}$

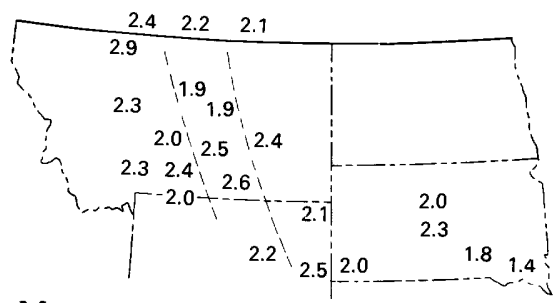

M. $\mathrm{CaO}$

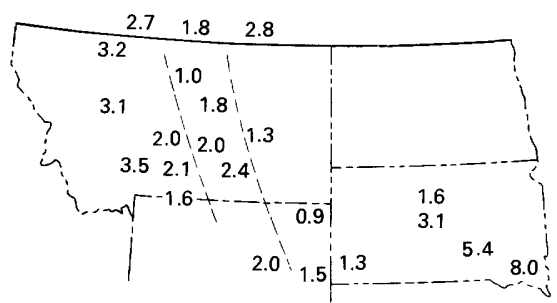

N. $\mathrm{Na}_{2} \mathrm{O}$

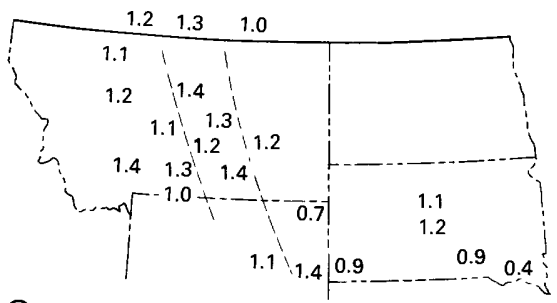

O. $\mathrm{K}_{2} \mathrm{O}$

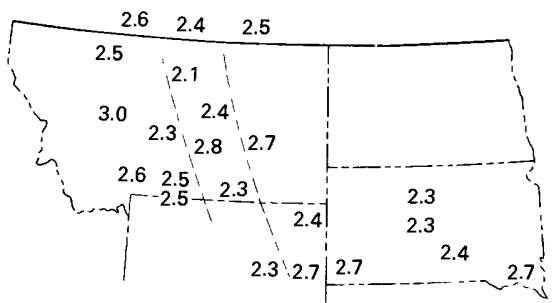

P. $\mathrm{H}_{2} \mathrm{O}^{-}$

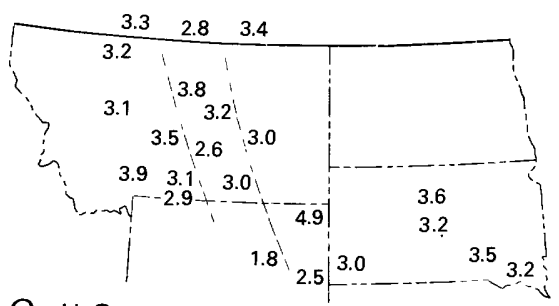

Q. $\mathrm{H}_{2} \mathrm{O}+$

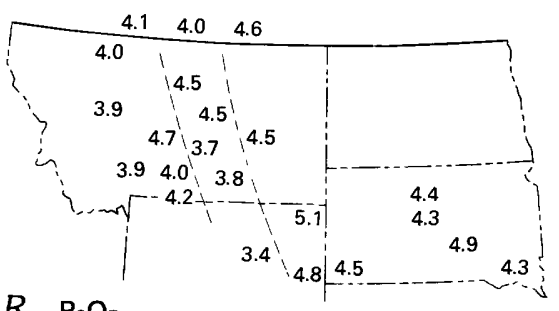

R. $\mathrm{P}_{2} \mathrm{O}_{5}$

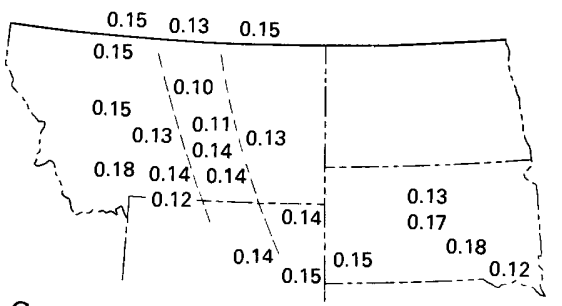

S. $\mathrm{TiO}_{2}$

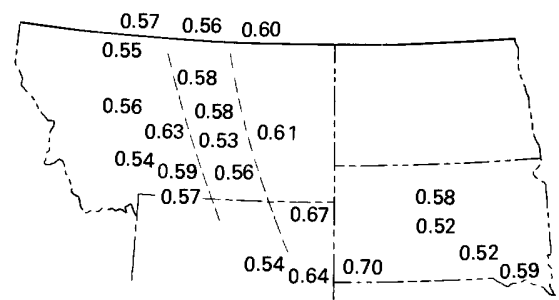

T. S , total

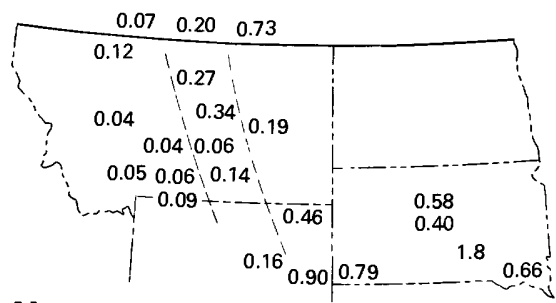

U. C, organic

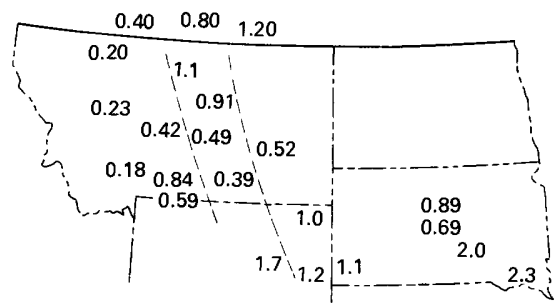

$V$. Mineral carbon

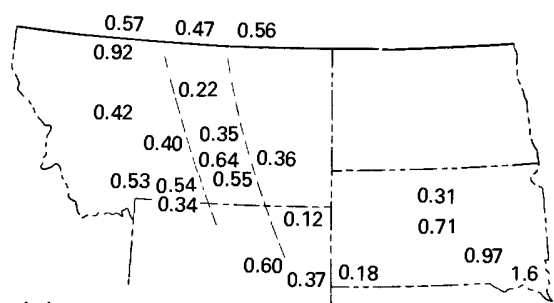

$A A . \mathrm{Zr}$

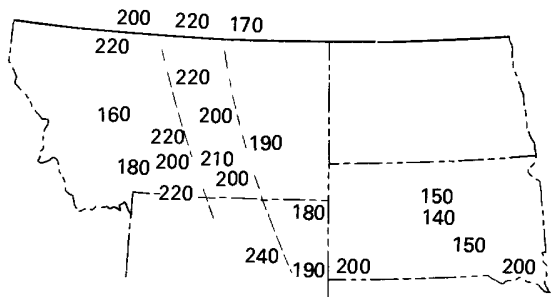

BB. $Y$

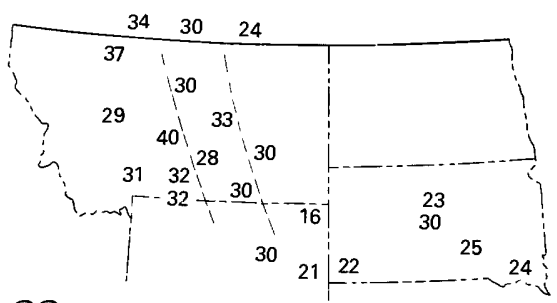

CC. $\mathrm{Yb}$

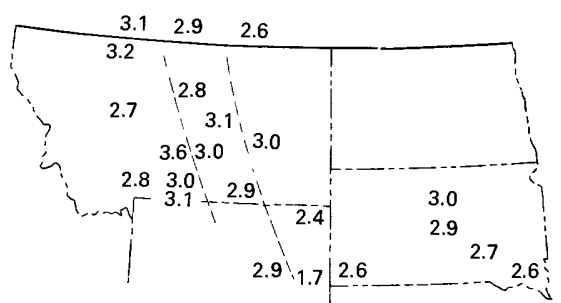

FIGURE 23.-Composition of chemically analyzed samples-Continued 
DD. La

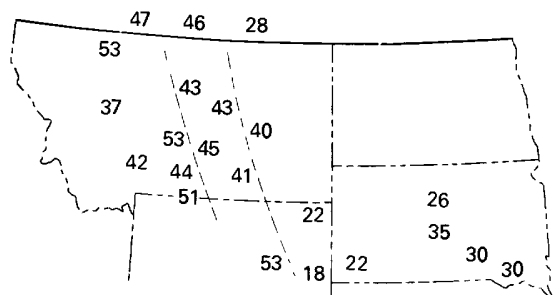

EE. Sc

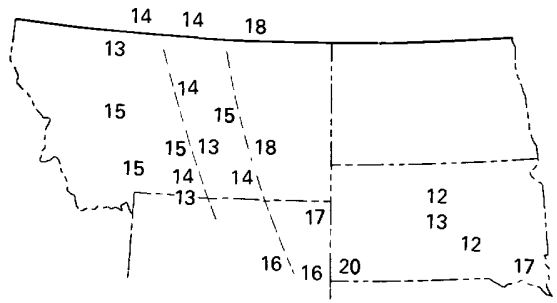

FF. B

JJ. Sr

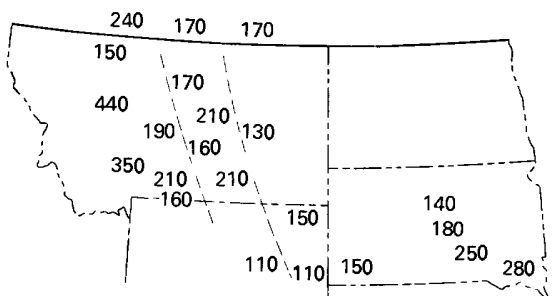

KK. $\mathrm{Mn}$

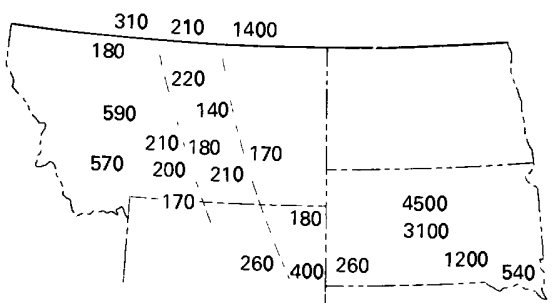

LL. Co

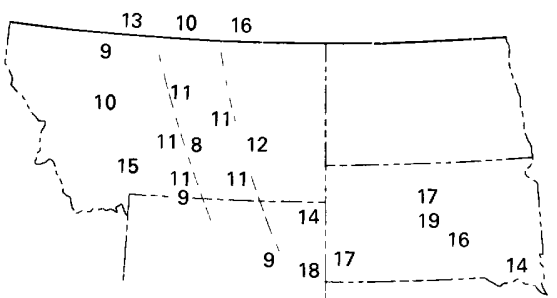

MM. Ni

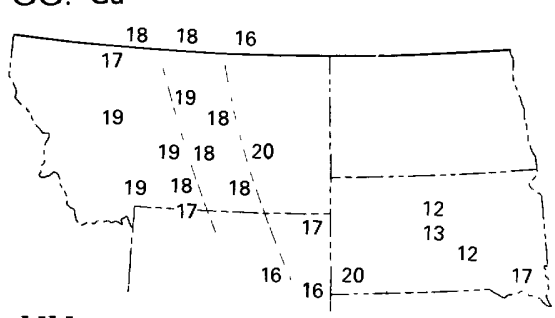

HH. $\mathrm{Pb}$

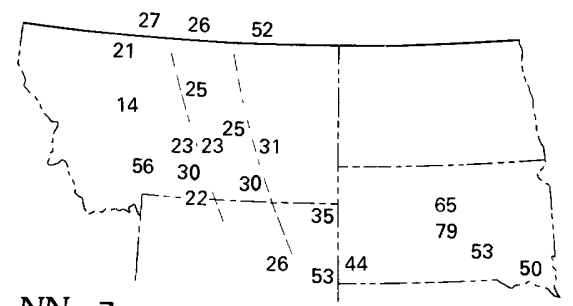

NN. Zn

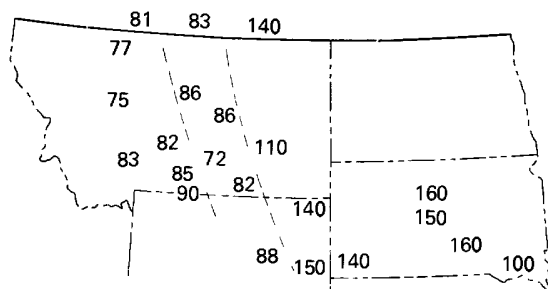

OO. $\mathrm{Cd}$

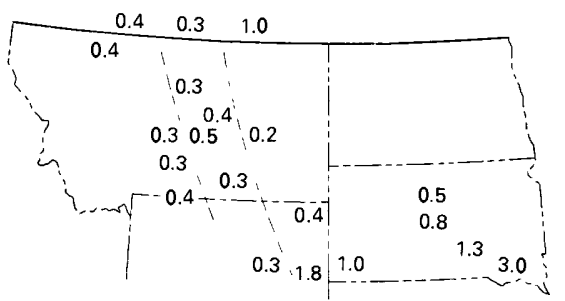

PP. $\mathrm{Cr}$

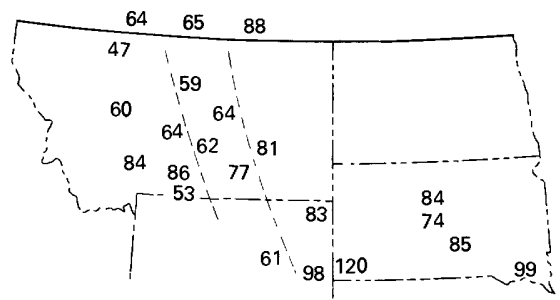

QQ. V

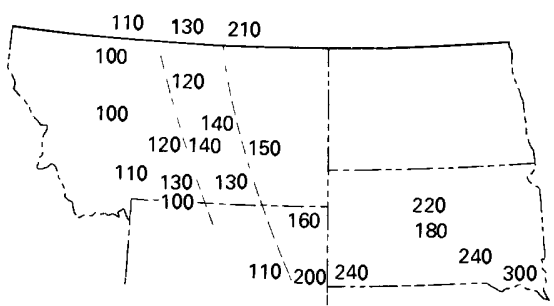

RR. $\mathrm{Cu}$

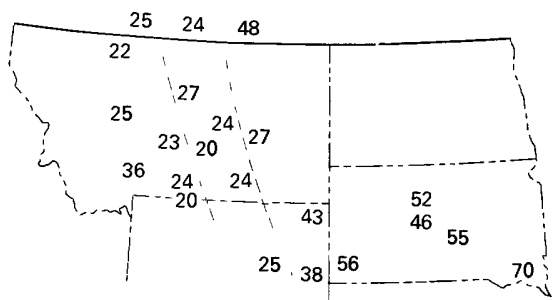

SS. Mo

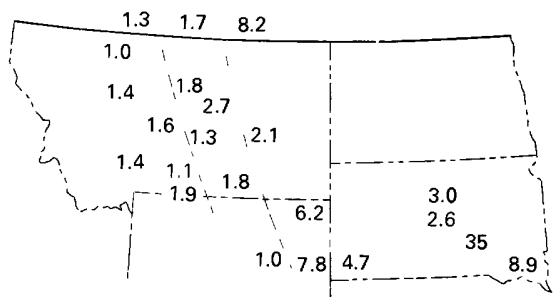

TT. Se

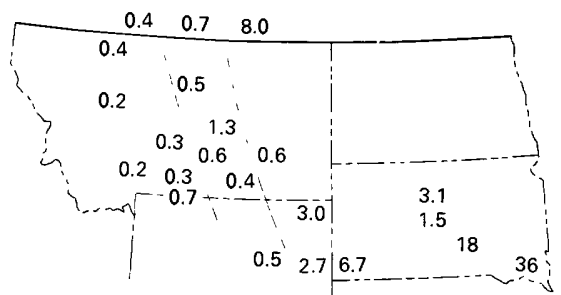

UU. As

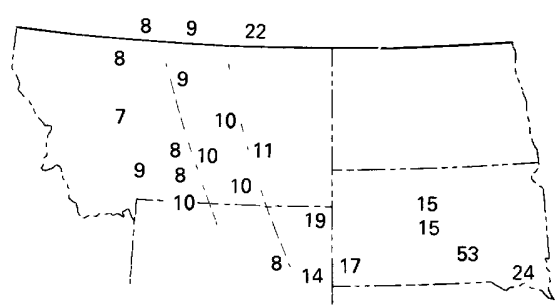

FIGURE 23.-Composition of chemically analyzed samples-Continued 
average 2 to 3 percent cristobalite. Samples from fossil zone 6 tend to be more argillaceous than those from zones 1 and 3 , and the $\mathrm{SiO}_{2}$ content is further decreased by large amounts of calcite in the marl of the Mobridge Member in eastern areas (pl. 1).

Alumina content of most of the Pierre Shale, ranging from an average of 12 to 16 percent $\mathrm{Al}_{2} \mathrm{O}_{3}$ for the lithologic groups (table 14, bentonite and marl excepted), is remarkably constant due to the offsetting effects of $\mathrm{Al}_{2} \mathrm{O}_{3}$ in clay and in plagioclase. Offsetting similarly accounts for the small size of regional (fig. $23 A, E$, and $I)$ and stratigraphic (table 13 ) variation. A few highly kaolinitic and beidellitic brackish-water samples, like 159807 and 159784 (table 1), account for most of the samples containing 20 percent or more $\mathrm{Al}_{2} \mathrm{O}_{3}$ (fig. 21). The 3- to 4-percent difference in $\mathrm{Al}_{2} \mathrm{O}_{3}$ between siltstone and shale (table 14) is due to half again more total clay in shale, only partly offset by feldspar differences. The 18-percent average $\mathrm{Al}_{2} \mathrm{O}_{3}$ in bentonite is due entirely to its very large amount of clay.

Iron $(\mathrm{Fe})$ occurs mostly in clay minerals in the Pierre Shale, but also as free iron oxides like hematite or goethite, to some extent in sulfur minerals, and sparingly in dolomite. Solubility in Na-citrate-dithionate solutions (Jackson, 1958) indicates that about onetenth of the Fe occurs as free oxides (Schultz, 1978, p. 14). Ferrous iron $(\mathrm{FeO})$ is much less abundant in most samples, generally about 1 percent, than the ferric form $\left(\mathrm{Fe}_{2} \mathrm{O}_{3}\right)$, generally 3 to 4 percent, because the latter is several times more abundant in the clay minerals (table 15). In marine organic-rich shale, however, pyrite is sufficiently abundant so that $\mathrm{FeO}$ is the dominant form. Also, in the marls the expected dilution of $\mathrm{FeO}$ by calcite is more than offset by above-average amounts of pyrite. Nearly equal $\mathrm{FeO}$ contents of siltstone and shale (table 14) must indicate some ferrous iron in dolomite, as has been demonstrated by Sabins (1962); thus, more $\mathrm{FeO}$ in the several percent more dolomite in the siltstone nearly offsets more $\mathrm{FeO}$ in slightly more pyrite in marine shale and more $\mathrm{FeO}$ in half again more clay in shale in general. In the Pierre Shale and equivalent rocks, as discussed in the section on "Environment of deposition", such dolomite seems to be almost as abundant in nonmarine as in marine siltstone. Relatively small amounts of total $\mathrm{Fe}$, about 4 percent (table 13), in fossil zones 1 and 3 reflect the relatively small amount of clay minerals. Pyrite in the Sharon Springs Member of fossil zone 2 and in the marl of the Mobridge Member in fossil zone 6 accounts for their high $\mathrm{FeO}$ contents. The regional distribution of $\mathrm{Fe}_{2} \mathrm{O}_{3}$ (fig. $23 \pi$ generally parallels that of total clay, with the largest amounts in the east.
Magnesium abundance ( $\mathrm{MgO})$, generally from 1 to about 4 percent, is related to clay and dolomite (table 15); in many rocks dolomite, though much less abundant than clay, is the more important factor. Thus, siltstone in general (table 14) and nearshore-marine siltstone in particular (fig. 21), because of their dolomite, contain more $\mathrm{MgO}$ than shale. Also, regionally, maximum amounts of $\mathrm{MgO}$ and dolomite occur in the western and middle zones and at locality 3-4 (fig. 23G, $L$ ). However, the smaller amounts of $\mathrm{MgO}$ in nonmarine rocks (fig. 21), 1.8 percent as compared with the 2.4 percent average in marine rock (table 14), is due to the smaller amounts of both clay and dolomite in the nonmarine rock. In organic-rich rock, the approximately 1 percent $\mathrm{MgO}$ is only about half that in most of the Pierre Shale, even when dilution by organic matter and the near absence of dolomite are taken into account; this low amount indicates that the clays themselves must be $\mathrm{Mg}$ deficient. Large amounts of Mg-bearing montmorillonite in bentonite (table 14) result in its relatively high average $\mathrm{MgO}$ content of $\mathbf{3 . 0}$ percent.

Calcium (Ca) abundance, averaging about 2 percent $\mathrm{CaO}$ in both marine and nonmarine rock, except marl, is related to clay minerals, plagioclase, calcite, and dolomite (table 15). Because of their high dolomite content, $\mathrm{CaO}$ in siltstone is about three times that of shale (table 14). Samples containing more than about 3 or 4 percent $\mathrm{CaO}$ generally contain calcite, but in marine rock, except marl, calcite is generally so sparse that it is a less important control of $\mathrm{CaO}$ distribution than is dolomite. The 5 percent or more average $\mathrm{CaO}$ values in southeastern South Dakota (fig. 23M) are due to calcite in marl beds, as are the 3 to 4 percent $\mathrm{CaO}$ for fossil zones 4 and 6 (table 13). The high $\mathrm{CaO}$ value in fossil zone 3 is due to the large amount of plagioclase in this zone. Average $\mathrm{CaO}$ in bentonite, 1.8 percent (table 14), is similar to that in most of the Pierre Shale.

Sodium $\left(\mathrm{Na}_{2} \mathrm{O}\right)$ occurs in clay minerals, mainly smectite, and in plagioclase. Although $\mathrm{Na}$ occurs mostly in the clay, the variation in amount is mostly due to variation in plagioclase (tables 14 and 15), and as the plagioclase is mostly fairly sodic $\left(\mathrm{An}_{20-40}\right)$, the control of plagioclase over $\mathrm{Na}_{2} \mathrm{O}$ distribution is even stronger than its control of $\mathrm{CaO}$. More plagioclase in nonmarine rock, especially the shale, accounts for its larger $\mathrm{Na}_{2} \mathrm{O}$ content (fig. 21, table 14). Abundant plagioclase also accounts for large $\mathrm{Na}_{2} \mathrm{O}$ values of the volcanic-rich rock (table 14) and of fossil zones 3 and 6 (table 13). The moderately large average of 1.3 percent $\mathrm{Na}_{2} \mathrm{O}$ in frothy-weathering shale, however, is due to an aboveaverage amount of exchangeable $\mathrm{Na}^{+}$ions on the expanding clay, as the plagioclase content is below 
average. The 1.5-percent average $\mathrm{Na}_{2} \mathrm{O}$ in bentonite is due not so much to exceptionally large amounts of exchangeable $\mathrm{Na}^{+}$ions on clay as to moderate amounts of $\mathrm{Na}^{+}$ions on a very large amount of smectite.

Potassium $\left(\mathrm{K}_{2} \mathrm{O}\right)$, averaging 2.5 percent in both marine and nonmarine rock, is controlled mostly by the clay minerals and only to a minor extent by potassium feldspar (table 15). The largest amounts of $\mathrm{K}_{2} \mathrm{O}$ reported, more than 3 percent, are mostly from samples at Dearborn River (loc. 2, fig. 23O) because of the highly illitic mixed-layer clay there (fig. 19C). The average $\mathrm{K}_{2} \mathrm{O}$ in volcanic-rich rocks of 2.4 percent is not particularly high, however, because volcanic-rich rock other than that at Dearborn River contains relatively little illite (table 9). The few nonmarine samples with less than 1 percent $\mathrm{K}_{2} \mathrm{O}$ all are highly kaolinitic, organic-rich, brackish-water samples. In contrast, the large $\mathrm{K}_{2} \mathrm{O}$ content of marine organic-rich shale, averaging 2.7 percent, comes from two sources: (1) exceptionally illitic mixed-layer clay together with a large proportion of free illite; and (2) several percent of authigenic potassium feldspar-examples in table 1 are samples 259561 and 259563. Fossil zones do not differ appreciably in $\mathrm{K}_{2} \mathrm{O}$ content. The 0.45 -percent average $\mathrm{K}_{2} \mathrm{O}$ in bentonite (table 14) could occur mostly in its smectite clay (Schultz, 1978, p. 16), but amounts above the average probably are in biotite; potassium feldspar is rare.

Water in both its forms $-\left(\mathrm{H}_{2} \mathrm{O}-\right)$ volatilized below $110^{\circ} \mathrm{C}$ and $\left(\mathrm{H}_{2} \mathrm{O}+\right)$ volatilized above $110^{\circ} \mathrm{C}$-should occur in amounts closely parallel to amounts of clay minerals, and generally does. Note, for example, the higher $\mathrm{H}_{2} \mathrm{O}$ content of clay-rich shale as compared with clay-poor siltstone in both marine and nonmarine rock (table 14). In contrast, the marine and nonmarine rock (table 14 and fig. 21) have generally similar water content, and regional variations are small (fig. $23 P, Q$ ). The three groups having 5 percent or more $\mathrm{H}_{2} \mathrm{O}+$ (table 14) are marine and nonmarine organic-rich shale and bentonite. Abundant $\mathrm{H}_{2} \mathrm{O}+$ is expected from bentonite because bentonite commonly contains 20 to 40 more clay than other groups of rock. A large amount of $\mathrm{H}_{2} \mathrm{O}+$ in nonmarine organic-rich rock could result from its content of kaolinite (table 6), as kaolinite contains two to three times as much structural $\mathrm{H}_{2} \mathrm{O}$ as other clay minerals, chlorite excepted. But such explanations do not apply to marine organic-rich shale, which is neither especially clay rich nor kaolinitic. Evidently the $\mathrm{H}^{+}$evolved when organic material is heated above $110^{\circ} \mathrm{C}$ oxidizes and is reported as $\mathrm{H}_{2} \mathrm{O}+$. The weight of hydrogen involved is small, but the resulting $\mathrm{H}_{2} \mathrm{O}+$ is evidently 10 to 20 percent of the weight of the organic matter.
MINOR ELEMENTS-SULFUR AND CARBON

Minor constituents in this report are $\mathrm{TiO}_{2}, \mathrm{P}_{2} \mathrm{O}_{5}$, forms of $\mathrm{S}, \mathrm{F}, \mathrm{Cl}$, and forms of $\mathrm{C}$. Occurrence of $\mathrm{S}$ in sulfide or sulfate minerals, of organic $\mathrm{C}$ in organic matter, and of mineral $\mathrm{C}$ in carbonate minerals is obvious enough, and these elements are discussed here. The other minor constituents cannot usually be related directly to specific, identified minerals. Occurrence of these other minor constituents is inferred from lines of reasoning such as are used for the trace elements, and accordingly they are discussed later with the trace elements.

Sulfur is much more abundant in marine than in nonmarine rocks (fig. 21, table 14). In nonmarine rocks $S$ is virtually absent except for an average of 0.35 percent $\mathrm{SO}_{3}$ in brackish-water organic-rich samples (table 14), mostly in secondary jarosite. In marine rock, $S$ is very abundant in organic-rich shale both as $\mathbf{S}^{-2}$ in pyrite and $\mathrm{SO}_{3}$ in secondary gypsum or jarosite. The marked association between total $\mathrm{S}$ and organic $\mathrm{C}$ in marine shale is to be expected, because the reducing conditions created by accumulating organic matter are favorable for the direct reduction of sulfate in normal marine water to sulfide as well as for the proliferation of sulfate-reducing bacteria which are important intermediaries in the reduction process (Degens, 1965). This association with organic matter also accounts for the high $S$ content in fossil zone 2 (table 13) and in eastern localities (fig. 23T). Above-average amounts of $\mathrm{S}$, about 1 percent, are common in marl. Sulfur in bentonite, averaging 0.49 percent, is mostly in secondary gypsum.

Organic $\mathrm{C}$ in organic matter is about equally abundant in marine and nonmarine rock (table 14). Its distribution, however, is very erratic (fig. 21), especially in the nonmarine rock where a few samples of carbonaceous or coaly shale contain very large amounts of organic $\mathrm{C}$, whereas most samples contain a few tenths of a percent or less. In contrast, most marine shale contains several tenths to nearly 1 percent organic $\mathrm{C}$. Within marine rock, most marl contains amounts of organic $\mathrm{C}$ slightly above average, and fissile black shale of the Sharon Springs Member contains several percent and accounts for the high average value in fossil zone 2 (table 13) and the high values in southeastern South Dakota (fig. $23 U$ ). Bentonite contains little organic $\mathrm{C}$.

Mineral carbon occurs almost entirely in calcite and dolomite (table 15), which accounts for the data in tables 13 and 14 and shown in figures $23 F, G$, and $V$. Some bentonite contains small amounts of calcite. 
TRACE ELEMENTS AND SOME MINOR ELEMENTS

\section{SOME TOOLS FOR DETERMINATION OF OCCURRENCE}

Trace elements and some of the minor elements in the Pierre Shale and equivalents mostly occur adsorbed on minerals, substituted in mineral structures composed of the major elements, and as essential components of minerals that occur in amounts too small to be detected by X-ray analysis of the whole sample. The mode of occurrence must, of necessity, be inferred from factors such as (1) the general geochemical behavior of each element and how it normally occurs in other sedimentary rock, (2) the relative abundance of the element in different kinds or groups of rock, (3) statistical relations between abundance of constituents in individual samples or groups of samples, and (4) examination of several specially prepared heavy-mineral and size fractions of samples. The second of these considerations has already been introduced in connection with the major constituents (table 14 and 15, figs. 21 and 23), and the others are introduced in the following subsections.

\section{OCGURRENCE OF ELEMENTS IN OTHER SHALE}

The occurrence of trace and some minor elements in other shale has been compiled (table 16) to assist in interpreting the element content of the Pierre Shale and its equivalents. All but a few of the trace elements seemingly can be adsorbed on or substituted in the structures of clay minerals. Most of the heavy metals listed in table 16 beginning with Co also are reported to occur in organic matter and associated pyrite. Barite might be a significant factor affecting $\mathrm{Ba}$ abundance, but in the Pierre Shale barite has been identified only in nodules. Carbonates commonly concentrate only in a few elements, such as $\mathrm{Fe}, \mathrm{Mn}$, and $\mathrm{Sr}$, that substitute for $\mathrm{Ca}$ ions in calcite, and $\mathrm{Fe}$ in dolomite. Hydroxides or oxides of $\mathrm{Fe}$ and $\mathrm{Mn}$ are reported to incorporate a wide range of trace elements (Jenne, 1968), but this occurrence seems not very important in the Pierre Shale. Apatite can concentrate several of the rare earths, and $\mathrm{F}$ or $\mathrm{Cl}$ may be essential constituents of apatite, but analyses of apatite in nodular material from the Pierre Shale do not show strong concentrations of these elements. Some heavy minerals that are highly resistant to weathering, such as zircon, ilmenite, anatase, allanite, or tourmaline, may concentrate several trace elements. More easily weathered heavy minerals, such as augite, that might be found near the volcanic source areas, could contain fairly large amounts of some heavy metals substituted for ferrous iron.
TABLE 16.-Likely modes of occurrence of trace and some minor elements in sedimentary rocks, compiled mostly from Tourtelot (1962), Rankama and Sahama (1950), Goldschmidt (1954), Krauskopf (1955; 1956), Goldberg and Arrhenius (1958), and Vine and E. B. Tourtelot (1969)

[X, important; $\mathbf{x}$, minor; italic type where applicable in the Pierre Shale and its equivalent: leaders (-.), not present]

\begin{tabular}{|c|c|c|c|c|c|c|c|}
\hline Element & Clay & $\begin{array}{c}\text { Organic } \\
\text { matter }\end{array}$ & $\begin{array}{l}\text { Sulfides- } \\
\text { pyrite }\end{array}$ & Calcite & $\begin{array}{c}\text { Hydrated } \\
\text { Mn-Fe oxides }\end{array}$ & Apatite & $\begin{array}{l}\text { Heavy } \\
\text { minerals }\end{array}$ \\
\hline 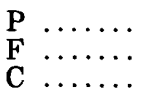 & $\begin{array}{l}x \\
X \\
X\end{array}$ & $\ddot{x}$ & $\begin{array}{l}\cdots \\
\cdots \\
\cdots\end{array}$ & $\begin{array}{l}\cdots \\
\cdots \\
\cdots\end{array}$ & $\begin{array}{l}\cdots \\
\cdots \\
\cdots\end{array}$ & $\begin{array}{l}\mathbf{x} \\
\boldsymbol{x} \\
\cdots\end{array}$ & $\begin{array}{l}\cdots \\
\cdots \\
\cdots\end{array}$ \\
\hline $\begin{array}{l}\text { Y,Yb,La } \\
\text { Zr. } \ldots \ldots \\
\text { Sn } \ldots \ldots \\
\text { Ti } \ldots \ldots\end{array}$ & $\begin{array}{l}\mathbf{x} \\
\mathbf{x} \\
\dddot{X}\end{array}$ & $\begin{array}{l}\cdots \\
\cdots \\
x\end{array}$ & $\begin{array}{l}\cdots \\
\cdots \\
\cdots \\
\cdots\end{array}$ & $\begin{array}{l}\mathbf{x} \\
\cdots \\
\cdots \\
\cdots\end{array}$ & $\begin{array}{l}\mathbf{x} \\
\mathbf{x} \\
\cdots \\
\mathbf{x}\end{array}$ & $\begin{array}{l}\mathbf{x} \\
\cdots \\
\cdots \\
\cdots\end{array}$ & $\begin{array}{l}X \\
X \\
X \\
X\end{array}$ \\
\hline $\begin{array}{l}\text { Sc } \ldots \ldots \\
\text { B } \ldots \ldots\end{array}$ & $\begin{array}{l}x \\
X\end{array}$ & $\begin{array}{l}\cdots \\
\cdots\end{array}$ & $\begin{array}{l}\cdots \\
\cdots\end{array}$ & $\begin{array}{l}\cdots \\
\cdots\end{array}$ & $\begin{array}{l}\mathbf{x} \\
\mathbf{x}\end{array}$ & $\begin{array}{l}\cdots \\
\cdots\end{array}$ & $\begin{array}{l}X \\
X\end{array}$ \\
\hline $\begin{array}{l}\mathrm{Ga} \ldots \ldots \\
\mathrm{Pb} \ldots \ldots \\
\mathrm{Ba} \ldots \ldots \\
\mathrm{Sr} \ldots \ldots \\
\mathrm{Mn} \ldots \ldots\end{array}$ & $\begin{array}{c}X \\
x \\
X \\
\cdots \\
x\end{array}$ & $\begin{array}{l}\cdots \\
\mathbf{x} \\
\cdots \\
\cdots \\
\cdots\end{array}$ & $\begin{array}{l}\cdots \\
\mathbf{x} \\
\cdots \\
\cdots \\
\cdots\end{array}$ & $\begin{array}{l}\cdots \\
\cdots \\
\ddot{X} \\
X\end{array}$ & $\begin{array}{l}\dddot{\mathrm{X}} \\
\mathrm{x} \\
\dddot{X}\end{array}$ & $\begin{array}{l}\cdots \\
\cdots \\
\cdots \\
\cdots \\
\cdots\end{array}$ & $\begin{array}{l}\cdots \\
\cdots \\
\cdots \\
\cdots \\
\cdots\end{array}$ \\
\hline $\begin{array}{l}\mathbf{C o} \ldots \ldots \\
\mathbf{N i} \ldots \ldots \\
\mathbf{Z n}_{\mathbf{n}} \ldots \ldots\end{array}$ & $\begin{array}{l}x \\
x \\
x\end{array}$ & $\begin{array}{c}\mathbf{x} \\
X \\
\mathbf{x}\end{array}$ & $\begin{array}{c}X \\
X \\
x\end{array}$ & 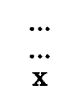 & $\begin{array}{l}X \\
X \\
X\end{array}$ & $\begin{array}{l}\cdots \\
\cdots \\
\cdots\end{array}$ & $\begin{array}{l}\cdots \\
\cdots \\
\cdots\end{array}$ \\
\hline $\begin{array}{l}\mathbf{C d} \ldots \ldots \\
\mathbf{C r} \ldots \ldots \\
\mathbf{V} \ldots \ldots\end{array}$ & $\begin{array}{l}\ddot{x} \\
x\end{array}$ & $\begin{array}{l}X \\
x \\
X\end{array}$ & $\begin{array}{l}\mathbf{x} \\
\mathbf{x} \\
\mathbf{x}\end{array}$ & $\begin{array}{l}\cdots \\
\cdots \\
\cdots\end{array}$ & $\begin{array}{l}\cdots \\
\mathbf{x} \\
\cdots\end{array}$ & $\begin{array}{l}\cdots \\
\cdots \\
\cdots\end{array}$ & $\begin{array}{l}\cdots \\
\cdots \\
\cdots\end{array}$ \\
\hline $\begin{array}{l}\text { Mo } \ldots \ldots \\
\text { Se ...... } \\
\text { As } \ldots \ldots \\
\text { U } \ldots \ldots \\
\end{array}$ & $\begin{array}{l}x \\
\cdots \\
\cdots \\
\cdots\end{array}$ & $\begin{array}{l}X \\
X \\
X \\
X\end{array}$ & $\begin{array}{l}\mathbf{X} \\
\mathbf{X} \\
\mathbf{X} \\
\mathbf{X}\end{array}$ & $\begin{array}{l}\cdots \\
\cdots \\
\cdots \\
\cdots\end{array}$ & $\begin{array}{l}\mathbf{x} \\
\mathbf{x} \\
\mathbf{x} \\
\cdots\end{array}$ & $\begin{array}{l}\cdots \\
\cdots \\
\cdots \\
\cdots\end{array}$ & $\begin{array}{l}\cdots \\
\cdots \\
\cdots \\
\cdots\end{array}$ \\
\hline
\end{tabular}

\section{CORRELATION COEFFICIENTS}

Correlation coefficients are a numerical expression of the tendency of two constituents to occur together. For example, if sulfur occurs only in pyrite in a group of samples and if the amount of each were measured with no error, then amounts of sulfur and pyrite would show a perfect correlation of +1.00 , and an $x-y$ plot of the two constituents would form a straight line. A zero correlation indicates no tendency to be associated, and a negative correlation indicates a tendency for the two constituents to vary inversely.

Correlation coefficients, normally expressed as twoplace decimals, are rounded to a single number and the decimal and all plus signs are omitted in order to make table 17 more readable. Thus, a coefficient of +0.43 is shown in table 17 simply as " 4 " and one of -0.47 as “-5". Conventional decimal correlation coefficients are used throughout the text, however. Correlation coefficients are given in table 17 for both marine and nonmarine rock, because for many constituents the coefficients are so different as to indicate considerably 
TABLE 17.-Correlation coefficients between mineral and chemical constituents in the Pierre Shale and equivalent rocks

[Conventional coefficients are multiplied by 10 and rounded to the nearest whole number. Bold numbers are for 134 marine shale and siltstone samples and lighter numbers below are for 58 nonmarine shale and siltstone samples. However, if the number of pairs of data used for the calculation of the coefficient is significantly fewer than the total number of marine or nonmarine samples, the number of pairs is given in parentheses next to the constituent. Lines separate related groups of constituents. Coefficients for fewer than nine valid pairs are not given]
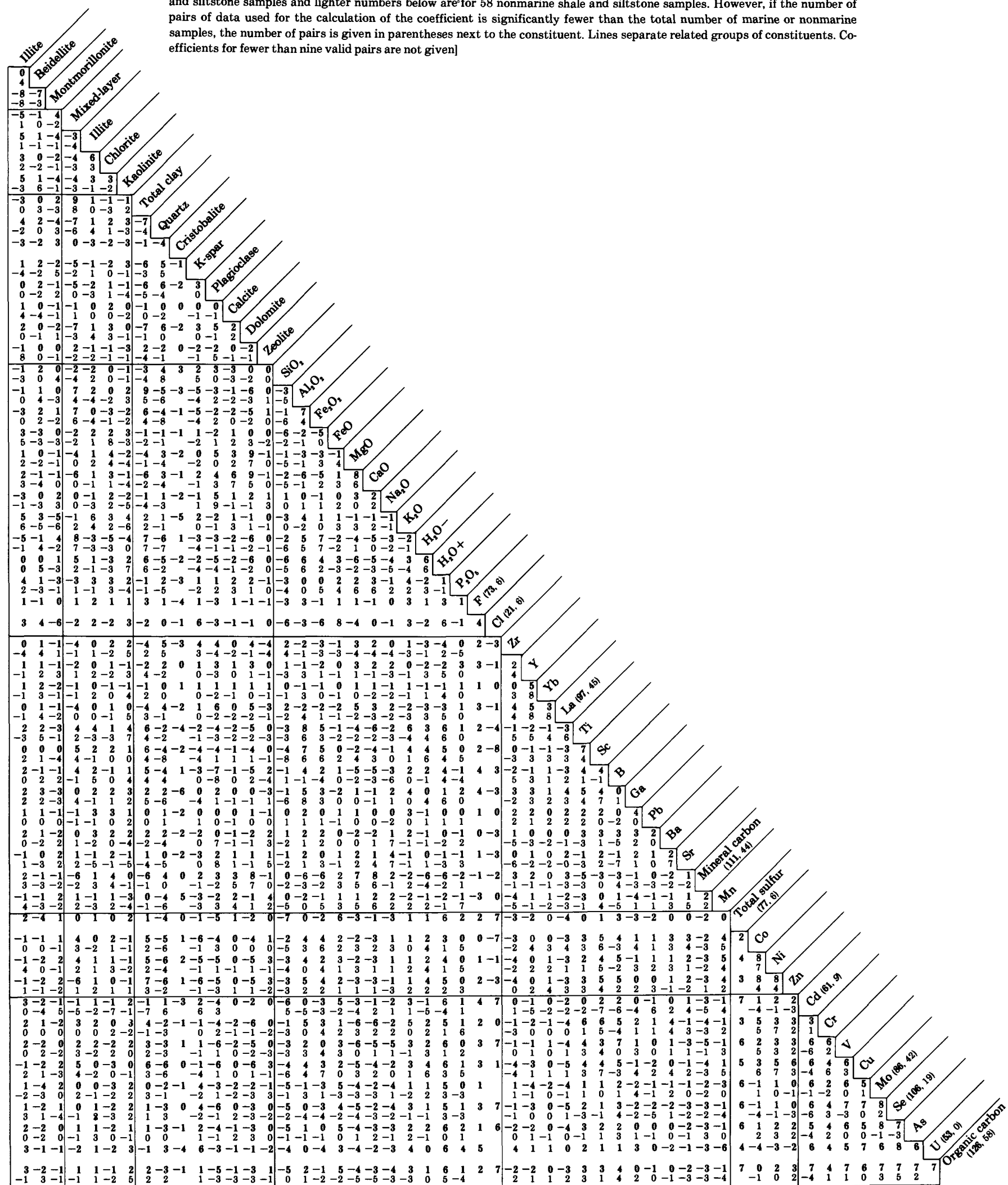
different associations. No data from marl or bentonite are included in the calculations. Logs of values were used in the calculations for all constituents in table 17 from $\mathrm{Zr}$ to organic $\mathrm{C}$, except for $\mathrm{TiO}_{2}$, which has a normal distribution of analytical values. Also, the order in which the elements are listed in table 17 is slightly changed from other tables in order to place $\mathrm{TiO}_{2}, \mathrm{~S}$, mineral $\mathrm{C}$, and organic $\mathrm{C}$ near trace elements with which they are closely related.

The significance of the magnitude of correlation coefficients is strongly dependent upon the number of pairs of values being compared. According to F. N. David (in Dixon and Massey, 1957, p. 464), a correlation coefficient of \pm 0.17 is statistically significant for the data from the 134 samples of marine rock, and one of \pm 0.25 is significant for the 58 samples of nonmarine rock, each at the 95-percent confidence level. This confidence level means that there are only 5 out of 100 chances for correlation coefficients as large as those mentioned arising from chance alone. As the number of pairs of observations decreases, the coefficient must become larger to be statistically significant at the 95-percent level, as for example, \pm 0.60 for constituents having only nine valid pairs of observations. No coefficients for fewer than nine pairs are given in table 17. Although relatively small correlation coefficients thus can have statistical significance, the geochemical meaning may be difficult to interpret.

In regard to the magnitude of correlation coefficients, Snedecor and Cochran $(1967$, p. 126) pointed out that the square of the correlation coefficient multiplied by 100 gives the percentage of the covariation that can be attributed to the relation between the two constituents involved. Thus, the coefficient of +0.70 between organic $\mathrm{C}$ and $\mathrm{U}$ in marine rock (table 17 ) indicates that about half of the variation of $U$ is due to its association with organic matter. A coefficient of +0.20 , which is about the 95-percent significance level for the full marine and nonmarine groups, accounts for only about 5 percent of the variation. All coefficients, regardless of size, are given in the table, except those having fewer than nine valid data pairs; but in general, discussion of any coefficient less than \pm 0.5 , which accounts for about a quarter of the variation, is limited to those coefficients that, along with other evidence, suggest insights into geochemical processes that otherwise might be obscure.

The aforementioned relations concerning significance level and percentage of variation are premised upon several assumptions: a normal distribution of values of the constituents being compared, independent variation of the constituents, and unbiased sampling. The assumption of normal distribution for many of the minor and trace elements is fairly well met by logarithmic transformation, and most major constituents meet this assumption fairly well without transformation. Major constituents, however, cannot vary independently; as a dominant constituent, like $\mathrm{SiO}_{2}$, varies, most other major elements must vary in the opposite direction-the constant-sum problem pointed out by Chayes (1960); but correlation coefficients are not used in this report to interpret the major elements. The minor and trace elements probably vary independently. The small differences in mineralogical composition of the analytical samples compared to the nonanalytical samples (fig. 20) suggest that bias in sampling is not prominent in the chemical data, even though the best outcrops rather than statistical design were used in sampling. Therefore, the use of correlation coefficients to interpret the chemical data in this report seems warranted.

The interpretation of correlation coefficients may be a matter quite different from the level of significance of correlation coefficients. As an example, quartz contains very low levels of impurities or substituted cations, but nevertheless in marine rock it has a correlation coefficient of +0.34 with $\mathrm{MgO}$, a coefficient that is twice that significant at the 95-percent level and that should account for 10 percent of the variation in $\mathrm{MgO}$. The reason is that both quartz and dolomite are abundant in nearshore marine rock and are less abundant or absent in offshore-marine rock. The much higher correlation coefficient of +0.87 between $\mathrm{MgO}$ and dolomite in marine rocks correctly points to the major cause for variation of $\mathrm{MgO}$ in marine rock. However, the -0.44 correlation between $\mathrm{MgO}$ and total clay minerals does not suggest the fact that most $\mathrm{MgO}$ actually occurs in the clay minerals (table 15); but in the clays $\mathrm{MgO}$ occurs in fairly uniform amounts in a fairly uniform amount of clay, and most of the $\mathrm{MgO}$ variation is due to dolomite. These coefficients for $\mathrm{MgO}$ are readily explained because the minerals in which it is an essential constituent can be determined directly. Though not generally so evident, similar relations are involved between trace and minor constituents.

HEAVY MINERALS AND SIZE FRACTIONATION

Examination of specially prepared samples provides the final line of evidence for interpreting minor and trace elements of the Pierre Shale and equivalent rocks. Heavy minerals (table 18) were separated from the silt-size fraction of six samples from the western part of the area primarily to clarify the importance of volcanic apatite in the distribution of $\mathrm{P}_{2} \mathrm{O}_{5}$, but the heavy minerals also give information on the occurrence of some other elements. Another group of 15 analytical 
TABLE 18.-Heavy minerals separated in bromoform from the 10 to $74 \mu \mathrm{m}$ fractions of selected samples of the Pierre Shale and equivalent rocks

[Separation and identification by R. F. Gantnier. In percent of the heavy-mineral fraction]

\begin{tabular}{|c|c|c|c|c|c|c|}
\hline \multirow{7}{*}{ 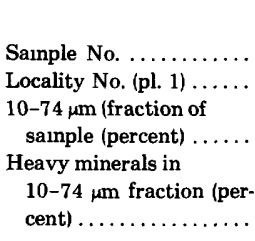 } & \multicolumn{4}{|c|}{ Nonmarine } & \multicolumn{2}{|c|}{ Marine } \\
\hline & \multirow{2}{*}{$\begin{array}{c}159835 \\
2\end{array}$} & \multirow{2}{*}{$\begin{array}{c}159834 \\
2\end{array}$} & \multirow{2}{*}{$\begin{array}{c}159825 \\
1\end{array}$} & \multirow{2}{*}{$\begin{array}{c}159803 \\
5\end{array}$} & \multirow{2}{*}{$\begin{array}{c}159778 \\
6\end{array}$} & \multirow{2}{*}{$\begin{array}{c}15976 \\
7\end{array}$} \\
\hline & & & & & & \\
\hline & & & & & & \\
\hline & 4.5 & \multirow[t]{2}{*}{3.5} & \multirow[t]{2}{*}{5.3} & \multirow[t]{2}{*}{7.5} & \multirow[t]{2}{*}{7.6} & \multirow[t]{2}{*}{6.5} \\
\hline & & & & & & \\
\hline & 0.244 & 0.229 & 0.209 & 0.013 & 0.026 & 0.115 \\
\hline Anatase & 0.8 & 4.7 & 0.5 & 1.1 & 4.7 & 3.4 \\
\hline Apatite ... & 14.3 & 4.7 & 1.4 & 2.2 & 7.7 & 9.6 \\
\hline Augite..$\ldots \ldots \ldots \ldots$ & 0 & .8 & 0 & 1.1 & 1.2 & 3.4 \\
\hline Biotite ......... & 1.1 & .8 & .5 & 0 & 1.2 & 11.9 \\
\hline Corundum ....... & 0 & .8 & 1.4 & .6 & .6 & .6 \\
\hline Diopside $\ldots \ldots \ldots$. & .4 & 0 & 0 & 0 & .6 & $\mathbf{0}$ \\
\hline Epidote .......... & 0 & 1.6 & 0 & 0 & 0 & 6.2 \\
\hline Garnet ... & 0 & 2.3 & .9 & 1.1 & 6.5 & 5.7 \\
\hline Muscovite ... & 0 & 0 & 0 & 1.1 & .6 & 1.7 \\
\hline Rutile..$\ldots \ldots \ldots$. & .4 & 2.3 & 0 & 0 & 2.4 & 1.1 \\
\hline Sphene..$\ldots \ldots \ldots$ & .8 & 2.3 & .9 & 2.2 & 1.8 & 1.7 \\
\hline Spinel . & .4 & 0 & .9 & 0 & 1.2 & 0 \\
\hline Staurolite.. & 0 & 0 & 0 & 0 & 1.2 & 0 \\
\hline Tourmaline ....... & 1.1 & 1.6 & 0 & 0 & .6 & 0 \\
\hline Zircon .......... & 12.8 & 27.9 & 22.7 & 20.8 & 27.4 & 21.5 \\
\hline Opaque minerals & 68.0 & 50.4 & 70.1 & 70.2 & 41.7 & 33.0 \\
\hline \multirow{2}{*}{\multicolumn{2}{|c|}{ No. of grains }} & & & & & \\
\hline & & 129 & 211 & 178 & 168 & 176 \\
\hline
\end{tabular}

samples representative of all the Pierre Shale and its equivalents was size fractionated primarily to investigate the chemical composition of the mixed-layer clay (Schultz, 1978, table 3). Routine determination of three constituents, $\mathrm{TiO}_{2}, \mathrm{P}_{2} \mathrm{O}_{5}$, and $\mathrm{MnO}$, as parts of the rapid chemical analyses gives an opportunity to compare their amounts in the whole sample and in the purified clay fraction (table 19). The heavy-mineral and size-fraction data are discussed under the pertinent elements.

\section{MINOR ELEMENTS $\left(\mathrm{TiO}_{2}, \mathrm{P}_{2} \mathrm{O}_{5}, \mathrm{~F}\right.$, AND $\left.\mathrm{Cl}\right)$}

Titanium $\left(\mathrm{TiO}_{2}\right)$ varies little in abundance between marine and nonmarine rock (table 14, fig. 21), its average for lithologic groups (except bentonite) ranges only from 0.45 to 0.67 percent, and it shows very little regional or stratigraphic variation (fig. $23 S$, table 13 ). The usual mode of occurrence for Ti in sedimentary rocks (table 16) is in clay minerals and in heavy minerals resistant to weathering and abrasion, such as rutile, anatase, and sphene. In the six samples for which heavy minerals were determined (table 18), only a few grains of these minerals were identified, and these could account for considerably less than 0.01 percent $\mathrm{TiO}_{2}$. Titanium commonly is concentrated in volcanic magnetite (David Lindsey, written commun., 1977) that probably makes up a considerable part of the large opaque fraction of the heavy minerals. However, heavy minerals normally are expected to be concentrated in coarse-grained sediment rather than in shale, so the greater abundance of $\mathrm{TiO}_{2}$ found in shale as compared with siltstone (table 14), together with large positive correlation coefficients of $\mathrm{TiO}_{2}$ with total clay minerals and with clay-related constituents like $\mathrm{Al}_{2} \mathrm{O}_{3}, \mathrm{H}_{2} \mathrm{O}+$, scandium (Sc), gallium $(\mathrm{Ga})$, and boron (B) (table 17), strongly imply concentration of $\mathrm{TiO}_{2}$ in the clays. However, in nonmarine rocks, the generally weaker correlations between $\mathrm{TiO}_{2}$ and these clayrelated constituents and the fairly strong correlations with the resistate elements $\mathrm{Zr}, \mathrm{Y}, \mathrm{Yb}$, and $\mathrm{La}$ (table 17) suggest that titaniferous resistate minerals may be more important than clay in nonmarine equivalents of the Pierre Shale.

If $\mathrm{TiO}_{2}$ occurs mostly in the clay minerals, then size fractionation that concentrates the clay minerals should also concentrate $\mathrm{TiO}_{2}$. Fifteen samples representative of the Pierre Shale and its equivalents have been fractionated to greater than $1 \mu \mathrm{m}, 1-0.5 \mu \mathrm{m}$, $0.5-0.25 \mu \mathrm{m}$, and less than $0.25 \mu \mathrm{m}$. All fractions received X-ray analysis, but only the less than $0.25 \mu \mathrm{m}$ fraction was chemically analyzed (table 19). Most of the whole samples are about two-thirds clay, and the less-than-0.25 $\mu \mathrm{m}$ fractions contain little or nothing but clay minerals. In parentheses in table 19 is shown the amount of $\mathrm{TiO}_{2}$ in the whole sample normalized to the percentage of clay in the less-than- $0.25-\mu \mathrm{m}$ fraction, referred to below as the normalized $\mathrm{TiO}_{2}$ value. For example, $\mathrm{TiO}_{2}$ in whole-sample 159766 is normalized as $0.52 / 60 \times 96=0.83$ percent. Four relations are possible between the three values for $\mathrm{TiO}_{2}$ in table 19:

TABLE 19.-Content of $\mathrm{TiO}_{2}, \mathrm{P}_{2} \mathrm{O}_{5}$, and $\mathrm{MnO}$ in 15 whole and fractionated samples representative of the Pierre Shale and equivalent rocks

(Amounts reported in whole samples normalized to anount of clay in the $0.25 \mu \mathrm{n}$ fraction in parentheses. All in percent. <, less than]

\begin{tabular}{|c|c|c|c|c|c|c|c|c|c|c|c|}
\hline \multirow{2}{*}{$\begin{array}{c}\text { Sainple } \\
\text { No. }\end{array}$} & \multirow{2}{*}{$\begin{array}{c}\text { Locality } \\
\text { No. }\end{array}$} & \multicolumn{2}{|c|}{ Clay minerals } & \multicolumn{2}{|c|}{$\mathrm{Tio}_{2}$} & \multicolumn{3}{|c|}{$\mathrm{P}_{2} \mathrm{O}_{6}$} & \multicolumn{3}{|c|}{$\mathrm{MnO}$} \\
\hline & & Whole & $.25 \mu \mathrm{m}$ & Whole $<$ & $0.25 \mu \mathrm{m}$ & i Whole & & $0.25 \mu \mathrm{m} \bar{V}$ & Whole & & $25 \mu \mathrm{in}$ \\
\hline \multicolumn{12}{|c|}{ Nonmarine } \\
\hline $\begin{array}{l}159835 \\
159834 \\
159825^{1} \\
1597666^{1} \\
159803^{2} \\
159812^{1} \\
159781^{2}\end{array}$ & $\begin{array}{l}2 \\
2 \\
1 \\
7 \\
5 \\
9 \\
6\end{array}$ & $\begin{array}{l}60 \\
70 \\
65 \\
60 \\
60 \\
60 \\
60\end{array}$ & $\begin{array}{r}100 \\
100 \\
100 \\
96 \\
99 \\
99 \\
99\end{array}$ & $\begin{array}{c}0.53(0.88) \\
.60(.86) \\
.55(.85) \\
.52(.83) \\
.57(.95) \\
.50(.82) \\
.55(.92)\end{array}$ & $\begin{array}{c}0.47 \\
.13 \\
.78 \\
.66 \\
1.2 \\
1.52 \\
1.0\end{array}$ & $\begin{array}{r}0.32(0.5 \\
.151 .2 \\
.21 .3 \\
.121 .1 \\
.13 \\
.11 . .2 \\
.021 .0\end{array}$ & $\begin{array}{l}.53) \\
.212 \\
.192 \\
.22 \\
.038\end{array}$ & $\begin{array}{c}0.21 \\
.06 \\
.19 \\
.16 \\
.17 \\
.16 \\
.22\end{array}$ & $\begin{array}{r}0.1110 .11 \\
.061 .0 \\
.051 .0 \\
.021 .0 \\
.041 .0 \\
.021 .0 \\
.011 .0\end{array}$ & $\begin{array}{l}18 \text { ) } \\
09 \text { ) } \\
08 \text { (3) } \\
037 \\
03 \text { (3) } \\
02 \text { ) }\end{array}$ & $\begin{array}{r}0.06 \\
.03 \\
.04 \\
.02 \\
.04 \\
.02 \\
.02\end{array}$ \\
\hline \multicolumn{12}{|c|}{ Marine } \\
\hline $\begin{array}{l}159778^{3} \\
159763 \\
159787^{3} \\
159727^{3} \\
259574 \\
239587^{3} \\
259543^{1} \\
259550\end{array}$ & $\begin{array}{r}6 \\
7 \\
8 \\
13 \\
18 \\
17 \\
22 \\
23\end{array}$ & $\begin{array}{l}65 \\
55 \\
65 \\
75 \\
65 \\
75 \\
75 \\
75\end{array}$ & $\begin{array}{r}99 \\
99 \\
100 \\
99 \\
100 \\
99 \\
99 \\
89\end{array}$ & $\begin{array}{l}.59(.90) \\
.60(1.1) \\
.65(1.0) \\
.65(.86) \\
.74(1.1) \\
.55(.73) \\
.61(.80) \\
.52(.62)\end{array}$ & $\begin{array}{l}.54 \\
.66 \\
.70 \\
.64 \\
.44 \\
.56 \\
.50\end{array}$ & $\begin{array}{l}.13(.2 \\
.231 .4 \\
.14(.2 \\
.171 .2 \\
.20(.3 \\
.151 .2 \\
.131 .1 \\
.14(.1\end{array}$ & $\begin{array}{l}.20) \\
.411 \\
.221 \\
.211 \\
.20) \\
.17) \\
.17)\end{array}$ & $\begin{array}{l}.24 \\
.16 \\
.12 \\
.16 \\
.18 \\
.31 \\
.21\end{array}$ & $\begin{array}{l}.031 .0 \\
.041 .0 \\
.021 \\
.03 \\
.031 .0 \\
.031 .0 \\
.044 .0 \\
.044 .0\end{array}$ & $\begin{array}{l}05\} \\
07) \\
03 \text { ) } \\
04 \text { ) } \\
05\} \\
04\rangle \\
05\} \\
05\}\end{array}$ & $\begin{array}{l}.02 \\
.02 \\
.01 \\
.01 \\
.01 \\
.03 \\
.02\end{array}$ \\
\hline Average & & 66 & 99 & $.58(.88)$ & .62 & .161 .2 & $.24)$ & .19 & .044 .0 & 06) & $\overline{.025}$ \\
\hline
\end{tabular}


(1) if $\mathrm{TiO}_{2}$ occurs only in the clay and is nearly uniformly distributed in the clay minerals, then the amount of $\mathrm{TiO}_{2}$ in the less-than-0.25- $\mu \mathrm{m}$ fraction should about equal the normalized $\mathrm{TiO}_{2}$ value (in parentheses); (2) if $\mathrm{TiO}_{2}$ is concentrated in the clay, but some small amount also occurs as heavy resistate minerals that are fractionated out of the less-than- $0.25-\mu \mathrm{m}$ fraction, then the amount of $\mathrm{TiO}_{2}$ in the less-than-0.25- $\mu \mathrm{m}$ fraction should be between that of the whole sample and the normalized $\mathrm{TiO}_{2}$ value; (3) if $\mathrm{TiO}_{2}$ is concentrated in heavy resistate minerals, but some also occurs in the clay, then the $\mathrm{TiO}_{2}$ content of the less-than-0.25- $\mu \mathrm{m}$ fraction should be some amount more than zero but less than that in the whole sample; and (4) if all $\mathrm{TiO}_{2}$ occurs as heavy resistate minerals fractionated from the less-than $-0.25-\mu \mathrm{m}$ fraction, then $\mathrm{TiO}_{2}$ in the less-than-0.25- $\mu \mathrm{m}$ fraction should be zero. Only 2 of the 15 samples show the first relation, 5 the second, and 8 the third; only one sample, 159834, even approaches the fourth relation. The average $\mathrm{TiO}_{2}$ concentration in the less-than-0.25- $\mu \mathrm{m}$ fractions is nearly the same as in the whole samples. These relations indicate that $\mathrm{TiO}_{2}$ in the clay minerals, on the average, is about in proportion to the abundance of the clay-about two-thirds of the rock-and the remaining one-third is in other minerals. The less-than-0.25- $\mu \mathrm{m}$ fractions actually are not representative of clay in the Pierre Shale as a whole-they are 90 to 100 percent mixed-layer clay-but correlation coefficients (table 17) indicate no strong tendency for $\mathrm{TiO}_{2}$ to occur with any particular clay mineral, except perhaps with kaolinite in nonmarine rocks, and none of the 15 samples contain much kaolinite. Therefore, the assumption that $\mathrm{TiO}_{2}$ is uniformly distributed in the clay minerals probably is a fairly good one. However, the assumption that $\mathrm{TiO}_{2}$ not in the clay minerals occurs in heavy resistate minerals that are fractionated out from the less-than-0.25- $\mu \mathrm{m}$ fraction is in some cases clearly not a good one. As indicated in the footnotes of table 19, anatase is detected in the two less-then-0.25- $\mu \mathrm{m}$ samples in which $\mathrm{TiO}_{2}$ is most concentrated, and anatase also occurs in other slightly larger size fractions. Titanium thus probably occurs both in clay minerals and in anatase in the Pierre Shale, as is inferred in table 15, but because of the uncertain role of finegrained anatase, the proportion of $\mathrm{TiO}_{2}$ assigned to each constituent involves a degree of uncertainty considerably greater than that for most of the other assignments.

Phosphorus occurs in amounts large enough to be detected by X-ray chiefly in the mineral francolite, a carbonate fluorapatite, mainly in the form of nodules formed around and replacing biotic matter such as shells or fecal pellets (Tourtelot and Cobban, 1968).
The apatite nodules may be concentrated in certain stratigraphic units, such as the upper part of the Virgin Creek Member along the Missouri River in which crab-bearing nodules are a characteristic feature, or they may be concentrated as a lag gravel of polished pebbles at local unconformities or diastems. Fish scales and bones, presumed to be made up of apatite, are conspicuous in parts of the organic-rich shale of the Sharon Springs Member. Diadochite, $\mathrm{Fe}_{2}\left(\mathrm{PO}_{4}\right)\left(\mathrm{SO}_{4}\right)(\mathrm{OH}) \cdot 5 \mathrm{H}_{2} \mathrm{O}$, has been observed as a weathering product of pyritic apatite nodules in the Pierre Shale (Schultz, 1965, p. B17).

These phosphate minerals occur sparsely in the Pierre Shale and may not indicate the mode of occurrence of the fraction of a percent of $\mathrm{P}_{2} \mathrm{O}_{5}$ common in most of the Pierre Shale. Although apatite is generally considered to be the most common mode of occurrence of $\mathrm{P}_{2} \mathrm{O}_{5}$ in sediments (table 16), anion-exchange data of Hofmann and others (1956) showed that clay minerals are quite capable of adsorbing a few tenths of a percent $\mathrm{P}_{2} \mathrm{O}_{5}$. The one- or two-tenths of a percent $\mathrm{P}_{2} \mathrm{O}_{5}$ common in most samples of Pierre Shale corresponds to 0.3 to 0.5 percent apatite, an amount below the detection limit by X-ray methods. Petrographic examination of thin sections and concentrates of particles coarser than $74 \mu \mathrm{m}$ (Tourtelot, 1962, p. 19) revealed no apatite in marine parts of the Pierre Shale. However, apatite is present in silt-size heavy mineral grains from some nonmarine and nearshore-marine samples (table 18).

Average $\mathrm{P}_{2} \mathrm{O}_{5}$ in lithologic groups (table 14) ranges from 0.06 to 0.22 percent, but mostly is fairly uniform from 0.11 to 0.16 percent. The expected effect on $\mathrm{P}_{2} \mathrm{O}_{5}$ content of fish bones and scales that are apparently abundant in the Sharon Springs Member is only barely perceptible in the 0.18-percent average of shale above bentonite (table 14), most of which is from the Sharon Springs Member, and in the 0.17-percent average of fossil zone 2 (table 13). The seven samples of marine organic-rich shale (table 14) from the Sharon Springs Member show no concentration of $\mathrm{P}_{2} \mathrm{O}_{5}$ at all. The 0.18-percent average $\mathrm{P}_{2} \mathrm{O}_{5}$ in fossil zone 6 (table 13) probably is due to the marl in the Mobridge Member, as marl has the most $\mathrm{P}_{2} \mathrm{O}_{5}$ of the lithologic groups. Regionally (fig. 23R), $\mathrm{P}_{2} \mathrm{O}_{5}$ abundance varies little. Concentration of $\mathrm{P}_{2} \mathrm{O}_{5}$ in heavy apatite is not clearly evident from the nearly equal average amounts in shale and siltstone, though nearshore marine rock generally has above-average amounts (fig. 21), and a few nonmarine samples, most probably volcanic rich (table 14), contain exceptionally large amounts of $\mathrm{P}_{2} \mathrm{O}_{5}$ of 0.3 percent or more. Correlation coefficients of $\mathrm{P}_{2} \mathrm{O}_{5}$ are small, except those with $\mathrm{Fe}, \mathrm{Ca}, \mathrm{Mg}$ and trace metals $\mathrm{Mn}, \mathrm{Co}$, nickel (Ni), chromium (Cr), and copper $(\mathrm{Cu})$ in nonmarine rock. Apatite is an unlikely host to 
concentrate most of these elements (table 16), but augite associated with volcanogenic apatite is a likely host for them. Heavy-mineral data from the few samples in table 18 do not indicate abundant augite, but in several other volcanic-rich nonmarine rocks augite is sufficiently abundant to be detected by X-ray (table 9).

The possibility of $\mathrm{P}_{2} \mathrm{O}_{5}$ occurring on the clay minerals was investigated by comparisons, similar to those made for $\mathrm{TiO}_{2}$, of the amount of $\mathrm{P}_{2} \mathrm{O}_{5}$ in 15 samples and in nearly pure clays separated form them (table 19). Nine of the 15 clay fractions contain more $\mathrm{P}_{2} \mathrm{O}_{5}$ than the unfractionated samples by an average factor of 1.2. This difference indicates that the usual small amounts of $\mathrm{P}_{2} \mathrm{O}_{5}$ occurring in much of the Pierre Shale are mostly on the clay minerals, as is inferred in table 15.

The 2 of the 15 fractionated samples that show the largest decrease in $\mathrm{P}_{2} \mathrm{O}_{5}$ in the less-than- $0.25 \mu \mathrm{m}$ fraction are both volcanic-rich claystone from Dearborn River (loc. 2, table 19). The possibility of significant apatite amounts in them was tested by heavy-mineral analyses of these two samples (table 18) and of four additional samples, two having slight increases and two having decreases in $\mathrm{P}_{2} \mathrm{O}_{5}$ content of the less-than-0.25 $\mu \mathrm{m}$ fraction. Apatite was found in all six samples, but amounts were not consistent in all samples with the relative amount of $\mathrm{P}_{2} \mathrm{O}_{5}$ in the whole sample and the less-than- $0.25 \mu \mathrm{m}$ fraction. Sample 159835, having the highest $\mathrm{P}_{2} \mathrm{O}_{5}$ content (table 19), also contains the most apatite (table 18), about 0.015 percent, calculated as follows: 4.5 percent silt $\times 0.244$ percent heavy minerals $\times 14.3$ percent apatite $=0.0158$. This much apatite corresponds to 0.006 percent $\mathrm{P}_{2} \mathrm{O}_{5}$ in the whole sample, a very small amount in itself, but this amount is only in the 10-to-74 $\mu \mathrm{m}$ size fraction. The next largest amount of apatite was found in sample 159763, a nearshore-marine siltstone from Elk Basin; the apatite grains in this and the other marine sample, 159778, are small and rounded, and the heavy-mineral fractions are small, so the amount of apatite is less than the grain frequency might indicate. The surprising feature of apatite abundance shown in table 18 is the small amount in samples 159834 and 159825 . Even though both are volcanic claystone from near the volcanic source and both show decreases in the amount of $\mathrm{P}_{2} \mathrm{O}_{5}$ in the less-then- $0.25 \mu \mathrm{m}$ fraction, only a few grains of apatite were found in each. Regardless of the erratic occurrence of apatite shown in table 18, a significant amount of volcanic apatite does occur in some volcanic-rich sediment in the west and in some nearshore marine siltstone.

Apatite, unlike anatase in the case of $\mathrm{TiO}_{2}$, is not a particularly resistant mineral. Its hardness and resistance to weathering or leaching are about the same as for plagioclase (Goldich, 1938). The minimal average $\mathrm{P}_{2} \mathrm{O}_{5}$ in organic-rich nonmarine rock, 0.06 percent (table 14), may be partly due to the leaching of apatite by organic acids that also developed kaolinite, thereby producing one of the larger correlation coefficients for $\mathrm{P}_{2} \mathrm{O}_{5},-0.36$, with kaolinite. Such leaching also reduced the amount of plagioclase in nonmarine organic-rich shale to about half that in most other nonmarine rocks. Like plagioclase, apatite is expected to decrease markedly in abundance from west to east in the Pierre Shale (figs. $19 N$ and 23E), and therefore apatite is not likely to be important to fine-grained offshore-marine shale, in which clay is probably the only significant host of $\mathrm{P}_{2} \mathrm{O}_{5}$.

Marl, on the other hand, rather consistently contains half again more $\mathrm{P}_{2} \mathrm{O}_{5}$ than most marine shale (table 14, 0.22 and 0.15 percent, respectively), even though the marl contains less clay. This larger amount indicates either some $\mathrm{P}_{2} \mathrm{O}_{5}$ substituted in calcite or biogenic apatite associated with biogenic calcite. Goldschmidt (1954, p. 464) estimated that marine limestone contains about 150 to 200 ppm phosphorus $(\mathrm{P})$, which corresponds to about 0.04 percent $\mathrm{P}_{2} \mathrm{O}_{5}$. Accordingly, the average content of 28 percent calcite in marl of the Pierre Shale (table 14) would contain only about 0.01 percent $\mathrm{P}_{2} \mathrm{O}_{5}$, or only a small part of the extra $\mathrm{P}_{2} \mathrm{O}_{5}$ in marl. Thus, biogenic apatite seems to be the more probable source of extra $\mathrm{P}_{2} \mathrm{O}_{5}$ in marl beds of the Pierre Shale. Marlowe (1971) reported a similar relation between apatite and calcite as well as dolomite in shallow marine carbonate rocks that may also be comparable to nearshore-marine siltstone of the Pierre Shale. Biogenic apatite, thus, may additionally explain the slightly higher average $\mathrm{P}_{2} \mathrm{O}_{5}$ content of the siltstone than of shale (table 14, fig. 21), even though the siltstone, like the marl, contains less clay.

Occurrence of $\mathrm{P}_{2} \mathrm{O}_{5}$, as shown in the foregoing discussion, is complex. It probably is mostly in the clay minerals, but volcanogenic apatite is important in some nonmarine sediment in the west, and biogenic apatite is significant in marine marl. Small amounts of both types of apatite probably occur in nearshoremarine siltstone.

Fluorine content averages about 0.07 percent throughout most of the marine part of the Pierre Shale and equivalent rocks (table 14). Fluorine may be slightly less abundant in the nonmarine rocks (fig. 21), but only six determinations were made. The number of analyses are insufficient to determine stratigraphic or regional variation.

Fluorine occurs in apatite (table 16), but only in an amount less than one-tenth that of the $\mathrm{P}_{2} \mathrm{O}_{5}$ in the apatite. As $\mathrm{P}_{2} \mathrm{O}_{5}$ averages 0.1 to 0.2 percent in the 
Pierre Shale, the 0.01 to 0.02 percent $F$ that apatite could contain accounts for only a small part of the average 0.07 percent $F$; and furthermore, apatite is not the major mode of occurrence of $P$ in the Pierre Shale. Some biotite contains as much as 5 percent $F$ and biotite was seen in some coarser Pierre equivalents (see also table 18). However, very biotitic bentonite (samples 259567, 259554, and 259544, table 1) is not especially rich in $\mathrm{F}$, so apparently biotite, like apatite, is not an important host of $\mathrm{F}$ in most of the Pierre Shale. Small but statistically significant positive correlation coefficients with such organic-related elements as $\mathrm{Cd}$, vanadium (V), $\mathrm{Cu}$, Se, and $\mathrm{U}$ might indicate some $\mathrm{F}$ in organic matter, but the very small difference in mean $\mathrm{F}$ content of organic-rich and other shale (table 14) indicates that concentration of $F$ in organic matter probably is not very important. The only possible remaining major site for $\mathrm{F}$ is in the clay minerals, where it proxies for structural hydroxyl ions.

Chlorite was determined for only 27 of the samples given standard wet-chemical analyses. Nevertheless, it shows a very strong affinity for organic matter, as indicated by its large positive correlation coefficients with organic matter and $S$ (table 17) and with organicassociated elements like $\mathrm{Cd}, \mathrm{V}, \mathrm{Se}$, and As. The mean content of $\mathrm{Cl}$ in the four samples having more than 1 percent organic carbon in which $\mathrm{Cl}$ was determined is 0.05 percent (table 14), or several times that in other samples. The approximately 0.01 percent $\mathrm{Cl}$ measured in most marine shale having little organic matter probably occurs with the clay minerals. Chlorine is above the detection limit of 0.01 percent in only one of the six nonmarine samples in which chlorine was determined and is therefore inferred in table 15 to occur in the nonmarine clays at a level below that in the marine clays.

TRACE ELEMENTS OCCURING MAINLY IN

HEAVY RESISTATES (Zr, Y, Yb, La, AND Sn)

Heavy resistate minerals are not transported so readily as the clay minerals, so they should tend to lag behind and be concentrated in coarse-grained sediment. Thus, resistate minerals should be most abundant in nonmarine as compared with marine rock, in nearshore-marine as compared with offshore-marine rock, in siltstone as compared with shale, in the west or central areas as compared with the east, and in fossil zones 1 and 3 . In fossil zone 6 , compositional features expected for minerals and major elements in regressive marine rock are weakly developed and may not be shown by the trace elements either. Correlation coefficients of heavy resistate-related elements should be positive with common coarse-grained detrital minerals like quartz and feldspars, with the chemical constit- uents like $\mathrm{SiO}_{2}$ of which the minerals are made, and also with other trace elements occurring mostly in heavy resistate minerals. Conversely, their correlation coefficients should be negative with clay-related constituents like total clay minerals, $\mathrm{Al}_{2} \mathrm{O}_{3}$, and $\mathrm{H}_{2} \mathrm{O} . \mathrm{Zr}$, $\mathrm{Y}, \mathrm{Yb}, \mathrm{La}$, and Sn satisfy most of these criteria.

Zirconium shows one of the narrowest ranges in abundance of any of the trace elements (fig. 22, table 12). Nevertheless, the small differences that $\mathrm{Zr}$ does show in its distribution are, with one exception discussed below, typical of a hard, chemically resistant, heavy detrital mineral like zircon. Zircon is one of the most consistently abundant heavy minerals found (table 18). Zirconium is more abundant in nonmarine than marine rocks and in coarse-grained sediment in general (table 14), it is more abundant in nearshorethan in offshore-marine rock (fig. 22), and it is particularly abundant in highly kaolinitic brackish-water sediment (fig. 22; table 1, samples 159857, 159784, and 159713). Regionally (fig. $23 A A$ ), $\mathrm{Zr}$ is most abundant in the central zone and least abundant in the east. Stratigraphically it is most abundant in fossil zones 1 and 3 (table 13). It has strong positive correlations with typically coarse clastic minerals like quartz and feldspars in the marine environment but has a -0.45 correlation coefficient with plagioclase in nonmarine rocks. Zircon is a typical accessory mineral of volcanic rocks, and it is consistently abundant in heavy-mineral separates of volcanic-rich rocks as a whole. The relatively high average of $260 \mathrm{ppm} \mathrm{Zr}$ in bentonite (table 14) is another indication that much of the zircon is of volcanic origin. The apparent disparity of the negative correlation coefficient between plagioclase and $\mathrm{Zr}$ in nonmarine rock could result from vastly different particle size. In the nonmarine rock the particle size of coarse volcanic plagioclase may have been so much greater than that of fine volcanic zircon that the two minerals tended to be separated when the sediment was reworked and a negative correlation coefficient resulted. During extended transport, however, plagioclase was reduced by abrasion and weathering that had little effect on the harder zircon. By the time the sediments reached a marine environment, plagioclase must have been sufficiently reduced in amount and particle size that the normally expected association between heavy zircon and still relatively coarsegrained plagioclase applied. Although it seems clear that much of the $\mathrm{Zr}$ in the Pierre Shale is in zircon, the small magnitude of the differences in $\mathrm{Zr}$ content between the shale and siltstone (table 14) suggests the possibility that some may occur in the clay minerals, as is indicated by the question mark in table 15.

Yttrium, $\mathrm{Yb}$, and La in general have similar geochemical properties (table 16). All have very narrow 
ranges of abundances similar to $\mathrm{Zr}$ (fig. 22), and according to Rankama and Sahama (1950, p. 519) notable amounts of the three elements may occur in zircon. Like $\mathrm{Zr}$, the three elements are generally most abundant in fossil zones 1 and 3 , where regressive marine siltstone is well developed; also like $\mathrm{Zr}$, they are not particularly abundant in rocks representing the final regressive stage of fossil zone 6 . The distribution of these elements, however, is not identical with that of $\mathrm{Zr}$. Regionally (fig. $23 B B, C C$, and $D D$ ), Y, Yb, and La are most abundant in the west, rather than in the middle zone as is $\mathrm{Zr}$. All are more abundant in nonmarine than in marine rock (table 14), particularly so relative to $\mathrm{Zr}$ in freshwater rock (fig. 22). In the nonmarine rock, $\mathrm{Y}, \mathrm{Yb}$, and $\mathrm{La}$ are not particularly abundant in the volcanic-rich sediment (table 14), but instead are concentrated in the more leached and reworked material, as is indicated by their consistently high content in brackish-water sediment (fig. 22), by especially high amounts of $\mathrm{La}$ in nonmarine organic-rich shale (table 14), and by the correlation coefficients of +0.31 to +0.48 of all three elements with kaolinite in nonmarine rock (table 17). In nonmarine rock the three elements are actually more abundant in shale than in siltstone (table 14) and their correlation coefficients with total clay, $\mathrm{Al}_{2} \mathrm{O}_{3}$, and $\mathrm{H}_{2} \mathrm{O}+$, though mostly small, are positive. Much of their association with clay, like that of $\mathrm{Zr}$, seems to be due to their strong association with kaolinite in highly weathered rock, apparently because of the resistate affinities of these elements. Occurrences of $\mathrm{Y}, \mathrm{Yb}$, and $\mathrm{La}$ are shown in table 15, however, also as questionably in clay minerals.

Reported associations of $\mathrm{Y}, \mathrm{Yb}$, and La with apatite and calcite (table 16) seem to be of little importance in the Pierre Shale. As to apatite, only one correlation coefficient of $\mathrm{Y}, \mathrm{Yb}$, or La with $\mathrm{P}_{2} \mathrm{O}_{5},+0.25$ of $\mathrm{Y}$ in marine rocks (table 17), is significant at the 95-percent level, and that just barely so. Relatively low amounts of $\mathrm{Y}, \mathrm{Yb}$, and $\mathrm{La}$ in volcanic-rich rock (table 14) indicate that volcanogenic apatite is not an important host. Measurements of $\mathrm{Y}$ and La in nearly pure apatite nodules from offshore-marine parts of the Pierre Shale average about $300 \mathrm{ppm}$ and $\mathrm{Yb}$ about $30 \mathrm{ppm}$. These values are 10 times the average content of the shale (table 14), but the average amount of apatite in the shale is no more than 0.3 to 0.5 percent, which could contribute no more than about $1 \mathrm{ppm} \mathrm{Y}$ and La or 0.1 $\mathrm{ppm} \mathrm{Yb}$ to the concentrations of these elements in the whole samples even if all $\mathrm{P}_{2} \mathrm{O}_{5}$ were in apatite, which it clearly is not. Furthermore, amounts of $\mathrm{Y}, \mathrm{Yb}$, and $\mathrm{La}$ are distinctly below average in marl in which biogenic apatite is inferred to occur. The small concentrations in marl also indicate that $\mathrm{Y}, \mathrm{Yb}$, or La do not sub- stitute in calcite in the Pierre Shale.

Tin was looked for in so few samples (24 nonmarine shale, 12 marine shale, 2 marl, and 11 bentonite samples) that the element was neither treated statistically nor is its stratigraphic or regional distribution shown. The principal reported occurrence of $\mathrm{Sn}$ (table 16) is in the heavy mineral cassiterite. The average Sn content of nonmarine rock of the Pierre Shale is about the same as in the marine rock (table 14), but in the 1.4-ppm average for nonmarine rock, 18 of the 24 samples are volcanic-rich shale in which Sn content is small. The much greater average abundance of $\mathrm{Sn}$ in ordinary nonmarine shale, $3.3 \mathrm{ppm}$, and the slightly greater content in marine siltstone than in marine shale are as expected for an element in a resistate mineral. As with $\mathrm{Zr}$ and $\mathrm{La}$, one puzzling aspect of Sn distribution is that it seems not particularly concentrated in volcanic-rich sediment but is nevertheless fairly abundant in bentonite (table 14). As far as the data go, the small amount of Sn in both marine and nonmarine organic-rich shale (table 14) seems to indicate that $\mathrm{Sn}$ is not concentrated in organic matter in the Pierre Shale, as it is interpreted to be in shale of Pennsylvanian age by Degens, Williams, and Keith (1957).

TRACE ELEMENTS OCCURRING ALMOST ENTIRELY IN CLAY MINERALS (Sc AND B)

Distribution features of these elements should be the opposite of those enumerated for the heavy resistaterelated trace elements. Gallium, reputedly one of the most clay-related elements (table 16), was initially included with Sc and B in this group. As will be shown, however, it soon became obvious that sufficient $\mathrm{Ga}$ also occurs in feldspar to appreciably influence its distribution.

Scandium, because of its smaller ionic size, behaves much differently from $\mathrm{Y}, \mathrm{Yb}$, and $\mathrm{La}$, which it otherwise resembles chemically (Rankama and Sahama, 1950 , p. 515). It is slightly more abundant in marine than in nonmarine rock (fig. 22), in offshore- than in nearshore-marine rock and in finer grained rock in general (table 14), and in the eastern area (fig. 23EE) where the finer grained rock is most abundant. Correlation coefficients of Sc are strongly positive with $\mathrm{TiO}_{2}$, with total clay minerals, and with such clay-associated constituents as $\mathrm{Al}_{2} \mathrm{O}_{3}, \mathrm{Fe}_{2} \mathrm{O}_{3}$, and $\mathrm{H}_{2} \mathrm{O}$. Clearly, the major host of Sc in the Pierre Shale is the clay minerals, with little preference for any clay mineral other than that expectable from their general abundance. Average Sc content of various fossil zones has a small range, from 14 to $19 \mathrm{ppm}$ (table 13). The maximum average in fossil zone 6 is due to large Sc content of 
four samples of marl from the Mobridge Member (samples 259531, 259553, 259556, and 259562, table 1), which might suggest some Sc in calcite. However, most marl from other fossil zones has Sc content below average, and Rankama and Sahama $(1950$, p. 516) reported negligible $\mathrm{Sc}$ in carbonate sediments. For these reasons, no Sc is inferred in calcite in the Pierre Shale. The small average Sc content of bentonite, about $9 \mathrm{ppm}$ (table 14), might suggest an inverse relation between Sc and montmorillonite, but this relation does not seem to apply to the rest of the Pierre Shale and its equivalents.

Boron in shale has been directly related by many investigators over the past 30 years to salinity of water in which the sediment was deposited (Landergren, 1945; Degens, Williams and Keith, 1957; Harder, 1959a, 1959b; Frederickson and Reynolds, 1960; Hirst, 1962; Potter and others, 1963; Nicholls, 1963; Tourtelot, 1964; and many others). The general distribution of $B$ in the Pierre Shale seems to be in keeping with this concept, the most B occurring in offshore-marine sediment and the least in the freshwater sediment (fig. 22), the content of $B$ increasing markedly from west to east (fig. $23 F F$ ), and the lowest $B$ contents occurring in fossil zones 3 and 6 (table 13) during the time of which nonmarine rock extended farthest to the east. The expected low B content of sediments in fossil zone 1, deposited during the Eagle regression, was not seen, perhaps because the regression is represented mainly by tongues of nearshore marine rock and the nonmarine rock does not extend very far east (pl. 1).

Although a few investigators have pointed out that $B$ may occur in several of the clay minerals (Fleet, 1965; Tourtelot and others, 1961), most emphasized the role of illite as the dominant host mineral and the importance of relating $B$ content to total illite content rather than to the total sample. In the marine rock of the Pierre Shale and equivalents, however, the small correlation between $B$ and illite $(+0.17$, table 16$)$ suggests that illite is not an important factor. Note, for example, that frothy-weathering shale, one of the least illitic of the lithologic groups (table 6), has the highest average $B$ content (133 ppm, table 14). The correlation coefficients of about +0.4 to +0.5 of $\mathrm{B}$ with mixedlayer clay, $\mathrm{Al}_{2} \mathrm{O}_{3}$, and $\mathrm{H}_{2} \mathrm{O}+$ in marine rock and with total clay minerals in both marine and nonmarine rock indicates that the total clay-mineral content is the most important factor controlling the occurrence of $B$ in the Pierre Shale and equivalent rock.

Boron content related to clay content of individual samples (fig. 24) shows the same general relation between B and environment of deposition as is shown in figure 22. However, the range of values in the freshwater and marine groups shown in figure 24 is so great as to make environmental interpretations from the B content of individual samples meaningless. A plot of B against Ga in the Pierre Shale (not shown here), as recommended by Keith and Degens (1959), showed relationships similar to those in figure 24 . Figure 24 and table 14 also show that much of the difference in average $B$ content between the freshwater and marine groups is due to exceptionally small

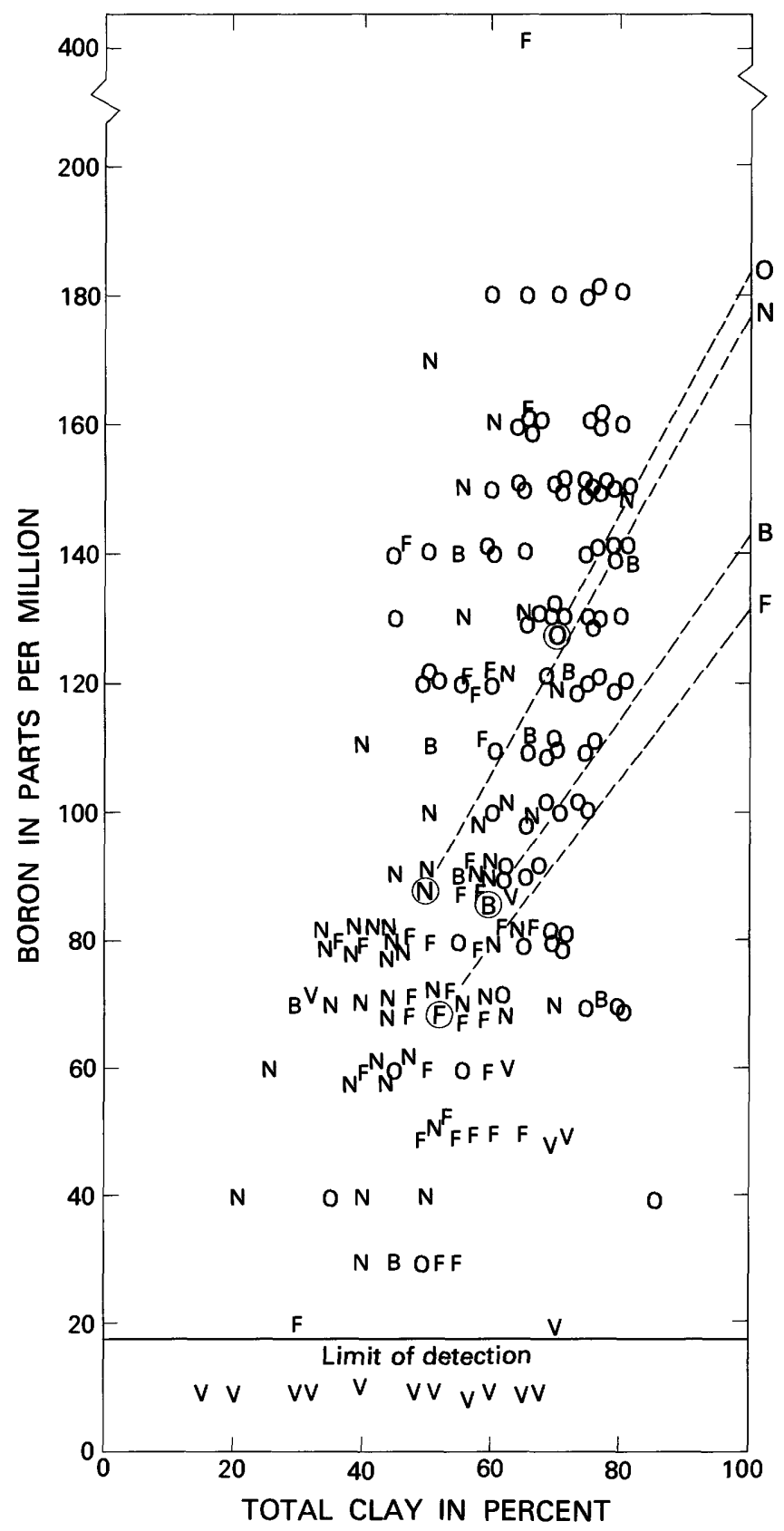

Figure 24.-Boron content related to total clay content and to environment of deposition. Samples are offshore-marine (O), nearshore-marine (N), brackish-water (B), and freshwater (F) or (V) if volcanic rich. Mean values for groups are circled and projected to 100 -percent clay. 
amounts of $B$ in most volcanic-rich samples. Exclusive of the volcanic-rich samples, the average B content of freshwater samples normalized to 100 percent clay is $176 \mathrm{ppm}$, or only slightly below the 180 -ppm normalized average for clay in marine samples. The small content of $B$ in volcanic-rich rock also parallels the relatively small B content of most bentonite (table 14). The moderately strong correlation coefficient between $\mathrm{B}$ and illite in nonmarine rock, +0.48 , therefore, seems to result almost entirely from the volcanic rock-that is, from the combination of its low illite and low B contents. In other nonmarine rock the clays, including illite, contain nearly the same average amount of $B$ as the clays in marine rock. However, in table 15 the B content for nonmarine clay, $140 \mathrm{ppm}$, is smaller than that for marine clay, $170 \mathrm{ppm}$, because these are averages for ordinary shale; the relatively high $B$ content of the samples of nonmarine organic-rich shale, which in figure 24 brings the average of all nonmarine clay, volcanic rich excepted, up to nearly the level of marine clay, are not included in the averages in table 15.

Boron distribution in rocks of Pierre age is complicated by large average amounts of $B$ in both marine and nonmarine organic-rich shale (table 14), a feature that is also reflected in fairly large correlation coefficients, +0.41 and +0.42 , of $B$ with organic $C$ (table 17 ). The opposite relation was reported by Eager and Spears (1966) in British Carboniferous sediment, but no relation was reported by Walker (1968) in other British Carboniferous sedimentary rock, and a similar lack of relationship in Pennsylvanian rock was reported by Keith and Degens (1959, table 2). Much of the high average content of $B$ in nonmarine organicrich rock in the Pierre Shale is due to one sample (159811, table 1) containing $410 \mathrm{ppm}$, an amount nearly double the next highest of $210 \mathrm{ppm}$ but which was supported by repeated analyses. Though we cannot explain the B content of sample 159811, even if it is excluded, the average $B$ content of the other 10 nonmarine organic-rich shale samples is about $100 \mathrm{ppm}$, which is still more than in other nonmarine rock (table 14).

Boron plotted against organic carbon for organicrich samples of Pierre Shale (fig. 25) shows no general relation either in the nonmarine or marine rocks, which suggests that the high $B$ contents of the organic-rich shale may result from factors other than the organic matter itself. One likely possibility for the marine group is authigenic monoclinic potassium feldspar, found only in fissile black shales of the Sharon Springs Member, that gives a characteristic X-ray pattern similar to that of feldspar in the Miocene Barstow Formation of California (Sheppard and Gude, 1965, 1973) where the potassium feldspar contains 2,000 to 3,000 ppm $\mathrm{B}^{+3}$ substituting for $\mathrm{Al}^{+3}$. However, a semiquantitative spectrographic analysis of the bentonite containing about three-fourths authigenic potassium feldspar (table 10, sample $K$ ) made to test this possible occurrence indicated only $150 \mathrm{ppm} \mathrm{B}$, an amount that would be insignificant in the few percent authigenic potassium feldspar in most marine organic-rich shale. Therefore, $B$ is shown in table 15 as questionably associated with organic matter.

\section{TRACE ELEMENTS HAVING MULTIPLE OCCURRENCES} ( $\mathrm{Ga}, \mathrm{Pb}, \mathrm{Ba}, \mathrm{Sr}, \mathrm{AND} \mathrm{Mn}$ )

These trace elements seem to occur mostly in clay minerals, but appreciable amounts also occur in other minerals. The other minerals tend to be coarse grained so that the mounts of the trace elements in them counterbalance the distribution of the elements in finegrained clay minerals. As a result, correlation coefficients are mostly small, regional and stratigraphic variations are weak, and average amounts in rock types tend to be similar. The reasoning behind the assignment of the element to individual host minerals usually is complex and is based upon modes of occur-

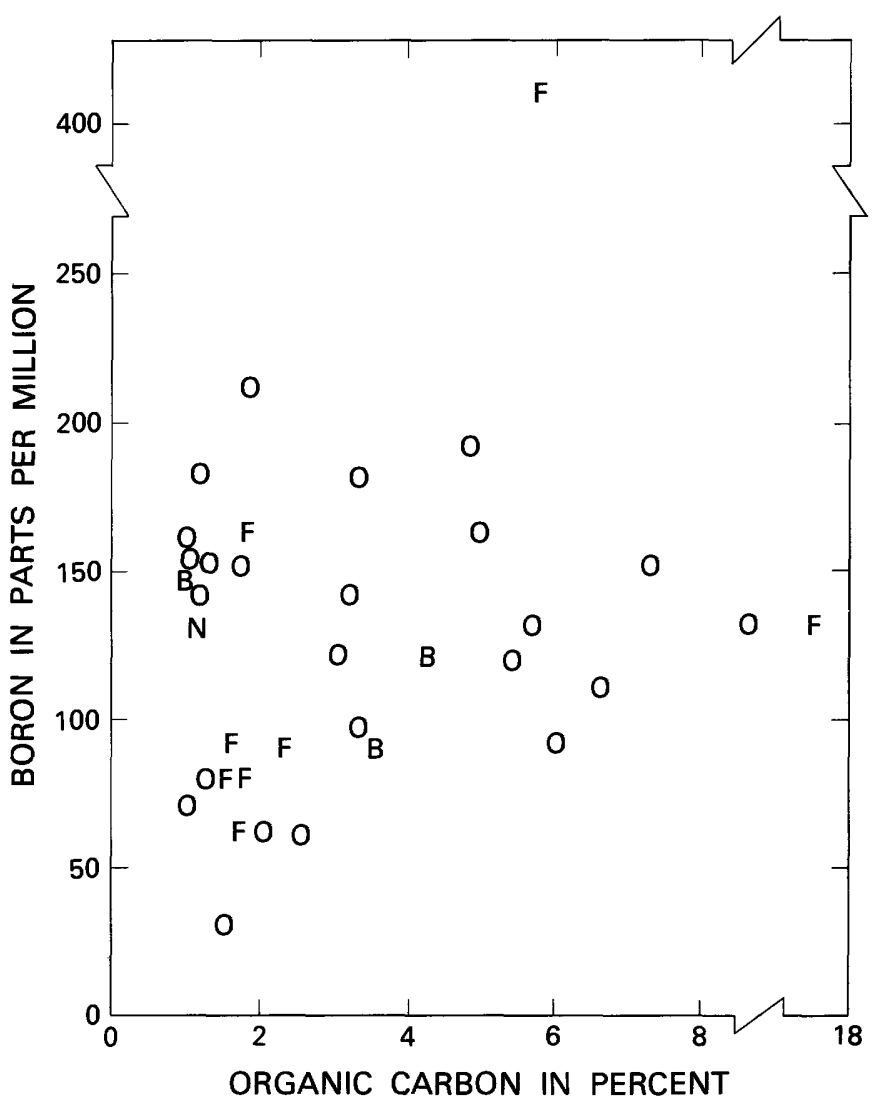

Figure 25.-Boron content of samples containing 1 percent or more organic carbon. Offshore-marine (O), nearshore-marine (N), brackish-water (B), and freshwater (F). 
rence reported from the literature (table 16) to an extent greater than for most other elements. Also, the amount assigned to individual minerals is generally more tenuous.

Gallium, like Sc, is strongly associated with $\mathrm{Al}_{2} \mathrm{O}_{3}$ and $\mathrm{TiO}_{2}$ (table 17) in both marine and nonmarine rocks of Pierre age, and it is more abundant in the more argillaceous fine-grained rock (table 14). Both relationships indicate concentration of $\mathrm{Ga}$ in clay minerals (table 16), where $\mathrm{Ga}^{+3}$ has long been known to substitute for $\mathrm{Al}^{+3}$. However, there is little correlation between $\mathrm{Ga}$ and total clay minerals, particularly in marine rock (table 17), and the lithologic and facies distributions of $\mathrm{Ga}$ differ in several respects from those of Sc and B. Gallium is slightly more abundant in nonmarine than in marine rock (table 14, fig. 22); it is more abundant in the west than in the east (fig. 23GG); it is equally abundant in nearshore and offshore marine sediments (fig. 22); and it is most abundant in brackish-water organic-rich shale (table 14, fig. 22). These distributions indicate that Ga may be concentrated in the coarser clay minerals like kaolinite that tend to be concentrated in nearshore rock; kaolinite is also especially abundant in some brackish-water organic-rich shale. At the same time, the usual amounts of kaolinite are so small and correlation coefficients of $\mathrm{Ga}$ with kaolinite so weak that some Albearing coarse-grained mineral in addition to kaolinite seems indicated as a major host of $\mathrm{Ga}$. The obvious candidate is plagioclase, in which $100 \mathrm{ppm} \mathrm{Ga}$ is inferred to substitute for $\mathrm{Al}$ in order to achieve average amounts of $\mathrm{Ga}$ determined for ordinary marine and nonmarine shale (table 15). That such a substitution is possible has been demonstrated by Goldsmith (1950). As both the clays and plagioclase are major Al-bearing minerals, correlation coefficients between $\mathrm{Ga}$ and $\mathrm{Al}_{2} \mathrm{O}_{3}$, particularly in nonmarine rock, are exceptionally large (table 17). Otherwise, $\mathrm{Ga}$ in plagioclase and in clays counterbalance so that correlation coefficients with total clay, individual clay minerals, or plagioclase are small, and stratigraphic and regional variation are weak (table 13, fig. 23). Bentonite contains a nearly average amount of $19 \mathrm{ppm} \mathrm{Ga}$, so the very large amount of montmorillonite that it contains must include less $\mathrm{Ga}$ than most other clay minerals in the Pierre Shale and its equivalents.

Lead $(\mathrm{Pb})$ content is almost identical in marine and nonmarine rocks as well as in offshore-marine, nearshore-marine, brackish-water, and freshwater samples (fig. 22). Neither shale and siltstone (table 14) nor stratigraphic zones (table 13) show consistent differences, and the regional variations are small (fig. $23 H H$ ). Only three correlation coefficients of $\mathrm{Pb}$, those with $\mathrm{Ga}, \mathrm{Cd}$, and $\mathrm{Se}$, are larger than \pm 0.30 before rounding, and those with $\mathrm{Cd}$ and Se involve so few pairs of data that they are not significant (table 17). Such a characterless distribution is typical of a trace element in the clays as well as in other minerals, especially coarse-grained ones. The other minerals, however, are not easily inferred.

The small but statistically significant correlation coefficients of $\mathrm{Pb}$ with illite and $\mathrm{K}_{2} \mathrm{O}$ (table 17) suggest substitution of $\mathrm{Pb}^{+2}$ (1.21-A cation radius) for $\mathrm{K}^{+}$ (1.33-A cation radius) in illite. The absence of correlation with the much more abundant illite layers in mixed-layer clay, and the highest average content of 31 ppm $\mathrm{Pb}$ observed in bentonite with no illite, however, do not agree with such a concentration of $\mathrm{Pb}$.

The relatively high $\mathrm{Pb}$ content of $26 \mathrm{ppm}$ in nonmarine organic-rich shale (table 14) might indicate that organic matter is a host of $\mathrm{Pb}$, an occurrence frequently reported in the literature, or is in associated pyrite (Rankama and Sahama, 1950, p. 736; Goldschmidt, 1954, p. 403; Krauskopf, 1956, p. 31; Goldberg and Arrhenius, 1958, p. 201; Keith and Degens, 1959 , p. 50-52). However, the $\mathrm{Pb}$ content of marine organic-rich shale is only average (table 14), and $\mathrm{Pb}$ shows no correlation with either organic matter or sulfur in marine or nonmarine rocks (table 17). Therefore, no $\mathrm{Pb}$ is shown as occurring in organic matter in the Pierre Shale (table 15).

One expectable occurrence of $\mathrm{Pb}$ is in potassium feldspar where it replaces $\mathrm{K}^{+}$because of their similar cation sizes, mentioned above. Correlation coefficients indicate no such relation, but the largest average amount of potassium feldspar is in the nonmarine siltstone that also has one of the largest average $\mathrm{Pb}$ contents (table 14). The potassium feldspar content of marine siltstone also is fairly large. Even so, the amount of potassium feldspar generally is so small that a large amount of $\mathrm{Pb}$ would have to occur in it to appreciably affect the distribution of $\mathrm{Pb}$. For lack of any other likely coarse-grained mineral host of $\mathrm{Pb}, 500$ ppm $\mathrm{Pb}$ is shown in potassium feldspar in the Pierre Shale (table 15), an amount sufficient to explain most of the observed distribution. In the authigenic potassium feldspar in the Sharon Springs Member (table 15, footnote 5) $\mathrm{Pb}$ content must be much less than that in other potassium feldspar; otherwise the cumulative average $\mathrm{Pb}$ content of the organic-rich marine shale would average about $30 \mathrm{ppm}$ rather than the observed $20 \mathrm{ppm}$.

Barium (Ba) content of the lithologic groups averages from $440 \mathrm{ppm}$ in marl to $920 \mathrm{ppm}$ in volcanicrich rock (table 14). Barium content differs little with environment of deposition (fig. 22) or by region (fig. $23 I I$ ). Most of the correlation coefficients for $\mathrm{Ba}$ are small (table 17), suggesting, as for $\mathrm{Pb}$, multiple modes 
of occurrence. The higher $\mathrm{Ba}$ content of both the marine and nonmarine fine-grained rocks indicates that most $\mathrm{Ba}$ occurs in the clay, even though its correlation coefficients with clay are small. The coefficients of +0.71 and +0.65 with plagioclase and $\mathrm{Na}_{2} \mathrm{O}$ in nonmarine rock show that $\mathrm{Ba}$ in plagioclase is responsible for much of the variability of $\mathrm{Ba}$ in nonmarine samples. Barium in plagioclase also explains the slightly larger average $\mathrm{Ba}$ content of the nonmarine rock and the maximum average content of the volcanic-rich rock (table 14). The slightly larger Ba contents of fossil zones 3 and 6 also probably result from their high plagioclase contents (table 13). Though most variance of $\mathrm{Ba}$ is due to plagioclase, nevertheless most $\mathrm{Ba}$ in most types of rock occurs in the clay minerals (table 15).

No such clear relation of $\mathrm{Ba}$ with plagioclase is shown in marine rock, probably because it contains only half as much plagioclase as the nonmarine rock, so variability due to $\mathrm{Ba}$ in the clay minerals more than counterbalances that due to $\mathrm{Ba}$ in plagioclase. Also, the correlation coefficient of $\mathrm{Ba}$ with total clay is small, which indicates that components other than clay or plagioclase influence Ba distribution. The only other minerals having even small positive but still statistically significant correlation coefficients with $\mathrm{Ba}$ are quartz and zeolite (table 17). Quartz is not a likely host of $\mathrm{Ba}$, but zeolite is. One zeolitic bentonite that is composed almost entirely of clinoptilolite from the Sharon Springs Member of the Pierre Shale near Chamberlain, S. D. (N, table 10), contains about 7,000 $\mathrm{ppm} \mathrm{Ba}$. The effects of such large amounts of $\mathrm{Ba}$ even in the 0.4-percent average amount of zeolite in offshore marine shale could be significant (table 15).

The average $\mathrm{Ba}$ content of $700 \mathrm{ppm}$ for bentonite (table 14) is much influenced by a single sample (259588, table 1 ) that contains $6,600 \mathrm{ppm} \mathrm{Ba}$, probably because of disseminated barite that is common in nodules in many beds of bentonite from the Sharon Springs Member around the Black Hills. This amount of $\mathrm{Ba}$ corresponds to about 1 percent barite, which might not ordinarily be detected by X-ray analysis of the bulk sample. Excluding this sample, the average Ba content of bentonite is $410 \mathrm{ppm}$, about one-tenth of which may occur in plagioclase and the rest, about 370 ppm, in the montmorillonite of bentonite. This amount is considerably less than in the clays of shale (table 15).

Strontium content of the Pierre Shale and its equivalents, though controlled mostly by the same multiple factors as $\mathrm{Ba}$ (table 15), shows considerably more variation between different groups of rock. The reasons are two fold. First, as in most sedimentary rock (table 16), Sr occurs in calcite, about $2,000 \mathrm{ppm}$ (table 15) judging from the marl (table 14), which has the highest average Sr content of the lithologic groups. In most of the Pierre Shale, however, calcite is so sparse that it has little control over $\mathrm{Sr}$ distribution. Second, and more important, a considerably higher proportion of $\mathrm{Sr}$ than $\mathrm{Ba}$ occurs in plagioclase-about the same amount as in the clays of the nonmarine rock (table 15). Because of this strong concentration in plagioclase, $\mathrm{Sr}$ is concentrated in nonmarine fresh- and brackish-water sediments (fig. 22), in volcanic-rich rock (table 14), in western areas (fig. 23JJ), and in fossil zone 3 (table 13). The fairly high Sr content of fossil zone 4, $250 \mathrm{ppm}$, might be explained by its above-average content of 4 percent calcite, but if so, the even higher calcite and plagioclase contents of fossil zone 6 should lead to a larger average $\mathrm{Sr}$ amount than the $250 \mathrm{ppm}$ found there.

Manganese is generally more abundant in marine than in nonmarine rock (table 14 , fig. 22). The average in different lithologic types, however, varies greatly within the marine (135 to $6,800 \mathrm{ppm}$ ) and the nonmarine (120 to $490 \mathrm{ppm}$ ) groups. The highest average amount, which is in marine siliceous shale, is due mainly to exceptionally large amounts of $\mathrm{Mn}, 34,600$ and 9,400 ppm, in samples 259533 and 259538 (table 1 ), in both of which fragments of nodular $\mathrm{Mn}-\mathrm{Fe}$ carbonate were detected. If these two samples are excluded, the mean Mn content of siliceous shale is 790 ppm, which is still considerably more than in most other shale and which probably is present in undetectable amounts of $\mathrm{Mn}-\mathrm{Fe}$ carbonate. Undetected $\mathrm{Mn}-\mathrm{Fe}$ carbonate may also be indicated by the above-average $\mathrm{Mn}$ in frothy-weathering shale, many beds of which are stratigraphically interbedded with or grade into siliceous shale (pl. 1) and which contain large $\mathrm{Mn}-\mathrm{Fe}$, carbonate nodules that are excluded from the shale samples. Such Mn-Fe nodular material accounts also for the high Mn content of fossil zones 4 and 5 (table 13) where siliceous and frothy-weathering shale are abundant. Another expectable carbonate host of large amounts of $\mathrm{Mn}$ is calcite (table 16). Manganese in calcite apparently produced the average $2,700 \mathrm{ppm}$ in marl, and the figure of $8,000 \mathrm{ppm}$ Mn inferred in calcite (table 15) came from marl. However, the weak correlation coefficients between $\mathrm{Mn}$ and calcite in most of the Pierre Shale, particularly in the marine rock (table 17), indicate that calcite is an important factor only in marl.

Manganese ions substituted in the structures of clay minerals of the Pierre Shale, as in shale in general (table 16), is one probable widespread occurrence of the element. However, chemical analyses of 15 purified clay samples from the Pierre Shale (table 19) average 0.025 percent $\mathrm{MnO}$, which corresponds to only about $200 \mathrm{ppm} \mathrm{Mn}$ in the clays. The 15 clay samples were 
given Jackson's (1958) Na-citrate-dithionate treatment, which dissolves Fe oxides and hydroxides and which, according to Anderson and Jenne (1970), also dissolves Mn oxides. An average of about one-third of the $\mathrm{Mn}$, about $150 \mathrm{ppm}$, was removed by the treatment and therefore is assumed to be in the form of Fe-Mnoxide (table 15, footnote 4). The average amount of $\mathrm{Fe}$ oxide removed, about 0.5 percent, is not very significant in the overall Fe content of the Pierre Shale, but the $150 \mathrm{ppm} \mathrm{Mn}$ is significant. The low average $\mathrm{Mn}$ content of ordinary nonmarine shale, $170 \mathrm{ppm}$ (table 14), however, indicates that Fe-Mn oxide generally may not be as important in nonmarine as in marine rock.

The amounts of $\mathrm{Mn}$ in $\mathrm{Mn}-\mathrm{Fe}$ carbonate, calcite, clay, and $\mathrm{Mn}-\mathrm{Fe}$ oxide account approximately for $\mathrm{Mn}$ in most of the Pierre Shale and its equivalents. However, these minerals account for no more than $300 \mathrm{ppm}$ of the average of $490 \mathrm{ppm} \mathrm{Mn}$ in nonmarine volcanicrich rock. The largest correlation coefficient observed for $\mathrm{Mn}$ is +0.68 with $\mathrm{P}_{2} \mathrm{O}_{5}$ in nonmarine rock (table 17). Volcanogenic apatite is found in the volcanic-rich rocks, but the 0.3 percent apatite permitted by the average 0.14 percent $\mathrm{P}_{2} \mathrm{O}_{5}$ in them seems much too small to contribute significantly to the total $\mathrm{Mn}$ amount, particularly as apatite is not commonly a host of $\mathrm{Mn}$ (table 16). Augite, like apatite, is found in volcanic-rich rock of the Pierre Shale and is a noted host of heavy metals, including several thousand parts per million Mn (Deer and others, 1963, p. 114-124; Wedepohl, 1971, p. 185). However, augite makes up no more than 1 percent of the volcanic rocks, an amount which, assuming even $5,000 \mathrm{ppm} \mathrm{Mn}$ in the augite, could account for no more than $50 \mathrm{ppm} \mathrm{Mn}$. The one remaining mineral that is especially abundant in the volcanic rock is plagioclase, which according to Wedepohl $(1971$, p. 185) may contain a few hundred $\mathrm{ppm} \mathrm{Mn}$. If $500 \mathrm{ppm} \mathrm{Mn}$ is assumed in plagioclase, as inferred in table 15, the 14-percent average plagioclase in volcanic-rich rock would contribute $70 \mathrm{ppm} \mathrm{Mn}$, still leaving about $100 \mathrm{ppm}$ of the $490 \mathrm{ppm} \mathrm{Mn}$ in volcanicrich rock unaccounted for. The $100 \mathrm{ppm}$ Mn may occur as opaque $\mathrm{Mn}$ or $\mathrm{Fe}$ oxide or in magnetite (table 15, footnote 4, and table 18); also note on table 19 that three of the four volcanic-rich samples (159835, 159834,159825 , and 159803) show decreases in $\mathrm{MnO}$ content after dithionate treatment (less than $0.25 \mu \mathrm{m}$ ), whereas the other three nonmarine samples do not.

The many factors that enter into distribution of $\mathrm{Mn}$ in the Pierre Shale result in two geographic areas of high Mn content (fig. $23 K K$ ). One area is in the east, where samples from three localities have an average in excess of 1,000 ppm $\mathrm{Mn}$, mainly due to $\mathrm{Mn}$ in the calcite of marl and to $\mathrm{Mn}-\mathrm{Fe}$ carbonate in siliceous shale. The other area is in the west, where samples from two localities have average contents in excess of $500 \mathrm{ppm} \mathrm{Mn}$, apparently due to $\mathrm{Mn}$ in large amounts of plagioclase, and possibly to $\mathrm{Mn}$ oxide, augite, or magnetite.

TRACE ELEMENTS ASSOCIATED WITH SULFUR OR ORGANIC MATTER

The elements Co, Ni, Zn, Cd, Cr, V, Cu, Mo, As, Se, and $U$ are all concentrated in marine organic-rich shale (table 14). The concentration ranges from large for Mo, $\mathrm{Se}$, and As to small for Co, which would not be included in this group except for other factors to be developed. The concentration of these elements in marine organicrich shale is responsible for most of their environmental (fig. 22), regional (fig. 23LL-UU), and stratigraphic (table 13) variations. All 11 elements commonly have been reported to be associated both with $S$ in pyrite and with organic matter (table 16).

INTERRELATIONS BETWEEN S (PYRITE), ORGANIC MATTER, AND THEIR RELATED ELEMENTS

Before the 11 trace elements of this group are considered individually, some interrelations between them, organic matter, and $S$ in marine and nonmarine rocks need to be pointed out. Figure 26 shows mean content of organic $\mathrm{C}, \mathrm{S}$, and all trace elements commonly thought to be associated with either of them (table 16) except $\mathrm{Cl}$, for which data are insufficient. In figure 26 all samples, marl and bentonite excepted, are divided into five groups according to their content of organic $\mathrm{C}$. The mean contents of organic $\mathrm{C}$ for each marine-nonmarine pair are not all exactly the same, but they are close. The percentage of organic $\mathrm{C}$ is about double or more in each successive group, so any trace elements concentrated in organic matter should show a corresponding increase. Obviously they do not.

Figure 26 shows four general relationships that are of considerable importance in the Pierre Shale. First, as previously inferred from table 14, in the Pierre Shale $\mathrm{Sn}$ and $\mathrm{Pb}$ are not concentrated in organic matter, because samples containing the most organic $\mathrm{C}$ do not contain the largest amounts of these elements. Second, marine rock containing the largest amount of organic $\mathrm{C}$ also contains the largest amounts of all 11 elements listed from Co to $U$ (table 14) but nonmarine rock shows no such relation; organic matter in the two types of organic-rich shale must have collected heavy metals differently. Third, in marine rock the amount of most of the 11 elements shows no consistent relationship with moderate amounts of organic C (less than 1 percent); although the group having the least organic $\mathrm{C}$ 
(less than 0.05 percent) rather consistently contains the least of these elements, the group includes one

\begin{tabular}{|c|c|c|c|c|c|}
\hline Group No. & 1 & 2 & 3 & 4 & 5 \\
\hline \multicolumn{6}{|c|}{ Number of samples in group } \\
\hline $\begin{array}{l}\text { Marine } \\
\text { Nonmarine }\end{array}$ & $\begin{array}{l}1 \\
10\end{array}$ & $\begin{array}{l}16 \\
25\end{array}$ & $\begin{array}{r}44 \\
7\end{array}$ & $\begin{array}{r}45 \\
5\end{array}$ & $\begin{array}{l}2 \\
1\end{array}$ \\
\hline \multicolumn{6}{|c|}{ Range of organic $\mathrm{C}$ within group } \\
\hline $\begin{array}{l}\text { Minimum } \\
\text { Maximum }\end{array}$ & $\begin{array}{r}<0.05 \\
<.05 \\
\end{array}$ & $\begin{array}{r}0.05 \\
.25 \\
\end{array}$ & $\begin{array}{c}0.25 \\
.5\end{array}$ & $\begin{array}{l}0.5 \\
1.0 \\
\end{array}$ & $\begin{array}{r}>1 . \\
17\end{array}$ \\
\hline \multicolumn{6}{|c|}{ Mean organic $\mathrm{C}$ of group } \\
\hline $\begin{array}{l}\text { Marine } \\
\text { Nonmarine }\end{array}$ & $\begin{array}{r}<0.05 \\
<.05\end{array}$ & $\begin{array}{r}0.18 \\
.12\end{array}$ & $\begin{array}{r}0.35 \\
.35\end{array}$ & $\begin{array}{r}0.68 \\
.77\end{array}$ & \\
\hline
\end{tabular}
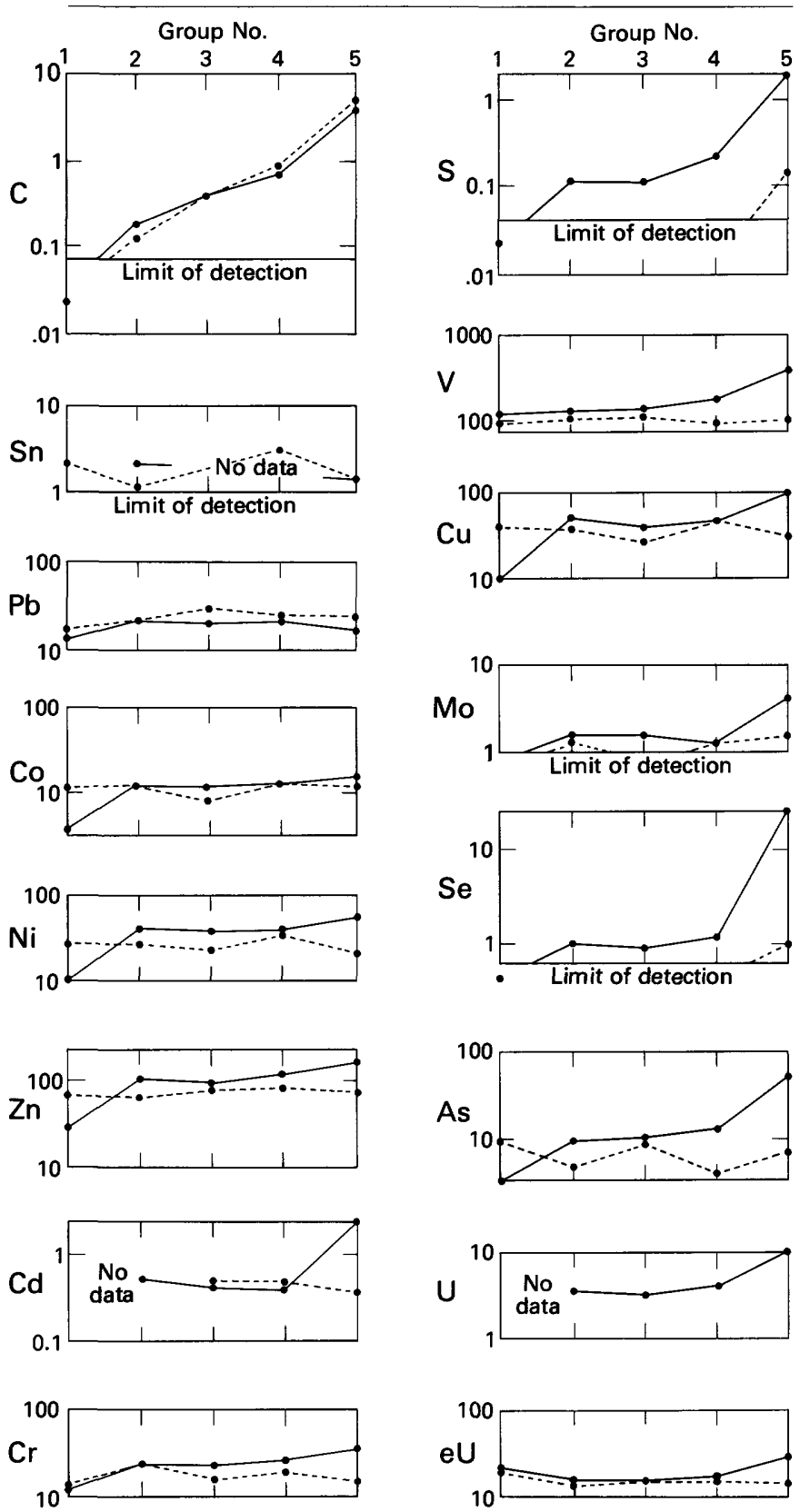

sample only and is, therefore, of little significance. Lack of consistent variation in the middle three groups for the 11 elements, except possibly for $\mathrm{V}$ and $\mathrm{As}$, indicates that small amounts of organic matter in marine parts of the Pierre Shale also must have collected heavy metals differently from the large amounts of organic matter in organic-rich marine shale. Table 15 reflects the just-mentioned second and third relations by having two columns for elements in organic matter: the left column is for ordinary shale and shows entries for only V and As, and only in marine shale; the right column is for organic-rich marine shale. The fourth relation shown on figure 26 is that the amount of $S$, mostly in pyrite, commonly parallels the amount of organic $\mathrm{C}$, a relation also indicated by the large correlation coefficient, +0.71 , between the two constituents in marine rock (table 17). Interpretations of which of the 11 elements actually occur in organic matter or pyrite, therefore, are difficult to make. As will be shown, correlation coefficients indicate a Co-Ni-Zn subgroup in which these elements are more closely related to each other (and to pyrite) than to the other elements of the group.

SULFUR-RELATED ELEMENTS (Co, Ni, AND Zn)

Cobalt, $\mathrm{Ni}$, and $\mathrm{Zn}$ all show very strong positive correlation coefficients with each other, especially in marine rocks where the coefficients, all larger than +0.75 , are among the highest observed. Their correlation coefficients with pyrite $(+0.22,+0.28$, and +0.21 , respectively -not shown in table 17) are small, perhaps in part because small amounts of pyrite are difficult to detect; but coefficients with total S (table 17) are only marginally larger, and the maximum coefficient observed, +0.38 between $\mathrm{Ni}$ and $\mathrm{S}$, accounts for only 15 percent of the total variation. Nevertheless, these coefficients are generally larger than those with organic matter and with the organic-associated elements listed from $\mathrm{Cd}$ to $\mathrm{U}$ (table 17). Any original genetic relationship of $\mathrm{Co}, \mathrm{Ni}$, and $\mathrm{Zn}$ with $\mathrm{S}$ may have been partly erased by oxidation of pyrite in the weathering zone.

Although apparently concentrated in pyrite, most $\mathrm{Co}, \mathrm{Ni}$, and $\mathrm{Zn}$ must occur in the more abundant clay minerals (table 15), and the amount of Co in pyrite must be very small, as the Co content of pyritic

FIGURE 26.-Trace elements reported to be associated with organic matter or $S$ (table 16) related to five groups of rock from the Pierre Shale and equivalent rocks having different contents of organic C. Solid line, marine samples; dotted line, nonmarine samples. Organic $\mathbf{C}$ and total $\mathrm{S}$ in percent; trace elements in parts per million. 
organic-rich marine shale is no larger than that of ordinary shale (table 14) and is only barely larger than the less organic-rich groups in figure 26. Accordingly, only a small part of the total Co content is shown in pyrite in table 15 . Amounts of $\mathrm{Ni}$ and $\mathrm{Zn}$ are one-fourth to one-third larger in pyritic organic-rich shale than in ordinary marine shale (table 14, fig. 26), so more $\mathrm{Ni}$ and $\mathrm{Zn}$ than Co are shown in pyrite. However, most $\mathrm{Ni}$ and $\mathrm{Zn}$ still must be assigned to the clay minerals. In organic-rich shale, for example, if $500 \mathrm{ppm} \mathrm{Ni}$ is assumed in 3.9 percent average pyrite (table 15), the pyrite would contribute only about $20 \mathrm{ppm} \mathrm{Ni}$. The remaining $35 \mathrm{ppm} \mathrm{Ni}$ must be in clay to approximately account for the measured average of $58 \mathrm{ppm} \mathrm{Ni}$. Thus, even in organic-rich marine shale, nearly two-thirds of the $\mathrm{Ni}$ occurs in clay, and in ordinary shale the amount is more than nine-tenths. Concentration in the clay of $\mathrm{Co}$ and $\mathrm{Ni}$ can be about the same in marine and nonmarine shale (table 15), with the generally smaller amounts of the elements in nonmarine shale simply reflecting a smaller average clay content. Such is not the case for $\mathrm{Zn}$, however. If the $180 \mathrm{ppm} \mathrm{Zn}$ in clay needed to account for average $\mathrm{Zn}$ in ordinary marine shale also occurred in the nonmarine clay, then the ordinary marine shale would have to contain $106 \mathrm{ppm}$ (59 percent $\times 180 \mathrm{ppm}=106 \mathrm{ppm}) \mathrm{Zn}$, or $21 \mathrm{ppm}$ more than was found. The average clay fraction in nonmarine shale must contain no more than $140 \mathrm{ppm} \mathrm{Zn}$ to account for the observed average of $85 \mathrm{ppm} \mathrm{Zn}$.

Fairly large amounts of $\mathrm{Co}, \mathrm{Ni}$, and $\mathrm{Zn}$ in the marine siliceous and frothy-weathering shale and moderate correlation coefficients with Mn suggest some concentration in or association with $\mathrm{Mn}-\mathrm{Fe}$ carbonate concretions; note that samples 259533 and 259538 (table 1), which contain detectable $\mathrm{Mn}-\mathrm{Fe}$ carbonate contain about double the average amount of $\mathrm{Co}$ and $\mathrm{Ni}$, and 259533 also has a fairly high $\mathrm{Zn}$ content. Regionally (fig. $23 L L-N N$ ), large averages for Co and particularly $\mathrm{Ni}$ and $\mathrm{Zn}$ occur in the east, and they result from abundant clay, pyrite, and $\mathrm{Mn}-\mathrm{Fe}$ carbonate. At Livingston (loc. 1) in the west, the large average $\mathrm{Ni}$ and $\mathrm{Co}$ (but not $\mathrm{Zn})$ content is mainly due to three samples from fossil zone 6 (table 13) and may reflect augite, in which these two elements, like $\mathrm{Mn}$, are commonly concentrated. Minimal contents of the three elements in fossil zones 1 and 3 (table 13) reflect the fact that, regardless of their multimineral associations, they occur mostly in the clay minerals, and in these two zones the total amount of clay minerals is minimal.

ORGANIC-MATTER-RELATED ELEMENTS (Cd; Cr, V, AND $\mathrm{Cu}$; Mo, Se, AND As; U)

Elements related to organic matter are grouped as follows: Those highly concentrated in organic matter in marine shale (Mo, Se, and As); those slightly to moderately concentrated in such organic matter $(\mathrm{Cr}, \mathrm{V}$, and $\mathrm{Cu}$ ); and those for which data are limited, especially for nonmarine rock (Cd and U). Equivalent uranium $(\mathrm{eU})$ is also discussed briefly.

Cadmium was determined in all of the bentonite samples and in most of the other marine samples, including all of the marl and all of the organic-rich shale. In the nonmarine rock, $\mathrm{Cd}$ was determined in all organic-rich samples, but only in one claystone sample (159766, table 1) and one siltstone sample (159768, table 1), so that comparisons between marine and nonmarine rock are significant only for the organic-rich rock. The two outstanding distributive features of $\mathrm{Cd}$ are its strong concentration in the organic-rich marine shale and its concentration in marl (table 14). Correlation coefficients between $\mathrm{Cd}$ and total $\mathrm{S}$ are large, which might indicate occurrence of $\mathrm{Cd}$ in pyrite; however, coefficients of $\mathrm{Cd}$ with the three pyriterelated elements (Co, $\mathrm{Ni}$, and $\mathrm{Zn}$ ) are notably small, even though, chemically, $\mathrm{Zn}$ is the element which $\mathrm{Cd}$ most closely resembles. On the other hand, correlation coefficients of $\mathrm{Cd}$ in marine rock are not only as strong with organic $\mathrm{C}$ as with $\mathrm{S}$, but they are equally strong with $\mathrm{V}, \mathrm{Cu}, \mathrm{Mo}, \mathrm{Se}, \mathrm{As}$, and U (table 17), all of which are also strongly correlated with organic $\mathrm{C}$. Because of these correlation coefficients, $\mathrm{Cd}$ is shown in table 15 to occur in organic matter of organic-rich marine shale rather than in pyrite. In nonmarine rock, however, $\mathrm{Cd}$ is not concentrated in organic matter, as indicated by low Cd amounts in organic-rich shale (fig. 26, table 14), even in one sample (159715, table $1 ; 0.4 \mathrm{ppm} \mathrm{Cd}$ ) containing 17 percent organic C. Nor does Cd seem to be concentrated in the small amounts of organic matter present in ordinary Pierre Shale, because in the range below 1 percent organic $\mathrm{C}$ (fig. 26) the amount of $\mathrm{Cd}$ actually increases with decreased organic matter. The approximately $0.5 \mathrm{ppm} \mathrm{Cd}$ present in shale containing less than 1 percent organic matter must occur in the clay minerals. In the marine organic-rich shale, however, several times more $\mathrm{Cd}(2 \mathrm{ppm})$ seems to occur in the organic matter than in the much more abundant clay $(0.5 \mathrm{ppm})$. The high average Cd content of marl of $2.2 \mathrm{ppm}$ does not seem to be related to the large amounts of calcite, but rather to two samples (259556 and 259562, table 1) that contain abundant organic matter. Without these two samples, the average $\mathrm{Cd}$ content of the remaining eight marl samples is 0.59 $\mathrm{ppm}$, which is very close to the average amount of $\mathrm{Cd}$ in ordinary shale. Evidently little or no Cd occurs in the calcite, even though substitution might be expected from the similar valence and radius of $\mathrm{Cd}^{+2}$ $(0.97 \mathrm{~A})$ and $\mathrm{Ca}^{+2}(0.99 \mathrm{~A})$ ions. The large amounts of Cd in samples 259556 and 259562 also account for 
much of the high Cd content of fossil zone 6 (table 13) and at localities 24-26 (fig. 23OO), but most of the high $\mathrm{Cd}$ content of the eastern area in general and of fossil zone 2 in particular is due to $\mathrm{Cd}$ in organic matter.

One surprising aspect of $\mathrm{Cd}$ distribution is the fairly large average amount of $1.5 \mathrm{ppm}$ in bentonite (table 14)-most other elements associated with organic matter or pyrite are less abundant in bentonite than in shale. The large average for bentonite, however, is due to extremely high values in two samples (259548 and 259572 , table 1 , both $11 \mathrm{ppm} \mathrm{Cd}$ ) from bentonite interbedded with organic-rich shale of the Sharon Springs Member. Perhaps the Cd migrated from Cd-rich black fissile shale into the bentonite where it was concentrated in the clay to the present level of $11 \mathrm{ppm}$. Excluding these two samples, the average $\mathrm{Cd}$ content of the 20 other bentonite samples is $0.55 \mathrm{ppm}$, or about the same as in most ordinary shale samples.

Chromium, V, and $\mathrm{Cu}$ all have correlation coefficients in the marine rock that are slightly stronger with organic $\mathrm{C}$ than with $\mathrm{S}$ (table 17), and their coefficients with the three pyrite-related elements $(\mathrm{Co}, \mathrm{Ni}$, and $\mathrm{Zn}$ ) are almost all smaller than with elements (Mo, $\mathrm{Se}$, As, and U) strongly related to organic matter. Therefore, the concentration of $\mathrm{Cr}, \mathrm{V}$, and $\mathrm{Cu}$, like that of $\mathrm{Cd}$, seems to be mainly in organic matter itself, even though the elements also show strong correlations with S. Because organic-rich marine shale contains only slightly more $\mathrm{Cr}(108 \mathrm{ppm})$ than ordinary marine shale $(90 \mathrm{ppm})$, the concentration of $\mathrm{Cr}$ in the organic matter must be small. Most $\mathrm{Cr}$ must occur in the clay minerals, a concentration that is suggested by large correlation coefficients with total clay and with several other clay-related constituents (table 17). In contrast to $\mathrm{Cr}, \mathrm{V}$ and $\mathrm{Cu}$ show moderately large concentrations in marine organic-rich shale. In such shale $\mathrm{Cu}$ averages $90 \mathrm{ppm}$ as compared with 20 to $48 \mathrm{ppm}$ in other marine rock types. The correlation coefficient of $\mathrm{Cu}$ with $\mathrm{S}$ $(+0.50)$ and the similar coefficients of $\mathrm{Cu}$ with $\mathrm{Ni}$ and $\mathrm{Zn}$ indicate, however, that small amounts of $\mathrm{Cu}$ may also occur in pyrite. Concentration of $\mathrm{V}$ in organic matter is the most pronounced and consistent of the three elements. Average $\mathrm{V}$ content in organic-rich marine shale of $490 \mathrm{ppm}$ is about three times that of ordinary shale (table 14). As previously shown (fig. 26), $\mathrm{V}$ is one of two elements that show a fairly consistent relation to small amounts of organic matter in ordinary marine shale; accordingly, $\mathrm{V}$ is so shown in table 15 , although the 4,000 ppm listed is arbitrarily assumed to be the same as for organic-rich shale. Even if the full 4,000 ppm $V$ is assumed, the less-than- 1 percent organic matter in ordinary marine shale would contribute no more than $40 \mathrm{ppm} \mathrm{V}$, leaving $130 \mathrm{ppm}$ in clay, which normalizes to $200 \mathrm{ppm}$ (table 15). The amount of $\mathrm{V}$ in non- marine clay must be less, as is also the case for $\mathrm{Cu}$. None of these three elements are concentrated in nonmarine organic matter (fig. 26).

Chromium, $\mathrm{Cu}$, and possibly $\mathrm{V}$, like $\mathrm{Mn}, \mathrm{Co}$, and $\mathrm{Ni}$, may be concentrated in volcanic augite or magnetite. The evidence for this concentration is partly the larger content of $\mathrm{Cr}, \mathrm{Cu}$, and $\mathrm{V}$ in volcanic-rich rock as compared with other nonmarine rock, and partly the mostly more positive correlation coefficients of these elements with $\mathrm{Mn}, \mathrm{Co}$, and $\mathrm{Ni}$ in the nonmarine as compared with the marine rocks. Large contents in volcanic-rich rock are mostly in the upper part of the section at locality 1 and to a lesser extent at localities 2,5 , and 6 (fig. $23 P P-R R$ ), so that fossil zone 6 has the largest average content of $\mathrm{Cr}$ and the second largest contents of $\mathrm{V}$ and $\mathrm{Cu}$ (table 13). Because of the relatively strong concentration of $\mathrm{V}$ and $\mathrm{Cu}$ in organic matter, fossil zone 2 has the largest average contents of these two elements. The large content of $\mathrm{Cr}, \mathrm{V}$, and $\mathrm{Cu}$ in the eastern area (fig. $23 P P-R R$ ) is due mainly to the abundance of marine clay and less so to abundant organic matter in a few samples. Excluding the organic-rich shale, the average content of $\mathrm{Cu}$ in the eastern zone is about $40 \mathrm{ppm}$, that of $\mathrm{V}$ is slightly below $200 \mathrm{ppm}$, and that of $\mathrm{Cr}$ is only a few parts per million below the 88-ppm average given for all samples from the eastern area. In bentonite beds the amount of all three elements is less than in shale, particularly for $\mathrm{Cr}$, which is only about one-tenth as abundant in bentonite as in shale (table 14).

Molybdenum, Se, and As all are strongly concentrated in marine organic-rich shale of the Sharon Springs Member and apparently to a lesser extent in marl (table 14). Only Se may be somewhat concentrated in nonmarine organic-rich rock (fig. 26). Only As content is parallel to the smaller amount of organic matter in ordinary marine shale (fig. 26) where some of it apparently occurs (table 15). Small amounts of the three elements probably occur with the clay minerals. Clay-bound Se and As may be slightly more abundant in the marine clay than in nonmarine clay, but Mo occurs in about equal amounts in both types of clay. The expected concentration of Se and As in pyrite (table 16) is supported by correlation coefficients with $\mathrm{S}$ that are almost as large as those with organic $\mathrm{C}$, but is not supported by the small and even negative correlations with the three S-associated elements, $\mathrm{Co}, \mathrm{Ni}$, and $\mathrm{Zn}$. Spectrographic analyses of pyritic nodules (not given here) indicate that Se, As, and possibly also Mo may be very erratically concentrated in pyrite, the first two elements proxying for $\mathrm{S}$. Large average amounts of all three elements in the east (fig. 23SS-UU) are due mainly to their large concentration in organic matter and less to smaller concentration in the clay minerals. 
Concentration in organic matter also accounts for the large amounts of Mo, Se, and As in fossil zone 2 (table 13). The much smaller concentration in fossil zone 6 and in the marl (table 14) is due mainly to the same two organic-rich marl samples (259556 and 259562, table 1) that also contain appreciable $\mathrm{V}, \mathrm{Cu}$, and $\mathrm{Cd}$. In bentonite, As and Se content is consistently low and Mo content is rather consistently high (table 14). The highest values of 8 and $9 \mathrm{ppm}$ Mo in two bentonite samples from the Sharon Springs Member (259548 and 259588, table 1) indicate that Mo, like Cd, may migrate into some bentonite from adjacent organic-rich shale, but that 1.5-2 ppm Mo in most other bentonite was probably retained by the bentonite clay from the original volcanic ash.

Uranium was determined in most of the samples from around the Black Hills and from the Missouri River where almost all of the Pierre Shale and equivalents is offshore marine (locs. 16-28, table 1). It was not determined in samples from further west, which would include all of the nonmarine and most nearshore marine Pierre equivalent rocks, so regional variations are not shown in figure 23 . Within the offshore marine rock, $U$ is obviously concentrated in the organic-rich shale (table 14) and, thus, also in fossil zone 2 (table 13). The slightly large average $U$ content of marine marl also probably is due to its above-average amount of organic matter. However, $U$ is probably not concentrated in the less abundant organic matter of ordinary shale (fig. 26). The $U$ content of nonmarine organic-rich rock was not determined directly, but judged from the low eU values in contrast to the high $\mathrm{eU}$ values of marine organic-rich shale (fig. 26 , table 14), the nonmarine organic matter does not contain much U. In bentonite, $\mathrm{U}$, like $\mathrm{Cd}$, is slightly more abundant than in ordinary shale, but, unlike $\mathrm{Cd}$ or Mo, the $\mathrm{U}$ content is not consistently large in bentonite from organic-rich parts of the Sharon Springs Member. Instead, U must be associated with the clay of bentonite in an average amount similar to that of the clay of shale.

Equivalent uranium $(\mathrm{eU})$ is a measure of the radioactivity of a sample caused by all radioactive elements, and the reported amount of $\mathrm{eU}$ is the amount of $U$ that would produce the same radioactivity. The amount of $\mathrm{U}$ in most groups of rock (table 14) is about one-fourth of the eU; therefore three-fourths of the radioactivity must be due to other elements, such as potassium. Thus, eU determinations are of limited usefulness. For example, only the very high $U$ content of marine organic-rich shale is reflected in its $e U$, but the moderately high $U$ content of marl is not. Data on eU are therefore excluded from many of the tables and figures.

\section{EFFECTS OF WEATHERING}

Weathering, as shown in the section "Suitability of outcrop samples-weathering," affects the mineralogy of most outcrop samples of the Pierre Shale and equivalent rocks only by oxidation of pyrite and by partial leaching of chlorite. Possible effects of weathering on the chemical composition of outcrop samples of Pierre Shale and equivalent rocks are evaluated by comparison, in table 20 , of the average composition of 9 drill-core samples from the Oahe Damsite with 13 outcrop samples from localities 20 to 24 along the Missouri River. All 22 of the samples are of marine shale from fossil zones 4 and 5. Also in table 20 is the average mineralogy of the two groups of samples, which shows the two changes due to weathering observed in the larger group of nonanalytical samples in table 3. Chlorite was recognized in all 9 of the chemically analyzed samples from cores, but in only 9 of the 13 outcrop samples. Change in $\mathrm{MgO}$ content that might be expected from removal of chlorite, however, is not conspicuous (table 20). Pyrite was recognized in three of the core samples but in none of the outcrop samples and has evidently been altered to gypsum. Other mineralogical differences probably reflect original differences in the shale.

Most of the small differences in the average chemical composition of the core and outcrop samples also probably represent original differences in mineralogy. For example, the higher $\mathrm{SiO}_{2}$ content of the core samples is due to more quartz and cristobalite. Of the trace elements, the resistate elements, $\mathrm{Zr}, \mathrm{Y}, \mathrm{Yb}$, and La, are least likely to be affected by weathering, and the largest amounts are not consistently in either the core or outcrop samples; therefore, their average amounts probably indicate the expectable magnitude of differences caused not by weathering but by original differences between small groups of samples. Constituents having differences not within this general order of magnitude are $\mathrm{Fe}_{2} \mathrm{O}_{3}, \mathrm{FeO}, \mathrm{H}_{2} \mathrm{O}-$, $\mathrm{S}$ and its forms, mineral and organic $\mathrm{C}, \mathrm{Mn}, \mathrm{Mo}$, and As. The large average of Mo in the core samples is due mostly to 10 ppm in one sample (259540, table 1); no explanation is obvious for this one value, and if it is excluded the average content of the remaining five core samples having valid determinations is $1.2 \mathrm{ppm} \mathrm{Mo}$, which is close to the average of surface samples. Less mineral $\mathrm{C}$ is not consistent with more calcite in outcrop samples and probably is not significant. More $\mathrm{Mn}$ in the core samples is due to $\mathrm{Mn}-\mathrm{Fe}$ carbonate in two samples and is not related to weathering. More $\mathrm{H}_{2} \mathrm{O}-$ in outcrop samples may be, in part, due to more clay, but most of the difference probably is caused by physical breakup 
TABLE 20.-Comparison of average compositions of nine samples ${ }^{1}$ from cores at Oahe Dam (loc. 22, pl. 1) with 13 samples from outcrops at localities 20 to 24, Pierre Shale

\begin{tabular}{|c|c|c|c|c|c|c|c|c|}
\hline \multirow{2}{*}{$\begin{array}{l}\text { Major and } \\
\text { minor } \\
\text { elements }\end{array}$} & \multicolumn{2}{|c|}{ Composition (percent) } & \multirow{2}{*}{$\begin{array}{l}\text { Trace } \\
\text { elements }\end{array}$} & \multicolumn{2}{|c|}{ Composition (ppm) } & \multirow[b]{2}{*}{ Minerals } & \multicolumn{2}{|c|}{ Composition (percent) } \\
\hline & Core & Outcrop & & Core & Outcrop & & Core & Outcrop \\
\hline $\mathrm{SiO}_{2}$ & 63.4 & 62.0 & $\mathrm{Zr}$ & 134 & 165 & \multicolumn{3}{|c|}{ Layers in mixed-layer clay } \\
\hline $\mathrm{Al}_{2} \mathrm{O}_{3} \ldots \ldots \ldots$ & 14.4 & 15.0 & $Y \ldots \ldots \ldots \ldots \ldots$ & 33 & 23 & Illite. . & 39 & 35 \\
\hline $\mathrm{Fe}$, total as $\mathrm{Fe}_{2} \mathrm{O}_{3}$. & 4.95 & 4.94 & $\mathrm{Yb} \ldots \ldots \ldots \ldots$ & 3 & 3 & Beidellite $\ldots \ldots \ldots$ & 28 & 35 \\
\hline $\mathrm{Fe}_{2} \mathrm{O}_{3} \ldots \ldots \ldots \ldots$ & 3.28 & 4.45 & La ............. & 32 & 42 & Montmorillonite .. & 33 & 30 \\
\hline & & & $\begin{array}{l}\mathrm{Sc} \ldots \ldots \ldots \ldots \ldots \\
\mathrm{Ga} \ldots \ldots \ldots \ldots \ldots\end{array}$ & $\begin{array}{l}14 \\
14\end{array}$ & $\begin{array}{l}16 \\
13\end{array}$ & \multicolumn{3}{|c|}{ Clay minerals in total clay } \\
\hline $\mathrm{MgO} \ldots \ldots \ldots \ldots$ & 2.13 & 2.10 & $B \ldots \ldots \ldots \ldots$ & 150 & 147 & Mixed-layer ....... & 80 & 83 \\
\hline $\mathrm{CaO} \ldots \ldots \ldots \ldots$ & 1.22 & 1.32 & & & & Illite. & 15 & 14 \\
\hline $\mathrm{Na}_{2} \mathrm{O} \ldots \ldots \ldots$ & 1.31 & 1.10 & $\mathrm{~Pb} \ldots \ldots \ldots \ldots$ & 22 & 17 & 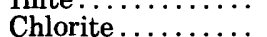 & 2.6 & $\begin{array}{r}14 \\
1.2\end{array}$ \\
\hline $\mathrm{K}_{2} \mathrm{O} \ldots \ldots \ldots \ldots$ & 2.26 & 2.36 & $\underset{\mathrm{Sr}}{\mathrm{Ba}} \cdots \cdots \cdots \cdots$ & $\begin{array}{l}779 \\
154\end{array}$ & $\begin{array}{l}666 \\
145\end{array}$ & Kaolinite $\ldots . . .$. & $\begin{array}{l}2.0 \\
2.7\end{array}$ & 1.6 \\
\hline $\begin{array}{l}\mathrm{H}_{2} \mathrm{O}-\cdots \cdots \cdots \cdots \\
\mathrm{H}_{2} \mathrm{O}+\ldots \cdots \cdots\end{array}$ & $\begin{array}{l}3.13 \\
4.38\end{array}$ & $\begin{array}{l}4.32 \\
4.34\end{array}$ & $\mathbf{M n} \ldots \ldots \ldots \ldots$ & 3,140 & 850 & \multicolumn{3}{|c|}{ Minerals in total sample } \\
\hline $\mathrm{TiO}_{2} \ldots \ldots \ldots$ & .52 & .56 & Co $\ldots \ldots \ldots \ldots$ & 19 & 17 & & & \\
\hline $\mathrm{P}_{2} \mathrm{O}_{5} \ldots \ldots \ldots \ldots$ & .11 & .11 & $\begin{array}{l}\mathrm{Ni} \\
\mathrm{Zn}\end{array} \ldots \ldots \ldots \ldots \ldots \ldots \ldots$ & $\begin{array}{r}78 \\
164\end{array}$ & $\begin{array}{r}68 \\
177\end{array}$ & $\begin{array}{l}\text { Total clay ....... } \\
\text { Quartz ......... }\end{array}$ & $\begin{array}{l}70 \\
15.6\end{array}$ & $\begin{array}{l}75 \\
14.8\end{array}$ \\
\hline S, total ......... & .46 & .19 & & & & Cristobalite ...... & 7.0 & 5.0 \\
\hline $\mathbf{S}^{-2} \ldots \ldots \ldots \ldots$ & .42 & .04 & Cd $\ldots \ldots \ldots \ldots$ & 1.0 & 1.0 & Plagioclase...... & 2.0 & 2.4 \\
\hline $\mathrm{SO}_{3} \ldots \ldots \ldots \ldots$ & .18 & .45 & $\begin{array}{l}\mathrm{Cr} \ldots \ldots \ldots \ldots \ldots \\
\mathrm{V} \ldots \ldots \ldots \ldots \ldots\end{array}$ & $\begin{array}{r}75 \\
190\end{array}$ & $\begin{array}{r}76 \\
184\end{array}$ & Calcite ......... & .5 & 1.1 \\
\hline $\mathbf{F} \ldots \ldots \ldots \ldots \ldots$ & .07 & .08 & $\mathrm{Cu} \ldots \ldots \ldots$ & 50 & 55 & Dolomite ....... & 0 & 0 \\
\hline $\mathrm{Cl} \ldots \ldots \ldots \ldots$ & .02 & .01 & & & & Siderite . . . . . . . & .5 & 0 \\
\hline C, organic ....... & .68 & .43 & Mo ............. & 3.0 & 1.1 & Gypsum ........ & 0 & .7 \\
\hline $\mathrm{C}$, mineral ....... & .23 & .12 & Se $\ldots \ldots \ldots \ldots \ldots$ & 1.6 & 1.6 & Jarosite ....... & 0 & 0 \\
\hline & & & As $\ldots \ldots \ldots \ldots \ldots$ & 16 & 8.3 & Pyrite ......... & & 0 \\
\hline & & & $\begin{array}{l}\mathrm{U} \\
\mathrm{eU}\end{array} \ldots \ldots \ldots \ldots \ldots$ & $14^{4.1}$ & 14 & Zeollte ........... & & \\
\hline
\end{tabular}

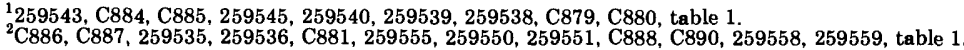

and hydration of the shale near the surface. Changes in $\mathrm{Fe}_{2} \mathrm{O}_{3}$ and $\mathrm{FeO}$ obviously result from oxidation, while total iron remains constant. Oxidation also nearly eliminates $\mathrm{S}^{-2}$, and much of it may be lost during weathering and is not retained as $\mathrm{SO}_{3}$ in gypsum. Nevertheless, the content of S-related elements, Co, $\mathrm{Ni}$, and $\mathrm{Zn}$, is not greatly affected. Organic $\mathrm{C}$ in the outcrop samples is about two-thirds that in the core samples. If the smaller amount of organic $C$ is due to weathering, then leaching of organic matter also can explain the smaller content of As in outcrop samples, as it is one of the two elements apparently concentrated in organic matter of ordinary marine shale (fig. 26 , table 15). Vanadium, the other such element, however, is not appreciably affected. Clearly, weathering has not greatly altered the chemical composition of outcrop samples of ordinary Pierre Shale.

Effects of weathering on the organic-rich shale of the Sharon Springs Member may be much more pronounced than on the rest of the Pierre Shale because of the large amounts of $\mathrm{H}_{2} \mathrm{SO}_{4}$ produced by oxidation of pyrite. The only core sample available to evaluate this possibility is 259595 (table 1). Concentration in this sample of elements associated with pyrite or organic matter is compared in table 21 with average concentration in six organic-rich outcrop samples from the
TABLE 21.-Comparison of average amounts of selected elements in outcrop and core samples of organic-rich shale from the Sharon Springs Member of the Pierre Shale

[N.d., no data; <, less than]

\begin{tabular}{|c|c|c|c|c|c|}
\hline & \multicolumn{3}{|c|}{$\begin{array}{c}\text { This study } \\
\text { (data from tables } 1 \text { and 14) }\end{array}$} & \multicolumn{2}{|c|}{$\begin{array}{c}\text { Kanssas } \\
\text { (Gill and others, 1972) }^{1}\end{array}$} \\
\hline & \multirow{2}{*}{$\begin{array}{l}\text { Ordinary } \\
\text { marine } \\
\text { shale }\end{array}$} & \multicolumn{2}{|c|}{ Organic-rich shale } & \multirow{2}{*}{$\begin{array}{c}\text { Core } \\
\text { samples, } \\
\text { depths } \\
25-190 \mathrm{ft}\end{array}$} & \multirow[t]{2}{*}{ Surface } \\
\hline & & $\begin{array}{l}\text { Core-sample } \\
259595\end{array}$ & $\begin{array}{l}\text { Surface } \\
\text { samples }\end{array}$ & & \\
\hline No. of samples .. & 62 & 1 & 6 & 33 & 6 \\
\hline \multicolumn{6}{|c|}{ In Percent } \\
\hline $\begin{array}{l}\mathrm{S} \text {, total ......... } \\
\mathrm{C} \text {, organic ...... }\end{array}$ & $\begin{array}{r}0.29 \\
.63\end{array}$ & $\begin{array}{l}2.7 \\
4.9\end{array}$ & $\begin{array}{l}4.1 \\
6.1\end{array}$ & $\begin{array}{l}3.6^{2} \\
4.3\end{array}$ & $\begin{array}{l}0.6^{3} \\
5.4\end{array}$ \\
\hline \multicolumn{6}{|c|}{ Elements concentrated in pyrite in parts per million } \\
\hline $\begin{array}{l}\text { Co } \ldots \ldots \ldots \ldots \ldots \\
\text { Ni } \ldots \ldots \ldots \ldots \ldots \ldots \\
\text { Zn } \ldots \ldots \ldots \ldots \ldots\end{array}$ & $\begin{array}{r}13 \\
39 \\
130\end{array}$ & $\begin{array}{r}20 \\
81 \\
260\end{array}$ & $\begin{array}{r}12 \\
55 \\
120\end{array}$ & $\begin{array}{r}15 \\
63 \\
250\end{array}$ & $\begin{array}{r}4 \\
14 \\
<180\end{array}$ \\
\hline \multicolumn{6}{|c|}{ Elements concentrated in orgamic matter in parts per million } \\
\hline 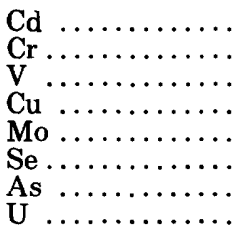 & $\begin{array}{c}0.54 \\
90 \\
170 \\
36 \\
1.4 \\
1.4 \\
13 \\
4.0\end{array}$ & $\begin{array}{c}7.0 \\
120 \\
390 \\
99 \\
17 \\
15 \\
43 \\
9.8\end{array}$ & $\begin{array}{l}1.4 \\
106 \\
510 \\
89 \\
97 \\
67 \\
125 \\
14\end{array}$ & $\begin{array}{l}\text { N.d. } \\
80 \\
290 \\
76 \\
24 \\
\text { n.d. } \\
\text { n.d. } \\
\text { n.d. }\end{array}$ & $\begin{array}{l}\text { N.d. } \\
140 \\
470 \\
210 \\
15 \\
\text { n.d. } \\
\text { n.d. } \\
\text { n.d. }\end{array}$ \\
\hline
\end{tabular}

${ }^{1}$ Semiquantitative spectrographic analyses, tables 1,2 , and 6 .

${ }^{2}$ Calculated from 7 percent average pyrite content.

${ }^{3}$ Calculated from 1 percent average gypsum and 3.2 percent average jarosite content. 
Sharon Springs Member and in ordinary shale from this study; also shown in table 21 is the average concentration of some of these elements in a much larger number of core samples of the Sharon Springs Member in Kansas and in samples from outcrops only a few hundred feet away (Gill and others, 1972). The elements associated with pyrite, $\mathrm{Co}, \mathrm{Ni}$, and $\mathrm{Zn}$, all appear to be significantly leached from surface outcrops of the Sharon Springs Member. The amount of these elements shown in pyrite in table 15 , therefore, may be underestimated. The eight organic-related elements (table 21) have been less affected by weathering, and some elements, notably $\mathrm{V}$ and possibly $\mathrm{Cr}$ and $\mathrm{Cu}$, may be actually concentrated by weathering. All of the organic-related elements, regardless of any redistribution in outcrop samples of the Sharon Springs due to weathering, are not so affected as to obscure their concentration relative to that in ordinary marine shale.

\section{INTERRELATED PHYSICAL AND GHEMICAL PROPERTIES}

Data on density, porosity, Atterberg limits, $\mathrm{pH}$, and heated and air-dried indices for the Pierre Shale given in table 1 together with information on cationexchange capacity (CEC) are summarized in table 22 as average values for different types of rock. The range of values is shown in figure 27 , regional variation of density and porosity in figure 28 , and differences in properties in unweathered and equivalent weathered rocks in table 23. Correlation coefficients between the physical and chemical properties and other selected data in table 24 help interpret factors underlying the physical properties. Density determinations and the heated and air-dried indices were made on most of the analytical samples. The $\mathrm{pH}, \mathrm{CEC}$, and Atterberg limits, however, were determined only for samples collected from the eastern part of the area at localities 16 to 28 (pl. 1), so that these properties are representative only of the fine-grained offshore-marine shale and marl present in the eastern area.

\section{GRAIN DENSITY}

The grain densities of marine and nonmarine rock of Pierre age are nearly identical (fig. 27), with the two cumulative curves superimposed except at their ends. For most samples grain densities differ only slightly from the average of about 2.6. This uniform grain density reflects the closely similar densities of the major mineral components. The densities of both quartz and plagioclase $\left(\mathrm{An}_{30}\right)$, the most abundant nonclay minerals, are about 2.65 , and that of most clay minerals is about 2.5 to 2.6. Densities as large as 2.8 given by Grim (1962, p. 266) are for iron-rich varieties of clay not common in the Pierre Shale and equivalents except possibly for minor amounts of chlorite. Accordingly, the grain densities in marine rocks correlate positively with quartz and negatively with total clay minerals, mixed-layer clay, and montmorillonite in the mixed-layer clay. This quartz-clay relationship accounts for the relatively small grin density of frothyweathering shale (table 22) and the relatively large grain density of clay-poor and quartz-rich nearshoremarine rock (fig. 27) and of siltstone in general (table 22). The organic-rich- and siliceous-shale groups (table 22) have small grain densities because of their organic matter and cristobalite (specific gravity 2.33 ) contents, and these rocks make up most of the 10 percent or so of the samples having grain densities less than 2.5 (fig. 27). The slightly below-average grain density of marine rock in the east (fig. 28) is due to frothy-weathering, siliceous, and organic-rich shale in that area. Weath-

TABLE 22.-Average values of physical properties and related data for various types of rock in the Pierre Shale and equivalent rocks [N.d., no data; porosity, liquid and plastic limits, and plasticity index in percent]

\begin{tabular}{|c|c|c|c|c|c|c|c|c|c|c|c|c|c|c|}
\hline & \multicolumn{8}{|c|}{ Marine } & \multicolumn{5}{|c|}{ Nonmarine } & \multirow[b]{2}{*}{ 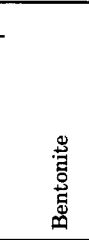 } \\
\hline & 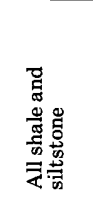 & 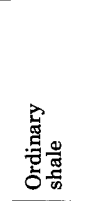 & 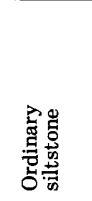 & 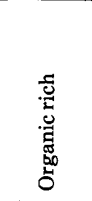 & 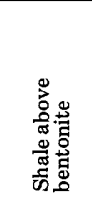 & 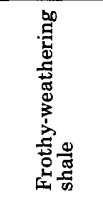 & 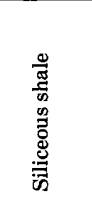 & 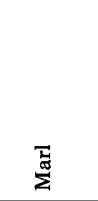 & 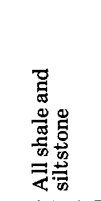 & 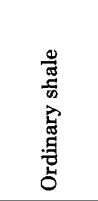 & 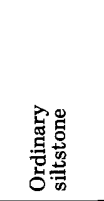 & 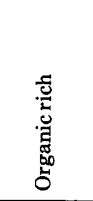 & 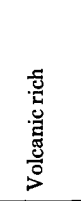 & \\
\hline $\begin{array}{l}\text { Heated index } \ldots \ldots \ldots \\
\text { Air-dried index } \ldots \ldots \ldots \\
\text { Bulk density } \ldots \ldots \ldots \\
\text { Grain density } \ldots \ldots \ldots \\
\text { Porosity } \ldots \ldots \ldots \ldots\end{array}$ & $\begin{array}{c}1.25 \\
1.74 \\
2.06 \\
2.60 \\
20.8\end{array}$ & $\begin{array}{c}1.32 \\
1.82 \\
2.10 \\
2.62 \\
19.8\end{array}$ & $\begin{array}{r}1.07 \\
1.93 \\
2.22 \\
2.67 \\
16.9\end{array}$ & $\begin{array}{l}1.42 \\
1.75 \\
1.72 \\
2.46 \\
30.1\end{array}$ & $\begin{array}{r}1.67 \\
2.00 \\
1.75 \\
2.46 \\
28.9\end{array}$ & $\begin{array}{l}1.10 \\
1.21 \\
1.92 \\
2.55 \\
24.7\end{array}$ & $\begin{array}{l}1.43 \\
1.57 \\
1.71 \\
2.44 \\
29.9\end{array}$ & $\begin{array}{l}1.00 \\
2.00 \\
1.82 \\
2.62 \\
30.5\end{array}$ & $\begin{array}{l}1.17 \\
1.61 \\
2.26 \\
2.58 \\
12.4\end{array}$ & $\begin{array}{c}1.08 \\
1.61 \\
2.26 \\
2.60 \\
13.1\end{array}$ & $\begin{array}{c}1.00 \\
1.50 \\
2.31 \\
2.65 \\
12.8\end{array}$ & $\begin{array}{c}1.18 \\
1.64 \\
2.11 \\
2.50 \\
15.6\end{array}$ & $\begin{array}{l}1.30 \\
1.70 \\
2.33 \\
2.57 \\
9.3\end{array}$ & $\begin{array}{l}1.46 \\
1.41 \\
1.96 \\
2.46 \\
20.3\end{array}$ \\
\hline $\begin{array}{l}\text { pH } \ldots \ldots \ldots \ldots \ldots \\
\text { Liquid limit } \ldots \ldots \ldots \ldots \\
\text { Plastic limit } \ldots \ldots \ldots \ldots \\
\text { Plasticity index } \ldots \ldots \\
\text { Cation-exchange } \\
\text { capacity }^{1} \ldots \ldots \ldots \ldots\end{array}$ & $\begin{array}{l}6.64 \\
80 \\
39 \\
41\end{array}$ & $\begin{array}{l}6.86 \\
68 \\
33 \\
35\end{array}$ & $\begin{array}{l}\text { n.d. } \\
\text { n.d. } \\
\text { n.d. } \\
\text { n.d. }\end{array}$ & $\begin{array}{l}3.28 \\
45 \\
35 \\
10\end{array}$ & $\begin{array}{l}3.58 \\
62 \\
50 \\
12\end{array}$ & $\begin{array}{c}7.71 \\
115 \\
40 \\
75\end{array}$ & $\begin{array}{l}7.24 \\
79 \\
50 \\
29\end{array}$ & $\begin{array}{l}8.34 \\
65 \\
28 \\
37\end{array}$ & $\begin{array}{l}\text { n.d. } \\
\text { n.d. } \\
\text { n.d. } \\
\text { n.d. }\end{array}$ & $\begin{array}{l}\text { n.d. } \\
\text { n.d. } \\
\text { n.d. } \\
\text { n.d. }\end{array}$ & $\begin{array}{l}\text { n.d. } \\
\text { n.d. } \\
\text { n.d. } \\
\text { n.d. }\end{array}$ & $\begin{array}{l}\text { n.d. } \\
\text { n.d. } \\
\text { n.d. } \\
\text { n.d. }\end{array}$ & $\begin{array}{l}\text { n.d. } \\
\text { n.d. } \\
\text { n.d. } \\
\text { n.d. }\end{array}$ & $\begin{array}{c}6.83 \\
110 \\
58 \\
52\end{array}$ \\
\hline
\end{tabular}

${ }^{1}$ In milliequivalents/100 grams, oven dried. 

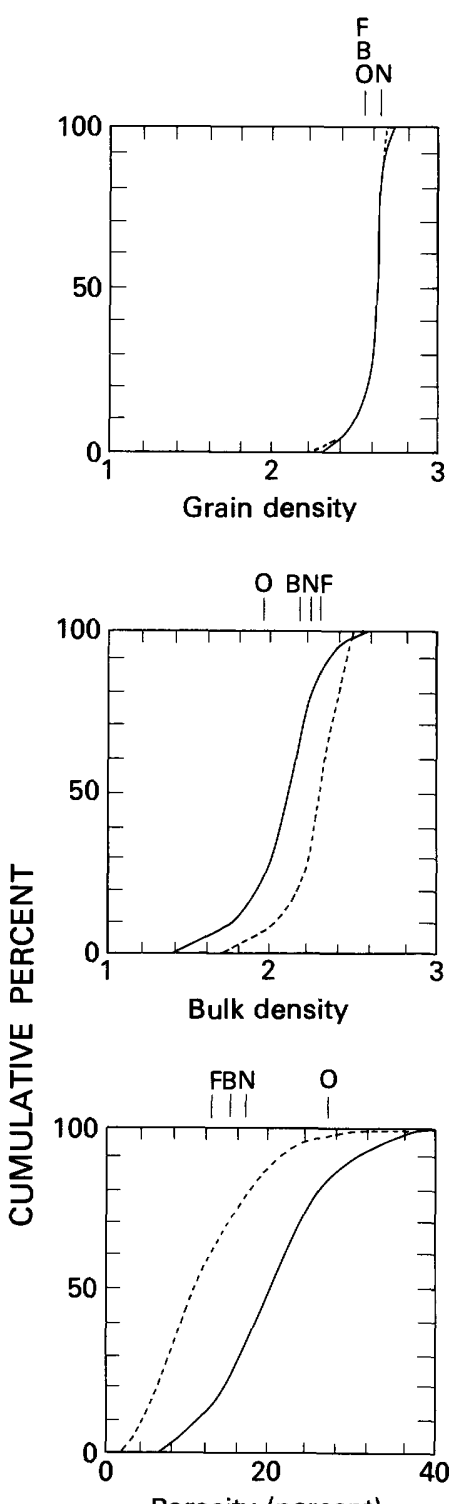

Porosity (percent)

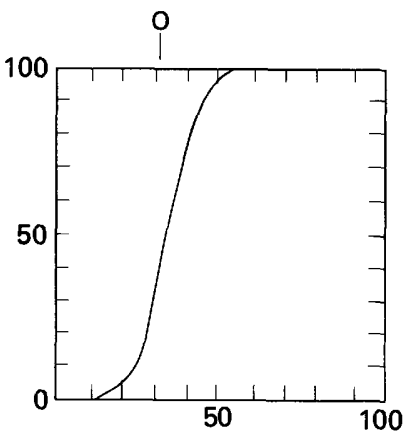

Cation exchange capacity (milliequivalents/100g)
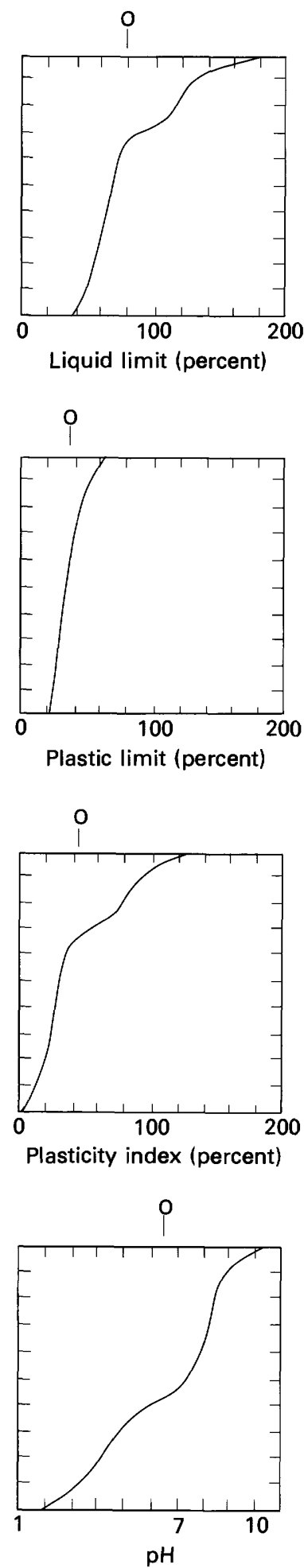

Figure 27.-Physical properties of the Pierre Shale and equivalent rocks. Bentonite and marl are excluded. Solid line, marine samples; dotted line, nonmarine samples. Short vertical lines above graphs indicate the arithmetic means of offshore-marine $(O)$, nearshore-marine $(N)$, brackish-water $(B)$, and freshwater $(F)$ samples. ering seems to decrease grain density slightly (table 23), possibly because of swelling and greater hydration of the clay minerals.

\section{BULK DENSITY AND POROSITY}

Bulk densities of marine and nonmarine rock, unlike the grain densities, are rather consistently different (fig. 27); the average bulk densities of marine lithologic groups range from 1.71 to 2.22 (table 22), and those of nonmarine groups range from 2.11 to 2.33 . Because grain densities of marine and nonmarine rock are nearly identical, and because porosity is related to both grain and bulk density by the equation porosity (percent $)=[1-$ (bulk density/grain density) $] 100$, porosity varies inversely to bulk density (fig. 27). Consequently, the average porosity of marine rock is nearly double that of nonmarine rock (table 22). The larger bulk density and smaller porosity of nonmarine rock means that the mineral grains are more closely packed than in the marine rock, a relationship that might result from poorer particle-size sorting in the nonmarine rock near the western sediment source. Inspection of figure 28, however, shows that variation in neither porosity nor bulk density is closely related to marine or nonmarine origin, because at many localities the averages for marine and nonmarine rock are nearly equal, and at several localities, notably $6,7,8,9$, and 14 , the bulk density is larger and the porosity is smaller for marine than for nonmarine rocks. Instead, the variation is regional, and, according to studies of mixed-layer clay (Hower and Hall, 1970; Schultz, 1978), the greater compaction at western localities is related to greater depth of burial or to tectonic factors. Such compaction of the western, predominantly nonmarine samples but not of the eastern, entirely marine samples is also reflected in the high correlation (table 24) between bulk and grain densities in marine rock $(+0.75)$ in contrast to the absence of significant correlation in nonmarine rock $(+0.16)$ where the usual density relations have been altered.

The small average bulk density of marl (table 22) is at first surprising, in view of the relatively high specific gravity of calcite (2.72). Much of the calcite in the marl is in the form of cocoliths that apparently do not pack well so that voids lower the bulk density and increase the porosity.

Weathering seems to affect the bulk density of the Pierre Shale and equivalents even less than the grain density (table 23).

$$
\text { pH }
$$

The slurry $\mathrm{pH}$ was determined by glass electrode on the leachate filtered from a slurry of the sample and distilled water after the slurry had been shaken one 
hour. The $\mathrm{pH}$ value depends upon the relative abundance of $\mathrm{H}^{+}$and $\mathrm{OH}^{-}$ions produced by hydrolization of compounds leachable from the sample. A pH of 7, given by distilled water, indicates an $\mathrm{H}^{+}$-ion concentration (also $\mathrm{OH}^{-}$) of $10^{-7}$ moles/liter, and is said to be neutral, or the solution is neutral. Thus, the higher the
$\mathrm{pH}$, the lower the concentration of $\mathrm{H}^{+}$ions; so a $\mathrm{pH}$ lower than 7 is said to be acid and one higher than 7 alkaline.

The average $\mathrm{pH}$ of the Pierre Shale, 6.64 (table 22), is nearly neutral, but the distribution of $\mathrm{pH}$ values is distinctly bimodal (fig. 27), with most values between
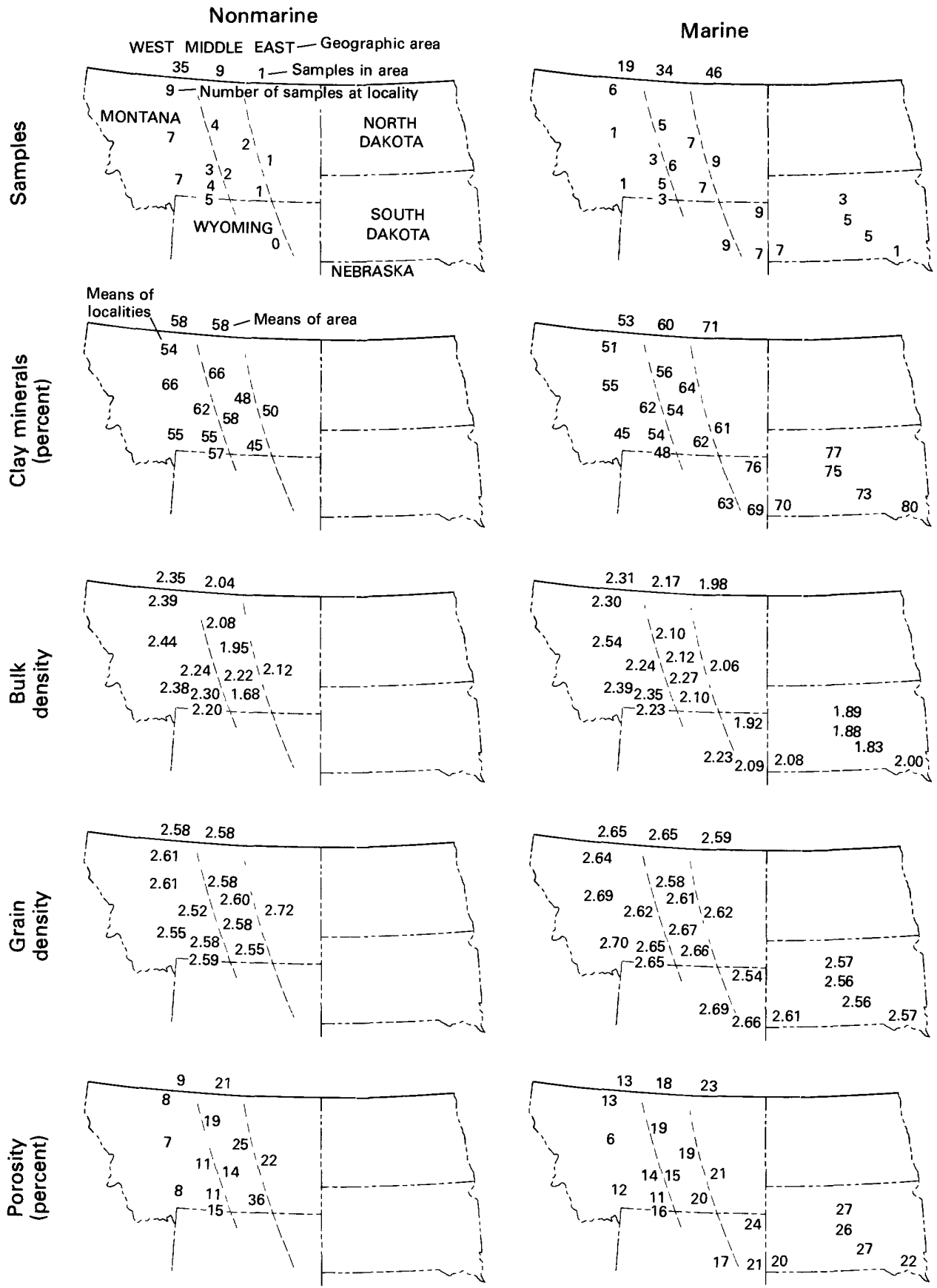

FIGURE 28.-Density and porosity of the Pierre Shale equivalent rocks by locality. Bentonite, marl, siliceous shale, shale containing more than 2 percent organic $\mathbf{C}$, and samples containing less than 40 percent clay minerals are not included. Additional locality information shown in figure 19. 
TABLE 23.-Comparison of average physical and other properties of nine shale samples from cores from Oahe Dam (loc. 22) and 13 shale samples from outcrops at localities 20 to 24

[Same samples as in table 20; porosity, liquid and plastic limits, and plasticity index in percent]

\begin{tabular}{|c|c|c|}
\hline & Core & Outcrop \\
\hline $\begin{array}{l}\text { Heated index } \ldots \ldots \ldots \ldots \ldots \ldots \ldots \ldots \\
\text { Air-dried index } \ldots \ldots \ldots \ldots \ldots \ldots \ldots \ldots \\
\text { Bulk density } \ldots \ldots \ldots \ldots \ldots \ldots \ldots \ldots \\
\text { Grain density } \ldots \ldots \ldots \ldots \ldots \ldots \ldots \ldots \\
\text { Porosity } \ldots \ldots \ldots \ldots \ldots \ldots \ldots\end{array}$ & $\begin{array}{l}1.00 \\
1.06 \\
1.83 \\
2.55 \\
28\end{array}$ & $\begin{array}{r}1.15 \\
1.27 \\
1.82 \\
2.49 \\
27\end{array}$ \\
\hline 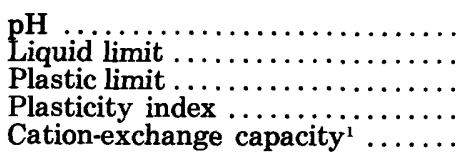 & $\begin{array}{c}8.93 \\
115 \\
45 \\
70 \\
33\end{array}$ & $\begin{array}{l}7.22 \\
110 \\
43 \\
67 \\
39\end{array}$ \\
\hline
\end{tabular}

${ }^{1}$ Milliequivalents/100 grams, oven dried.

either 2 to 5 (acid) or 7 to 9 (alkaline). For the organicrich marine shale (table 22), which contains much pyrite, and the somewhat less pyritic and organic-rich group of shale above bentonite, the $\mathrm{pH}$ is much lower than for other lithologic groups of marine rock. Correlation coefficients (table 24) indicate that $\mathrm{pH}$ is related positively to mineral $\mathrm{C}$ (carbonate), $\mathrm{Na}_{2} \mathrm{O}$, chlorite, and somewhat less to $\mathrm{CaO}$. These constituents, except possibly chlorite, are alkaline when hydrolized. The $\mathrm{pH}$ is negatively correlated to organic $\mathrm{C}$ and forms of $\mathrm{S}$, which are themselves highly correlated, and to the heated index and air-dried index. Most of these correlations arise from weathering.
The original pH of almost all, if not all, unweathered Pierre Shale probably was alkaline; weathering, mainly of pyrite, has produced the bimodal, partly acid, distribution of $\mathrm{pH}$ values shown in figure 27. Average $\mathrm{pH}$ for unweathered core samples and for more or less weathered outcrop samples, 8.93 and 7.22 , respectively (table 23), are both alkaline, but the outcrop samples are less so. The $\mathrm{pH}$ of individual core samples (table 25) ranges from 8.07 to 10.15 , none being acid. The $\mathrm{pH}$ of the outcrop samples ranges from 4.41 to 8.70 , four being acid and nine alkaline. All six of the outcrop samples having detectable calcite are alkaline. Sample C881, which originally contained appreciable pyrite judged from its 4-percent gypsum, is strongly acid. The six outcrop samples that originally contained little or no pyrite or calcite, or just enough of each to counterbalance one another are either acid or basic. Oxidation of pyrite produces acid solutions. If no calcite is present to neutralize such acid solutions, as it is in the marl, then the acid solutions leach the most susceptible of the clay minerals, chlorite. Reduced chlorite content in such acidic (low $\mathrm{pH}$ ) rock leads to the positive correlation between chlorite and $\mathrm{pH}$ (table 24).

Acidification of the Pierre Shale near the surface by weathering also can account for the small differences in the average heated index and the air-dried index (table 23). Hydrogen ions would replace some exchangeable $\mathrm{Na}^{+}$. Once between the smectite layers, the

TABLE 24.-Correlation coefficients between physical properties and selected constitutients of the Pierre Shale and equivalent rocks

IConventional coefficients are multiplied by 10 and rounded to the nearest whole number. For the bulk and grain densities, the bold numbers above are for 119 marine samples and the lighter numbers below are for 58 nonmarine samples. For $\mathrm{pH}$, cationexchange capacity, and Atterberg limits, coefficients are calculated from 60 samples, all marine. Coefficients for fewer than nine valid pairs are not given].

Layers of

mixed-layer clay

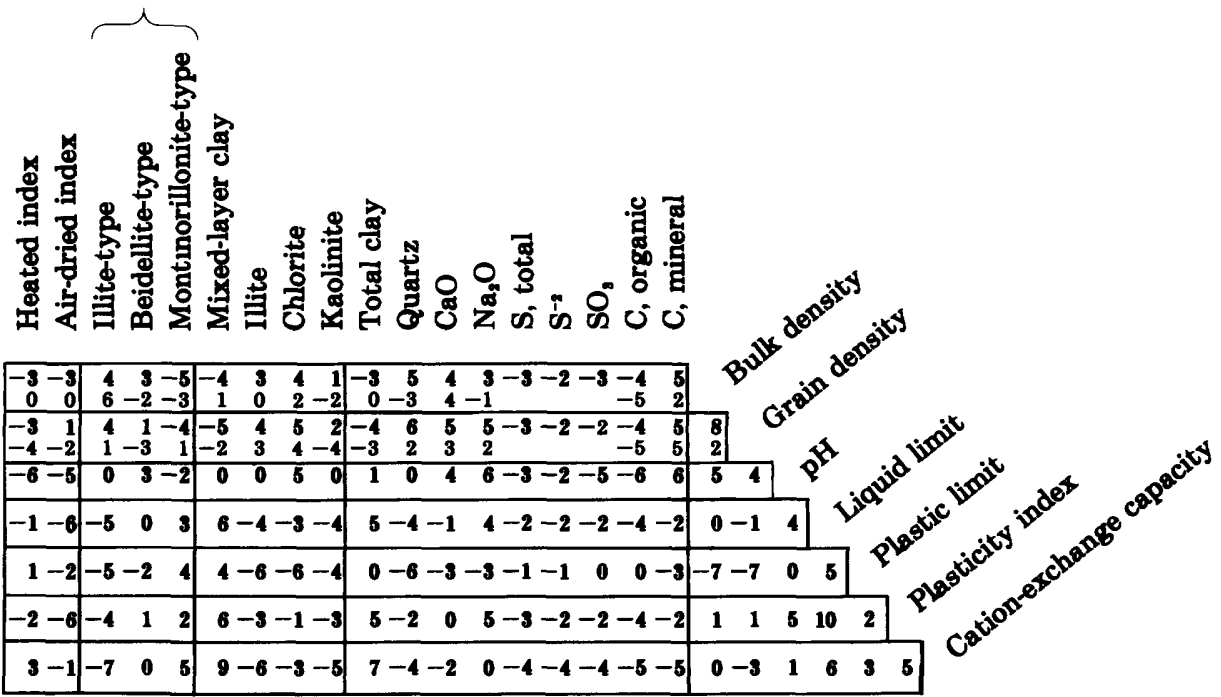


TABLE 25.-Atterberg limits, $p H$, and content of some minerals in nine shale samples from core from Oahe Dam (loc. 22) and 13 shale samples from outcrops at localities 20 to 24 .

[Same samples as in table 20; minerals in percent; leaders (---), not detected; N.d., no data]

\begin{tabular}{|c|c|c|c|c|c|c|c|c|}
\hline $\begin{array}{l}\text { Sample Shale type } \\
\text { No. }\end{array}$ & $\mathrm{pH}^{\mathrm{F}}$ & $\begin{array}{l}\text { Plastic } \\
\text { limit }\end{array}$ & $\begin{array}{l}c_{\text {Liquid }} \\
\text { limit }\end{array}$ & $\begin{array}{l}\text { Plasticity } \\
\text { index }\end{array}$ & Cristobalite & $e^{\text {Calcite }}$ & Pyrite & Gypsun \\
\hline \multicolumn{9}{|c|}{ Core samples } \\
\hline 259543 . . Ordinary ... & 9.00 & 48 & 115 & 67 & -- & --- & 1 & -..- \\
\hline $\mathrm{C} 884 \ldots \quad$ do $\ldots \ldots$ & 8.07 & 37 & 114 & 77 & -.. & 2 & 2 & -- \\
\hline $\mathrm{C} 885 \ldots$ & 8.38 & 35 & 112 & 77 & $\ldots$ & --- & 2 & --- \\
\hline $259545 \ldots$ & 9.15 & 40 & 136 & 96 & --- & 2 & --- &.-- \\
\hline \multicolumn{9}{|l|}{259540 . . Frothy- } \\
\hline weathering & N.d. & N.d. & N.d. & --- & --- & --- & --- & --- \\
\hline $259539 \ldots$ & N.d. & 49 & 155 & 106 & --- & --- & --- & --- \\
\hline 259538 . . Siliceous ... & 9.00 & 49 & 64 & 15 & 30 & --- & --- & -- \\
\hline $\mathrm{C} 878 \ldots . \quad$ do $\ldots \ldots$ & 8.18 & 340 & 93 & 53 & 18 & -- & --- & --- \\
\hline \multicolumn{9}{|c|}{ C880 .... Frothy- } \\
\hline weathering & 10.15 & 62 & 132 & 70 & --- & -- & --- & -- \\
\hline
\end{tabular}

\begin{tabular}{|c|c|c|c|c|c|c|c|c|}
\hline \multicolumn{9}{|c|}{ Outcrop samples } \\
\hline \multicolumn{9}{|l|}{ C886 .... Frothy- } \\
\hline weathering & 8.37 & 34 & 101 & 68 & --- & 3 & --- & --- \\
\hline $\mathrm{C} 887 \ldots$ & 4.41 & 42 & 65 & 23 & -- & -- & --- & -- \\
\hline $259535 \ldots$ & 7.90 & 44 & 117 & 73 & -- & 1 & --- & -- \\
\hline 259536 . . Siliceous . ... & 8.45 & 46 & 52 & 6 & 40 & 1 & --- & --- \\
\hline \multicolumn{9}{|l|}{259546 . . Frothy. } \\
\hline weathering & 8.60 & 39 & 143 & 104 & --- & -- & --- & -- \\
\hline C881 .... Ordinary ... & 4.72 & 39 & 76 & 37 & --- & --- & --- & 4 \\
\hline 259555 . . Siliceous .... & 5.50 & 49 & 125 & 76 & 5 & -.- & --- & --- \\
\hline \multicolumn{9}{|l|}{259550 . . Frothy- } \\
\hline weathering & 8.70 & 48 & 155 & 107 & --- & 1 & --- & -- \\
\hline do. ...... & 8.35 & 52 & 183 & 131 & -- & 1 & --- & -- \\
\hline do. ..... & 7.70 & 41 & 113 & 72 & --- & --- & --- & 1 \\
\hline $\mathrm{C} 890 \ldots . . \quad$ do. ..... & 8.18 & 35 & 101 & 66 & --- & 4 & --- & 1 \\
\hline 259558 . . Siliceous .... & 5.70 & 50 & 78 & 28 & --- & --- & --- & --- \\
\hline \multicolumn{9}{|l|}{259559 . . Frothy } \\
\hline weathering & 8.20 & 41 & 132 & 91 & -- & --- & --- & --- \\
\hline
\end{tabular}

$\mathrm{H}^{+}$enters into the layers and displaces $\mathrm{Al}^{+3}$ or $\mathrm{Mg}^{+2}$ into interlayer positions where they hydrate to form double $\mathrm{H}_{2} \mathrm{O}$ layers instead of the single $\mathrm{H}_{2} \mathrm{O}$ layers characteristic of smectite with the original $\mathrm{Na}^{+}$, thereby accounting for the higher air-dried index of the outcrop samples. If the interlayer $\mathrm{Al}^{+3}$ and $\mathrm{Mg}^{+2}$ become sufficiently abundant they could develop into thermally stable hydroxide sheets such as are indicated by an increase in the heated index from 1.00 to 1.15 (table 23).

\section{ATTERBERG LIMITS}

Atterberg limits, defined by Terzaghi and Peck (1948), are a measure of the range in water content in which a material is plastic. The plastic limit is the minimum water content, expressed as percent of ovendried material, at which the material can be rolled into a long thin rod. The liquid limit is the maximum water content at which the material can just barely withstand small shearing stresses without becoming liquid. The plasticity index is the difference between the liquid and plastic limits.

The liquid limit ranges from 37 to 183 percent and the plastic limit ranges from only 23 to 62 percent (fig. 27). The wide range of the plasticity index, from 3 to 131 percent, thus must result mostly from the wideranging liquid limit, a relationship also indicated by the nearly perfect correlation $(+0.96)$ between the two indices. The fairly strong correlation between liquid and plastic limits (table 24) shows that they are probably controlled by at least some of the same factors.

Correlation coefficients (table 24) show that total clay minerals, mixed-layer clay, and montmorillonite, especially $\mathrm{Na}$-saturated montmorillonite, have a marked influence on the liquid limit and the plasticity index, whereas only the amount of montmorillonite and mixed-layer clay, and little else, appreciably affects the plastic limit. Thus, frothy-weathering shale, with its abundant $\mathrm{Na}$ montmorillonite, has a very high liquid limit and plasticity index (table 22), but its plastic limit is only slightly higher than for most other shale. Calcite, cristobalite, and organic matter have the expected effect as dilutants of plastic clay and cause a decrease in Atterberg limits of most marl, siliceous shale, and organic-rich shale, except that cristobalite also acts as a cement and increases the amount of water needed to make siliceous shale plastic. Calcite, even in amounts of only several percent, has a surprisingly large effect in lowering the liquid limit (samples 259564 and 259547, table 1).

The distribution of values for the liquid limit and plasticity index (fig. 27), like that of the $\mathrm{pH}$ values, is distinctly bimodal. The acidic samples, as just shown in the preceding section on $\mathrm{pH}$, result from weathering, mainly of pyrite; Grim (1962, p. 206) indicates that acidification should lower the plastic limits of montmorillonite. Such a relationship is also indicated for samples of Pierre Shale and equivalents by the moderately large positive correlation coefficients of the liquid limit and plasticity index with $\mathrm{pH}$ (table 24), so apparently the bimodal distribution of all three factors is related to weathering. The plastic limit is uncorrelated with $\mathrm{pH}$, is monomodal, and is apparently unaffected by weathering. However, the smaller liquid limit and plasticity index expected for weathered low$\mathrm{pH}$ samples is barely shown by the outcrop samples in table 23 as compared with the core samples; the differences are only slightly more than for the plastic limit, which supposedly is unaffected by weathering. Reasons for the small differences appear to be two fold 
and are evident from data for the 22 individual samples from the weathering study (table 25). First, the group of nine core samples includes two highly siliceous shales (259538 and C878) having exceptionally low liquid limits and plasticity indices; whereas, the 13 outcrop samples include only one highly siliceous shale (259536) whose low liquid limit and plasticity index is unrelated to weathering. If these three siliceous shales are excluded, average liquid limits for cores and outcrops are, respectively, 127 and 116 , and average plasticity indices are 82 and 73-larger differences than with the three highly siliceous shale samples included, but still not large differences. The second reason for the small differences in table 23 is that only 4 of the 13 outcrop samples are acid, and the liquid limit and plasticity index are appreciably affected only if weathering changes the $\mathrm{pH}$ of the rock to acid. Of the nine outcrop samples that retain the original basic $\mathrm{pH}$ of the unweathered rock, all but the highly siliceous sample 259536 have a relatively high liquid limit-more than 100 and comparable with those of the core samples. However, three of the four outcrop samples that are acid (C887, C881, and 259558; the exception is 259555) have liquid limits considerably less than 100 and correspondingly low plasticity indices. The two parameters for all three samples apparently have been lowered about 50 units by weathering. Even such a large decrease for three samples, however, when averaged with the other 10 outcrop samples and added to effects of siliceous shale, makes weathering appear in table 23 to have only a small effect on liquid limit and plasticity index, when, in fact, the effect can be large, but only on particular kinds of samples.

Most bentonite from the Pierre Shale has Atterberg limits higher than those for most of the shale (table 22), as would be expected from its high content of montmorillonite, but the differences between bentonite and shale are surprisingly small. Sodium bentonite used for drilling mud has a liquid limit of several hundred percent, but the highest measured for a $\mathrm{Na}$ bentonite from the Pierre Shale is 143 percent (sample 259537, table 1). One bentonite sample (259544, table 1$)$ in which the clay is 75 percent $\mathrm{Na}$ montmorillonite has a liquid limit of only 47 percent and a plasticity index of 5; it does not even swell or disintegrate in water. Its mineralogical composition is normal, except that it is one of the few bentonites samples that contains pyrite.

\section{CATION-EXCHANGE CAPACITY}

Cation-exchange capacities of the Pierre Shale mostly range from 30 to 50 milliequivalents $/ 100$ grams (fig. 27 , and, as indicated by the correlation coefficients (table 24), are controlled almost entirely by the content of montmorillonite in the mixed-layer clay. Cationexchange capacities of bentonite are mostly about double those of the shale (table 22).

\section{CONGLUSIONS}

The Pierre Shale and equivalent rocks consist in the western part of the area of 2,000 to $5,000 \mathrm{ft}$ of mostly nonmarine claystone, sandstone, and conglomerate that in places contain abundant easily recognized volcanic material; in the east of less than $500 \mathrm{ft}$ to $1,000 \mathrm{ft}$ of fine-grained dark-gray marine shale of various types and subordinate lenses of marl; and in the middle of approximately equal amounts of nonmarine rock and fine-grained marine shale separated by tongues of regressive nearshore marine siltstone and sandstone and overlying brackish-water deposits. This mass of rock is made up mainly of clay minerals, quartz, and feldspar (table 26). Clay minerals are dominant, except that quartz may be most abundant in the coarser rocks but even there rarely exceeds 50 percent. Plagioclase is less prominent in all but some nonmarine rocks, and other minerals rarely exceed a few percent. In all types of rock the most abundant clay by far is mixed-layer illite-smectite; $20-60$ percent of the layers at all but one locality are illite-type, and the others are two types of expanding smectite layers, beidellite and montmorillonite, of which beidellite-type layers make up a fairly constant proportion of about 35 percent of the layers and montmorillonite-type make up the remainder. At the Dearborn River locality, 60-80 percent illite-type layers in the mixed-layer clay result from diagenesis. Illite that is not mixed layered is the next most abundant clay, and chlorite and kaolinite are least abundant. Nonmarine rock is considerably more variable in composition, and the amount of plagioclase is much higher and of quartz slightly higher than in marine rock, but the average clay minerals and proportions of layers in the mixedlayer clay are similar. The average amount of organic matter is also similar, but in nonmarine rock almost all of it occurs in highly organic coaly beds, whereas in almost all marine rocks, a fraciton of a percent is widely disseminated. Pyrite is present only in marine rocks. Dolomite is found only in coarse-grained shallowmarine and nearshore nonmarine rock. Other minerals are found sporadically or by special separations.

Sediment came from two major terrains in the west, one volcanic, the other nonvolcanic. The Elkhorn Mountains Volcanics, only a few tens of miles west of the area sampled, was clearly the dominant single source of volcanic detritus. The average composition of the volanics, judged from the surviving minerals, was dacitic. Much of the plagioclase occurs as large phenocrysts, some of which have compositions more 
TABLE 26.-Summary of the mineralogy, in percent, typical of the Pierre Shale and equivalent rocks

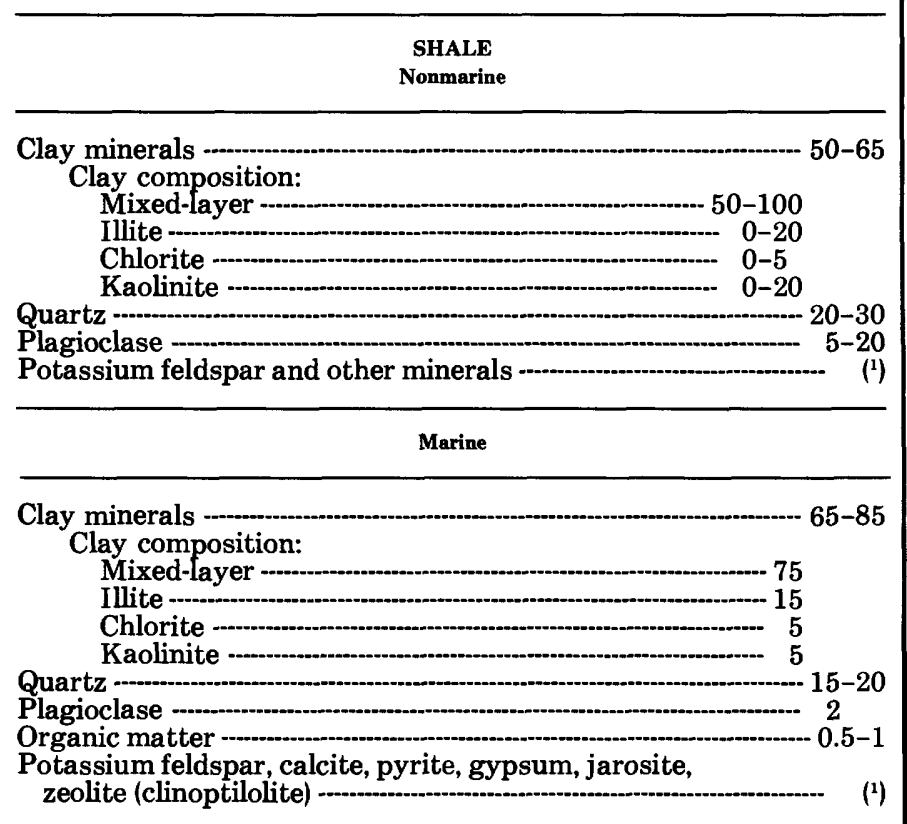

SILTSTONE AND SANDSTONE

Marine and nonmarine

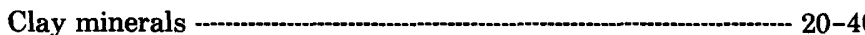

Clay composition:

Mixed-layer -.-on

Illite -

Chlorite -......-10

Kaolinite - -

Quartz ---on

Potassium feldspar --on

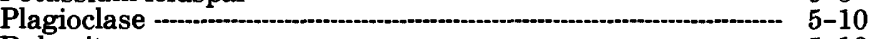

Dolomite -

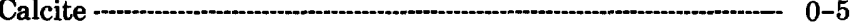

Augite and zeolites (heulandite and laumontite) -........-...- $\left.\quad{ }^{2}\right\rangle$

${ }^{1}$ A minor amount.

${ }^{2}$ Volcanic-rich rock only.

calcic than the usual $\mathrm{An}_{20-40}$ range found in the eastern part of the area. Most of the quartz is fine grained and probably formed during rapid late-stage crystallization or devitrification of glass. Except possibly for quartz, the glass in most rock altered almost exclusively to mixed-layer illite-smectite; zeolite minerals occur sporadically as small amounts of heulandite in the fine-grained volcanic-rich rocks and as large amounts of laumontite, frequently with chlorite, in coarse-grained equivalents. Nonvolcanic detritus was eroded from a broad area to the west that was not covered by volcanic rock. This area supplied the illite, most of the chlorite, kaolinite, and potassium feldspar. Limited optical data indicate that perhaps half or less of the coarse-grained quartz is of nonvolcanic origin and, because the ratio of fine-grained quartz to mixedlayer clay is about the same in volcanic-rich rock and fine-grained offshore marine shale, much of the fine- grained quartz in the shale probably came from the volcanics. If so, volcanic-derived detritus makes up two-thirds to three-fourths of the Pierre Shale and equivalent rocks in the area studied. By the time eastward-flowing rivers had carried the sediments near the shoreline of the Pierre sea, volcanic and nonvolcanic detritus were well homogenized.

Near the shoreline three processes appreciably affected the composition of the sediment. First, currents in the shallow sea carried seaward the finer grained particles, which were dominated by mixed-layer clay but also included appreciable amounts of other clay minerals and much fine-grained quartz. Coarser grained particles that survived the trip across the coastal plain, including much quartz and most of the feldspar, settled to the bottom near the edge of the sea. Second, rhombs of dolomite were formed on the shallow sea bottom, augmenting the detrital sediment by about 10 percent. Similar dolomite, however, formed in lakes on the landward side of the shoreline and makes up only a slightly smaller amount of such nonmarine rock as of marine rock. Authigenic intergranular calcite cement is also more common in coarse-grained sediments than in the shale. Third, organic matter that accumulated in some brackish coastal swamps locally produced water sufficiently acid to leach all feldspar and probably some of the clay minerals, and to develop kaolinite; in most swampy areas the sediments were not appreciably altered, however.

The fine-grained clay minerals, quartz, and a small amount of feldspar winnowed from the nearshoremarine sediments form the bulk of ordinary offshoremarine shale, to which authigenic components like organic matter, pyrite, clinoptilolite, and calcite mostly contributed only a fraction of a percent. In places, and at different times, however, unusual amounts of normally minor components resulted in distinctive types of rock. During marine regressions when the sea was unusually shallow, the calcite shells of marine microorganisms, mostly cocoliths and foramininifera, were preserved to form marl beds in which authigenic organic matter, pyrite, and probably apatite are slightly more abundant than in most shale. At other times proliferation of radiolaria added opal to the shale which later recrystallized to disordered cristobalite or quartz cement to develop unusually hard siliceous shale. At still other times, extremely slow deposition concentrated organic matter, pyrite, and sporadic authigenic potassium feldspar relative to the detrital minerals, and the sediment compacted to still another distinctive type of tough, dark, very fissile, organicrich shale. Except for the unusual amounts of mostly authigenic minerals just mentioned, these shales and marl contain the same relative amounts of detrital clay 
minerals and quartz as nearby ordinary shale.

Conversion of volcanic-rich sediments to mixed-layer illite-smectite apparently occurred mostly near the volcanic source. The few percent more illite-type layers found in nonmarine rock farther to the east may have developed in later cycles of deposition and weathering on the coastal plain where the more beidellitic layers fixed $\mathrm{K}^{+}$and changed to nonexpanding illite. The nearly identical composition of clay in nonmarine and marine rocks as a whole indicates that few additional illite-type layers developed in the marine environment. The only evidence for illite development in the marine environment is that the mixed-layer clay in offshoremarine rocks that were deposited very slowly is slightly more illitic than equivalent marine clay farther west, but the amount of rock and the differences are too small to influence appreciably the marine average.

The precursors of bentonite beds, wind-transported ash-fall tuffs, apparently were of about the same composition as the tuff of the nonmarine volcanic-rich rocks, averaging that of dacite, but it evidently came from an earlier more explosive phase of the magma. Glass, therefore, was more abundant, plagioclase phenocrysts were somewhat more calcic, and rapid quenching preserved some of the high-temperature character of the plagioclase. Devitrification of most bentonite beds evidently occurred sometime after burial. For reasons that are explained elsewhere (Schultz, 1978, p. 26-27), the glass altered to a wholly smectitic clay, containing mostly montmorillonitetype, fewer beidellite-type, and no illite-type layers, in contrast to the mixed-layer illite-smectite of watertransported rocks. A few ash falls that settled to the sea floor during times of very slow deposition and that evidently altered in close contact with seawater were altered to clinoptilolite; small amounts of clinoptilolite found sporadically in offshore-marine shale may also be authigenically altered from volcanic glass. One bentonite bed, for unknown reasons, altered mostly to potassium feldspar.

Distribution of chemical elements obviously must reflect the abundance of the minerals in which they occur (table 15). Thus, the amount of $\mathrm{SiO}_{2}$ is highest in the coarser grained nearshore rocks of the central geographic area where quartz is most abundant, whereas the amount of $\mathrm{Al}_{2} \mathrm{O}_{3}$ shows almost no regional variation because the high $\mathrm{Al}_{2} \mathrm{O}_{3}$ content in the abundant clay of offshore-marine shale in the east is almost exactly balanced by a high $\mathrm{Al}_{2} \mathrm{O}_{3}$ content in the abundant plagioclase of the nonmarine rocks of the west. Distribution of other major rock-forming elements is equally obvious.

Sulfur is very sparse in nonmarine rock due to the near absence of pyrite. Chlorine is most abundant in marine rock due partly to $\mathrm{Cl}$ in marine organic matter and partly to more $\mathrm{Cl}$ in marine clay minerals. Fluorine also may be slightly more abundant in marine clay minerals, but data are sparse. Phosphorous probably occurs mostly adsorbed on the clay minerals; amounts of $\mathrm{P}_{2} \mathrm{O}_{5}$ that are slightly above average occur in marl owing to authigenic apatite, in volcanic-rich rock owing to volcanic apatite, and in nearshore marine siltstone owing probably to both types of apatite. Titanium is concentrated in fine-grained rocks both in the clay minerals and in anatase. The anatase is of such small grain size that it is not separated from the clay minerals by natural sedimentary processes, so the relative importance of the two modes of occurrence is difficult to interpret.

Trace elements, except some in organic-rich shale and in marl, occur largely either in heavy resistate minerals or in clay minerals. Those in heavy resistates, $\mathrm{Zr}, \mathrm{Y}, \mathrm{Yb}, \mathrm{La}$, and Sn, are most abundant in the coarser rocks and near the sediment source in western nonmarine rocks. Of the many trace elements that are largely in the clay minerals, only Sc and B occur almost exclusively in them; the rest also occur in other minerals in such a way that elemental viariation show's little or no relation to clay-mineral variation. Solution or alteration of minerals by weathering on the coastal plain, adsorption by clay of some of these dissolved elements from relatively concentrated seawater solutions, incorporation of elements into authigenic minerals, desorption and redistribution before and after burial, and modern outcrop weathering also have influenced the distribution of trace elements.

Gallium, $\mathrm{Ba}, \mathrm{Sr}$, and $\mathrm{Mn}$ substitute in plagioclase feldspar and $\mathrm{Pb}$ substitutes mainly in potassium feldspar. Concentration of $\mathrm{Sr}$ in plagioclase is a major reason for the greater abundance of $\mathrm{Sr}$ in nonmarine than in marine rocks in general and in volcanic-rich rock in particular. Large concentrations of $\mathrm{Mn}, \mathrm{Ni}, \mathrm{Cr}$, $\mathrm{V}$, and possibly Co and $\mathrm{Zn}$ in small amounts of volcanic augite, biotite, and magnetite raise the amount of these elements in volcanic-rich rock to slightly above average. Weathering of the augite and much of the plagioclase, biotite, and probably the magnetite on the coastal plain put both major and trace elements of these minerals into solution. In the nearshore area authigenic dolomite removed $\mathrm{Ca}, \mathrm{Mg}$, and small amounts of $\mathrm{Fe}$ from solution. In marine waters biogenic calcite incorporated dissolved $\mathrm{Ca}, \mathrm{Sr}$, and $\mathrm{Mn}$; carbonate nodules, fragments of which were included in some shale samples, incorporated large amounts of $\mathrm{Ca}, \mathrm{Fe}, \mathrm{Mn}$, and evidently some $\mathrm{Co}, \mathrm{Ni}, \mathrm{Zn}$, and $\mathrm{Cu}$. Adsorption from seawater increased the content of $B, M n$, $\mathrm{Zn}, \mathrm{Cr}, \mathrm{V}, \mathrm{Cu}, \mathrm{Se}$, and As in clay minerals.

Large amounts of pyrite and organic matter in 
marine organic-rich shale have concentrated 11 trace elements: $\mathrm{Co}, \mathrm{Ni}$, and $\mathrm{Zn}$ mainly in pyrite, and $\mathrm{Cr}, \mathrm{Cd}$, $\mathrm{V}, \mathrm{Cu}, \mathrm{Mo}$, Se, As, and $\mathrm{U}$ in organic matter. Only Mo, $\mathrm{Se}, \mathrm{As}$, and possibly $\mathrm{Cd}$ and $\mathrm{U}$ are so highly concentrated in marine organic matter that they make a major contribution to the content of these elements in the Pierre Shale and its equivalents as a whole. Only V and As show evidence of being concentrated in the small amounts of organic matter in most marine shale, and only Se shows evidence of even minor concentration in nonmarine organic-rich rock.

Bentonite contains average or below-average amounts of most trace elements and is not an important residence site of trace elements in the Pierre Shale and equivalent rocks. However, a few elements, notably $\mathrm{Cd}$ and $\mathrm{Mo}$, apparently have migrated into bentonite beds from adjacent organic-rich shale in which these elements are highly concentrated.

Weathering effects on most outcrop samples are minor. Major alteration of mineralogy is evident only in outcrops of organic-rich shale, where highly acid conditions caused by oxidation of large amounts of pyrite have leached nearly all the chlorite, probably some $\mathrm{Fe}$ and $\mathrm{Mg}$ from the other clay minerals, and most of the plagioclase. Gypsum and jarosite are found in many places. Loss of elements associated with pyrite-Co, $\mathrm{Ni}$, and $\mathrm{Zn}-$ is significant only in such organic-rich marine shale, and most of the elements concentrated in the organic matter are not grossly affected. Some physical properties were greatly changed in the minority of samples in which the $\mathrm{pH}$ was decreased by weathering from the usual values for fresh shale between 8 and 10 to values between 2 and 6 . This change occurs in rocks containing enough acidproducing pyrite to overcome the calcite, chlorite, and $\mathrm{Na}$ smectite that determined the original alkaline condition. Such a change in $\mathrm{pH}$ does not affect the plastic limit much, but it decreases markedly the liquid limit and, hence, the plasticity index. Bulk and grain densities of most rock is not much changed by weathering of the types of outcrops sampled.

Bulk density of shale of Pierre age increases from about 2.0 in the east to about 2.4 in the west because of greater compaction in the west, apparently due to greater overburden of younger sediments. However, as explained elsewhere (Schultz, 1978), mineralogy does not show the expected relation to compaction and apparently has not been altered by burial diagenesis except at the Dearborn River locality.

Shale of the Pierre and equivalent rocks is fairly similar to other shallow-water marine shales (table 27). Ordinary marine shale of Pierre age contains one-half as much $\mathrm{CaO}$, one-third as much mineral $\mathrm{C}$, four-fifths
TABLE 27.-Chemical composition of the Pierre Shale compared with the average composition for other rocks [N.d., no data]

\begin{tabular}{|c|c|c|c|}
\hline & \multirow{2}{*}{$\begin{array}{c}\text { Pierre Shale and } \\
\text { equivalent rocks } \\
\begin{array}{c}\text { Ordinary marime } \\
\text { shale }\end{array}\end{array}$} & \multicolumn{2}{|c|}{$\begin{array}{c}\text { Other rocks } \\
\text { (Turekian and Wedepohl, 1961) }\end{array}$} \\
\hline & & $\begin{array}{c}\text { Shallow- } \\
\text { marine shale }\end{array}$ & $\begin{array}{c}\text { Deep-sea } \\
\text { clay }\end{array}$ \\
\hline \multicolumn{4}{|c|}{ Major and minor elements in percent } \\
\hline $\begin{array}{l}\mathrm{SiO}_{2} \ldots \ldots \ldots \ldots \\
\mathrm{Al}_{2} \mathrm{O}_{3} \ldots \ldots \ldots \ldots \\
\mathrm{Fe} \text {, total }\end{array}$ & $\begin{array}{l}61 \\
16\end{array}$ & $\begin{array}{l}59^{1} \\
15\end{array}$ & $\begin{array}{l}54 \\
16\end{array}$ \\
\hline $\begin{array}{r}\text { as } \mathrm{Fe}_{2} \mathrm{O}_{3} \ldots \ldots \\
\mathrm{Fe}_{2} \mathrm{O}_{3} \ldots \ldots \ldots \ldots \\
\mathrm{FeO} \ldots \ldots \ldots \ldots\end{array}$ & $\begin{array}{l}5.4 \\
4.2 \\
1.1\end{array}$ & $\begin{array}{l}6.7 \\
\text { N.d. } \\
\text { n.d. }\end{array}$ & $\begin{array}{l}9.3 \\
\text { N.d. } \\
\text { n.d. }\end{array}$ \\
\hline $\begin{array}{l}\mathrm{MgO} \ldots \ldots \ldots \\
\mathrm{CaO} \ldots \ldots \cdots \cdots \\
\mathrm{na}_{2} \mathrm{O} \ldots \ldots \cdots \\
\mathrm{K}_{2} \mathrm{O} \ldots \ldots \ldots\end{array}$ & $\begin{array}{l}2.1 \\
1.2 \\
1.1 \\
2.6\end{array}$ & $\begin{array}{l}2.5 \\
3.1 \\
1.2 \\
3.2\end{array}$ & $\begin{array}{l}3.5 \\
4.1 \\
5.2 \\
3.0\end{array}$ \\
\hline $\begin{array}{l}\mathrm{H}_{2} \mathrm{O}-\ldots \ldots \cdots \\
\mathrm{H}_{2} \mathrm{O}+\ldots \ldots \cdots \\
\mathrm{TiO}_{2} \ldots \ldots \cdots \cdots \\
\mathrm{P}_{2} \mathrm{O}_{5} \ldots \ldots \cdots \cdots\end{array}$ & $\begin{array}{c}\left.\begin{array}{c}3.4 \\
4.8\end{array}\right\} \\
.65 \\
.15\end{array}$ & $\begin{array}{r}5.0^{2} \\
.77 \\
.16\end{array}$ & $\begin{array}{l}\text { n.d. } \\
\text { n.d. } \\
.77 \\
.34\end{array}$ \\
\hline $\begin{array}{l}\mathbf{S}, \text { total } \ldots \ldots \ldots \\
\mathbf{S}^{-2} \ldots \ldots \ldots \ldots \ldots \\
\mathbf{S O}_{3} \ldots \ldots \ldots \ldots\end{array}$ & $\begin{array}{l}.30 \\
.18 \\
.31\end{array}$ & $\begin{array}{l}.24 \\
\text { n.d. } \\
\text { n.d. }\end{array}$ & $\begin{array}{l}\text { n.d. } \\
\text { n.d. }\end{array}$ \\
\hline $\begin{array}{l}\mathbf{F} \ldots \ldots \ldots \ldots \\
\mathrm{Cl} \ldots \ldots \ldots \ldots \\
\mathrm{C} \text {, organic } \ldots \ldots \\
\mathrm{C} \text {, mineral } \ldots \ldots\end{array}$ & $\begin{array}{l}.070 \\
.013 \\
.61 \\
.24\end{array}$ & $\begin{array}{l}.074 \\
.018 \\
.80^{2} \\
.70^{2}\end{array}$ & $\begin{array}{l}. .13 \\
\text { n.d. } \\
\text { n.d. }\end{array}$ \\
\hline \multicolumn{4}{|c|}{ Trace elements in parts per million } \\
\hline 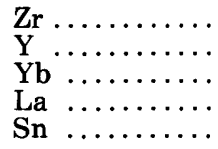 & $\begin{array}{l}170 \\
26 \\
2.8 \\
30 \\
1.3\end{array}$ & $\begin{array}{c}160 \\
26 \\
2.6 \\
92 \\
6\end{array}$ & $\begin{array}{r}150 \\
90 \\
15 \\
115 \\
1.5\end{array}$ \\
\hline $\begin{array}{l}\mathrm{Sc} \ldots \ldots \ldots \ldots \ldots \\
\mathrm{Ga} \ldots \ldots \ldots \ldots \ldots \\
\mathrm{B} \ldots \ldots \ldots \ldots\end{array}$ & $\begin{array}{r}18 \\
18 \\
120\end{array}$ & $\begin{array}{r}13 \\
19 \\
100\end{array}$ & $\begin{array}{r}19 \\
20 \\
230\end{array}$ \\
\hline $\begin{array}{l}\mathrm{Pb} \ldots \ldots \ldots \ldots \\
\mathrm{Ba} \ldots \ldots \cdots \cdots \\
\mathrm{Sr} \ldots \ldots \cdots \cdots \\
\mathrm{Mn} \ldots \ldots \ldots \cdots\end{array}$ & $\begin{array}{r}22 \\
730 \\
140 \\
500\end{array}$ & $\begin{array}{r}20 \\
580 \\
300 \\
850\end{array}$ & $\begin{array}{r}80 \\
2300 \\
180 \\
6700\end{array}$ \\
\hline $\begin{array}{l}\text { Co } \ldots \ldots \ldots \ldots \ldots \\
\text { Ni } \ldots \ldots \ldots \ldots \ldots \\
\mathrm{Zn}\end{array}$ & $\begin{array}{r}13 \\
39 \\
130\end{array}$ & $\begin{array}{l}19 \\
68 \\
95\end{array}$ & $\begin{array}{r}74 \\
225 \\
165\end{array}$ \\
\hline $\begin{array}{l}\mathrm{Cd} \ldots \ldots \ldots \ldots \\
\mathrm{Cr} \ldots \ldots \ldots \ldots \\
\mathrm{V} \\
\mathrm{Cu} \\
\mathrm{Cu}\end{array}$ & $\begin{array}{c}.53 \\
. \quad 90^{.53} \\
. \quad 36 \\
. \quad 36\end{array}$ & $\begin{array}{r}90^{.3} \\
130 \\
45\end{array}$ & $\begin{array}{l}90^{.42} \\
120 \\
250\end{array}$ \\
\hline $\begin{array}{l}\text { Mo } \ldots \ldots \ldots \ldots \ldots \\
\text { Se } \ldots \ldots \ldots \ldots \ldots \\
\text { As } \ldots \ldots \ldots \ldots \\
\text { U } \ldots \ldots \ldots \ldots\end{array}$ & $\begin{array}{c}1.4 \\
1.4 \\
13 \\
4.0\end{array}$ & $\begin{array}{c}2.6 \\
.6 \\
13 \\
3.7\end{array}$ & $\begin{array}{l}27 \\
13 \\
1.3\end{array}$ \\
\hline
\end{tabular}

${ }^{1}$ Corrected from original publication (K. K. Turekian, written commun., 1972). ${ }^{2}$ From Mason (1958, p. 147); total $\mathrm{H}_{2} \mathrm{O}$.

as much $\mathrm{K}_{2} \mathrm{O}$ and total $\mathrm{Fe}$, and about half again more $\mathrm{H}_{2} \mathrm{O}$ because most of the chemical studies in the literature, summarized by Turekian and Wedepohl (1961), are of geologically older, more illitic shale that con- 
tains more calcite and probably more Fe oxides than the more smectitic Pierre Shale and its equivalents. Four of the trace elements differ by more than a factor of two: La, Sn, Sr, and Se. Less than half as much Sr content in ordinary Pierre Shale is clearly due to its small calcite content. The higher Se content of the Pierre Shale and equivalents is probably due to the large amount of altered volcanics in them (Lakin, 1973). The amounts of $\mathrm{La}$ in the Pierre Shale is less than one-third that in the average shale. The $92 \mathrm{ppm}$ in average shale was originally reported as $18.4 \mathrm{ppm}$ in European and Japanese shale by Minami (1935), but Wedepohl (1960) concluded that this value was too low for these rocks and amended it. Since then Fenner and Hagner (1967) have reported $36 \mathrm{ppm}$ in the Devonian Esopus Shale in New York and Vine and E. B. Tourtelot (1969, table 3) reported a 30-ppm average for black shale in the United States, so perhaps $92 \mathrm{ppm}$ is unrealistically high for La in most shale. No explanation is apparent for the nearly five-fold difference in Sn.

The much different composition of ordinary Pierre Shale relative to deep-sea clay (table 27) results almost entirely from large amounts of $\mathrm{Fe}$ oxides in the latter (Turekian and Wedepohl, 1961). According to Goldberg and Arrhenius (1958), Y, Yb, La, Sc, B, Pb, Ba, $\mathrm{Mn}, \mathrm{Co}, \mathrm{Ni}, \mathrm{Cr}$, and $\mathrm{Mo}$ are concentrated mostly in $\mathrm{Fe}$ oxide, and all these elements, except $\mathrm{Se}$ and $\mathrm{Cr}$, are several times as abundant in the deep-seal clay as in shale of Pierre age. The previously discussed high La content reported for the average shallow-water shale relative to the Pierre Shale is apparently not due to more Fe oxides in the former, because of the eleven elements that should be concentrated in iron oxide, more than half-Y, $\mathrm{Yb}, \mathrm{Sc}, \mathrm{B}, \mathrm{Pb}$, and $\mathrm{B}$-are as abundant or more abundant in the Pierre Shale. Iron oxides are of little importance in the Pierre Shale and equivalents for two reasons. First, the deep-sea clay of the Atlantic and Pacific Oceans includes much early altered Fe-rich basalt, in contract to the relatively Fe-poor dacite parent of much of the Pierre sediment. Second, Goldberg and Arrhenius (1958) pointed out that $\mathrm{Fe}$ oxide accumulations depend on the length of time the sediment is in contact with seawater, and the rates of deposition in the Pacific and Atlantic Ocean of, respectively, $1 \mathrm{~mm} / 1,000$ years and $3 \mathrm{~mm} / 1,000$ years (Wedepohl, 1960) are much less than even the minimum rate of deposition in the Pierre sea of $20 \mathrm{~mm} / 1,000$ years (Gill and Cobban, 1973, p.36).

Trace-element distribution in marine and nonmarine parts of the Pierre Shale and its equivalents are in many cases not the same as those found by Keith and Degens (1959) in Pennsylvanian shale. In marine Penn- sylvanian shale the amounts of $\mathrm{B}$ and $\mathrm{Mn}$ are much larger, $\mathrm{Sr}$ and $\mathrm{Ni}$ slightly larger, and $\mathrm{Ga}$ and $\mathrm{Cr}$ smaller than in nonmarine shale. In marine and nonmarine rocks of Pierre age the relative amounts of $\mathrm{B}, \mathrm{Mn}, \mathrm{Ni}$, and $\mathrm{Ga}$ are qualitatively similar, though nowhere near the more than two-fold differences in Pennsylvanian shale; the small difference in $\mathrm{Ni}$ is due almost entirely to more clay in marine than in nonmarine parts of the Pierre and not that the clay contains more Ni (table 15), and abundances of $\mathrm{Sr}$ and $\mathrm{Cr}$ are reversed. In organic matter of Pennsylvanian shale, $\mathrm{Ni}$ and $\mathrm{V}$ are concentrated in marine rock, $\mathrm{Cu}, \mathrm{Pb}$, and $\mathrm{Sn}$ in nonmarine rock, and $\mathrm{Zn}$ is strongly concentrated and Mo weakly concentrated in both. In marine rocks of Pierre age the same relationship holds for $\mathrm{Ni}$ and $\mathrm{V}$, except that $\mathrm{Ni}$ is inferred to be concentrated more in pyrite than in organic matter; $\mathrm{Cu}$ is concentrated in marine and not nonmarine organic matter; $\mathrm{Pb}$ is only slightly concentrated in nonmarine organic matter (table 14) if at all (fig. 22), and Sn is definitely not so concentrated; $\mathrm{Zn}$ is concentrated in marine rock only and apparently more in pyrite than in organic matter; and Mo is concentrated only in marine organic matter, apparently to an extent 10 to 20 times that in Pennsylvanian shale. Pyrite concentrates $\mathrm{Mn}, \mathrm{Pb}, \mathrm{Ni}, \mathrm{Co}, \mathrm{Cu}$, and $\mathrm{As}$ in rocks of Pennsylvanian age, and all these elements except $\mathrm{Ni}$ are more concentrated in nonmarine pyrite. In rocks of Pierre age pyrite concentrates $\mathrm{Co}, \mathrm{Ni}, \mathrm{Zn}$, and possibly $\mathrm{Cu}$ only in marine organic-rich shale, and nonmarine rocks contain little pyrite. Thus, details of trace-element distribution may vary considerably in different depositional settings and may simply reflect concentration of elements in the environment.

Boron amounts, particularly in illite, are widely believed to be the most reliable trace-element indicator of salinity, but this is not so in the Pierre Shale and equivalent rocks. The following elements are concentrated in clay minerals in marine relative to nonmarine rock of Pierre age by the following percentages: $\mathbf{B}(21)$, $\mathrm{Mn}(33), \mathrm{Zn}(29), \mathrm{Cr}(32), \mathrm{V}(18), \mathrm{Cu}(25), \mathrm{Se}(300)$, and $\mathrm{As}(67)$. Thus, $\mathrm{B}$ is no more reliable a salinity indicator than $\mathrm{Mn}, \mathrm{Zn}, \mathrm{Cr}, \mathrm{V}$, or $\mathrm{Cu}$, it is less reliable than Se or As, and even these latter two elements show considerable overlap in marine and nonmarine rocks (fig. 22). Though illite is the second most abundant clay mineral in shale of Pierre age, the limited concentration of $\mathrm{B}$ that does occur in the marine rocks is in the clay minerals in general and not specifically in illite. In rocks of Pierre age, probably the best environmental indicator is organic matter as reflected by the mediumto dark-gray color of the marine shale, contrasted with the pale pastel colors of most nonmarine rock, coaly beds and some volcanic-rich rocks excepted. 


\section{REFERENCES CITED}

American Geological Institute, (Margaret Gary, Robert McAfee, Jr., and C. L. Wolf, eds.), 1972, Glossary of geology, with a foreword by Ian Campbell: Washington, $857 \mathrm{p}$.

Anderson, B. J., and Jenne, E. A., 1970, Free-iron and -manganese oxide content of reference clays: Soil Science, v. 109 , no. 3, p. 163-169.

Barnett, P. R., 1961, Spectrographic analysis for selected minor elements in Pierre Shale: U.S. Geological Survey Professional Paper 391-B, $10 \mathrm{p}$.

Blatt, Harvey, and Christie, J. M., 1963, Undulatory extinction in quartz of igneous and metamorphic rocks and its significance in provenance studies of sedimentary rocks: Journal of Sedimentary Petrology, v. 33, no. 3, p. 559-579.

Bowen, N. L., 1922, The reaction principle in petrogenesis: Journal of Geology, v. 30, no. 3, p. 177-198.

Bramlette, M. N., and Posjnak, Eugene, 1933, Zeolitic alteration of pyroclastics: American Mineralogist, v. 18, no. 4, p. 167-171.

Calvert, S. E., 1966, Accumulation of diatomaceous silica in the sediments of the Gulf of California: Geological Society of American Bulletin, v. 77, no. 6, p. 569-596.

Chayes, Felix, 1960, On correlation between variables of constant sum: Journal of Geophysical Research, v. 65, no. 12, p. 4185-4193.

Cobban, W. A., 1953, An Upper Cretaceous section near Mosby, Montana: in J. M. Parker, ed., Billings Geological Society Guidebook, 4th Annual Field Conference, 1953: Little Rocky Mountains, Montana-southwestern Saskatchewan, p. 98-101.

Crandell, D. R., 1952, Origin of the Crow Creek Member of the Pierre Shale in central South Dakota: American Association of Petroleum Geologists Bulletin, v. 36, no. 9, p. 1754-1765.

Davis, J. C., 1970, Petrology of Cretaceous Mowry Shale of Wyoming: American Association of Petroleum Geologists Bulletin, v. 54 , no. 3 , p. $487-502$.

Deer, W. A., Howie, R. A., and Zussman, J., 1963, Rock-forming minerals, v. 2, Chain silicates: New York, John Wiley, 379 p.

Deffeyes, K. S., 1959, Zeolites in sedimentary rocks: Journal of Sedimentary Petrology, v. 29, no. 4, p. 602-609.

Degens, E. T., 1965, Geochemistry of sediments-A brief survey: Englewood Cliffs, N. J., Prentice-Hall, 342 p.

Degens, E. T., Williams, E. G., and Keith, M. L., 1957, Geochemical criteria for differentiating marine from fresh-water shales, pt. 1 of Environmental studies of Carboniferous sediments: American Association of Petroleum Geologists Bulletin, v. 41, no. 11, p. 2427-2455.

Dixon, W. J., and Massey, F. J., Jr., 1957, Introduction to statistical analysis ( $2 \mathrm{~d}$ ed.): New York, McGraw-Hill, $488 \mathrm{p}$.

Eagar, R. M. C., and Spears, D. A., 1966, Boron content in relation to organic carbon and to paleosalinity in certain British upper Carboniferous sediments: Nature, v. 209, no. 5019, p. 177-181.

Fenner, P., and Hagner, A. F., 1967, Correlation of variations of trace elements and mineralogy of the Esopus Formation, Kingston, New York: Geochimica et Cosmochimica Acta, v. 31, no. 2, p. 237-261.

Fleet, M. E. L., 1965, Preliminary investigations into the sorption of boron by clay minerals: Clay Minerals Bulletin, v. 6, no. 1, p. 3-16.

Frederickson, A. F., and Reynolds, R. C., Jr., 1960, How measuring paleosalinity aids exploration: Oil and Gas Journal, v. 58, no. 5, p. 154-155, 157-158.

Gill, J. R., and Cobban, W. A., 1961, Stratigraphy of lower and middle parts of the Pierre Shale, northern Great Plains, in Short papers in the geologic and hydrologic sciences: U.S. Geological Survey Professional Paper 424-D, p. D185-D191.
1965, Stratigraphy of the Pierre Shale, Valley City and Pembina Mountain areas, North Dakota: U.S. Geological Survey Professional Paper 392-A, 20 p.

1966, The Red Bird section of the Upper Cretaceous Pierre Shale in Wyoming, with a section on A new echinoid from the Cretaceous Pierre Shale of eastern Wyoming, by P. M. Kier: U.S. Geological Survey Professional Paper 393-A, 73 p.

1973. Stratigraphy and geologic history of the Montana Group and equivalent rocks, Montana, Wyoming, and North and South Dakota: U.S. Geological Survey Professional Paper $776,37 \mathrm{p}$

Gill, J. R., Cobban, W. A., and Schultz, L. G., 1972a, Correlation, ammonite zonation, and a reference section for the Montana Group, central Montana: Montana Geological Society Annual Field Conference Guidebook, 21, p. 91-97.

$1972 \mathrm{~b}$, Stratigraphy and composition of the Sharon Springs Member of the Pierre Shale in western Kansas: U.S. Geological Survey Professional Paper 728, 50 p.

Goldberg, E. D., and Arrhenius, G. O. S., 1958, Chemistry of Pacific pelagic sediments: Geochimica et Cosmochimica Acta, v. 13, nos. 2-3, p. 153-212.

Goldich, S. S., 1938, A study in rock-weathering: Journal of Geology, v. 46 , no. 1 , p. 17-58.

Goldschmidt, V. M., 1954, Geochemistry: Oxford, England, Clarendon Press, $730 \mathrm{p}$.

Goldsmith, J. R., 1950, Gallium and germanium substitutions in synthetic feldspars: Journal of Geology, v. 58, no. 5, p. 518-536.

Grim, R. E., 1962, Applied clay mineralogy: New York, McGrawHill, 422 p.

1968, Clay mineralogy (2d ed.): New York, McGraw-Hill, $596 \mathrm{p}$.

Harder, Hermann, 1959a, Beitrag zur Geochemie des Bors, Part 1, Bor in Mineralen und magmatischen Gesteinen: Nachrichten der Akademie der Wissenschaften in Gottingen, MathematischPhysikalische Klasse, no. 5, p. 67-122.

1959b, Beitrag zur Geochemie des Bors, Part 2, Bor Sedimenten: Nachrichten der Akademie der Wissenschaften in Gottingen, Mathematisch-Physikalische Klasse, no. 6, p. 123-183.

Hashimoto, Isao, and Jackson, M. L., 1960, Rapid dissolution of allophane and kaolinite-halloysite after dehydration, in Ada Swineford, ed., Clay and clay minerals: National Conference on Clays and Clay Minerals, 7th, Washington, D. C., 1958, Proceedings, p. 102-113.

Hirst, D. M., 1962, The location and distribution of trace elements, [pt.] 2 of The geochemistry of modern sediments from the Gulf of Paria: Geochimica et Cosmochimica Acta, v. 26, no. 11, p. 1147-1187.

Hofmann, Ulrich, Weiss, Armin, Koch, G., Mehler, A., and Scholz, A., 1956, Intracrystalline swelling, cation exchange, and anion exchange of minerals of the montmorillonite group and of kaolinite, in Ada Swineford, ed., Clays and clay minerals: National Conference on clays and clay minerals, 4th, University Park, Pa., 1955, Proceedings, National Academy of Sciences-National Research Council Publication 456, p. 273-287.

Hose, R. K., 1955, Geology of the Crazy Woman Creek area, Johnson County, Wyoming: U.S. Geological Survey Bulletin 1027-B, p. 33-118 [1956]

Hower, John, and Hall, M. L., 1970, Clay petrology of the upper Cretaceous Two Medicine Formation, central Montana [abs.]: Clay Minerals Conference, 19th Annual, Miami Beach, Florida, 1970, Program and Abstracts, p. 24.

Huffman, Claude, Jr., 1963, Ion-exchange separation and spectrophotometric determination of cadmium, in Short papers in geology, hydrology, and topography: U.S. Geological Survey Professional Paper 450-E, p. E126-E127. 
Huffman, Claude, Jr., and Bartel, A. J., 1964, Ion-exchange separation of tin from silicate rocks, in Geological Survey Research 1964: U.S. Geological Survey Professional Paper 501-D, p. D131-D133.

Jackson, M. L., 1958, Soil chemical analysis: Englewood Cliffs, N. J., Prentice-Hall, 498 p.

Jenne, E. A., 1968, Controls on $\mathrm{Mn}, \mathrm{Fe}, \mathrm{Co}, \mathrm{Ni}, \mathrm{Cu}$, and $\mathrm{Zn}$ concentrations in soils and water-the significant role of hydrous $\mathrm{Mn}$ and $\mathrm{Fe}$ oxides, in Trace inorganics in water: American Chemical Society, 153d Annual Meeting, Miami Beach, Fla., 1967, Symposium, p. 337-387.

Keith, M. L., and Degens, E. T., 1959, Geochemical indicators of marine and fresh-water sediments, in P. H. Abelson, ed., Researches in geochemistry: London, John Wiley, p. 38-61.

Klepper, M. R., Weeks, R. A., and Ruppel, E. T., 1957, Geology of the southern Elkhorn Mountains, Jefferson and Broadwater Counties, Montana, U.S. Geological Survey Professional Paper 292,82 p. [1958].

Knechtel, M. M., and Patterson, S. H., 1955, Bentonite deposits of the northern Black Hills district, Montana-Wyoming, and South Dakota: U.S. Geological Survey Mineral Investigations Field Studies Map MF-36 [1956].

1956, Bentonite deposits in marine Cretaceous formations of the Hardin district, Montana and Wyoming, with a section on Laboratory procedures used for testing the bentonites, by $\mathrm{S}$. H. Patterson: U.S. Geological Survey Bulletin 1023, 116 p.

Krauskopf, K. B., 1955, Sedimentary deposits of rare metals, in A. M. Bateman, ed., Economic Geology fiftieth anniversary volume: Urbana, Ill., Economic Geology Publishing Co., p. 411-463.

1956, Factors controlling the concentrations of thirteen rare metals in sea-water: Geochimica et Cosmochimica Acta, v. 9, nos. 1-2, p. 1-32.

Lakin, H. W., 1973, Selenium in our environment, in E. L. Kothny, ed., Trace elements in the environment: American Chemical Society, 162d meeting, Washington, D. C., 1971, symposium, p. $96-111$.

Landergren, Sture, 1945, Contribution to the geochemistry of boron, [pt.] II, The distribution of boron in some Swedish sediments, rocks, and iron ores. The boron cycle in the upper atmosphere: Arkiv fơr Kemi, Mineralogi och Geologi, v. 19, no. 5, paper 26, 31 p.

MacEwan, D. M. C., 1961, Montmorillonite minerals, in George Brown, ed., The X-ray identification and crystal structures of clay minerals (2d ed.): London, Mineralogical Society, Clay Minerals Group, p. 143-207.

Madsen, B. M., and Murata, K. J., 1970, Occurrence of laumontite in Tertiary sandstones of the central Coast Ranges, California, in Geological Survey Research 1970: U.S. Geological Survey Professional Paper 700-D, p. D188-D195.

Marlowe, J. I., 1971, Dolomite, phosphorite, and carbonate diagenesis on a Caribbean sea mount: Journal of Sedimentary Petrology, v. 41, no. 3, p. 809-827.

Mason, B. H., 1958, Principles of geochemistry (2d ed.): New York, John Wiley, 310 p.

Minami, E., 1935, Selen-Gehalte von eropäischen und japanischen Tonschiefern: Gesellschaff der Wissenschaflen zu Gottingen, Abhandlung; Nachrichten Mathematisch-Physikalische Klasse, Fachgruppe IV, Mineralogie und Geologie, v. 1, no.12, p. 143-145.

Mizutani, Shinjiro, 1970, Silica minerals in the early stage of diagenesis: Sedimentology, v. 15, no. 2, p. 419-436.

Mumpton, F. A., 1960, Clinoptilolite redefined: American Mineralogist, v. 45, nos. 3-4, p. 351-369.
Murata, K. J., and Larson, R. R., 1975, Diagenesis of Miocene siliceous shales, Temblor Range, California: U.S. Geological Survey Journal of Research, v. 3, no. 5, p. 553-566.

Nicholls, G. D., 1963, Environmental studies in sedimentary geochemistry: Science Progress, v. 51, no. 201, p. 12-31.

Parham, W. E., 1970, Clay mineralogy and geology of Minnesota's kaolin clays: Minnesota Geological Survey Special Publication Series SP-10, 142 p.

Pettijohn, F. J., 1957, Sedimentary rocks (2d ed.): New York, Harper and Brothers, $718 \mathrm{p}$.

Potter, P. E., Shimp, N. F., and Witters, J., 1963, Trace elements in marine and fresh-water argillaceous sediments: Geochimica et Cosmochimica Acta, v. 27, no. 6, p. 669-694.

Rader, L. F., and Grimaldi, F. S., 1961, Chemical analyses for selected minor elements in Pierre Shale: U.S. Geological Survey Professional Paper 391-A, p. A1-A45.

Rankama, K. K., and Sahama, T. G., 1950, Geochemistry: Chicago, Ill. University of Chicago Press, 912 p.

Reynolds, W. R., 1970, Mineralogy and stratigraphy of lower Tertiary clays and claystones of Alabama: Journal of Sedimentary Petrology, v. 40, no. 3, p. 829-838.

Richards, P. W., 1955, Geology of the Bighorn Canyon-Hardin area, Montana and Wyoming: U.S. Geological Survey Bulletin $1026,93 \mathrm{p}$.

Roberts, A. E., 1972, Cretaceous and early Tertiary depositional and tectonic history of the Livingston area, southwestern Montana: U.S. Geological Survey Professional Paper 526-C, p. $\mathrm{C} 1-\mathrm{C} 120$.

Rubey, W. W., 1930, Lithologic studies of fine-grained upper Cretaceous sedimentary rocks of the Black Hills region: U.S. Geological Survey Professional Paper 165-A; 54 p.

Sabins, F. F., Jr., 1962, Grains of detrital, secondary, and primary dolomite from Cretaceous strata of the Western Interior: Geological Society of America Bulletin, v. 73, no. 10, p. 1183-1196.

Schultz, L. G., 1964, Quantitative interpretation of mineralogical composition from X-ray and chemical data for the Pierre Shale: U.S. Geological Survey Professional Paper 391-C, p. C1-C31. 1965, Mineralogy and stratigraphy of the lower part of the Pierre Shale, South Dakota and Nebraska: U.S. Geological Survey Professional Paper 392-B, p. B1-B19.

1978, Mixed-layer clay in the Pierre Shale, northern Great Plains region: U.S. Geological Survey Professional Paper 1064-A, p. A1-A28.

Shapiro, Leonard, and Brannock, W. W., 1956, Rapid analysis of silicate rocks: U.S. Geological Survey Bulletin 1036-C, p. C19-C56.

Sheppard, R. A., and Gude, A. J., 3d, 1964, Potash feldspar of possible economic value in the Barstow Formation, San Bernardino County, California: U.S. Geological Survey Circular 500, 7 p.

1973, Boron-bearing potassium feldspar of authigenic origin in closed-basin deposits: U.S. Geological Survey Journal of Research, v. 1, no. 4, p. 377-382.

Slaughter, Maynard, and Earley, J. W., 1965, Mineralogy and geological significance of the Mowry bentonites, Wyoming: Geological Society of America Special Paper 83, $95 \mathrm{p}$.

Smith, J. R., and Yoder, H. S., Jr., 1956, Variations in X-ray powder diffraction patterns of plagioclase feldspars: American Mineralogist, v. 41, nos. 7-8, p. 632-647.

Smith, J. V., 1956, The powder patterns and lattice parameters of plagioclase feldspars; [pt.] I, The soda-rich plagioclases: Mineralogical Magazine, v. 31, no. 232, p. 47-68.

Snedecor, G. W., and Cochran, W. G., 1967, Statistical methods (6th ed.): Ames, Iowa, Iowa State University Press, 593 p.

Spears, D. A., and Rice, C. M., 1973, An Upper Carboniferous tonstein of volcanic origin: Sedimentology, v. 20, p. 281-294. 
Terzaghi, Karl, and Peck, R. B., 1948, Soil mechanics in engineering practice: New York, John Wiley, 566 p.

Tourtelot, H. A., 1960, Origin and use of the word "shale": American Journal of Science, v. 258-A (Bradley Volume), p. 335-343.

1961, Thin sections of clay and shale: Journal of Sedimentary Petrology, v. 31, no. 1, p. 131-132.

1962, Preliminary investigation of the geologic setting and chemical composition of the Pierre Shale, Great Plains region: U.S. Geological Survey Professional Paper 390, 74 p.

1964, Minor-element composition and organic carbon content of marine and nonmarine shales of Late Cretaceous age in the western interior of the United States: Geochimica et Cosmochimica Acta, v. 28, no. 10, p. 1579-1604.

1971, Chemical compositions of rock types as factors in our environment, in H. L. Cannon and H. C. Hopps, Environmental geochemistry in health and disease: Geological Society of America Memoir 123, p. 13-29.

Tourtelot, H. A., and Cobban, W. A., 1968, Stratigraphic significance and petrology of phosphate nodules at the base of the Niobrara Formation, east flank of the Black Hills, South Dakota: U.S. Geological Survey Professional Paper 594-L, p. L1-L22 [1969].

Tourtelot, H. A., Huffman, Claude, Jr., and Rader, L. F., 1964, Cadmium in samples of the Pierre Shale and some equivalent stratigraphic units, Great Plains Region, in Short papers in geology and hydrology: U.S. Geological Survey Professional Paper 475-D, p. D73-D78.
Tourtelot, H. A., and Schultz, L. G., 1961, Core from the Irish Creek well, Ziebach County, South Dakota: U.S. Geological Survey open-file report, $20 \mathrm{p}$.

Tourtelot, H. A., Schultz, L. G., and Huffman, Claude, Jr., 1961, Boron in bentonite and shale from the Pierre Shale, South Dakota, Wyoming, and Montana, in Short papers in the geologic and hydrologic sciences: U.S. Geological Survey Professional Paper 424-C, p. C288-C292.

Turekian, K. K., and Wedepohl, K. H., 1961, Distribution of elements in some major units of the Earth's crust: Geological Society of America Bulletin, v. 72, no. 2, p. 175-191.

Viele, G. W., and Harris, F. G., 3d, 1965, Montana Group stratigraphy, Lewis and Clark County, Montana: American Association of Petroleum Geologists Bulletin, v. 49, no. 4, p. 379-417.

Vine, J. D., and Tourtelot, E. B., 1969, Geochemical investigations of some black shales and associated rocks: U.S. Geological Survey Bulletin 1314-A, p. A1-A43 [1970].

Walker, C. T., 1968, Evaluation of boron as a paleosalinity indicator and its application to offshore prospects: American Association of Petroleum Geologists Bulletin, v. 52, no. 5, p. 751-766.

Wedepohl, K. H., 1960, Spurenanalytische Untersuchungen an Tiefseetonen aus dem Atlantik; ein Beitrag zur Deutung der geochemischen Sonderstallung von pelagischen Tonen: Geochimica et Cosmochimica Acta, v. 18, no. 3-4, p. 200-231 [includes English summ.].

1971, Geochemistry: New York, Holt, Rinehart, and Winston, $231 \mathrm{p}$. 


\section{INDEX}

[Italic page numbers indicate major references]

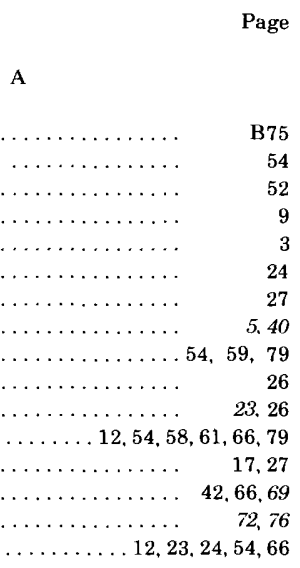

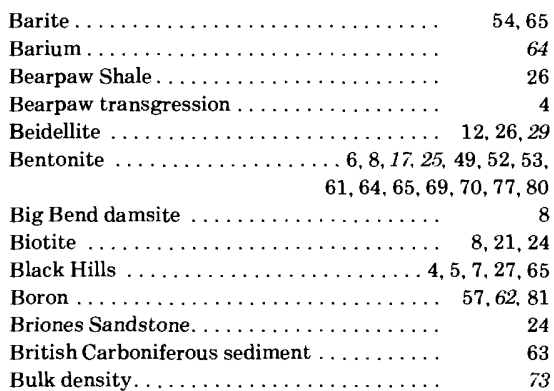

C

Cadmium. . . . . . . . . . . . . . . . Calcite $\ldots \ldots \ldots \ldots \ldots 12,13,21,24,30,31,49,52$ $54,59,61,62,68,76,78$

Calcium $\ldots \ldots \ldots \ldots \ldots \ldots \ldots \ldots \ldots \ldots, \quad 42,52$ Carbon $\ldots \ldots \ldots \ldots \ldots \ldots \ldots \ldots \ldots \ldots, 40,53,66$ organic................

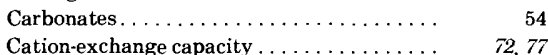

Cation-exchange capacity $\ldots \ldots \ldots \ldots \ldots \ldots$
Cations, exchangeable. $\ldots \ldots \ldots \ldots \ldots \ldots \ldots$

Cementing material . .................... 18

Chemical analysis . . . . . . . . . . . . . .

Chlorine .................. 42.79

Chlorite ................. 8,9,13,15,16,23, $30,60,70,77,78$

Chromium ................. 66,69

Claggett Shale $\ldots \ldots \ldots \ldots \ldots \ldots \ldots \ldots$

Claggett transgression

66,69
4

Clay minerals $\ldots \ldots \ldots \ldots \ldots \ldots, 2,12,13,15,24,26$ $29,59,76,79$

Clinoptilolite . . . . . . . . . . 13, 27, 39, 65, 78, 79

Coal. ....................... 6

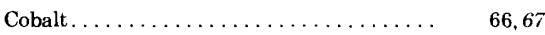

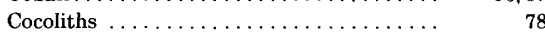

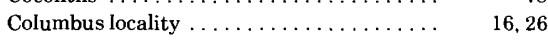

Composition................... 12, 40,78

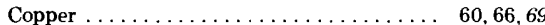

Correlation coefficient. . . . . . . . $\ldots \ldots \ldots \ldots, \quad 54,76$

Cristobalite $\ldots \ldots \ldots \ldots \ldots \ldots \ldots \ldots \ldots \ldots \ldots \ldots \ldots, 12,18,26,31,49$,

Page

Crow Creek Member $\mathrm{B} 4,20,21,30,40$ Cut Bank locality.

16,30

9

Dearborn River locality. . . . . . . . 5, 11, 12, 22, 24 ,

Dearborn River locality............ $5,11,12,22,24$,
$26,29,53,59.77$

Deep-sea clay . . . . . . . . . . . . . . 81

DeGrey Member $\ldots \ldots \ldots \ldots \ldots \ldots \ldots \ldots \ldots \ldots \ldots \ldots \ldots \ldots \ldots \ldots \ldots \ldots, 4,20$

Density .................... $\pi_{2}$

Depositional environment. ........... 3.13

Derivation of sediments . . . . . . . . . . . 3

Devitrification .................. 26,79

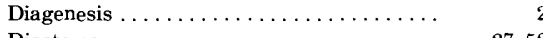

Diastems $\ldots \ldots \ldots \ldots \ldots \ldots \ldots \ldots \ldots \ldots, 27,58$

$\begin{array}{ll}\text { Diatoms } \ldots \ldots \ldots \ldots \ldots \ldots \ldots \ldots \ldots \ldots \ldots \ldots \ldots \ldots & 18 \\ \text { Distribution of elements } \ldots \ldots \ldots \ldots \ldots \ldots & 44\end{array}$

Dolomite . . . . . .

$\begin{array}{r}59,77,78 \\ \hline\end{array}$

\section{$\mathbf{E}$}

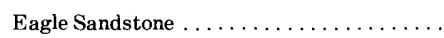

Elemental abundance $\ldots \ldots \ldots \ldots \ldots \ldots$

Elgin Creek locality . . . . . . . . . . . .

Elk Basin locality $\ldots \ldots \ldots \ldots \ldots \ldots \ldots \ldots, 30,49,59$

Elk Butte Member.............. $5,7,20$

Elkhorn Mountains volcanic center . . . . . . 28, 30, 31

Elkhorn Mountains Volcanics .......... 3, 77

Environment of deposition . . . . . . . . . $\quad 3,13$

Exchangeable cations . . . . . . . $\ldots \ldots \ldots .11,18$

Expansible clay .................. 6

F

Feldspar . . . . . . . . . 8, 12, 13, 15, 16, 25, 27 . $31,53,63,64,78$

Fish fossils . . . . . . . . . . . . . . . . 58

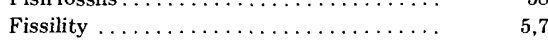

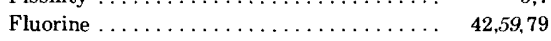

Foramininifers . . . . . . . . . .

Fossil zones . . . . . . . . . . . . . .

Fossils, ammonites . . . . . . . . . . .

fish $\ldots \ldots \ldots \ldots \ldots \ldots \ldots \ldots \ldots \ldots \ldots \ldots$

Fox Hills regression. . . . . . . . . . . .

Fox Hills Sandstone $\ldots \ldots \ldots \ldots \ldots \ldots$

Francolite........................ 58

Frothy-weathering shale $\ldots \ldots \ldots \ldots \ldots \ldots, 17,62,65$

G

Gallium. . . . . . . . . $\ldots \ldots \ldots \ldots, 57,61,64$

Gammon Member ............... 4,27

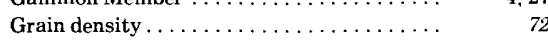

Gregory Member $\ldots \ldots \ldots \ldots \ldots \ldots \ldots \ldots, 4,6,7,20$

Gypsum . . . . . . . . . . $53,71,75,80$

H, I

Heavy minerals . . . . . . . . . . . . $\quad 56.57$ resistates.................. 60

Hell Creek Formation . . . . . . . . . . . . 5

Heulandite $\ldots \ldots \ldots \ldots \ldots \ldots \ldots \ldots \ldots \ldots \ldots \ldots \ldots \ldots \ldots \ldots, 24,27,39,78$

Horsethief Sandstone $\ldots \ldots \ldots \ldots \ldots \ldots \ldots \ldots, \quad 5$
Page

Illite $\ldots \ldots$ B12, 15, 22, 26, 29, 30,53, $62,64,77,78,81$

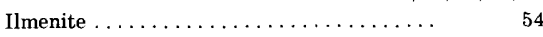
Ionic exchange. $\ldots \ldots \ldots \ldots \ldots \ldots \ldots \ldots \ldots \ldots \ldots \ldots \ldots \ldots \ldots \ldots \ldots \ldots, 11,72,77$

Irish Creek well locality ............. 8 Iron. . . . . . . . . .

\section{J, K}

Jarosite $\ldots \ldots \ldots \ldots \ldots \ldots .9,12,13,15,16,31,53,80$ Judith River Formation . . . . . . . $\ldots \ldots \ldots, 4$ Judith River regression. . . . . . . . . . .

Kaolinite . . . . . . . . 12, 15, 16, 26, 30, 58, 59 , Kara Bentonitic Member............. $\quad \begin{array}{r}64,77,78 \\ 7\end{array}$

L.

Lance Formation $\ldots \ldots \ldots \ldots \ldots \ldots \ldots \ldots \ldots \ldots \ldots \ldots$

Lanthanum ................ 42,60

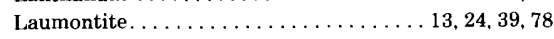

Leaching. . . . . . . . $9 \ldots \ldots \ldots \ldots \ldots$

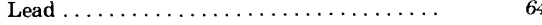

Lennep Sandstone . . . . . . . . . . . . .

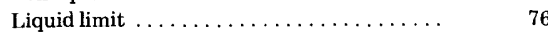

Lithology $\ldots \ldots \ldots \ldots \ldots \ldots \ldots \ldots \ldots$

Livingston Group ................

Livingston locality .............. 24,29

$\mathbf{M}$

Magnesium ..................... 9,52

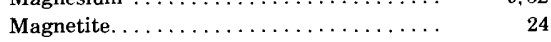

Major elements $\ldots \ldots \ldots \ldots \ldots \ldots \ldots \ldots . \ldots \ldots \ldots$

definition ................... 40

Manganese................... 65.68

Marl .............. 8, 19, 31, 49, 58, 62, 78, 79

Marl....

Methods of sampling . ....................

Mineral composition ................ 9, 12,40

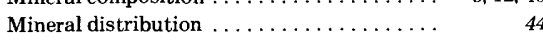

Minor elements . . . . . . . $\ldots \ldots \ldots \ldots . \quad 53,57$

definition................. 40

Mitten Member ................. 4

Mixed-layer clay $\ldots \ldots \ldots \ldots \ldots \ldots 12,15,16,23,29,53$,
76,77

Mobridge Member . . . . . . . . . . . . 4, 20, 58,62

Molybdenum . . . . . . . . . . . . $\ldots \ldots \ldots, 64,69$

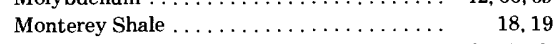

Montmorillonite $\ldots \ldots \ldots \ldots \ldots \ldots 12,17,23,24,26$,

Monument Hill Member ...................

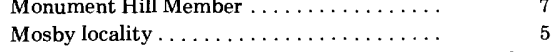

Mowry Shale ................ 18,27

\section{$\mathrm{N}, \mathrm{O}$}

Nickel . . . . . . . . . . . $\ldots \ldots \ldots \ldots, 66,67$

Niobrara Formation. . . . . . . . . 4, 20, 27, 30, 31

Nonanalytical samples $\ldots \ldots \ldots \ldots \ldots \ldots \ldots, \quad 5$

Oahe Dam................... 8

Occurrence of elements . . . . . . . . . . . 44

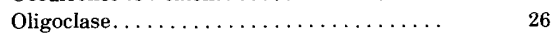

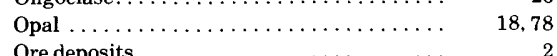


Page

Organic-matter-related elements . . . . . . .

Organic-rich shale

$\mathrm{B} 15$
68

$15,49,53$
Organic carbon.

$\mathbf{P}$

Parkman Sandstone $\ldots \ldots \ldots \ldots \ldots \ldots$

Pedro Bentonit

Pedro bentonite pit

Pembina Member

$\mathrm{pH}, \ldots$.

Phillipsite. .

nodules $\ldots \ldots \ldots \ldots \ldots \ldots \ldots \ldots$

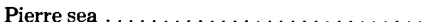

Plagioclase $\ldots \ldots \ldots \ldots \ldots \ldots 12,21,22,23,26,27,52$ $64,65,66,77$

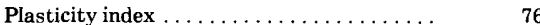

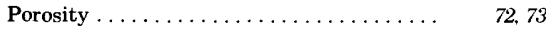

Potassium .....................

Precision of analyses.

Pyrite $\ldots \ldots \ldots \ldots \ldots, 8,12,13,16,20,27,31,52,53$, $66,68,70,72,75,77,78,81$ Pyroxene .......................

Q, R

Quartz

$13,15,18-21,22,26,30$

$31,39,49,77$

Radiolaria

18,78

Rates of deposition

Red Bird locality

Red Bird Silty

Regional variation . .

Rhyolite . .

Rock-forming constituents
81
5
4
28
60,79
27

40,44

Page

Page

S

St. Mary River Formation. . . . . . . . . . . B5

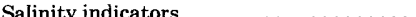

Salt Creek locality

Sampling

Scandium $\ldots \ldots \ldots \ldots \ldots \ldots \ldots \ldots \ldots$ source.

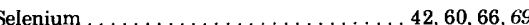

Shale $\ldots \ldots \ldots \ldots \ldots \ldots \ldots \ldots, 5,15,49,52$

Sharon Springs Member $\ldots \ldots \ldots \ldots, 4,6,8,9,17,20$ $26,27,31,53,58,65,70,71,7$

Shawmut locality 26

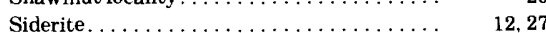

Siliceous shale ...................

Siltstone. . . . . . . . . . . 6, 8, 15, 49, 52, 59, 79

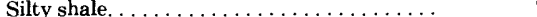

Sioux Quartzite . . . . . . . . . . . . . $\quad 20,40$

Size fractionation. . . . . . . . . . . . . . .

Smectite $\ldots \ldots \ldots \ldots \ldots \ldots \ldots \ldots \ldots 12,25,27,77$

Smectitic clay..................... 8,9

Sodium ..................... . $\quad 52$

Source of sediments. . . . . . . . . . .

Statistical analysis $\ldots \ldots \ldots \ldots \ldots \ldots \ldots$

Stratigraphy

variation

Strontium. . .

ts

Sulfuric acid . . . . . . . . . . . . . . .

$\mathrm{T}$

40,42
3

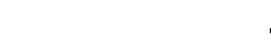

$\mathrm{T}$

Telegraph Creek-Eagle regression. . .......

Telegraph Creek Formation . .

Tin.

Titanium....

Tourmaline.
Trace elements

distribution

B $40,54,60,61,63$ $66,70,79$

Trash zone

Tuff. ...................... $\quad 21,25$

Two Medicine Formation . ...........

21,25
4

U, V

Uranium . . .

$40,42,60,66,70$

Vanadium.

$60,66,69$

Verendrye Member

$4,6,7,39$

Virgelle Sandstone Member

Virgin Creek Member

Volcanic debris. ...

Volcanic-rich rock

claystone

sandstone

shale. . .

siltstone.

4
$4,6,58$

7,25

61

59

39

8,21

W, X, Y, Z

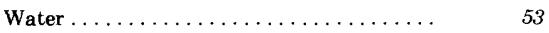

Weathering $\ldots \ldots \ldots \ldots \ldots \ldots \ldots, 6,7,8,31,70,80$

Wheeler bridge area ................ 4

Wyola-Parkman locality ........... $\quad 30$

$X$-ray analysis $\ldots \ldots \ldots \ldots \ldots \ldots \ldots \ldots \ldots, 9,11,15$

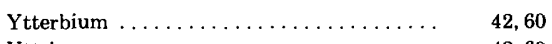

Yttrium $\ldots \ldots \ldots \ldots \ldots \ldots \ldots \ldots, \quad 42,60$

Zeolite................ 12, 13, 15, 23, 24, 26, 27,

$\begin{array}{rr} & \\ \text { Zinc. } \ldots \ldots \ldots \ldots \ldots \ldots \ldots \ldots \ldots \ldots . & 39,65,78 \\ 42,66,67\end{array}$

Zircon................... 12,54,60

Zirconium................. 


\section{TABLE 1}

IStandard rock analyses by M. Seerveld, E. L. Munson and V. C. Smith. Rapid rock analses by Leonard Shapiro, Paul Elmore, S. D. Botts, M. D. Mack, Gillison Cloe, Lowell Artis, and H. Smith.

Fluorine in rapid rock analyses by $\mathrm{P}$. M. Montalto

Sulfur analyses by Sara Berthold and e. L. Munson.

Organic C and mineral $\mathrm{C}$ analyses by E. J. Fennelly, Wayne Mountjoy and I. C. Frost. Spectrographic analyses for $\mathrm{Zr}, \mathrm{Y}, \mathrm{Yb}, \mathrm{La}, \mathrm{Sc}, \mathrm{Ga}, \mathrm{B}, \mathrm{Ba}, \mathrm{Sr}, \mathrm{Mn}, \mathrm{Co}, \mathrm{Ni}$, and $\mathrm{Cr}$ by $\mathrm{P} . \mathrm{R}$.

Barnett and N. M. Conklin.

Chemical analyses for minor elements:

Sn, Cd, and As by Claude Huffman and Ardith Bartel;

Pb by J. I. Dinnin and W. D. Gross;

Zn by J. I. Dinnin, Claude Huffman, and Ardith Bartel;

V by Wayne Mountjoy, W. D. Gross and H. H. Lipp;

Cu by J. I. Dinnin and G. T. Barrow;

Mo by D. L. Ferguson, Claude Huffman, and Ardith Bartel;

Se by G. T. Barrow;

U by G. A. Kinser, I. H. Barlow, and J. W. Budinski.

eU by L. M. Lee.

Bulk density by M. K. Balazs and E. L. Munson.

Grain density by M. K. Balazs, F. H. Neuerburg, and E. L. Munson.
Liquid limit, plastic limit, and plasticity index by T. C. Nichols and John Halbert.

pH by Dorothy Carroll and H. C. Starkey.

Codes for locality: from 1 in the west to 28 in the east; general locations are on plate 1; exact sample locations are in table 2.

Codes for fossil zones: from 6 for the youngest rocks at the tops of sampled sections to 1 at the bottom, as shown on plate 1 .

Codes for environment: 1 , freshwater; 2 , brackish water; 3 , nearshore marine; 4 , offshore marine.

Codes for rock type: 1, sandstone or siltstone; 2 , argillaceous sandstone or siltstone; 3 , silty shale or claystone; 4 , shale or claystone; 5 , marl; 6 , bentonite.

Codes for modifier of rock type: 0 , no modifier, 1 , ordinary, none of the following; 2 , fissile, organic rich; 3, frothy-weathering; 4, siliceous; 5, volcanic or tuffaceous; 6 , coaly; 7, within $1 \mathrm{ft}$ above bentonite; 8 , biotitic; 9 , sandy; 10 , calcareous; 11 , glauconitic; 12 , hard, nonplastic.

Codes for collapse and spacing characteristics of smectite:

Heated codes: 1 , good collapse at $300^{\circ} \mathrm{C} ; 2$, incomplete collapse at $300^{\circ} \mathrm{C}$ complete at $550^{\circ} \mathrm{C}$ (fig. $5 \mathrm{~A}$ ); 3 , shightly incomplete collapse at $550^{\circ} \mathrm{C}$ (fig. $5 B$ ) or considerable noncollapse (fig. $5 C, D$ ).

Air dried codes: 1.0 , gives $d$-spacing near $12.5 \mathrm{~A} ; 2.0$, gives $d$-spacing near $15 \mathrm{~A}$

Leaders (--), no data; $\S$, less than; $N$, not detected]

\section{TABLE 2}


TABLE 1.-Chemical, mineralogical, and physical-properties data for 226 samples of Pierre Shale and equivalent rocks

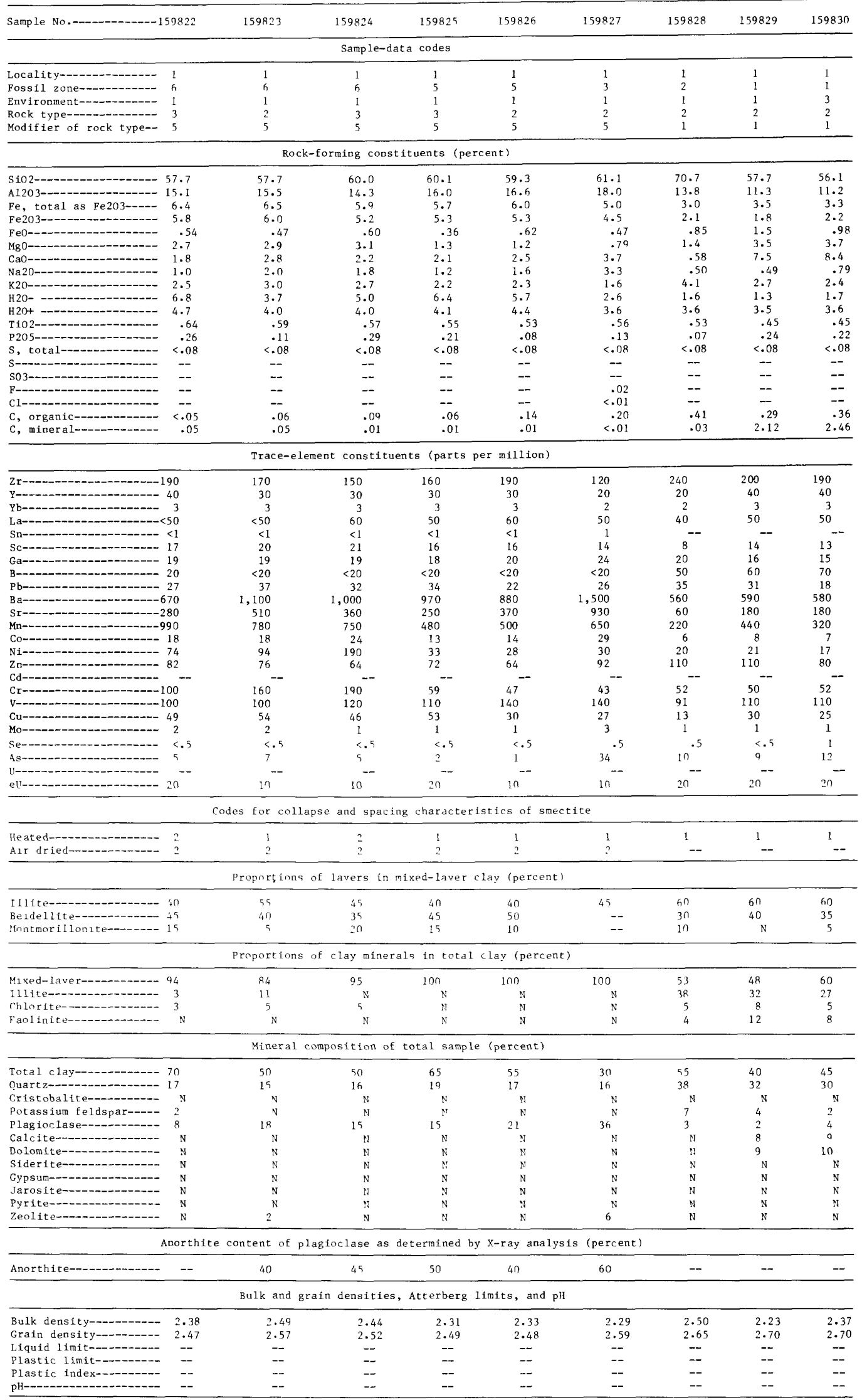


TABLE 1.-Chemical, mineralogical, and physical-properties data for 226 samples of Pierre Shale and equivalent rocks-Continued

\begin{tabular}{|c|c|c|c|c|c|c|c|c|c|}
\hline Sample No.‥--- 1 & 159833 & 159834 & 159835 & 159836 & 159837 & 159838 & 159839 & 159840 & 159841 \\
\hline \multicolumn{10}{|c|}{ Sample-data codes } \\
\hline Locality-_- & 2 & 2 & 2 & 2 & 2 & 2 & 2 & 2 & 2 \\
\hline Fossil zone-- & 5 & 4 & 4 & 4 & 3 & 3 & 2 & 1 & 1 \\
\hline Environment-------- & 2 & 1 & 1 & 1 & 1 & 1 & 1 & 1 & 2 \\
\hline Rock type-- & 3 & 3 & 3 & 1 & 2 & 3 & 3 & 3 & 3 \\
\hline Modifier of rock type-- & 5 & 5 & 5 & 5 & 5 & 5 & 5 & 5 & 1 \\
\hline & & & $c$-forning $c$ & ituents (pe & ent) & & & & \\
\hline S102-二--_- & 57.9 & 61.1 & 54.3 & 67.7 & 52.7 & 59.0 & 65.7 & 64.4 & 63.2 \\
\hline Al203---- & 16.7 & 15.3 & 13.2 & 14.9 & 14.1 & 16.5 & 15.9 & 17.6 & 17.5 \\
\hline $\mathrm{Fe}$, total as $\mathrm{Fe} 203-$ & 7.2 & 4.7 & 4.7 & 1.7 & 8.5 & 6.3 & 3.3 & 3.6 & $4 \cdot 2$ \\
\hline Fe203-- & & 3.6 & 3.6 & 1.3 & 6.9 & 5.0 & 1.9 & 2.0 & 3.4 \\
\hline Fe0-----_- & 1.1 & .96 & .96 & .32 & 1.4 & 1.2 & 1.3 & 1.4 & .71 \\
\hline MgO--_- & 2.0 & 1.8 & 2.1 & 2.1 & 5.7 & 1.8 & 1.3 & 1.4 & 1.2 \\
\hline CaO--_- & 2.6 & 2.7 & 8.4 & 1.2 & 6.1 & 2.0 & 2.0 & .44 & .19 \\
\hline Na 20------ & 2.2 & .39 & .84 & 2.4 & 1.5 & 1.7 & 1.2 & .33 & .82 \\
\hline K20--_- & 3.0 & 3.2 & 3.8 & 2.5 & 2.0 & 3.8 & 2.8 & 3.6 & 3.1 \\
\hline H2O- --- & 3.6 & 4.4 & 3.1 & 1.8 & $4 \cdot 3$ & 3.3 & 2.8 & 3.0 & 3.2 \\
\hline H2O+ - & 3.5 & 4.3 & 3.8 & 4.4 & 2.9 & 3.3 & 3.3 & 4.6 & 5.0 \\
\hline T102- & .68 & .60 & .53 & .24 & .74 & .60 & .51 & .60 & .56 \\
\hline 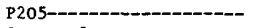 & .16 & .15 & .32 & .07 & .38 & .07 & .01 & .01 & .15 \\
\hline$s$, total- & $<.08$ & $<.08$ & $<.08$ & $<.08$ & $<.08$ & $<.08$ & $<.08$ & $<.08$ & $<.08$ \\
\hline S-1-n & -- & -- & -- & - & -- & -- & - & -- & -- \\
\hline S03- & -- & - & -- & -- & -- & -- & -- & - & - \\
\hline 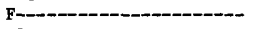 & -- & -- & -- & -- & -- & -- & - & .08 & -- \\
\hline Cl-_- & -- & -- & - & -- & -- & -- & -- & $<.01$ & -- \\
\hline C, organic----- & .06 & .24 & $<.05$ & .07 & .10 & .06 & $<.05$ & .16 & .78 \\
\hline c, mineral-_-_-_. & .08 & .35 & 1.60 & $<.01$ & .02 & .36 & .27 & .02 & $<.01$ \\
\hline & & Trace- & ment const & nts (parts & million) & & & & \\
\hline Zr- & & 170 & 170 & 110 & 120 & 170 & 240 & 200 & 150 \\
\hline Y & & 30 & 30 & 30 & 30 & 20 & 30 & 30 & 30 \\
\hline 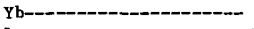 & 3 & 3 & 2 & 3 & 2 & 2 & 3 & 3 & 3 \\
\hline Lam-_-_-_-_- & & 50 & $<50$ & $<50$ & $<50$ & 50 & 60 & 50 & 70 \\
\hline 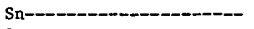 & & 1 & $<1$ & 1 & $<1$ & 4 & 2 & -- & -- \\
\hline 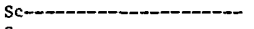 & & 15 & 16 & 8 & 26 & 16 & 9 & 15 & 14 \\
\hline Ga--_-_-_----_---------- & 20 & 20 & 16 & 18 & 18 & 19 & 18 & 24 & 24 \\
\hline 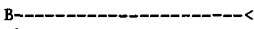 & & 50 & 60 & $<20$ & $<20$ & 50 & 90 & 130 & 110 \\
\hline 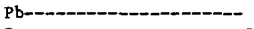 & & 20 & 16 & 20 & 17 & 21 & 18 & 30 & 23 \\
\hline 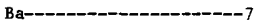 & 740 & 440 & 560 & 1,200 & 560 & 1,200 & 270 & 420 & 820 \\
\hline 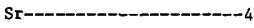 & & 80 & 340 & 1,800 & 780 & 240 & 280 & 110 & 110 \\
\hline 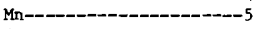 & & 420 & 2,000 & 310 & 1,200 & 640 & 320 & 90 & 50 \\
\hline 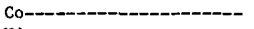 & 14 & 13 & 10 & 4 & 24 & 13 & 5 & 8 & 4 \\
\hline N1-_- & 18 & 24 & 17 & 4 & 11 & 11 & 3 & 19 & 9 \\
\hline 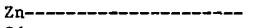 & 66 & 92 & 87 & 34 & 61 & 62 & 61 & 120 & 84 \\
\hline & $0^{--}$ & - & -- & -- & $0^{--}$ & -- & - & -- & -- \\
\hline 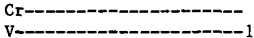 & 48 & 48 & 49 & 20 & 260 & 25 & 6 & 46 & 50 \\
\hline & 130 & 110 & 91 & 25 & 160 & 110 & 120 & 120 & 38 \\
\hline Cu----------------------- & 35 & 24 & 31 & 11 & 40 & 28 & 8 & 31 & 24 \\
\hline Mo--_-_- & 1 & 1 & 1 & $<1$ & 1 & 3 & 2 & 2 & 1 \\
\hline Se----_- & $<.5$ & $<.5$ & $<.5$ & $<.5$ & $<.5$ & $<.5$ & $<.5$ & .5 & 1 \\
\hline As---D-- & 2 & 10 & 38 & 1 & 2 & 1 & 1 & 4 & 3 \\
\hline 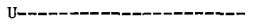 & -- & -- & -- & - & - & -- & -- & -- & -- \\
\hline 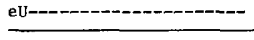 & 20 & 20 & 20 & 10 & 10 & 20 & 20 & 20 & 20 \\
\hline & & des for $c$ & apse and sp & $g$ characte & tics of sme & & & & \\
\hline Heat ed--- & 1 & 1 & 1 & 1 & 1 & 1 & 1 & 1 & 1 \\
\hline Afr dried-- & 1 & -- & -- & 1 & 2 & - & -- & -- & - \\
\hline & & Proporti & of layers & ixed-layer & ay (percent & & & & \\
\hline Illite---_- & 60 & 65 & 80 & 80 & 50 & 75 & 65 & 70 & 60 \\
\hline Beidellite- & 30 & 25 & 10 & -- & 40 & 25 & 35 & 30 & 30 \\
\hline Montmorillonite------- & 10 & 10 & 10 & - & 10 & $\mathrm{~N}$ & $\mathrm{~N}$ & N & 10 \\
\hline & & Proporti & of clay $\mathrm{mi}$ & 1s in tota & lay (percen & & & & \\
\hline Mixed-1ayer-_---_--_-- & 100 & 100 & 100 & 100 & 100 & 97 & 92 & 87 & 72 \\
\hline Illite-- & $\mathrm{N}$ & $\mathrm{N}$ & $\mathrm{N}$ & $\mathrm{N}$ & $\mathrm{N}$ & $\mathrm{N}$ & N & 6 & $2 n$ \\
\hline Chlorite---n-- & $\mathrm{N}$ & $\mathrm{N}$ & $\mathrm{N}$ & $\mathrm{N}$ & $\mathrm{N}$ & 2 & 4 & $\mathrm{~N}$ & 3 \\
\hline Kaolinite- & $\mathrm{N}$ & $\mathrm{N}$ & $\mathrm{N}$ & $\mathrm{N}$ & $\mathrm{N}$ & 1 & 4 & 7 & 5 \\
\hline & & Miner & composition & total samp & (percent) & & & & \\
\hline Total clay-- & 65 & 70 & 60 & 15 & 30 & 70 & 60 & 70 & 65 \\
\hline Quartz-- & 14 & 26 & 16 & 24 & 9 & 18 & 30 & 30 & 27 \\
\hline Cristobalite- & $\mathrm{N}$ & $\mathrm{N}$ & $\mathrm{N}$ & $\mathrm{N}$ & $\mathrm{N}$ & $\mathrm{N}$ & $\mathrm{N}$ & $\mathrm{N}$ & $\mathrm{N}$ \\
\hline Potassium feldspar----- & 2 & 1 & $\mathrm{~N}$ & $\mathrm{~N}$ & $\mathrm{~N}$ & $\mathrm{~N}$ & $\mathrm{~N}$ & $\mathrm{~N}$ & $\mathrm{~N}$ \\
\hline Plagioc lase--- & 20 & 2 & 5 & 21 & 16 & 10 & 7 & 1 & 5 \\
\hline Calcite- & 1 & 3 & 12 & $\mathrm{~N}$ & N & 3 & 2 & $\mathrm{~N}$ & $\mathrm{~N}$ \\
\hline Dolomite-- & $\mathrm{N}$ & $\mathrm{N}$ & $\mathrm{N}$ & $\mathrm{N}$ & $\mathrm{N}$ & $\mathrm{N}$ & $\mathrm{N}$ & $\mathrm{N}$ & $\mathrm{N}$ \\
\hline Siderite-- & $\mathrm{N}$ & $\mathrm{N}$ & $\mathrm{N}$ & $\mathrm{N}$ & $\mathrm{N}$ & $\mathrm{N}$ & $\mathrm{N}$ & $\mathrm{N}$ & $\mathrm{N}$ \\
\hline Gyps um-- & $\mathrm{N}$ & $\mathrm{N}$ & N & $\mathrm{N}$ & $\mathrm{N}$ & $\mathrm{N}$ & N & N & $\mathrm{N}$ \\
\hline Jarosite-- & $\mathrm{N}$ & $\mathrm{N}$ & $\mathrm{N}$ & $\mathrm{N}$ & $\mathrm{N}$ & $\mathrm{N}$ & $\mathrm{N}$ & $\mathrm{N}$ & $\mathrm{N}$ \\
\hline Pyrite--_------ & $\mathrm{N}$ & $\mathrm{N}$ & $\mathrm{N}$ & $\mathrm{N}$ & $\mathrm{N}$ & $\mathrm{N}$ & $\mathrm{N}$ & $\mathrm{N}$ & $\mathrm{N}$ \\
\hline Zeolite-- & N & $\mathrm{N}$ & $\mathrm{N}$ & 10 & $\mathrm{~N}$ & $\mathrm{~N}$ & $\mathrm{~N}$ & $\mathrm{~N}$ & $\mathrm{~N}$ \\
\hline & Anorthi & ontent o & agioclase & etermined & -ray ana 1 & (percent) & & & \\
\hline Anorthite---------- & 40 & 45 & 50 & 30 & 40 & 20 & 15 & - & 20 \\
\hline & & Bulk an & ain densit & Atterberg & $\mathrm{mits}$, and $\mathrm{p}$ & & & & \\
\hline Bulk density- & 2.47 & 2.34 & 2.47 & 2.45 & 2.49 & 2.50 & 2.37 & 2.46 & 2.45 \\
\hline Grain density--------- & 2.61 & 2.57 & 2.61 & 2.49 & 2.64 & 2.54 & 2.62 & 2.64 & 2.60 \\
\hline Liquid limit------- & -- & -- & -- & -- & -- & -- & -- & -- & -- \\
\hline Plastic limit------ & -- & -- & -- & -- & -- & -- & -- & -- & -- \\
\hline Plastic index- & -- & -- & -- & -- & -- & -- & -- & -- & -- \\
\hline pH--- & -- & -- & -- & - & -- & -- & -- & - & -- \\
\hline
\end{tabular}


TABLE 1.-Chemical, mineralogical, and physical-properties data for 226 samples of Pierre Shale and equivalent rocks-Continued

\begin{tabular}{|c|c|c|c|c|c|c|c|c|c|}
\hline Sample Ao.........-1 & 159842 & 159843 & 159844 & 159845 & $15984 \hbar$ & 159847 & 159848 & 159849 & 159850 \\
\hline \multicolumn{10}{|c|}{ Sample-data codes } \\
\hline 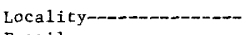 & & 3 & 3 & 3 & 3 & 4 & 4 & 4 & 4 \\
\hline Fossil zone-- & & 4 & 4 & 2 & 2 & 6 & 6 & 5 & 5 \\
\hline $\begin{array}{l}\text { Environment-- } \\
\text { Rock type-- }\end{array}$ & $\begin{array}{l}3 \\
2\end{array}$ & $\begin{array}{l}3 \\
2\end{array}$ & $\begin{array}{l}1 \\
2\end{array}$ & $\frac{1}{2}$ & $\begin{array}{l}1 \\
6\end{array}$ & ${ }_{3}^{1}$ & $\frac{1}{2}$ & $\begin{array}{l}3 \\
2\end{array}$ & $\begin{array}{l}3 \\
3\end{array}$ \\
\hline Modifier of rock type-- & & 1 & 1 & 1 & 8 & 5 & 5 & & \\
\hline \multicolumn{10}{|c|}{ Rock-forming constituents (percent) } \\
\hline sin2--_-_-_-_-_-_-_- & 59.4 & 57.8 & 55.1 & 56.2 & 57.5 & 60.7 & 68.3 & 51.9 & 68.4 \\
\hline A1203-- & 12.9 & 11.6 & 13.3 & 12.8 & 16.9 & 14.2 & 14.2 & 12.2 & 13.9 \\
\hline Fe, total as Fe203---- & 3.7 & 3.6 & 3.8 & 3.9 & 4.0 & 4.0 & $\begin{array}{l}3.7 \\
2.7\end{array}$ & $\begin{array}{l}3.9 \\
3.0\end{array}$ & $\begin{array}{l}5.1 \\
4.4\end{array}$ \\
\hline Fe203-- & $2 \cdot 3$ & $2 \cdot 2$ & 2.5 & 2.8 & 3.7 & 2.8 & 2.7 & 3.0 & $\begin{array}{l}4.4 \\
.60\end{array}$ \\
\hline & $\begin{array}{l}1.3 \\
3.4\end{array}$ & $\begin{array}{l}1.3 \\
4.8\end{array}$ & $\begin{array}{l}1.2 \\
4.1\end{array}$ & $\begin{array}{l}1.0 \\
4.9\end{array}$ & .24 & 1.1 & .86 & .84 & $\begin{array}{l}.60 \\
1.2\end{array}$ \\
\hline CaO- & 5.2 & $\begin{array}{l}4.0 \\
5.4\end{array}$ & $\begin{array}{l}4.1 \\
6.4\end{array}$ & 4.8 & $\begin{array}{l}3.0 \\
1.3\end{array}$ & $\begin{array}{l}2.3 \\
4.4\end{array}$ & ${ }^{1.9} .96$ & $\begin{array}{l}4.44 \\
8.7\end{array}$ & \\
\hline Na20-- & .93 & 1.2 & 1.5 & 1.0 & 2.4 & 1.7 & 1.9 & .95 & .65 \\
\hline K20---_- & 2.6 & 2.2 & 2.8 & 2.5 & .25 & 2.9 & 2.9 & 2.6 & 2.4 \\
\hline H2O- -- & 1.8 & 2.8 & 3.0 & 3.8 & 9.2 & 3.0 & 2.8 & 2.6 & 3.1 \\
\hline H2O+ & 4.0 & 3.2 & 3.1 & 3.7 & 4.7 & 3.4 & 3.3 & 3.4 & 4.4 \\
\hline 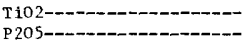 & .51 & .47 & .47 & .49 & .48 & .48 & .49 & .48 & .66 \\
\hline $\begin{array}{l}\text { P205- } \\
\text { s, total- }\end{array}$ & $\begin{array}{r}.17 \\
<.08\end{array}$ & $\begin{array}{l}-14 \\
<08\end{array}$ & $\begin{array}{r}.09 \\
<.08\end{array}$ & $\begin{array}{r}.12 \\
<.08\end{array}$ & $<<07$ & $\begin{array}{r}.18 \\
<08\end{array}$ & $\begin{aligned} .05 \\
<.08\end{aligned}$ & $\begin{array}{r}.19 \\
<.08\end{array}$ & $\begin{array}{r}.12 \\
<.08\end{array}$ \\
\hline & -- & - & $\ldots$ & - & -0 & -0.8 & $<-08$ & -10 & $<.08$ \\
\hline so3-- & -- & -- & -- & -- & -- & -- & - & -- & $\overline{--}$ \\
\hline F-10-- & -- & -- & - & -- & -- & -- & -- & -- & $=$ \\
\hline c, organic-- & .77 & .26 & $<.05$ & $<.05$ & .07 & $<.05$ & $<.05$ & $\overline{.29}$ & .53 \\
\hline c, mineral--- & 1.51 & 1.81 & 1.89 & 1.70 & .04 & .76 & .01 & 2.59 & .02 \\
\hline \multicolumn{10}{|c|}{ Trace-element constituents (parts per million) } \\
\hline 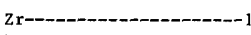 & & 260 & 170 & 190 & 380 & 180 & 180 & 200 & 210 \\
\hline 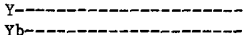 & 30 & 40 & 40 & 40 & 50 & 30 & 30 & 30 & 20 \\
\hline Yba-- & $5^{3}$ & 3 & 3 & 3 & 4 & 3 & 2 & 3 & 3 \\
\hline 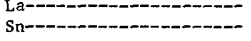 & 50 & 50 & $<50$ & $<50$ & 70 & 50 & 50 & $<50$ & 60 \\
\hline $\mathrm{sc}-$ & 13 & $14^{--}$ & $14^{--}$ & $13^{--}$ & 12 & $\begin{array}{r}4 \\
14\end{array}$ & $\frac{1}{7}$ & $15^{--}$ & $11^{--}$ \\
\hline Gar-..-. & 16 & 14 & 16 & 16 & 18 & 17 & 18 & 15 & 18 \\
\hline B------ & & 70 & 70 & 60 & 30 & 50 & 50 & 80 & 150 \\
\hline 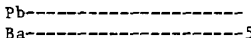 & & 13 & 19 & 20 & 24 & 13 & 17 & 14 & 17 \\
\hline 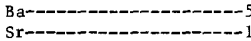 & & 430 & 580 & son & 210 & 610 & 1,100 & 480 & 860 \\
\hline Mr- & & 170 & 280 & 170 & 170 & 240 & 220 & 140 & 80 \\
\hline & & 210 & 260 & 200 & 80 & 300 & & 430 & 90 \\
\hline No-- & $\begin{array}{r}8 \\
24\end{array}$ & $\begin{array}{r}7 \\
20\end{array}$ & 9 & 10 & $<3$ & 9 & $\begin{array}{r}8 \\
15\end{array}$ & 8 & $\begin{array}{r}8 \\
18\end{array}$ \\
\hline $\mathrm{zn}-\cdots$ & 86 & 65 & 62 & 79 & 48 & 68 & 31 & 68 & $\begin{array}{l}16 \\
98\end{array}$ \\
\hline Cd----_--_- & & -- & -- & -- & .4 & - & -- & -- & $<.3$ \\
\hline Cr-- & 51 & 46 & 40 & 42 & 5 & 42 & 30 & 45 & 83 \\
\hline V- & 94 & 81 & 88 & 26 & 25 & 61 & 100 & 88 & 190 \\
\hline Cur- & 20 & 13 & 15 & 17 & 5 & 14 & 27 & 26 & 27 \\
\hline Mo- & 2 & $<<5$ & $1<5$ & 1 & $3<5$ & $<1$ & $<1{ }^{2}$ & $<<.5$ & ${ }^{1} .5$ \\
\hline As-m- & $11{ }^{3}$ & 8 & 4 & $16^{-3}$ & 4 & 4 & 9 & 6 & $13^{.3}$ \\
\hline 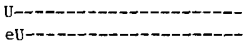 & $10^{--}$ & $10^{--}$ & $20^{--}$ & $20^{--}$ & $10^{--}$ & $10^{--}$ & $20^{--}$ & $20^{--}$ & $30^{--}$ \\
\hline \multicolumn{10}{|c|}{ Codes for collapse and spacing characteristics of smectite } \\
\hline Heated-- & 1 & 1 & 1 & 1 & 1 & 1 & 1 & 1 & 1 \\
\hline Air dried-- & -- & 2 & 1 & 2 & 1 & - & 2 & 2 & 2 \\
\hline \multicolumn{10}{|c|}{ Proportions of layers in mixed-layer clay (percent) } \\
\hline I11ite-- & 75 & 50 & $4 n$ & 40 & $\mathrm{~N}$ & 65 & 50 & 55 & 55 \\
\hline Beidellite-------- & 20 & 35 & 25 & 30 & 18 & 30 & 35 & 35 & 30 \\
\hline Montmarillonite------- & 5 & 15 & 35 & 30 & 82 & 5 & 15 & 10 & 15 \\
\hline \multicolumn{10}{|c|}{ Proportions of clay minerals in total clay (percent) } \\
\hline Mixed-Iayer----_------ & 60 & 70 & 61 & 66 & 100 & 63 & 70 & 67 & 69 \\
\hline Iltite-- & 30 & 22 & 33 & 27 & $\mathrm{~N}$ & 32 & 26 & 25 & 22 \\
\hline Chlorite-- & 6 & 5 & 4 & 4 & $\mathrm{~N}$ & 3 & $\frac{2}{2}$ & 3 & $\mathrm{~N}$ \\
\hline Kaolinite------------ & 4 & 3 & 2 & 3 & $\mathrm{~N}$ & 2 & 2 & 5 & 9 \\
\hline & & Minera & mpositio & total $=$ & le (perce & & & & \\
\hline Total clay- & 55 & 45 & 45 & 50 & 85 & 55 & 50 & 45 & 55 \\
\hline Quartz-- & 29 & 26 & 23 & 23 & 8 & 25 & 28 & 23 & 36 \\
\hline Cristobalite-- & $\mathrm{N}$ & $\mathrm{N}$ & ${ }^{\mathrm{N}}$ & $2^{\mathrm{N}}$ & 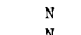 & N & ${ }^{\mathrm{N}}$ & ${ }^{\mathrm{N}}$ & N \\
\hline 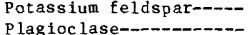 & $5^{N}$ & $9^{\mathrm{N}}$ & 2 & ${ }_{8}^{2}$ & $3^{\mathrm{N}}$ & $12^{\mathrm{N}}$ & $\frac{1}{12}$ & 2 & $4^{N}$ \\
\hline Calcite- & 5 & $\mathrm{~N}$ & 5 & $\mathrm{~N}$ & 1 & 6 & $\mathrm{~N}$ & 7 & $\mathrm{~N}$ \\
\hline Dolomite--- & 7 & 14 & 10 & 13 & $\mathrm{~N}$ & $\mathrm{~N}$ & $\mathrm{~N}$ & 13 & $\mathrm{~N}$ \\
\hline Siderite-- & $\mathrm{N}$ & $\mathrm{N}$ & $\mathrm{N}$ & $\mathrm{s}$ & $\mathrm{N}$ & $\mathrm{N}$ & $\mathrm{N}$ & $\mathrm{N}$ & N \\
\hline 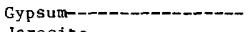 & $\mathrm{N}$ & $\mathrm{N}$ & N & & $\mathrm{N}$ & $\mathrm{N}$ & $M$ & $\mathrm{~N}$ & $\mathrm{~N}$ \\
\hline $\begin{array}{l}\text { Jarosite-- } \\
\text { Pyrite--o-- }\end{array}$ & $\mathrm{N}$ & $\mathrm{N}$ & $\mathrm{N}$ & $\mathrm{N}$ & $\mathrm{N}$ & $\mathrm{N}$ & $\mathrm{N}$ & $\mathrm{N}$ & $\mathrm{N}$ \\
\hline 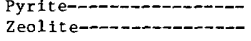 & $\underset{N}{N}$ & $\begin{array}{l}\mathrm{N} \\
\mathrm{N}\end{array}$ & $\stackrel{\mathrm{N}}{\mathrm{N}}$ & $\begin{array}{l}\mathrm{N} \\
\mathrm{N}\end{array}$ & $\begin{array}{l}\mathrm{N} \\
\mathrm{N}\end{array}$ & $\begin{array}{l}\mathrm{N} \\
\mathrm{N}\end{array}$ & $\begin{array}{l}\mathrm{N} \\
\mathrm{N}\end{array}$ & $\begin{array}{l}\mathrm{N} \\
\mathrm{N}\end{array}$ & $\begin{array}{l}\mathrm{N} \\
\mathrm{N}\end{array}$ \\
\hline & Anorthi & ontent of & gioclase & determir & y $x$-ray & ysis (pe & & & \\
\hline Anorthite--- & -- & 20 & 20 & 30 & 40 & 30 & 40 & -- & -- \\
\hline & & Bulk and & in dens $\mathrm{t}$ & , Attert & 1 imits, & & & & \\
\hline Bulk density------- & 2.54 & 2.40 & 2.44 & 2.36 & 2.04 & 2.46 & 2.37 & 2.26 & 2.21 \\
\hline Grain density- & 2.69 & 2.65 & 2.65 & 2.61 & 2.44 & 2.63 & 2.62 & 2.71 & 2.64 \\
\hline $\begin{array}{l}\text { Liquid limit- } \\
\text { Plastic 1imit- }\end{array}$ & -- & $=-$ & $\overline{--}$ & $=$ & $=-$ & $\overline{--}$ & $\bar{z}$ & $\bar{z}+$ & $\overline{--}$ \\
\hline $\begin{array}{l}\text { Plastic index } \\
\text { Plastic inde }\end{array}$ & -- & -- & -- & -- & -- & -- & -- & -- & -- \\
\hline pH-D- & -- & -- & -- & -- & -- & -- & -- & -- & -- \\
\hline
\end{tabular}


TABLE 1.-Chemical, mineralogical, and physical-properties data for 226 samples of Pierre Shale and equivalent rocks-Continued

\begin{tabular}{|c|c|c|c|c|c|c|c|c|c|}
\hline Sample No.---_-_-_- & 159851 & 159852 & 159853 & 159854 & 159855 & 159856 & 159857 & 159858 & 159799 \\
\hline \multicolumn{10}{|c|}{ Sample-đata codes } \\
\hline Locality- & 4 & 4 & 4 & 4 & 4 & 4 & 4 & 4 & 5 \\
\hline Fossil zone--- & 4 & 4 & 4 & 3 & 2 & 1 & 1 & 1 & 5 \\
\hline Environment---------- & 3 & 1 & 1 & 1 & 3 & 1 & 1 & 3 & 3 \\
\hline Rock type-- & 3 & 3 & 3 & 3 & 3 & 3 & 3 & 2 & 2 \\
\hline Modifier of rock type-- & 1 & 1 & 1 & 1 & 1 & 1 & 5 & 1 & 1 \\
\hline & & Rocl & orming cor & ituents ( & cent) & & & & \\
\hline Si02----_- & 66.1 & 62.3 & 65.4 & 66.1 & 56.2 & 68.3 & 64.2 & 51.2 & 61.7 \\
\hline Al203- & 14.0 & 13.7 & 13.4 & 13.4 & 14.9 & 13.8 & 20.6 & 12.2 & 14.2 \\
\hline $\mathrm{Fe}$, total as Fe203-- & 5.3 & 4.2 & 3.8 & 4.2 & 6.2 & $4 \cdot 2$ & 2.7 & 3.5 & 4.6 \\
\hline Fe 203- & 4.9 & 3.0 & 2.7 & 3.6 & 5.2 & 3.2 & 2.5 & 1.5 & 3.3 \\
\hline FeO-n- & .40 & 1.1 & 1.0 & .57 & .88 & .88 & .22 & 1.8 & 1.2 \\
\hline 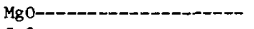 & 1.2 & 3.1 & 2.5 & 2.3 & 3.3 & 1.7 & .58 & 5.5 & 3.0 \\
\hline 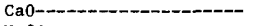 & .38 & 2.5 & 2.0 & .90 & 2.9 & .23 & .24 & 8.0 & 2.4 \\
\hline Na20-n- & .67 & 1.0 & 1.3 & .93 & .88 & .81 & .08 & 1.4 & 1.4 \\
\hline K20--1- & 2.0 & 2.9 & 2.7 & 3.8 & 2.4 & 2.8 & .17 & 2.3 & 2.4 \\
\hline H $20-$ & 4.9 & 2.7 & 2.5 & 4.3 & 3.9 & 3.2 & 3.5 & 1.8 & 3.2 \\
\hline H2O+ - - & 4.5 & 3.7 & 3.5 & 4.0 & 5.4 & 3.9 & 7.6 & 3.2 & 3.9 \\
\hline T102-------- & .60 & .53 & .49 & .50 & .61 & .60 & .85 & .49 & .52 \\
\hline P205- & .07 & .15 & .13 & .25 & .44 & .18 & .01 & .15 & .12 \\
\hline $\mathrm{s}$, tota1- & $<.08$ & $<.08$ & $<.08$ & $<.08$ & $<.08$ & $<.08$ & $<.08$ & .13 & $<.08$ \\
\hline 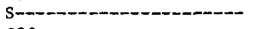 & -- & -- & -- & -- & -- & -- & -- & .07 & -- \\
\hline S03--------- & -- & -- & - & - & - & -- & - & .16 & -- \\
\hline 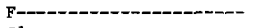 & -- & -- & .07 & -- & -- & -- & -- & -- & $\rightarrow$ \\
\hline 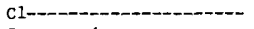 & -- & -- & $<.01$ & -- & -- & -- & -- & -- & -- \\
\hline$c$, organic---- & .61 & $<.05$ & .05 & $<.05$ & .53 & $<.05$ & .17 & .40 & .31 \\
\hline$c$, minera 1-- & $<.01$ & .86 & .67 & .02 & .84 & .01 & $<.01$ & 2.69 & .60 \\
\hline & & Trace-ele & at constit & ats (part & er millio & & & & \\
\hline Zr--1-n- & 150 & 220 & 210 & 220 & 150 & 270 & 330 & 300 & 200 \\
\hline 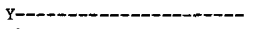 & 20 & 30 & 30 & 30 & 30 & 100 & 30 & 50 & 30 \\
\hline 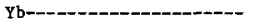 & 2 & 3 & 3 & 3 & 2 & 8 & 3 & 4 & 3 \\
\hline La-- & 50 & 50 & 50 & 60 & 60 & 190 & $<50$ & 90 & 50 \\
\hline 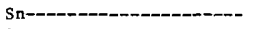 & - & -- & -- & 4 & -- & -- & 1 & -- & -- \\
\hline 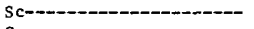 & 16 & 14 & 13 & 14 & 8 & 10 & 12 & 8 & 14 \\
\hline 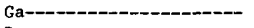 & 18 & 18 & 18 & 18 & 14 & 18 & 25 & 18 & 19 \\
\hline 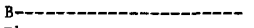 & 120 & 70 & 70 & 70 & 100 & 90 & 110 & 60 & 100 \\
\hline Pb---_--_- & 14 & 14 & 20 & 11 & 10 & 28 & 21 & 25 & 23 \\
\hline Ba-- &, 100 & 610 & 440 & 430 & 300 & 680 & 300 & 240 & 660 \\
\hline 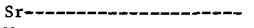 & 150 & 140 & 110 & 120 & 40 & 210 & 30 & 130. & 160 \\
\hline Mn----_- & 70 & 120 & 100 & 180 & 20 & 110 & 40 & 490 & 250 \\
\hline 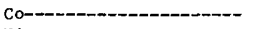 & 10 & 10 & 8 & 9 & 6 & 32 & 3 & $<3$ & 10 \\
\hline 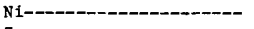 & 13 & 24 & 24 & 25 & 18 & 51 & 6 & 24 & 29 \\
\hline 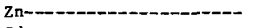 & 89 & 97 & 63 & 78 & 110 & 110 & 30 & 100 & 70 \\
\hline Cd-Den & .4 & - & -- & - & .5 & -- & - & -- & -- \\
\hline Cr--_-_-_-_-_-_-_-_- & 76 & 53 & 54 & 62 & 53 & 48 & 21 & 4 & 70 \\
\hline v-_- & 160 & 86 & 87 & 70 & 130 & 120 & 82 & 76 & 150 \\
\hline Cu-n-_- & 18 & 21 & 17 & 38 & 39 & a & 17 & 14 & 19 \\
\hline 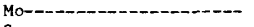 & 2 & $<1$ & $<1$ & $<1$ & 1 & 1 & ' & & 1 \\
\hline 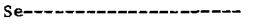 & .5 & $<.5$ & $<.5$ & $<.5$ & .5 & $<.5$ & $<.5$ & $<.5$ & .5 \\
\hline As & 12 & 3 & 4 & 6 & 12 & 4 & 2 & 9 & 14 \\
\hline U- & -- & -- & -- & -- & -- & -- & -- & -- & -- \\
\hline ev-_-_-_-- & 20 & 20 & 20 & 20 & 20 & 20 & $<10$ & 10 & 20 \\
\hline & Co & for colla & and spac & charact & stics of & tite & & & \\
\hline Heated-_- & 1 & 1 & 1 & 1 & 1 & 1 & 3 & 1 & 1 \\
\hline Air dried--_- & 2 & -- & 1 & 2 & 2 & 2 & -- & 2 & 2 \\
\hline & & oportions & layers in & Lxed-1aye & lay (perc & & & & \\
\hline Illite-1- & 45 & 60 & 45 & 55 & 50 & 50 & 20 & 40 & 50 \\
\hline Beidellite-_- & 30 & 35 & 35 & 30 & 35 & 35 & 70 & 35 & 35 \\
\hline Montmorillonite-_- & 25 & 5 & 20 & 15 & 15 & 15 & 10 & 25 & 15 \\
\hline & & oportions & clay mine & Is in tot & clay (per & & & & \\
\hline Mixed-layer-_- & 81 & 72 & 66 & 70 & 70 & 65 & 30 & 47 & 64 \\
\hline Illite-- & 15 & 20 & 26 & 30 & 19 & 28 & $\mathrm{~N}$ & 38 & 24 \\
\hline Chlorite-- & 1 & 3 & 4 & $\mathrm{~N}$ & $\mathrm{~N}$ & 3 & $\mathrm{~N}$ & 10 & 6 \\
\hline Kaolinite-- & 3 & 5 & 4 & $\mathrm{~N}$ & 11 & 4 & 70 & 5 & 6 \\
\hline & & Mineral $c$ & osition o & total sam & (percent & & & & \\
\hline Total clay- & 60 & 55 & 55 & 60 & 60 & 60 & $6 n$ & 45 & 55 \\
\hline Quartz-- & 29 & 28 & 32 & 30 & 22 & 32 & 38 & 20 & 27 \\
\hline Cristobalite- & $\mathrm{N}$ & $\mathrm{N}$ & $\mathrm{N}$ & $\mathrm{N}$ & $\mathrm{N}$ & $\mathrm{N}$ & $\mathrm{N}$ & $\mathrm{N}$ & $\mathrm{N}$ \\
\hline Potassium feldspar---- & $\mathrm{N}$ & 1 & 1 & 1 & 1 & 3 & $\mathrm{~N}$ & 2 & 2 \\
\hline Plagioclase-- & 4 & 5 & 6 & 6 & 6 & 5 & $\mathrm{~N}$ & 9 & 9 \\
\hline Calcite-- & $\mathrm{n}$ & $\mathrm{N}$ & 1 & $\mathrm{~N}$ & $\mathrm{~N}$ & $\mathrm{~N}$ & $\mathrm{~N}$ & 4 & $\mathrm{~N}$ \\
\hline Dolonite--_-_-_L_- & $\mathrm{N}$ & 7 & 4 & $\mathrm{~N}$ & 7 & $\mathrm{~N}$ & N & 17 & 6 \\
\hline Siderite--_--_-_--_--- & $\mathrm{N}$ & $\mathrm{N}$ & $\mathrm{N}$ & $\mathrm{N}$ & $\mathrm{N}$ & $\mathrm{n}$ & $\mathrm{N}$ & $\mathrm{N}$ & $\mathrm{N}$ \\
\hline Gypsum---- & $\mathrm{N}$ & $\mathrm{N}$ & $\mathrm{N}$ & $\mathrm{N}$ & $\mathrm{N}$ & $\mathrm{N}$ & $\mathrm{N}$ & $\mathrm{N}$ & $\mathrm{N}$ \\
\hline Jarosite-- & $\mathrm{N}$ & $\mathrm{N}$ & $\mathrm{N}$ & $\mathrm{N}$ & $\mathrm{N}$ & $\mathrm{N}$ & $\mathrm{N}$ & $\mathrm{N}$ & $\mathrm{N}$ \\
\hline Pyrite-- & $\mathrm{N}$ & $\mathrm{N}$ & $\mathrm{N}$ & $\mathrm{N}$ & $\mathrm{N}$ & $\mathrm{N}$ & $\mathrm{N}$ & $\mathrm{N}$ & $\mathrm{N}$ \\
\hline Zeolite-- & $\mathrm{N}$ & $\mathrm{N}$ & $\mathrm{N}$ & $\mathrm{N}$ & $\mathrm{N}$ & $\mathrm{N}$ & $\mathrm{N}$ & $\mathrm{N}$ & $\mathrm{N}$ \\
\hline & northite & ent of $\mathrm{p} 1$ & oclase as & termined & $x$-ray an & is (per & & & \\
\hline Anorthite--_- & - & 30 & $2 n$ & -- & -- & -- & -- & 30 & $3 n$ \\
\hline & & $11 \mathrm{k}$ and $\mathrm{gr}$ & densitie & Atterber & imits, an & & & & \\
\hline Bulk density--------- & 2.17 & 2.37 & 2.40 & 2.45 & 2.25 & $2 \cdot 32$ & 2.35 & 2,53 & 2.24 \\
\hline Grain density- & 2.57 & 2.64 & 2.68 & 2.57 & 2.61 & 2.59 & 2.54 & 2.68 & 2.65 \\
\hline Liquid limit-------- & - & -- & -- & - & - & -- & -- & -- & -- \\
\hline Plastic limit-------- & - & -- & -- & - & -- & $-\infty$ & -- & - & -- \\
\hline $\begin{array}{l}\text { Plastic index- } \\
\text { pH }\end{array}$ & -- & $=$ & $\ddot{-}$ & -- & -- & -- & -- & -- & -- \\
\hline pH- - & & -- & - & -- & -- & -- & -- & -- & -- \\
\hline
\end{tabular}


TABLE 1.-Chemical, mineralogical, and physical-properties data for 226 samples of Pierre Shale and equivalent rocks-Continued

\begin{tabular}{|c|c|c|c|c|c|c|c|c|c|}
\hline Sample No.--_-_-- & 159800 & 159801 & 159802 & 159803 & 159804 & 159805 & 159806 & 159807 & 159776 \\
\hline \multicolumn{10}{|c|}{ Sample-data codes } \\
\hline Locality--_-_- & 5 & 5 & 5 & 5 & 5 & 5 & 5 & 5 & 6 \\
\hline Fossil zone---- & 4 & 4 & 4 & 3 & 3 & 2 & 2 & 1 & 6 \\
\hline Environment--------- & 4 & 4 & 4 & 1 & 1 & 3 & 3 & 2 & 1 \\
\hline Rock type----- & 1 & 3 & 6 & 2 & 2 & 2 & 3 & 3 & 3 \\
\hline Modifier of rock type-- & 5 & 1 & 8 & 5 & 6 & 5 & 1 & 5 & 1 \\
\hline & & & orming c & ituents ( $\mathrm{p}$ & ent) & & & & \\
\hline Si02- & 26.0 & 62.5 & 65.3 & 57.0 & 72.6 & 62.0 & 60.4 & 55.7 & 57.5 \\
\hline A1203- & 10.7 & 15.7 & 13.6 & 18.7 & 12.7 & 11.9 & 15.1 & 21.6 & 16.3 \\
\hline $\mathrm{Fe}$, total as $\mathrm{Fe} 203-$ & 5.6 & 5.4 & 2.5 & 5.5 & 2.7 & 3.3 & 5.2 & 4.6 & 7.1 \\
\hline Fe203------------ & 3.8 . & 4.4 & 2.3 & 5.0 & 2.3 & 2.4 & 4.0 & 4.3 & 5.7 \\
\hline Fe0---- & 1.6 & .93 & .17 & .41 & .32 & .84 & 1.1 & .24 & 1.3 \\
\hline MgO--D-_-- & 1.1 & 1.4 & 2.1 & 1.4 & .77 & 3.6 & 2.6 & 1.4 & 2.5 \\
\hline $\mathrm{CaO}=$ & 28.8 & .9 & 1.7 & 3.3 & .42 & 4.5 & 1.7 & .92 & 1.1 \\
\hline Na 20-_- & 1.8 & 1.1 & .52 & 2.5 & .52 & .75 & .62 & .74 & .83 \\
\hline K20- & 1.0 & 2.6 & .70 & 2.1 & 2.7 & 2.3 & 2.9 & 1.2 & 3.0 \\
\hline H2O- & 1.7 & 3.7 & 7.5 & 4.6 & 2.6 & 1.9 & 3.3 & 5.2 & 5.6 \\
\hline H $20+$ & 2.1 & 4.9 & 4.4 & 4.0 & 3.7 & 3.3 & 5.1 & 7.7 & 5.1 \\
\hline TiO2- & .52 & .66 & .10 & .57 & .62 & .45 & .62 & 1.00 & .67 \\
\hline P205-- & .37 & .22 & .05 & .13 & .02 & .17 & .18 & .05 & .20 \\
\hline $\mathrm{s}$, total & 2.14 & $<.08$ & $<.08$ & $<.08$ & $<.08$ & $<.08$ & $<.08$ & $<.08$ & $<.08$ \\
\hline 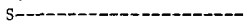 & 2.10 & -- & -- & - & -- & - & -- & -- & -- \\
\hline S03- & .10 & -- & -- & -- & -- & -- & -- & - & -- \\
\hline F--- & -- & -- & -- & .05 & -- & - & -- & -- & -- \\
\hline Cl-m-n- & -- & -- & -- & .01 & - & -- & -- & -- & -- \\
\hline c, organic-- & .19 & .71 & .09 & .20 & .84 & .18 & .51 & .22 & .73 \\
\hline$c$, mineral-_. & 5.16 & .03 & .10 & .05 & .05 & 1.52 & .53 & .05 & .01 \\
\hline & & Trace-e & nt const & nts (parts & $r$ million & & & & \\
\hline Zr-- & 140 & 170 & 60 & 180 & 270 & 220 & 140 & 340 & 170 \\
\hline 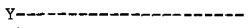 & $<30$ & 40 & 20 & 30 & 40 & 30 & 30 & 80 & 40 \\
\hline Yb-- & $<3$ & 4 & 2 & 3 & 3 & 3 & 3 & 6 & 3 \\
\hline La----- & $<50$ & 50 & $<50$ & $<50$ & 80 & 50 & $<50$ & 120 & $<50$ \\
\hline Sn----1- & $<1$ & -- & 3 & 2 & -- & 2 & -- & -- & -- \\
\hline Sc--1-- & 9 & 18 & 6 & 15 & 9 & 14 & 17 & 18 & 18 \\
\hline Ga-D- & 15 & 22 & 16 & 20 & 12 & 17 & 18 & 23 & 19 \\
\hline B-C. - & $<20$ & 80 & 30 & $<20$ & 50 & 70 & 90 & 70 & 50 \\
\hline 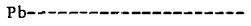 & 13 & 16 & 26 & 25 & 23 & 25 & 30 & 19 & 36 \\
\hline 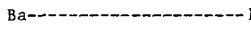 & 200 & 590 & 160 & 1,200 & 460 & 540 & 550 & 450 & 710 \\
\hline Sr-n--n-- & 660 & 160 & 210 & 660 & 80 & 100 & 80 & 100 & 300 \\
\hline Mn--- &, 000 & 240 & 220 & 380 & 30 & 320 & 250 & 110 & 240 \\
\hline 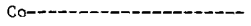 & 8 & 12 & $<4$ & 12 & 4 & 9 & 9 & 19 & 24 \\
\hline Ni-------- & 18 & 34 & 4 & 23 & 7 & 24 & 32 & 11 & 90 \\
\hline Zn- & 70 & 90 & 39 & 74 & 49 & 74 & 100 & 120 & 120 \\
\hline 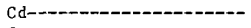 & -- & $<\cdot 3$ & .3 & -- & .4 & - & .3 & -- & -- \\
\hline Cr-D-- & 6 & 93 & 5 & 54 & 51 & 54 & 94 & 30 & 110 \\
\hline 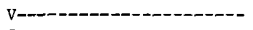 & 90 & 180 & 17 & 110 & 49 & 100 & 150 & 130 & 150 \\
\hline Cu--.-- & 13 & 18 & 4 & 47 & 16 & 18 & 16 & 22 & 74 \\
\hline Mo--1-- & 2 & 1 & 4 & 2 & 1 & 1 & 1 & 2 & $<1$ \\
\hline 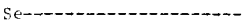 & $<.5$ & .5 & $<.5$ & $<.5$ & $<.5$ & $<.5$ & .5 & $<.5$ & $<.5$ \\
\hline As-a-n- & 4 & 7 & 1 & 4 & 3 & 12 & 15 & 2 & 3 \\
\hline 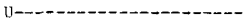 & & -- & -- & -- & -- & $\cdots$ & -- & -- & -- \\
\hline e & $<10$ & $2 n$ & in & 20 & 20 & 20 & 30 & 10 & 10 \\
\hline & & is for $\mathrm{col}$ & e and $s p$ & ig characte & tics of $s$ & ite & & & \\
\hline Heated---- & 1 & 1 & 1 & 1 & 1 & 1 & 1 & 3 & 2 \\
\hline Air dried-- & -- & 2 & $?$ & 2 & ? & 2 & 2 & 2 & 2 \\
\hline & & roportion & lavers & lixed-layer & av (perce & & & & \\
\hline I 111 te--- & 30 & 55 & v & in & 50 & 55 & 55 & 25 & 50 \\
\hline Beidellite-- & $4 n$ & 45 & 35 & 45 & 35 & in & 35 & 60 & 45 \\
\hline Montmorillonite--_-_---- & 30 & in & 65 & 5 & 15 & 5 & 10 & 15 & 5 \\
\hline & & ruportion & clay mi & $1 s$ in tote & lay (perc & & & & \\
\hline Mixed-1ayer---- & 88 & 75 & 100 & 100 & 69 & 54 & 69 & 66 & 93 \\
\hline Illite---10--1 & $\mathrm{N}$ & 17 & $\mathrm{~N}$ & $\mathrm{~N}$ & 21 & 32 & 20 & $\mathrm{~N}$ & $\mathrm{~N}$ \\
\hline Chlorite- & $\mathrm{N}$ & 3 & $\mathrm{~N}$ & N & $\mathrm{N}$ & 5 & 4 & $\mathrm{~N}$ & 3 \\
\hline Kaolinite-- & 12 & 5 & $\mathrm{~N}$ & $\mathrm{~N}$ & 10 & 9 & 7 & 34 & 4 \\
\hline & & Mineral & pposition & total sam & (percent) & & & & \\
\hline Total clay- & 15 & 70 & 75 & 60 & 50 & 35 & 60 & 75 & 65 \\
\hline Qุuartz-.............. & 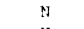 & 26 & 27 & 11 & 45 & 34 & 27 & 16 & 16 \\
\hline Cristobalite---------- & $\mathrm{N}$ & $\mathrm{N}$ & $\mathrm{N}$ & $\mathrm{N}$ & $\mathrm{N}$ & $\mathrm{N}$ & $\mathrm{N}$ & $\mathrm{N}$ & $\mathrm{N}$ \\
\hline Potassium feldspar---.- & $\mathrm{N}$ & 1 & $\mathrm{~N}$ & $\mathrm{~N}$ & 4 & 1 & $\mathrm{~N}$ & 1 & 4 \\
\hline Plag foclase-- & 38 & h & $\mathrm{N}$ & 24 & 3 & 4 & 4 & 6 & 4 \\
\hline Calcite-- & 35 & $\mathrm{~N}$ & 1 & $\mathrm{~N}$ & $\mathrm{~N}$ & 3 & $\mathrm{~N}$ & $\mathrm{~N}$ & $\mathrm{~N}$ \\
\hline Dolomite-n & $\mathrm{N}$ & $\mathrm{N}$ & $\mathrm{N}$ & $\mathrm{N}$ & "1 & 10 & 4 & $\mathrm{~N}$ & $\mathrm{~N}$ \\
\hline Siderite------------ & $\mathrm{N}$ & $\mathrm{N}$ & $\mathrm{N}$ & $\mathrm{N}$ & $\mathrm{N}$ & $\mathrm{N}$ & $\mathrm{N}$ & $\mathrm{N}$ & $\mathrm{N}$ \\
\hline Gypsum--1- & $\mathrm{N}$ & $\mathrm{M}$ & $\mathrm{N}$ & $\mathrm{N}$ & $\mathrm{N}$ & $\mathrm{N}$ & $\mathrm{N}$ & $\mathrm{N}$ & $\mathrm{N}$ \\
\hline Jarosite-------- & $\mathrm{N}$ & $\mathbb{N}$ & $\mathrm{N}$ & $\mathrm{N}$ & N & $\mathrm{N}$ & $\mathrm{N}$ & $\mathrm{N}$ & $\mathrm{N}$ \\
\hline Pyrite----- & N & $\mathrm{N}$ & $\mathrm{N}$ & $\mathrm{N}$ & $\mathrm{N}$ & $\mathrm{N}$ & $\mathrm{N}$ & $\mathrm{N}$ & $\mathrm{N}$ \\
\hline Zeolite--n-_- & $\mathrm{N}$ & N & N & $\mathrm{N}$ & N & $\mathrm{N}$ & $\mathrm{N}$ & N & N \\
\hline & northite & ntent of & ioclase & letermined & $X-r a y$ ana & is (perce & & & \\
\hline Anorthite--- & -- & 20 & -- & 40 & -- & -- & 30 & 30 & -- \\
\hline & & Bulk and & in densit & Atterber & mits, and & & & & \\
\hline Bulk density------ & 2.62 & 2.21 & 1.96 & 2.29 & 2.18 & 2.41 & 2.29 & 2.26 & 2.24 \\
\hline Grain density------- & 2.73 & 2.58 & 2.47 & 2.52 & 2.60 & 2.63 & 2.62 & 2.45 & 2.52 \\
\hline Liquid limit-- & -- & - & - & -- & -- & - & -- & - & -- \\
\hline Plastic limit-------- & -- & -- & -- & -- & -- & -- & -- & -- & -- \\
\hline Plastic index------ & -- & - & -- & -- & -- & -- & -- & -- & - \\
\hline pH- - & - & -- & -- & -- & -- & -- & -- & -- & -- \\
\hline
\end{tabular}


COMPOSITION AND PROPERTIES, NORTHERN GREAT PLAINS REGION

TABLE 1.-Chemical, mineralogical, and physical-properties data for 226 samples of Pierre Shale and equivalent rocks-Continued

\begin{tabular}{|c|c|c|c|c|c|c|c|c|c|}
\hline Sample No.--_---_--- & 159777 & 159778 & 159779 & 159780 & 159781 & 159782 & 159783 & 159784 & 159785 \\
\hline \multicolumn{10}{|c|}{ Sample-data codes } \\
\hline Locality--_-_-_-_-_--- & 6 & 6 & 6 & 6 & 6 & 6 & 6 & 6 & 6 \\
\hline Fossil zone-- & 6 & 5 & 5 & 5 & 4 & 3 & 2 & 1 & 1 \\
\hline Environment--_---_--- & 1 & 3 & 3 & 1 & 1 & 1 & 3 & 2 & 3 \\
\hline Rock type-- & 1 & 3 & 3 & 3 & 3 & 2 & 2 & 3 & 3 \\
\hline Modifier of rock type-- & 5 & 1 & 1 & 6 & 1 & 1 & 1 & 6 & 1 \\
\hline \multicolumn{10}{|c|}{ Rock-forming constituents (percent) } \\
\hline SiO2-_- & 62.5 & 63.6 & 61.1 & 69.5 & 67.7 & 62.7 & 61.7 & 55.0 & 61.3 \\
\hline A1203-- & 17.3 & 14.6 & 16.4 & 13.8 & 15.6 & 13.0 & 11.9 & 20.0 & 14.3 \\
\hline $\mathrm{Fe}$, total as $\mathrm{Fe} 203$ & 5.4 & 5.1 & 6.0 & 2.6 & 3.8 & 4.3 & 3.6 & 4.3 & 4.6 \\
\hline Fe203- & 2.2 & 3.8 & 4.1 & 1.8 & 2.9 & 2.6 & 1.7 & 3.8 & 3.8 \\
\hline Fe0---- & 2.9 & 1.2 & 1.7 & .74 & .80 & 1.5 & 1.7 & .49 & .74 \\
\hline MgO--_--_- & 1.7 & 2.2 & 2.1 & .78 & 1.5 & $3 \cdot 3$ & 4.0 & .81 & 2.9 \\
\hline $\mathrm{CaO}---1-1-$ & 2.6 & 1.2 & 1.3 & .38 & .80 & 3.5 & 4.3 & .37 & 2.9 \\
\hline Na 20-_- & 4.3 & 1.3 & 1.3 & .93 & 1.4 & 1.3 & 1.4 & .28 & .57 \\
\hline 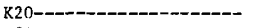 & 1.6 & 2.6 & 3.0 & 2.6 & 2.5 & 2.6 & 2.5 & 1.6 & 2.9 \\
\hline H $20-$ & 1.3 & 3.8 & 3.8 & 3.1 & 3.6 & 1.9 & 1.6 & 4.8 & 3.4 \\
\hline H2O+ - & 2.7 & 3.8 & 4.8 & 3.9 & 3.4 & 3.2 & 2.9 & 7.3 & 4.1 \\
\hline 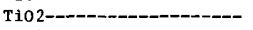 & .61 & .59 & .59 & .53 & .53 & .49 & .50 & 1.00 & .54 \\
\hline P205- & .27 & .13 & .17 & .02 & .02 & .13 & .15 & .06 & .18 \\
\hline $\mathrm{s}$, total- & $<.08$ & $<.08$ & $<.08$ & $<.08$ & $<.08$ & $<.08$ & .16 & $<.08$ & $<.08$ \\
\hline S-- & -- & -- & -- & -- & -- & -- & $<.01$ & -- & -- \\
\hline so3-- & -- & -- & -- & -- & -- & -- & .40 & -- & -- \\
\hline F---1- & -- & .07 & -- & -- & -- & -- & -- & -- & -- \\
\hline Cl---_- & -- & .04 & -- & -- & -- & -- & -- & -- & - \\
\hline c, organic--_-_-_---- & .11 & .26 & .62 & 1.81 & .13 & .25 & .42 & 4.29 & .34 \\
\hline c, mineral-_-_-_- & .09 & .13 & .10 & $<.01$ & $<.01$ & 1.25 & 1.56 & .04 & .84 \\
\hline & & Trace-ele & it constit & its (part: & er millior & & & & \\
\hline Zr-_- & 150 & 160 & 160 & 220 & 260 & 220 & 220 & 310 & 130 \\
\hline Y-- & 20 & 30 & 30 & 30 & 20 & 30 & 30 & 70 & 30 \\
\hline $\begin{array}{l}\mathrm{Yb}---1-1- \\
\mathrm{La}-\end{array}$ & 3 & 3 & 3 & 2 & 2 & 3 & 3 & 5 & 3 \\
\hline Lan--_- & 70 & $<50$ & $<50$ & 60 & 50 & $<50$ & 50 & 110 & 50 \\
\hline 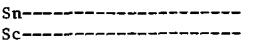 & $<1$ & $16^{--}$ & -- & -- & -- & -- & -- & - & -- \\
\hline Sc--_-_-_- & 18 & $\begin{array}{l}16 \\
17\end{array}$ & 17 & 8 & 8 & 13 & 13 & 22 & 14 \\
\hline Ba--- & $\begin{array}{r}20 \\
<20\end{array}$ & $\begin{array}{l}17 \\
80\end{array}$ & 21 & 18 & 18 & 16 & 18 & 22 & 17 \\
\hline & $\begin{array}{r}20 \\
18\end{array}$ & 20 & $\begin{array}{r}100 \\
26\end{array}$ & $\begin{array}{r}120 \\
20\end{array}$ & $\begin{array}{l}80 \\
28\end{array}$ & $\begin{array}{l}80 \\
24\end{array}$ & $\begin{array}{l}80 \\
22\end{array}$ & $\begin{array}{r}120 \\
36\end{array}$ & $\begin{array}{r}120 \\
32\end{array}$ \\
\hline Ba--_- 1 & 400 & 650 & 740 & 590 & 510 & 550 & 540 & 380 & 570 \\
\hline 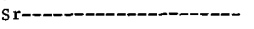 & 600 & 160 & 220 & 140 & 260 & 120 & 150 & 110 & 100 \\
\hline Mn----- & 380 & 290 & 230 & 40 & 90 & 270 & 210 & 40 & 200 \\
\hline Co----_--_-_- & 14 & 13 & 13 & 4 & 5 & 11 & 9 & 17 & 8 \\
\hline Ni-_-_. & 43 & 37 & 39 & 8 & 12 & 24 & 25 & 15 & 23 \\
\hline Zn--_-n- & 75 & 99 & 96 & 59 & 52 & 75 & 92 & 120 & 100 \\
\hline Cd--_-_-_--- & - & -- & .3 & .4 & - & -- & -- & .3 & \\
\hline 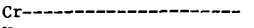 & 220 & 83 & 96 & 49 & 41 & 58 & 60 & 48 & 68 \\
\hline v---_-_-_-_-_- & 130 & 140 & 160 & 100 & 92 & 110 & 120 & 170 & 180 \\
\hline Cu--_-_-_-_-_-_- & 31 & 7 & 30 & 7 & 13 & 20 & 14 & 35 & 23 \\
\hline 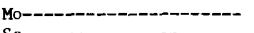 & 1 & 1 & 2 & I & 1 & 1 & 1 & 1 & 2 \\
\hline 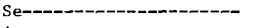 & $<.5$ & $<.5$ & 1 & 1 & $<.5$ & $<.5$ & .5 & $<.5$ & $<.5$ \\
\hline 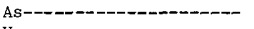 & 2 & 10 & 13 & 5 & 4 & 14 & 10 & 7 & 12 \\
\hline U-U- & $10^{--}$ & $20^{--}$ & $20^{--}$ & $10^{--}$ & $10^{--}$ & $20^{--}$ & $10^{--}$ & $10^{--}$ & $20^{--}$ \\
\hline & co & for colla & and spac & characte & stics of $s$ & tite & & & \\
\hline 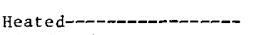 & 2 & I & 1 & 1 & 1 & 1 & 1 & 1 & 1 \\
\hline Air dried-_- & -- & 2 & 2 & 1 & 2 & - & - & 2 & 2 \\
\hline & & portions & 1ayers in & xed-1ayer & Iay (perce & & & & \\
\hline I11ite- & $6 n$ & 50 & 50 & 45 & 55 & 60 & $6 n$ & 45 & 50 \\
\hline Beidellite-- & 30 & 40 & 40 & 45 & 40 & 35 & 35 & 50 & 40 \\
\hline Montmorillonite-- & 10 & 10 & 10 & 10 & 5 & 5 & 5 & 5 & 10 \\
\hline & & portions & clay mine & s in tota & clay (perc & & & & \\
\hline Mixed-layer--_-_-_-_-_- & 38 & 62 & 64 & 68 & 86 & 50 & 46 & 56 & 53 \\
\hline Ill ite-- & 12 & 29 & 25 & 23 & 9 & 32 & 37 & in & 40 \\
\hline Chlorite-- & 34 & 5 & 4 & $\mathrm{~N}$ & N & 6 & 6 & $N$ & 4 \\
\hline Kaolinite-- & 16 & 4 & 7 & 9 & 5 & 12 & 11 & 34 & 3 \\
\hline & & Mineral & osition o & cotal samp & (percent) & & & & \\
\hline Tota1 clay=- & 20 & 65 & 60 & 55 & 60 & 40 & 45 & 70 & 60 \\
\hline Quartz-- & 21 & 25 & 23 & 38 & 30 & 32 & 32 & 23 & 28 \\
\hline Cristobalite- & $\mathrm{N}$ & $\mathrm{N}$ & $\mathrm{N}$ & ? & $\mathrm{N}$ & $\mathrm{N}$ & $\mathrm{N}$ & $\mathrm{N}$ & $\mathbb{N}$ \\
\hline Potassium feldspar----- & $\mathrm{N}$ & $\mathrm{N}$ & 2 & 2 & $\mathrm{M}$ & 2 & 2 & $\mathrm{~N}$ & $\mathrm{~N}$ \\
\hline Plagioclase-- & 30 & 7 & 10 & 6 & 9 & 9 & 10 & $\mathrm{~N}$ & 3 \\
\hline Calcite--- & $\mathrm{N}$ & 1 & $\mathrm{~N}$ & $\mathrm{~N}$ & $\mathrm{~N}$ & $\mathrm{~N}$ & $\mathrm{~N}$ & n & $\mathrm{N}$ \\
\hline nolomite---_- & $\mathrm{N}$ & $\mathrm{N}$ & 1 & N & N & 9 & 12 & $\mathrm{~N}$ & 7 \\
\hline Siderite--_-_-_-_-_-- & n & PI & $\mathrm{N}$ & $\mathrm{N}$ & n & $\mathrm{M}$ & $\mathrm{N}$ & $\mathrm{N}$ & $\mathrm{N}$ \\
\hline Gypsum- & $\mathrm{N}$ & $\mathrm{N}$ & n & $n$ & $\mathrm{~N}$ & $\mathrm{~N}$ & $\mathrm{~N}$ & $\mathrm{~N}$ & $\mathrm{~N}$ \\
\hline Jarosite-- & $\mathrm{N}$ & $\mathrm{N}$ & $\mathrm{N}$ & $\mathrm{N}$ & N! & $\mathrm{N}$ & $\mathrm{N}$ & $\mathrm{N}$ & $\mathrm{N}$ \\
\hline Pyrite-- & n & $\mathrm{N}$ & $\mathrm{N}$ & 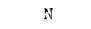 & $\mathrm{N}$ & $\mathrm{N}$ & $\mathrm{N}$ & 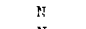 & NT \\
\hline Zeolite--- & $\mathrm{N}$ & $\mathrm{v}$ & n! & $\mathrm{N}$ & $\mathrm{N}$ & $\$$ & $\mathrm{~N}$ & $\mathrm{~N}$ & $\mathrm{~N}$ \\
\hline & northite & tent of $\mathrm{pl}$ & loclase as & termined & $y$-ray an & is (perc & & & \\
\hline Anor thite---- & 40 & 30 & 20 & $2 n$ & 30 & $2 n$ & -- & -- & -- \\
\hline & & $\mathrm{s} \mathrm{k}$ and $\mathrm{gr}$ & densitic & Atterber & imits, anc & & & & \\
\hline Bulk density--_-_----- & 2.34 & 2.31 & 2.27 & 2.21 & 2.32 & 2.41 & $2.5 n$ & 2.18 & 2.28 \\
\hline Grain density-- & 2.66 & 2.63 & 2.63 & 2.56 & 2.56 & 2.ha & 2.68 & 2.49 & 2.65 \\
\hline Liquid limit-- & -- & - & - & -- & -- & -- & -- & -- & -- \\
\hline Plastic limit---- & -- & -- & -- & -- & -- & -- & -- & -- & -- \\
\hline Plastic index- & -- & $\overline{-}$ & -- & -- & -- & $\overline{--}$ & - & $\begin{array}{l}-- \\
--\end{array}$ & $\overline{-}$ \\
\hline pH--D-D-- & & -- & -- & -- & -- & -- & -- & -- & - \\
\hline
\end{tabular}


TABLE 1.-Chemical, mineralogical, and physical-properties data for 226 samples of Pierre Shale and equivalent rocks-Continued

\begin{tabular}{|c|c|c|c|c|c|c|c|c|}
\hline 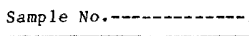 & 59786 & 159763 & 159764 & 159765 & 159766 & 159767 & $\mathrm{C} 870$ & 159768 \\
\hline \multicolumn{9}{|c|}{ Sample-dat a codes } \\
\hline Locality- & 6 & 7 & 7 & 7 & 7 & 7 & 7 & 7 \\
\hline Fossil zone--- & 1 & 5 & 5 & 5 & 4 & 3 & 2 & 2 \\
\hline Environment---- & 3 & 3 & 1 & 1 & 1 & 1 & 3 & 3 \\
\hline Rock type-- & 2 & 2 & 3 & 6 & 3 & 2 & 3 & 2 \\
\hline Modifier of rock type-- & 1 & 1 & 6 & 8 & 1 & 1 & 1 & 1 \\
\hline \multicolumn{9}{|c|}{ Rock-forming constituents (percent) } \\
\hline SiO2-- & 61.8 & 63.0 & 69.5 & 58.2 & 65.0 & 73.0 & 58.97 & 65.7 \\
\hline A1 203 & 11.9 & 15.1 & 13.9 & 17.5 & 15.0 & 13.1 & 12.78 & 11.5 \\
\hline $\mathrm{Fe}$, total as Fe203---- & 2.5 & 5.8 & 2.9 & 4.6 & 4.5 & 2.1 & 4.23 & 3.4 \\
\hline $\mathrm{Fe} 203-$ & 1.4 & 4.6 & 2.5 & 4.1 & 3.2 & 1.8 & 3.23 & 2.6 \\
\hline 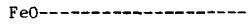 & .95 & 1.1 & .35 & .43 & 1.2 & .31 & .90 & .76 \\
\hline MgO------ & 4.2 & 2.0 & .77 & 2.8 & 1.6 & 1.0 & 3.52 & $3 \cdot 1$ \\
\hline 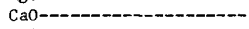 & 5.0 & 1.1 & .29 & 1.5 & .58 & .11 & 4.3 & 3.1 \\
\hline Na20-- & 1.2 & 1.0 & .55 & 2.2 & 1.8 & .76 & .72 & 1.3 \\
\hline K20---1-- & 2.5 & 3.3 & 2.3 & .44 & 3.1 & 2.2 & 2.41 & 2.3 \\
\hline H2O- - - & 1.7 & 3.2 & 3.0 & 7.9 & 3.0 & 2.4 & 2.73 & 2.2 \\
\hline $\mathrm{H} 2 \mathrm{O}+$ & 2.4 & $4 \cdot 6$ & 4.7 & 4.5 & 3.9 & $4 \cdot 2$ & 3.5 & 2.6 \\
\hline TiO2-- & .47 & .50 & .57 & .33 & .52 & .62 & .56 & .49 \\
\hline P205-_- & .17 & .23 & .04 & .01 & .12 & .02 & .19 & .17 \\
\hline s, total-- & $<.08$ & $<.08$ & $<.08$ & $<.08$ & $<.08$ & $<.08$ & .30 & $<.08$ \\
\hline 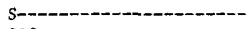 & -- & -- & -- & -- & -- & -- & $<.01$ & -- \\
\hline So3-- & -- & - & -. & -- & -- & -- & .74 & -- \\
\hline F-1- & -- & -- & -- & - & -- & .05 & .07 & -- \\
\hline 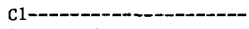 & -- & -- & -- & -- & -- & $<.01$ & .01 & -- \\
\hline c, organic----n--- & .28 & .36 & 1.53 & $<.05$ & .96 & .37 & .40 & .22 \\
\hline c, mineral-_-_------ & 1.86 & .01 & $<.01$ & .04 & .01 & .03 & 1.25 & .96 \\
\hline & & Trace-e & constit & (parts $p$ & illion) & & & \\
\hline 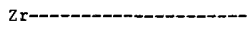 & & 190 & 260 & 190 & 160 & 300 & 150 & 210 \\
\hline 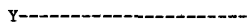 & & 30 & 30 & 20 & 40 & 40 & 15 & 20 \\
\hline 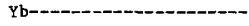 & & 3 & 2 & 2 & 4 & 4 & 3 & 2 \\
\hline 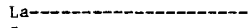 & 50 & $<50$ & 60 & 60 & 60 & 80 & 30 & $<40$ \\
\hline 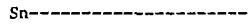 & -- & - & 1 & 2 & 3 & - & -- & -- \\
\hline Sc----1-- & 10 & 16 & 8 & 6 & 14 & 12 & 15 & 10 \\
\hline 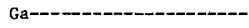 & & 19 & 18 & 18 & 22 & 16 & 7 & 14 \\
\hline B-- & & 70 & 90 & 30 & 50 & 80 & 70 & 80 \\
\hline $\mathrm{Pb}$ b---- & & 39 & 39 & 38 & 34 & 39 & 15 & 30 \\
\hline Ba----D- & & 620 & 460 & 360 & 530 & 510 & 300 & 660 \\
\hline 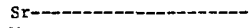 & 170 & 150 & 100 & 190 & 180 & 120 & 150 & 110 \\
\hline Mn---_-_-_-_-_-_-_-_-- & & 350 & 70 & 140 & 210 & 60 & 230 & 150 \\
\hline 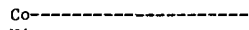 & 6 & 12 & 4 & 2 & 16 & 4 & 7 & 7 \\
\hline 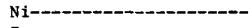 & 12 & 38 & 11 & 4 & 37 & 12 & 30 & 16 \\
\hline 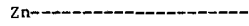 & 52 & 110 & 64 & 44 & 90 & 76 & 130 & 83 \\
\hline 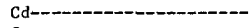 & -- & -- & .4 & .4 & .5 & -- & .5 & .3 \\
\hline 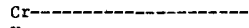 & 45 & 97 & 47 & 6 & 50 & 49 & 70 & 54 \\
\hline 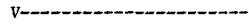 & 100 & 120 & 58 & 30 & 58 & 40 & 150 & 130 \\
\hline 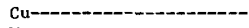 & 10 & 23 & 14 & 8 & 25 & 15 & 30 & 18 \\
\hline 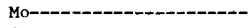 & $<1$ & 3 & 2 & 1 & 3 & $<1$ & $<10$ & 2 \\
\hline Se-- & $<.5$ & 1 & 1 & $<.5$ & $<.5$ & 1 & 1 & .5 \\
\hline As-- & 5 & 14 & 7 & 1 & 5 & 4 & 13 & 9 \\
\hline U-U-- & $10^{--}$ & $20^{--}$ & $10^{--}$ & $<10^{--}$ & $20^{--}$ & $10^{--}$ & $\begin{array}{r}<10 \\
10\end{array}$ & $10^{--}$ \\
\hline & & for $c o l$ & and spac & haracteri & $s$ of smect & & & \\
\hline Heated-_-_-_-_-_-_-_- & 1 & 1 & 1 & 1 & I & 1 & 1 & 1 \\
\hline Air dried-- & 2 & 2 & -- & 1 & 1 & 1 & 2 & 2 \\
\hline & & roportion & layers in & $d$-layer $c$ & (percent) & & & \\
\hline Illite-n-_-_-_-_-_-_- & 55 & 50 & 45 & $\mathrm{~N}$ & 40 & 50 & 55 & 35 \\
\hline Beidelitite-- & 35 & 40 & 40 & 13 & 40 & 40 & - & 40 \\
\hline Montmorillonite--- & 10 & 10 & 15 & 87 & 20 & 10 & -- & 25 \\
\hline & & toportion & clay mine & in tota 1 & (percent) & & & \\
\hline Mixed-layer---_-_-_-_ & 55 & 65 & 62 & 100 & 55 & 57 & 57 & 67 \\
\hline Illite-- & 28 & 26 & 21 & $\mathrm{~N}$ & 35 & 25 & 30 & 25 \\
\hline Chlorite--- & 6 & 6 & $\mathrm{~N}$ & $\mathrm{~N}$ & 4 & $\mathrm{~N}$ & 7 & 3 \\
\hline Kaolinite- & 11 & 3 & 17 & $\mathrm{~N}$ & 6 & 18 & 6 & 5 \\
\hline & & Mineral & & & rcent) & & & \\
\hline Total clay-- & 40 & 55 & 55 & 80 & 60 & 50 & 60 & 45 \\
\hline Quartz-- & 31 & 27 & 40 & 10 & 29 & 45 & 27 & 35 \\
\hline Cristobalite--- & $\mathrm{N}$ & $\mathrm{N}$ & $\mathrm{N}$ & $\mathrm{N}$ & $\mathrm{N}$ & $\mathrm{N}$ & $\mathrm{N}$ & $\mathrm{N}$ \\
\hline Potassium feldspar-- & 2 & 2 & 2 & $\mathrm{~N}$ & $\mathrm{~N}$ & 2 & $\mathrm{~N}$ & 3 \\
\hline Plagioclase-- & 8 & 7 & 4 & 5 & 8 & 4 & 3 & 7 \\
\hline Calcite-- & $\mathrm{N}$ & $\mathrm{N}$ & $\mathrm{N}$ & $\mathrm{N}$ & $\mathrm{N}$ & $\mathrm{N}$ & 1 & $\mathrm{~N}$ \\
\hline Dolomite- & 14 & 1 & $\mathrm{~N}$ & $\mathrm{~N}$ & $\mathrm{~N}$ & $\mathrm{~N}$ & 10 & 8 \\
\hline Siderite--_- & $\mathrm{N}$ & $\mathrm{N}$ & $\mathrm{N}$ & N & $\mathrm{N}$ & $\mathrm{N}$ & $\mathrm{N}$ & $\mathrm{N}$ \\
\hline Gypsum- & $\mathrm{N}$ & $\mathrm{N}$ & $\mathrm{N}$ & $\mathrm{N}$ & $\mathrm{N}$ & $\mathrm{N}$ & 1 & $\mathrm{~N}$ \\
\hline Jarosite-- & $\mathbf{N}$ & $\mathrm{N}$ & $\mathrm{N}$ & N & $\mathrm{N}$ & $\mathrm{N}$ & $\mathrm{N}$ & $\mathrm{N}$ \\
\hline Pyrite-- & $\mathbf{N}$ & $\mathrm{N}$ & $\mathrm{N}$ & $\mathrm{N}$ & $\mathrm{N}$ & $\mathrm{N}$ & $\mathrm{N}$ & $\mathrm{M}$ \\
\hline Zeolite-- & $\mathrm{N}$ & $\mathrm{N}$ & $\mathrm{N}$ & $\mathrm{N}$ & $\mathrm{N}$ & $\mathrm{N}$ & $\mathrm{N}$ & $\mathrm{N}$ \\
\hline & Anorthi & atent of & oclase as & rmined by & ay ana $1 y s i$ & ent) & & \\
\hline Anorthite- & 35 & 20 & -- & 60 & 30 & -- & - & 40 \\
\hline & & Bulk and & densitie & terberg 1 & $\mathrm{~s}$, and $\mathrm{pH}$ & & & \\
\hline Bulk density- & 2.40 & 2.22 & 2.22 & 2.06 & 2.20 & 2.29 & -- & 2.24 \\
\hline Grain density- & 2.65 & 2.64 & 2.55 & 2.48 & 2.61 & 2.59 & -- & 2.65 \\
\hline Liquid limit- & -- & -- & - & -- & -- & -- & 37 & -- \\
\hline Plastic limit- & -- & -- & -- & -- & -- & -- & 23 & -- \\
\hline Plastic index-- & - & - & -- & -- & -- & -- & 14 & -- \\
\hline pH-------O-- & -- & -- & -- & -- & -- & -- & -- & - \\
\hline
\end{tabular}


TABLE 1.-Chemical, mineralogical, and physical-properties data for 226 samples of Pierre Shale and equivalent rocks-Continued

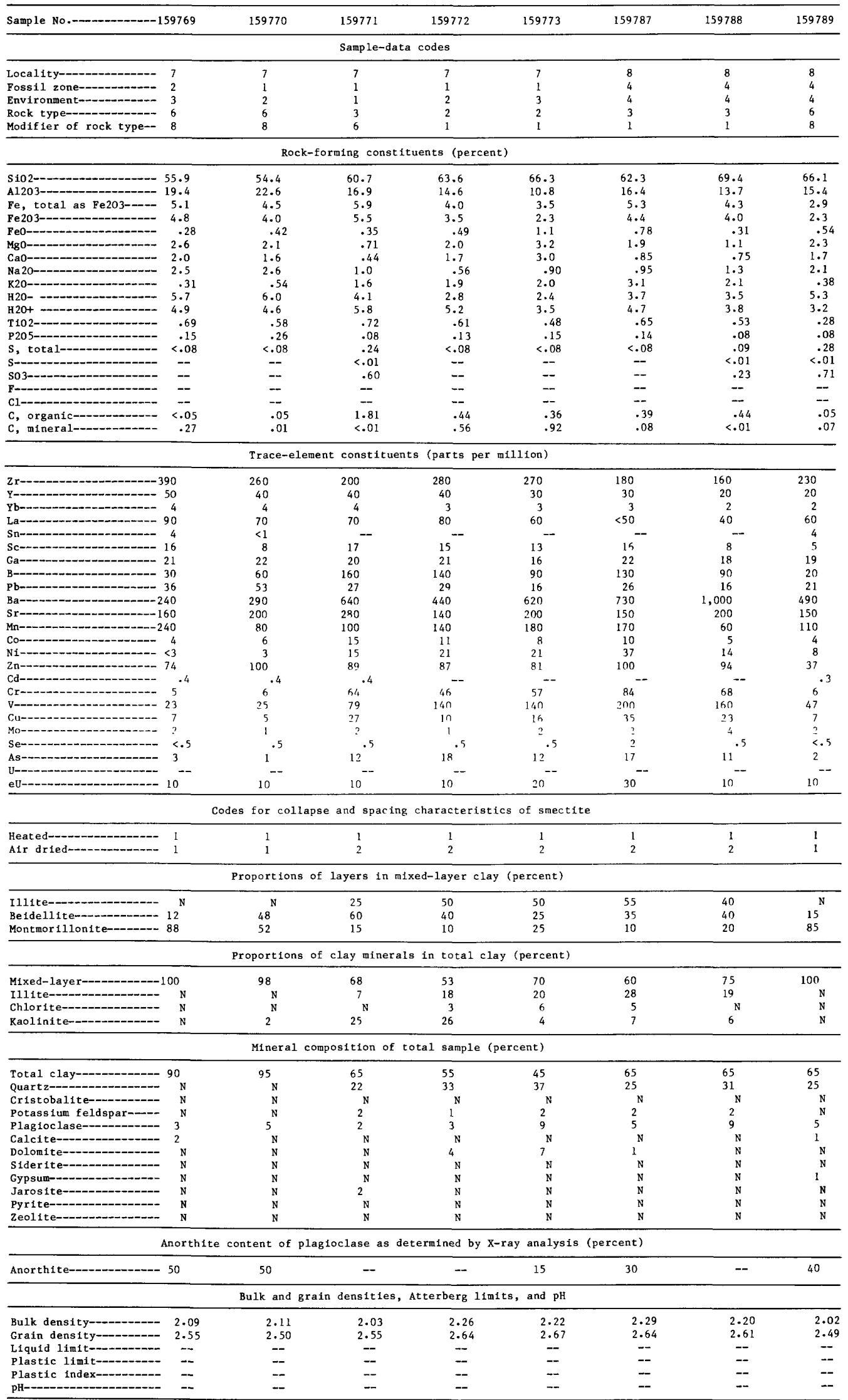


TABLE 1.-Chemical, mineralogical, and physical-properties data for 226 samples of Pierre Shale and equivalent rocks-Continued

\begin{tabular}{|c|c|c|c|c|c|c|c|c|c|c|c|}
\hline Sample No.--_- & 159790 & 159791 & 159792 & 159793 & 159794 & 159795 & 159796 & 159797 & 159810 & 159811 & 159812 \\
\hline & & & & Sample-dat & ta codes & & & & & & \\
\hline Locality----_--_-_---- & 8 & 8 & 8 & 8 & 8 & 8 & 8 & 8 & 9 & 9 & 9 \\
\hline Fossil zone--- & 4 & 3 & 2 & 2 & 1 & 1 & 1 & 1 & 4 & 4 & 3 \\
\hline Env ironment-- & 1 & 1 & 3 & 3 & 3 & 2 & 3 & 3 & 4 & 1 & 1 \\
\hline Rock type-- & 3 & 3 & 3 & 3 & 2 & 2 & 2 & 2 & 3 & 3 & 3 \\
\hline Modifier of rock type-- & 6 & 1 & 1 & 1 & 1 & 1 & 11 & 1 & 1 & 6 & 3 \\
\hline & & & Rock-form & ing const $i$ & tuents (pe & rcent) & & & & & \\
\hline SiO2--- & 65.3 & 65.0 & 62.2 & 62.6 & 62.5 & 74.3 & 63.1 & 64.5 & 68.2 & 58.9 & 60.8 \\
\hline A1203- & 16.0 & 15.6 & 15.5 & 13.5 & 11.0 & 10.0 & 12.1 & 10.9 & 13.9 & 14.2 & 14.2 \\
\hline $\mathrm{Fe}$, total as $\mathrm{Fe} 203-$ & 2.8 & 3.2 & 5.2 & 4.4 & 2.9 & 5.3 & 4.1 & 3.4 & 3.5 & 3.3 & 4.2 \\
\hline $\mathrm{Fe} 203-$ & 2.4 & 2.3 & 3.4 & 3.4 & 1.8 & 2.4 & 2.5 & 1.4 & 3.1 & 2.8 & 3.3 \\
\hline Fe0-1- & .36 & .85 & 1.6 & .94 & 1.0 & 2.6 & 1.4 & 1.8 & .32 & .47 & .79 \\
\hline $\mathrm{MgO}$ & 1.1 & 2.4 & 2.3 & 3.3 & 4.2 & 1.5 & 3.4 & 3.7 & 1.5 & 1.0 & 3.1 \\
\hline $\mathrm{CaO}-$ & .70 & 1.3 & 1.3 & 2.8 & 4.7 & .62 & 3.3 & 4.0 & .16 & .18 & 2.9 \\
\hline 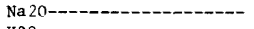 & 1.4 & 1.1 & 1.4 & 1.5 & .91 & 1.2 & .93 & 1.1 & 1.0 & 1.1 & 1.6 \\
\hline K20--1- & 2.6 & 3.4 & 2.4 & 2.4 & 2.3 & 2.0 & 2.3 & 2.2 & 2.1 & 2.5 & 2.6 \\
\hline $\mathrm{H} 20-$ & 3.9 & 2.5 & 2.9 & 2.8 & 1.7 & 1.4 & 2.1 & 1.2 & 4.0 & 3.3 & 3.2 \\
\hline H $20+$ & $4 \cdot 3$ & 4.0 & 4.7 & 3.4 & 2.3 & 2.9 & 3.5 & 3.0 & 4.5 & 5.2 & 3.2 \\
\hline TiO2--- & .57 & .57 & .66 & .51 & .48 & .33 & .54 & .48 & .61 & .48 & .50 \\
\hline 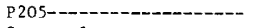 & .11 & .14 & .14 & .18 & .16 & .13 & .17 & .17 & .02 & .02 & .11 \\
\hline S, total- & $<.08$ & $<.08$ & $<.08$ & $<.08$ & $<.08$ & $<.08$ & $<.08$ & .15 & $<.08$ & $<.08$ & $<.08$ \\
\hline 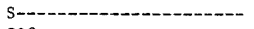 & -- & -- & -- & -- & -- & -- & -- & .10 & -- & -- & -- \\
\hline 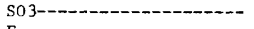 & -- & -- & -- & -- & -- & -- & -- & .12 & -- & -- & -- \\
\hline F-1--- & -- & -- & -- & -- & -- & -- & -- & .05 & -- & -- & -- \\
\hline Cl-1-2- & -- & -- & -- & -- & -- & -- & -- & .01 & - & -- & -- \\
\hline c, organic--- & 1.67 & .38 & .68 & .42 & .11 & .17 & .31 & .34 & .74 & 5.76 & .08 \\
\hline$c$, mineral-_-__-_-_- & $<.01$ & .38 & .40 & .90 & 1.83 & .16 & 1.21 & 1.44 & $<.01$ & $<. n 1$ & .92 \\
\hline & & Trace & e-element & constituent & ts (parts p & per millio & & & & & \\
\hline 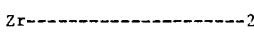 & & 200 & 170 & 180 & 280 & 160 & 230 & 300 & 200 & 160 & 190 \\
\hline Y--1--1- & & 30 & 30 & 30 & 30 & 20 & 30 & 30 & 20 & 30 & 30 \\
\hline Yb--- & 3 & 4 & 3 & 3 & 4 & 2 & 3 & 3 & 2 & 2 & 3 \\
\hline La--_-_-_-_-_- & 60 & 60 & $<50$ & 60 & 50 & 50 & 60 & 50 & 40 & $5 n$ & 50 \\
\hline 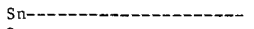 & & -- & -- & -- & -- & -- & -- & -- & -- & -- & -- \\
\hline Sc- & & $1 \mathrm{~h}$ & 16 & 16 & 13 & 6 & 12 & 12 & 12 & 15 & 14 \\
\hline 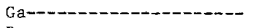 & 20 & 20 & 20 & 18 & 17 & 13 & 19 & 16 & 18 & 19 & 19 \\
\hline 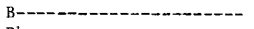 & 60 & 90 & 70 & 100 & 80 & 70 & 80 & 80 & 140 & 410 & 80 \\
\hline Pb-1-- & 30 & 37 & 21 & 25 & 22 & 15 & 38 & 11 & 7 & $<1$ & 10 \\
\hline Ba-- & & 520 & 640 & 550 & 510 & 520 & 570 & 540 & 850 & 690 & 610 \\
\hline Sr--- & 210 & 90 & 170 & 160 & 120 & 130 & 180 & 140 & 110 & 90 & 170 \\
\hline Мn--w- & & 190 & 250 & 320 & 150 & 140 & 220 & 180 & 90 & 60 & 250 \\
\hline Co--1-1-_- & 9 & 9 & 12 & 9 & 6 & 8 & 8 & 8 & 9 & 10 & 9 \\
\hline Ni-C.N- & 15 & 28 & 36 & 30 & 20 & 10 & 19 & 19 & 26 & 19 & 18 \\
\hline & 74 & 72 & 86 & 84 & 60 & 40 & 70 & 56 & 95 & 64 & 71 \\
\hline 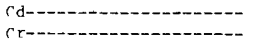 & $64^{.4}$ & 64 & .7 & .5 & -- & -- & -- & - & .5 & $5^{.3}$ & -- \\
\hline $\mathrm{r}$ & $\begin{array}{r}54 \\
100\end{array}$ & $\begin{array}{r}64 \\
110\end{array}$ & 80 & $\begin{array}{r}73 \\
130\end{array}$ & $\begin{array}{r}54 \\
12 n\end{array}$ & 35 & $\begin{array}{r}50 \\
130\end{array}$ & $\begin{array}{r}53 \\
120\end{array}$ & $\begin{array}{r}81 \\
180\end{array}$ & $\begin{array}{l}56 \\
90\end{array}$ & $\begin{array}{l}31 \\
90\end{array}$ \\
\hline & 19 & & 160 & 130 & 120 & $12 n$ & 130 & 120 & $\begin{array}{r}180 \\
23\end{array}$ & $\begin{array}{l}90 \\
27\end{array}$ & 90 \\
\hline & $<1$ & 26 & 27 & 22 & 12 & 8 & $1 ?$ & 12 & 23 & 22 & 23 \\
\hline Me--1- & .5 & $\begin{array}{l}2 \\
<.5\end{array}$ & 1 & 1 & $<<<$ & $<1<$ & $<1,5$ & $<1<5$ & ${ }^{3} .5$ & $\begin{array}{l}3 \\
2\end{array}$ & $\frac{1}{<.5}$ \\
\hline & 10 & 10 & $9^{.5}$ & $\begin{array}{r}1 \\
11\end{array}$ & ${ }_{7}^{<.5}$ & $l_{6}^{<.5}$ & $12^{.5}$ & 8 & $10^{.3}$ & 12 & 6 \\
\hline U--1-- & -- & -- & & -- & - & -- & -- & -- & -- & - & -- \\
\hline ell--_-_-_- & $2 n$ & 20 & $2 n$ & 10 & 20 & 10 & 20 & 10 & 10 & 20 & 20 \\
\hline & & Codes for & collapse a & nd spacing & characteri & istics of & smectite & & & & \\
\hline Heated----_- & l & 1 & 2 & 1 & 1 & 1 & 1 & I & 2 & 1 & 1 \\
\hline Air dried---_-_-_- & 2 & - & 2 & 1 & - & - & -- & - & 2 & 1 & 1 \\
\hline & & Proport & ions of $1 a$ & yers in mix & xed-1ayer & clay (perce & ent) & & & & \\
\hline 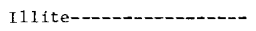 & $5 n$ & 55 & 45 & $4 n$ & 55 & 60 & 55 & 55 & 45 & 40 & 35 \\
\hline Beidellite--. & 35 & 35 & 35 & $3 n$ & $3 n$ & 30 & 30 & 35 & 40 & 50 & 40 \\
\hline Montmorillonite------- & 15 & 10 & $2 n$ & 30 & 15 & 10 & 15 & in & 25 & in & 25 \\
\hline & & Proport & ions of $\mathrm{cl}$ & ay minerals & s in total & clay (perc & cent) & & & & \\
\hline Mixed-1ayer---_---_--_- & $5 ?$ & 56 & 70 & 62 & 51 & 53 & 56 & 44 & 78 & 75 & 74 \\
\hline Illite-- & 26 & 30 & 18 & 29 & 31 & 12 & 27 & $3 n$ & 17 & 21 & $? 1$ \\
\hline Chlorite-- & N & 6 & 5 & a & 9 & 25 & a & 14 & $\mathrm{~N}$ & s & 3 \\
\hline Kaolinite--- & 12 & 8 & 7 & 3 & a & 10 & 8 & 12 & 5 & 4 & 2 \\
\hline & & Mine & ral compos & ition of to & otal sample & e $($ percent $)$ & & & & & \\
\hline Tota1 clay--_--_-_-- & 6n & 55 & 6n & $5 n$ & 40 & $3 n$ & 45 & 35 & 65 & 65 & 60 \\
\hline Quartz------------- & 29 & 33 & 26 & 30 & 35 & 48 & 34 & 38 & 30 & 25 & 23 \\
\hline Cristobalite-- & $"$ & $\mathrm{~N}$ & $\mathrm{~N}$ & s & N & n & $\mathrm{N}$ & $\mathrm{N}$ & $\mathrm{N}$ & $\mathbb{N}$ & $\mathrm{N}$ \\
\hline Potassium feldspar----- & 2 & 2 & n & 2 & 2 & 2 & 2 & 2 & 1 & 1 & 1 \\
\hline Plagioclase-_- & 10 & 8 & $a$ & 7 & fi & 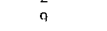 & 8 & $a$ & 5 & 5 & 8 \\
\hline Calcite-- & N & : & $\mathrm{N}$ & $\mathrm{N}$ & $\mathrm{r}^{*}$ & Na & $\mathrm{N}$ & $\mathrm{N}$ & $\mathrm{N}$ & $\mathrm{N}$ & $\mathrm{N}$ \\
\hline Dolomite--------_--_---- & in & 3 & 3 & 7 & 14 & 1 & $a$ & 11 & $\mathrm{~N}$ & $\mathrm{~N}$ & 7 \\
\hline Siderite--1-- & $\mathrm{N}$ & n & $\mathrm{N}$ & v & $\mathrm{M}$ & $\mathrm{N}$ & $\mathrm{N}$ & $\mathrm{N}$ & $\mathrm{N}$ & $\mathrm{N}$ & $\mathrm{N}$ \\
\hline 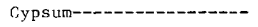 & $\because$ & $\mathrm{N}$ & It & $\mathrm{M}$ & $\mathrm{N}$ & N & $N$ & $\mathrm{~N}$ & $\mathrm{~N}$ & $\mathrm{~N}$ & $\mathrm{~N}$ \\
\hline Jarosite--- & $\mathrm{N}$ & M & M & NT & $\mathrm{N}$ & $n$ & $\mathrm{~N}$ & $\mathrm{~N}$ & $\mathbb{N}$ & s] & "1: \\
\hline Pyrite---- & $!$ & n & N & $\mathrm{N}$ & N & $n$ & $\mathrm{~N}$ & $\mathrm{~N}$ & $\mathrm{~N}$ & $\mathrm{~N}$ & n: \\
\hline 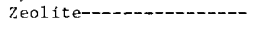 & $\mathrm{N}$ & $\mathrm{N}$ & $\mathrm{N}$ & N & গ় & N & N & $\mathrm{N}$ & $\mathrm{N}$ & $\mathrm{N}$ & $\mathrm{N}$ \\
\hline & Anorthi & content & of plagioc & lase as det & termined by & y x-ray ans & alysis (p & ent) & & & \\
\hline Anorthite---------- & 30 & $2 n$ & $2 n$ & - & 20 & 20 & 20 & 20 & 20 & $3 n$ & $2 n$ \\
\hline & & Bulk ar & nd grain de & ensities, A & Atterberg 1 & limits, and & & & & & \\
\hline Bulk, density---- & 2.22 & 2.23 & 2.23 & $\therefore 19$ & $? .36$ & 2.23 & 2.37 & 2.35 & 2.12 & 1.83 & 2.26 \\
\hline Grain density------- & 2.54 & 2.63 & 2.62 & 2.73 & 2.75 & 2.69 & 2.66 & $2.7 n$ & 2.57 & 2.43 & 2.62 \\
\hline Liquid limit-- & - & -- & -- & -- & -- & -- & -- & -- & -- & -- & -- \\
\hline Plastic limit-- & -- & -- & -- & -- & -- & -- & -- & -- & -- & -- & -- \\
\hline Plastic index----- & -- & -- & -- & -- & -- & -- & -- & -- & -- & -- & $=$ \\
\hline 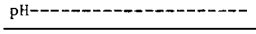 & - & -- & -- & -- & -- & -- & -- & -- & - & -- & \\
\hline
\end{tabular}


TABLE 1.-Chemical, mineralogical, and physical-properties data for 226 samples of Pierre Shale and equivalent rocks-Continued

\begin{tabular}{|c|c|c|c|c|c|c|c|c|c|c|}
\hline Sample No._-_-_- & 59813 & 159814 & 159815 & 159816 & C871 & 159817 & 159818 & 159819 & 159820 & 159821 \\
\hline & & & Sam & e-data $c$ & & & & & & \\
\hline Locality--_-_-_-_-_---- & 9 & 9 & 9 & 9 & 9 & 9 & 9 & 9 & 9 & 9 \\
\hline Fossil zone-- & 3 & 3 & 3 & 2 & 2 & 2 & 2 & 1 & 1 & 1 \\
\hline Environment----------- & 1 & 1 & 3 & 4 & 4 & 4 & 4 & 1 & 2 & 3 \\
\hline Rock type-- & 2 & 3 & 2 & 3 & 4 & 6 & 3 & 3 & 4 & 2 \\
\hline Modifier of rock type-- & 5 & 1 & 1 & 1 & 1 & 8 & 1 & 1 & 6 & 1 \\
\hline & & & k-forming & onstituer & (percen & & & & & \\
\hline $\mathrm{SiO} 2-$ & 80.0 & 64.0 & 65.4 & 60.6 & 55.32 & 51.2 & 61.7 & 67.0 & 51.6 & 62.9 \\
\hline A1 203- & 9.6 & 14.8 & 13.5 & 15.5 & $16 \cdot 39$ & 17.2 & 15.8 & 13.4 & 17.8 & 13.2 \\
\hline $\mathrm{Fe}$, total as $\mathrm{Fe} 203$ & 1.6 & 4.0 & 4.2 & 6.4 & 6.48 & 4.3 & 5.5 & 4.4 & 6.8 & 3.7 \\
\hline Fe 203 & 1.3 & 2.7 & 2.9 & 6.0 & 5.10 & 4.0 & 5.1 & 3.5 & 6.2 & 2.7 \\
\hline $\mathrm{FeO}--$ & .26 & 1.2 & 1.2 & .34 & 1.24 & .28 & .40 & .80 & .51 & .92 \\
\hline 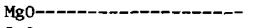 & .64 & 1.4 & 2.7 & 1.6 & 1.91 & 4.3 & 2.0 & 1.4 & 2.4 & 2.6 \\
\hline 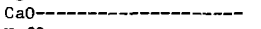 & .24 & .36 & 2.0 & .24 & 1.25 & 2.1 & .41 & 1.1 & .24 & 2.8 \\
\hline Na 20-D-- & 1.7 & 1.8 & 2.2 & 1.1 & .90 & .61 & 1.2 & 1.3 & 1.3 & 1.2 \\
\hline K20-- & 2.0 & 2.4 & 2.1 & 2.2 & 2.21 & .28 & 2.1 & 1.8 & 1.0 & 2.0 \\
\hline H 20- & 1.2 & 3.7 & 2.5 & 5.1 & 3.98 & 11.7 & 4.6 & 3.1 & 8.2 & 3.0 \\
\hline H $20+$ & 2.0 & 4.3 & 3.1 & 5.4 & 6.16 & 6.5 & 5.3 & 4.0 & 7.3 & 3.9 \\
\hline 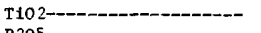 & .53 & .53 & .57 & .67 & .66 & .42 & .67 & .48 & .70 & .51 \\
\hline P205--ינ- & .03 & .03 & .16 & .14 & .14 & .08 & .14 & .09 & .17 &. $\mathrm{It}$ \\
\hline s, total- & $<.08$ & $<.08$ & .11 & .27 & 1.30 & $<.08$ & $<.08$ & $<.08$ & .88 & .44 \\
\hline 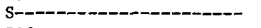 & -- & - & $<.01$ & .03 & .10 & -- & -- & -- & $<.01$ & .34 \\
\hline so3--_- & -- & -- & .28 & .61 & 3.00 & -- & -- & -- & 2.20 & .24 \\
\hline F--- & -- & -- & - & .05 & .06 & -- & -- & -- & -- & -- \\
\hline 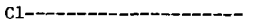 & -- & -- & -- & $<.01$ & $<.01$ & -- & -- & -- & -- & -- \\
\hline c, organic-_- & .06 & 1.76 & .19 & .59 & $<.50$ & $<.05$ & .70 & .53 & 1.01 & .78 \\
\hline c, minera1-_-_-_-_--- & $<.01$ & .03 & .54 & $<.01$ & .04 & .13 & $<.01$ & .19 & $<.01$ & .88 \\
\hline & & Trace- & ement con & ituents & rts per & 1ion) & & & & \\
\hline 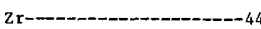 & & 300 & 200 & 150 & 150 & 320 & 150 & 200 & 220 & 250 \\
\hline 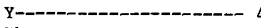 & & 40 & 30 & 30 & 15 & 70 & 30 & 30 & 40 & 30 \\
\hline 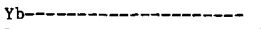 & 3 & 4 & 3 & 3 & 3 & 4 & 3 & 2 & 3 & 3 \\
\hline La--_-_-_-_-_-_-_---- & 60 & 70 & 50 & $<50$ & 30 & 100 & $<50$ & 60 & 70 & $<50$ \\
\hline Sn-- - & -- & -- & -- & -- & -- & 2 & -- & -- & -- & -- \\
\hline 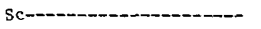 & 4 & 15 & 16 & 18 & 15 & 12 & 17 & 13 & 18 & 10 \\
\hline Ga-_-_- & 10 & 22 & 18 & 23 & 15 & 19 & 22 & 19 & 21 & 18 \\
\hline 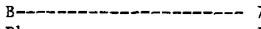 & 70 & 80 & 50 & 100 & 70 & 40 & 90 & 120 & 140 & 80 \\
\hline 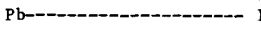 & & 12 & 12 & 24 & 7 & 33 & 19 & 18 & 24 & 17 \\
\hline $\mathrm{Ba}----$ & & 600 & 600 & 680 & 300 & 370 & 570 & 830 & 780 & 580 \\
\hline Sr---- & & 140 & 180 & 140 & 150 & 220 & 140 & 310 & 180 & 250 \\
\hline 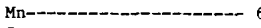 & 60 & 130 & 380 & 300 & 230 & 210 & 200 & 400 & 430 & 170 \\
\hline 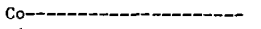 & 4 & 10 & 13 & 17 & 15 & $<3$ & 15 & 11 & 12 & 8 \\
\hline N1--- & 9 & 19 & 36 & 44 & 30 & 35 & 44 & 16 & 21 & 15 \\
\hline Zn---- & 35 & 74 & 84 & 110 & 130 & 83 & 120 & 90 & 74 & 80 \\
\hline 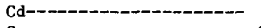 & -- & -- & -- & .4 & .5 & .4 & $<.3$ & -- & $<\cdot 3$ & $<.3$ \\
\hline 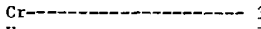 & 30 & 46 & 78 & 91 & 70 & 3 & 88 & 50 & 36 & 38 \\
\hline 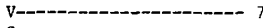 & 70 & 180 & 46 & 79 & 150 & 15 & 180 & 140 & 140 & 110 \\
\hline 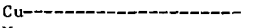 & 6 & 10 & 23 & 28 & 70 & 14 & 40 & 20 & 31 & 33 \\
\hline 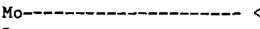 & $<1$ & 2 & 1 & 2 & $<10$ & 3 & 2 & & 3 & 1 \\
\hline 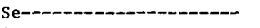 & $<.5$ & $<.5$ & $<.5$ & .5 & 1 & $<.5$ & .5 & $<.5$ & .5 & $<.5$ \\
\hline As-- & 4 & 6 & 6 & 17 & 17 & 2 & 16 & 8 & 3 & 6 \\
\hline U-n- & - & -- & -- & -- & $<10.0$ & -- & -- & -- & -- & -- \\
\hline 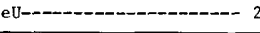 & 20 & 20 & 20 & 10 & 10 & $<10$ & 10 & 10 & 10 & 10 \\
\hline & & les for co & apse and & acing ch & cteristi & of smect & & & & \\
\hline Heated-----_--_--_--_--- & 1 & 1 & 1 & 2 & 2 & 2 & 2 & 1 & 2 & 1 \\
\hline A1r dried--_- & 1 & 1 & 1 & 2 & 2 & 2 & 2 & 2 & 2 & 2 \\
\hline & & Proportio & of layer & in mixed & yer clay & ercent) & & & & \\
\hline 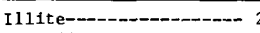 & 20 & 35 & 35 & 40 & 50 & $\mathrm{~N}$ & 45 & 35 & 30 & 35 \\
\hline Beidellite-- & & 45 & 40 & 40 & -- & 16 & 40 & 40 & 40 & 40 \\
\hline Montmorillonite---_---- & 35 & 20 & 25 & 20 & -- & 84 & 15 & 25 & 30 & 25 \\
\hline & & Proportio & of clay & Inerals 1 & otal cla & (percent) & & & & \\
\hline 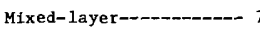 & 79 & 67 & 82 & 81 & 68 & 100 & 83 & 76 & 88 & 70 \\
\hline Illite-- & 16 & 26 & 10 & 12 & 20 & $\mathrm{~N}$ & 12 & 13 & $\mathrm{~N}$ & 15 \\
\hline Chlorite-- & $\mathrm{N}$ & 3 & 3 & $\mathrm{~N}$ & 4 & $\mathrm{~N}$ & $\mathrm{~N}$ & 3 & $\mathrm{~N}$ & 3 \\
\hline 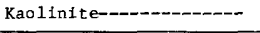 & 5 & 4 & 5 & 7 & 8 & $\mathrm{~N}$ & 5 & 8 & 12 & 12 \\
\hline & & Minera & compositi & of tota & ample (p & ent) & & & & \\
\hline Tota1 clay-- & 30 & 65 & 50 & 65 & 70 & 90 & 60 & 60 & 80 & 40 \\
\hline Quartz-- & 54 & 28 & 29 & 20 & 15 & $\mathrm{~N}$ & 21 & 33 & 9 & 30 \\
\hline Cristobalite-- & $\mathrm{N}$ & $\mathrm{N}$ & $\mathrm{N}$ & $\mathrm{N}$ & $\mathrm{N}$ & $\mathrm{N}$ & $\mathrm{N}$ & $\mathrm{N}$ & $\mathrm{N}$ & $\mathrm{N}$ \\
\hline Potassium feldspar----- & 7 & 2 & 2 & 2 & $\mathrm{~N}$ & $\mathrm{~N}$ & 1 & 1 & $\mathrm{~N}$ & 5 \\
\hline Plagioclase-- & 12 & 10 & 14 & 6 & 4 & 4 & 6 & 7 & $\mathrm{~N}$ & 6 \\
\hline Calcite------ & $\mathrm{N}$ & $\mathrm{N}$ & $\mathrm{N}$ & $\mathrm{N}$ & $\mathrm{N}$ & 3 & $\mathrm{~N}$ & $\mathrm{~N}$ & $\mathrm{~N}$ & $\mathrm{~N}$ \\
\hline Dolomite---------- & $\mathbf{N}$ & $\mathrm{N}$ & $\mathrm{N}$ & $\mathrm{N}$ & $\mathrm{N}$ & $\mathrm{N}$ & $\mathrm{N}$ & 1 & $\mathrm{~N}$ & 8 \\
\hline Siderite-- & $\mathrm{N}$ & $\mathrm{N}$ & $\mathrm{N}$ & $\mathrm{N}$ & $\mathrm{N}$ & $\mathrm{N}$ & $\mathrm{N}$ & $\mathrm{N}$ & $\mathrm{N}$ & $\mathrm{N}$ \\
\hline 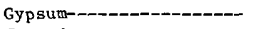 & $\mathrm{N}$ & $\mathrm{N}$ & $\mathrm{N}$ & $\mathrm{N}$ & 2 & $\mathrm{~N}$ & $\mathrm{~N}$ & $\mathrm{~N}$ & $\mathrm{~N}$ & $\mathrm{~N}$ \\
\hline Jarosite-- & $\mathrm{N}$ & $\mathrm{N}$ & $\mathrm{N}$ & $\mathrm{N}$ & 1 & $\mathrm{~N}$ & $\mathrm{~N}$ & $\mathrm{~N}$ & 7 & $\mathrm{~N}$ \\
\hline Pyrite-- & $\mathrm{N}$ & $\mathrm{N}$ & $\mathrm{N}$ & $\mathrm{N}$ & $\mathrm{N}$ & $\mathrm{N}$ & $\mathrm{N}$ & $\mathrm{N}$ & $\mathrm{N}$ & $\mathrm{N}$ \\
\hline Zeolite------ & $\mathrm{N}$ & $\mathrm{N}$ & $\mathrm{N}$ & $\mathrm{N}$ & $\mathrm{N}$ & 2 & $\mathrm{~N}$ & $\mathrm{~N}$ & $\mathrm{~N}$ & $\mathrm{~N}$ \\
\hline An & northit & intent of & lagioclas & as deter & d by $x-$ & analysi & percent) & & & \\
\hline Anorthite---_-_-_-- 3 & 30 & 30 & 30 & -- & - & -- & 30 & - & -- & - \\
\hline & & Bulk and & grain dens & ties, Att & erg $\operatorname{limi}$ & and $\mathrm{pH}$ & & & & \\
\hline Bulk density-- & 2.06 & 2.16 & 2.04 & 2.10 & - & 2.01 & 2.07 & 1.90 & 2.01 & 2.16 \\
\hline Grain density--- & 2.63 & 2.51 & 2.63 & 2.54 & - & 2.31 & 2.56 & 2.63 & 2.54 & 2.61 \\
\hline Liquid limit- & -- & -- & -- & -- & 56 & -- & -- & -- & -- & -- \\
\hline Plastic limit-- & -- & -- & -- & -- & 32 & -- & -- & -- & -- & -- \\
\hline Plastic index- & -- & -- & -- & -- & 24 & -- & - & -- & - & -- \\
\hline 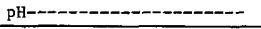 & -- & -- & - & -- & -- & -- & -- & -- & -- & -- \\
\hline
\end{tabular}


TABLE 1.-Chemical, mineralogical, and physical-properties data for 226 samples of Pierre Shale and equivalent rocks-Continued

\begin{tabular}{|c|c|c|c|c|c|c|c|c|c|}
\hline Sample No.-----_-----159709 & 159710 & 159711 & 159712 & 159713 & 159714 & 159715 & 159716 & 159717 & 159718 \\
\hline \multicolumn{10}{|c|}{ Sample-data codes } \\
\hline Locality-_-_-_- 10 & 10 & 10 & 10 & 10 & 10 & 10 & 10 & 10 & 10 \\
\hline Fossil zone---w-_- 6 & 5 & 5 & 5 & 5 & 4 & 3 & 3 & 3 & 2 \\
\hline Environment------------ 3 & 3 & 4 & 1 & 1 & 3 & 1 & 1 & 3 & 3 \\
\hline Rock type---------- 2 & 2 & 3 & 1 & 2 & 2 & 2 & 2 & 1 & 2 \\
\hline Modiffer of rack type-- 1 & 1 & 1 & $i$ & 6 & 1 & 6 & 1 & 1 & 1 \\
\hline & & $k-$ formin & constituer & s (percen & & & & & \\
\hline S102-_-_-- 64.5 & 67.6 & 62.7 & 80.7 & 70.9 & 64.2 & 49.6 & 74.1 & 72.1 & 66.8 \\
\hline Al203- 12.6 & 12.4 & 14.6 & 9.8 & 13.9 & 12.1 & 11.3 & 10.5 & 7.4 & 11.4 \\
\hline Fe, total as Fe203-- 4.2 & 4.1 & 5.2 & 1.4 & 2.2 & 3.6 & 1.2 & 3.0 & 1.7 & 3.4 \\
\hline Fe203-_-_-_- 3.1 & 3.3 & 4.0 & 1.1 & 1.8 & 2.2 & .80 & 2.4 & 1.0 & 2.3 \\
\hline Fe0-- 1.0 & .71 & 1.1 & .29 & .39 & 1.3 & .39 & .50 & .59 & 1.0 \\
\hline $\mathrm{MgO}$ & 2.2 & 2.7 & .53 & .64 & 2.7 & .50 & 1.7 & 2.8 & 3.1 \\
\hline $\mathrm{Ca}-1$ & 2.1 & 1.4 & .34 & .19 & 3.6 & .12 & 1.4 & 4.7 & 2.9 \\
\hline $\mathrm{Na} 2 \mathrm{O}-\mathrm{-}$ & 1.6 & 1.9 & 1.0 & .68 & 1.9 & .35 & 1.0 & $1 \cdot 1$ & 1.1 \\
\hline K20- & 2.5 & 2.5 & 1.9 & 1.8 & 2.4 & 1.5 & 2.3 & 1.9 & 2.4 \\
\hline B20- - & $2 \cdot 3$ & 2.7 & 1.0 & 2.2 & 1.5 & 3.6 & .67 & .51 & 1.7 \\
\hline H2O+ ---------------- 3.0 & 2.6 & 3.9 & 2.1 & 4.5 & 2.6 & 7.3 & 2.8 & 1.5 & 3.0 \\
\hline T102- & .52 & .56 & .46 & .99 & .49 & .54 & .48 & .35 & .48 \\
\hline P205- $\quad .17$ & .16 & .18 & .08 & .03 & .15 & .04 & .10 & .11 & .14 \\
\hline s, total--------------- & $<.08$ & .17 & .12 & $<.08$ & .27 & .12 & $<.08$ & $<.08$ & .24 \\
\hline 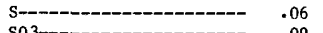 & -- & $<.01$ & $<.01$ & -- & .14 & .08 & -- & -- & .20 \\
\hline S03- .09 & -- & .42 & .30 & - & .32 & .11 & -- & -- & .10 \\
\hline F-1-- & -- & & - & -- & -- & - & -- & -- & -- \\
\hline c, organic-- & .79 &.$\overline{.67}$ & $\overline{.15}$ & $\overline{2.33}$ & -94 & $\overline{17} \overline{30}$ & $-\overline{30}$ & $-\overline{0-}$ & $-\overline{38}$ \\
\hline c, mineral-_._....... .77 & .47 & .31 & $<.01$ & .01 & 1.08 & $\begin{array}{r}17.30 \\
.01\end{array}$ & $\begin{array}{l}.30 \\
.36\end{array}$ & $\begin{array}{l}2.03 \\
1.67\end{array}$ & $\begin{array}{r}.38 \\
1.02\end{array}$ \\
\hline & Trace- & ement co & ftuents & arts per & 11ion) & & & & \\
\hline 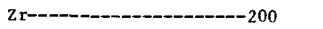 & 290 & 190 & 210 & 470 & 260 & 160 & 270 & 360 & 260 \\
\hline Y--1-- 30 & 30 & 30 & $<20$ & 40 & 40 & 30 & 30 & 20 & 40 \\
\hline $\mathrm{Yb}-\mathrm{-}$ & 3 & 3 & $<2$ & 3 & 4 & 3 & 3 & 2 & 3 \\
\hline La--_-_-_-_-_--_--- 60 & 50 & 60 & 40 & 70 & 60 & 60 & 50 & $<40$ & 60 \\
\hline 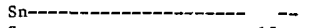 & -- & -- & -- & -- & -- & -- & -- & -- & -- \\
\hline Sc---_-_-- 15 & 13 & 16 & 4 & 11 & 12 & 10 & 7 & 5 & 14 \\
\hline 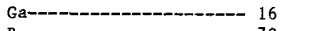 & 19 & 22 & 8 & 18 & 18 & 18 & 12 & 9 & 17 \\
\hline B- & 60 & 70 & 20 & 80 & 40 & 130 & 80 & 40 & 70 \\
\hline 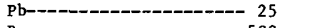 & 19 & 23 & 31 & 39 & 10 & 27 & 27 & 17 & 36 \\
\hline Ba---------------------580 & 600 & 500 & 430 & 460 & 660 & 830 & 510 & 420 & 460 \\
\hline 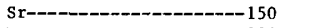 & 260 & 160 & 100 & 110 & 190 & 230 & 90 & 80 & 120 \\
\hline $\mathrm{Mn}----$ & 180 & 220 & 70 & 170 & 380 & 220 & 560 & 260 & 230 \\
\hline 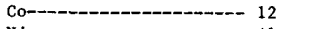 & 11 & 11 & 3 & 16 & 9 & 8 & 8 & 4 & 9 \\
\hline N1---------------------- 41 & 29 & 30 & 6 & 22 & 18 & 48 & 16 & 10 & 32 \\
\hline Zn--- 110 & 94 & 93 & 130 & 110 & 94 & 62 & 72 & 30 & 77 \\
\hline 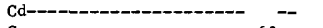 & - & .3 & -- & .4 & $<.3$ & .4 & -- & -- & \\
\hline Cr-- & 71 & 83 & 30 & 44 & 37 & 67 & 45 & 38 & 91 \\
\hline 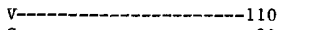 & 110 & 140 & 55 & 76 & 86 & 79 & 150 & 120 & 88 \\
\hline Cu--_- & 32 & 29 & 12 & 16 & 16 & 40 & 18 & 6 & 15 \\
\hline 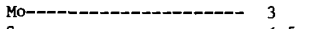 & 1 & 1 & $<1$ & $<1$ & $<1$ & 2 & $<1$ & $<1$ & 2 \\
\hline Se--1- & .5 & 1 & $<.5$ & .5 & .5 & 2 & $<.5$ & $<.5$ & $<.5$ \\
\hline As---_-_--_--_-_----- 16 & 10 & 13 & 2 & 3 & 8 & 4 & 3 & 3 & 9 \\
\hline U-W-- & -- & -- & -- & -- & -- & -- & -- & -- & -- \\
\hline & 20 & 10 & 10 & 10 & 10 & 10 & 10 & 20 & 20 \\
\hline & des for co & apse and & acing cha & cteristic & of smect & & & & \\
\hline Heated------_-- & 1 & 1 & 1 & 1 & 1 & 2 & 1 & 1 & 1 \\
\hline Air dried-- & 2 & 2 & -- & -- & 2 & - & - & 2 & 2 \\
\hline & Proportio & of laye & in mixed- & yer clay & ercent) & & & & \\
\hline Illite-_L 35 & 35 & 35 & 10 & 25 & 30 & 60 & 60 & 20 & 55 \\
\hline Beidellite----------- 35 & 35 & 35 & 35 & 40 & 35 & 30 & -- & 45 & 35 \\
\hline Montmorillonite-------- 30 & 30 & 30 & 55 & 35 & 35 & 10 & -- & 35 & 10 \\
\hline & Proportio & of clay & nerals in & otal clay & (percent) & & & & \\
\hline Mixed-layer--_-- 50 & 64 & 68 & 45 & 37 & 76 & 40 & 29 & 24 & 46 \\
\hline 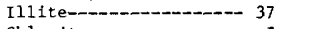 & 28 & 25 & 18 & 10 & 16 & 12 & 40 & 31 & 37 \\
\hline Chlorite--_-_- 7 & 4 & 4 & $\mathrm{~N}$ & $\mathrm{~N}$ & 3 & $\mathrm{~N}$ & 7 & 5 & 6 \\
\hline Kaolinite-_...... 6 & 4 & 3 & 37 & 53 & 5 & 48 & 24 & 40 & 11 \\
\hline & Minera & composit & of total & $\operatorname{ample}(p e$ & ent) & & & & \\
\hline Total clay--_----- 50 & 45 & 60 & 30 & 45 & 50 & 50 & 35 & 20 & 40 \\
\hline Quartz-- & 35 & 23 & 60 & 45 & 28 & 38 & 51 & 52 & 37 \\
\hline Cristobalite--_-_- N & $\mathrm{N}$ & $\mathrm{N}$ & $\mathrm{N}$ & $\mathrm{N}$ & $\mathrm{N}$ & $\mathrm{N}$ & $\mathrm{N}$ & $\mathrm{N}$ & $\mathrm{N}$ \\
\hline Potassium feldspar--- 4 & 2 & $\mathrm{~N}$ & 3 & 3 & 3 & $\mathrm{~N}$ & 5 & 5 & 3 \\
\hline Plagioclase-- & 11 & 7 & 7 & 3 & 9 & 4 & 5 & 9 & 8 \\
\hline Calcite---_--_-_-- N & $\mathrm{N}$ & $\mathrm{N}$ & $\mathrm{N}$ & $\mathrm{N}$ & 2 & $\mathrm{~N}$ & $N$ & 3 & $\mathrm{~N}$ \\
\hline Dolomite----------- 6 & 4 & 3 & $\mathrm{~N}$ & $\mathrm{~N}$ & 8 & $\mathrm{~N}$ & N & 11 & 7 \\
\hline Siderite--------- & $\mathrm{N}$ & $\mathrm{N}$ & $\mathrm{N}$ & $\mathrm{N}$ & $\mathrm{N}$ & $\mathrm{N}$ & $\mathrm{N}$ & $\mathrm{N}$ & $\mathrm{N}$ \\
\hline 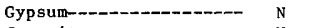 & $\mathrm{N}$ & $\mathrm{N}$ & $\mathrm{N}$ & $\mathrm{N}$ & $\mathrm{N}$ & $\mathrm{N}$ & N & $\mathrm{N}$ & $\mathrm{N}$ \\
\hline Jarosite------------ & $\mathrm{N}$ & $\mathrm{N}$ & N & $\mathrm{N}$ & $\mathrm{N}$ & $\mathrm{N}$ & $\mathrm{N}$ & $\mathrm{N}$ & $\mathrm{N}$ \\
\hline Pyrite---_--_-_--- & $\mathrm{N}$ & $\mathrm{N}$ & $\mathrm{N}$ & $\mathrm{N}$ & $\mathrm{N}$ & $\mathrm{N}$ & $\mathrm{N}$ & $\mathrm{N}$ & $\mathrm{N}$ \\
\hline Zeolite----_- N & $\mathrm{N}$ & $\mathrm{N}$ & $\mathrm{N}$ & $\mathrm{N}$ & $\mathrm{N}$ & $\mathrm{N}$ & $\mathrm{N}$ & $\mathrm{N}$ & $\mathrm{N}$ \\
\hline Anorthit & intent of & agiocla & as determ & ed by $x-r$ & analys $i$ & ercent) & & & \\
\hline Anorthite--_-_-_- 20 & 30 & -- & 20 & -- & 40 & -- & 20 & 15 & 30 \\
\hline & Bulk and & rain dens & ies, Atte & erg limit & and $\mathrm{pH}$ & & & & \\
\hline Bulk density--------- 2.16 & 2.13 & 2.14 & 2.17 & 2.13 & 2.17 & 2.14 & 2.28 & 1.87 & 2.18 \\
\hline Grain density--_-- 2.72 & 2.66 & 2.64 & 2.65 & 2.57 & 2.68 & 2.14 & 2.68 & 2.70 & 2.67 \\
\hline Liquid limit----- -- & -- & -- & -- & -- & -- & -- & -- & -- & -- \\
\hline P1astic limit----- -- & -- & - & -- & -- & -- & -- & -- & - & -- \\
\hline Plastic index-- -- & -- & -- & - & - & -- & - & -- & - & -- \\
\hline pH---_-_-_-_-_-_-_- & -- & - & - & -- & -- & -- & -- & -- & -- \\
\hline
\end{tabular}


TABLE 1.-Chemical, mineralogical, and physical-properties data for 226 samples of Pierre Shale and equivalent rocks-Continued

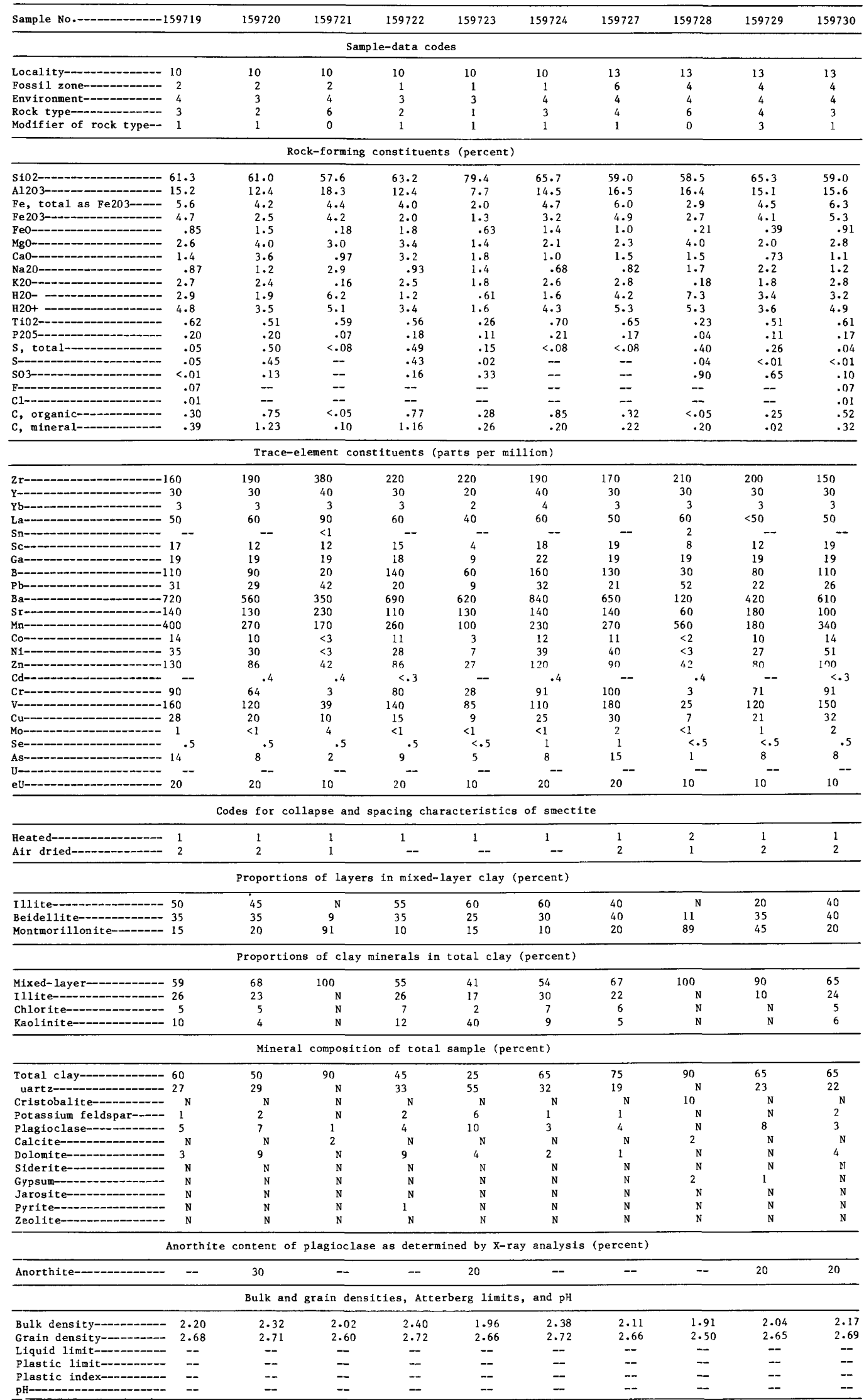


TABLE 1.-Chemical, mineralogical, and physical-properties data for 226 samples of Pierre Shale and equivalent rocks-Continued

\begin{tabular}{|c|c|c|c|c|c|c|c|c|c|c|}
\hline Sample No.--_-_-_-_- & 159731 & 159732 & 159733 & 159734 & 159735 & 159736 & 159750 & C875 & 159751 & 159752 \\
\hline & & & Sam & -data co & & & & & & \\
\hline Locality----------- & 13 & 13 & 13 & 13 & 13 & 13 & 14 & 14 & 14 & 14 \\
\hline Fossil zone---1- & 3 & 3 & 2 & 2 & 1 & 1 & 5 & 5 & 4 & 4 \\
\hline Environment------------ & 2 & 3 & 4 & 4 & 3 & 3 & 4 & 4 & 4 & 4 \\
\hline Rock type---- & 2 & 2 & 3 & 4 & 2 & 2 & 3 & 4 & 3 & 6 \\
\hline Modifier of rock type-- & 5 & 1 & 1 & 7 & 1 & 1 & 3 & 1 & 1 & 8 \\
\hline & & & -forming & nstituen & (percent) & & & & & \\
\hline Si02--- & 71.8 & 61.9 & 60.8 & 61.3 & 70.8 & 53.3 & 61.8 & 61.16 & 64.3 & 55.7 \\
\hline A1203-- & 13.9 & 12.7 & 16.5 & 15.2 & 11.0 & 10.7 & 15.1 & 16.23 & 17.0 & 21.0 \\
\hline $\mathrm{Fe}$, total as $\mathrm{Fe} 203-$ & 2.4 & 3.9 & 6.5 & 4.6 & 3.6 & 2.6 & 5.4 & 5.34 & 3.9 & 4.6 \\
\hline Fe203- & 2.2 & 2.9 & 5.5 & 4.0 & 2.5 & .52 & 5.1 & 3.10 & 3.5 & $4 \cdot 3$ \\
\hline Feo---D-- & .20 & .92 & .89 & .58 & .96 & 1.9 & .26 & 2.04 & .32 & .30 \\
\hline $\mathrm{MgO} 0-1-0-0-1$ & .73 & 3.6 & 1.7 & 2.9 & 2.3 & 5.2 & 2.0 & 1.92 & 1.4 & 2.8 \\
\hline CaO--D- & 2.1 & 3.4 & .80 & 1.4 & 1.4 & 8.8 & .65 & .71 & .12 & .84 \\
\hline Na20--- & 2.5 & 1.5 & 1.0 & 1.1 & .78 & 1.6 & 1.1 & 1.57 & .93 & 1.8 \\
\hline K20--- & 1.4 & 2.7 & 2.6 & 2.2 & 2.3 & 2.1 & 2.0 & 2.67 & 3.2 & .38 \\
\hline H2D- - & 2.0 & 2.3 & 3.9 & 4.9 & 1.5 & 1.2 & 4.6 & 2.84 & 2.8 & $6 \cdot 1$ \\
\hline H2O+ - & 2.2 & 3.1 & 5.1 & 4.4 & 3.3 & 2.3 & 4.8 & 4.59 & 5.3 & 6.0 \\
\hline TiO2-- & .47 & .52 & .70 & .63 & .61 & .37 & .53 & .63 & .75 & .35 \\
\hline P205- & .03 & .15 & .17 & .16 & .16 & .16 & .11 & .11 & .07 & .12 \\
\hline S, tota1- & $<.08$ & $<.08$ & $<.08$ & $<.08$ & $<.08$ & .73 & .40 & 1.07 & $<.08$ & $<.08$ \\
\hline 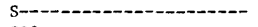 & -- & -- & -- & -- & - & .48 & .03 & .64 & -- & -- \\
\hline SO3---1- & - & -- & -- & -- & -- & .63 & .93 & 1.07 & -- & -- \\
\hline 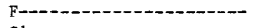 & -- & -- & -- & -- & - & - & -- & .05 & -- & -- \\
\hline Cl-1- & -- & -- & -- & -- & -- & -- & -- & $<.01$ & -- & -- \\
\hline c, organic---- & .13 & .19 & .50 & .17 & .49 & .91 & .41 & 1.00 & .66 & $<.05$ \\
\hline c, mineral-_-_. & .03 & 1.21 & .03 & .30 & .52 & 2.28 & .02 & .03 & $<.01$ & .02 \\
\hline & & Trace-e & ment cons & tuents $(t$ & ts per mi & ion) & & & & \\
\hline 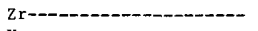 & 270 & 210 & 170 & 150 & 240 & 230 & 170 & 150 & 170 & 220 \\
\hline 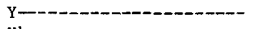 & 20 & 30 & 30 & 30 & 30 & 40 & 30 & 30 & 30 & 30 \\
\hline 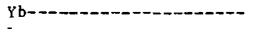 & 2 & 3 & 3 & 3 & 3 & 3 & 3 & 3 & 3 & 2 \\
\hline 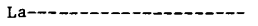 & 50 & 50 & $<50$ & 50 & 50 & 50 & $<50$ & 30 & 50 & 80 \\
\hline Sn--.-- & -- & - & -- & -- & -- & -- & -- & -- & -- & $<1$ \\
\hline 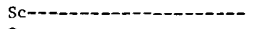 & 8 & 14 & 18 & 16 & 11 & 13 & 15 & 15 & 19 & $<6$ \\
\hline Ga-- & 17 & 19 & 23 & 20 & 16 & 14 & 21 & 15 & 21 & 20 \\
\hline B--1-- & 30 & 70 & 90 & 110 & 170 & 80 & 100 & 70 & 150 & 50 \\
\hline 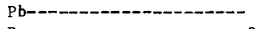 & 24 & 21 & 41 & 27 & 40 & 16 & 22 & 15 & 26 & 20 \\
\hline Ва------ & 200 & 570 & 770 & 510 & 940 & 750 & 570 & 700 & 680 & 260 \\
\hline Sr---1-- & 630 & 140 & 130 & 160 & 120 & 260 & 210 & 70 & 110 & 180 \\
\hline Mn- & 60 & 220 & 180 & 190 & 180 & 300 & 130 & 230 & 100 & 90 \\
\hline 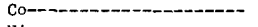 & 11 & 9 & 14 & 11 & 10 & 7 & 9 & 15 & 10 & 5 \\
\hline 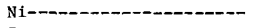 & 12 & 22 & 42 & 28 & 28 & 19 & 20 & 30 & 31 & 15 \\
\hline Zn----_- & 44 & 60 & 110 & 92 & 100 & 64 & 90 & 130 & 98 & 28 \\
\hline 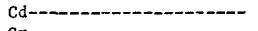 & -- & -- & $<.3$ & -- & -- & .4 & -- & - & $<.3$ & .3 \\
\hline 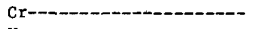 & 83 & 70 & 91 & 72 & 75 & 40 & 61 & 70 & 110 & 4 \\
\hline 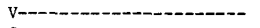 & 91 & 100 & 160 & 120 & 170 & 92 & 160 & 150 & 200 & 29 \\
\hline Cu-- & 26 & 15 & 29 & 29 & 13 & 18 & 20 & 30 & 25 & 5 \\
\hline Mo--_- & 3 & 1 & 1 & 1 & $<1$ & 5 & 1 & $<10$ & 2 & 2 \\
\hline 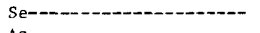 & $<.5$ & $<.5$ & $<.5$ & $<.5$ & $<.5$ & 1 & 1 & 1 & .5 & $<.5$ \\
\hline As--1-1- & 4 & 7 & 19 & 12 & 8 & 9 & 11 & 10 & 6 & 1 \\
\hline U- & -- & -- & -- & -- & -- & -- & -- & $<10.0$ & -- & - \\
\hline 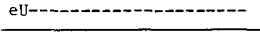 & 10 & 10 & 10 & 10 & 20 & 20 & 20 & 20 & 30 & 10 \\
\hline & Co & s for col & pse and $s$ & cing cha & teristics & f smectit & & & & \\
\hline Heated----_- & 1 & 1 & 1 & 2 & 1 & 1 & 1 & 1 & 2 & 2 \\
\hline Air dried-_-_- & 2 & 2 & 2 & 2 & 2 & 2 & 2 & 1 & 2 & 1 \\
\hline & & roportion & of layers & mixed-1 & er clay ( & rcent) & & & & \\
\hline 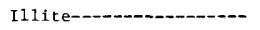 & 20 & 40 & 50 & 30 & 55 & 40 & 30 & 55 & 50 & $\mathrm{~N}$ \\
\hline Beidellite--- & 30 & 45 & 35 & 35 & 30 & 15 & 35 & -- & 35 & 20 \\
\hline Montmorillonite------- & 50 & 15 & 15 & 35 & 15 & 45 & 35 & -- & 15 & 80 \\
\hline & & roportion & of clay $n$ & erals in & tal clay & ercent) & & & & \\
\hline Mixed-layer-----_--_-- & 96 & 58 & 71 & 82 & 60 & 58 & 90 & 74 & 75 & 100 \\
\hline 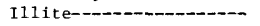 & 4 & 33 & 20 & 15 & 25 & 27 & 10 & 17 & 16 & $\mathrm{~N}$ \\
\hline Chlorite-- & $\mathrm{N}$ & 4 & 3 & 1 & 6 & 7 & $\mathrm{~N}$ & 3 & $\mathrm{~N}$ & $\mathrm{~N}$ \\
\hline Kaolinite-- & $\mathrm{N}$ & 5 & 6 & 2 & 9 & 8 & $\mathrm{~N}$ & 6 & 9 & $\mathrm{~N}$ \\
\hline & & Mineral & ompositio & of total & mple (per & nt) & & & & \\
\hline Total clay- & 45 & 45 & 65 & 70 & 50 & 35 & 70 & 75 & 70 & 90 \\
\hline Quartz- & 30 & 29 & 22 & 21 & 45 & 27 & 20 & 22 & 25 & $\mathrm{~N}$ \\
\hline Cr1stobalite- & $\mathrm{N}$ & $\mathrm{N}$ & $\mathrm{N}$ & $\mathrm{N}$ & $\mathrm{N}$ & $\mathrm{N}$ & $\mathrm{N}$ & $\mathrm{N}$ & $\mathrm{N}$ & $\mathrm{N}$ \\
\hline Potassium feldspar--... & 5 & 3 & $\mathrm{~N}$ & 1 & 1 & 3 & 1 & $\mathrm{~N}$ & 2 & $\mathrm{~N}$ \\
\hline Plagioclase-- & 21 & 9 & 7 & 6 & 4 & 10 & 5 & 3 & 5 & 6 \\
\hline Calcite--------- & $\mathrm{N}$ & $\mathrm{N}$ & $\mathrm{N}$ & $\mathrm{N}$ & $\mathrm{N}$ & 2 & $\mathrm{~N}$ & $\mathrm{~N}$ & $\mathrm{~N}$ & $\mathrm{~N}$ \\
\hline Dolom1te--_-_-_-_-_-_-_- & $\mathrm{N}$ & 10 & $\mathrm{~N}$ & 2 & 4 & 19 & $\mathrm{~N}$ & $\mathrm{~N}$ & $\mathrm{~N}$ & $\mathrm{~N}$ \\
\hline Siderite------- & $\mathrm{N}$ & $\mathrm{N}$ & $\mathrm{N}$ & $\mathrm{N}$ & $\mathrm{N}$ & $\mathrm{N}$ & $\mathrm{N}$ & $\mathrm{N}$ & $\mathrm{N}$ & $\mathrm{N}$ \\
\hline Gypsum--1--_-- & $\mathrm{N}$ & $\mathrm{N}$ & $\mathrm{N}$ & $\mathrm{N}$ & $\mathrm{N}$ & 1 & $\mathrm{~N}$ & $\mathrm{~N}$ & $\mathrm{~N}$ & $\mathrm{~N}$ \\
\hline Jarosite-- & $\mathrm{N}$ & $\mathrm{N}$ & $\mathrm{N}$ & $\mathrm{N}$ & $\mathrm{N}$ & $\mathrm{N}$ & 3 & $\mathrm{~N}$ & $\mathrm{~N}$ & $\mathrm{~N}$ \\
\hline Pyrite------ & $\mathrm{N}$ & $\mathrm{N}$ & $\mathrm{N}$ & $\mathrm{N}$ & $\mathrm{N}$ & 1 & $\mathrm{~N}$ & 2 & $\mathrm{~N}$ & $\mathrm{~N}$ \\
\hline Zeolite------ & $\mathrm{N}$ & $\mathrm{N}$ & $\mathrm{N}$ & $\mathrm{N}$ & $\mathrm{N}$ & $\mathrm{N}$ & $\mathrm{N}$ & $\mathrm{N}$ & $\mathrm{N}$ & $\mathrm{N}$ \\
\hline & horthite & tent of & gloclase & determ & by $\mathrm{x}-\mathrm{ra}$ & analys is & rcent) & & & \\
\hline Anorthite-----_-- & 40 & -- & -- & - & -- & 30 & 30 & - & -- & 45 \\
\hline & & Bulk and & ain densi & es, Atte & rg limits & and $\mathrm{pH}$ & & & & \\
\hline Bulk density--- & 1.68 & 2.10 & 2.12 & 2.13 & 2.16 & 2.01 & 2.03 & -- & 2.12 & 2.09 \\
\hline Grain density- & 2.63 & 2.69 & 2.68 & 2.58 & 2.67 & 2.68 & 2.58 & - & 2.63 & 2.49 \\
\hline Liquid limit---- & -- & -- & -- & -- & -- & -- & -- & 46 & -- & -- \\
\hline Plastic limit-_- & - & -- & -- & -- & -- & -- & -- & 23 & -- & -- \\
\hline Plastic index----- & -- & -- & -- & -- & -- & -- & -- & 23 & -- & -- \\
\hline pH-- & -- & - & -- & -- & -- & -- & - & -- & - & - \\
\hline
\end{tabular}


COMPOSITION AND PROPERTIES, NORTHERN GREAT PLAINS REGION

TABLE 1.-Chemical, mineralogical, and physical-properties data for 226 samples of Pierre Shale and equivalent rocks-Continued

\begin{tabular}{|c|c|c|c|c|c|c|c|c|c|}
\hline Sample No.-..-_-_---159753 & 159754 & 159755 & 159756 & 159757 & 159758 & 159759 & 159760 & 159761 & 159762 \\
\hline \multicolumn{10}{|c|}{ Sample-data codes } \\
\hline Locality--_--_-_--- 14 & 14 & 14 & 14 & 14 & 14 & 14 & 14 & 14 & 14 \\
\hline Fossil zone----- 4 & 3 & 3 & 3 & 2 & 2 & 2 & 1 & 1 & 1 \\
\hline Environment----_--_---- 4 & 2 & 1 & 1 & 4 & 4 & 4 & 3 & 3 & 4 \\
\hline Rock type------- 4 & 3 & 3 & 2 & 3 & 6 & 3 & 2 & 2 & 5 \\
\hline Modifier of rock type- 1 & 6 & 3 & 5 & 1 & 8 & 7 & 1 & 1 & 0 \\
\hline \multicolumn{10}{|c|}{ Rock-forming constituents (percent) } \\
\hline $\mathrm{Si02}$ & 64.0 & 71.9 & 69.2 & 58.2 & 49.1 & 62.8 & 62.3 & 67.1 & 48.3 \\
\hline Al203- 16.9 & 15.5 & 12.3 & 15.7 & 17.4 & 17.0 & 14.7 & 12.9 & 10.4 & 13.0 \\
\hline $\mathrm{Fe}$, total as Fe203-- 5.0 & 2.8 & 3.9 & 1.4 & 7.4 & 3.9 & 4.9 & 3.9 & 3.1 & 3.8 \\
\hline Fe203- & 1.7 & 3.6 & $1 \cdot 2$ & 6.9 & 3.5 & 4.1 & 1.9 & 2.1 & 2.5 \\
\hline FeO-- & 1.0 & .23 & .15 & .41 & .35 & .72 & 1.8 & .87 & 1.2 \\
\hline $\mathrm{MgO}$ & .74 & 1.0 & .83 & 1.5 & 4.0 & 2.7 & 3.4 & 3.3 & 2.4 \\
\hline CaO-_-60 & .37 & .57 & 2.7 & .21 & 4.3 & .89 & 2.6 & 3.4 & 9.1 \\
\hline Na20-- & 1.6 & 2.1 & 3.4 & .79 & 1.0 & .79 & 1.2 & .67 & 1.2 \\
\hline K20- & 2.8 & 1.7 & 2.1 & 2.6 & .24 & 2.2 & 2.4 & 2.2 & 2.0 \\
\hline $\mathrm{H} 20-$ & 2.0 & 3.0 & 1.5 & 4.2 & 9.1 & 5.2 & 2.2 & 1.5 & 3.5 \\
\hline $\mathrm{H} 2 \mathrm{O}+$ & 4.9 & 2.8 & 1.8 & 6.6 & 6.0 & 5.3 & 3.9 & 3.3 & 4.5 \\
\hline Ti02-- & .63 & .56 & .52 & .76 & .39 & .58 & .50 & .41 & .49 \\
\hline P205-_-08 & .03 & .01 & .11 & .15 & .08 & .21 & .16 & .16 & .17 \\
\hline $\mathrm{S}$, total-_- $<.08$ & .18 & $<.08$ & .14 & $<.08$ & .30 & $<.08$ & .40 & $<.08$ & 1.70 \\
\hline s- & .05 & -- & $<.01$ & - & .02 & $-\infty$ & .29 & -- & 1.10 \\
\hline 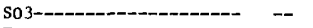 & .31 & -- & .35 & -- & .69 & -- & .28 & -- & 1.50 \\
\hline 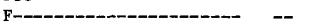 & -- & -- & .03 & - & -- & -- & -- & -- & - \\
\hline c1-------_-_-_---_------ & -- & -- & $<.01$ & -- & -- & -- & -- & -- & -- \\
\hline c, organic--_-_-_- $\quad .55$ & 3.48 & .11 & .08 & .71 & $<.05$ & .55 & 1.11 & .25 & 2.02 \\
\hline c, mineral---_------ $<.01$ & $<.01$ & .03 & .01 & $<.01$ & .42 & .05 & .65 & 1.30 & 2.05 \\
\hline \multicolumn{10}{|c|}{ Trace-element constituents (parts per million) } \\
\hline $\mathrm{Zr}-\mathrm{C}$ & 320 & 270 & 150 & 150 & 150 & 170 & 200 & 300 & 160 \\
\hline Y------ 30 & 60 & 30 & 30 & 30 & 40 & 40 & 20 & 40 & 20 \\
\hline 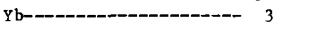 & 5 & 2 & 3 & 3 & 3 & 4 & 3 & 3 & 2 \\
\hline La--_-_- 50 & 90 & 50 & $<50$ & $<50$ & 60 & 60 & 50 & 60 & 50 \\
\hline Sn--_____- -- & -- & $<1$ & & & 1 & -- & 1 & -- & -- \\
\hline Sc--_- 20 & 16 & 7 & 12 & 25 & 16 & 17 & 13 & 13 & 8 \\
\hline Ga--- & 22 & 14 & 19 & 20 & 18 & 20 & 17 & 16 & 16 \\
\hline B----- & 90 & 30 & $<20$ & 130 & 90 & 100 & 130 & 110 & 60 \\
\hline 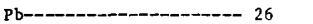 & 23 & 16 & 15 & 18 & 28 & 21 & 23 & 22 & 42 \\
\hline $\mathrm{Ba}-$ & 640 & 440 & 810 & 780 & 560 & 580 & 830 & 730 & 680 \\
\hline Sr--W- & 140 & 270 & 810 & 140 & 140 & 160 & 100 & 130 & 150 \\
\hline $\mathrm{Mn}-$ & 90 & 60 & 50 & 100 & 420 & 190 & 150 & 200 & 300 \\
\hline Co--1-_- 12 & 14 & 14 & 10 & 10 & 12 & 10 & 10 & 8 & 6 \\
\hline 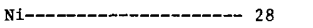 & 24 & 18 & 11 & 33 & 42 & 46 & 26 & 24 & 13 \\
\hline Zn--100 & 70 & 32 & 46 & 96 & 45 & 110 & 87 & 72 & 100 \\
\hline $\mathrm{cd}-1-1-3$ & $<.3$ & -- & -- & $<.3$ & .5 & .7 & .3 & - & 1.2 \\
\hline $\mathrm{Cr}-\mathrm{-r}-\mathrm{s}$ & 50 & 53 & 66 & 110 & 68 & 66 & 71 & 69 & 34 \\
\hline V--1-170 & 81 & 78 & 95 & 180 & 20 & 140 & 160 & 140 & 160 \\
\hline Cu------_- & 21 & 16 & 10 & 36 & 3 & 36 & 24 & 14 & 24 \\
\hline Mo--_-1-1-_-1 & $<1$ & $<1$ & 1 & $<1$ & 3 & 2 & $<1$ & $<1$ & 20 \\
\hline Se--_-_-_-_-_-_-_-_-- 1 & 1 & $<.5$ & $<.5$ & 2 & .5 & 2 & 1 & 1 & 5 \\
\hline 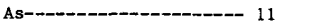 & 7 & 3 & 7 & 25 & 2 & 11 & 9 & 5 & 16 \\
\hline U-口-- - & -- & - & -- & - & -- & - & - & -- & -- \\
\hline 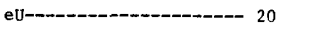 & 20 & 10 & 20 & 20 & 10 & 20 & 20 & 20 & 20 \\
\hline
\end{tabular}

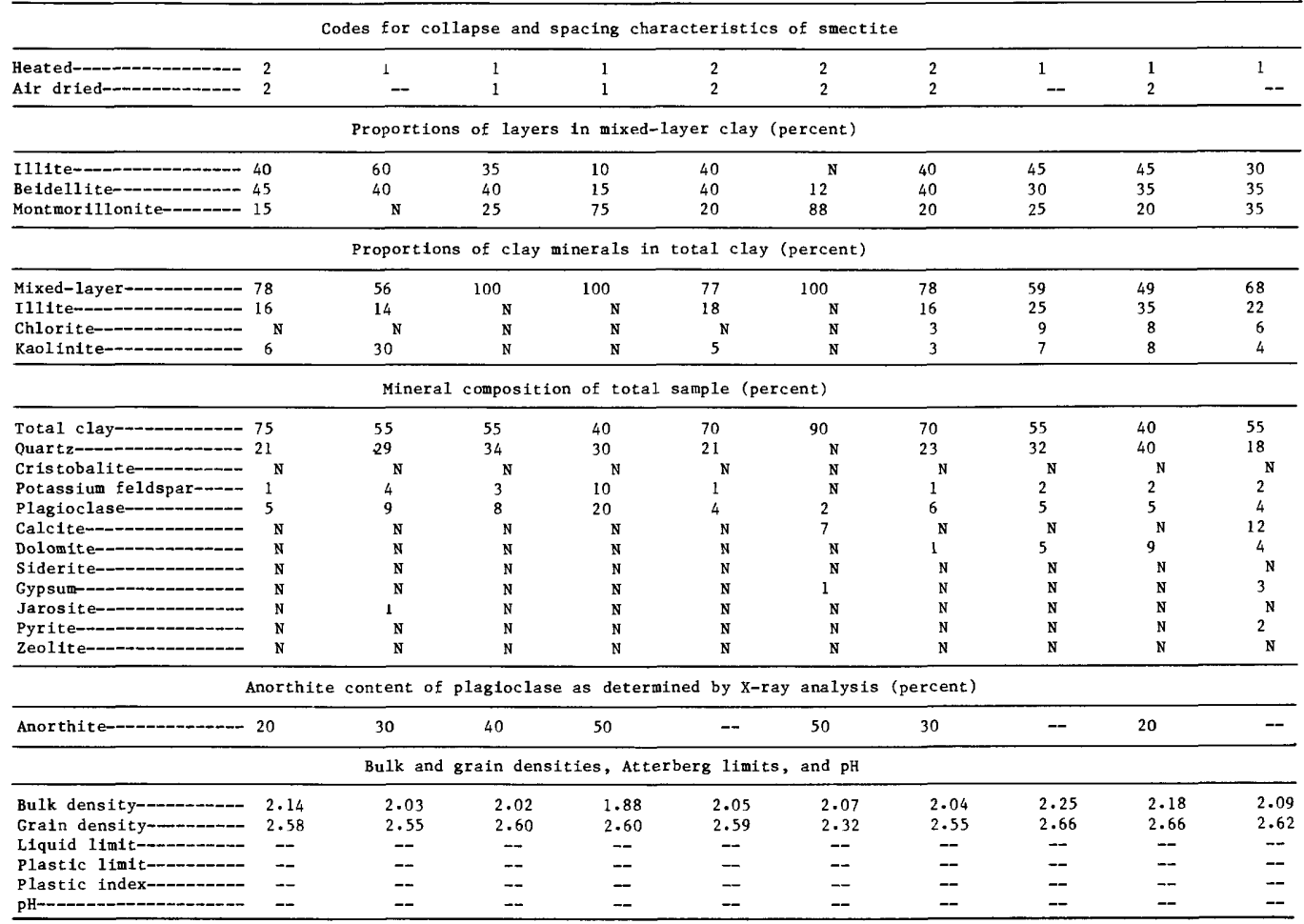


TABLE 1.-Chemical, mineralogical, and physical-properties data for 226 samples of Pierre Shale and equivalent rocks-Continued

\begin{tabular}{|c|c|c|c|c|c|c|c|c|c|}
\hline Sample No.-_-_-_-159737 & 159738 & 159739 & 159740 & 159741 & 159742 & 159743 & 159744 & 159745 & 159746 \\
\hline \multicolumn{10}{|c|}{ Sample-data codes } \\
\hline Local1ty---------- 15 & 15 & 15 & 15 & 15 & 15 & 15 & 15 & 15 & 15 \\
\hline Foss11 zone--- 6 & 6 & 5 & 4 & 4 & 3 & 3 & 3 & 2 & 2 \\
\hline Environment----------- 1 & 4 & 4 & 4 & 4 & 3 & 3 & 3 & 4 & 4 \\
\hline Rock type---_-_---- 3 & 4 & 3 & 6 & 3 & 2 & 3 & 2 & 3 & 4 \\
\hline Modifier of rock type-- 1 & 1 & 1 & 8 & 1 & 1 & 1 & 1 & 1 & 1 \\
\hline & & ck-form1 & constitu & ts (perce & & & & & \\
\hline S102-1- 60.0 & 60.7 & 60.0 & 56.7 & 63.0 & 64.7 & 60.6 & 62.5 & 61.0 & 58.8 \\
\hline A1203- 14.6 & 15.6 & 16.2 & 20.5 & 16.7 & 12.1 & 16.5 & 11.8 & 16.1 & 17.7 \\
\hline $\mathrm{Fe}$, total as $\mathrm{Fe} 203---4$ & 6.1 & 5.8 & 4.3 & 4.6 & 3.3 & 6.1 & 3.3 & 6.6 & 5.6 \\
\hline Fe203- & 5.4 & 4.8 & 3.8 & 4.2 & 2.0 & 5.2 & 2.2 & 6.1 & 5.2 \\
\hline Fe0-- & .64 & .90 & .46 & .35 & 1.2 & .80 & 1.0 & .41 & .34 \\
\hline MgO-- & 2.3 & 2.4 & 2.9 & 1.7 & 3.2 & 1.7 & 3.9 & 1.4 & 1.4 \\
\hline Ca0--- & .54 & .61 & .82 & .33 & 3.0 & .56 & 3.5 & .46 & .22 \\
\hline Na20-- & 1.1 & 1.4 & 2.5 & 1.5 & 1.5 & 1.2 & 1.6 & 1.1 & .72 \\
\hline K20-1- 3.1 & 2.7 & 3.1 & .43 & 2.4 & 2.3 & 2.6 & 2.4 & 2.6 & 2.7 \\
\hline H2O- - 2.0 & $4: 2$ & 3.3 & 4.9 & 3.8 & 1.9 & 3.3 & 1.9 & 3.6 & 4.3 \\
\hline $\mathrm{H} 2 \mathrm{O}+\mathrm{C}_{-1}$ & 4.7 & 4.7 & 4.8 & $4 \cdot 9$ & 3.0 & 5.3 & 3.0 & 5.2 & 6.1 \\
\hline T102-_- .56 & .66 & .65 & .29 & .64 & .48 & .66 & .46 & .69 & .69 \\
\hline P205---------------- $\quad .12$ & .15 & .20 & .13 & .08 & .11 & .11 & .11 & .17 & .14 \\
\hline $\mathrm{s}$, tota1- $<.08$ & $<.08$ & .34 & .36 & .15 & .19 & .28 & .19 & .33 & $<.08$ \\
\hline 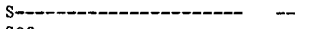 & -- & .28 & $<.01$ & $<.01$ & .14 & $<.01$ & $<.01$ & .02 & - \\
\hline SO3--------------------- & -- & .15 & .89 & .37 & .13 & .70 & .48 & .78 & -- \\
\hline 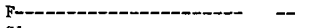 & -- & -- & -- & -- & -- & .06 & -- & -- & -- \\
\hline 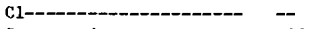 & -- & -- & -- & -- & -- & $<.01$ & -- & -- & -- \\
\hline c, organic---------- $\quad .12$ & .43 & .43 & .07 & .42 & .29 & .81 & .29 & .57 & .94 \\
\hline c, mineral--_--_-_-- $\quad .89$ & .01 & .06 & .02 & .01 & 1.06 & .01 & 1.03 & .01 & .01 \\
\hline & Trac & lement c & stituents & parts per & .111on) & & & & \\
\hline Zr------160 & 150 & 170 & 220 & 200 & 260 & 160 & 250 & 170 & 140 \\
\hline 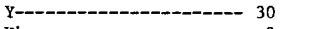 & 20 & 40 & 40 & 30 & 30 & 30 & 30 & 30 & 30 \\
\hline 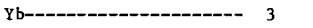 & 2 & 4 & 3 & 3 & 3 & 3 & 3 & 3 & 2 \\
\hline La----------------------- 50 & $<50$ & 50 & 70 & 50 & 50 & $<50$ & 50 & $<50$ & 50 \\
\hline $\mathrm{Sn}---1$ & - & -- & 3 & - & -- & - & - & -- & - \\
\hline 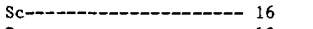 & 19 & 19 & $<6$ & 19 & 13 & 18 & 13 & 18 & 25 \\
\hline 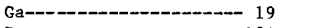 & 19 & 20 & 21 & 23 & 18 & 21 & 16 & 22 & 20 \\
\hline B - - & 80 & 140 & $<20$ & 130 & 60 & 120 & 60 & 100 & 160 \\
\hline Pb---_- 23 & 29 & 21 & 14 & 18 & 16 & 29 & 30 & 24 & 22 \\
\hline $\mathrm{Ba}=--1-0$ & 810 & 750 & 480 & 700 & 500 & 500 & 500 & 740 & 1,100 \\
\hline Sr--100 & 150 & 130 & 140 & 180 & 130 & 80 & 110 & 200 & 130 \\
\hline 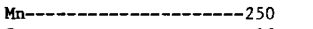 & 170 & 280 & 160 & 100 & 180 & 120 & 160 & 200 & 100 \\
\hline Co---D-- 12 & 9 & 14 & 7 & 12 & 10 & 11 & 9 & 14 & 12 \\
\hline N1--- & 30 & 40 & 30 & 29 & 23 & 33 & 18 & 34 & 31 \\
\hline 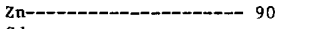 & 98 & 110 & 42 & 99 & 68 & 120 & 59 & 150 & 140 \\
\hline 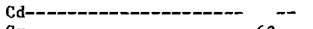 & -- & - & .6 & - & -- & <.3 & -- & $<.3$ & $<.3$ \\
\hline 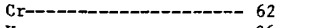 & 91 & 100 & 5 & 84 & 63 & 75 & 55 & 84 & 100 \\
\hline v------------------- 86 & 160 & 200 & 19 & 160 & 91 & 160 & 83 & 160 & 200 \\
\hline 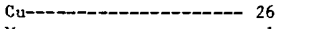 & 34 & 27 & 12 & 29 & 16 & 36 & 19 & 37 & 29 \\
\hline 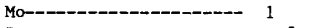 & 2 & 3 & 4 & 1 & 3 & 2 & 1 & 1 & 6 \\
\hline Se--n- & .5 & 1 & $<.5$ & $<.5$ & $<.5$ & .5 & .5 & .5 & 1 \\
\hline 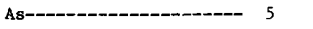 & 14 & 16 & 1 & 8 & 8 & 17 & 9 & 16 & 14 \\
\hline 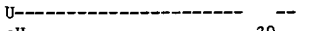 & -- & -- & -- & - & -- & -- & - & -- & - \\
\hline eU--n- 20 & 20 & 20 & 10 & 20 & 10 & 20 & 30 & 20 & 20 \\
\hline & des for & llapse an & spacing $c$ & racterist & of smec & & & & \\
\hline Heated----------------- 1 & 2 & 2 & 2 & 2 & 2 & 2 & 2 & 2 & 2 \\
\hline Air drfed--------_--- 2 & 2 & 2 & 1 & 2 & 2 & 2 & 2 & 2 & 2 \\
\hline & Proport & is of lay & in mixe & layer cla & percent) & & & & \\
\hline 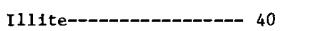 & 40 & 45 & $\mathbf{N}$ & 40 & 35 & 45 & 40 & 40 & 40 \\
\hline Beidellite----------- 35 & 30 & 40 & 15 & 45 & 35 & 30 & 40 & 45 & 40 \\
\hline Montmorillonite--.--_- 25 & 30 & 15 & 85 & 15 & 30 & 25 & 20 & 15 & 20 \\
\hline & Proport & is of cla & ninerals & total $\mathrm{cl}$ & (percent & & & & \\
\hline Mixed-1ayer---------- 44 & 75 & 60 & 100 & 77 & 68 & 75 & 64 & 81 & 68 \\
\hline Ill1te-- & 18 & 27 & $\mathrm{~N}$ & 15 & 18 & 17 & 24 & 12 & 21 \\
\hline Chlorite-------------- 12 & 4 & 5 & $\mathrm{~N}$ & 3 & 4 & 3 & 5 & $\mathrm{~N}$ & N \\
\hline Kaolinite------------- 6 & 3 & 8 & N & 5 & 10 & 5 & 7 & 7 & 11 \\
\hline & Mine & composi & on of tot & sample & cent) & & & & \\
\hline Total clay------------- 50 & 70 & 60 & 95 & 70 & 40 & 70 & 40 & 60 & 75 \\
\hline Quartz-- 27 & 22 & 22 & 2 & 24 & 33 & 22 & 31 & 24 & 20 \\
\hline Cristobalite------- N & $\mathrm{N}$ & $\mathrm{N}$ & $\mathrm{N}$ & $\mathrm{N}$ & $\mathrm{N}$ & $\mathrm{N}$ & $\mathrm{N}$ & $\mathbf{N}$ & $\mathbf{N}$ \\
\hline Potassium feldspar---- 1 & 2 & 2 & $\mathrm{~N}$ & $\mathrm{~N}$ & 5 & $\mathrm{~N}$ & 5 & 2 & 1 \\
\hline Plagloclase-m----- 8 & 8 & 5 & 4 & 7 & 10 & 8 & 10 & 6 & 3 \\
\hline Calc1te--_-_-_-_-_- & $\mathbf{N}$ & $\mathbf{N}$ & $\mathrm{N}$ & 1 & $\mathbf{N}$ & $\mathrm{N}$ & N & $\mathbf{N}$ & $\mathbf{N}$ \\
\hline Dolomite--_-_-_-_-_- 7 & $\mathrm{~N}$ & $\mathrm{~N}$ & $\mathrm{~N}$ & $\mathrm{~N}$ & 8 & $\mathrm{~N}$ & 10 & $\mathrm{~N}$ & $\mathrm{~N}$ \\
\hline 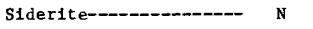 & $\mathbf{N}$ & $\mathrm{N}$ & $\mathrm{N}$ & $\mathrm{N}$ & $\mathrm{N}$ & $\mathrm{N}$ & $\mathrm{N}$ & $\mathrm{N}$ & $\mathrm{N}$ \\
\hline 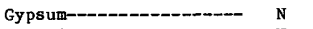 & $\mathrm{N}$ & $\mathrm{N}$ & 1 & $\mathrm{~N}$ & $\mathbf{N}$ & 1 & 1 & $\mathrm{~N}$ & $\mathrm{~N}$ \\
\hline Jarosite------------ & $\mathrm{N}$ & $\mathbf{N}$ & 1 & $\mathrm{~N}$ & $\mathbf{N}$ & $\mathbf{N}$ & $\mathrm{N}$ & 3 & $\mathrm{~N}$ \\
\hline Pyrite-------_-_----- & $\mathbf{N}$ & 1 & $\mathrm{~N}$ & $\mathbf{N}$ & $\mathrm{N}$ & $\mathrm{N}$ & $\mathrm{N}$ & $\mathrm{N}$ & $\mathrm{N}$ \\
\hline 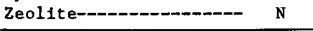 & $\mathbf{N}$ & $\mathrm{N}$ & N & $\mathrm{N}$ & $\mathrm{N}$ & N & $\mathbf{N}$ & $\mathrm{N}$ & $\mathbf{N}$ \\
\hline Anorth: & content & plagioc1 & as dete & ned by $x$ & y analys & (percent & & & \\
\hline Anorthite------------- 30 & 30 & - & 50 & 30 & 30 & 30 & 30 & 30 & -- \\
\hline & Bulk a & grain de & ies, At & berg $11 \mathrm{~m}$ & and $\mathrm{pH}$ & & & & \\
\hline Bulk density--_-_-- 2.12 & 2.03 & 2.02 & 2.14 & 2.13 & 2.00 & 2.06 & 1.98 & 2.11 & 2.07 \\
\hline Grain density-____. 2.72 & 2.63 & 2.63 & 2.56 & 2.59 & 2.65 & 2.63 & 2.61 & 2.60 & 2.59 \\
\hline L1quid 11mit--------- -- & -- & - & -- & -- & - & - & -- & -- & -- \\
\hline Plast1c l1mit-_ & -- & -- & - & -- & -- & -- & - & -- & - \\
\hline Plast1c Index---------- & -- & -- & -- & -- & -- & -- & -- & -- & - \\
\hline 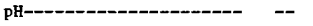 & -- & -- & -- & -- & -- & - & -- & -- & -- \\
\hline
\end{tabular}


COMPOSITION AND PROPERTIES, NORTHERN GREAT PLAINS REGION

TABLE 1.-Chemical, mineralogical, and physical-properties data for 226 samples of Pierre Shale and equivalent rocks-Continued

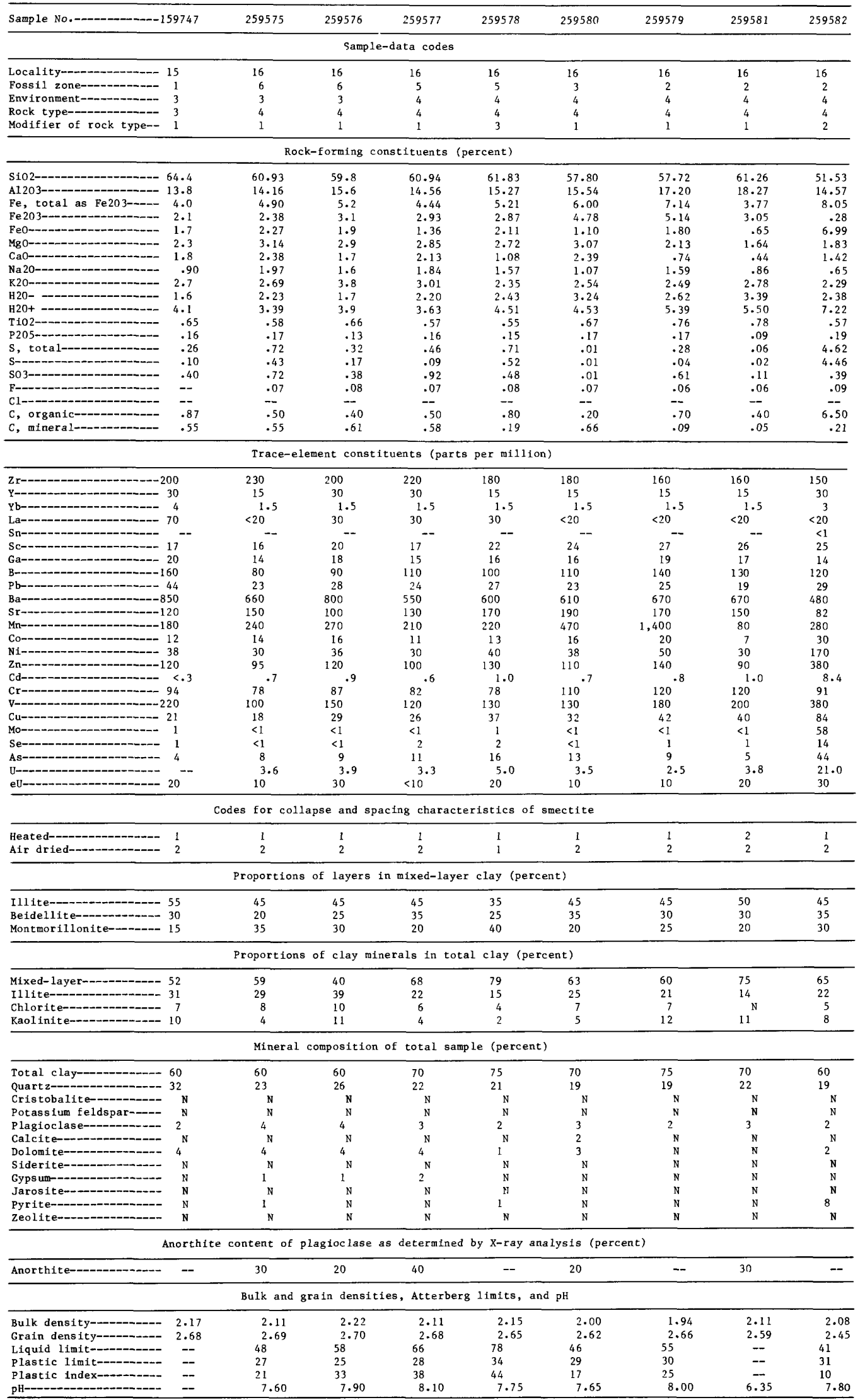


TABLE 1.-Chemical, mineralogical, and physical-properties data for 226 samples of Pierre Shale and equivalent rocks-Continued

\begin{tabular}{|c|c|c|c|c|c|c|c|c|c|}
\hline 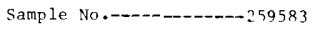 & 259590 & 259589 & 0,877 & 259586 & 299587 & 250588 & 259584 & C876 & 259591 \\
\hline \multicolumn{10}{|c|}{ Sample-data codes } \\
\hline Locality------------- 17 & 17 & 17 & 17 & 17 & 17 & 17 & 17 & 17 & 17 \\
\hline Fossil zone----------- 5 & 5 & 5 & 5 & 4 & 2 & 2 & 2 & 2 & 2 \\
\hline Environment---------- 4 & 4 & 4 & 4 & 4 & 4 & 4 & 4 & 4 & 4 \\
\hline Rock type--.-- 4 & 4 & 4 & 4 & 4 & 4 & h & 4 & 4 & 4 \\
\hline Modifier of rock type-- 3 & 1 & 3 & 1 & 3 & 1 & n & 1 & 1 & 7 \\
\hline \multicolumn{10}{|c|}{ Rock-forming constituents (percent) } \\
\hline $\sin 2-1-0-0$ & $5 \dot{8.9}$ & 61.5 & 58.09 & 60.67 & 58.1 & 42.8 & 58.5 & 57.68 & 49.3 \\
\hline AL203-- & 17.7 & $1^{5} \cdot 0$ & 16.36 & 17.15 & 17.8 & 15.7 & 17.4 & 17.93 & 13.0 \\
\hline $\mathrm{Fe}$, total as $\mathrm{Fe} 203----4 . n$ & $5 . n$ & 5.0 & 6.49 & 5.86 & 5.4 & 10.2 & 5.6 & 6.05 & 5.6 \\
\hline Fe203-- 3.4 & 4.7 & 3.4 & 5.97 & 5.44 & 4.8 & 9.1 & 5.0 & 5.39 & 4.2 \\
\hline 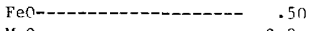 & $.3 n$ & 1.0 & .47 & .38 & .50 & .10 & .50 & .59 & 1.3 \\
\hline 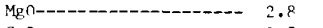 & 1.5 & 2.8 & 1.74 & 1.89 & 1.6 & 1.8 & 2.0 & 1.72 & 1.8 \\
\hline $\mathrm{Can-1-1.5}$ & .68 & .88 & .95 & .36 & .38 & 2.7 & .68 & .78 & 1.0 \\
\hline Na 20--1-1 & .72 & .90 & .68 & 1.01 & .62 & .62 & .72 & .69 & .62 \\
\hline K20--- . & 2.4 & 2.2 & 2.00 & 2.54 & 2.6 & .52 & 2.4 & 2.66 & 1.9 \\
\hline H20- & 4.9 & 4.6 & 5.52 & 3.28 & 5.2 & 9.8 & 5.3 & 4.42 & 7.3 \\
\hline $\mathrm{H} 2 \mathrm{O}+-\mathrm{-}-\mathrm{-}-\mathrm{-}$ & 5.3 & 4.4 & 4.88 & 5.07 & 5.2 & h.o & 5.2 & 5.98 & 7.5 \\
\hline Ti02- & .74 & .60 & .65 & .71 & .74 & .17 & .70 & .69 & .55 \\
\hline 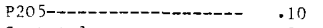 & .05 & .09 & .15 & .12 & .10 & .04 & .10 & .29 & .13 \\
\hline S, total-- & .25 & .58 & .18 & .23 & $.3 n$ & 3.15 & .24 & .05 & 3.11 \\
\hline 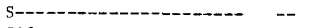 & .03 & .45 & $n ?$ & .02 & .02 & .27 & .14 & .04 & .85 \\
\hline 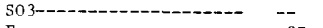 & .55 & .33 & .64 & .52 & $.7 n$ & $7.2 n$ & .24 & .02 & 5.62 \\
\hline 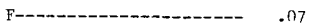 & .06 & .07 & .07 & .05 & .n8 & .08 & .05 & .07 & .08 \\
\hline 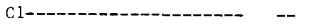 & -- & -- &.$n 1$ & -- & -- & -- & -- & $<.01$ & -- \\
\hline c, organic------n--- & $.7 n$ & $.5 n$ & $<.50$ & .40 & $.9 n$ & .05 & .40 & $<.5 n$ & $5.7 n$ \\
\hline c, mineral----_--- & $<.12$ & .21 & $<. n_{1}$ &.$n 2$ & $<.02$ & $<.02$ & .02 & .02 & $<.02$ \\
\hline \multicolumn{10}{|c|}{ Trace-element constituents (parts per million) } \\
\hline 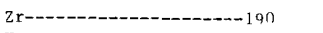 & 180 & 240 & 70 & 190 & 190 & $12 n$ & 170 & $7 n$ & 170 \\
\hline Y-15-15 & 15 & 15 & 15 & 15 & 15 & in & 15 & 15 & 15 \\
\hline Yb-- 1.9 & 3 & 1.5 & 3 & 1.5 & 3 & 1.5 & 3 & 3 & 1.5 \\
\hline La+---- & $<20$ & 30 & 30 & $<20$ & $<2 n$ & $<2 n$ & $<2 n$ & $3 n$ & 30 \\
\hline 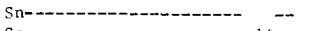 & -- & -- & - & - & -- & -- & -- & & -- \\
\hline Sc------1--14 & 26 & 22 & 15 & .75 & 29 & 10 & 24 & 15 & 20 \\
\hline 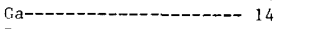 & 18 & 15 & 15 & 17 & 20 & 15 & 19 & 15 & 11 \\
\hline B-1--10 & 120 & 120 & 70 & 120 & 180 & 130 & 120 & 70 & 90 \\
\hline Pb---1-1- & $3 n$ & 24 & 15 & 18 & 30 & 19 & 23 & 15 & 12 \\
\hline 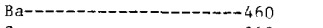 & fon & $48 n$ & $3 n n$ & 500 & $66 n$ & 6,607 & 600 & $70 n$ & 320 \\
\hline 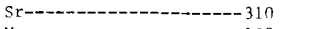 & 180 & 170 & 150 & 140 & 120 & $3 ? 0$ & 190 & $7 n$ & 76 \\
\hline 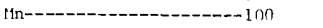 & 150 & 220 & $15 n$ & $2 n n$ & $12 n$ & on & $15 n$ & 150 & 160 \\
\hline Co--1-1- 3 & 15 & 14 & 15 & 17 & 17 & 2 & 14 & 15 & 15 \\
\hline $\mathrm{Ni}-\mathrm{-}-\mathrm{-}$ & $3 ?$ & $3 n$ & 30 & 44 & 42 & 5 & 38 & $3 n$ & 60 \\
\hline 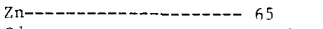 & 140 & $10 n$ & 160 & $13 n$ & $17 n$ & 40 & $14 n$ & 190 & 160 \\
\hline 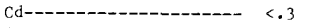 & $<.3$ & $<.3$ & -- & $<.3$ & .3 & .5 & $<.3$ & .5 & I.6 \\
\hline Cr-a-n-o- 35 & 42 & 82 & $7 n$ & $a_{5}$ & $11^{n}$ & h & $1 \mathrm{nn}$ & 70 & 76 \\
\hline 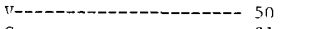 & 160 & $10 n$ & $15 n$ & 210 & $12 n$ & $3 n$ & $14 n$ & $15 n$ & $25 n$ \\
\hline 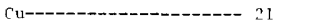 & 41 & 29 & 70 & 40 & $4^{a}$ & 13 & 37 & $7 n$ & 65 \\
\hline Mo---1- 5 & $<1$ & $<1$ & $<1 n$ & $<1$ & 1 & ? & 4 & $<1 n$ & $4^{\circ}$ \\
\hline 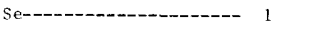 & 1 & 1 & 8 & 1 & 2 & 1 & 1 & 5 & in \\
\hline 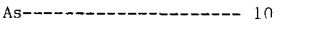 & 14 & 12 & $2 ?$ & 11 & 13 & $2 n$ & 12 & 11 & 53 \\
\hline U-1-1- 5.8 & 3.5 & 3.6 & $<10 . n$ & $3 \cdot 2$ & 5.3 & 1.1 & 3.5 & $<10.0$ & 8.8 \\
\hline 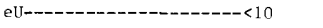 & $2 n$ & $2 n$ & in & $2 n$ & 30 & $<1 n$ & $<10$ & $1 n$ & 20 \\
\hline
\end{tabular}

\begin{tabular}{|c|c|c|c|c|c|c|c|c|c|c|}
\hline Heated--1-- & 1 & 2 & 2 & 1 & 2 & 2 & 2 & 2 & 1 & 2 \\
\hline Air dried- & 2 & 2 & 2 & 2 & 2 & 2 & 2 & 2 & 2 & 2 \\
\hline \multicolumn{11}{|c|}{ Proportions of layers in mixed-layer clay (percent) } \\
\hline 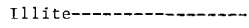 & 15 & 40 & 35 & -- & 40 & 40 & ฯ & 35 & 50 & 35 \\
\hline Beide11ite-------------- & 20 & 13 & 35 & -- & 40 & 30 & $2 n$ & 40 & -- & 20 \\
\hline Montmorillonite------- & 65 & 45 & $3 n$ & -- & 20 & 30 & 80 & 25 & -- & 45 \\
\hline \multicolumn{11}{|c|}{ Proportions of clay minerals in total clay (percent) } \\
\hline Mixed-layer-- & 95 & 82 & 84 & 82 & 83 & 74 & 100 & 82 & 72 & 86 \\
\hline Ilifte-- & 4 & 11 & 10 & 15 & 12 & 18 & $\mathrm{~N}$ & 12 & 22 & 14 \\
\hline Chlorite---------------- & 1 & 1 & 3 & 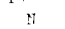 & 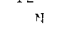 & $\mathrm{N}$ & N & $\mathrm{N}$ & 2 & $\mathrm{~N}$ \\
\hline Kaol inite--- & $\mathrm{N}$ & b & 3 & 3 & 5 & 8 & N & f & 4 & $\mathrm{~N}$ \\
\hline \multicolumn{11}{|c|}{ Mineral composition of total sample (percent) } \\
\hline Total clay------------ & 85 & 75 & 75 & 80 & $8 n$ & 75 & 80 & $8 n$ & 80 & 60 \\
\hline Ouartz- & 8 & $2 n$ & 3 & 18 & 19 & 19 & $n$ & 17 & 20 & 15 \\
\hline Cristobalite---- & 5 & v & $\mathrm{N}$ & QT & I & $\mathrm{N}$ & $\mathrm{N}$ & v & $\mathrm{M}$ & $\mathrm{N}$ \\
\hline Potassium feldspar-- & $\mathrm{N}$ & n & $\mathrm{n}$ & $\mathrm{N}$ & $\mathrm{N}$ & $n^{2}$ & 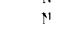 & $\mathrm{N}$ & $\mathrm{N}$ & 1 \\
\hline Plagioclase--- & 4 & 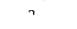 & 2 & 1 & 2 & $?$ & :1 & 1 & 1 & 1 \\
\hline Calcite-- & $\mathrm{N}$ & $\mathrm{N}$ & $\mathrm{N}$ & $\mathrm{r}:$ & $\mathrm{N}$ & $\mathrm{N}$ & $\ddot{q}$ & $\mathrm{~N}$ & $\mathrm{~N}$ & $\mathrm{~N}$ \\
\hline 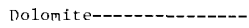 & N & $\mathrm{N}$ & 2 & s. & " & $\mathrm{M}$ & : & $\mathrm{N}$ & $\mathrm{N}$ & $\mathrm{N}$ \\
\hline Siderite---O-- & $\mathrm{N}$ & $\mathrm{N}$ & $\mathrm{N}$ & $\mathrm{N}$ & у & N & $\mathrm{N}$ & $\mathrm{N}$ & $\mathrm{N}$ & गุ \\
\hline Gypsum--_-_ & $\mathrm{N}$ & $?$ & $\mathrm{v}$ & $\because$ & $\mathrm{N}$ & n & 5 & 1 & $\mathrm{~N}$ & 4 \\
\hline Jarosite-- & $\mathrm{N}$ & $\mathrm{N}$ & ข & 1 & 1 & 2 & 15 & $\mathrm{~N}$ & $\mathrm{~N}$ & 6 \\
\hline Pyrite--------------- & $\mathrm{N}$ & i) & is & $\mathrm{N}$ & N & is & $\mathrm{N}$ & $\mathrm{N}$ & $\mathrm{N}$ & 1 \\
\hline 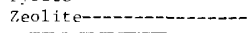 & N & N & "T & N & N & $\mathrm{N}$ & N & N & $\mathrm{N}$ & $\mathrm{N}$ \\
\hline \multicolumn{11}{|c|}{ Anorthite content of plagioclase as determined by $\mathrm{v}$-ray analvsis (percent) } \\
\hline Anorthite-------------- & -- & -- & -- & -- & -- & -- & - & -- & -- & -- \\
\hline \multicolumn{11}{|c|}{ Bulk and grain densities, Atterberg limits, and $\mathrm{pH}$} \\
\hline Bulk density - & 1.86 & 1.82 & 1.89 & -- & 1.85 & 1.85 & 1.27 & 1.99 & -- & 1.60 \\
\hline Grain density- & $\therefore .88$ & 2.53 & 2.56 & -- & 2.51 & 2.53 & 2.45 & 2.50 & - & 2.33 \\
\hline Liquid limit-- & 92 & 75 & 91 & 61 & 69 & 67 & 96 & 72 & 54 & 62 \\
\hline Plastic limit--- & 43 & 37 & 30 & 36 & 29 & $4 n$ & 53 & 35 & 33 & 46 \\
\hline Plastic index------ & 49 & 38 & S1 & 26 & $4 n$ & 27 & 43 & 37 & 21 & 16 \\
\hline pH--------------------- & 7.05 & $4.3 n$ & 7.95 & 4.25 & 4.50 & 3.80 & 3.70 & 5.15 & 4.22 & 2.30 \\
\hline
\end{tabular}


COMPOSITION AND PROPERTIES, NORTHERN GREAT PLAINS REGION

TABLE 1.-Chemical, mineralogical, and physical-properties data for 226 samples of Pierre Shale and equivalent rocks-Continued

\begin{tabular}{|c|c|c|c|c|c|c|c|c|c|}
\hline Sample No.---_--_---259592 & 259593 & 259594 & 259585 & 259565 & 259567 & 259568 & 259569 & $25956 h$ & 259570 \\
\hline \multicolumn{10}{|c|}{ Sample-data codes } \\
\hline Locality-1 17 & 17 & 17 & 17 & 18 & 18 & 18 & 18 & 18 & 18 \\
\hline Fossil zone-- & 2 & 1 & 1 & 6 & 5 & 5 & 5 & 5 & 3 \\
\hline Environment--_-_-_-_-- 4 & 4 & 4 & 4 & 4 & 4 & 4 & 4 & 4 & 3 \\
\hline Rock typen- 4 & 6 & 4 & 4 & 4 & h & 4 & 4 & 4 & 3 \\
\hline Modifier of rack type-- 7 & 0 & 1 & 1 & 1 & q & 1 & 1 & 1 & 1 \\
\hline & & $k$-formin & constitue & (percen & & & & & \\
\hline Sin2 & 52.7 & 51.5 & 61.9 & $f^{0} .01$ & 52.3 & 50.74 & 57.5 & 58.2 & 60.2 \\
\hline Al203- & 17.1 & 14.8 & 15.9 & 19.67 & 15.0 & $16.1 ?$ & 18.1 & 16.9 & 15.9 \\
\hline $\mathrm{Fe}$, total as Fe203- $\quad 6.4$ & 4.2 & 4.2 & $5 . n$ & $5 . n$ n & 5.4 & 5.84 & 6.4 & 5.8 & 5.5 \\
\hline $\mathrm{Fe} 203-\ldots .7$ & 3.7 & 2.8 & 3.6 & 3.99 & 4.7 & $? .6 ?$ & 3.4 & 5.4 & 2.7 \\
\hline Fe0- & $1 . n$ & 1.3 & 1.3 & .99 & .60 & 2.90 & 2.7 & .40 & $? .5$ \\
\hline $\operatorname{Mgn}-1-2.2$ & 4.2 & $? . h$ & 2.3 & 2.39 & 4.4 & $\therefore 31$ & 1.9 & 1.9 & 2.4 \\
\hline $\mathrm{CaO}-$ & 1.4 & 1.8 & 1.4 & 1.19 & 2.7 & 1.88 & 1.1 & 1.4 & 1.8 \\
\hline Na20-1- .47 & $.3 n$ & $1 . n$ & .59 & $1 . n 1$ & .54 & 1.34 & $1 . n$ & .56 & 1.2 \\
\hline K2n- $20-2$ & .12 & 2.8 & 2.8 & 3.22 & .53 & $3 . \mathrm{nn}$ & 2.7 & $2 . ?$ & $? .4$ \\
\hline H2O- - 6.8 & 13.1 & 1.9 & 1.9 & 3.54 & 9.2 & $2 . n 7$ & $2 . n$ & 5.4 & 2.9 \\
\hline $\mathrm{H} 2 \mathrm{n}+-$ & 5.4 & 4.1 & 4.5 & 4.05 & 5.0 & 4.54 & $\ddot{5 . n}$ & 6.7 & 3.8 \\
\hline $\operatorname{Tin} 2-\ldots$ & .56 & .73 & .78 & .66 & .42 & .69 & .76 &. . h6 & .70 \\
\hline P205 & .05 & .14 & .16 & .17 & .12 & .18 & .12 & .08 & .11 \\
\hline $\mathrm{S}$, tota1- .14 & .24 & .11 & .21 & .07 & .40 & $.5 n$ & .45 & .44 & .41 \\
\hline S-10- -- & .21 & $\ldots$ & .02 &.$n^{3}$ & $<. n t$ & .42 & .41 & .02 & .40 \\
\hline S03-- & .06 & -- & .49 & .13 & .99 & ? ? & .12 & 1.05 & .03 \\
\hline F-- & .08 & .08 & .08 & .07 & .08 & .07 & .07 &.$n 7$ & .05 \\
\hline 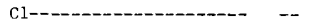 & -- & -- & -. & -- & $\ldots$ & -- & $\ldots$ & -- & -- \\
\hline c, organic- & $<.05$ & $.8 n$ & .50 & .20 & $<.05$ & .60 & .20 & $.3 n$ & .60 \\
\hline $\mathrm{c}$, minera1--_-_- $<.02$ & .05 & .67 & .37 & .08 & .24 & .34 & .25 & $<. n_{2}$ & .48 \\
\hline & Trace & lement co & tituents & arts per & IIion) & & & & \\
\hline $\mathrm{Zr}-(-1-1$ & 450 & $2 ? n$ & 210 & $2 n n$ & 280 & $3 n$ & 190 & 190 & 220 \\
\hline Y-10-10 & $3 n$ & 15 & 15 & 30 & 15 & $3 n$ & 15 & 15 & 15 \\
\hline yb- & 3 & 1.5 & 3 & 3 & 1.5 & ? & 3 & 1.5 & 1.5 \\
\hline Lam-_-_-_- & $7 n$ & $3 n$ & $3 n$ & $3 n$ & 30 & $3 n$ & 3n & $<? n$ & $<2 n$ \\
\hline $\mathrm{Sn}_{\mathrm{n}-1-\mathrm{H}}$ & -- & - & - & -- & -- & - & -- & -- & -- \\
\hline $\mathrm{Sc}-(-1-1-1$ & 15 & $2 n$ & $2 ?$ & 23 & 17 & $? 3$ & $? 4$ & 22 & 22 \\
\hline fra- & 14 & 19 & 13 & $i a$ & ח? & 19 & 24 & ?1 & 18 \\
\hline B-- & $3 n$ & 150 & 180 & $8 n$ & $i n$ & $12 n$ & $\operatorname{lin}$ & 100 & $7 n$ \\
\hline $\mathrm{Pb}=--1-1-13$ & $4 n$ & 23 & 22 & 24 & 24 & 34 & 26 & 74 & 21 \\
\hline $\mathrm{Ba}-$ & 200 & $\sin$ & 920 & $\sin$ & 790 & 910 & 790 & 700 & $73 n$ \\
\hline $\mathrm{Sr}-\cdot-$ & 170 & 170 & 160 & $12 n$ & 130 & $15 n$ & 150 & 160 & 150 \\
\hline $\mathrm{Mn}-(-\infty+\ldots+\infty-10 \mathrm{n}$ & 120 & 150 & $50 n$ & 240 & $43 n$ & $44 n$ & $\mathrm{n}$ an & $3 ? n$ & 390 \\
\hline Co-- & 3 & 11 & 16 & 14 & 9 & $2 n$ & 20 & 27 & $2 n$ \\
\hline $\mathrm{Ni}-(-24$ & 2.9 & 38 & 45 & 36 & 14 & 4? & 47 & $4 n$ & 42 \\
\hline 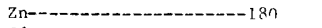 & 53 & $13 n$ & $13 n$ & $12 n$ & 62 & 1 ifn & 1 an & 120 & $13 n$ \\
\hline Cd-a & .8 & .3 & $<.3$ & $<.3$ & .9 & .3 & .7 & $<.3$ & .8 \\
\hline $\mathrm{Cr}-$ & 4 & 95 & $11 n$ & an & 17 & 130 & $12 n$ & 94 & 110 \\
\hline$v-(-2-1-230$ & 30 & 210 & $2 n n$ & 120 & 40 & 210 & 210 & $15 n$ & 130 \\
\hline $\mathrm{Cu}-1+0-10$ & 11 & 34 & 25 & 24 & 16 & 30 & 45 & 35 & 35 \\
\hline Mo--1- & $<1$ & $<1$ & $<1$ & $<1$ & 4 & $<1$ & $<1$ & 3 & 1 \\
\hline $\mathrm{Se}-(-2$ & $<1$ & 3 & 1 & ? & $<1$ & 1 & $?$ & $<1$ & 1 \\
\hline Asm- & 4 & in & 15 & 9 & 3 & 18 & 12 & 11 & 10 \\
\hline 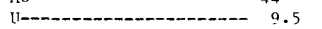 & 3.2 & $4 \cdot n$ & 3.4 & 3.7 & 5.2 & 4.7 & $3 . n$ & 3.2 & 2.7 \\
\hline eाI-W- & 10 & $2 n$ & 10 & $2 n$ & $2 n$ & $4 n$ & $2 n$ & 30 & 20 \\
\hline & des for $c$ & lapse and & pacing $\mathrm{ch}$ & cteristi & of smect & & & & \\
\hline 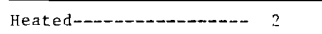 & 2 & 1 & 1 & 1 & 2 & I & 1 & 2 & 1 \\
\hline 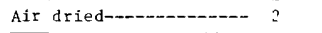 & ? & $\therefore$ & -- & $?$ & 2 & 2 & 2 & 2 & 2 \\
\hline & Proporti & of lave & in mixed & yer clay & percent) & & & & \\
\hline 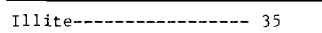 & $\mathrm{N}$ & 55 & 55 & 35 & n & $5 n$ & $5 n$ & 35 & 45 \\
\hline Beidellite-- & $19^{1 / 2}$ & $4 n$ & $4 n$ & 35 & $2 n$ & 35 & 35 & 35 & 25 \\
\hline Montmorillonite-------- 45 & 81 & 5 & 5 & $3 n$ & 80 & 15 & 15 & 3n) & 30 \\
\hline & Proporti & of clay & inerals $i$ & ota $1 \mathrm{cla}$ & (percent) & & & & \\
\hline 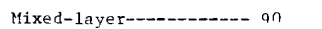 & $10 n$ & 51 & 55 & 63 & inn & fin & $5 ?$ & 82 & fl \\
\hline Illite-- & $\mathrm{N}$ & 31 & $3 n$ & 25 & it & 21 & $n$ & 12 & 21 \\
\hline Chlorite---- & $\mathrm{N}$ & $n$ & 5 & h & $\mathrm{N}$ & $a$ & h & N $\mathrm{N}$ & 9 \\
\hline Yaclinite-n........ N & $\mathrm{N}$ & 9 & 8 & h & "r & in & $1^{7}$ & 6 & 9 \\
\hline & Miner & composit & n of tota & ample $(p$ & cent) & & & & \\
\hline Total clay-_-_.-...- 80 & 100 & 55 & 70 & 70 & sn & $7 n$ & 75 & 75 & 70 \\
\hline Ouartz- & $\mathrm{v}$ & $3 n$ & 28 & 22 & $\mathrm{M}$ & 29 & 19 & 18 & $2 n$ \\
\hline Cristobalite--- & $\mathrm{N}$ & M & \% & N & $\mathrm{N}$ & $\mathrm{M}$ & $\mathrm{N}$ & $\pi$ & $\mathrm{N}$ \\
\hline Potassium feldspar---- & $\mathrm{N}$ & $\mathrm{r}$ & if & $\mathrm{N}$ & 1 & 1 & " & N & $\mathrm{N}$ \\
\hline Plagioclasem- & s & 1 & 1 & 4 & 1 & 1 & 2 & 2 & 3 \\
\hline 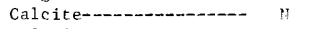 & พ & $\mathrm{N}$ & $n$ & n & $?$ & 3 & 1 & ल & ल \\
\hline Dolomite-- & N & 5 & 3 & : & is & $\mathrm{r}$ & in & "s & 4 \\
\hline Siderite---1-_- & $\mathrm{N}$ & $\mathrm{N}$ & 'T & א & in & N & $\mathrm{N}$ & $\pi$ & v \\
\hline Gypsum-_-_-_-_-_-_-_- & " & $\mathrm{N}$ & 1 & ला & ? & ข & $\mathrm{N}$ & 2 & !! \\
\hline Jarosite-- & in & $\mathrm{N}$ & צִ & พู & $\mathrm{p}$ & in & $\mathrm{N}$ & $\mathrm{N}$ & $\mathrm{N}$ \\
\hline Pyrite--_-_- N & NT & is & s & זฺ & it & "y & 2 & N? & 2 \\
\hline Zeolite-- N & N & "T & N & v & 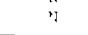 & 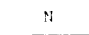 & ris & is & $M$ \\
\hline Anorthi & ontent & lagiocia & as deter & ned by $\mathrm{v-}$ & y analysi & (percent) & & & \\
\hline 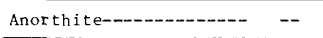 & -- & -- & -- & $3 n$ & $2 n$ & -- & $3 n$ & -- & - \\
\hline & Rulk an & rain der & ties, Att & erg $1 \mathrm{imi}$ & , and $\mathrm{pH}$ & & & & \\
\hline Bulk density-------- 1.85 & 1.96 & $2 . n h$ & 2.13 & 1.96 & 2.02 & 1.96 & 2.11 & 2.03 & 2.13 \\
\hline Grain density- $\quad 2.47$ & $? .31$ & 2.67 & 2.68 & 2.60 & 2.42 & .68 & 2.62 & 2.54 & 2.51 \\
\hline Liquid limit---------- 68 & 123 & 51 & 5.4 & an & 97 & 61 & $7 n$ & 73 & 49 \\
\hline Plastic limit------ 45 & 61 & 25 & 26 & $3 n$ & 54 & 31 & 34 & 30 & $2 h$ \\
\hline Plastic index--..- 23 & $n_{2}$ & 26 & 28 & $3 n$ & 43 & $3 n$ & $3 n$ & 34 & 23 \\
\hline $\mathrm{pH}-\cdots$ & $8.2 n$ & 8.75 & $8.7 n$ & 7.90 & 7.90 & 9.65 & 8.45 & 7.50 & - \\
\hline
\end{tabular}


TABLE 1.-Chemical, mineralogical, and physical-properties data for 226 samples of Pierre Shale and equivalent rocks-Continued

\begin{tabular}{|c|c|c|c|c|c|c|c|c|c|}
\hline Sample No.----------259571 & 259572 & 259573 & 259574 & 259595 & 259531 & C896 & 259532 & 259533 & 259530 \\
\hline \multicolumn{10}{|c|}{ Sample-data codes } \\
\hline Locality-_-_-_-_-- 18 & 18 & 18 & 18 & 19 & 20 & 20 & 20 & $2 n$ & 21 \\
\hline Fossil zone--- & 2 & 2 & 1 & 2 & 6 & 5 & 5 & 5 & 6 \\
\hline Environment------------ 4 & 4 & 4 & 4 & 4 & 4 & 4 & 4 & 4 & 4 \\
\hline Rock type--_-_-_-_ 4 & 6 & 4 & 4 & 4 & 5 & 4 & 4 & 4 & 4 \\
\hline Modifler of rock type-- 1 & 0 & 2 & 1 & 2 & $n$ & 3 & 3 & 4 & 1 \\
\hline & & Rock-form & g consti & ents (per & & & & & \\
\hline $\mathrm{S} 102-$ & 51.2 & 58.4 & 62.1 & 52.4 & 58.0 & 56.20 & 59.7 & 62.83 & 62.0 \\
\hline A1203 17.9 & 18.6 & 13.6 & 15.6 & 15.5 & 16.7 & 15.19 & 16.3 & 8.36 & 16.2 \\
\hline Fe, total as Fe203--- 6.2 & 3.4 & 5.2 & 4.4 & 6.3 & 5.4 & 5.40 & 5.9 & 4.20 & 5.5 \\
\hline $\mathrm{Fe} 203-3.8$ & 3.2 & 4.6 & 2.6 & 5.0 & 4.4 & 4.58 & 4.3 & 2.06 & 4.6 \\
\hline Feo-- & .20 & .50 & 1.6 & 1.2 & .90 & .74 & 1.4 & 1.93 & .80 \\
\hline $\mathrm{MgO} 0-$ & 3.6 & 1.0 & 2.0 & 1.5 & 2.4 & 2.27 & 2.2 & 1.67 & 2.4 \\
\hline $\mathrm{CaO}$ & 1.8 & 1.1 & 1.1 & .59 & 2.1 & 3.46 & 1.0 & 3.07 & .64 \\
\hline Na20- & .26 & .87 & .45 & 1.1 & .91 & 1.92 & 1.2 & .91 & 1.1 \\
\hline K20-1- 2.7 & .08 & 2.7 & 3.0 & 2.6 & 3.5 & 2.50 & 2.6 & 1.21 & 2.4 \\
\hline H2O- & 11.2 & 3.3 & 1.9 & 3.0 & 2.7 & 3.95 & 3.6 & 2.62 & 4.0 \\
\hline $\mathrm{H} 2 \mathrm{O}+-$ & 6.4 & $4 \cdot 1$ & 3.7 & 7.0 & 5.2 & 3.47 & 4.4 & 3.22 & 4.3 \\
\hline Ti02-- & .58 & .67 & .74 & .62 & .70 & .53 & .68 & .33 & .65 \\
\hline P205- & .08 & .13 & .20 & .20 & .18 & .14 & .10 & .15 & .11 \\
\hline S, total-_-_-_-_-- 1.79 & 1.18 & 1.50 & 1.16 & 2.70 & .14 & .72 & .67 & .66 & .09 \\
\hline S-1- 1.76 & $<.01$ & .20 & .99 & 1.17 & -- & .05 & .56 & .60 & -- \\
\hline SO3- & 2.94 & 3.26 & .42 & 3.82 & -- & 1.67 & .27 & .16 & -- \\
\hline F--1-1 & .11 & .08 & .10 & .08 & .08 & .08 & .07 & .04 & .07 \\
\hline C1-- & -- & -- & -- & -- & -- & .01 & -- & - & -- \\
\hline c, organic-------- 1.70 & $<.05$ & 3.30 & 1.80 & 4.90 & .40 & $.1 n$ & .80 & $.3 n$ & .40 \\
\hline $\mathrm{C}$, mineral--- $\quad .05$ & $<.02$ & $<.02$ & .19 & $<.02$ & .44 & .49 & .12 & 1.48 & $<.02$ \\
\hline & Trac & e-element & nstituent & (parts $\mathrm{p}$ & million) & & & & \\
\hline Zr-- & 440 & 200 & 2.20 & 160 & 190 & 150 & 170 & 91 & 180 \\
\hline 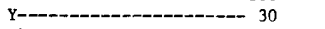 & 70 & 15 & 30 & 15 & 30 & 15 & 30 & 30 & 30 \\
\hline Yb--- & 3 & 3 & 3 & 3 & 3 & 3 & 3 & 3 & 3 \\
\hline La-1-_-_L_- 30 & 70 & $<20$ & 30 & $<20$ & 30 & 30 & 30 & $<20$ & 30 \\
\hline Sn--- & 1 & -- & -- & $<1$ & -- & -- & -- & -- & -- \\
\hline Sc----_----------- 25 & 13 & 20 & 20 & 27 & 21 & 15 & 23 & 12 & 19 \\
\hline 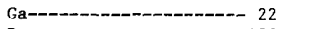 & 18 & 22 & 16 & 16 & 16 & 15 & 17 & 7 & 14 \\
\hline B-_- 150 & 20 & 180 & 210 & 160 & 150 & 150 & 160 & 140 & 130 \\
\hline 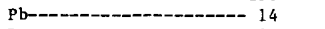 & 28 & 17 & 11 & 7 & 28 & 15 & 27 & 13 & 25 \\
\hline 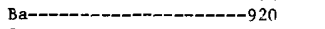 & 840 & 880 & 990 & 900 & 800 & 700 & 840 & 340 & 770 \\
\hline 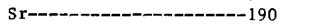 & 170 & 140 & 120 & 160 & 120 & 150 & 130 & 110 & 190 \\
\hline 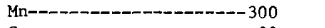 & 190 & $6 n$ & 160 & 220 & 2,300 & 460 & 260 & 34,600 & 140 \\
\hline $\mathrm{CO}-\mathrm{C}$ & 20 & 5 & 14 & $2 n$ & 24 & 15 & 20 & 22 & 10 \\
\hline 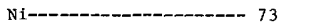 & 90 & 20 & 52 & 81 & 85 & 70 & 67 & 94 & 36 \\
\hline $\mathrm{zn}-1-190$ & 230 & 55 & 170 & 260 & 170 & 150 & 160 & 180 & 110 \\
\hline Cd--D- 1.6 & 11.0 & 2.1 & 1.8 & 7.0 & $<.3$ & .8 & .5 & .4 & .5 \\
\hline $\mathrm{Cr}-\mathrm{C}$ & 4 & 120 & 120 & 120 & 100 & 70 & 100 & 50 & 96 \\
\hline V-D-_- & $5 n$ & 540 & 300 & 390 & 300 & $15 n$ & 280 & 200 & 160 \\
\hline Cu--_-_- 84 & 13 & 150 & 40 & 99 & 56 & 70 & 45 & 36 & 29 \\
\hline Mo--1-_-_-_- 2 & 2 & 28 & 2 & 17 & 3 & $<\ln$ & 1 & 1 & 2 \\
\hline Se--_-_-_-_-_-_-_-_--- 9 & 1 & 33 & 5 & 15 & 1 & 3 & 2 & 2 & 1 \\
\hline 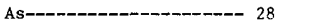 & 17 & 31 & 16 & 43 & 19 & 7 & 12 & 14 & 10 \\
\hline U-10 6.4 & 6.9 & 12.0 & 4.3 & 9.8 & 3.2 & $<10.9$ & 2.9 & 1.3 & 2.7 \\
\hline eU---- 20 & 10 & 30 & 20 & 20 & 20 & 20 & $<10$ & $<10$ & $<10$ \\
\hline & Codes for & ollapse & spacing & aracteri & cs of smec & & & & \\
\hline 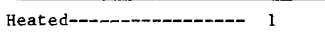 & 2 & 2 & 1 & 1 & 1 & 1 & 1 & 1 & 2 \\
\hline Air dried-_-_-_-_ 2 & 2 & 2 & -- & 2 & 2 & 1 & 1 & 1 & 2 \\
\hline & Propor & ions of 1 & rs in mi & 1-1ayer c & (percent) & & & & \\
\hline Illite---------------- 55 & $\mathrm{~N}$ & 45 & 60 & 45 & 60 & 35 & 40 & 30 & 35 \\
\hline 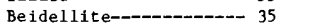 & 10 & $2 n$ & 35 & 20 & 35 & -- & 25 & 20 & 35 \\
\hline Montmorillonite------- 10 & 90 & 35 & 5 & 35 & 5 & -- & 35 & 50 & 30 \\
\hline & Propor & ions of $\mathrm{c}$ & minera1 & in total & $y$ (percent & & & & \\
\hline Mixed-layer------------ 53 & 100 & 68 & 50 & 72 & 57 & 77 & 75 & 80 & \\
\hline Illite-- 25 & $\mathrm{~N}$ & 28 & 30 & 19 & 25 & 19 & 16 & 17 & 17 \\
\hline Chlorite-- & $\mathrm{N}$ & $\mathrm{N}$ & 9 & 2 & 7 & 2 & 3 & $\mathrm{~N}$ & 2 \\
\hline Kaolinite-------------- 14 & $\mathrm{~N}$ & 4 & 11 & 7 & 11 & 2 & 6 & 3 & 4 \\
\hline & Min & ral compos & ion of to & al sample & ercent) & & & & \\
\hline Total clay--_-_- 65 & 90 & 60 & 65 & 65 & 75 & 75 & 80 & 45 & 75 \\
\hline Quartz-- 21 & $\mathrm{~N}$ & 23 & 29 & 18 & 21 & 15 & 18 & 4 & 19 \\
\hline Cristobalite- & $\mathrm{N}$ & $\mathrm{N}$ & $\mathrm{N}$ & $\mathrm{N}$ & $\mathrm{N}$ & $\mathrm{N}$ & $\mathrm{N}$ & 35 & $\mathrm{~N}$ \\
\hline Potassium feldspar--_-- N & $\mathrm{N}$ & $\mathrm{N}$ & $\mathrm{N}$ & $\mathrm{N}$ & $\mathrm{N}$ & $\mathrm{N}$ & 1 & $\mathrm{H}$ & $\mathrm{N}$ \\
\hline Plagioclase- & $\mathrm{N}$ & 2 & 1 & 1 & 1 & 3 & $i$ & 1 & 3 \\
\hline Calcite- & $\mathrm{N}$ & $\mathrm{N}$ & $\mathrm{N}$ & $\mathrm{N}$ & 3 & 5 & 1 & $\mathrm{~N}$ & $\mathrm{~N}$ \\
\hline Dolomite-- & $\mathrm{N}$ & $\mathrm{N}$ & I & $\mathrm{N}$ & $\mathrm{N}$ & $\mathrm{N}$ & $\mathrm{N}$ & $\mathrm{N}$ & $\mathrm{N}$ \\
\hline Siderite-----_-------- & $\mathrm{N}$ & N & $\mathrm{N}$ & $\mathrm{N}$ & $\mathrm{N}$ & $\mathrm{N}$ & $\mathrm{N}$ & 14 & $\mathrm{~N}$ \\
\hline Gypsum--_-_-_-_-__-_- & 4 & 3 & 1 & 1 & $\mathrm{~N}$ & 2 & $\mathrm{~N}$ & $\mathrm{n}$ & $\mathrm{N}$ \\
\hline Jarosite----_-_-_-_-_- & 3 & 4 & $\mathrm{~N}$ & 6 & N & $\mathrm{N}$ & $\mathrm{N}$ & $\mathrm{N}$ & $\mathrm{N}$ \\
\hline Pyrite-- & $\mathrm{N}$ & $\mathrm{N}$ & 2 & $\mathrm{~N}$ & $\mathrm{~N}$ & 1 & 1 & 1 & $\mathrm{~N}$ \\
\hline Zeolite-- & $\mathrm{N}$ & $\mathrm{N}$ & $\mathrm{N}$ & $\mathrm{N}$ & $\mathrm{M}$ & $\mathrm{N}$ & $\mathrm{N}$ & $\mathrm{N}$ & 2 \\
\hline Anorth1 & content & f plagioc & ise as de & mined by & ray analy & (percent & & & \\
\hline Anorthite----------- & -- & -- & -- & -- & -- & -- & - & - & - \\
\hline & Bulk & nd grain & sities, & erberg 1 & $\mathrm{ts}$, and $\mathrm{pH}$ & & & & \\
\hline Bulk density--_- 2.16 & 1.82 & 1.61 & 2.20 & 2.07 & 1.88 & -- & 1.95 & 1.82 & 1.78 \\
\hline Grain density- & 2.37 & 2.54 & 2.63 & 2.48 & 2.64 & -- & 2.61 & 2.52 & 2.55 \\
\hline Liquid limit- & 118 & 43 & 47 & $\ldots$ & $\ldots$ & 101 & 121 & 66 & 76 \\
\hline Plastic linit--_- & 61 & 40 & 31 & -- & -- & 34 & 50 & 57 & 42 \\
\hline Plastic index-- & 57 & 3 & 16 & -- & -- & 68 & 71 & 9 & 34 \\
\hline pH---- & 3.70 & 3.15 & 7.80 & 3.55 & 8.15 & 8.37 & 8.50 & 8.50 & 8.50 \\
\hline
\end{tabular}


COMPOSITION AND PROPERTIES, NORTHERN GREAT PLAINS REGION

TABLE 1.-Chemical, mineralogical, and physical-properties data for 226 samples of Pierre Shale and equivalent rocks-Continued

\begin{tabular}{|c|c|c|c|c|c|c|c|c|c|}
\hline Sample No.--_- & C887 & 259535 & 259536 & 259534 & 259541 & 259542 & 259546 & 259544 & 259543 \\
\hline \multicolumn{10}{|c|}{ Sample-data codes } \\
\hline Locality--------------- & & 2.1 & 21 & 22 & 22 & 22 & 22 & 22 & 22 \\
\hline Fossil zone-- & 5 & 4 & 4 & 6 & 5 & 5 & 5 & 5 & 5 \\
\hline Environment--_---_--- & 4 & 4 & 4 & 4 & 4 & 4 & 4 & 4 & 4 \\
\hline Rock type---------- & 4 & 4 & 4 & 5 & 6 & 6 & 4 & 6 & 4 \\
\hline Modifier of rock type-- & 3 & 3 & 4 & 0 & 12 & 0 & 3 & 3 & 1 \\
\hline & & & forming co & :ituents & rcent) & & & & \\
\hline SiO2-_-_-_-_-_-_- & 62.88 & 60.7 & 74.8 & 58.2 & 2.21 .24 & 56.67 & 50.0 & 56.6 & 60.23 \\
\hline A1203----- & 14.77 & 14.9 & 9.1 & 15.4 & 7.52 & 18.86 & 17.3 & 19.3 & 15.92 \\
\hline $\mathrm{Fe}$, total as Fe203---- & 5.61 & 5.3 & 3.0 & 5.7 & 35.98 & 5.61 & 5.5 & 6.2 & 6.09 \\
\hline Fe203- & 5.03 & 4.7 & 2.6 & 4.8 & 1.51 & 3.29 & 4.8 & $5 . n$ & 3.46 \\
\hline 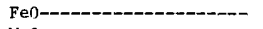 & .52 & .50 & $.4 n$ & .80 & 31.02 & 2.79 & .60 & 1.1 & 2.37 \\
\hline MgO- & 1.86 & 2.2 & 1.2 & 2.8 & 2.89 & 2.39 & 2.4 & 2.0 & 2.12 \\
\hline Can--_-- & .76 & 1.0 & 1.4 & 2.9 & 3.43 & 1.47 & .49 & 2.3 & .91 \\
\hline Na20-- & .65 & 1.6 & .34 & 1.2 & .58 & 1.52 & 1.3 & 2.3 & 1.27 \\
\hline 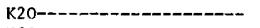 & 2.30 & 2.5 & 1.4 & 3.1 & .12 & .55 & $? .0$ & 1.8 & 2.79 \\
\hline H2O- - & 4.63 & 4.0 & 3.8 & 3.5 & 1.50 & 6.15 & 4.0 & 3.7 & 2.95 \\
\hline H2O+ - - & 4.80 & 4.5 & $3 . n$ & 4.8 & 1.92 & 5.14 & 4.8 & 3.4 & 5.19 \\
\hline Tin2-- & . fn & .50 & .38 & .63 & .07 & $.2 ?$ & .66 & .35 & .61 \\
\hline P205--י-- & .10 & .12 & .05 & .21 & .10 & .07 & .10 & .29 & .13 \\
\hline$s$, total-a-s & .04 & .19 & .01 &. $\mathrm{ln}^{n}$ & .37 & $.4 n$ & .07 & 1.19 & .86 \\
\hline 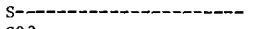 & .01 & -- & -- & -- & .37 & .39 & -- & 1.13 & .84 \\
\hline so3-- 3 & .07 & -- & -- & -- & .01 & .03 & - & .15 & .06 \\
\hline 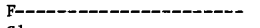 &.$n 7$ & .07 & .05 & .07 & .03 & .07 & .10 & .06 & .07 \\
\hline 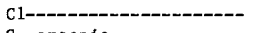 & $<.01$ & -- & -- & -- & -- & $\cdots$ & - & -- & - \\
\hline c, organfc- & .40 & .30 & .40 & .23 & $<.05$ & .15 & .40 & .08 & 1.00 \\
\hline C, mineral--_-_-_-_-- & $<.01$ & .11 & .14 & .52 & 6.80 & .24 & .12 & .10 & .05 \\
\hline & & Trace-e & ent consti & ents (par & per million & & & & \\
\hline 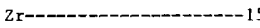 & & 160 & 110 & 200 & 94 & 200 & 190 & $22 n$ & 170 \\
\hline 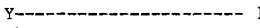 & & 30 & 15 & $3 n$ & $3 n$ & $3 n$ & $3 n$ & 15 & $3 n$ \\
\hline Yb------------------ & 3 & 3 & 3 & 3 & $<10$ & 3 & 3 & 3 & 3 \\
\hline 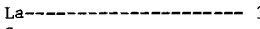 & 30 & $3 n$ & 30 & 30 & $<20$ & 70 & 70 & 30 & 30 \\
\hline 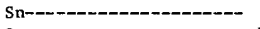 & -- & -- & -- & -- & -- & -- & -- & -- & -- \\
\hline Sc---D- & 15 & 18 & a & 17 & $<5$ & in & 18 & 6 & 19 \\
\hline Ga-D-D_- & 7 & 12 & h & 14 & 14 & 20 & 18 & 20 & 20 \\
\hline 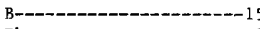 & & 160 & 120 & $1 \mathrm{nn}$ & 40 & 8n & 180 & 80 & 160 \\
\hline $\mathrm{Pb}-\mathrm{P}-\mathrm{-O-}$ & 15 & 21 & 18 & 22 & $3 n$ & 38 & 29 & 41 & 26 \\
\hline Ba-----_- & & 1,200 & 410 & 760 & $16 n$ & 360 & 670 & 1,200 & 1,300 \\
\hline $\mathrm{Sr}-\mathrm{-}$ & 50 & 190 & 63 & 150 & 77 & 170 & 110 & $53 n$ & 190 \\
\hline 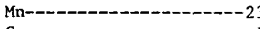 & & 1,200 & 1,500 & 400 & 22,200 & $52 n$ & $35 n$ & 470 & $33 n$ \\
\hline 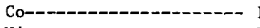 & 15 & 16 & 11 & 13 & $<5$ & 9 & 27 & 12 & 19 \\
\hline 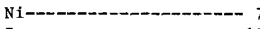 & 70 & 49 & $3 n$ & 38 & 12 & 28 & 140 & 31 & 72 \\
\hline $2 n---+-1$ & & 120 & 93 & 1 1no & 42 & 110 & 190 & 65 & 240 \\
\hline 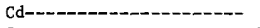 & .8 & .3 & .3 & .4 & .5 & $1 . n$ & .8 & .5 & 1.8 \\
\hline Cr--_- & $7 n$ & 86 & 68 & $9 n$ & 6 & 10 & 95 & 5 & 100 \\
\hline V--1- & 50 & 200 & 170 & 160 & $2 n$ & की & $23 n$ & 40 & $30 n$ \\
\hline Cu-- & 70 & 38 & 21 & 25 & 4 & 11 & 38 & 33 & 53 \\
\hline 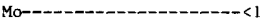 & 10 & 2 & 1 & 2 & 2 & 2 & 1 & 2 & 1 \\
\hline 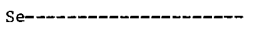 & 2 & 1 & $<1$ & 1 & $<1$ & 1 & 2 & 1 & 3 \\
\hline As- & 11 & 15 & 4 & 11 & 9 & 5 & 10 & 3 & 9 \\
\hline 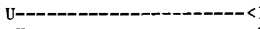 & 10.0 & 2.0 & 1.5 & 2.9 & 3.3 & 8.5 & 5.0 & 8.3 & 5.0 \\
\hline eUl------ & 20 & 10 & 10 & 20 & $<10$ & $<10$ & 10 & $<10$ & 20 \\
\hline & & des for col & se and spa & ig charac & istics of $\mathrm{s}$ & etite & & & \\
\hline Heated-_- & 1 & 1 & 1 & 1 & 1 & 1 & 1 & 1 & 1 \\
\hline Air dried-- & 1 & 1 & 2 & 2 & 1 & 1 & 1 & 1 & 1 \\
\hline & & Proportion & f layers i & gixed-1ax & clay (perce & & & & \\
\hline Il1ite--_-_-_-_-_- & 40 & 40 & 40 & 50 & $\mathrm{~N}$ & $\mathrm{~N}$ & 49 & $\mathrm{~N}$ & 45 \\
\hline Beidellite--_-_-_------ & -- & 30 & 45 & 45 & - & 16 & 35 & 10 & 40 \\
\hline Montmorillonite-------- & -- & 30 & 15 & 5 & -- & 84 & 25 & 90 & 15 \\
\hline & & Proportion & f clay min & als in $t$ & clay (perc & & & & \\
\hline Mixed-1ayer-- & 82 & 81 & 76 & 70 & $10 n$ & $10 n$ & 78 & 100 & 76 \\
\hline I111te-- & 16 & 16 & 20 & 17 & II & $\mathrm{N}$ & 14 & $\because$ & 17 \\
\hline Chlorite-- & 1 & 2 & 2 & 7 & N & ला & 3 & $\mathrm{~N}$ & 3 \\
\hline Kaolinite-- & $\mathrm{i}$ & 1 & 2 & 6 & " & ฟ้ & 5 & " & 4 \\
\hline & & Mineral & mposition & total $s$ & le $($ percent $)$ & & & & \\
\hline Total clay- & 75 & 75 & $5 n$ & 65 & 40 & $10 n$ & $8 n$ & 75 & 75 \\
\hline Quartz- & 15 & 16 & 11 & 21 & $\mathrm{~N}$ & $\mathrm{~N}$ & If & $\mathrm{N}$ & 15 \\
\hline Cristobalite-- & $\mathrm{N}$ & $\mathrm{r}$ & 40 & $\mathrm{~N}$ & n! & v & $\mathrm{r}$ & $\mathrm{N}$ & N \\
\hline Potassium feldspar---- & $\mathrm{N}$ & $\mathrm{N}$ & 1 & $\mathrm{~N}$ & $\mathrm{~N}$ & $\mathrm{~N}$ & $\mathrm{~N}$ & $\mathrm{~N}$ & $!$ \\
\hline Plagioclase-- & 4 & 3 & 1 & 3 & $\mathrm{~N}$ & in & 3 & 10 & 2 \\
\hline Calcite------- & $\mathrm{N}$ & 1 & 1 & 3 & $\mathrm{~N}$ & N & $\mathrm{N}$ & N & N \\
\hline Dolomite----- & ?! & $\mathrm{N}$ & $\mathrm{N}$ & 2 & $\mathrm{~N}$ & N & ข้ & $\mathrm{n}$ & N \\
\hline Siderite--- & $\mathrm{N}$ & $N$ & $\mathrm{~N}$ & $\mathrm{~N}$ & 60 & 2 & $\mathrm{~N}$ & $\mathrm{~N}$ & $\mathrm{~N}$ \\
\hline Gypsum--_-_-_-_- & $\mathrm{NH}$ & $\mathrm{N}$ & in & $\mathrm{N}$ & y & n! & N & $\mathrm{N}$ & $\mathrm{N}$ \\
\hline Jarosite-------- & $\mathrm{N}$ & N & N & $\mathrm{N}$ & $\mathrm{N}$ & $\mathrm{N}$ & $\mathrm{N}$ & $\mathrm{N}$ & $M$ \\
\hline Pyrite--_- & $\mathrm{N}$ & w & N & $\mathrm{N}$ & $\mathrm{N}$ & N & $\mathrm{N}$ & 2 & 1 \\
\hline Zeolite--_-_- & 3 & $\mathrm{~N}$ & $\mathrm{~N}$ & $\mathrm{~N}$ & $\mathrm{rr}^{\mathrm{r}}$ & $\mathrm{N}$ & $\mathrm{N}$ & $\mathrm{N}$ & 1 \\
\hline & Anorthi & ntent of & gioclase a & determin & by $X$-ray ane & is (per & & & \\
\hline Anorthite---- & -- & -- & -- & -- & -- & -- & -- & 55 & -- \\
\hline & & Bulk and & in densiti & , Atterb & Iimits, anc & & & & \\
\hline Bulk density-- & -- & 1.87 & 1.71 & 1.86 & 2.71 & 2.09 & $1.9 n$ & $2 . n n$ & 1.92 \\
\hline Grain density-- & -- & 2.56 & 2.35 & 2.60 & 3.20 & 2.49 & 2.43 & 2.65 & 2.52 \\
\hline Liquid limit---_-- & 65 & 117 & 52 & -- & 32 & 140 & 143 & 47 & 115 \\
\hline Plastic límit--------- & 42 & 44 & 46 & -- & 23 & 65 & 39 & 42 & 48 \\
\hline Plastic index-- & 23 & 13 & 6 & -- & 9 & 75 & 104 & 5 & 67 \\
\hline pH-D-O- & 4.41 & 7.90 & 8.45 & - & 9.25 & 9.65 & 8.60 & $9.2 n$ & 9.00 \\
\hline
\end{tabular}


TABLE 1.-Chemical, mineralogical, and physical-properties data for 226 samples of Pierre Shale and equivalent rocks-Continued

\begin{tabular}{|c|c|c|c|c|c|c|c|c|c|c|}
\hline Sample No._-_-_-_- & $\mathrm{c} 881$ & $\mathrm{C} 884$ & $\mathrm{C} 885$ & 259545 & 259540 & 259539 & 259554 & 259537 & 259538 & $\mathrm{C} 878$ \\
\hline & & & Samp1 & data codes & & & & & & \\
\hline Locality-- & 22 & 22 & 22 & 23 & 22 & $? 2$ & 22 & 22 & $2 ?$ & 22 \\
\hline Fossil zone- & 5 & 5 & 5 & 5 & 4 & 4 & 4 & 4 & 4 & 4 \\
\hline Environment---------- & 4 & 4 & 4 & 4 & 4 & 4 & 4 & 4 & 4 & 4 \\
\hline Rock type----_- & 4 & 4 & 4 & 4 & 4 & 4 & h & 6 & 4 & 4 \\
\hline Modifier of rock type-- & $i$ & 1 & 1 & 1 & 3 & 3 & 8 & 0 & 4 & 4 \\
\hline & & & -forming $c$ & stituents & ercent) & & & & & \\
\hline $\sin 2-1-1-1$ & 61.79 & 60.68 & 50.42 & 61.3 & 68.0 & 62.1 & 56.6 & 57.6 & 69.7 & 69.04 \\
\hline A1203--1- & 14.32 & $14.4 \pi$ & 14.11 & 15.1 & 13.7 & 16.4 & 19.7 & 19.1 & 10.4 & 12.37 \\
\hline $\mathrm{Fe}$, total as Fe20 3-- & 5.84 & 5.60 & 5.40 & 5.4 & 4.2 & 4.3 & 5.6 & 4.4 & 3.8 & 4.25 \\
\hline Fe203- & 5.44 & .3 .28 & 3.18 & 3.8 & 3.2 & 3.3 & 5.0 & 3.3 & 2.6 & 2.29 \\
\hline FeO--1-- & .36 & 2.09 & $2.0 n$ & 1.4 & .90 & .90 & .50 & 1.0 & 1.1 & 1.20 \\
\hline 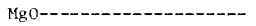 & 2.14 & 2.14 & 2.18 & 2.2 & 1.9 & 2.8 & 2.7 & 2.6 & 1.4 & 1.70 \\
\hline CaO-_-_Ln_- & .94 & 1.97 & 2.35 & 1.3 & .76 & .98 & 2.4 & 1.4 & 1.0 & .76 \\
\hline Na20-- & .82 & 1.38 & 1.42 & 1.4 & 1.2 & 1.4 & 2.0 & 2.2 & 1.0 & 1.34 \\
\hline 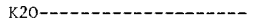 & 2.31 & 2.50 & $\therefore .46$ & 2.7 & 2.0 & 1.6 & .89 & .64 & 1.6 & 1.98 \\
\hline H2O- & 4.18 & 1.80 & 1.90 & 3.6 & 2.9 & 4.5 & 4.6 & $7 . n$ & 3.3 & 2.94 \\
\hline H $20+-$ & 4.63 & 4.4 ? & 4.26 & $4 \cdot 5$ & 3.9 & 4.9 & 4.1 & 4.5 & 3.5 & 4.02 \\
\hline Tin2- & .57 & .58 & .55 & .58 & .48 & .44 & .63 & .24 & .42 & .48 \\
\hline P205- & .12 & .17 & .21 & .10 & .07 & .05 & $.2 n$ & .07 & .09 & .07 \\
\hline$S$, total & .44 & .76 & .54 & .32 & $.3 n$ & .25 & .21 & .05 & .32 & .32 \\
\hline 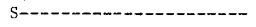 & $<.01$ & .66 & .49 & .29 & .27 & .23 & $<.01$ & -- & .31 & .27 \\
\hline S03--1- & 1.10 & .26 & .12 & .05 & .07 & .05 & .52 & -- & .03 & .12 \\
\hline F-- & .07 & .07 & .07 & .07 & .07 & .13 & .08 & .05 & .05 & .05 \\
\hline Cl-- & .01 & .02 & .04 & -- & -- & - & -- & -- & -- & .01 \\
\hline C, organic-a- & $<.5 n$ & 1.17 & 1.30 & .70 & .20 & .17 & $<.05$ & .06 & .30 & $<.50$ \\
\hline C, mineral------------- & .01 & .49 & .65 & $.2^{8}$ & .04 & .04 & $<.0 ?$ & .04 & .35 & .08 \\
\hline & & Trace-e1 & ment const & uents (par & per mîl & on) & & & & \\
\hline Zr--1-- & 150 & $7 n$ & $7 n$ & 170 & $19 n$ & $2 \mathrm{nn}$ & 410 & 230 & 120 & 70 \\
\hline 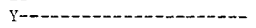 & 15 & $3 n$ & 30 & 30 & 30 & $7 n$ & 15 & $3 n$ & $3 n$ & 15 \\
\hline Yb---_- & 3 & 3 & 3 & 3 & 3 & 3 & 1.5 & 3 & 3 & 3 \\
\hline La-1- & $3 n$ & $3 n$ & 30 & $3 n$ & 30 & $7 n$ & $7 n$ & 70 & $<20$ & 30 \\
\hline $\mathrm{Sn}-\mathrm{n}$ & -- & -- & -- & -- & -- & -- & -- & -- & -- & -- \\
\hline Sc- - & 15 & 15 & 15 & 17 & 12 & 12 & 8 & 8 & 9 & 15 \\
\hline f & 7 & 15 & 15 & 15 & 12 & 16 & 14 & 29 & 8 & 7 \\
\hline B-1- & $15 n$ & 150 & $15 n$ & $15 n$ & 160 & 140 & 60 & 90 & 140 & 150 \\
\hline 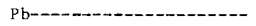 & 15 & 15 & 15 & 25 & 25 & 27 & 31 & 32 & 18 & 15 \\
\hline 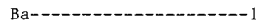 &, 500 & 700 & $70 !)$ & $1,5 n 0$ & 470 & $62 n$ & 620 & 700 & 720 & 700 \\
\hline Sr- & 150 & 150 & $15 n$ & 200 & $13 n$ & 170 & 240 & 220 & 92 & 150 \\
\hline 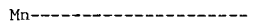 & 690 & 7,400 & $8,6 \cap 0$ & $5 \mathrm{nn}$ & $25 n$ & $25 n$ & 520 & 220 & 9,400 & 850 \\
\hline $\mathrm{CO}-\mathrm{C}-\mathrm{H}$ & 15 & 15 & 15 & 21 & 16 & 11 & 19 & $<4$ & 32 & 15 \\
\hline Ni-O- & 70 & 70 & 70 & 61 & 65 & 58 & 92 & 40 & 90 & 70 \\
\hline 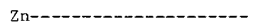 & 170 & 170 & $17 n$ & 160 & 150 & 140 & 87 & 40 & 120 & 130 \\
\hline 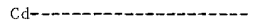 & 1.0 & .5 & .8 & .8 &.$\hbar$ & .8 & 1.0 & .8 & .3 & .8 \\
\hline 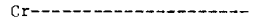 & $7 n$ & 70 & $7 n$ & 99 & 72 & 6n & 10 & 5 & 72 & 70 \\
\hline 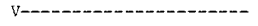 & 150 & 150 & 150 & 250 & 190 & $20 n$ & $6 n$ & $20 n$ & 170 & 150 \\
\hline Cu-C- & 70 & 70 & $7 n$ & 33 & $3 n$ & 25 & 13 & I & $3 n$ & 70 \\
\hline Mo $-\cdots+-1$ & $<10$ & $<10$ & $<\ln$ & 1 & in & 2 & $<1$ & $<1$ & 1 & $<10$ \\
\hline 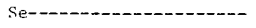 & 1 & $?$ & 2 & 1 & 1 & 2 & $<1$ & $<1$ & 1 & 1 \\
\hline As--- & 13 & 16 & 19 & 12 & 10 & h & 3 & 2 & 31 & 15 \\
\hline U----_- & $<\ln . n$ & $<10 . n$ & $<\ln . n$ & 2.5 & 5.6 & 5.3 & 8.4 & 9.5 & 2.2 & $<10.0$ \\
\hline ev-- & $<$ in & 30 & $2 n$ & $2 n$ & 10 & in & in & $<10$ & $<10^{-}$ & 10 \\
\hline & & les for $\operatorname{col} 1$ & pse and $\mathrm{sp}$ & ing, charac & ristics & E smectit & & & & \\
\hline 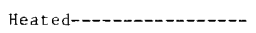 & 1 & 1 & I & 1 & 1 & 1 & i & 1 & 1 & 1 \\
\hline Air dried-_- & 2 & $i$ & 1 & 2 & 1 & $i$ & 1 & 1 & 1 & 1 \\
\hline & & Proportions & of layers & mixed-1ay & clay $(p$ & (rent) & & & & \\
\hline Illite-1- & 45 & 45 & $4 n$ & 45 & 35 & $3 n$ & NT & $\mathrm{N}$ & 40 & 45 \\
\hline Reidelitte------------ & -- & -- & -- & $4 n$ & 20 & 15 & 16 & 10 & 39 & -- \\
\hline Montmorillonite---.--- & -- & -- & -- & 15 & 45 & 55 & 84 & 90 & 35 & -- \\
\hline & & Proportion: & of c1ay mi & rals in to & 1 clay & $\operatorname{ercen}()$ & & & & \\
\hline Mixed-layer-- & 94 & 79 & 77 & 73 & 85 & $7 \mathrm{~b}$ & 100 & $1 \cap n$ & 81 & 80 \\
\hline Illite-- & 15 & 15 & 18 & $\therefore 1$ & 10 & 19 & M & $\mathrm{v}$ & 14 & $1 \mathrm{~h}$ \\
\hline Ch1orite--- & 1 & 2 & 3 & 4 & 3 & 3 & $\%$ & $\mathrm{MT}$ & 2 & 2 \\
\hline Faolinite---_-_-_-_-- & $\mathrm{N}$ & 4 & 2 & 2 & 2 & 3 & $\mathrm{~N}$ & $\mathbb{N}$ & 3 & 2 \\
\hline & & Minera1 & omposition & f total sa & 1e (perc & & & & & \\
\hline Total clay------------ & 75 & 70 & 70 & 75 & 65 & 80 & 80 & 95 & 50 & 65 \\
\hline nuartz-- & 17 & 17 & 19 & 17 & 13 & 19 & $\mathrm{~N}$ & $\mathrm{~N}$ & 11 & 15 \\
\hline Cristobalite--- & $\mathrm{N}$ & n & $\mathrm{M}$ & $\mathrm{N}$ & 15 & If & $\mathrm{N}$ & $\mathrm{N}$ & 30 & 18 \\
\hline Potassium feldspar----- & $\mathrm{N}$ & $\mathrm{N}$ & v & $\mathrm{s}^{\mathrm{T}}$ & n & $\because$ & N & $\mathrm{N}$ & N & $\mathrm{N}$ \\
\hline Plagioclase--- & 1 & 2 & 1 & 3 & 5 & 1 & 10 & $\mathrm{~N}$ & 1 & 1 \\
\hline Calcite-- & v & 2 & $\mathrm{~N}$ & 2 & $\mathrm{~N}$ & is & 1 & N & $\mathrm{N}$ & $\mathrm{N}$ \\
\hline nolomice-_- & $\mathrm{N}$ & $\mathrm{N}$ & $\mathrm{v}$ & $\mathrm{v}$ & n & $\mathrm{N}$ & $\mathrm{N}$ & $\mathrm{N}$ & N & $\mathrm{N}$ \\
\hline Siderite--u------- & $\mathrm{N}$ & $\mathrm{N}$ & 3 & $\mathrm{~N}$ & $\because$ & N & $\mathrm{N}$ & $\mathrm{N}$ & 3 & $\mathrm{~N}$ \\
\hline Gypsum- & 4 & NT & $\mathrm{T}$ & y & i & $\mathrm{N}$ & 2 & v & $\mathrm{N}$ & $\mathrm{N}$ \\
\hline Jarosite- & $\mathrm{N}$ & M & $\mathrm{N}$ & s & nT & ‥ & $n$ & $\mathrm{v}$ & $\mathrm{N}$ & $\mathrm{N}$ \\
\hline 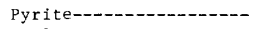 & $\mathrm{N}$ & 2 & 2 & דִ & N: & $\mathrm{s}$ & $\mathrm{N}$ & $\pi$ & $\mathrm{N}$ & $\mathrm{N}$ \\
\hline Zeolite-- & 3 & 4 & 4 & 3 & $\mathrm{~N}$ & $\mathrm{~N}$ & ${ }^{* T}$ & $\mathrm{~N}$ & $\mathrm{~N}$ & 3 \\
\hline & Anorthite & ontent of & agioclase & deterinine & by V-rav & nalysis & ercent) & & & \\
\hline Anorthite------- & -- & -- & -- & -- & -- & -- & 50 & -- & -- & -- \\
\hline & & Bulk and & ain densit & s, Atterbe & limits & and $\mathrm{pH}$ & & & & \\
\hline Bulk density------- & -- & -- & -- & 1.88 & 1.81 & 1.87 & $2.0 n$ & 2.04 & 1.67 & -- \\
\hline Grain density-_. & -- & -- & -- & 2.56 & 2.54 & 2.56 & 2.58 & 2.51 & 2.45 & -- \\
\hline Liquid limit------- & 76 & 114 & 112 & 136 & -- & 155 & 115 & 143 & 64 & 03 \\
\hline Plastic limit- & 34 & $3 i$ & 35 & $4 n$ & -- & 49 & 48 & 56 & 49 & 40 \\
\hline Plastic Index-- & 37 & 77 & 77 & $a_{6}$ & -- & $\operatorname{lng}$ & 67 & 87 & 15 & 53 \\
\hline pH-- & 4.72 & $8 . n 7$ & 8.38 & 9.15 & -- & -- & $7.4 n$ & 9.40 & 9.00 & 8.18 \\
\hline
\end{tabular}


COMPOSITION AND PROPERTIES, NORTHERN GREAT PLAINS REGION

TABLE 1.-Chemical, mineralogical, and physical-properties data for 226 samples of Pierre Shale and equivalent rocks-Continued

\begin{tabular}{|c|c|c|c|c|c|c|c|c|c|}
\hline Sample 1o.-- & C879 & $\mathrm{c} 88 \mathrm{n}$ & $25955 ?$ & 259553 & 259564 & 259555 & 259550 & 259551 & C888 \\
\hline \multicolumn{10}{|c|}{ Sample-data codes } \\
\hline Locality--_-_-_-_- & 22 & 22 & 23 & 23 & $? 3$ & 23 & 23 & 23 & 23 \\
\hline Fossil zone-- & 4 & 4 & 6 & 6 & 6 & 5 & 4 & 4 & 4 \\
\hline 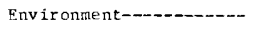 & 3 & 4 & 4 & 4 & 4 & 4 & 4 & 4 & 4 \\
\hline Rock type---1- & 5 & 4 & 4 & 5 & 4 & 4 & 4 & 4 & 4 \\
\hline Modifier of rock type-- & $n$ & 3 & 1 & 0 & in & 4 & 3 & 3 & 3 \\
\hline & & Roc & orming co & tuents ( & (cent) & & & & \\
\hline Si02- & 27.96 & $58.9 n$ & 61.7 & 31.14 & 55.5 & 61.4 & $65 . n$ & 65.3 & 59.81 \\
\hline AI203- & h. 60 & 16.83 & 15.2 & 9.17 & 15.2 & 15.8 & 14.7 & 15.2 & 15.70 \\
\hline $\mathrm{Fe}$, total as $\mathrm{Fe} 203$ & 5.94 & 5.50 & 5.4 & 4.45 & h. 3 & 4.8 & 4,6 & 3.7 & 5.34 \\
\hline $\mathrm{Fe} 203-$ & 1.21 & $3.8 n$ & $4 \cdot 6$ & .92 & 3.5 & $4 \cdot 2$ & 3.9 & 3.3 & 4.95 \\
\hline $\mathrm{FeO}-$ & 4.26 & 1.53 & .70 & 3.18 & .4 & $.5 n$ & . אח & $.4 n$ & .39 \\
\hline Mgo--1-1- & 2.89 & 2.69 & 1.8 & 1.20 & 2.4 & 2.2 & 2.1 & .2 & 2.27 \\
\hline $\mathrm{Can}-\mathrm{Ca}_{-}$ & $25 . n 6$ & .99 & 1.3 & $23 . k^{2}$ & 4.2 & .63 & 1.4 & 1.1 & 1.34 \\
\hline Na20- & .53 & 1.39 & .66 & .39 & 1.2 & .71 & 1.7 & 1.3 & 1.19 \\
\hline K2O-- & 1.25 & 2.70 & 2.2 & 1.71 & $\therefore h$ & 2.2 & 2.1 & 1.7 & 2.60 \\
\hline H2O- & 1.43 & $4 \cdot 30$ & 5.2 & l. 1 ก & 2.4 & $5 . n$ & 3.5 & 4.4 & 4.68 \\
\hline $\mathrm{H} 2 \mathrm{O}+$ & 2.09 & 4.75 & 4.5 & $4 \cdot 42$ & $4 \cdot 0$ & 5.0 & 4.0 & 3.9 & 4.67 \\
\hline Tin 2 & .28 & .56 &. $\mathrm{An}^{n}$ & .37 & $.6 n$ & .58 & .52 & .48 & .57 \\
\hline P205- & .26 & .11 & .13 & .40 & $.1^{\circ}$ &.$\cap 6$ & .14 & .07 & .13 \\
\hline $\mathrm{S}$, total- & .45 & .48 &.$n^{2}$ & $n .07$ & .93 &.$n_{2}$ &. $\mathrm{oh}$ & .01 & .21 \\
\hline s-m-20-1 & .43 & .44 & -- & 1.93 & .87 & -- & -. & -- & .01 \\
\hline S03---- & .04 & .00 & -- & .36 & .16 & -- & -- & -- & .50 \\
\hline F-1 & .06 & .09 & .07 &.$n 9$ & .07 &.$n a$ & .06 & . DA & .08 \\
\hline Cl-1-- & .02 & .03 & $\ldots$ & -. & -- & -- & -- & -- & .01 \\
\hline C, organic-- & $1.5 n$ & $<.5 n$ & $.5 n$ & 2.60 & $1.3 n$ & 1.10 & .24 & $.2 n$ & $<.50$ \\
\hline $\mathrm{c}$, mineral--_-_- & 5.50 & .10 & $<.02$ & 4.83 & .50 & $<.02$ & .17 &. $\mathrm{nf}$ & .07 \\
\hline & & Trace-el & nt consti & its (part & er millio & & & & \\
\hline 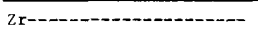 & 70 & $15 n$ & 140 & $15 n$ & $18 n$ & $2 n n$ & 200 & $? 2 n$ & 150 \\
\hline 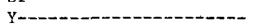 & 15 & 30 & 30 & 15 & 15 & 37 & 15 & $3 n$ & $3 n$ \\
\hline vb--1-10-1 & 1.5 & 3 & 3 & 1.5 & $<5$ & 3 & 3 & 3 & 3 \\
\hline 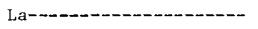 & 30 & $3 n$ & 30 & $<2 n$ & $<20$ & 70 & $3 n$ & 70 & in \\
\hline $\mathrm{Sn}$ & -- & -. & -- & -- & -- & 2 & -- & -- & -- \\
\hline Sc--- & 7 & 15 & 19 & 22 & 22 & 20 & 15 & 14 & 15 \\
\hline Ga-D-D-O- & 2 & 15 & 12 & 12 & 18 & 16 & 11 & 15 & 15 \\
\hline 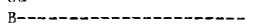 & 30 & 150 & 130 & $6 \pi$ & $8 n$ & $14 n$ & $14 n$ & $13 n$ & $15 n$ \\
\hline 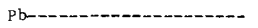 & 7 & 30 & 21 & 13 & 25 & 15 & 17 & 17 & 15 \\
\hline Ba-- & $15 n$ & 300 & $52 n$ & $4 n n$ & $81 n$ & 450 & fino & 590 & 300 \\
\hline 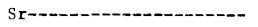 & 700 & $15 n$ & $12 n$ & $65 n$ & 1 an & $1 \geq 0$ & 200 & 170 & 150 \\
\hline $\mathrm{Mn}-\mathrm{-}$ &, $40 n$ & hyo & 280 & 840 & 890 & $33 n$ & $2 n n$ & 840 & $1,9 \cap 0$ \\
\hline Co-- & 15 & 30 & 12 & 16 & 21 & 29 & ?? & 12 & 15 \\
\hline 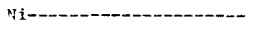 & 30 & $15 n$ & 29 & 57 & 49 & 15 & 41 & 100 & $7 n$ \\
\hline Zn--- & 70 & $20 n$ & $13 n$ & $15 n$ & $13 n$ & $3 \mathrm{fin}$ & $13 n$ & 150 & $2 n n$ \\
\hline $\mathrm{Cd}-\cdots$ & .8 & .8 & $<.3$ & .7 & .9 & 1.5 & .3 & .3 & 1.4 \\
\hline 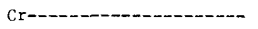 & $3 n$ & 70 & 93 & QQ & 92 & Qn & 79 & $5 a^{\circ}$ & 70 \\
\hline v-1- & $7 n$ & 150 & 210 & ח10 & $15 n$ & $31 n$ & $15 n$ & $18 n$ & 150 \\
\hline Cu--- & 15 & 70 & 32 & 49 & 29 & 81 & 26 & 44 & 70 \\
\hline Mo--1-_- & $<\ln$ & $<19$ & $<1$ & $<1$ & $<1$ & 2 & $<1$ & $<1$ & $<10$ \\
\hline Se--1-n- & 1 & 1 & 2 & 30 & 2 & 2 & 1 & $<1$ & 3 \\
\hline As----- & 17 & 24 & 12 & 21 & 18 & $a$ & 5 & 7 & 5 \\
\hline U-W-1- & $<1 n . n$ & $<\ln ^{n} .0$ & 4.5 & 8.1 & 3.4 & 5.7 & 2.8 & 3.1 & $<10.0$ \\
\hline eUm--- & $<10$ & $<10$ & $<10$ & $<1 n$ & $2 n$ & $2 n$ & $2 n$ & 20 & 20 \\
\hline & & for coll & e and $s p a$ & charact & stics of & & & & \\
\hline 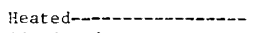 & 1 & I & 1 & 1 & I & 2 & 1 & 1 & 1 \\
\hline Air dried-- & -- & 1 & ? & 2 & 2 & 2 & 1 & 1 & 1 \\
\hline & & oportions & layers i & xed-1aye & lay (perc & & & & \\
\hline 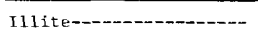 & 35 & 40 & 35 & 45 & $4 n$ & 35 & $2 n$ & 25 & 35 \\
\hline Beidellite---- & - & -- & $3 n$ & 30 & 29 & 35 & 45 & 20 & - \\
\hline Montmorillonite-------- & -- & -- & 35 & 25 & 35 & 30 & 35 & 55 & -- \\
\hline & & oportions & c1ay min & is in tot & clay (per & & & & \\
\hline Mixed-layer---.-..--.. & 81 & 88 & 76 & 63 & 51 & 88 & 85 & 87 & 88 \\
\hline Illite- & 17 & 9 & 18 & 21 & 22 & 12 & 12 & 11 & 10 \\
\hline Ch1orite-- & 2 & 1 & 3 & 6 & in & $\mathrm{N}$ & ? & 1 & 1 \\
\hline Kaolinite-- & $\mathrm{N}$ & ? & 3 & in & 7 & N & $i$ & 1 & 1 \\
\hline & & Mineral & position & otal san & (percent & & & & \\
\hline Total clay-_-_- & 40 & sก & 75 & 45 & 70 & 80 & 75 & $7 n$ & 80 \\
\hline Quart $z-\cdots$ & 12 & 13 & 13 & a & 19 & in & 19 & 12 & 14 \\
\hline Cristobalite- & $\mathrm{N}$ & 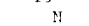 & in & $\mathrm{NT}$ & $\mathrm{N}$ & 5 & 5 & 15 & $\mathrm{p}$ \\
\hline Potassium feldspar-..- & $\mathrm{N}$ & $\mathrm{N}$ & n: & $\mathrm{n}$ & Nit & $\mathrm{N}$ & $\mathrm{N}$ & N & $\mathrm{N}$ \\
\hline Plagioclase-- & $\mathrm{N}$ & 2 & 3 & $\mathrm{~N}$ & 2 & 2 & 5 & 4 & 2 \\
\hline Calcite-- & 38 & $\mathrm{~N}$ & $\mathrm{~N}$ & 40 & 8 & $\mathrm{~N}$ & 1 & 1 & $\mathrm{~N}$ \\
\hline nolomite- & 4 & $\mathrm{~N}$ & "1) & $\mathrm{N}$ & м & $\mathrm{N}$ & N & $\mathrm{H}$ & $\mathrm{N}$ \\
\hline Siderite-- & 3 & $\mathrm{~N}$ & i & N & N & $\mathrm{N}$ & n & n & $\mathrm{N}$ \\
\hline Gypsum-- & $\mathrm{N}$ & $\mathrm{N}$ & $"$ & $\mathrm{~N}$ & N & M & $\mathrm{N}$ & "1 & 1 \\
\hline Tarosite- - & $\mathrm{N}$ & is & in & $\mathrm{n}$ & $\mathrm{N}$ & $\mathrm{N}$ & $\mathrm{N}$ & N & $\mathrm{N}$ \\
\hline Pyrite-- & 2 & N & $\mathrm{N}$ & 4 & 1 & $\mathrm{~N}$ & $\mathrm{~N}$ & $\mathrm{~N}$ & " \\
\hline Zeolite- & $\mathrm{v}$ & $\mathrm{N}$ & i & $\mathrm{N}$ & N & N & $\mathrm{N}$ & 1 & 3 \\
\hline & orthite & tent of & foclase & termined & Y-ray a & is (per & & & \\
\hline Anorthite---- & -- & -- & -- & -- & -- & -- & 30 & $3 n$ & -- \\
\hline & & sulk and & n densiti & Atterber & imits, ar & & & & \\
\hline Bulk density- & -. & -- & 1.66 & 1.62 & 1.91 & 1.72 & 1.8 .8 & 1.78 & -- \\
\hline Grain density-- & -- & -- & 2.51 & 2.61 & 2.62 & 2.47 & 2.53 & 2.53 & -- \\
\hline Liquid I Imit-- & 61 & 132 & -. & 55 & 68 & 125 & 155 & 183 & 113 \\
\hline Plastic limit-- & 20 & 62 & -- & 36 & 33 & 49 & 48 & 52 & 41 \\
\hline Plastic index- & 41 & 70 & -- & 19 & 35 & 75 & 107 & 171 & 72 \\
\hline $\mathrm{pH} \rightarrow-$ & $8.5 n$ & 10.15 & -- & -. & 0.20 & $5.5 n$ & 8.70 & 8.35 & 7.70 \\
\hline
\end{tabular}


TABLE 1.-Chemical, mineralogical, and physical-properties data for 226 samples of Pierre Shale and equivalent rocks-Continued

\begin{tabular}{|c|c|c|c|c|c|c|c|c|c|}
\hline Samp le No.--_-_--- & C889 & $\mathrm{C} 890$ & 259547 & 259548 & 259549 & C891 & 259556 & 259557 & 259558 \\
\hline \multicolumn{10}{|c|}{ Sample-data codes } \\
\hline Locality-_- & 23 & 23 & 2.3 & 23 & 23 & 23 & 24 & 24 & 24 \\
\hline Fossil zone-- & 4 & 4 & 2 & $?$ & 2 & 2 & 6 & 5 & 5 \\
\hline Environment------_-- & 3 & 4 & 4 & 4 & 4 & 4 & 4 & 4 & 4 \\
\hline Rock type--_- & 5 & 4 & 4 & 6 & 4 & 4 & 5 & 6 & 4 \\
\hline Modifier of rock type-- & 0 & 3 & 1 & 0 & 2 & 2 & 0 & 0 & 4 \\
\hline & & Rock- & eming cons & Euents (pe & ent) & & & & \\
\hline SiO2-- & 35.25 & 56.87 & 53.56 & 47.12 & 34.85 & 47.42 & 39.91 & 53.39 & 61.38 \\
\hline A1 203- & 9.76 & 15.92 & 17.04 & 20.79 & 9.22 & 12.81 & 12.70 & 20.21 & 15.06 \\
\hline $\mathrm{Fe}$, total as Fe203-- & 3.78 & 4.90 & 5.00 & 3.27 & 15.81 & 5.30 & 5.65 & 2.60 & 5.11 \\
\hline $\mathrm{Fe} 203-$ & 3.78 & 4.73 & .68 & 2.65 & .62 & .67 & 2.71 & 2.30 & 4.79 \\
\hline 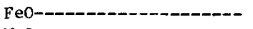 & $<.01$ & .13 & 3.89 & .56 & 13.67 & 4.17 & 2.65 & .27 & .29 \\
\hline 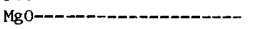 & 2.00 & 2.39 & 1.74 & 3.06 & .64 & .84 & 1.42 & 2.47 & 2.07 \\
\hline CaO--- & 21.65 & 2.97 & 3.80 & .81 & 1.73 & 1.21 & 14.62 & 1.84 & .87 \\
\hline Na 20----------------- & .64 & 1.72 & .89 & .70 & .51 & .83 & .49 & .19 & .25 \\
\hline K20------ & 2.18 & 3.05 & 3.25 & .36 & 2.28 & 2.89 & 2.45 & .08 & 2.62 \\
\hline H20- - - & 2.71 & 3.31 & 3.09 & 11.62 & 3.40 & 2.88 & 2.29 & 11.22 & 5.87 \\
\hline $\mathrm{H} 2 \mathrm{O}+-$ & 2.77 & 4.27 & 5.58 & 7.30 & $7.5 \hbar$ & 8.35 & 5.40 & 6.19 & 4.83 \\
\hline Ti02---- & .37 & .56 & .61 & .24 & .47 & .50 & .50 & .41 & .55 \\
\hline P205- & .23 & .13 & .29 & .09 & .14 & .12 & .13 & .02 & .15 \\
\hline S, total-- & .08 & .53 & 1.17 & 1.87 & 13.29 & 3.51 & 1.36 & .40 & .04 \\
\hline S--- & .01 & .01 & 1.02 & .26 & 9.71 & 1.57 & .92 & .09 & .02 \\
\hline 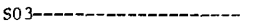 & .18 & 1.31 & .37 & 4.01 & 8.95 & 4.85 & 1.10 & .78 & .05 \\
\hline 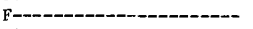 & .08 & .08 & .10 & .26 & .07 & .08 & .07 & .07 & .08 \\
\hline C1---1--1-- & .02 & .01 & - & $-\infty$ & -- & .13 & -- & -- & -- \\
\hline$c$, organic--- & .10 & $<.50$ & 1.20 & $<.05$ & 8.50 & 7.40 & 2.90 & .10 & .90 \\
\hline c, mineral--_-_.-- & 4.68 & .49 & .76 & $<. \cap 2$ & $<.02$ & .01 & 2.94 & .03 & .02 \\
\hline & & Trace-elem & constits & is (parts & million) & & & & \\
\hline $\mathrm{Zr}-\mathrm{-}$ & 70 & 70 & 200 & 160 & 140 & 70 & 150 & 130 & 180 \\
\hline Y Y --_-_- & 15 & 15 & 70 & 30 & 15 & 15 & 30 & 15 & $3 n$ \\
\hline 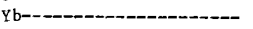 & 1.5 & 3 & 3 & 3 & $<5$ & 3 & 3 & 1.5 & 3 \\
\hline La------_-----_------- & $<20$ & 30 & 30 & $<20$ & 30 & $<20$ & 30 & $<20$ & 30 \\
\hline Sn----1-- & -- & -- & 2 & 3 & 3 & 1 & $<1$ & -- & -- \\
\hline 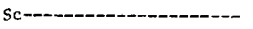 & 7 & 13 & 24 & 5 & 11 & 7 & 24 & 9 & 18 \\
\hline 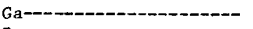 & 2 & 15 & 18 & 18 & 9 & 7 & 20 & 18 & 14 \\
\hline 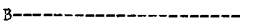 & 30 & $15 n$ & 180 & 230 & 130 & 150 & 120 & 160 & 150 \\
\hline 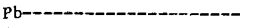 & 7 & 15 & 22 & 29 & 25 & 15 & 39 & 19 & 15 \\
\hline Ba-C-O-_- & 150 & 300 & 500 & 220 & 560 & 300 & 530 & 70 & 400 \\
\hline 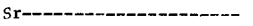 & 700 & 150 & 170 & 110 & 130 & 70 & 400 & 31 & 87 \\
\hline 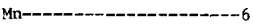 & 100 & 2,500 & 400 & 240 & 140 & 150 & 350 & 150 & 680 \\
\hline Co----D-_- & 15 & 15 & 27 & 18 & 20 & 3 & 20 & 3 & 24 \\
\hline 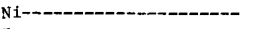 & 30 & 70 & 85 & 72 & 65 & 30 & 78 & 10 & 72 \\
\hline Zn----1- & 90 & 170 & 230 & 330 & 120 & 80 & 210 & 38 & 260 \\
\hline 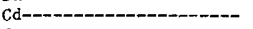 & .5 & 1.5 & 1.20 & 11.0 & 3.5 & 3.5 & 10.0 & .6 & 1.5 \\
\hline $\mathrm{Cr}-$ & $70^{\circ}$ & 70 & 110 & 14 & 130 & 70 & 120 & 7 & 84 \\
\hline v- & 70 & 150 & 250 & 580 & 740 & 300 & 380 & 80 & 240 \\
\hline 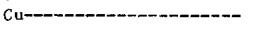 & 30 & 70 & 92 & 38 & 71 & 70 & 79 & 5 & 65 \\
\hline MO----------------------- & $<10$ & $<10$ & 1 & 9 & 350 & 70 & 11 & 6 & $<1$ \\
\hline Se---------------------- & 2 & 2 & 3 & 5 & 120 & 50 & 35 & 2 & 1 \\
\hline As---1--_- & 11 & 8 & 8 & 32 & 490 & 41 & 39 & 6 & 8 \\
\hline 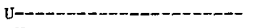 & $<10.0$ & $<10.0$ & 9.0 & 2.9 & 7.8 & 10.0 & 9.2 & .9 & 3.1 \\
\hline 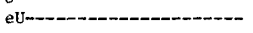 & $<10$ & 20 & 20 & 20 & 80 & 40 & 10 & $<10$ & $<10$ \\
\hline & & for collap & and spac & characte & ties of $\mathrm{s}$ & tite & & & \\
\hline Heated---_--_--_-- & 1 & 1 & 1 & 2 & 1 & 2 & 1 & 1 & 2 \\
\hline Air dried--------- & - & 1 & 1 & 2 & - & - & - & 2 & 2 \\
\hline & & oportions & layers in & xed-1 ayer & ay (perce & & & & \\
\hline Illite-- & 40 & 45 & 50 & $\mathrm{~N}$ & 60 & 50 & 55 & ก & 40 \\
\hline Beidel11te--- & -- & -- & 30 & 24 & 30 & - & 35 & $31 "$ & 30 \\
\hline Montmorillonite-_-_-_- & -- & -- & 20 & 76 & 10 & $\cdots$ & 10 & 69 & 30 \\
\hline & & oportions & clay mine & s in tota & lay (perc & & & & \\
\hline Mixed-layer-_- & 78 & 88 & 68 & 100 & 59 & 64 & 50 & 100 & 86 \\
\hline Illite-1- & 16 & 9 & 14 & $\mathrm{~N}$ & 27 & 26 & 30 & $\mathrm{~N}$ & 14 \\
\hline Chlorite---------_----- & 2 & $\mathrm{v}$ & 5 & $\mathrm{~N}$ & $\mathrm{~N}$ & $\mathrm{~N}$ & 7 & $\mathrm{~N}$ & $\mathrm{~N}$ \\
\hline Kaolinite-- & 4 & 3 & 13 & in & 14 & $10^{10}$ & 13 & $\mathrm{~N}$ & N \\
\hline & & Mineral $\mathrm{cc}$ & osition o & otal samp & (percent) & & & & \\
\hline Total clay------------- & $5 n$ & 80 & 75 & 90 & 45 & 60 & 50 & 100 & 80 \\
\hline Quartz- & 8 & 15 & 14 & 1 & 14 & 20 & 12 & 1 & 17 \\
\hline Cristobalite--- & $\mathrm{N}$ & $\mathrm{N}$ & N & $\mathrm{N}$ & $\mathrm{N}$ & 4 & $\mathrm{N}$ & $\mathrm{N}$ & $\mathrm{N}$ \\
\hline Potassium feldspar----- & $\mathrm{N}$ & $\mathrm{N}$ & $\mathrm{N}$ & N & 3 & 3 & $\mathrm{~N}$ & it & $\mathrm{N}$ \\
\hline Plagioclase-- & $\mathrm{N}$ & 1 & 1 & $\mathrm{~N}$ & $\mathrm{~N}$ & $\mathrm{~N}$ & 1 & v & 1 \\
\hline Calcite----_--_-_--_--- & 37 & 4 & 6 & $\mathrm{~N}$ & $\mathrm{~N}$ & $\mathrm{~N}$ & 24 & $\mathrm{~N}$ & $\mathrm{~N}$ \\
\hline Dolomite-- & 4 & $\mathrm{~N}$ & $\mathrm{~N}$ & $\mathrm{~N}$ & $\mathrm{~N}$ & $\mathrm{~N}$ & $\mathrm{~N}$ & $\mathrm{~N}$ & $\mathrm{~N}$ \\
\hline Siderite--_---_-_-_--- & $\mathrm{N}$ & $\mathrm{N}$ & $\mathrm{N}$ & $\mathrm{N}$ & $\mathrm{N}$ & $\mathrm{N}$ & $\mathrm{N}$ & $\mathrm{N}$ & $\mathrm{N}$ \\
\hline Gypsum--_--_-_-_-_-_-- & $\mathrm{N}$ & 1 & 1 & 3 & 5 & $\mathrm{~N}$ & $2^{N}$ & $\mathrm{~N}$ & $\mathrm{~N}$ \\
\hline Jarosite-------------- & $\mathrm{N}$ & $\mathrm{N}$ & $\mathrm{N}$ & 5 & 5 & 5 & $\mathrm{~N}$ & 2 & $\mathrm{~N}$ \\
\hline Pyrite- & $\mathrm{N}$ & $\mathrm{N}$ & 2 & $\mathrm{~N}$ & 15 & 2 & 2 & $\mathrm{~N}$ & $\mathrm{~N}$ \\
\hline Zeolite------_----_--- & $\mathrm{N}$ & N & $\mathrm{N}$ & $\mathrm{N}$ & $\mathrm{N}$ & $\mathrm{N}$ & $\mathrm{N}$ & $\mathrm{N}$ & $\mathrm{N}$ \\
\hline & Inorthite & tent of $\mathrm{p} 1$ & oclase as & termined & Y-ray ana & is (perce & & & \\
\hline Anor thite---_------- & -- & -- & -- & -- & -- & - & -- & -- & -- \\
\hline & & Bulk and $\mathrm{gr}$ & densitie & At terberg & mits, and & & & & \\
\hline Bulk density-- & -- & -- & 1.94 & 1.81 & 1.55 & - & 1.68 & 1.65 & 1.73 \\
\hline Grain density-- & -- & -- & 2.61 & 2.40 & 2.61 & -- & 2.61 & 2.29 & 2.49 \\
\hline Liquid linit---------- & 94 & 101 & $8 n$ & 122 & 47 & 50 & -- & 95 & 78 \\
\hline Plastic limit-- & 28 & 35 & 35 & 58 & 34 & 36 & -- & 93 & 50 \\
\hline Plastic index-------- & 66 & on & 45 & 64 & 13 & 15 & -- & 12 & 28 \\
\hline $\mathrm{pH}-$ & 8.18 & 8.23 & 7.95 & 2.85 & 1.90 & 1.91 & 7.70 & - & 5.70 \\
\hline
\end{tabular}


COMPOSITION AND PROPERTIES, NORTHERN GREAT PLAINS REGION

B111

TABLE 1.-Chemical, mineralogical, and physical-properties data for 226 samples of Pierre Shale and equivalent rocks-Continued

\begin{tabular}{|c|c|c|c|c|c|c|c|c|}
\hline Sample No.-----------259559 & 259550 & 259561 & 259562 & 259563 & $2595 \geq 9$ & 250528 & $25952 \mathrm{~h}$ & 259527 \\
\hline \multicolumn{9}{|c|}{ Sample-data codes } \\
\hline Locality-_-_-_-_- 24 & 24 & 24 & 25 & 26 & .27 & 27 & 28 & 28 \\
\hline Fossil zone--_- 4 & 4 & 2 & 6 & 2 & 5 & 3 & 2 & 2 \\
\hline Environment---- & 3 & 4 & 4 & 4 & 4 & 4 & 4 & 4 \\
\hline Rock type--1-1- 4 & 5 & 4 & 5 & 4 & 4 & 5 & 4 & 4 \\
\hline Modifier of rock type-- 3 & $n$ & 2 & $n$ & 7 & 4 & $n$ & 7 & 2 \\
\hline & & orming $c$ & Eituents & (cent) & & & & \\
\hline Si02-- & 30.8 & $65 . ?$ & 43.7 & 64.61 & $70 . ?$ & 10.6 & 58.52 & 58.0 \\
\hline A1203- 16.76 & 9.0 & 12.4 & 14.2 & 14.10 & 10.9 & 5.2 & $14.4 n$ & 15.5 \\
\hline $\mathrm{Fe}$, total as $\mathrm{Fe} 203-\cdots 5.09$ & 2.6 & 2.2 & 5.3 & 2.73 & 3.5 & 2.1 & 4.60 & 3.4 \\
\hline $\mathrm{Fe} 203-$ & 1.5 & 1.1 & 3.9 & .92 & 3.2 & 1.7 & 3.40 & 2.3 \\
\hline FeO-D- & $1 . n$ & 1.0 & 1.3 & 1.53 & .40 & .30 & $1 . n n$ & 1.0 \\
\hline Mgo-- & $1 \cdot 3$ & .61 & 1.6 & 1.78 & 1.7 & .24 & 1.14 & $1 . n$ \\
\hline CaO-- & 26.4 & $.2 n$ & 11.6 & .38 & .89 & 37.1 & .12 & $.2 n$ \\
\hline Na20- 1.15 & .32 & .23 & .39 & .35 & $.3 n$ & .22 & .3 & .37 \\
\hline K20--1- 2.55 & 2.0 & 3.3 & $2 . h$ & 3.37 & 1.4 & 1.2 & 3.75 & 3.1 \\
\hline H20- & 1.5 & 2.7 & 2.6 & 2.85 & 5.2 & 1.5 & 4.11 & 3.7 \\
\hline $\mathrm{H} 2 \mathrm{O}+-$ & 2.1 & $4 \cdot n$ & 4.1 & 5.48 & 3.5 & 3.5 & 6.46 & $4 . n$ \\
\hline Ti02- & .36 & .59 & .53 & .71 & .42 & .22 & .74 & .73 \\
\hline P205-- & .21 & .17 & .08 & .08 & .05 & $.2 n$ & .30 & .10 \\
\hline $\mathrm{s}$, total-_- .05 & .34 & .56 & 1.87 & .42 & .01 & .02 & .28 & 1.19 \\
\hline S- & .27 & .45 & 1.64 & .27 & -- & -- & .25 & .96 \\
\hline S03-1- & .19 & .27 & .58 & .37 & -- & -- & .08 & .58 \\
\hline F- & .07 & .07 & .08 &.$n 9$ & .06 & .06 & .08 & .08 \\
\hline CI---1-- & -- & -- & -- & -- & -- & -- & -- & -- \\
\hline c, organic--- & .70 & $5.4 n$ & $2.5 n$ & 3.10 & .50 & .14 & 4.80 & 5.60 \\
\hline c, mineral---_- $\quad . n_{4}$ & 5.93 & .05 & 2.42 & $<.0 ?$ & $<.02$ & 7.86 & .05 & .02 \\
\hline & Trace-e & nt const & ents (par & per millic & & & & \\
\hline 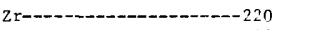 & 120 & 300 & 160 & $24 \pi$ & $13 n$ & 82 & 350 & 270 \\
\hline Y & 13 & 30 & 15 & 15 & 30 & 15 & 30 & 15 \\
\hline $\mathrm{Yb}-1-1-10-1$ & 1.5 & 3 & 1.5 & 3 & 3 & 1.5 & 3 & 3 \\
\hline La-DS- 70 & $<20$ & $3 n$ & $<20$ & 30 & $3 n$ & $<20$ & 30 & 30 \\
\hline 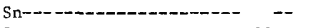 & -- & 2 & 1 & 3 & -- & -- & -- & -- \\
\hline Sc--W- 20 & 21 & 16 & 24 & 16 & 15 & 15 & 21 & 14 \\
\hline $\mathrm{Ga}-(-\mathrm{n}$ & 9 & 18 & 21 & 19 & 7 & 6 & 17 & 15 \\
\hline B-W-140 & 40 & $12 n$ & in & $14 n$ & 130 & 40 & 180 & 130 \\
\hline $\mathrm{Pb}-\mathrm{C}$ & 17 & 19 & 8 & 14 & 10 & 15 & 23 & 25 \\
\hline Ва--- & $22 n$ & $46 n$ & 510 & $39 n$ & 260 & 240 & $52 n$ & $60 n$ \\
\hline Sr--- & $86 n$ & 36 & 340 & 73 & 64 & 1,300 & 41 & 51 \\
\hline $\mathrm{Mn}-\cdots-10-10$ & 1,900 & $8 n$ & $30 n$ & an & 579 & 4,200 & 80 & $9 n$ \\
\hline Co-1- 16 & 10 & $<5$ & 22 & $<4$ & s & 12 & 6 & 9 \\
\hline $\mathrm{Ni}-\mathrm{N}$ & 34 & 15 & 56 & 14 & $4 n$ & 39 & 15 & 23 \\
\hline $\mathrm{Zn}-\mathrm{Z}_{-1}$ & 8.5 & 37 & $18 n$ & 53 & 140 & sก & 70 & 63 \\
\hline Cd-D- $<.3$ & .4 & 1.6 & 6.5 & .8 & .7 & .5 & $1 . n$ & $1 . n$ \\
\hline Cr--1- & 78 & $10 n$ & 100 & 130 & 66 & 60 & $2 n 0$ & 130 \\
\hline V-D-D-160 & $10 n$ & 550 & $31 n$ & 340 & 220 & 70 & 640 & 560 \\
\hline $\mathrm{Cu}-\mathrm{Cu}$ & 19 & 115 & 78 & 74 & 32 & 18 & 115 & 45 \\
\hline MO-WL_L 1 & 1 & 22 & 9 & 18 & 2 & 1 & 13 & 43 \\
\hline Se--_-_L_L 2 & 2 & 160 & 30 & 25 & $\bar{i}$ & $<1$ & 30 & 28 \\
\hline As-- & 8 & 100 & 30 & 38 & 4 & 6 & 38 & 45 \\
\hline U-- & 3.3 & 28.0 & 6.7 & $24 \cdot 0$ & 1.6 & 1.6 & 18.0 & 4.6 \\
\hline eJ--_-_-_-_-_- $<10$ & 10 & 30 & 20 & 20 & $<10$ & $<10$ & 30 & 30 \\
\hline & des for col & e and $s p$ & ng chara & istics of & ectite & & & \\
\hline Heated------------------ 1 & 1 & 1 & 1 & 1 & 2 & 1 & 1 & 2 \\
\hline Air dried-- & - & -- & 2 & 2 & 2 & 2 & 2 & 2 \\
\hline & Proportion & Iayers & mixed-1ay & clay (per & & & & \\
\hline Illite------------------ 35 & 45 & 55 & 45 & 45 & 30 & 45 & 45 & 45 \\
\hline Beidellite--_-_-_-_-_ 40 & 30 & 35 & 40 & 35 & 20 & 45 & 40 & 40 \\
\hline Montmorillonite------- 25 & 25 & 10 & 15 & 20 & 50 & 10 & 15 & 15 \\
\hline & Proportion & clay $\mathrm{mi}$ & aIs in $t$ & clay (pe & & & & \\
\hline Mixed-1ayer-1- 86 & 66 & 60 & 56 & 64 & 88 & 70 & 77 & 75 \\
\hline IIlite- 10 & 17 & 27 & 24 & 24 & 10 & 17 & 16 & 16 \\
\hline ChIorite----------- N & $\mathrm{N}$ & N & 5 & $\mathrm{~N}$ & 2 & 3 & $\mathrm{~N}$ & $\mathrm{~N}$ \\
\hline Kaolinite----_--- 4 & 17 & 13 & 15 & 12 & N & 10 & 7 & 9 \\
\hline & Mineral & aposition & total $s$ & e (percen & & & & \\
\hline Total clay---_--- 80 & 40 & 50 & 55 & 60 & 55 & 35 & 65 & 65 \\
\hline Quartz- 15 & 8 & 25 & 12 & 25 & 7 & 4 & 21 & 23 \\
\hline Cristobalite-_-_- $\mathrm{N}$ & $\mathrm{N}$ & $\mathrm{N}$ & $\mathrm{N}$ & $\mathrm{N}$ & 35 & $\mathrm{~N}$ & $\mathrm{~N}$ & $\mathrm{~N}$ \\
\hline Potassium feldspar---- $\mathrm{N}$ & $\mathrm{N}$ & 7 & 1 & 7 & $\mathrm{~N}$ & $\mathrm{~N}$ & 7 & 5 \\
\hline Plagioclase--- & 1 & $\mathrm{~N}$ & $\mathrm{~N}$ & $\mathrm{~N}$ & 1 & n & N & $\mathrm{N}$ \\
\hline Calcite- & 44 & N & 21 & N & $\mathrm{N}$ & 62 & $\mathrm{~N}$ & $\mathrm{~N}$ \\
\hline 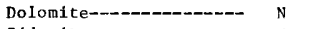 & 4 & $\mathrm{n}$ & $\mathrm{N}$ & $\mathrm{N}$ & พ & $\mathrm{N}$ & $\mathrm{N}$ & $\mathrm{N}$ \\
\hline Siderite---------------- & $\mathrm{N}$ & $\mathrm{N}$ & $\mathrm{v}$ & N & $\mathrm{N}$ & $\mathrm{N}$ & i & $\mathrm{N}$ \\
\hline Gypsum=-----------'---- & $\mathrm{N}$ & $\mathrm{N}$ & N & $\mathrm{N}$ & 1 & $\mathrm{~N}$ & $\mathrm{~N}$ & 1 \\
\hline Jarosite-_-_- & $\mathrm{N}$ & $\mathrm{N}$ & 1 & 1 & $\mathrm{~N}$ & $\mathrm{~N}$ & $\mathrm{~N}$ & 2 \\
\hline 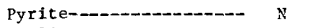 & $\mathrm{N}$ & $\mathrm{N}$ & 5 & M & $\because$ & $\mathrm{N}$ & N & 2 \\
\hline Zeolite--1-- N & $\mathrm{N}$ & $\mathrm{N}$ & $\mathrm{N}$ & $\mathrm{N}$ & $\mathrm{N}$ & $\mathrm{N}$ & $\mathrm{N}$ & $\mathrm{N}$ \\
\hline Anorth & ontent of & Loc Iase & letermin & y Y-ray & sis (pe & & & \\
\hline Anorthfte----------- -- & -- & -- & -- & -- & -- & -- & -- & -- \\
\hline & Bulk and & in densit & , Atterb & limits, a & & & & \\
\hline Bulk density-_-__-_ 2.00 & 2.09 & 1.33 & 1.64 & 1.42 & 1.62 & 1.71 & 1.46 & 1.70 \\
\hline Grain density-- & 2.65 & 2.33 & 2.56 & 2.44 & 2.36 & 2.68 & 2.39 & 2.37 \\
\hline Liquid limit-- & - & -- & -- & 61 & 77 & 51 & 57 & -- \\
\hline Plasțic limit---------- 41 & -- & -- & -- & 57 & 61 & 28 & 53 & -- \\
\hline P1astic index--------- 91 & -- & -- & -- & 4 & 16 & 23 & 4 & -- \\
\hline $\mathrm{pH}-$ & 8.35 & - & -- & 4.10 & 8.30 & 8.15 & 4.00 & -- \\
\hline
\end{tabular}


TABLE 2.-Location of chemically analyzed samples from the Pierre Shale and equivalent rocks, northern Great Plains region

\begin{tabular}{|c|c|c|c|c|}
\hline $\begin{array}{l}\text { Sample } \\
\text { No. }\end{array}$ & Section & Township & Range & County \\
\hline \multicolumn{5}{|c|}{ Livingston, Mont. (locahity 1) } \\
\hline $\begin{array}{l}159822 \\
159823 \\
159824 \\
159825 \\
159826\end{array}$ & 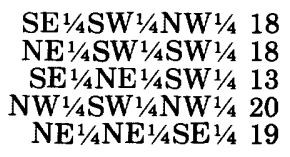 & $\begin{array}{l}2 \mathrm{~S} . \\
2 \mathrm{~S} . \\
2 \mathrm{~S} . \\
2 \mathrm{~S} . \\
2 \mathrm{~S} .\end{array}$ & $\begin{array}{l}9 \mathrm{E} . \\
9 \mathrm{E} . \\
8 \mathrm{E} . \\
9 \mathrm{E} . \\
9 \mathrm{E} .\end{array}$ & $\begin{array}{l}\text { Park } \\
\text { Do. } \\
\text { Do. } \\
\text { Do. } \\
\text { Do. }\end{array}$ \\
\hline $\begin{array}{l}159827 \\
159828 \\
159829 \\
159830\end{array}$ & 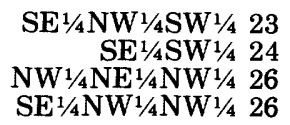 & $\begin{array}{l}2 \mathrm{~S} . \\
2 \mathrm{~S} . \\
2 \mathrm{~S} . \\
2 \mathrm{~S} .\end{array}$ & $\begin{array}{l}8 \mathrm{E} . \\
8 \mathrm{E} . \\
8 \mathrm{E} . \\
8 \mathrm{E} .\end{array}$ & $\begin{array}{l}\text { Do. } \\
\text { Do. } \\
\text { Do. } \\
\text { Do. }\end{array}$ \\
\hline
\end{tabular}

Dearborn River, Mont. (locality 2)

\begin{tabular}{|c|c|c|c|c|}
\hline $\begin{array}{l}159833 \\
159834 \\
159835 \\
159836 \\
159837\end{array}$ & $\begin{array}{ll}\text { NE }^{1 / 4} \text { SW }^{1 / 4} \text { SW }^{1 / 4} & 21 \\
\text { SW }^{1 / 4} \text { NE }^{1 / 4} \text { SW }^{1 / 4} & 21 \\
\text { NE }^{1 / 4} \text { NE }^{1 / 4} \text { SW }^{1 / 4} & 21 \\
\text { NE }^{1 / 4} \text { NE }^{1 / 4} \text { SW }^{1 / 4} & 21 \\
\text { SW }^{1 / 4} \mathrm{SE}^{1 / 4} \text { NW }^{1 / 4} & 21\end{array}$ & $\begin{array}{l}17 \mathrm{~N} . \\
17 \mathrm{~N} . \\
17 \mathrm{~N} . \\
17 \mathrm{~N} . \\
17 \mathrm{~N} .\end{array}$ & $\begin{array}{ll}5 & W . \\
5 & W . \\
5 & W . \\
5 & W . \\
5 & W .\end{array}$ & $\begin{array}{l}\text { Lewis and Clark } \\
\text { Do. } \\
\text { Do. } \\
\text { Do. } \\
\text { Do. }\end{array}$ \\
\hline $\begin{array}{l}159838 \\
159839 \\
159840 \\
159841 \\
159842\end{array}$ & $\begin{array}{rl}\mathrm{NW}^{1 / 4} \mathrm{SW}^{1 / 4} \mathrm{NE}^{1 / 4} & 21 \\
\mathrm{SW}^{1 / 4} \mathrm{NW}^{1 / 4} \mathrm{NE}^{1 / 4} & 21 \\
\mathrm{SE}^{1 / 4} \mathrm{SW}^{1 / 4} \mathrm{SE}^{1 / 4} & 16 \\
\mathrm{NW}^{1 / 4} \mathrm{SE}^{1 / 4} \mathrm{SE}^{1 / 4} & 16 \\
\mathrm{NE}^{1 / 4} \mathrm{SE}^{1 / 4} \mathrm{SE}^{1 / 4} & 16\end{array}$ & $\begin{array}{l}17 \mathrm{~N} . \\
17 \mathrm{~N} . \\
17 \mathrm{~N} . \\
17 \mathrm{~N} . \\
17 \mathrm{~N} .\end{array}$ & $\begin{array}{ll}5 & W . \\
5 & W . \\
5 & W . \\
5 & W . \\
5 & W .\end{array}$ & $\begin{array}{l}\text { Do. } \\
\text { Do. } \\
\text { Do. } \\
\text { Do. } \\
\text { Do. }\end{array}$ \\
\hline
\end{tabular}

\begin{tabular}{|c|c|c|c|c|}
\hline \multicolumn{5}{|c|}{ August-Choteau, Mont. (locality 3) } \\
\hline $\begin{array}{l}159843 \\
159844 \\
159845 \\
159846\end{array}$ & 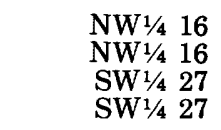 & $\begin{array}{l}20 \mathrm{~N} . \\
20 \mathrm{~N} . \\
23 \mathrm{~N} . \\
23 \mathrm{~N} .\end{array}$ & $\begin{array}{l}5 \mathrm{~W} . \\
5 \mathrm{~W} . \\
5 \mathrm{~W} . \\
5 \mathrm{~W} .\end{array}$ & $\begin{array}{l}\text { Lewis and Clark } \\
\text { Do. } \\
\text { Teton } \\
\text { Do. }\end{array}$ \\
\hline \multicolumn{5}{|c|}{ Cut Bank, Mont. (locality 4) } \\
\hline $\begin{array}{l}159847 \\
159848 \\
159849 \\
159850 \\
159851 \\
159852\end{array}$ & $\begin{array}{cr}\text { SW }^{1 / 4} \text { NW }^{1 / 4} & 5 \\
\text { SW }^{1 / 4} \text { NW }^{1 / 4} & 5 \\
\text { SW }^{1 / 4} \text { NW }^{1 / 4} & 35 \\
\text { NW }^{1 / 4} \text { NW W }^{1 / 4} & 3 \\
\text { NE }^{1 / 4} \text { NE }^{1 / 4} & 4 \\
\text { NE }^{1 / 4} \text { SE }^{1 / 4} & 28\end{array}$ & $\begin{array}{l}31 \mathrm{~N} . \\
31 \mathrm{~N} . \\
36 \mathrm{~N} . \\
36 \mathrm{~N} . \\
36 \mathrm{~N} . \\
37 \mathrm{~N} .\end{array}$ & $\begin{array}{l}9 \mathrm{~W} . \\
9 \mathrm{~W} . \\
9 \mathrm{~W} . \\
8 \mathrm{~W} . \\
8 \mathrm{~W} . \\
8 \mathrm{~W} .\end{array}$ & $\begin{array}{r}\text { Glacier } \\
\text { Do. } \\
\text { Do. } \\
\text { Do. } \\
\text { Do. } \\
\text { Do. }\end{array}$ \\
\hline $\begin{array}{l}159853 \\
159854 \\
159855 \\
159856 \\
159857 \\
159858\end{array}$ & $\begin{array}{rl}\mathrm{NE}^{1 / 4} \mathrm{SE}^{1 / 4} & 28 \\
\mathrm{SE}^{1 / 4} \mathrm{SE}^{1 / 4} & 36 \\
\mathrm{NW}^{1 / 4} & 18 \\
\mathrm{SE}^{1 / 4} \mathrm{NE}^{1 / 4} & 11 \\
\mathrm{SE}^{1 / 4} \mathrm{SW}^{1 / 4} & 16 \\
\mathrm{NW}^{1 / 4} \mathrm{SW}^{1 / 4} & 35\end{array}$ & $\begin{array}{l}37 \mathrm{~N} . \\
30 \mathrm{~N} . \\
35 \mathrm{~N} . \\
33 \mathrm{~N} . \\
31 \mathrm{~N} . \\
32 \mathrm{~N} .\end{array}$ & $\begin{array}{l}8 \mathrm{~W} . \\
8 \mathrm{~W} . \\
5 \mathrm{~W} . \\
6 \mathrm{~W} . \\
5 \mathrm{~W} . \\
5 \mathrm{~W} .\end{array}$ & $\begin{array}{c}\text { Do. } \\
\text { Do. } \\
\text { Do. } \\
\text { Do. } \\
\text { Pondera } \\
\text { Glacier }\end{array}$ \\
\hline \multicolumn{5}{|c|}{ Shawmut, Mont. (locality 5) } \\
\hline $\begin{array}{l}159799 \\
159800 \\
159801 \\
159802 \\
159803\end{array}$ & 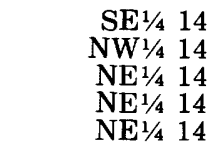 & $\begin{array}{l}6 \mathrm{~N} . \\
6 \mathrm{~N} . \\
6 \mathrm{~N} . \\
6 \mathrm{~N} . \\
6 \mathrm{~N} .\end{array}$ & $\begin{array}{l}15 \mathrm{E} . \\
15 \mathrm{E} . \\
15 \mathrm{E} . \\
15 \mathrm{E} . \\
15 \mathrm{E} .\end{array}$ & $\begin{array}{c}\text { Wheatland } \\
\text { Do. } \\
\text { Do. } \\
\text { Do. } \\
\text { Do. }\end{array}$ \\
\hline $\begin{array}{l}159804 \\
159805 \\
159806 \\
159807\end{array}$ & $\begin{array}{rr}\text { NW }^{1 / 4} \mathrm{SE}^{1 / 4} & 18 \\
\text { Center }^{18} & 18 \\
\mathrm{~W}^{1 / 2} \mathrm{NW}^{1 / 4} & 13 \\
\mathrm{NE}^{1 / 4} \mathrm{NE}^{1 / 4} & 14\end{array}$ & $\begin{array}{l}6 \mathrm{~N} . \\
6 \mathrm{~N} . \\
6 \mathrm{~N} . \\
6 \mathrm{~N} .\end{array}$ & $\begin{array}{l}16 \mathrm{E} . \\
16 \mathrm{E} . \\
15 \mathrm{E} . \\
15 \mathrm{E} .\end{array}$ & $\begin{array}{c}\text { Do. } \\
\text { Wheatland } \\
\text { Do. } \\
\text { Do. }\end{array}$ \\
\hline
\end{tabular}

TABLE 2.-Location of chemically analyzed samples from the Pierre Shale and equivalent rocks, northern Great Plains region-Continued

\begin{tabular}{|c|c|c|c|c|}
\hline $\begin{array}{l}\text { Sample } \\
\text { No. }\end{array}$ & Section & Township & Range & County \\
\hline \multicolumn{5}{|c|}{ Columbus, Mont. (locality 6) } \\
\hline $\begin{array}{l}159776 \\
159777 \\
159778 \\
159779 \\
159780 \\
159781\end{array}$ & $\begin{array}{rl}\mathrm{SE}^{1 / 4} \mathrm{SW}^{1 / 4} \mathrm{NE}^{1 / 4} & 10 \\
\mathrm{NE}^{1 / 4} \mathrm{NE}^{1 / 4} \mathrm{NE}^{1 / 4} & 21 \\
\mathrm{E}^{1 / 2} \mathrm{SW}^{1 / 4} \mathrm{NE}^{1 / 4} & 22 \\
\mathrm{SW}^{1 / 4} \mathrm{NE}^{1 / 4} \mathrm{SE}^{1 / 4} & 22 \\
\mathrm{NW}^{1 / 4} \mathrm{NW}^{1 / 4} \mathrm{SW}^{1 / 4} & 25 \\
\mathrm{SE}^{1 / 4} \mathrm{NW}^{1 / 4} \mathrm{SW}^{1 / 4} & 31\end{array}$ & $\begin{array}{l}2 \mathrm{~S} . \\
2 \mathrm{~S} . \\
2 \mathrm{~S} . \\
2 \mathrm{~S} . \\
2 \mathrm{~S} . \\
2 \mathrm{~S} .\end{array}$ & $\begin{array}{l}20 \mathrm{E} . \\
20 \mathrm{E} . \\
20 \mathrm{E} . \\
20 \mathrm{E} . \\
20 \mathrm{E} . \\
21 \mathrm{E} .\end{array}$ & $\begin{array}{c}\text { Stillwater } \\
\text { Do. } \\
\text { Do. } \\
\text { Do. } \\
\text { Do. } \\
\text { Do. }\end{array}$ \\
\hline $\begin{array}{l}159782 \\
159783 \\
159784 \\
159785 \\
159786\end{array}$ & $\begin{array}{lr}\mathrm{NE}^{1 / 4} \mathrm{SW}^{1 / 4} \mathrm{NE}^{1 / 4} & 2 \\
\mathrm{NE}^{1 / 4} \mathrm{SE}^{1 / 4} \mathrm{NE}^{1 / 4} & 4 \\
\mathrm{SW}^{1 / 4} \mathrm{NE}^{1 / 4} \mathrm{SW}^{1 / 4} & 35 \\
\mathrm{NW}^{1 / 4} \mathrm{NE}^{1 / 4} \mathrm{NE}^{1 / 4} & 2 \\
\mathrm{NE}^{1 / 4} \mathrm{NW}^{1 / 4} \mathrm{NE}^{1 / 4} & 1\end{array}$ & $\begin{array}{l}3 \mathrm{~S} . \\
3 \mathrm{~S} . \\
2 \mathrm{~S} . \\
3 \mathrm{~S} . \\
3 \mathrm{~S} .\end{array}$ & $\begin{array}{l}21 \mathrm{E} . \\
22 \mathrm{E} . \\
22 \mathrm{E} . \\
22 \mathrm{E} . \\
22 \mathrm{E} .\end{array}$ & $\begin{array}{r}\text { Do. } \\
\text { Carbon } \\
\text { Do. } \\
\text { Do. } \\
\text { Do. }\end{array}$ \\
\hline
\end{tabular}

Elk Basin, Wyo. (locality 7)

$159763 \quad \mathrm{NW}^{1 / 4} \mathrm{SE}^{1 / 4} \mathrm{SE}^{1 / 4} 36$ $159764 \mathrm{NW}^{1 / 4} \mathrm{SW}^{1 / 4} \mathrm{NW}^{1 / 4} 20$ $159765 \mathrm{NW}^{1 / 4} \mathrm{SW}^{1 / 4} \mathrm{NW}^{1 / 4} 20$ $159766 \mathrm{SW}^{1 / 4} \mathrm{SW}^{1 / 4} \mathrm{NW}^{1 / 4} 20$

$159767 \quad \mathrm{SW}^{1 / 4} \mathrm{SE}^{1 / 4} \mathrm{NE}^{1 / 4} 19$ C870

$159768 \mathrm{SW}^{1 / 4} \mathrm{SW}^{1 / 4} \mathrm{NE}^{1 / 4} 19$ $159769 \mathrm{SW}^{1 / 4} \mathrm{SW}^{1 / 4} \mathrm{NE}^{1 / 4} 19$ $159770 \quad \mathrm{SW}^{1 / 4} \mathrm{SW}^{1 / 4} \mathrm{NE}^{1 / 4} 19$ 159771 NE $1 / 4$ NW $^{1 / 4} \mathrm{SE}^{1 / 4} 19$ $159772 \quad \mathrm{NE}^{1 / 4} \mathrm{NW}^{1 / 4} \mathrm{SE}^{1 / 4} 19$ $159773 \quad \mathrm{SW}^{1 / 4} \mathrm{NW}^{1 / 4} \mathrm{SE}^{1 / 4} 19$

9 S. 23 E. Carbon ${ }^{1}$ $58 \mathrm{~N} .99 \mathrm{~W}$. Park $58 \mathrm{~N} .99 \mathrm{~W}$. Do. $58 \mathrm{~N} .99 \mathrm{~W}$. Do. $58 \mathrm{~N} .99 \mathrm{~W} . \quad$ Do $6 \mathrm{~S} .23 \mathrm{E}$. Carbon ${ }^{1}$ 58 N. 99 W. Park 58 N. $99 \mathrm{~W} . \quad$ Do. $58 \mathrm{~N} .99 \mathrm{~W}$. Do $58 \mathrm{~N}$. $99 \mathrm{~W}$. Do 58 N. 99 W. Park 58 N. $99 \mathrm{~W} . \quad$ Do.

Womans Pocket, Mont. (locality 8)

\begin{tabular}{|c|c|c|c|c|}
\hline $\begin{array}{l}159787 \\
159788 \\
159789 \\
159790 \\
159791 \\
159792\end{array}$ & 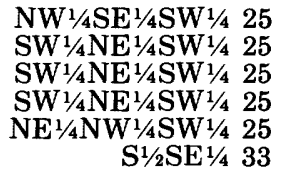 & $\begin{array}{l}8 \mathrm{~N} . \\
8 \mathrm{~N} . \\
8 \mathrm{~N} . \\
8 \mathrm{~N} . \\
8 \mathrm{~N} . \\
8 \mathrm{~N} .\end{array}$ & $\begin{array}{l}20 \mathrm{E} . \\
20 \mathrm{E} . \\
20 \mathrm{E} . \\
20 \mathrm{E} . \\
20 \mathrm{E} . \\
22 \mathrm{E} .\end{array}$ & $\begin{array}{c}\text { Golden Valley } \\
\text { Do. } \\
\text { Do. } \\
\text { Do. } \\
\text { Do. } \\
\text { Do. }\end{array}$ \\
\hline $\begin{array}{l}159793 \\
159794 \\
159795 \\
159796 \\
159797\end{array}$ & $\begin{array}{rr}\text { W }^{1 / 2} \mathrm{SW}^{1 / 4} & 33 \\
\mathrm{NE}^{1 / 4} \mathrm{SE}^{1 / 4} \mathrm{NW}^{1 / 4} & 25 \\
\mathrm{NW}^{1 / 4} \mathrm{SW}^{1 / 4} \mathrm{NE}^{1 / 4} & 25 \\
\mathrm{NW}^{1 / 4} \mathrm{SW}^{1 / 4} \mathrm{NE}^{1 / 4} & 25 \\
\mathrm{SE}^{1 / 4} \mathrm{SW}^{1 / 4} & 5\end{array}$ & $\begin{array}{l}8 \mathrm{~N} \\
8 \mathrm{~N} \\
8 \mathrm{~N} \\
8 \mathrm{~N} \\
7 \mathrm{~N}\end{array}$ & $\begin{array}{l}22 \mathrm{E} . \\
20 \mathrm{E} . \\
20 \mathrm{E} . \\
20 \mathrm{E} . \\
22 \mathrm{E} .\end{array}$ & $\begin{array}{l}\text { Do. } \\
\text { Do. } \\
\text { Do. } \\
\text { Do. } \\
\text { Do. }\end{array}$ \\
\hline
\end{tabular}

Judith River, Mont. (locality 9)

\begin{tabular}{|c|c|c|c|c|}
\hline $\begin{array}{l}159810 \\
159811 \\
159812 \\
159813\end{array}$ & $\begin{array}{rl}N^{1} W^{1 / 4} & 26 \\
N^{1 / 4} & 26 \\
N^{1 / 4} & 26 \\
W^{1 / 2} S^{1 / 4} N^{1 / 4} & 31\end{array}$ & $\begin{array}{l}24 \mathrm{~N} . \\
24 \mathrm{~N} . \\
24 \mathrm{~N} . \\
23 \mathrm{~N} .\end{array}$ & $\begin{array}{l}17 \mathrm{E} . \\
17 \mathrm{E} . \\
17 \mathrm{E} . \\
17 \mathrm{E} .\end{array}$ & $\begin{array}{l}\text { Blaine } \\
\text { Do. } \\
\text { Do. } \\
\text { Fergus }\end{array}$ \\
\hline $\begin{array}{l}159814 \\
159815 \\
159816 \\
C 871 \\
159817\end{array}$ & $\begin{array}{rr}W^{1 / 2} \mathrm{SW}^{1 / 4} \mathrm{NE}^{1 / 4} & 31 \\
\mathrm{~W}^{1 / 2} \mathrm{SW}^{1 / 4} \mathrm{NE}^{1 / 4} & 31 \\
\mathrm{NE}^{1 / 4} \mathrm{SE}^{1 / 4} \mathrm{SW}^{1 / 4} & 12 \\
\mathrm{NW}^{1 / 4} & 31 \\
\mathrm{SE}^{1 / 4} \mathrm{NE}^{1 / 4} \mathrm{SW}^{1 / 4} & 12\end{array}$ & $\begin{array}{l}23 \mathrm{~N} . \\
23 \mathrm{~N} . \\
22 \mathrm{~N} . \\
18 \mathrm{~N} . \\
22 \mathrm{~N} .\end{array}$ & $\begin{array}{l}17 \mathrm{E} . \\
17 \mathrm{E} . \\
17 \mathrm{E} . \\
19 \mathrm{E} . \\
17 \mathrm{E} .\end{array}$ & $\begin{array}{l}\text { Do. } \\
\text { Do. } \\
\text { Do. } \\
\text { Do. } \\
\text { Do. }\end{array}$ \\
\hline $\begin{array}{l}159818 \\
159819 \\
159820 \\
159821\end{array}$ & 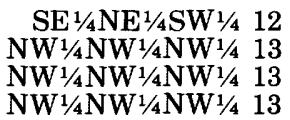 & $\begin{array}{l}22 \mathrm{~N} . \\
22 \mathrm{~N} . \\
22 \mathrm{~N} . \\
22 \mathrm{~N} .\end{array}$ & $\begin{array}{l}17 \mathrm{E} . \\
17 \mathrm{E} . \\
17 \mathrm{E} . \\
17 \mathrm{E} .\end{array}$ & $\begin{array}{r}\text { Fergus } \\
\text { Do. } \\
\text { Do. } \\
\text { Do. }\end{array}$ \\
\hline
\end{tabular}


TABLE 2.-Location of chemically analyzed samples from the Pierre Shale and equivalent rocks, northern Great Plains region-Continued

\begin{tabular}{|c|c|c|c|c|}
\hline $\begin{array}{l}\text { Sample } \\
\text { No. }\end{array}$ & Section & Township & Range & County \\
\hline \multicolumn{5}{|c|}{ Salt Creek, Wyo. (locality 10) } \\
\hline $\begin{array}{l}159709 \\
159710 \\
159711 \\
159712 \\
159713\end{array}$ & 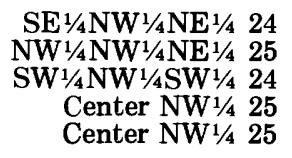 & $\begin{array}{l}39 \mathrm{~N} . \\
39 \mathrm{~N} . \\
39 \mathrm{~N} . \\
39 \mathrm{~N} . \\
39 \mathrm{~N} .\end{array}$ & $\begin{array}{l}78 \mathrm{~W} . \\
78 \mathrm{~W} . \\
78 \mathrm{~W} . \\
78 \mathrm{~W} . \\
78 \mathrm{~W} .\end{array}$ & $\begin{array}{c}\text { Natrona } \\
\text { Do. } \\
\text { Do. } \\
\text { Do. } \\
\text { Do. }\end{array}$ \\
\hline $\begin{array}{l}159714 \\
159715 \\
159716 \\
159717 \\
159718 \\
159719\end{array}$ & $\begin{array}{rr}\mathrm{SW}^{1 / 4} \mathrm{NW}^{1 / 4} & 25 \\
\mathrm{SE}^{1 / 4} \mathrm{SE}^{1 / 4} \mathrm{SW}^{1 / 4} & 5 \\
\mathrm{SE}^{1 / 4} \mathrm{SE}^{1 / 4} \mathrm{SW}^{1 / 4} & 4 \\
\mathrm{SW}^{1 / 4} \mathrm{SW}^{1 / 4} \mathrm{SE}^{1 / 4} & 4 \\
\mathrm{NW}^{1 / 4} \mathrm{NW}^{1 / 4} \mathrm{NE}^{1 / 4} & 9 \\
\mathrm{NW}^{1 / 4} \mathrm{SE}^{1 / 4} \mathrm{SE}^{1 / 4} & 4\end{array}$ & $\begin{array}{l}39 \mathrm{~N} . \\
38 \mathrm{~N} . \\
38 \mathrm{~N} . \\
38 \mathrm{~N} . \\
38 \mathrm{~N} . \\
38 \mathrm{~N} .\end{array}$ & $\begin{array}{l}78 \mathrm{~W} . \\
78 \mathrm{~W} . \\
78 \mathrm{~W} . \\
78 \mathrm{~W} . \\
78 \mathrm{~W} . \\
78 \mathrm{~W} .\end{array}$ & $\begin{array}{l}\text { Do. } \\
\text { Do. } \\
\text { Do. } \\
\text { Do. } \\
\text { Do. } \\
\text { Do. }\end{array}$ \\
\hline $\begin{array}{l}159720 \\
159721 \\
159722 \\
159723 \\
159724\end{array}$ & $\begin{array}{rr}\mathrm{SW}^{1 / 4} \mathrm{SE}^{1 / 4} \mathrm{SW}^{1 / 4} & 3 \\
\mathrm{SW}^{1 / 4} \mathrm{NW}^{1 / 4} & 8 \\
\mathrm{SE}^{1 / 4} \mathrm{SE}^{1 / 4} \mathrm{SW}^{1 / 4} & 3 \\
\mathrm{NW}^{1 / 4} \mathrm{SW}^{1 / 4} \mathrm{SE}^{1 / 4} & 3 \\
\mathrm{NW}^{1 / 4} \mathrm{NE}^{1 / 4} \mathrm{NE}^{1 / 4} & 34\end{array}$ & $\begin{array}{l}39 \mathrm{~N} . \\
39 \mathrm{~N} . \\
39 \mathrm{~N} . \\
39 \mathrm{~N} . \\
40 \mathrm{~N} .\end{array}$ & $\begin{array}{l}79 \mathrm{~W} . \\
79 \mathrm{~W} . \\
79 \mathrm{~W} . \\
79 \mathrm{~W} . \\
79 \mathrm{~W} .\end{array}$ & $\begin{array}{l}\text { Do. } \\
\text { Do. } \\
\text { Do. } \\
\text { Do. } \\
\text { Do. }\end{array}$ \\
\hline
\end{tabular}

\begin{tabular}{|c|c|c|c|c|}
\hline \multicolumn{5}{|c|}{ Hardin, Mont. (locality 13) } \\
\hline $\begin{array}{l}159727 \\
159728 \\
159729 \\
159730 \\
159731\end{array}$ & $\begin{array}{rr}\mathrm{SE}^{1 / 4} & 9 \\
\mathrm{NW}^{1 / 4} \mathrm{SW}^{1 / 4} & 9 \\
\mathrm{SE}^{1 / 4} \mathrm{SE}^{1 / 4} & 8 \\
\mathrm{SE}^{1 / 4} \mathrm{SW}^{1 / 4} & 8 \\
\mathrm{NE}^{1 / 4} \mathrm{SE}^{1 / 4} & 18\end{array}$ & $\begin{array}{l}1 \mathrm{~S} . \\
1 \mathrm{~S} . \\
1 \mathrm{~S} . \\
1 \mathrm{~S} . \\
1 \mathrm{~S} .\end{array}$ & $\begin{array}{l}35 \mathrm{E} . \\
35 \mathrm{E} . \\
35 \mathrm{E} . \\
35 \mathrm{E} . \\
35 \mathrm{E} .\end{array}$ & $\begin{array}{c}\text { Big Horn } \\
\text { Do. } \\
\text { Big Horn } \\
\text { Do. } \\
\text { Do. }\end{array}$ \\
\hline $\begin{array}{l}159732 \\
159733 \\
159734 \\
159735 \\
159736\end{array}$ & $\begin{array}{rr}\mathrm{NW}^{1 / 4} \mathrm{NW}^{1 / 4} & 18 \\
\mathrm{NW}^{1 / 4} \mathrm{NW}^{1 / 4} & 18 \\
\mathrm{NE}^{1 / 4} \mathrm{NE}^{1 / 4} & 13 \\
\mathrm{NE}^{1 / 4} \mathrm{NW}^{1 / 4} & 13 \\
\mathrm{SE}^{1 / 4} \mathrm{SW}^{1 / 4} & 1\end{array}$ & $\begin{array}{l}1 \mathrm{~S} . \\
1 \mathrm{~S} . \\
1 \mathrm{~S} . \\
1 \mathrm{~S} . \\
2 \mathrm{~S} .\end{array}$ & $\begin{array}{l}35 \mathrm{E} . \\
35 \mathrm{E} . \\
34 \mathrm{E} . \\
34 \mathrm{E} . \\
34 \mathrm{E} .\end{array}$ & $\begin{array}{l}\text { Do. } \\
\text { Do. } \\
\text { Do. } \\
\text { Do. } \\
\text { Do. }\end{array}$ \\
\hline
\end{tabular}

Mosby, Mont. (locality 14)

\begin{tabular}{|c|c|c|c|c|c|}
\hline $\begin{array}{l}159750 \\
\text { C875 } \\
159751 \\
159752 \\
159753\end{array}$ & $\begin{array}{r}\text { NW }^{1 / 4} \mathrm{NW}^{1 / 4} \mathrm{NE}^{1 / 4} \\
\mathrm{SW}^{1 / 4} \mathrm{NE}^{1 / 4} \\
\mathrm{SW}^{1 / 4} \mathrm{NE}^{1 / 4} \\
\mathrm{SE}^{1 / 4} \mathrm{NW}^{1 / 4}\end{array}$ & $\begin{array}{r}4 \\
13 \\
4 \\
4 \\
4\end{array}$ & $\begin{array}{l}14 \mathrm{~N} . \\
11 \mathrm{~N} . \\
14 \mathrm{~N} . \\
14 \mathrm{~N} . \\
14 \mathrm{~N} .\end{array}$ & $\begin{array}{l}31 \mathrm{E} . \\
31 \mathrm{E} . \\
31 \mathrm{E} . \\
31 \mathrm{E} . \\
31 \mathrm{E} .\end{array}$ & $\begin{array}{l}\text { Garfield } \\
\text { Rosebud } \\
\text { Garfield } \\
\text { Do. } \\
\text { Do. }\end{array}$ \\
\hline $\begin{array}{l}159754 \\
159755 \\
159756 \\
159757\end{array}$ & $\begin{array}{r}\mathrm{SW}^{1 / 4} \mathrm{SE}^{1 / 4} \mathrm{NW}^{1 / 4} \\
\mathrm{NE}^{1 / 4} \mathrm{SW}^{1 / 4} \\
\mathrm{NE}^{1 / 4} \mathrm{SW}^{1 / 4} \\
\text { SW1 }^{1 / 4} \mathrm{SW}^{1 / 4} \mathrm{NW}^{1 / 4}\end{array}$ & $\begin{array}{l}4 \\
4 \\
4 \\
4\end{array}$ & $\begin{array}{l}14 \mathrm{~N} . \\
14 \mathrm{~N} . \\
14 \mathrm{~N} . \\
14 \mathrm{~N} .\end{array}$ & $\begin{array}{l}31 \mathrm{E} . \\
31 \mathrm{E} . \\
31 \mathrm{E} . \\
31 \mathrm{E} .\end{array}$ & $\begin{array}{l}\text { Do. } \\
\text { Do. } \\
\text { Do. } \\
\text { Do. }\end{array}$ \\
\hline $\begin{array}{l}159758 \\
159759 \\
159760 \\
159761 \\
159762\end{array}$ & $\begin{array}{r}\text { NW }^{1 / 4} \mathrm{NW}^{1 / 4} \mathrm{SW}^{1 / 4} \\
\mathrm{NW}^{1 / 4} \mathrm{NW}^{1 / 4} \mathrm{SE}^{1 / 4} \\
\mathrm{NE}^{1 / 4} \mathrm{SE}^{1 / 4} \\
\mathrm{SE}^{1 / 4} \mathrm{SE}^{1 / 4} \\
\mathrm{SE}^{1 / 4} \mathrm{SW}^{1 / 4} \mathrm{SE}^{1 / 4}\end{array}$ & $\begin{array}{l}4 \\
5 \\
5 \\
5 \\
5\end{array}$ & $\begin{array}{l}14 \mathrm{~N} \\
14 \mathrm{~N} \\
14 \mathrm{~N} \\
14 \mathrm{~N} \\
14 \mathrm{~N}\end{array}$ & $\begin{array}{l}31 \mathrm{E} . \\
31 \mathrm{E} . \\
31 \mathrm{E} . \\
31 \mathrm{E} . \\
31 \mathrm{E} .\end{array}$ & $\begin{array}{l}\text { Do. } \\
\text { Do. } \\
\text { Do. } \\
\text { Do. } \\
\text { Do. }\end{array}$ \\
\hline
\end{tabular}

Porcupine dome, Mont. (locality 15)

\begin{tabular}{|c|c|c|c|c|}
\hline $\begin{array}{l}159737 \\
159738 \\
159739 \\
159740 \\
159741 \\
159742\end{array}$ & 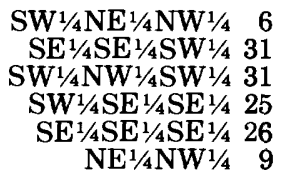 & $\begin{array}{l}6 \mathrm{~N} . \\
7 \mathrm{~N} . \\
7 \mathrm{~N} . \\
7 \mathrm{~N} . \\
7 \mathrm{~N} . \\
7 \mathrm{~N} .\end{array}$ & $\begin{array}{l}40 \mathrm{E} . \\
40 \mathrm{E} . \\
40 \mathrm{E} . \\
39 \mathrm{E} . \\
39 \mathrm{E} . \\
38 \mathrm{E} .\end{array}$ & $\begin{array}{c}\text { Rosebud } \\
\text { Do. } \\
\text { Do. } \\
\text { Do. } \\
\text { Do. } \\
\text { Do. }\end{array}$ \\
\hline $\begin{array}{l}159743 \\
159744 \\
159745 \\
159746 \\
159747\end{array}$ & $\begin{array}{rr}\text { SW }^{1 / 4} \mathrm{SW}^{1 / 4} & 10 \\
\text { NW }^{1 / 4} \text { NW }^{1 / 4} & 6 \\
\text { SE }^{1 / 4} \text { NW }^{1 / 4} \text { SE }^{1 / 4} & 23 \\
\text { NW }^{1 / 4} \text { SW }^{1 / 4} \text { SE }^{1 / 4} & 23 \\
\text { SW }^{1 / 4} \text { NE }^{1 / 4} \text { NE }^{1 / 4} & 22\end{array}$ & $\begin{array}{l}7 \mathrm{~N} . \\
8 \mathrm{~N} . \\
12 \mathrm{~N} . \\
12 \mathrm{~N} . \\
12 \mathrm{~N}\end{array}$ & $\begin{array}{l}38 \mathrm{E} . \\
38 \mathrm{E} . \\
37 \mathrm{E} . \\
37 \mathrm{E} . \\
37 \mathrm{E} .\end{array}$ & $\begin{array}{l}\text { Do. } \\
\text { Do. } \\
\text { Do. } \\
\text { Do. } \\
\text { Do. }\end{array}$ \\
\hline
\end{tabular}

TABLE 2.-Location of chemically analyzed samples from the Pierre Shale and equivalent rocks, northern Great Plains region-Continued

\begin{tabular}{|c|c|c|c|c|}
\hline $\begin{array}{l}\text { Sample } \\
\text { No. }\end{array}$ & Section & Township & Range & County \\
\hline \multicolumn{5}{|c|}{ Red Bird, Wyo. (locality 16) } \\
\hline $\begin{array}{l}259575 \\
259576 \\
259577 \\
259578\end{array}$ & $\begin{array}{ll}\mathrm{SE}^{1 / 4} \mathrm{NE}^{1 / 4} & 22 \\
\mathrm{SE}^{1 / 4} \mathrm{NE}^{1 / 4} & 22 \\
\mathrm{SE}^{1 / 4} \mathrm{NE}^{1 / 4} & 22 \\
\mathrm{SE}^{1 / 4} \mathrm{NE}^{1 / 4} & 22\end{array}$ & $\begin{array}{l}38 \mathrm{~N} . \\
38 \mathrm{~N} . \\
38 \mathrm{~N} . \\
38 \mathrm{~N} .\end{array}$ & $\begin{array}{l}62 \mathrm{~W} . \\
62 \mathrm{~W} . \\
62 \mathrm{~W} . \\
62 \mathrm{~W} .\end{array}$ & $\begin{array}{c}\text { Niobrara } \\
\text { Do. } \\
\text { Do. } \\
\text { Do. }\end{array}$ \\
\hline $\begin{array}{l}259580 \\
259579 \\
259581 \\
259582\end{array}$ & $\begin{array}{rl}\mathrm{SE}^{1 / 4 N N^{1 / 4}} & 22 \\
\mathrm{SE}^{1 / 4} \mathrm{NE}^{1 / 4} & 22 \\
\mathrm{SW}^{1 / 4} \mathrm{NE}^{1 / 4} & 23 \\
\mathrm{SW}^{1 / 4} \mathrm{NE}^{1 / 4} & 23\end{array}$ & $\begin{array}{l}38 \mathrm{~N} . \\
38 \mathrm{~N} . \\
38 \mathrm{~N} . \\
38 \mathrm{~N} .\end{array}$ & $\begin{array}{l}62 \mathrm{~W} . \\
62 \mathrm{~W} . \\
62 \mathrm{~W} . \\
62 \mathrm{~W} .\end{array}$ & $\begin{array}{l}\text { Do. } \\
\text { Do. } \\
\text { Do. } \\
\text { Do. }\end{array}$ \\
\hline
\end{tabular}

\begin{tabular}{|c|c|c|c|c|}
\hline \multicolumn{5}{|c|}{ Northern Black Hills (locality 17) } \\
\hline $\begin{array}{l}259583 \\
259590 \\
259589 \\
C 877 \\
259586\end{array}$ & $\begin{array}{rr}\mathrm{SE}^{1 / 4} \mathrm{SE}^{1 / 4} & 6 \\
\mathrm{NW}^{1 / 4 \mathrm{SW}^{1 / 4}} & 20 \\
\mathrm{SW}^{1 / 4} \mathrm{NE}^{1 / 4} & 19 \\
& 6 \\
\mathrm{SW}^{1 / 4} \mathrm{SW}^{1 / 4} \mathrm{SW}^{1 / 4} & 8\end{array}$ & $\begin{array}{l}51 \mathrm{~N} . \\
12 \mathrm{~N} . \\
15 \mathrm{~N} . \\
52 \mathrm{~N} . \\
7 \mathrm{~S} .\end{array}$ & $\begin{array}{r}67 \mathrm{~W} \\
3 \mathrm{E} . \\
2 \mathrm{E} . \\
67 \mathrm{~W} \\
56 \mathrm{E} .\end{array}$ & $\begin{array}{l}\text { Crook }^{2} \\
\text { Butte }^{3} \\
\text { Harding }^{3} \\
\text { Crook }^{2} \\
\text { Carter }^{1}\end{array}$ \\
\hline $\begin{array}{l}259587 \\
259588 \\
259584 \\
\mathrm{C} 876\end{array}$ & 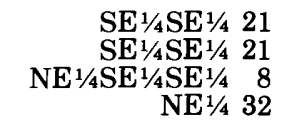 & $\begin{aligned} 7 \mathrm{~S} . \\
7 \mathrm{~S} . \\
51 \mathrm{~S} . \\
54 \mathrm{~N} .\end{aligned}$ & $\begin{array}{l}56 \mathrm{E} . \\
56 \mathrm{E} . \\
67 \mathrm{~W} . \\
67 \mathrm{~W} .\end{array}$ & $\begin{array}{r}\text { Do. } \\
\text { Do. } \\
\text { Crook }{ }^{2} \\
\text { Do. }\end{array}$ \\
\hline $\begin{array}{l}259591 \\
259592 \\
259593 \\
259594 \\
259585\end{array}$ & 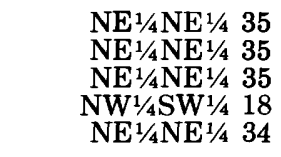 & $\begin{array}{l}12 \mathrm{~N} . \\
12 \mathrm{~N} . \\
12 \mathrm{~N} . \\
11 \mathrm{~N} . \\
51 \mathrm{~N} .\end{array}$ & $\begin{array}{r}2 \mathrm{E} . \\
2 \mathrm{E} . \\
2 \mathrm{E} . \\
2 \mathrm{E} . \\
67 \mathrm{~W} .\end{array}$ & $\begin{array}{l}\text { Butte }^{3} \\
\text { Do. } \\
\text { Do. } \\
\text { Do. } \\
\text { Crook }^{2}\end{array}$ \\
\hline \multicolumn{5}{|c|}{ Southeastern Black Hills, S. Dak. (locality 18) } \\
\hline $\begin{array}{l}259565 \\
259567 \\
259568 \\
259569 \\
259566\end{array}$ & $\begin{array}{rr}\text { SE}^{1 / 4} \text { SE }^{1 / 4} & 31 \\
\text { SW }^{1 / 4} \text { SE }^{1 / 4} & 20 \\
\text { SW }^{1 / 4} \text { SW }^{1 / 4} & 7 \\
\text { SE1 }^{1 / 4} \text { NE }^{1 / 4} & 17 \\
\text { NW }^{1 / 4} \text { SE }^{1 / 4} & 5\end{array}$ & $\begin{array}{l}7 \mathrm{~N} . \\
5 \mathrm{~N} . \\
1 \mathrm{~N} . \\
7 \mathrm{~S} . \\
6 \mathrm{~N} .\end{array}$ & $\begin{array}{l}11 \mathrm{E} . \\
13 \mathrm{E} . \\
15 \mathrm{E} . \\
8 \mathrm{E} . \\
10 \mathrm{E} .\end{array}$ & $\begin{array}{l}\text { Meade } \\
\text { Do. } \\
\text { Pennington } \\
\text { Fall River } \\
\text { Meade }\end{array}$ \\
\hline $\begin{array}{l}259570 \\
259571 \\
259572 \\
259573 \\
259574\end{array}$ & $\begin{array}{rl}N^{1} 1 / 4 N^{1} / 4 & 26 \\
\text { SW }^{1 / 4} \text { NW }^{1 / 4} & 32 \\
\text { NE }^{1 / 4} \text { NE }^{1 / 4} & 31 \\
\text { NE }^{1 / 4} \text { NE }^{1 / 4} & 31 \\
\text { NE }^{1 / 4} \text { NE }^{1 / 4} & 31\end{array}$ & $\begin{array}{l}7 \mathrm{~S} . \\
7 \mathrm{~S} . \\
7 \mathrm{~S} . \\
7 \mathrm{~S} . \\
7 \mathrm{~S} .\end{array}$ & $\begin{array}{l}7 \mathrm{E} . \\
7 \mathrm{E} . \\
7 \mathrm{E} . \\
7 \mathrm{E} . \\
7 \mathrm{E} .\end{array}$ & $\begin{array}{c}\text { Fall River } \\
\text { Do. } \\
\text { Do. } \\
\text { Do. } \\
\text { Do. }\end{array}$ \\
\hline
\end{tabular}

Irish Creek well, S. Dak. (locality 19)

$259595 \quad$ NE$^{1 / 4} \mathrm{NE}^{1 / 4} \mathrm{SE}^{1 / 4} 17 \quad 15$ N. 20 E. Ziebach

Mobridge, S. Dak. (locality 20)

\begin{tabular}{|c|c|c|c|c|}
\hline $\begin{array}{l}259531 \\
\text { C886 } \\
259532 \\
259533\end{array}$ & 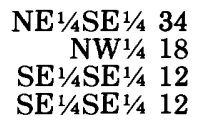 & $\begin{array}{rl}124 & \mathrm{~N} . \\
18 \mathrm{~N} . \\
124 \mathrm{~N} . \\
124 \mathrm{~N} .\end{array}$ & $\begin{array}{c}79 \mathrm{~W} . \\
30 \mathrm{E} . \\
80 \mathrm{E} . \\
80 \mathrm{~W} .\end{array}$ & $\begin{array}{c}\text { Walworth } \\
\text { Corson } \\
\text { Walworth } \\
\quad \text { Do. }\end{array}$ \\
\hline \multicolumn{5}{|c|}{ Cheyenne Agency, S. Dak. (locality 21) } \\
\hline $\begin{array}{l}259530 \\
\text { C887 } \\
259535 \\
259536\end{array}$ & $\begin{array}{rr}\mathrm{SE}^{1 / 4} & 6 \\
\mathrm{SE}^{1 / 4} & 29 \\
& 35 \\
\mathrm{NW}^{1 / 4} & 30\end{array}$ & $\begin{array}{rl}15 & \mathrm{~N} . \\
16 \mathrm{~N} . \\
13 \mathrm{~N} . \\
118 \mathrm{~N} .\end{array}$ & $\begin{array}{l}26 \mathrm{E} . \\
31 \mathrm{E} . \\
31 \mathrm{E} . \\
78 \mathrm{E} .\end{array}$ & $\begin{array}{r}\text { Dewey } \\
\text { Do. } \\
\text { Do. } \\
\text { Potter }\end{array}$ \\
\hline
\end{tabular}


TABLE 2.-Location of chemically analyzed samples from the Pierre Shale and equivalent rocks, northern Great Plains region-Continued

\begin{tabular}{|c|c|c|c|c|}
\hline $\begin{array}{l}\text { Sample } \\
\text { No. }\end{array}$ & Section & Township & Range & County \\
\hline \multicolumn{5}{|c|}{ Pierre-Oahe, S. Dak. (locality 22) } \\
\hline $\begin{array}{l}259534 \\
259541 \\
259542 \\
259546 \\
259544 \\
259543\end{array}$ & $\begin{array}{r}\mathrm{SE}^{1 / 4} \mathrm{NW}^{1 / 4} \mathbf{1 8} \\
30 \\
30 \\
\mathrm{NW}^{1 / 4} \mathbf{3 5} \\
30 \\
30\end{array}$ & $\begin{array}{l}8 \mathrm{~N} . \\
6 \mathrm{~N} . \\
6 \mathrm{~N} . \\
7 \mathrm{~N} . \\
6 \mathrm{~N} . \\
6 \mathrm{~N} .\end{array}$ & $\begin{array}{l}24 \mathrm{E} . \\
31 \mathrm{E} . \\
31 \mathrm{E} . \\
28 \mathrm{E} . \\
31 \mathrm{E} . \\
31 \mathrm{E} .\end{array}$ & $\begin{array}{r}\text { Haakon } \\
\text { Stanley } \\
\text { Do. } \\
\text { Do. } \\
\text { Do. } \\
\text { Do. }\end{array}$ \\
\hline $\begin{array}{l}\text { C881 } \\
\text { C884 } \\
\text { C885 } \\
259545 \\
259540 \\
259539\end{array}$ & $\begin{array}{lr}\mathrm{SE}^{1 / 4} & 36 \\
\mathrm{SE}^{1 / 4} & 36 \\
\mathrm{SE}^{1 / 4} & 36 \\
& 30 \\
\mathrm{NE}^{1 / 4} & 1 \\
\mathrm{NE}^{1 / 4} & 1\end{array}$ & $\begin{array}{rl}6 & \mathrm{~N} . \\
6 \mathrm{~N} . \\
6 \mathrm{~N} . \\
6 \mathrm{~N} . \\
111 \mathrm{~N} . \\
111 \mathrm{~N} .\end{array}$ & $\begin{array}{l}30 \mathrm{E} . \\
30 \mathrm{E} . \\
30 \mathrm{E} . \\
31 \mathrm{E} . \\
80 \mathrm{~W} . \\
80 \mathrm{~W} \text {. }\end{array}$ & $\begin{array}{r}\text { Do. } \\
\text { Do. } \\
\text { Do. } \\
\text { Do. } \\
\text { Hughes } \\
\text { Hughes }\end{array}$ \\
\hline $\begin{array}{l}259554 \\
259537 \\
259538 \\
\text { C878 } \\
\text { C879 } \\
\text { C880 }\end{array}$ & $\begin{array}{rr}\text { NW }^{1 / 4} \mathrm{NE}^{1 / 4} & 15 \\
\mathrm{NE}^{1 / 4} & 1 \\
\mathrm{NE}^{1 / 4} & 1 \\
& 1 \\
& 1 \\
& 1\end{array}$ & $\begin{array}{l}6 \mathrm{~N} . \\
111 \mathrm{~N} . \\
111 \mathrm{~N} . \\
111 \mathrm{~N} . \\
111 \mathrm{~N} . \\
111 \mathrm{~N} .\end{array}$ & $\begin{array}{l}29 \mathrm{E} . \\
80 \mathrm{~W} \text {. } \\
80 \mathrm{~W} \text {. } \\
80 \mathrm{~W} \text {. } \\
80 \mathrm{~W} \text {. } \\
80 \mathrm{~W} \text {. }\end{array}$ & $\begin{array}{r}\text { Stanley } \\
\text { Hughes } \\
\text { Do. } \\
\text { Do. } \\
\text { Do. } \\
\text { Do. }\end{array}$ \\
\hline
\end{tabular}

Chamberlain, S. Dak. (locality 23)

\begin{tabular}{|c|c|c|c|c|}
\hline $\begin{array}{l}259552 \\
259553 \\
259564 \\
259555\end{array}$ & $\begin{array}{rl}\text { NW }^{1 / 4} \text { SW }^{1 / 4} & 21 \\
\text { SE}^{1 / 4} \text { SW }^{1} / 4 & 21 \\
\text { SW }^{1 / 4} \text { SW }^{1 / 4} & 32 \\
\text { NW }^{1} / 4 & 12\end{array}$ & $\begin{array}{r}106 \mathrm{~N} . \\
106 \mathrm{~N} . \\
3 \mathrm{~S} . \\
105 \mathrm{~N} .\end{array}$ & $\begin{array}{c}73 \mathrm{~W} . \\
73 \mathrm{~W} . \\
29 \mathrm{E} . \\
71 \mathrm{~W} .\end{array}$ & $\begin{array}{l}\text { Lyman } \\
\text { Do. } \\
\text { Jones } \\
\text { Brule }\end{array}$ \\
\hline $\begin{array}{l}259550 \\
259551 \\
\mathrm{C} 888 \\
\mathrm{C} 889 \\
\mathrm{C} 890\end{array}$ & $\begin{array}{rr}\text { SE1/4 } & 22 \\
\text { SE}^{1 / 4} & 22 \\
\text { NW }^{1 / 4} \text { NE}^{1 / 4} & 17 \\
\text { NW}^{1 / 4} \text { NE}^{1 / 4} & 17 \\
\text { NW}^{1 / 4} \text { NE}^{1 / 4} & 17\end{array}$ & $\begin{array}{l}104 \mathrm{~N} . \\
104 \mathrm{~N} . \\
104 \mathrm{~N} . \\
104 \mathrm{~N} . \\
104 \mathrm{~N} .\end{array}$ & $\begin{array}{l}72 \mathrm{~W} . \\
72 \mathrm{~W} . \\
71 \mathrm{~W} . \\
71 \mathrm{~W} . \\
71 \mathrm{~W} .\end{array}$ & $\begin{array}{r}\text { Lyman } \\
\text { Do. } \\
\text { Do. } \\
\text { Do. } \\
\text { Do. }\end{array}$ \\
\hline $\begin{array}{l}259547 \\
259548 \\
259549 \\
\text { C891 }\end{array}$ & $\begin{array}{ll}\text { NW }^{1 / 4} \text { NE }^{1 / 4} & 17 \\
\text { NW }^{1 / 4} \text { NE }^{1 / 4} & 17 \\
\text { NW }^{1 / 4} \text { NE }^{1 / 4} & 17 \\
\text { NW }^{1 / 4} \text { NE }^{1 / 4} & 17\end{array}$ & $\begin{array}{l}104 \mathrm{~N} . \\
104 \mathrm{~N} . \\
104 \mathrm{~N} . \\
104 \mathrm{~N} .\end{array}$ & $\begin{array}{l}71 \mathrm{~W} . \\
71 \mathrm{~W} . \\
71 \mathrm{~W} . \\
71 \mathrm{~W} .\end{array}$ & $\begin{array}{l}\text { Do. } \\
\text { Do. } \\
\text { Do. } \\
\text { Do. }\end{array}$ \\
\hline
\end{tabular}

TABLE 2.-Location of chemically analyzed samples from the Pierre Shale and equivalent rocks, northern Great Plains region-Continued

\begin{tabular}{|c|c|c|c|c|}
\hline $\begin{array}{l}\text { Sample } \\
\text { No. }\end{array}$ & Section & Township & Range & County \\
\hline \multicolumn{5}{|c|}{ Wheeler bridge, S. Dak. (locality 24) } \\
\hline $\begin{array}{l}259556 \\
259557 \\
259558 \\
259559 \\
259560 \\
259561\end{array}$ & $\begin{array}{rr}\text { SW }^{1 / 4} \text { SW }^{1 / 4} & 18 \\
\text { SW }^{1 / 4} \text { NE }^{1 / 4} & 18 \\
\text { SW }^{1 / 4} \text { NE }^{1 / 4} & 18 \\
\text { SE }^{1 / 4} & 7 \\
\text { SE }^{1 / 4} & 7 \\
\text { SE }^{1 / 4} \text { NW }^{1 / 4} & 36\end{array}$ & $\begin{array}{l}96 \mathrm{~N} . \\
96 \mathrm{~N} . \\
96 \mathrm{~N} . \\
96 \mathrm{~N} . \\
96 \mathrm{~N} . \\
95 \mathrm{~N} .\end{array}$ & $\begin{array}{l}67 \mathrm{~W} . \\
67 \mathrm{~W} . \\
67 \mathrm{~W} . \\
67 \mathrm{~W} . \\
67 \mathrm{~W} . \\
65 \mathrm{~W} .\end{array}$ & $\begin{array}{c}\text { Gregory } \\
\text { Do. } \\
\text { Do. } \\
\text { Do. } \\
\text { Do. } \\
\text { Charles Mix }\end{array}$ \\
\hline \multicolumn{5}{|c|}{ Niobrara, Nebr. (locality 25) } \\
\hline 259562 & NW $1 / 424$ & $30 \mathrm{~N}$. & $7 \mathrm{~W}$. & Knox \\
\hline \multicolumn{5}{|c|}{ Yankton, S. Dak. (locality 26) } \\
\hline 259563 & NE $1 / 427$ & $93 \mathrm{~N}$. & $56 \mathrm{~W}$. & Yankton \\
\hline
\end{tabular}

Eastern Dakotas (locality 27)

\begin{tabular}{|c|c|c|c|c|}
\hline $\begin{array}{l}259529 \\
259528\end{array}$ & $\begin{array}{lr}\mathrm{NE}^{1 / 4} & 35 \\
\mathrm{NE}^{1 / 4} & 9\end{array}$ & $\begin{array}{l}122 \mathrm{~N} . \\
140 \mathrm{~N} .\end{array}$ & $\begin{array}{l}60 \mathrm{~W} . \\
58 \mathrm{~W} .\end{array}$ & $\begin{array}{l}\text { Brown }^{3} \\
\text { Barnes }^{4}\end{array}$ \\
\hline \multicolumn{5}{|c|}{ Pembina, N. Dak. (locahty 28) } \\
\hline $\begin{array}{l}259526 \\
259527\end{array}$ & $\begin{array}{rr}\mathrm{SE}^{1 / 4} \mathrm{SE}^{1 / 4} & 18 \\
\mathrm{SW}^{1 / 4} & 25\end{array}$ & $\begin{array}{l}163 \mathrm{~N} . \\
161 \mathrm{~N} .\end{array}$ & $\begin{array}{l}57 \mathrm{~W} . \\
57 \mathrm{~W} .\end{array}$ & $\begin{array}{c}\text { Cavalier } \\
\text { Do. }\end{array}$ \\
\hline
\end{tabular}

${ }^{1}$ Montana.

${ }^{2}$ Wyoming.

${ }^{3}$ South Dakota.

${ }^{4}$ North Dakota. 